\title{
Wpływ rewitalizacji terenów poprzemysłowych na organizację przestrzeni centralnej w Manchesterze Lyonie i todzi
}


盗 


\section{JAROSŁAW KAZIMIERCZAK}

\section{Wplyw rewitalizacji terenów poprzemyslowych na organizacje przestrzeni centralnej w Manchesterze Lyonie i todzi}




\title{
Jarosław Kazimierczak - Uniwersytet Łódzki, Wydział Nauk Geograficznych Instytut Geografii Miast i Turyzmu, Pracownia Rewitalizacji Miast 90-142 Łódź, ul. Kopcińskiego 31
}

\author{
RECENZENCI \\ Lydia Coudroy de Lille, Janusz Stodczyk \\ REDAKTOR WYDAWNICTWA UŁ \\ Bogusława Kwiatkowska
}

SKŁAD I ŁAMANIE

AGENT PR

PROJEKT OKŁADKI

Barbara Grzejszczak

Na okładce wykorzystano mapy opracowane przez Autora

Projekt został sfinansowany ze środków Narodowego Centrum Nauki przyznanych na podstawie decyzji numer DEC-2011/03/N/HS4/03145

C Copyright by Uniwersytet Łódzki, Łódź 2014

Wydane przez Wydawnictwo Uniwersytetu Łódzkiego

Wydanie I. W.06620.14.0.D

ISBN (wersja drukowana) 978-83-7969-189-0

ISBN (ebook) 978-83-7969-741-0
Wydawnictwo Uniwersytetu Łódzkiego
90-131 Łódź, ul. Lindleya 8
www.wydawnictwo.uni.lodz.pl
e-mail: ksiegarnia@uni.lodz.pl
tel. (42) 6655863 , faks (42) 6655862




\section{SPIS TREŚCI}

Wprowadzenie

Rozdzial 1. Problematyka badawcza w świetle literatury ...................................................

1.1. Podstawy teoretyczne ................................................................................................ 11

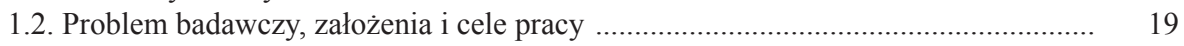

1.3. Zakres pojęciowy …….................................................................................... 26

Rozdzial 2. Procedura badaweza …............................................................................. 39

2.1. Założenia metodologiczne i model struktury procesu badawczego ......................... 39

2.2. Charakterystyka parametrów ............................................................................ 43

2.3. Materiały źródłowe i ich ocena .......................................................................... 53

Rozdział 3. Ewolucja przestrzeni centralnej w miastach europejskich ............................. 59

3.1. Przestrzeń centralna $w$ miastach europejskich $\mathrm{w}$ okresie przedindustrialnym ......... $\quad 59$

3.2. Przestrzeń centralna w miastach europejskich w okresie industrialnym i przekształ-

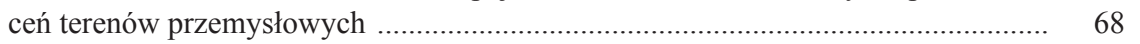

Rozdzial 4. Rewitalizacja jako element ksztaltowania przestrzeni centralnej we współczesnych miastach europejskich

4.1. Istota rewitalizacji w procesie kształtowania przestrzeni centralnej w miastach europejskich

4.2. Formy przekształceń przestrzeni centralnej w miastach europejskich pod wpływem rewitalizacji wewnątrzmiejskich terenów poprzemysłowych 1 9

\section{,} 3 3 59 59

Rozdzial 5. Przeksztalcenia organizacji przestrzeni centralnej w Manchesterze ....

5.1. Geneza przestrzeni centralnej w Manchesterze ........................................................ 87

5.2. Przestrzeń centralna w Manchesterze przed rewitalizacją ....................................... 97

5.3. Cechy współczesnej przestrzeni centralnej w Manchesterze .................................. 101

5.4. Wnioski …............................................................................................ 128

Rozdział 6. Przekształcenia organizacji przestrzeni centralnej w Lyonie ........................ 131

6.1. Geneza przestrzeni centralnej w Lyonie ................................................................ 131

6.2. Przestrzeń centralna w Lyonie przed rewitalizacją ................................................... 141

6.3. Cechy współczesnej przestrzeni centralnej w Lyonie ........................................... 148

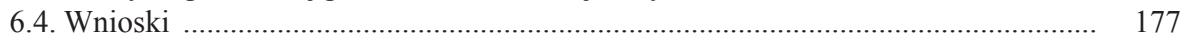


Rozdzial 7. Przekształcenia organizacji przestrzeni centralnej w Lodzi

7.1. Geneza przestrzeni centralnej w Łodzi ................................................................ 179

7.2. Przestrzeń centralna w Łodzi przed rewitalizacją ...................................................... 191

7.3. Cechy współczesnej przestrzeni centralnej w Łodzi .............................................. 194

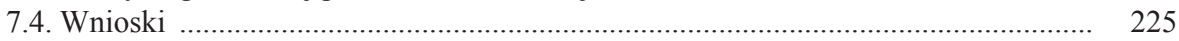

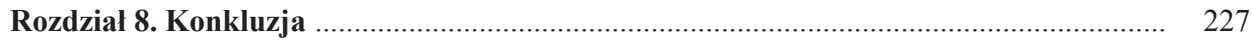

8.1. Rewitalizacja a rozwój przestrzeni centralnej w mieście europejskim w świetle wy-

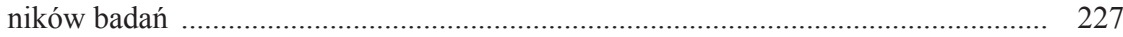

8.2. Rekomendacje dla sposobu kształtowania przestrzeni centralnej w Łodzi ............. 236

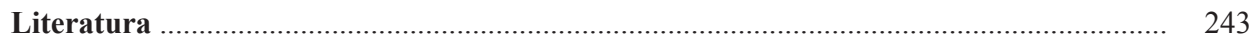

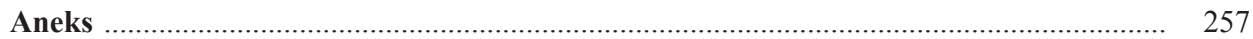

Revitalization of post-industrial urban areas and its impact on organization of central space in Manchester, Lyon and Lódź. Summary ........................................................... 259

L'effet de la revitalisation des friches industrielles dans l'organisation de l'espace central á Manchester, Lyon et Lódź. Resumé . ...................................................................... 263

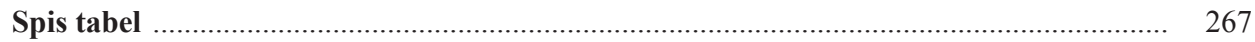

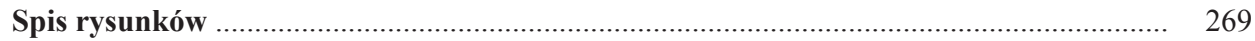

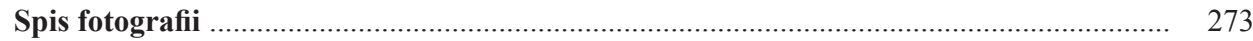




\section{WPROWADZENIE}

W studiach geograficznych szczególne miejsce zajmują rozważania na temat istoty centrum miasta, które jest odzwierciedleniem przestrzennej, funkcjonalnej oraz społeczno-kulturalnej kondycji miasta w kolejnych etapach jego rozwoju. Współcześni badacze definiują ten obszar w zróżnicowany sposób, lecz pozostając na uboczu tej dyskusji, nie ma wątpliwości co do tego, że w każdym mieście istnieje pewnego rodzaju przestrzeń o charakterze centralnym. Można przez nią rozumieć przestrzeń kluczową dla organizacji życia miejskiego, która jest wyrażona w jej morfologii oraz wyposażeniu instytucjonalnym. Jest ona zmienna w czasie, gdyż stanowi odwzorowanie rozwoju przestrzenno-funkcjonalnego miasta. Niekoniecznie natomiast jest związana $\mathrm{z}$ centrum miasta $\mathrm{w}$ ujęciu geometrycznym. W historii budowy miast można zidentyfikować wiele sił i procesów, które wpływały na jej kształtowanie i sposób ewolucji. Jednym z kluczowych procesów, który modyfikuje współczesną centralną przestrzeń miast, jest rewitalizacja rozumiana w literaturze jako proces ponownego wielowymiarowego ożywienia zdegradowanych obszarów miejskich. Pojęcie rewitalizacji ma łacińską etymologię i oznacza nadanie ponownego życia. Wydaje się ono szczególnie trafne w odniesieniu do dawnych terenów przemysłowych, które odegrały znaczącą rolę w rozwoju wielu miast europejskich, a w rezultacie kryzysu i upadku przemysłu utraciły swoje pierwotne, często wiodące, znaczenie w strukturze przestrzenno-funkcjonalnej miast. $\mathrm{W}$ wyniku procesu rewitalizacji tereny te są „odzyskiwane” dla społecznego użytkowania w wymiarze przestrzennym, gospodarczym i kulturowym. W efekcie działań naprawczych niejednokrotnie zyskują one także istotną pozycję w hierarchii terenów miejskich, wpływając tym samym na sposób organizacji przestrzeni centralnej w mieście.

Bezpośrednią inspiracją autora pracy do podjęcia badań nad konsekwencjami omawianego zjawiska była realizacja pierwszych i plany kolejnych dużych projektów rewitalizacyjnych w jego rodzinnym mieście - Łodzi. Wraz z obserwacją prekursorskich działań naprawczych historycznej łódzkiej tkanki miejskiej pojawiły się dylematy: czy rezultaty działań realizowanych w ramach szeroko pojmowanego procesu rewitalizacji terenów poprzemysłowych uwzględniają historyczny kształt przestrzeni centralnej miasta? Jaki wpływ na istniejącą przestrzeń centralną miasta ma proces kształtowania nowej przestrzeni centralnej na terenach poprzemysłowych? Jakie reperkusje niosły ze sobą podobne projekty rewitalizacyjne w innych miastach europejskich? Podjęta praca jest próbą naukowej odpowiedzi na te pytania. 
Przedstawione wyniki studiów w istotnym stopniu pochodzą z badań realizowanych w ramach projektu badawczego Narodowego Centrum Nauki pt. „Wpływ rewitalizacji terenów poprzemysłowych na kształtowanie przestrzeni publicznej w centrum miasta - identyfikacja czynników w świetle teorii rozwoju miast. Angielsko-francusko-polskie studium porównawcze" (UMO-2011/03/N/HS4/03145).

Układ i treść pracy podporządkowano przyjętym celom. Opracowanie składa się z trzech części: teoretyczno-metodologicznej, analityczno-empirycznej oraz z konkluzji uporządkowanych w ośmiu rozdziałach.

Pierwszy rozdział ma charakter wprowadzający i teoretyczny. Prezentuje założenia teoretyczne, problem badawczy oraz charakterystykę istoty przestrzeni centralnej miast europejskich oraz relacji, które w niej można wyróżnić. Są to zagadnienia kluczowe dla rozważań podejmowanych w kolejnych rozdziałach.

Rozdział drugi ma charakter metodologiczny, który przedstawia model struktury procesu badawczego, dokonano charakterystyki przyjętych parametrów, opisano sposób prezentacji wyników oraz możliwości zastosowania opracowanej metody. Rozdział kończy krytyczna ocena materiału źródłowego.

Rozdział trzeci i czwarty mają charakter analityczno-empiryczny. Zawierają one analizę ewolucji przestrzeni centralnej w mieście do okresu industrializacji, w mieście poprzemysłowym oraz specyfikę procesu rewitalizacji wewnątrzmiejskich terenów poprzemysłowych jako jednego z czynników kształtujących współczesną przestrzeń centralną miast europejskich.

Kolejne rozdziały opisują studia przypadków trzech miast: Manchesteru, Lyonu i Łodzi. W celu zachowania logiki wywodu w rozdziale piątym, szóstym i siódmym zachowano taką samą strukturę. Ułatwi to w istotny sposób odbiór prezentowanych wyników pracy. Ta część pracy ma charakter empiryczny.

Pracę zamyka rozdział podsumowujący, który przedstawia wnioski stanowiące generalną konkluzję z badań prowadzonych nad wpływem rewitalizacji terenów poprzemysłowych na organizację przestrzeni centralnej w Manchesterze, Lyonie i Łodzi. Zawiera także rekomendacje dla kształtowania przestrzeni centralnej Łodzi na podstawie analizy doświadczeń Manchesteru i Lyonu.

Schemat merytoryczny pracy przedstawia rysunek W.1.

$\mathrm{Na}$ schemacie merytorycznym pracy nakreślono układ strukturalny pracy, w którym wskazane zostały powiązania występujące pomiędzy rozdziałami oraz podjętymi w ich ramach rozważaniami teoretycznymi, metodycznymi i empiryczno-analitycznymi. W prowadzonych studiach można wyróżnić dwa wiodące nurty tematyczne. Skoncentrowane są one wokół istoty przestrzeni centralnej w miastach europejskich oraz istoty kształtowania relacji w tej przestrzeni, w których pryncypialne miejsce zajmuje rewitalizacja wewnątrzmiejskich terenów poprzemysłowych. Przedstawiony schemat jest jedynie uproszczonym obrazem graficznym konstrukcji przeprowadzonego wywodu. W opracowaniu zagadnienia nie są analizowane rozłącznie, lecz wzajemnie się przenikają w ramach każdego rozdziału oraz pomiędzy kolejnymi częściami pracy. 


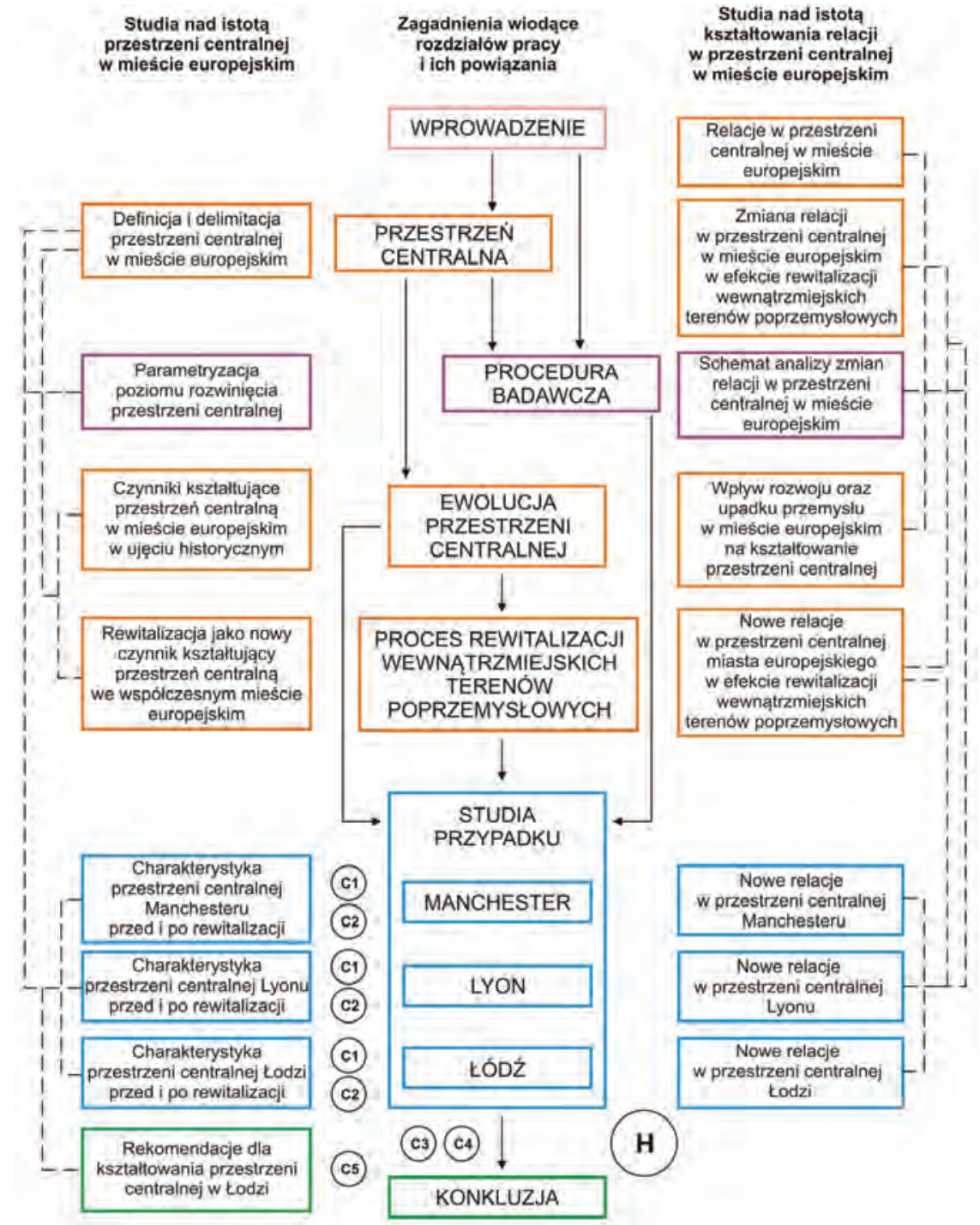

Rozdzialy:

\begin{tabular}{|c|}
\hline Wprowadzające \\
\hline Koncepcyjno-teoretyczne \\
\hline Metodyczne \\
\hline Empiryczne \\
\hline Podsumowujące \\
\hline
\end{tabular}

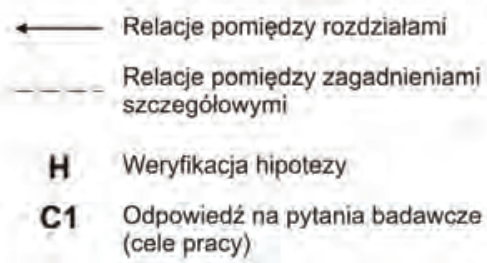

Rys. W.1. Schemat merytoryczny pracy

Źródło: opracowanie autora 



\section{Rozdział 1}

\section{PROBLEMATYKA BADAWCZA}

W historii budowy i rozwoju miast obszar identyfikowany z centrum miejskim podlegał przekształceniom, ulegał kryzysom i ponownemu rozkwitowi, co miało swoje odbicie w formie urbanistyczno-architektonicznej oraz w wyposażeniu instytucjonalnym. Jednym z czynników, który spowodował największe zmiany w wewnętrznych strefach miejskich był rozwój przemysłu, który jako działalność miastotwórcza często zajmował obszary wewnątrzmiejskie. W rezultacie zaburzony został kształtowany od wieków tradycyjny (klasyczny) model struktury przestrzenno-funkcjonalnej miast (Kaczmarek 2001; Słodczyk 2012). Dalszy rozpad historycznie ukształtowanej przestrzeni publicznej wzrósł wraz z kryzysem i upadkiem przemysłu w miastach w połowie XX w. Obserwowane od lat 60 . XX w. w Europie Zachodniej zjawisko ponownego zagospodarowania miejskich terenów poprzemysłowych $\mathrm{w}$ ramach procesu rewitalizacji, stwarza możliwość przywrócenia utraconej w XIX w. spójności przestrzeni publicznej miast. Szczególne znaczenie w tym procesie zajmują śródmiejskie (wewnątrzmiejskie) obszary postindustrialne.

\subsection{Podstawy teoretyczne}

$\mathrm{Na}$ każdym etapie rozwoju cywilizacji europejskiej pojawiały się koncepcje kształtowania nowych przestrzeni miejskich bądź to w formie nowych miast, bądź jako fragmentu miasta zaprojektowanego według obowiązujących ówcześnie nowoczesnych trendów w urbanistyce i architekturze. Znaczna liczba nowych koncepcji powstała $\mathrm{w}$ okresie uprzemysłowienia miast wraz $\mathrm{z}$ pogorszeniem się jakości życia $\mathrm{w}$ ośrodkach miejskich oraz $\mathrm{w}$ efekcie rosnących $\mathrm{w}$ siłę ruchów pozytywistycznego i socjalistycznego w Europie od połowy XIX w. Celem twórców projektów „miast idealnych” w XIX i XX w. było usprawnienie funkcjonowania ośrodków miejskich poprzez ograniczenie ich rozwoju przestrzennego i racjonalizację przestrzeni miejskiej, poprawę infrastruktury komunikacyjnej oraz polepszenie m.in. warunków zamieszkania, pracy, wypoczynku. Wśród 
koncepcji, które miały istotny wpływ na rozwój urbanistyki i zostały zrealizowane kompleksowo lub jedynie częściowo, należy wskazać na miasto liniowe (Ciudad Linear) Arturo Sorii y Maty w Madrycie oraz miasto-ogród Ebenezera Howadra (Jałowiecki i Szczepański 2010; Paszkowski 2011; Słodczyk 2012). Projekty teoretyczne, które koncentrowały się stricte na racjonalnym kształtowaniu funkcji przemysłowej w „nowoczesnym” mieście zaproponowali m.in. Karol Fourier (Falanster), Jean Baptiste Godin (Familister), Robert Owen (New Lanark), a następnie Tony Garnier - miasto przemysłowe (Cité Industrielle), Eugen Henard - miasto racjonalne, Le Corbusier - miasto promieniste, koncepcja miasta przemysłowego Ludwika Hilberseimera z lat 40. XX w. oraz idee urbanistyczne ze Związku Sowieckiego realizowane w latach 30. XX w., m.in. Nikolai Milutina (Chmielewski 2001; Jałowiecki i Szczepański 2010; Majer 2010; Ostrowski 1975; Paszkowski 2011; Słodczyk 2012). Po drugiej wojnie światowej powstała idea „nowych miast”, które doczekały się realizacji przede wszystkim w Wielkiej Brytanii i w Stanach Zjednoczonych Ameryki Północnej (Aldridge 1979; Liszewski, Gryszkiewicz i Kaczmarek 1989; Matczak 1989). Powstawały one w celu zapobieżenia niekontrolowanemu rozrostowi istniejących aglomeracji miejskich. Nowo powstałe miasta nawiązywały po części do howardowskiego modelu miasta-ogrodu, koncepcji new towns ${ }^{1}$, miast-stolic czy miast-satelit. Idea nowych miast zakładała trwałość funkcji przemysłowej w mieście jako integralnego czynnika stymulującego powodzenie oraz ich rozwój gospodarczy w przyszłości (Kaczmarek 2001). Problematyce nowych terenów przemysłowych w mieście poświęcono wiele studiów z zakresu szeroko rozumianej geografii miast. Podejmowali to zagadnienie w swoich pracach zarówno badacze polscy, jak i zagraniczni, m.in.: R. Allman (1997), Z. Arct (1974), M. Battiau (1976), T. Broniewski (1980), P. Bruyelle (1954), J. M. Chmielewski (2001), W. Czarnecki (1983), K. Dumała (1974), K. Dziewoński (1991), P. Gabert (1964), E. Goldzmat (1971, 1980), W. Kalinowski (1966), J. Kotlicka (2008), M. Laferrère (1960), B. Malisz (1981), M. Nietyksza i W. Pruss (1973), K. Pawłowski (1972), J. Regulski (1986), H. Syrkus (1984), T. Tołwiński (1948), J. Tonlemonde (1966).

Nowe przestrzenie miejskie znajdują się wciąż w kręgu zainteresowania badaczy miast z racji permanentnego charakteru tego zjawiska w każdej kolejnej epoce historycznej. Nie istnieje bowiem miasto, którego budowa została zakończona i nigdy zapewne takie nie powstanie. W. Michalski (1989) twierdzi, że ,żadne z miast nie jest zawsze nowe” oraz ,że każde miasto było kiedyś nowe”. Oznacza to de facto, że w każdym mieście i na każdym etapie jego rozwoju można zidentyfikować zarówno „nowe”, jak i „stare” fragmenty przestrzeni miejskiej.

Rozważania nad istotą nowych przestrzeni miejskich prowadził m.in. S. Liszewski (2006), który przyjmuje za Stownikiem języka polskiego (Szymczak 1978), że „nowa” w tym kontekście ma trzy znaczenia:

\footnotetext{
${ }^{1}$ Związana z deglomeracją brytyjskich metropolii według planu Patrica Abecrombiego.
} 
- nowa, jako młoda, co sugeruje czas powstania;

- nowa, jako świeżo założona;

- nowa, jako następna, czyli inna od poprzedniej, od dotychczas spotykanej.

W rezultacie S. Liszewski (2006) rozumie przez nowe przestrzenie w mieście nowo zorganizowany pod względem administracyjnym, morfologicznym, gospodarczym lub społecznym fragment przestrzeni miejskiej powstałej współcześnie, wyraźnie odróżniający się w otoczeniu pełnioną funkcją lub fizjonomią. Użyte tu określenie „współczesny” odnosi się jednak do czasu nowoczesności w ujęciu historycznym, czyli dla każdego kolejnego założenia urbanistycznego w procesie budowy miast. Nowość miasta (przestrzeni) może mieć w tym ujęciu dwa znaczenia:

- techniczne - tak długo dopóki nie nastąpi dekapitalizacja lub śmierć technologiczna „,nowoczesności”;

- społeczne - tak długo, jak będzie uznawana przez społeczność lokalną za nowe.

S. Liszewski (2006) zauważa, że nowość przestrzeni może przejawiać się w trzech postaciach: jako nowe funkcje, czyli treści, nowe formy (kształt, wielkość, organizacja) oraz nowe położenie, inaczej - lokalizacja.

Szerokiego przeglądu „nowych” przestrzeni miejskich i ich charakterystyki w polskich miastach dokonali S. Liszewski (2006) i J. J. Parysek (2006). Zagadnienie kształtowania nowych przestrzeni miejskich było także podejmowane w różnych ujęciach badawczych m.in. przez: S. Gzella (2000), B. Jałowieckiego (1989), A. Jelonka (1989), S. Liszewskiego (1999), L. Mierzejewską (2006), A. Tölle (2006), P. Trzepacza (2006).

Szczególnie istotną wydaje się kwestia delimitacji „nowej” przestrzeni miejskiej w ujęciu morfologicznym, gdyż może ona przysporzyć pewnych problemów. W aspekcie „nowych miast”, S. Liszewski, J. Gryszkiewicz i S. Kaczmarek (1989) zwracają uwagę na kryterium genezy miasta. Wyraża się ona w układzie przestrzennym (urbanistycznym) i architektonicznym poprzez zachowanie jednolitości koncepcji planistycznej, powstanie miasta nie w sposób ewolucyjny, lecz rewolucyjny, czyli w stosunkowo niedługim czasie. Wydaje się jednak, że to kryterium może dotyczyć nie tylko miast, ale także fragmentów przestrzeni miejskiej. Rozumie się przez nie nowe jednostki morfologiczno-funkcjonalne założone w nowej lokalizacji na terenie niezabudowanym (na „surowym korzeniu”, łac. in cruda radice) bądź w wyniku przekształceń ilościowych i przede wszystkim jakościowych starych jednostek przestrzennych, które uległy dekapitalizacji technicznej i społecznej. W tym kontekście szczególne miejsce zajmuje rewitalizacja ${ }^{2}$, czyli proces przekształceń

${ }^{2}$ Analiza pojęcia „rewitalizacja” w odniesieniu do innych terminów stosowanych w geografii miast, urbanistyce czy architekturze, takich jak: renowacja, rewaloryzacja, rehabilitacja, regeneracja itp. była przedmiotem licznych studiów, podjętych m.in w pracach P. Lorensa (2007) i w pracy zbiorowej pod redakcją Z. Ziobrowskiego, D. Ptaszyckiej-Jackowskiej, A. Rębowskiej i A. Geisslera (2000). Zestawienia znaczenia terminu rewitalizacja w języku polskim, angielskim i francuskim dokonała ponadto S. Kaczmarek (2001). W kontekście szerokiej dyskusji 
przestrzeni miejskiej, który S. Kaczmarek (2010) rozumie jako „sekwencję planowych działań, które mają na celu ożywienie gospodarcze oraz zmianę struktury przestrzennej i funkcjonalnej zdegradowanych obszarów miasta" (s. 8).

We współczesnych studiach miejskich rewitalizacji jest przypisywane kluczowe znaczenie w procesie podtrzymania ciągłości rozwojowej miast. Wiąże się on z kształtowaniem nowoczesnej formy urbanistyczno-architektonicznej, z zachowaniem jednak tożsamości miast lub ich fragmentów w wymiarze kulturowym i materialnym. Ranga rewitalizacji we współczesnej urbanistyce jest bardzo wysoka, co odzwierciedlają ujęcia badawcze, traktujące ten proces m.in. jako nowy wymiar w budowie miast (Kaczmarek 2001), bądź też jako nową doktrynę urbanistyczną (Paszkowski 2011). Prezentowana rozprawa podejmuje natomiast dyskusję nad rolą procesu rewitalizacji dawnych terenów przemysłowych w kontekście przekształceń historycznie kształtowanej przestrzeni centralnej miast europejskich.

Rewitalizacja jest zjawiskiem relatywnie młodym, które zachodzi w miastach europejskich i amerykańskich od około 40 lat. W opracowaniach naukowych wyróżniane są głównie trzy rodzaje obszarów, które poddawane są procesom naprawczym:

1) śródmieścia i wielofunkcyjne przedwojenne obszary zabudowy miejskiej jako obszary problemowe o charakterze społecznym, ekonomicznym, funkcjonalnym i przestrzennym, związane z dekapitalizacją historycznej tkanki miejskiej;

2) blokowiska jako zdegradowane społecznie i przestrzennie tereny monofunkcyjne, wymagające humanizacji;

3) tereny poprzemysłowe, do których zalicza się także tereny pokolejowe, tereny pogórnicze, nieużytkowane tereny magazynowe i składowe, tereny poportowe i postoczniowe. B. Domański (2000) przez tereny poprzemysłowe rozumie „tereny, które przestały być miejscem produkcji przemysłowej lub przestały pełnić funkcje pomocnicze dla tej produkcji w obszarze zakładów przemysłowych (np. magazynowo-składowe, transportowe, administracyjne) łącznie z obszarami niedokończonych inwestycji przemysłowych" (s. 108).

Z. Ziobrowski i B. Domański (2010) wyróżniają także rewitalizację krajobrazu miast ze szczególnym uwzględnieniem sylwety miasta i systemu przestrzeni publicznej. Można jednak przyjąć, że tak sformułowany rodzaj rewitalizacji wiąże się również z przekształceniami wyżej wymienionych obszarów.

Poszczególne tereny zdegradowane, zaliczone do szeroko rozumianej grupy przestrzeni poprzemysłowych, bardzo często stanowią przedmiot osobnych studiów szczegółowych. Proces rewitalizacji w polskiej i światowej literaturze przedmiotu obejmuje także inne tereny, np. zdegradowane nabrzeża rzek i zbiorników wodnych, które są analizowane jako oddzielna kategoria terenów w mieście lub są rozpatrywane jako integralny element wszystkich wcześniej wymienionych rodzajów obszarów (m.in. Bassett, Griffiths i Smith 2002; Bernat 2010; Breen i Rigby 1996; Czyżewska 2009; Graczyk 2009; Januchta-Szostak 2011; Lorens

terminologicznej prowadzonej w krajowych studiach miejskich dalsze jej rozwinięcie w niniejszym opracowaniu uznano za nieuzasadnione. 
2009; Pancewicz 2004). Wyróżnia się także problematykę reutylizacji opuszczonych terenów wojskowych, na co zwraca uwagę m.in. W. Jarczewski i M. Kuryło (2009), J. Olenderek, R. Lamorski i J. Lewandowski (2010) oraz E. Muszyńska i B. Brzezińska-Kwaśny (2010).

Od lat 90 . XX w. w Polsce studia nad szeroko rozumianymi procesami odnowy obszarów wewnątrzmiejskich nabrały wyraźnego przyspieszenia, co należy wiązać m.in. ze skutkami transformacji ustrojowo-gospodarczej, uruchomieniem mechanizmów rynkowych, kształtujących zróżnicowanie cen ziemi w polskich miastach, przemianami społeczno-demograficznymi, zmianą sposobu użytkowania ziemi, przybierającą postać sub-urbanizacji, oraz wzrastającym poczuciem odpowiedzialności społecznej i władz lokalnych względem historycznych dzielnic miejskich (m.in. Jaroszewska-Brudnicka 2011; Majer 2010; Markowski i Stawasz 2007; Markowski, Stawasz i Sikora 2005; Paszkowski 2011; Pawłowski 2007; Stawasz 2007; Ziobrowski i in. 2000). Istotną rolę w procesie odnowy polskich miast pełnią tereny poprzemysłowe zlokalizowane w obszarach śródmiejskich. Ich dynamiczny przyrost wiąże się z procesem deindustrializacji miast polskich po 1989 r. (Gasidło 1998). Z. Ziobrowski i B. Domański (2010) oszacowali skalę degradacji miast w Polsce, wskazując na około 120 tys. ha terenów wymagających rewitalizacji. Stanowi to około $22 \%$ ogółu terenów zainwestowanych. Wśród nich największy udział mają tereny historycznych śródmieść - około 52\%, tereny poprzemysłowe - około $20 \%$ i blokowiska - około $12 \%$.

Wzrost zainteresowania polskich badaczy procesem rewitalizacji zaowocował znacznym zróżnicowaniem i specjalizacją studiów. W krajowej literaturze przedmiotu można wyróżnić co najmniej trzy nurty badań nad omawianym procesem: socjologiczny, architektoniczny (techniczny) oraz geograficzny.

Podstawowym celem rewitalizacji jest zmiana ekonomicznych podstaw funkcjonowania zdegradowanego obszaru. Szeroki pogląd w tej kwestii prezentują D. Sikora i M. Turała (2005), którzy do podstawowych celów rewitalizacji zaliczają przede wszystkim odwrócenie negatywnych trendów, takich jak degradacja przestrzeni i zabudowy, nasilenie się patologii społecznych, marginalizacja obszaru, odpływ zamożnych warstw społeczeństwa i dewastacja cennych architektonicznie obiektów. W literaturze przedmiotu zgodnie prezentowane jest twierdzenie, że rewitalizacja jest procesem wielowymiarowym (Gasidło 1998; Kaczmarek 2001, 2005, 2010; Lorens 2007, 2010; Lorens i Martyniuk-Pęczek 2009; Markowski i Stawasz 2007; Ziobrowski i Jarczewski 2010; Zuziak 1998). Badacze procesu wyróżniają najczęściej wymiar przestrzenny, gospodarczy, społeczny, kulturowy i środowiskowy (ekologiczny). T. Markowski i D. Stawasz (2007) stwierdzili, że wielowymiarowy proces rewitalizacji ma przynosić pozytywne efekty w szeroko pojmowanym procesie odnowy miast, a do najważniejszych z nich zaliczyli: stymulację rozwoju gospodarczego miasta, adaptację starych funkcji obszaru do nowych potrzeb, wprowadzenie do obszaru nowych funkcji, zapobieganie marginalizacji terenów, tworzenie nowych miejsc pracy, zmianę wizerunku obszaru, 
podniesienie jakości życia na danym terenie, odnowę architektoniczną, odnowę zasobów mieszkaniowych, integrację obszaru z resztą miasta. W ujęciu tym zwraca się uwagę na konieczność przeciwdziałania negatywnym konsekwencjom zaburzenia historycznie kształtowanej hierarchii terenów miejskich, m.in. poprzez marginalizację nieprzekształconych obszarów miejskich. Często jednak, tego typu skutki działań rewitalizacyjnych o charakterze pejoratywnym pozostają poza kręgiem zainteresowań badaczy miast, za wyjątkiem nielicznych studiów (m.in. Kochanowska 2002; Szymski 2006).

W krajowej literaturze przedmiotu bardzo często sięga się do doświadczeń krajów zachodnioeuropejskich. Dotyczą one m.in. studiów w zakresie wpływu rewitalizacji na rozwój przestrzenno-ekonomiczny miasta i regionu miejskiego bądź też zdegradowanych regionów przemysłowych. Badania te koncentrują się przede wszystkim na następstwach procesów inwestycyjnych inicjowanych na zdegradowanych terenach śródmiejskich i postindustrialnych w kontekście m.in. racjonalnego użytkowania ziemi $\mathrm{w}$ mieście, kształtowania się wysokości renty gruntowej oraz generowania nowych miejsc pracy. Tematykę tę podjęli m.in.: D. Adams i C. Watkins (2002), S. K. Al Naib (1990), D. Bell i M. Jayne (2004), J. Berry i S. McGreal, B. Deddis (1993), T. Brintley, Y. Rydin i G. Stoker (1996), J. M. Hall (1990), R. Imrie i H. Thomas (1993), P. Jones i J. Evans (2009), L. Kennedy (2004), N. Lewis (1992). W literaturze polskiej zagadnienie to rozwijali m.in.: B. Domański (2000a, 2009), K. Gasidło (1998), R. Guzik (2009), S. Kaczmarek (2001, 2005), P. Lorens (2007, 2010), K. Skalski (2009), Ziobrowski i in. (2000), Z. Ziobrowski i W. Jarczewski (2009) oraz Z. Zuziak (1998). Problematyka zarządzania miastem $\mathrm{w}$ aspekcie procesów naprawczych uwzględniająca również prawne uwarunkowania procesu rewitalizacji na poziomie krajowym doczekała się także licznych opracowań naukowych w literaturze światowej: K. Bassett, R. Griffiths i I. Smith (2002), T. Blackman (1995), M. Carley (2000), T. Dixon, N. Otsuka i H. Abe (2011), N. Otsuka i A. Reeve (2007), które na gruncie polskim podejmowali m.in.: M. Bryx (2009), T. Domański (1997), Z. Jakubczyk i J. Słodczyk (2005), K. Janas, W. Jarczewski i W. Wańkowicz (2010), T. Markowski (1999), W. Pęski (1999), N. Ratajczak i D. Drzazga (2005), W. Rydzik (2009), Z. Ziobrowski (2010). Aplikacyjne studia porównawcze, których celem jest próba implementacji wybranych zagranicznych mechanizmów działań rewitalizacyjnych w polskich uwarunkowaniach prawno-gospodarczych, stanowią istotny udział w krajowym dorobku w zakresie rewitalizacji terenów miejskich. Również sam proces zarządzania szeroko rozumianymi działaniami związanymi z rewitalizacją zdegradowanych fragmentów miast został szeroko opisany, zwłaszcza w literaturze francuskiej, m.in. przez D. Boudrona (1999), J. Donzelota i C. Mevel (2001), M. Huret (1997). Francuscy badacze miast koncentrują się w swych pracach przede wszystkim na analizie procesu rewitalizacji w ujęciu systemowym, ogólnokrajowym i regionalnym, co wynika z przyjętych mechanizmów realizacji procesu we Francji, podczas gdy autorzy opracowań anglojęzycznych skupiają 
swoją uwagę na analizie konkretnych przypadków (m.in. Al Naib 1990; Brownill 1990; Couch i Dennemann 2000; Kennedy 2004; Ogden 1992). Osobnym zagadnieniem w literaturze światowej jest także analiza form współpracy pomiędzy podmiotami publicznymi i prywatnymi na rzecz skutecznej realizacji procesu rewitalizacji (m.in. Carley 2000). Również w polskiej literaturze przedmiotu coraz częściej podejmowane są studia zarówno z zakresu zarządzania procesem rewitalizacji, jak również polityki miejskiej uwzględniającej problemy przekształceń terenów poprzemysłowych (m.in. W. Jarczewski i J. Jeżak (2010), T. Markowski (1999), A. Noworól (2007), T. Topaczewska (2005), Z. Ziobrowski (2010)).

Analizy zagranicznych doświadczeń w zakresie planowania, zarządzania i realizacji procesu naprawczego $\mathrm{w}$ miastach dokonano także $\mathrm{w}$ ramach projektu badawczego „Rewitalizacja miast w Polsce”. Był on zrealizowany w latach 20092010 przez Instytut Rozwoju Miast w Krakowie wraz ze Szkołą Główną Handlową w Warszawie, Uniwersytetem Jagiellońskim oraz Stowarzyszeniem Forum Rewitalizacji. Jego wymiernym efektem były studia poświęcone analizie i ocenie doświadczeń niemieckich (Bryx i Jadach-Sepioło 2009), brytyjskich (Guzik 2009) i francuskich (Skalski 2009), które posłużyły następnie do opracowania modelu procesu rewitalizacji dla miast w Polsce (Janas, Jarczewski i Wańkowicz 2010; Jarczewski i Jeżak 2010; Muzioł-Węcławowicz 2010; Ziobrowski 2010). Studia te mają charakter kompleksowy i wnoszą istotny wkład empiryczny i aplikacyjny w rozwój polskiej literatury przedmiotu. Systematyczne ujęcie wieloaspektowej charakterystyki pierwszych doświadczeń w realizacji procesu rewitalizacji zdegradowanych terenów miejskich w Polsce było także przedmiotem opracowań P. Lorensa $(2007,2010)$ oraz pracy zbiorowej pod redakcją naukową Z. Ziobrowskiego, D. Ptaszyckiej-Jackowskiej, A. Rębowskiej, A. Geisslera (2000).

Rewitalizacja wewnątrzmiejskich terenów poprzemysłowych prowadzi do wygenerowania nowej jednostki morfologiczno-funkcjonalnej, rozumianej też jako „nowa” przestrzeń miejska. S. Kaczmarek (2001), analizując rewitalizację, sformułowała tę tezę, odwołując się do studiów M. R. G. Conzena (1960, 1962), który na podstawie wyników studiów nad rozwojem przestrzennym dwóch średniowiecznych miast angielskich - Alnwick i Newcastle przedstawił koncepcję pierwotnego i wtórnego cyklu przemian morfologicznych działki miejskiej. Wyróżnił on cztery podstawowe fazy zabudowy: początkową (inaczej inicjalną, charakterystyczną tylko dla cyklu pierwotnego), wypełniającą, kulminacji i recesji. Krańcową formą ostatniej z faz jest ugór miejski (ang. urban fallow), który charakteryzuje się czasowym opuszczeniem oraz zniszczeniem, wynikającym z kryzysu społeczno-gospodarczego. Studia podjęte przez M. Kotera (1974, 1976, 1990), które polegały na analizie kwartałów śródmiejskich XIX-wiecznego miasta przemysłowego na przykładzie Łodzi, potwierdziły uniwersalność metody zaproponowanej przez M. R. G. Conzena.

Metoda ta umożliwia analizę przekształceń działek przemysłowych, co wykorzystała w swoich badaniach m.in. J. Kotlicka (2008). S. Kaczmarek (2001) 
wprowadziła do literatury geograficznej termin „poprzemysłowy ugór miejski”, w klasycznym ujęciu morfologicznym, przy założeniu, że faza recesji w przypadku tych terenów odbiega jednak częściowo od tej wskazanej przez Conzena. Wiąże się to $\mathrm{z}$ faktem, że na terenach poprzemysłowych mimo głębokiego kryzysu lub utraty pierwotnej funkcji zachowana zostaje bardzo często pierwotna zabudowa oraz kompozycja przestrzenna. W tym kontekście rewitalizację należy identyfikować z działaniami naprawczymi, zmierzającymi do wtórnego zagospodarowania miejskiego ugoru poprzemysłowego, które obejmują wymiar przestrzenny i funkcjonalny. Tym samym niepełne wydaje się ujęcie funkcjonalne zaproponowane przez K. Gasidłę (1998), który wśród trzech wyróżnionych przez siebie rodzajów nieużytkowanych terenów poprzemysłowych za ugory poprzemysłowe uważa obszary formalnie lub faktycznie porzucone przez właściciela lub syndyka ${ }^{3}$.

Wtórny proces zagospodarowania terenów poprzemysłowych charakteryzujących się wysoką podatnością na rewitalizację i potencjałem lokowania instytucji metropolitalnych(Lorens 2005) może prowadzić do wykształcenia nowej przestrzeni miejskiej o charakterze centralnym. W ujęciu morfologicznym i funkcjonalnym rewitalizacja terenów poprzemysłowych jest związana z wykluczeniem ze struktury przestrzenno-funkcjonalnej miasta obszarów monofunkcyjnych na rzecz polifunkcyjnych o przemieszanych funkcjach, na co zwraca uwagę m.in. D. Kochanowska (2002a). Wykształcenie nowej jednostki morfologicznej niesie ze sobą zmiany w organizacji przestrzennej całego miasta. Charakter zmian zależy od przekształceń morfologicznych oraz rodzaju i rangi instytucji, które zostaną ulokowane na terenie poprzemysłowym $\mathrm{w}$ ramach procesu rewitalizacji. W pewnych skrajnych sytuacjach przekształcenia zdegradowanych terenów miejskich mogą prowadzić do zaburzenia historycznie ukształtowanej hierarchii terenów miejskich, w efekcie uzyskania przez nowy obszar bardziej atrakcyjnego wyposażenia instytucjonalnego oraz ciekawszej kompozycji przestrzennej niż wcześniej istniejące tereny miejskie, które identyfikowano z przestrzenią centralną w mieście. W tym świetle za negatywną zmianę należy traktować degradację materialną (techniczną) bądź mentalną (społeczną) historycznych jednostek centralnych. Ze względu na fakt, że zjawisko przewartościowania hierarchii terenów miejskich było dość powszechne w historii budowy miast, nie każdą taką zmianę należy traktować jako negatywną. Może ona nieść ze sobą pozytywne skutki w sytuacji, gdy jest realizowana w wyniku świadomych, planowych działań, wynikających z potrzeb miasta na określonym etapie jego rozwoju, a jego reperkusją jest dalszy rozwój i wzrost przestrzeni centralnej w mieście. Za przykład może posłużyć

${ }^{3}$ Wśród dwóch pozostałych rodzajów nieużytkowanych terenów poprzemysłowych K. Gasidło (1998) wyróżnił:

• „odłogowane” w oczekiwaniu na korzystne możliwości zagospodarowania lub sprzedaży w przyszłości;

- przetrzymywane przez dotychczasowego właściciela w nadziei ewentualnego ponownego wykorzystania w dotychczasowej funkcji. 
zjawisko „przesuwania się” centrum miejskiego ze średniowiecznego rdzenia do obszaru przydworcowego w dobie rozwoju kolei w miastach XIX-wiecznych. Jeżeli w takiej sytuacji dochodziło do degradacji starej przestrzeni centralnej, to taką zmianę można uznać za destabilizującą dalszy rozwój obszaru centralnego. Jeżeli natomiast nastąpiło rozszerzenie przestrzeni centralnej na nowe obszary i tym samym przyczyniło się do wzmocnienia przestrzeni centralnej jako całości, mimo przewartościowania hierarchii terenów miejskich, to taką zmianę można traktować jako pozytywną w procesie rozwojowym miasta. Problem zmian hierarchii terenów miejskich będących rezultatem działań planistycznych był jak dotąd przedmiotem rozważań w literaturze geograficznej sporadyczny (Bury, Markowski i Regulski 1993; Parysek 2006). Zagadnienie to także analizowano w kontekście koncepcji reżimu miejskiego (Sagan 2000). Problem ten wydaje się szczególnie istotny $\mathrm{w}$ aspekcie programów rewitalizacji wewnątrzmiejskich terenów poprzemysłowych, których rezultatem jest wygenerowanie nowej przestrzeni miejskiej o charakterze centralnym, czyli nowej przestrzeni centralnej. Spostrzeżenie to rodzi zasadnicze pytanie o istotę relacji, które istnieją pomiędzy starą (istniejącą wcześniej) i nową przestrzenią centralną oraz o czynniki, które te relacje kształtują. Kluczowa w tym przypadku jest morfogeneza oraz przebieg procesu kształtowania przestrzeni centralnej w mieście. Ważna $\mathrm{w}$ tym kontekście jest również identyfikacja rangi nowej przestrzeni centralnej oraz wykrycie prawidłowości w procesie jej generowania na przykładzie wybranych miast europejskich.

Zagadnienie rewitalizacji wewnątrzmiejskich terenów poprzemysłowych i jej wpływu na kształtowanie przestrzeni centralnej w mieście nie zostało dotychczas opisane w literaturze geograficznej. Wydaje się, że w celu pełnej analizy tego zagadnienia konieczne jest przeprowadzenie badań retrospektywnych z uwzględnieniem aktualnego stanu wiedzy w zakresie historii budowy i planowania miast oraz dotychczasowego dorobku morfologii miast. Ponadto, studia $\mathrm{z}$ zakresu rewitalizacji miejskich terenów poprzemysłowych wymagają integracji ujęcia przestrzennego i funkcjonalnego, wpisując się tym samym w postulat K. Dziewońskiego (1962) oraz wskazywany przez M. Kotera (1994) kierunek rozwoju badań w zakresie morfologii miast. Na potrzebę zintegrowanego ujęcia studiów morfologicznych i funkcjonalnych zwracał także uwagę H. Carter (1973).

\subsection{Problem badawczy, założenia i cele pracy}

Przedstawione założenia teoretyczne oraz pojawiające się pytania stały się impulsem do podjęcia szczegółowych badań nad określeniem wpływu rewitalizacji terenów poprzemysłowych na reorganizację przestrzeni centralnej w miastach europejskich. Wybór problematyki badawczej wynika również z potrzeby „wypełnienia luki" w literaturze przedmiotu. Praca przedstawia zintegrowane studia nad 
strukturą morfologiczną i funkcjonalną przestrzeni centralnej współczesnych miast europejskich. Istotą problemu badawczego jest odpowiedź na pytanie: $\mathrm{w}$ jaki sposób rewitalizacja wewnątrzmiejskich terenów poprzemysłowych zmienia organizację przestrzeni centralnej w miastach europejskich?

Przyjęte założenia badawcze pozwalają implikować następującą tezę: w wyniku procesu rewitalizacji wewnątrzmiejskich terenów poprzemysłowych powstaje nowa przestrzeń centralna, która $\mathrm{w}$ relacjach ze starą przestrzenią centralną prowadzi do:

1) kooperacji starej i nowej przestrzeni centralnej;

2) konkurencji pomiędzy starą i nową przestrzenią centralną;

3) konglomeracji kilku niezależnych i niezintegrowanych lokalizacji przestrzeni centralnej.

Pojęcia kooperacji i konkurencji wywodzą się z ekonomii, lecz są adaptowane z powodzeniem także do badań społecznych i geograficznych, np. w kontekście funkcjonowania klastrów przedsiębiorczości w układzie miejskim. Konglomeracja to proces tworzenia się konglomeratu. Pojęcie to stosowane jest głównie w chemii i wykorzystywane także w geografii fizycznej. Wskazane relacje kooperacyjne, konkurencyjne i konglomeracyjne stanowią specyficzne formy koegzystencji starej i nowej przestrzeni centralnej. W dysertacji przyjęto, że możliwa jest ich identyfikacja zarówno z pomięciem studiów o podłożu ekonomicznym, jak i badań społecznych, a za wystarczającą uznano analizę formy, czyli treści materialnej i przestrzennej, które same w sobie zwierają informację dla użytkownika o funkcji miejsca. Założenie to sankcjonują studia przeprowadzone m.in. przez K. Dziewońskiego (1956), który uznaje miasto za historycznie ukształtowany typ osiedla, wyznaczony istnieniem konkretnej społeczności, skoncentrowanej na pewnym obszarze, o odrębnej organizacji, uznanej prawnie oraz wytwarzającej w ramach swojej działalności zespół trwałych urządzeń materialnych o specyficznej fizjonomii, która odzwierciedla odrębny typ krajobrazu. Definicja ta stała się punktem wyjściowym m.in. dla badań S. Liszewskiego (1997, 1999, 2006, 2008) nad przestrzenią miejską i jej organizacją oraz studiów nad strukturalistyczną funkcją miejsca A. Suliborskiego (2010).

Celem pracy jest weryfikacja hipotezy badawczej na przykładzie Manchesteru, Lyonu i Łodzi, co wymagać będzie udzielenia naukowo udokumentowanych odpowiedzi na pięć pytań:

1) Jak ewoluowała przestrzeń centralna $w$ analizowanych miastach do momentu podjęcia działań rewitalizacyjnych wewnątrzmiejskich terenów poprzemysłowych (C1, por. rys. W.1)?

2) Jak zmieniła się organizacja przestrzeni centralnej po realizacji procesu rewitalizacji wewnątrzmiejskich terenów poprzemysłowych (C2)?

3) Czym charakteryzuje się współczesna przestrzeń centralna w analizowanych miastach oraz jakie podobieństwa i różnice można w niej wykazać (C3)? 
4) Czy efekty zrealizowanego procesu rewitalizacji wewnątrzmiejskich terenów poprzemysłowych, wyrażające się w sposobie zagospodarowania i użytkowania wykształconej przestrzeni centralnej, są zdeterminowane morfogenezą historycznej (starej) przestrzeni centralnej w każdym z badanych ośrodków? Jeżeli tak, to dlaczego, i co z tego wynika dla organizacji współczesnej przestrzeni centralnej (jako całości)? Jeżeli nie, to co jest istotą uniwersalnego przebiegu zdarzeń (C4)?

5) Jakie są rekomendacje dla sposobu kształtowania przestrzeni centralnej w Łodzi na podstawie analizy doświadczeń Manchesteru i Lyonu (C5)?

Ostatni cel pracy wiąże się z przyjęciem założenia na etapie koncepcyjnym, że Łódź, jako miasto post-socjalistyczne, które rozwijało się w II połowie XX w. w odmiennych uwarunkowaniach społeczno-gospodarczych, posiada znacznie mniejsze doświadczenie $\mathrm{w}$ realizacji projektów rewitalizacyjnych niż Lyon i Manchester. Jest to zdeterminowane sztucznym wydłużeniem okresu industrializacji śródmieść miast polskich po II wojnie światowej aż do lat 90 . XX w. i co wynikało z uprzywilejowania działalności przemysłowej w okresie gospodarki centralnie planowanej. W rezultacie w polskich miastach proces przekształceń terenów poprzemysłowych jest znacznie krótszy w porównaniu z ośrodkami zachodnioeuropejskimi, które posiadają znacznie większe doświadczenie w zakresie opracowania i wdrażania polityki rewitalizacyjnej zdegradowanych obszarów śródmiejskich. Studia poświęcone temu zagadnieniu prowadził Instytut Rozwoju Miast w Krakowie wraz ze Szkołą Główną Handlową w Warszawie, Uniwersytetem Jagiellońskim oraz Stowarzyszeniem Forum Rewitalizacji w latach 2009-2010 w ramach projektu „Rewitalizacja miast w Polsce”. Opracowane rekomendacje dla sposobu kształtowania przestrzeni centralnej w Łodzi zostały przygotowane $\mathrm{w}$ oparciu zarówno o zidentyfikowane dobre praktyki, jak również i potencjalnie negatywne skutki rewitalizacji. Rekomendacje uwzględniają także lokalny kontekst ewolucji Łodzi zgodnie z twierdzeniem J. Robinson (2006), że każde miasto posiada własną, niepowtarzalną ścieżkę rozwoju.

Zakres przestrzenny badań obejmuje obszar śródmiejski trzech miast: Łodzi, Manchesteru i Lyonu. W każdym mieście prowadzono badania:

1) w mezoskali, które obejmują przekształcane lub przekształcone wewnątrzmiejskie tereny poprzemysłowe, w wyniku których wykształcona została nowa przestrzeń centralna;

2) w makroskali, które obejmują przestrzeń centralną miasta sensu largo, składającą się z historycznej (starej) i nowej przestrzeni centralnej.

W Manchesterze zakres przestrzenny badań obejmuje:

1) tereny poprzemysłowe w rejonie Castlefield, City Centre i Gaythorn przeznaczone do rewitalizacji zgodnie z City Centre Local Plan opracowany przez Central Manchester Development Corporation (C.M.D.C.);

2) obszar śródmiejski w granicach: Great Ancoats Road, Swan Street, Miller Street i Cheetham Hill Road na wschodzie, New Bridge Street na północy, rzeki Irwell na zachodzie oraz Mancunian Way na południu (rys. 1.1). 


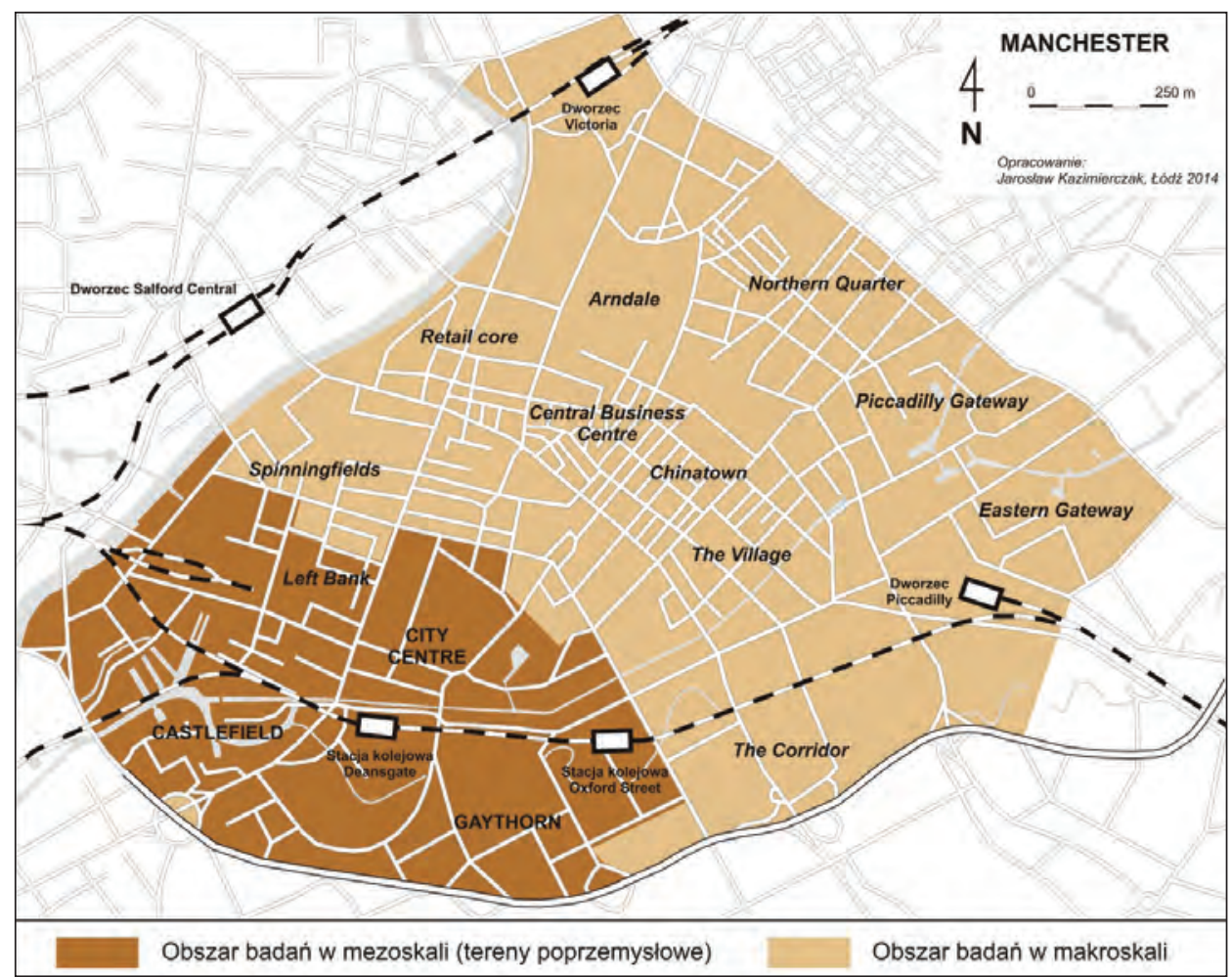

Rys. 1.1. Obszar badań terenowych w Manchesterze

Źródło: opracowanie autora

W Lyonie zakres przestrzenny badań obejmuje:

1) teren poprzemysłowy $\mathrm{w}$ Confluence, objęty działaniami w ramach I etapu przekształceń przestrzenno-funkcjonalnych - ZAC 1 (ZAC, czyli zone d'aménagement concerté) oraz obszar w południowej części półwyspu, na którym budowane jest Muzeum Confluence;

2) obszar Starego Lyonu (Vieux Lyon), południową część pierwszej dzielnicy (Les Terreaux w $1^{\text {er }}$ arrondissement), obszar drugiej dzielnicy ( $2^{\mathrm{e}}$ arrondissement), Part-Dieu w trzeciej dzielnicy ( $3^{\mathrm{e}}$ arrondissement) oraz Cité internationale w szóstej dzielnicy ( $6^{\mathrm{e}}$ arrondissement) (rys. 1.2).

W Łodzi zakres przestrzenny badań obejmuje:

1) dawne tereny przemysłowe ograniczone ulicami: Zachodnią na wschodzie, Drewnowską na północy, Karskiego na zachodzie i Ogrodową na południu (współcześnie Manufaktura) oraz teren przyszłego Nowego Centrum Łodzi, które wyznacza przebieg ulic Kopcińskiego na wschodzie, Narutowicza na północy, Sienkiewicza na zachodzie i Tuwima na południu; 
2) obszar śródmiejski w granicach kolei obwodowej identyfikowany ze strefą wielkomiejską w Uchwale ws. Strategii rozwoju przestrzennego Lodzi 2020+, wyznaczonej w oparciu o zakres przestrzenny zabudowy historycznej i stanowiącej centrum miasta (rys. 1.3).

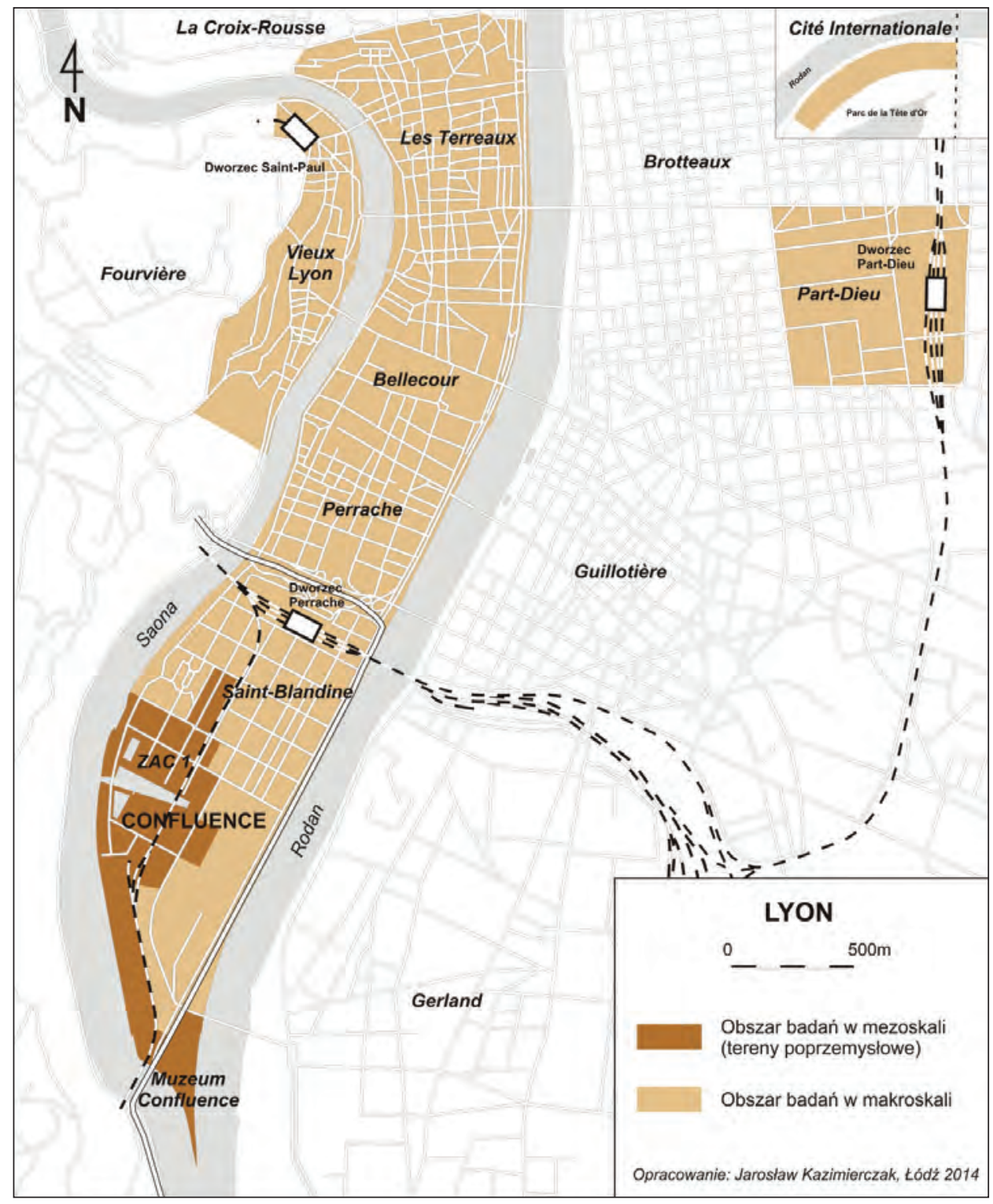

Rys. 1.2. Obszar badań terenowych w Lyonie

Źródło: opracowanie autora 


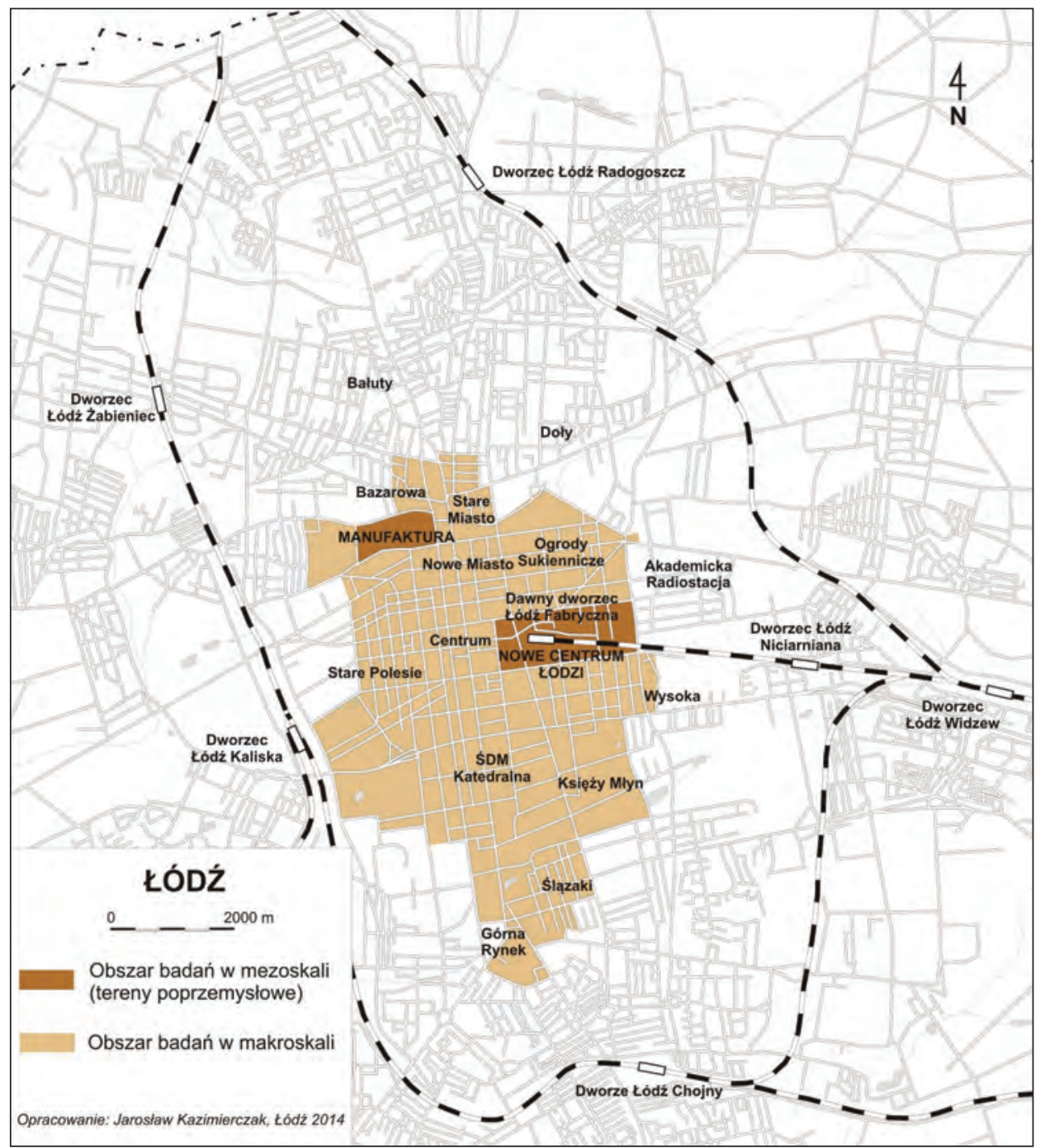

Rys. 1.3. Obszar badań terenowych w Łodzi

Źródło: opracowanie autora

W opinii I. Sagan (2000) studia porównawcze mają współcześnie coraz większe znaczenie ze względu na wzrastające dążenie do unifikacji struktur w skali globalnej i zaniku głębokich różnic systemowych. Studia porównawcze pozwalają zatem lepiej zrozumieć i opisać istotę badanych zjawisk. Wybór Manchesteru, Lyonu i Łodzi do studium przypadku został dokonany na podstawie następujących kryteriów:

1) są to miasta europejskie, w których rewitalizacja wewnątrzmiejskich terenów poprzemysłowych generuje przestrzeń centralną; 
2) są to miasta, w których zakończył się proces rewitalizacji wewnątrzmiejskich terenów poprzemysłowych i istnieje możliwość zbadania i oceny ich skutków, w kontekście przekształceń organizacji przestrzeni centralnej;

3) są to miasta komplementarne w stosunku do stolicy;

4) są to miasta, które posiadają zbliżoną liczbę mieszkańców;

5) Lyon i Manchester znajdują się w krajach, które mają bardzo duże doświadczenie w zakresie realizacji procesu rewitalizacji terenów poprzemysłowych i jednocześnie reprezentują odmienny sposób (model) działań rewitalizacyjnych, co dodatkowo umożliwia ewentualne opracowanie rekomendacji w aspekcie kształtowania przestrzeni centralnej w Łodzi, która jest miastem o najmniejszym doświadczeniu w realizacji projektów naprawczych spośród analizowanych w pracy;

6) są to miasta rozwijające się w drugiej połowie XX w. w odmiennych uwarunkowaniach polityczno-gospodarczych, które warunkują współczesne procesy rozwojowe;

7) są to miasta, które posiadają wykształcone śródmieście;

8) są to miasta, w których proces kształtowania przestrzeni centralnej był na tyle odmienny, by można było prześledzić różny wpływ procesu rewitalizacji na jej przekształcenia oraz zidentyfikować czynniki, które determinują współczesne relacje pomiędzy nową i starą przestrzenią centralną.

Dodatkowymi czynnikami determinującymi wybór obszaru badań są licznie występujące w literaturze porównania Łodzi i Lyonu do Manchesteru. Ten ostatni jest uważany za „pierwsze przemysłowe miasto świata” (Kidd 1993, 1997), które zbudowało swoją potęgę przede wszystkim na przemyśle włókienniczym. W literaturze mowa jest o „Lyonie jako francuskim Manchesterze” (np. Tölle 2009) ze względu na rozwój przemysłowego Lyonu, związanego pierwotnie z produkcją jedwabiu, a następnie wytwórczością włókienniczą. W polskiej literaturze często używa się natomiast pojęcia „Łódź - polski Manchester”. Szczegółowe studia porównawcze poświęcone tym dwóm miastom zostały podjęte w łódzkim ośrodku geograficznym przy współpracy z Manchester Metropolitan University w latach 90. XX w. (Liszewski i Young 1997), co stanowi kolejny czynnik wpływający na dobór miast do studium przypadku. Dodatkowo, Łódź i Lyon to miasta partnerskie, a ośrodki akademickie w obu miastach (Uniwersytet Łódzki i Université Lumière Lyon 2) konsekwentnie zacieśniają współpracę. Czynniki te mogą w przyszłości implikować pogłębione studia o charakterze teoretycznym i aplikacyjnym nad podjętą problematyką badawczą.

Zakres czasowy pracy uwarunkowany został celami pracy. Za początek badań uznaje się okres powstania każdego z analizowanych miast (Lyon - I w. p.n.e., Manchester - I w. n.e., Łódź - XV w.). Szczegółowe studia empiryczne prowadzone są w latach 1988-2013 dla Manchesteru, 1998-2013 dla Lyonu i 2000-2013 dla Łodzi. Zróżnicowanie czasowe badań wynika z trudności w zdobyciu porównywalnego materiału $\mathrm{w}$ trzech badanych miastach $\mathrm{w}$ trzech różnych krajach. W każdym $\mathrm{z}$ analizowanych miast dokonano analizy rezultatów procesu 
rewitalizacji wewnątrzmiejskich terenów poprzemysłowych i ich wpływu na reorganizację przestrzeni centralnej. Do stanu na 2013 r. odnosi się także analiza i ocena planów zagospodarowania przestrzennego oraz projektów rewitalizacyjnych przyjętych do realizacji w Lyonie i Łodzi po 2013 r.

\subsection{Zakres pojęciowy}

Podjęta problematyka badawcza wymaga wyjaśnienia kluczowych pojęć niezbędnych do pełnego zrozumienia istoty przestrzeni centralnej w mieście europejskim. Pierwszym z nich jest pojęcie przestrzeni miejskiej. W geografii polskiej szczegółowe studia nad tym zagadnieniem prowadził S. Liszewski (2008). Badacz, wychodząc od definicji przestrzeni geograficznej ${ }^{4}$ zaproponowanej przez S. Leszczyckiego (1972, za: Lisowski 2003), uznał przestrzeń miejską za część (podprzestrzeń, przestrzeń cząstkową) przestrzeni geograficznej, która odznacza się specyficzną organizacją i krajobrazem, w której dominuje pozarolnicza działalność człowieka, a obszar ma określony formalnie status prawny. Tak rozumiana i delimitowana przestrzeń miejska uwzględnia wszystkie elementy, na podstawie których dokonuje się identyfikacji miasta jako jednostki osadniczej będącej w opozycji do jednostek o charakterze niemiejskim. Natomiast odmienność tych elementów decyduje o wewnętrznym zróżnicowaniu części miast (fragmentów przestrzeni miejskiej) oraz miast między sobą. W tym przypadku można mówić o różnym sposobie organizacji przestrzeni miejskiej ${ }^{5}, \mathrm{z}$ uwzględnieniem czynników sprawczych, które decydują o specyficznym urządzeniu konkretnej jednostki miejskiej. S. Liszewski (1999) przez organizację przestrzeni miejskiej rozumie „sposób urządzenia przestrzeni zgodny zarówno z indywidualnymi, jak i wspólnymi potrzebami mieszkańców miasta" (s. 52). Organizację przestrzeni zurbanizowanej można zdefiniować na podstawie analizy stosunków prawnowłasnościowych (podział na działki, bloki, osiedla), morfologii (budowa wewnętrzna, identyfikowana z planem miasta, i zewnętrzna, czyli fizjonomia zabudowy), organizacji funkcjonalnej, czyli sposobu użytkowania ziemi, organizacji administracyjno-instytucjonalnej oraz organizacji życia społecznego. S. Kaczmarek

${ }^{4}$ Przestrzeń geograficzna to jakościowo zróżnicowana powierzchnia Ziemi, w której można wyróżnić środowisko przyrodnicze i antropogeniczne.

${ }^{5}$ Organizacja przestrzeni jest przedmiotem zainteresowania wielu geografów, a jej ujęcie zależy od problemu badawczego, jaki jest rozwiązywany. Dla przykładu, A. Wolaniuk (2010), analizując rolę uniwersytetów w organizacji przestrzeni, określa ją jako sposób użytkowania - zajęcia przestrzeni europejskiej przez uniwersytety, ich rozmieszczenie, lokalizację, oddziaływanie przez społeczność (studentów, profesorów) w przestrzeni społeczno-ekonomicznej. Zagadnienie organizacji przestrzeni w różnym kontekście społecznym, gospodarczym, kulturowym i innych podejmowali m.in.: Dziewoński 1967, Jałowiecki i Szczepański 2010, Jakóbczyk-Gryszkiewicz, Marcińczak i Siejkowska 2006, Kaczmarek 2000, Kaczmarek 2001, Lisowski 1990, Liszewski 1999, Majer 2010, Marcińczak 2009, Marcińczak i Sagan 2011, Otok 1987, Wallis 1979, 1990 i inni. 
(2001), rozwijając pogląd S. Liszewskiego, stwierdza, że organizacja przestrzeni miejskiej charakteryzuje się zróżnicowaniem, zmiennością w czasie, która ma charakter cykliczny przez co może podlegać kryzysom, i odzwierciedla poziom rozwoju cywilizacyjnego. Potwierdza w ten sposób tezę J. Beaujeu-Garnier i G. Chabot (1971), którzy uznali, że miasto zmienia się, dostosowuje do określonej formy cywilizacyjnej, której jest wyrazem. W tym rozumieniu, pochodną stadium organizacji przestrzeni miejskiej jest jej wyposażenie, które determinuje jakość warunków życia w mieście. D. Szymańska (2009) utożsamia natomiast organizację przestrzeni miasta przede wszystkim ze strukturą morfologiczną, czyli rozplanowaniem miasta, oraz z budową zewnętrzną (kształt i fizjonomia, czyli wygląd zabudowy). Elementy te odnosi do trwałych form danej jednostki osadniczej zarówno w ujęciu historycznym, jak i współczesnym.

Ważnym elementem, który jest wskazywany jako czynnik determinujący sposób organizacji przestrzeni miejskiej, są uwarunkowania przyrodnicze, głównie fizjograficzne (m.in. Dziewoński 1962; Koter 1974). Ze względu na postęp techniczny ich znaczenie współcześnie coraz częściej maleje, o czym świadczą m.in. działania związane z osuszaniem akwenów wodnych pod rozbudowę miast lub infrastruktury miejskiej, np. w Holandii i Japonii. Niemniej analiza uwarunkowań topograficznych ma szczególne znaczenie w badaniach geograficzno-historycznych, które polegają na identyfikacji kolejnych faz rozwoju miasta, bądź jego poszczególnych części, zasięgu terytorialnego tych faz oraz identyfikacji czynników wpływających na genezę i ewolucję przestrzeni miejskiej. Przyjęta problematyka badawcza zadecydowała, że w niniejszym opracowaniu skoncentrowano się na ujęciu morfologicznym i funkcjonalnym studiów nad organizacją przestrzeni miejskiej, przyjmując, że determinuje ona jej pozostałe wymiary.

I. Sagan (2000), analizując organizację przestrzeni miejskiej, wyróżniła cztery strefy: centralną, czyli średniowieczne jądro miasta; strefę przekształceń, obejmującą w dużej mierze obszary dawnych przedmieść; nowych osiedli mieszkaniowych; oraz peryferyjną o wielofunkcyjnym charakterze: przemysłowo-składowym, rekreacyjnym, rolniczym oraz mieszkaniowym. Jest to klasyfikacja oparta głównie na kryterium przestrzenno-funkcjonalnym. Niewątpliwie każda z wyróżnionych stref posiada specyficzne cechy morfologiczne, które są odzwierciedleniem pełnionych przez nie funkcji. Podział przyjęty przez I. Sagan (2000) ma jednak daleko idący charakter uogólniający. Zdaniem S. Liszewskiego (2008), w badaniach roli czynnika funkcjonalnego $\mathrm{w}$ organizacji przestrzeni miejskiej należy poddać dokładniejszej analizie dwa elementy związane z przestrzennym wyrazem funkcji: różnorodność form (czyli funkcji) w różnych fragmentach przestrzeni miejskiej oraz kierunki użytkowania ziemi, które są wyrazem różnorodności struktur form użytkowania ziemi w konkretnych jednostkach przestrzennych miasta ${ }^{6}$.

${ }^{6}$ Klasyfikację form użytkowania ziemi w miastach zaproponował S. Liszewski (1977), który rozwinął analizę przeprowadzoną przez K. Bromka (1966). 
Integralnym elementem struktury przestrzenno-funkcjonalnej miasta jest jego „centrum”. Zdaniem R. Barthesa (1980), ma ono szczególne znaczenie dla organizacji miast w cywilizacji zachodniej, w której „centrum” jest miejscem, gdzie skupiają się wartości: duchowe (kościoły), władza (biura), pieniądze (banki), towary (sklepy i wielkie domy towarowe), słowa (plac), kawiarnie i promenady. We współczesnej literaturze przedmiotu istnieje znaczna liczba pojęć określających zróżnicowane formy przestrzenno-funkcjonalne „,entrum” miasta. Wyróżnia się, m.in.: rdzeń (ang. core), ścisłe centrum (ang. hard core), historyczne (zabytkowe) centrum miasta, dzielnicę finansową, w skrócie CBD (ang. Central Business District) oraz śródmieście, które jest charakterystyczne dla miast europejskich i oznacza najczęściej najstarszą przestrzeń w mieście (Juchnowicz 1971). W ujęciu morfologicznym i instytucjonalnym wskazane jednostki charakteryzują się istotnym zróżnicowaniem. Przyjęta problematyka pracy wymaga bliższej analizy zagadnienia centrum miasta i śródmieścia, które stanowią punkt wyjściowy do dalszych rozważań nad przestrzenią centralną.

B. Maliszowa (1974) identyfikuje śródmieście z obszarem o funkcjach mieszkalnych, którego dominantę stanowią funkcje usługowe. Położenie w środku ciężkości układów różnych rodzajów komunikacji tworzy obszar miasta najintensywniej zabudowany, a zarazem jest największym ośrodkiem pracy i aktywności. M. Nowakowski (1990) stwierdza ponadto, że śródmieście to historycznie wykształcona centralna część miasta, na obszarze której najintensywniej występuje zwarta zabudowa mieszkaniowa, przemieszana $\mathrm{z}$ obiektami usługowymi oraz administracyjnymi. Podstawowymi atrybutami umożliwiającymi wyróżnienie dzielnicy śródmiejskiej są zatem: centralne położenie - w środku układu miejskiego, morfogeneza oraz fizjonomia. Zauważyć trzeba, że w każdym mieście może wykształcić się tylko jeden obszar o charakterze śródmiejskim ${ }^{7}$. Jak twierdzi B. Maliszowa (1974) śródmieście występuje tylko w miastach z przeszłością, które jednocześnie przekroczyły pewien próg wielkości, podczas gdy centrum miasta można zidentyfikować w każdym mieście. S. Juchnowicz (1971) zwraca także uwagę na fakt, że „o ile obszar śródmieścia w rozwiniętych układach miejskich wyróżnia się w sposób widoczny (często wyznaczają go elementy układu komunikacyjnego względnie odmienny charakter zabudowy), o tyle obszar centrum miasta, który może zawierać kilka koncentracji o różnym użytkowaniu (np. centrum administracyjne, handlowe, kulturalne) jest trudniejsze do zdefiniowania" (s. 11).

Z. Rykiel (1995), prowadząc rozważania na temat istoty centrum i peryferii w ujęciu dynamicznym, deterministycznym i probabilistycznym, stwierdził, że

${ }^{7}$ W tym kontekście należy pominąć wielkie skupiska miejskie jak konurbacje czy megalopolis. Ciekawą formą osadniczą są także miasta-zlepieńce składające się co najmniej z dwóch historycznie ukształtowanych osiedli miejskich, które w wyniku ekspansji przestrzennej i decyzji administracyjnej traktowane są współcześnie jako jeden organizm miejski. W ujęciu morfologicznym są to jednostki złożone, które może charakteryzować współistnienie dwóch obszarów śródmiejskich. Zagadnienie to zostało szeroko omówione przez R. Szmytkie (2009). 
podział ten jest niewystarczający. W rezultacie zaproponował nowy, w którym wyróżnił: rdzeń, sub-rdzenie, sub-peryferie i peryferie. W tym kontekście wskazał na występujące w dużym mieście cztery strefy: centrum ścisłego, centrum rozszerzonego, semi-peryferii (lub peryferii bliskich) oraz peryferii (peryferii dalekich). Analizując wyróżnione strefy w czterech głównych płaszczyznach, za jakie uznał: formalną (administracyjną), fizyczno-urbanistyczną, ekonomiczną i społeczno-kulturową, stwierdził, że w polskim mieście ścisłe centrum należy utożsamiać z najstarszą częścią śródmieścia. Centrum rozszerzone to obszar zabudowy XIX-wiecznej, często poddanej przekształceniom. Tak identyfikowana organizacja przestrzenna miasta koresponduje z podziałem zaproponowanym przez I. Sagan (2000) oraz z interpretacją śródmieścia i centrum w polskich miastach w rozumieniu S. Juchnowicza (1971), B. Maliszowej (1971) i M. Nowakowskiego (1990). Kierując się kryterium ekonomicznym, Z. Rykiel (1995) zlokalizował główną dzielnicę handlową lub biurową oraz CBD w ramach centrum rozszerzonego.

Specyfiką ośrodków miejskich w Polsce jest lokalizacja centrum miejskiego w granicach dzielnicy śródmiejskiej. W miastach Europy Zachodniej wykształciło się pojęcie city wywodzące się z języka angielskiego i określające "miasto". Odnosi się ono współcześnie do najważniejszej i najstarszej części miasta, identyfikowanej z jego centrum. Pojęcie to jest jednak wypierane przez zapożyczony z Ameryki Północnej termin CBD. Jego odpowiednikiem w miastach francuskich określającym dzielnicę finansową jest centre des affairs. Zdaniem S. Liszewskiego i W. Maika (2000) centrum miasta może wyewoluować z dzielnicy śródmiejskiej (centralnej), która w miarę wzrostu liczby mieszkańców i rangi miasta ulega daleko idącym zmianom. Proces ten wiąże się z przejmowaniem przez kształtujące się centrum nowych funkcji, które uzupełniają lub wypierają tradycyjne dla śródmieścia funkcje handlowe, administracyjne czy religijne. Zmniejszeniu ulega także liczba mieszkańców, co jest reperkusją malejącej dochodowości funkcji mieszkaniowej w konfrontacji z innymi funkcjami wielkomiejskimi (m.in. Górka 1995; Liszewski i Maik 2000; Słodczyk 2001). W tym ujęciu centrum jest częścią przestrzeni miejskiej, która rozwija się w sposób ewolucyjny, przybierając zróżnicowane formy przestrzenno-funkcjonalne na wyższym, bardziej zaawansowanym etapie rozwoju niż śródmieście.

M. Castells (1982) uznawał centrum miejskie za pojęcie wieloznaczne i wyróżnił trzy sposoby jego rozumienia. W pierwszym była to część miasta, która została określona przestrzennie poprzez zbieg ulic bądź też jako plac miejski, koncentrujący życie społeczności miejskiej. Jest to centrum integrujące o znaczeniu symbolicznym. W podobnym aspekcie istotę centrum miasta pojmował A. Wallis (1979), który zwracał uwagę na jego wartości kulturowe i symboliczne, twierdząc, że jest ono miejscem integracji członków społeczności miejskiej, która stwarza możliwości zaspokajania spontanicznych potrzeb tej zbiorowości oraz zapewnia warunki do jej rozwoju. W drugim ujęciu Castellsa, o charakterze ekologicznym, centrum jest miejscem wymiany i koordynacji aktywności zdecentralizowanych. 
$\mathrm{Na}$ tej podstawie przedstawiciele tzw. szkoły chicagowskiej opracowali koncepcję CBD. Współcześnie jednak koncentracje działalności wielkomiejskiej często zajmują przestrzeń peryferyjną w stosunku do tradycyjnego centrum, stąd też ujęcie to wydaje się już nieaktualne. W trzecim ujęciu centrum traktowane jest jako przestrzeń działalności ludycznej ${ }^{8}$, koncentracji rozrywki, obszar, w którym najlepiej można poczuć „klimat wielkiego miasta”.

Zagadnieniu centrum miasta poświęcono w literaturze geograficznej szczególne miejsce, co wynika z rangi tego obszaru w strukturze przestrzenno-funkcjonalnej miasta. Szerokiego przeglądu cech identyfikujących centrum w opinii polskich i zagranicznych autorów dokonała A. Wolaniuk (1997):

- centrum miasta jest podstawą ciągłości historycznej naczelnych wartości miejskiego społeczeństwa i narodu;

- jest największym ośrodkiem usługowym danej jednostki osadniczej, miejscem koncentracji instytucji usługowych, obejmujących organizację życia politycznego, administracyjnego, gospodarczego, społecznego, kulturalnego, rozrywkowego, selektywnej produkcji i zamieszkania;

- niezmodernizowane centrum bywa obszarem konfliktowym między możliwościami starej zniszczonej zabudowy a wymogami lokalizacyjnymi nowoczesnych funkcji centrum;

- zlokalizowane w centrum instytucje mają zazwyczaj charakter unikatowy;

- jest miejscem wymiany i koordynacji zdecentralizowanych działań;

- ulega ciągłym przemianom funkcjonalnym;

- jest największym i najważniejszym ośrodkiem usługowym miasta i regionu, który go otacza, położonym w rejonie głównych węzłów komunikacyjnych, często silnie zanieczyszczonym.

Ponadto, B. Jałowiecki i M. S. Szczepański (2010) utożsamiają centrum miasta z przestrzenią publiczną, wskazując na okresowy i okazjonalny charakter przebywania w nim mieszkańców miasta. Ujęcie to ściśle odnosi się do symbolicznego wymiaru centrum miasta. Niezależnie od morfologii i programu instytucjonalnego jest to obszar, z którym identyfikuje się lokalne społeczeństwo. Poczucie tożsamości mieszkańców miasta wyraża się szczególnie w silnej potrzebie ochrony centrum miejskiego jako specyficznej formy dziedzictwa kulturowego, kształtowanego przez wcześniejsze pokolenia. W tym kontekście istota rewitalizacji nabiera unikatowej wartości w procesie tworzenia wspólnego wspomnienia - „mémoire collective” według Maurice Halbwachs (1992) - mieszkańców konkretnego obszaru.

Różnorodność kryteriów, na podstawie których możliwa jest identyfikacja centrum miasta, przyczyniła się do powstania licznych i odmiennych koncepcji delimitacji tego obszaru. Pierwsze próby wyznaczania granic centrum miasta

${ }^{8}$ Do koncepcji przestrzeni ludycznej nawiązywał w swoich pracach B. Jałowiecki (Jałowiecki i Szczepański 2010). Koncepcja ta zakłada, że centrum jest przede wszystkim miejscem atrakcji turystycznych, konsumpcji, pokazowej rozrywki oraz kultury masowej, która w miastach postindustrialnych zajmuje bardzo często uprzednią przestrzeń przemysłową. 
podjęto w Wielkiej Brytanii i Stanach Zjednoczonych Ameryki Północnej, gdzie jako miernik przyjmowano między innymi cenę ziemi i powierzchnię wynajmu lokali (Carter 1973). W polskiej literaturze geograficznej, metody i wskaźniki delimitacji centrum miasta były przedmiotem analizy m.in. Z. Górki (1995), A. Jelonka (1989), S. Juchnowicza (1971), M. Nowakowskiego (1990), J. Paryska, E. Guarino i L. Mierzejewskiej (1995), J. Słodczyka (2001) oraz A. Wolaniuk (2008). Wśród kryteriów wykorzystywanych w metodach delimitacji centrum miasta wyróżnia się najczęściej: fizjonomiczne, funkcjonalne, izokinetyczne, demograficzne i ekonomiczne. Ze względu na wielopłaszczyznowość istoty centrum miasta większość badaczy wskazuje wyraźnie na konieczność stosowania kilku kryteriów w procedurze delimitacyjnej. Problematyka pracy wymaga skoncentrowania się przede wszystkim na metodach fizjonomicznych i funkcjonalnych.

W literaturze geograficznej szczególny nacisk kładzie się na metody delimitacji oparte na kryterium funkcjonalnym, w rezultacie analizy fizjonomiczne mają raczej charakter dopełniający. Wśród elementów fizjonomicznych bądź krajobrazowych, jak nazywa je J. Słodczyk (2001), umożliwiających wyróżnienie centralnej części miasta, akcentuje się najczęściej analizę: gęstości i układu ulic, wielkości działek budowlanych i ich położenia, gęstości i zwartości zabudowy, wysokości zabudowy, typu budynków i okresu ich powstania (wieku zabudowy) oraz sposobu zlokalizowania budynków względem ulicy. Z. Górka (1995) wskazuje także na funkcje zabudowy jako element fizjonomiczny. Studia literatury z zakresu morfologii miast umożliwiają także wyróżnienie innych „elementów zewnętrznych", które podlegają analizie przy delimitacji centrum miasta, m.in.: materiał, z jakiego wykonane są budynki, kolorystyka budynków czy stan techniczny zabudowy. Ponadto J. Słodczyk (2001) wskazuje na analizę układu komunikacyjnego jako odrębną metodę delimitacji centrum miejskiego ${ }^{9}$. Można jednak przyjąć, że układ komunikacyjny składa się z liniowych elementów morfologicznych i tym samym włączyć analizę tego elementu zagospodarowania miasta w ramy metod fizjonomicznych. Przydatna może być także analiza rozmieszczenia punktowych elementów morfologicznych, takich jak np. pomniki. Ich koncentracja w historycznym centrum miasta wyraża przestrzeń tożsamości społeczności lokalnej, przestrzeń symboliczną (Cudny 2011; Kazimierczak 2011). Również A. Wolaniuk (2008) wskazuje na „pomniki i inne budowle” jako element fizjonomiczny umożliwiający identyfikację centrum w przestrzeni miejskiej. Ta sama autorka zalicza osobno układ przestrzenny jako ten element analizy, który z morfologicznego punktu widzenia jest najistotniejszy w procesie delimitacyjnym.

Do metod delimitacji centrum na podstawie kryterium fizjonomicznego (krajobrazowego) zalicza się przede wszystkim bezpośrednią obserwację terenową, analizę materiałów kartograficznych, w tym także map GIS, oraz interpretację

${ }^{9}$ Często stosowana w tym przypadku jest metoda grafów, polegająca na delimitacji centrum miasta na podstawie liczby Königa (m.in. Jażdżewska 2008; Parysek, Guarino i Mierzejewska 1995). 
zdjęć lotniczych. De facto elementy, które zostają poddane analizie, należałoby raczej podzielić na morfologiczne, uwzględniające badania planu miasta, czyli budowę wewnętrzną centrum miasta, i na fizjonomiczne, w których szczegółowym studiom podlegają cechy wizualne, jak określają je J. J. Parysek, E. Guarlino i L. Mierzejewska (1995). Oprócz wskazanych wcześniej, można także wyróżnić inne elementy materialne, które może obejmować obserwacja terenowa, takie jak: nocne oświetlenie, często wskazujące użytkownikom miasta, jakie rejony miejskie są najbardziej prestiżowe lub najbardziej wartościowe ze względu na walory historyczne substancji miejskiej ${ }^{10}$, oraz m.in. mała architektura (lampy miejskie, ławki), elementy infrastruktury miejskiej (przystanki komunikacji miejskiej, kioski), nawierzchnia dróg, placów, ciągów pieszych oraz formy zieleni miejskiej.

W kontekście zróżnicowania ujęć badawczych w ramach metod fizjonomicznych delimitacji centrum miasta, bliższej analizie należy poddać relację pomiędzy pojęciami morfologia, fizjonomia oraz krajobraz miasta. Analiza krajobrazowa środowiska miejskiego wykazuje silny związek z badaniami morfologicznymi, co potwierdzają opinie licznych badaczy miast. Studia krajobrazowe są często utożsamiane $\mathrm{z}$ badaniami fizjonomicznymi, tym samym należy wnioskować, że podstawowym elementem krajobrazu miast jest jego forma materialna, fizjonomia. Zdaniem E. Heczko-Hyłowej (1984) fizjonomia jest synonimem krajobrazu. Jest to obraz, widok środowiska, czyli przestrzeni. Jest ona też syntezą elementów antropogenicznych i naturalnych. Podobny pogląd został wyrażony w definicji krajobrazu zurbanizowanego przyjętego na Europejskim Kongresie Architektury w 2000 r., określając go jako część terytorium, którego forma i charakter wywodzą się od czynników naturalnych i antropomorficznych oraz zachodzących między nimi relacji, które są postrzegane przez mieszkańców tego obszaru (Cattaneo 2007). J. W. R. Whitehand (1981) nazwał współczesny krajobraz miejski odbiciem skumulowanych działań kolejnych pokoleń, natomiast M. Koter (1974) - wypadkową nakładania się i wzajemnego zacierania różnych warstw osadniczych w długim procesie kształtowania się miasta. Kluczem do zrozumienia stanu krajobrazu w dowolnym etapie jego rozwoju jest zrozumienie, jaką ten krajobraz przechodził ewolucję, co wiąże studia krajobrazowe z badaniami morfologicznymi (morfologii sensu stricto) i morfogenetycznymi (morfologii sensu largo).

Dokładnej analizy zagadnień teoretycznych morfologii miast dokonał M. Koter (1994). Przez fizjonomię rozumie on budowę zewnętrzną miasta, czyli jego formę, kształt oraz sylwetę. Wraz z rozplanowaniem miasta, czyli jego budową wewnętrzną, odzwierciedloną w planie miasta, fizjonomia współtworzy morfologię sensu stricto. W szerszym aspekcie zdefiniował natomiast morfologię sensu largo, w skład której wchodzi analiza elementów kształtujących budowę wewnętrzną i zewnętrzną oraz ich geneza, czyli morfogeneza. W ramach tej ostatniej wyróżnił natomiast badania z zakresu: stratygrafii - polegające na datowaniu

${ }^{10}$ Zwraca na to uwagę m.in. J. Słodczyk (2001). 
poszczególnych elementów budujących współczesne jednostki morfologiczne na podstawie tzw. zabytków przewodnich, morfologii rozwojowej - uwzględniającej zewnętrzne i wewnętrzne procesy przekształcające formę architektoniczną i urbanistyczną, morfologię ewolucyjną - na podstawie której można określić genezę i charakter ewolucji jednostek morfologicznych oraz morfologię porównawczą, której celem jest klasyfikacja i typologia miast na podstawie cech morfologicznych i morfogenetycznych.

Metody delimitacji centrum miasta w oparciu o kryterium funkcjonalne są bardziej zróżnicowane od „fizjonomicznych”. Wyróżnia się wśród nich przede wszystkim metody badania sposobu użytkowania ziemi oraz analizy funkcji, poprzez rozmieszczenie placówek usługowych, typowych dla centrum miasta głównie działalności centrotwórczych, reprezentowanych przez sektor III i IV. Analiza użytkowania ziemi została szeroko opisana w literaturze przedmiotu zarówno w kontekście badań całego miasta, śródmieścia oraz centrum miasta, jak i jego specyficznych form przestrzenno-funkcjonalnych, takich jak np. CBD (m.in. Bromek 1966; Bromek i Mydel 1972; Carter 1973; Górka 1995, 2004; Juchnowicz 1971; Liszewski 1978; Murphy i Vance 1954; Wolaniuk 2008). Badania tego typu obejmują inwentaryzację poszczególnych budynków, a bardziej szczegółowe - zdjęcia użytkowania poszczególnych kondygnacji (Górka 1988; Juchnowicz 1971). Innym sposobem badań jest zaznaczenie w postaci kartograficznej placówek usługowych o charakterze ogólnomiejskim i analizy ich koncentracji bądź rozmieszczenia umożliwiającej określenie zasięgu przestrzennego centrum miasta. S. Juchnowicz (1971), prowadząc badania nad użytkowaniem ziemi w śródmieściach polskich miast, skoncentrował się natomiast na obliczeniu odsetka powierzchni użytkowanej przez funkcje śródmiejskie. Interesującą metodą jest także analiza lokalizacji instytucji centrotwórczych umożliwiająca wyznaczenie środka ciężkości, zwanego również centroidem bądź środkiem grawitacyjnym. Jest to metoda matematyczna, na podstawie której możliwa jest obserwacja przemieszczania się centroidu dla wydzielonych grup instytucji w różnych przekrojach czasowych. Wymaga ona jednak założenia, że centrum miasta ma charakter punktowy (geometryczny) i jest odzwierciedlone w postaci środka ciężkości instytucji centrotwórczych, co można uznać za dość daleko idące uogólnienie ${ }^{11}$. Niemniej, centroid umożliwia prześledzenie ewolucji „,preferencji lokalizacyjnych” konkretnych grup instytucji w różnych okresach historycznych.

Każda $\mathrm{z}$ powyższych metod $^{12}$ wymaga precyzyjnego określenia zbioru analizowanych funkcji, czyli działalności skoncentrowanej w poszczególnych budynkach, usług lub instytucji, charakterystycznych dla centrum miasta. Zbiór ten

${ }^{11}$ Z metody centroidu korzystała m.in. A. Wolaniuk (1997) do analizy przemieszczenia się centrum Łodzi w wybranych latach w XIX i XX w.

${ }^{12}$ Ze względu na bogatą literaturę $\mathrm{w}$ zakresie metod delimitacji centrum miasta na podstawie kryterium funkcjonalnego w niniejszym opracowaniu pominięto charakterystykę poszczególnych parametrów i wskaźników. 
jest zróżnicowany i zależy m.in. od specyfiki obszaru (miasta), który podlega analizie, oraz od założeń badawczych, przyjętych przez konkretnego autora analizy. W literaturze geograficznej wskazuje się najczęściej na funkcje śródmiejskie, takie jak: handel, administrację i kulturę (Górka 1995) bądź handel detaliczny, usługi i administrację oraz użytkowanie towarzyszące - komunikację, zieleń i użytkowanie gospodarcze (Słodczyk 2001). S. Juchnowicz (1971) wyróżnił sześć form użytkowania ziemi typu śródmiejskiego: 1) handel detaliczny i żywienie; 2) usługi obejmujące instytucje kultury (biblioteki, muzea, filharmonie, sale wystaw, kina, teatry, kościoły), instytucje usługowe (banki, kancelarie adwokackie, ubezpieczenia, przedstawicielstwa przedsiębiorstw, redakcje i wydawnictwa dzienników, siedziby organizacji społecznych i zawodowych, biura projektów, hotele, dworce kolejowe i autobusowe), naukę (instytuty badawcze, szkoły wyższe), lecznictwo; 3) administrację o zasięgu krajowym, wojewódzkim, miejskim (władze polityczne, sądy); 4) komunikację (występujące w obrębie bloku parkingi, dojazdy); 5) zieleń śródmiejską; 6) powierzchnie gospodarcze związane z powierzchnią mieszkalną. W studiach miejskich wyróżnia się także usługi sektora III i IV: handlowe, hotelowe i gastronomiczne, kulturalne, naukowe, zarządzania i obsługi bankowej, zarządzania nieruchomościami, szeroko rozumianą administrację i działalność „biurową” (Wolaniuk 2008).

Istotnym czynnikiem determinującym zbiór analizowanych instytucji czy form użytkowania ziemi w centrum miasta jest okres analizy (epoka historyczna) oraz stadium rozwoju gospodarczego konkretnego miasta. W kontekście współczesnych wielkich ośrodków miejskich i delimitacji ich centrów, w literaturze geograficznej bardzo często funkcje centrotwórcze identyfikuje się z funkcjami metropolitalnymi, które także nazywane są wielkomiejskimi. Funkcje metropolitalne stanowią przedmiot zainteresowania wielu badaczy miast (m.in. Breathnach 2000; Dicken 1998; Hall 1998; Ilnicki 2003; Liszewski i Maik 2000; Maik 2003; Markowski i Marszał 2006; Markowski i Stawasz 2007; Parysek 2003; Słodczyk i Fortuński 2003; Wolaniuk 2010). W literaturze geograficznej funkcje metropolitalne są rozumiane jako specyficzna forma funkcji miejskich o charakterze egzogenicznym, które pojawiły się na określonym etapie rozwoju miasta, a warunkiem niezbędnym dla ich wykształcenia jest osiągnięcie przez miasto pewnej progowej wielkości zaludnienia, przy której następuje kumulacja i oddziaływanie na siebie różnorodnych funkcji prowadzące do wytworzenia się wyspecjalizowanych funkcji wyższego rzędu (Maik 2003). W opinii S. Liszewskiego i W. Maika (2000) współczesne wielkie miasta rozwijają się dzięki koncentracji działalności finansowej, ubezpieczeniowej i marketingowej oraz wyspecjalizowanych usług w zakresie ochrony zdrowia, edukacji, kultury, badań naukowych i administracji gospodarczej. T. Markowski i T. Marszał (2006) uważają, że funkcje metropolitalne są to funkcje egzogeniczne o znaczeniu i zasięgu co najmniej ponadregionalnym w rozumieniu christallerowskim. Polegają one na pełnieniu działalności najwyższego rzędu, która zaliczana jest do sektora IV, 
zwłaszcza funkcje o charakterze decyzyjnym, związane z obecnością instytucji reprezentujących struktury kierowania, zarządzania i kontroli w skali międzynarodowej. Wśród funkcji metropolitalnych wyróżniają: polityczne, religijne, kulturalne, naukowe, edukacyjne, turystyczne, gospodarcze, finansowe, komunikacyjne $\mathrm{i}$ informacyjne.

W podobny sposób funkcje metropolitalne rozumie A. Wolaniuk (1997), która uważa, że funkcje metropolitalne wyznaczane są poprzez instytucje reprezentujące sektor usług wyższego rzędu, usług unikatowych, w tym ważniejszych instytucji administracyjnych, których zasięg oddziaływania wykracza poza granice jednostki osadniczej oraz administracyjnej. Zdaniem tej autorki, instytucje metropolitalne, które utożsamia z wielkomiejskimi, grupują się w dziesięć działów: 1) instytucje finansowe i ubezpieczeniowe (banki i ubezpieczenia); 2) placówki naukowe (szkolnictwo wyższe, instytuty naukowo-badawcze, centralne ośrodki badawczo-rozwojowe); 3) wyspecjalizowane szpitale; 4) wymiar sprawiedliwości (sądy, prokuratury); 5) środki masowego przekazu (radio, telewizja, tygodniki, dzienniki o zasięgu ponadregionalnym); 6) hotele i ogólnokrajowe biura podróży; 7) komunikacja i łączność (lotniska, administracja kolejowa i samochodowa oraz telekomunikacyjna wyższego szczebla zarządzania); 8) placówki życia kulturalnego (muzea, teatry, filharmonie, biura artystyczne); 9) administracja państwowa, wojskowa, policyjna, pożarnicza, organizacje polityczne, społeczne, wyznaniowe i związkowe, naukowe i kulturalne oraz 10) inne instytucje gospodarcze o charakterze metropolitalnym. We współczesnym świecie, w którym przepływ informacji i wiedzy dokonuje się nie tylko drogą wirtualną, ale także w istotnej części poprzez bezpośredni kontakt, można przypuszczać, że wzrośnie znaczenie „instytucji przemysłu konferencyjnego", który generuje także ruch turystyczny do dużych miast (metropolii). P. Soldatos (1987) zwraca uwagę na tzw. strefę wydarzeń, która kształtuje współczesne metropolie. Dla jej sprawnego funkcjonowania w mieście niezbędne są: miejsca organizacji kongresów, konferencji, sympozjów i zjazdów oraz wielkich spotkań; miejsca organizacji festiwali i wydarzeń artystycznych; miejsca, w których odbywają się targi, promocje, imprezy gospodarcze i wystawy; ośrodki organizacji imprez sportowych i obiekty widowiskowe.

Funkcje typowe dla centrum miasta są zmienne w czasie. Jest to reperkusja rozwoju cywilizacyjnego i ewolucji miast, które stanowią przestrzeń integrującą formy pozarolniczej działalności danej społeczności, właściwe dla konkretnego okresu w dziejach ludzkości. Zmienność instytucji centrotwórczych w czasie wyraża się w postaci utraty dominującej pozycji wśród jednej grupy instytucji w wyniku wzrostu znaczenia innych funkcji, które są kluczowe dla danego etapu rozwoju miasta i jego dalszej ewolucji w wymiarze przestrzennym, ekonomicznym, społecznym i kulturowym. Przyjmując, że wyrazem wewnętrznej organizacji działalności funkcji egzogenicznej (instytucji centrotwórczych) jest wytworzenie centrum wielkomiejskiego (Wolaniuk 1997), może to w rezultacie prowadzić do 
rozszerzania się obszaru centralnego, przesuwania się go w przestrzeni miejskiej bądź wykształcenia nowego obszaru, pełniącego taką rolę w układzie miejskim ${ }^{13}$.

Zmienność instytucji centrotwórczych w czasie znajduje także swój wyraz w ewolucji ich „preferencji lokalizacyjnych”. Wiąże się ona przede wszystkim z trudnościami dostosowania „starego" obszaru koncentracji pewnej grupy instytucji do potrzeb nowych funkcji, które wymagają już innych, nowocześniejszych form zagospodarowania przestrzennego. W rezultacie powstają nowe jednostki przestrzenne o odmiennej i „nowoczesnej” formie urbanistycznej i architektonicznej. Wraz z rosnącą złożonością miasta, jako struktury morfologicznej i funkcjonalnej, instytucje te ulegały dyspersji w przestrzeni miejskiej, w zgodzie z założeniem o zmienności preferencji lokalizacyjnych. W konsekwencji w złożonych układach morfologicznych powstały specyficzne formy zagospodarowania przestrzennego o różnym stopniu zwartości. Oznacza to, że tereny te mogły być od siebie odseparowane obszarami zurbanizowanymi nieposiadającymi cech przestrzenno-funkcjonalnych typowych dla centrum miasta. W tym kontekście można wyróżnić przestrzeń centralną miasta, rozumianą jako część przestrzeni miejskiej, składającą się ze zróżnicowanych jednostek i elementów morfogenetycznych, które w wyniku rozwoju miasta oraz oddziaływania licznych sił i procesów o charakterze endogenicznym i egzogenicznym zyskały najwyższą rangę $w$ hierarchii terenów miejskich. Mogą ją tworzyć proste elementy przestrzenne, takie jak: ulice i place z przyległymi kwartałami bądź bardziej złożone formy morfologiczne, np. dzielnice.

Określenie „przestrzeń centralna” miasta pojawia się w literaturze przedmiotu przy okazji prób uściślenia położenia fragmentu analizowanej przestrzeni miejskiej w strukturze przestrzenno-funkcjonalnej miasta (m.in. Jałowiecki i Szczepański 2010; Majer 2010). W niniejszej pracy koncepcja przestrzeni centralnej w mieście zrywa $\mathrm{z}$ takim konserwatywnym ujęciem geodezyjnym ${ }^{14}$. Przez przestrzeń centralną należy rozumieć część przestrzeni miejskiej, która odznacza się specyficzną organizacją i krajobrazem, w której koncentrują się instytucje typowe dla centrum

${ }^{13} \mathrm{Na}$ dynamikę procesów ekspansji centrum miasta zwracał uwagę m.in. grecki architekt i urbanista Constantinos Doxiadis (1914-1975), twórca koncepcji miasta dynamicznego (dyna polis) w układzie pasmowo-koncentrycznym. Wyszedł on z założenia konieczności zachowania proporcji pomiędzy rozwojem przestrzennym miasta a rozwojem jego centrum, dla którego należy przewidzieć możliwość rozwoju terytorialnego (Paszkowski 2011). W przypadku dyna polis proces ekspansji miał charakter rozszerzania się centrum miasta na sąsiednie, zewnętrzne - uprzednio peryferyjne względem centrum - obszary.

${ }^{14} \mathrm{~W}$ rozumieniu przestrzeni geodezyjnej (Dziewoński 1967) będącej częścią przestrzeni geonomicznej (Boudeville 1961, Dziewoński 1967), czyli konkretnej i fizycznej przestrzeni ziemskiej. Z. Rykiel i M. Pirveli (2005) uważają, że w ten sposób nie tyle konkretyzuje, ile raczej banalizuje się pojęcie przestrzeni. $\mathrm{Z}$ metodologicznego punktu widzenia badania regionalne, nawiązujące - bezpośrednio lub pośrednio (za pośrednictwem ekonomicznych teorii lokalizacji) - do klasycznych kategorii pojęciowych geografii są więc krokiem wstecz w stosunku do teorii geografii społeczno-ekonomicznej. 
miasta (centralne, unikatowe). W tym aspekcie - „centralna” oznacza najważniejsza - w wymiarze instytucjonalnym i morfologicznym, niezależnie od położenia w układzie miejskim. Jest to przestrzeń reprezentacyjna, która jest wyrażona poprzez koncentrację najbardziej okazałych obiektów architektonicznych w mieście oraz znaczny udział przestrzeni publicznej ${ }^{15}$. W odróżnieniu od klasycznego rozumienia centrum miasta $\mathrm{w}$ ujęciu przestrzennym i funkcjonalnym, przestrzeń centralna może rozwinąc się także na obszarach peryferyjnych w stosunku do geometrycznego środka miasta.

Proces kształtowania przestrzeni centralnej w mieście ma charakter permanentny, analogicznie do specyfiki rozwoju miasta, jako układu przestrzenno-funkcjonalnego. Ewolucja przestrzeni centralnej może się wiązać z transformacją istniejących form morfologiczno-instytucjonalnych opisanych w przestrzeni miejskiej konkretną lokalizacją lub z generowaniem nowych form w innych - „nowych” lokalizacjach. W tym kontekście należy wyróżnić dychotomiczny podział na „starą" i „nową” przestrzeń centralną w mieście. Nawiązując do koncepcji starej i nowej przestrzeni miejskiej S. Liszewskiego (2006), nowa przestrzeń centralna ma w tym ujęciu trzy znaczenia:

- nowa, czyli młoda;

- nowa, czyli ta, która powstała w innej „nowej” lokalizacji;

- nowa, czyli nowoczesna, którą charakteryzuje koncentracja budynków zbudowanych według najnowszych (dla danej epoki) trendów w architekturze, często z wykorzystaniem oryginalnych form urbanistyczno-architektonicznych, nowych funkcji i instytucji odpowiadających aktualnym potrzebom mieszkańców i użytkowników miasta, co w rezultacie prowadzi do wykształcenia nowej przestrzeni publicznej, spełniającej wymogi estetyczne dla danej epoki, w której powstała.

W każdym z miast i na każdym etapie jego rozwoju można wyróżnić „starą” i ,nową" przestrzeń centralną.

Proces generowania „nowej” przestrzeni centralnej w nowej lokalizacji może wynikać:

- ze zmian preferencji lokalizacyjnych instytucji centrotwórczych;

- z deficytu fizycznej (terytorialnej) rezerwy rozwojowej wewnątrz istniejącej dotychczas (,starej”) przestrzeni centralnej;

- z braku możliwość dostosowania „starej” przestrzeni centralnej do aktualnych potrzeb instytucji centralnych, typowych dla danej epoki.

15 Jest ona wyróżniana nie na podstawie kryterium własności terenu, lecz w oparciu o kryterium dostępności i społecznego charakteru jej użytkowania (Gehl 2009; Ghirardo 1999; Hołub 2002; Lorens 2007, 2010a; Karta Przestrzeni Publicznej 2009; Wojnarowska 2011). Oznacza to, że przestrzeń centralna może być fragmentem przestrzeni miejskiej, który jest własnością prywatną, i tym samym podlegać pewnym fizycznym ograniczeniom w dostępności z uwagi na kwestie bezpieczeństwa bądź sposobu organizacji jej wykorzystania. 
Ostatnia ze wskazanych możliwości wynika z niskiej podatności na przekształcenia morfologiczne zabytkowej substancji materialnej „starej” przestrzeni centralnej. W każdym mieście może zaistnieć sytuacja, w której kumulują się wszystkie ze wskazanych czynników prowadzących do powstania „nowej” przestrzeni centralnej w innej lokalizacji.

Ewolucyjny charakter rozwoju przestrzeni centralnej opiera się na założeniu, że „nowa" przestrzeń centralna w wyniku rozwoju przestrzennego i funkcjonalnego miasta $z$ czasem także ulega dekapitalizacji technicznej i społecznej w świetle wygenerowania nowocześniejszych jednostek przestrzenno-funkcjonalnych o charakterze centralnym, czyli „,nowej” przestrzeni centralnej. Tym samym można stwierdzić, że podlega ona koniunkturze, wiążącej się z przemiennie występującymi okresami wzrostu, stabilizacji i kryzysu. W konsekwencji w procesie ewolucji przestrzeni centralnej można wyróżnić określone stadia rozwoju, będące egzemplifikacją zmian koniunkturalnych $\mathrm{w}$ przestrzeni centralnej $\mathrm{w}$ miastach europejskich. Odpowiadają one - opisanemu już wcześniej - cyklowi przemian zagospodarowania terenów miejskich opracowanemu przez M. R. G. Conzena $(1960,1962)$ i obejmują wszystkie cztery fazy cyklu zagospodarowania przestrzeni. Wyróżnić także można cykl pierwotny, związany z powstaniem „nowej” przestrzeni centralnej w innej lokalizacji, bądź cykl wtórny, związany z ponownym zagospodarowaniem "starej” przestrzeni centralnej, dostosowanych do aktualnych potrzeb instytucji centrotwórczych. Proces kształtowania „nowej” przestrzeni centralnej może także wiązać się z wtórnym zagospodarowaniem innych terenów miejskich, które wcześniej pełniły odmienne funkcje, i w tym kontekście należy go wiązać m.in. z procesem rewitalizacji wewnątrzmiejskich terenów poprzemysłowych.

Proces generowania „nowej” przestrzeni centralnej w mieście w zmienionej lokalizacji wywołuje zaistnienie zmiennych w czasie relacji pomiędzy „nową" $\mathrm{i}$ „starą" przestrzenią centralną. Są one odzwierciedlone w modyfikacji historycznie ukształtowanej hierarchii terenów miejskich. Istotną rolę w tym procesie pełnią także wewnątrzmiejskie ugory poprzemysłowe, które stanowią współcześnie atrakcyjny obszar lokalizacji instytucji metropolitalnych, co w rezultacie prowadzi do zmian w organizacji przestrzeni centralnej w miastach. 


\section{Rozdział 2}

\section{PROCEDURA BADAWCZA}

W dotychczasowych studiach miejskich nie podejmowano zagadnienia transformacji przestrzeni centralnej $\mathrm{w}$ mieście oraz wpływu rewitalizacji terenów poprzemysłowych na jej organizację. Zdaniem autora przestrzeń centralna jest możliwa do identyfikacji na każdym etapie rozwoju miasta. Składa się ona z form starych i nowych, które w wyniku ewolucji miasta i generowania nowych instytucji wielkomiejskich, wymagających odpowiedniego zagospodarowania, mogą zastąpić formy wcześniej istniejące lub z nimi współistnieć w odrębnych lokalizacjach. Współcześnie, drugi ze wskazanych wariantów wiąże się często $\mathrm{z}$ rewitalizacją wewnątrzmiejskich terenów poprzemysłowych, co w rezultacie skutkuje wykształceniem relacji przestrzenno-funkcjonalnych pomiędzy „starą” i „nową" przestrzenią centralną w mieście. Zasadne staje się zatem pytanie o istotę tych relacji oraz o czynniki, które je determinują. Zdaniem M. Kuleszy (2011) przestrzeń miejska jest instytucjonalnym i plastycznym odzwierciedleniem działalności człowieka na określonym terenie, uwarunkowanej oddziaływaniem licznych czynników wewnętrznych i zewnętrznych, czasem powstania i długością jej istnienia. Przyjmując, że przestrzeń centralna stanowi integralną i kluczową część przestrzeni miejskiej, uzasadnione wydaje się być zawarte w tezie spostrzeżenie o odmiennym wpływie rewitalizacji na organizację tej przestrzeni w różnych miastach. Zważając na fakt, że podjęta problematyka badawcza nie była dotychczas przedmiotem analizy w literaturze, niezbędne jest przedstawienie w niniejszym opracowaniu przyjętego algorytmu postępowania badawczego.

\subsection{Założenia metodologiczne i model struktury procesu badawczego}

Badania nad zależnościami zachodzącymi pomiędzy rewitalizacją wewnątrzmiejskich terenów poprzemysłowych i zmianami w organizacji przestrzeni centralnej w mieście wymagają ujęcia dynamicznego, w którym przestrzeń centralna poddana zostaje analizie morfogenetycznej, oraz ujęcia statycznego, które umożliwia rejestrację przemian morfologicznych i instytucjonalnych w wybranym etapie 
procesu rozwoju przestrzeni centralnej, czyli w jego konkretnym stanie (rys. 2.1). W tym kontekście rewitalizacja traktowana jest jako proces o charakterze egzogenicznym, będący jednym z wielu czynników prowadzących do zmian $\mathrm{w}$ organizacji przestrzeni centralnej w ujęciu historycznym. Celem badacza jest identyfikacja i interpretacja tych zmian.

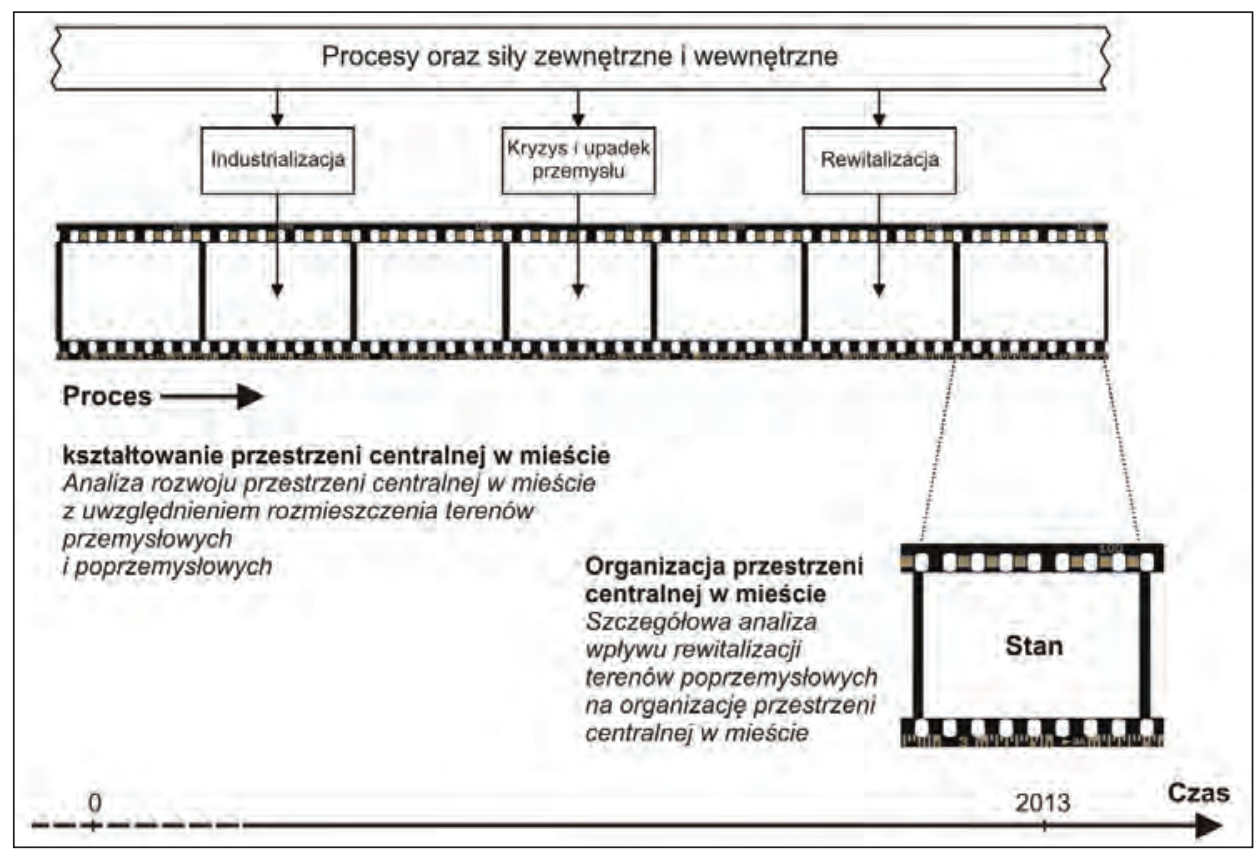

Rys. 2.1. Ideogram graficzny przedstawiający sposób kształtowania przestrzeni centralnej w mieście oraz zmian jej organizacji

Źródło: opracowanie autora na podstawie M. Koter (1994)

Tematyka pracy oraz przyjęte założenia badawcze zadecydowały o wyborze studium przypadku (inaczej: analiza przypadku, ang. case study) jako podstawowej metody umożliwiającej wyczerpującą analizę skutków rewitalizacji w każdym $\mathrm{z}$ miast z osobna. Studium przypadku polega na jednoczesnym stosowaniu wielu metod o charakterze cząstkowym, które pozwalają na opracowanie szczegółowych wniosków (w zakresie jednego przypadku, czyli miasta). W celu skonfrontowania wyników analiz i zobiektywizowania oceny badanego zagadnienia w Manchesterze, Lyonie i Łodzi podjęto także porównawcze studium przypadku.

W procesie badawczym przekształceń przestrzeni centralnej w mieście można wyróżnić pięć etapów (rys. 2.2). Pierwsze cztery są obligatoryjne dla uzyskania wartościowych poznawczo (naukowo) wyników. Mają one charakter empiryczny i teoretyczny. Piąty etap jest natomiast opcjonalny i zależy od przyjętych celów pracy. Ma on charakter aplikacyjny. 


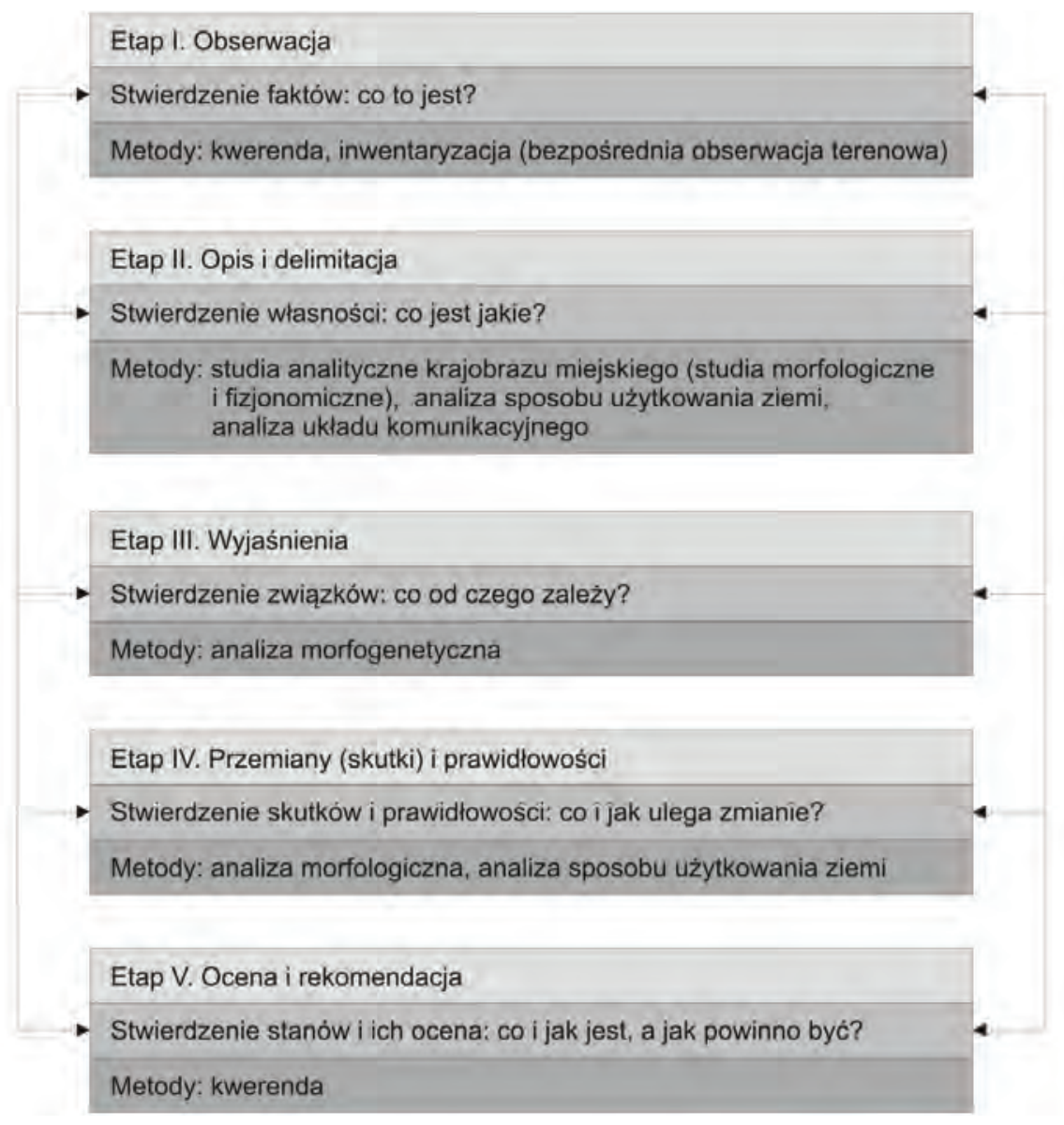

Rys. 2.2. Ideogram graficzny pokazujący algorytm postępowania badawczego w zakresie przekształceń przestrzeni centralnej w mieście

Źródło: opracowanie autora na podstawie A. Matczak (1992)

Pierwszy etap procesu badawczego to obserwacja (eksploracja). Jej celem jest stwierdzenie występowania w mieście przestrzeni centralnej i odpowiedź na pytanie: co to jest? Zdaniem A. Matczaka (1992) eksploracja dostarcza faktów, które są punktem wyjścia $\mathrm{W}$ naukowym poznaniu. W zakresie geografii miast badacz uzyskuje dane w sposób bezpośredni, poprzez badania in situ, a następnie analizę zebranego materiału o charakterze pierwotnym oraz w sposób pośredni poprzez analizę materiału wtórnego. Obserwacja dostarcza faktów naukowych wtedy, gdy jest ona przeprowadzona zgodnie z regułami postępowania naukowego, a fakty te są zapisane językiem odpowiednim dla geografii miast. Ich zgromadzenie nie tworzy wiedzy naukowej, lecz poprzedza czynności związane z klasyfikacją i eksplifikacją (Matczak 1992). Obserwacja stanowi podłoże 
teoretyczne, wprowadzające do studiów nad istotą przestrzeni centralnej w mieście oraz prowadzi do jej identyfikacji w ramach studium przypadku poprzez: kwerendę literatury, kwerendę opracowań kartograficznych, planistycznych i statystycznych oraz inwentaryzację urbanistyczną, której integralnym elementem jest dokumentacja fotograficzna. Obserwację w tym ujęciu można podzielić na studia kameralne, których celem jest zebranie możliwie najbardziej szczegółowych informacji o obszarze badań, oraz badania in situ, polegające na zebraniu materiału pierwotnego oraz weryfikacji i uzupełnieniu danych wtórnych.

Po ustaleniu faktów następuje drugi etap badań, czyli ich uporządkowany opis. Wiąże się on z ustaleniem części składowych analizowanej przestrzeni centralnej oraz z identyfikacją ich właściwości w ramach studium przypadku konkretnego miasta. W badaniach uwzględnia się przede wszystkim wymiar morfologiczny (morfologia sensu stricto) oraz instytucjonalny. Celem tego etapu badań jest ustalenie odpowiedzi na pytanie: co to jest stara i nowa przestrzeń centralna $\mathrm{w}$ danym mieście? Integralnym elementem opisu części składowych przestrzeni centralnej jest ich delimitacja na podstawie: studiów analitycznych krajobrazu miejskiego, analizy sposobu użytkowania ziemi, analizy układu komunikacyjnego.

Trzeci etap badań to wyjaśnienie (eksplifikacja). Jego istotą jest poszukiwanie związków i zależności pomiędzy starą i nową przestrzenią centralną w mieście w ramach studium przypadku. W rozpoznaniu przyczyn skutków oraz skutków przyczyn niezbędna jest analiza morfogenetyczna dotycząca genezy i rozwoju przestrzeni centralnej w mieście. Uwzględnia ona także oddziaływanie sił i procesów o charakterze wewnętrznym i zewnętrznym na sposób ewolucji przestrzeni centralnej. Analizy te obejmują kwerendę materiałów kartograficznych oraz studia pisanych źródeł historycznych. Umożliwiają one badania nad przekształceniami przestrzennymi i instytucjonalnymi przestrzeni centralnej wybranych miast w ujęciu retrospektywnym. Celem trzeciego etapu badań jest odpowiedź na pytanie: od czego zależy wygenerowanie nowej przestrzeni centralnej oraz jak ewoluowała istniejąca wcześniej przestrzeń centralna w mieście?

Kolejny etap obejmuje analizę skutków wywołanych przez rewitalizację, ich wpływu na organizację przestrzeni centralnej w mieście (w ramach studium przypadku) oraz ewentualną identyfikację prawidłowości i różnic tego procesu (w ramach porównawczego studium przypadku). Rewitalizacja wewnątrzmiejskich terenów poprzemysłowych prowadzi do wygenerowania nowej przestrzeni centralnej w mieście, co niesie ze sobą konsekwencje dla organizacji przestrzeni centralnej w mieście, jako nowego układu. Reperkusje tego procesu mogą być zróżnicowane, co oznacza, że istnieje potrzeba wyjaśnienia przyczyn ich odmienności zarówno w wymiarze morfologicznym, jak i instytucjonalnym. Dotyczy to rozpoznania efektu kooperacji, efektu konkurencji oraz efektu konglomeracji starej i nowej przestrzeni centralnej w mieście. Istotą czwartego etapu badań w wąskim ujęciu jest uzyskanie odpowiedzi na pytanie: jakim zmianom podlega organizacja przestrzeni centralnej w wyniku rewitalizacji wewnątrzmiejskich 
terenów poprzemysłowych? W tym miejscu może zostać zakończona analiza w ramach pojedynczego studium przypadku, którego celem jest identyfikacja zakresu przekształceń przestrzenno-funkcjonalnych w każdym z miast z osobna. W szerszym kontekście podejmowane są natomiast studia porównawcze, których celem jest odnalezienie podobieństw i różnic $\mathrm{w}$ ramach większego zbioru miast, umożliwiających wskazanie bardziej ogólnych prawidłowości w zakresie wpływu rewitalizacji wewnątrzmiejskich terenów poprzemysłowych na zmiany w organizacji przestrzeni centralnej w mieście.

Piąty etap to krytyczna ocena wpływu rewitalizacji wewnątrzmiejskich terenów poprzemysłowych na organizację przestrzeni centralnej $\mathrm{w}$ mieście. W przypadku porównawczego studium przypadku jej efektem jest katalog rekomendacji dla transformacji przestrzeni centralnej w mieście, które znajduje się na niższym poziomie zaawansowania procesu rewitalizacji niż miasto lub miasta, na podstawie doświadczeń których jest ten katalog opracowany. W sytuacji analizy jednego tylko miasta rekomendacje mogą dotyczyć optymalizacji procesu kształtowania przestrzeni centralnej. W obu przypadkach istotne jest odniesienie się do dokumentów i planów rewitalizacji terenów poprzemysłowych (kwerenda w pierwszym etapie badań) oraz ich ocena. Clou dla tego etapu analizy jest odpowiedź na pytanie: co i jak jest, a jak powinno/może być?

\subsection{Charakterystyka parametrów}

Przyjęty algorytm postępowania badawczego wymaga sprecyzowania cech morfologicznych i funkcjonalnych dla obszarów, które poddane zostały analizie w kolejnych etapach studiów analitycznych (II, III i IV), oraz określenia szczegółowych parametrów, wykorzystanych w całym procesie badawczym.

Od strony metodycznej wyróżnić można dwa typy parametrów w zależności od kryterium podstawy odniesienia. Są to parametry służące do oceny:

a) bezwzględnej, które umożliwiają jednoznaczną ocenę konkretnego zjawiska bez konieczności odwoływania się do wielkości osiąganych przez inne miasta;

b) względnej, które są formułowane na podstawie analizy porównawczej zbioru miast i są prawdziwe jedynie w kontekście przyjętej bazy odniesienia.

W pracy wykorzystano parametry o charakterze względnym, co uwarunkowane jest trudnościami w formułowaniu mierników o charakterze bezwzględnym oraz brakiem wzorca przestrzeni centralnej, szczególnie w kontekście kształtowania nowej przestrzeni centralnej na terenach poprzemysłowych.

Parametry można podzielić na ilościowe i jakościowe. Przez parametr rozumie się liczbowo wymierną cechę, która, opisując wybrany aspekt rzeczywistości, nie podlega uprzednio operacjom agregacji, czyli odpowiedniego łączenia wielkości, które rodzajowo są odmienne. Parametry muszą być bezpośrednio lub pośrednio 
kwantyfikowalne. W pracy wykorzystano parametry bezpośrednio kwantyfikowalne, identyfikowane z ilościowymi oraz parametry jakościowe, które poddano pośredniej kwantyfikacji w celu ich operacjonalizacji.

Ocena wpływu rewitalizacji na organizację przestrzeni centralnej w mieście wiąże się z dwustopniowym procesem analitycznym:

1) Identyfikacją intensywności zmian morfologicznych i funkcjonalnych terenów poprzemysłowych w procesie kształtowania przestrzeni centralnej w każdym $\mathrm{z}$ analizowanych miast $\mathrm{w}$ czasie $T_{1}$ (przed rewitalizacją) i $T_{2}$ (po rewitalizacji).

2) Identyfikacją relacji, jakie zostały wykształcone pomiędzy starą (historyczną) przestrzenią centralną a nową przestrzenią centralną wygenerowaną w efekcie przekształceń morfologiczno-instytucjonalnych (w czasie $T_{2}$ ).

Takie ujęcie problemu wymagało opracowania odmiennego zestawu cech morfologicznych i funkcjonalnych oraz parametrów je opisujących, na podstawie których można zdiagnozować badane zjawiska. Dla analizy intensywności zmian na terenach poprzemysłowych wyróżniono 8 parametrów opisujących cechy morfologiczne, które zostały zgrupowane w 3 komponentach (grupach cech) oraz 3 parametry z zakresu sposobu użytkowania terenów poprzemysłowych jako zestaw cech w ramach jednego komponentu (tab. 2.1 i 2.2).

Tabela 2.1. Zestawienie parametrów morfologicznych w ramach analizy pierwszego stopnia

\begin{tabular}{|l|c|}
\hline \multicolumn{1}{|c|}{ Nazwa cechy i parametry } & Jednostka miary \\
\hline $\begin{array}{l}\text { 1. Intensywność zmian układu komunikacyjnego na terenach poprzemy- } \\
\text { słowych }\end{array}$ & $\mathrm{m}$ \\
\hline 1.1. Długość dróg kołowych w czasie $T_{1} \mathrm{i} T_{2}$ & $\mathrm{~m}$ \\
\hline 1.2. Długość naziemnych linii kolejowych w czasie $T_{1} \mathrm{i} T_{2}$ & $\mathrm{~m}$ \\
\hline 1.3. Długość nowych linii tramwajowych w czasie $T_{1} \mathrm{i} T_{2}$ & ha \\
\hline \begin{tabular}{l} 
2. Intensywność zmian zabudowy terenów poprzemysłowych \\
\hline 2.1. Powierzchnia zabudowy w czasie $T_{1} \mathrm{i} T_{2}$
\end{tabular} & ha \\
\hline $\begin{array}{l}\text { 2.2. Powierzchnia nowo wzniesionej zabudowy (wybudowanej w ra- } \\
\text { mach rewitalizacji) w czasie } T_{1} \mathrm{i} T_{2}\end{array}$ & - \\
\hline $\begin{array}{l}\text { 2.3. Powierzchnia zachowanej dawnej zabudowy użytkowanej przez } \\
\text { przemysł w czasie } T_{1} \mathrm{i} T_{2}\end{array}$ & ha \\
\hline $\begin{array}{l}\text { 3. Intensywność zmian fizjonomii terenów poprzemysłowych } \\
\text { 3.1. Powierzchnia dawnej zabudowy użytkowanej przez przemysł, która } \\
\text { została poddana renowacji } \mathrm{i} \text { adaptacji na nowe funkcje w ramach } \\
\text { procesu rewitalizacji w czasie } T_{1} \mathrm{i} T_{2}\end{array}$ & $\mathrm{~m}$ \\
\hline $\begin{array}{l}\text { 3.2. Długość ogólnodostępnej linii dostępu do wody (rzeki, kanały, zbior- } \\
\text { niki wodne) w czasie } T_{1} \mathrm{i} T_{2} \text { (od rozpoczęcia procesu rewitalizacji) }\end{array}$ & \\
\hline
\end{tabular}

Źródło: opracowanie autora. 
Tabela 2.2. Zestawienie parametrów z zakresu sposobu użytkowania w ramach analizy pierwszego stopnia

\begin{tabular}{|c|c|}
\hline Nazwa cechy i parametry & Jednostka miary \\
\hline 1. Intensywność zmian w zakresie użytkowania terenów poprzemysłowych & - \\
\hline $\begin{array}{l}\text { 1.1. Powierzchnia zabudowy zajmowanej przez funkcję usługową w cza- } \\
\text { sie } T_{1} \mathrm{i} T_{2}\end{array}$ & ha \\
\hline $\begin{array}{l}\text { 1.2. Powierzchnia zabudowy zajmowanej przez funkcję mieszkaniową } \\
\text { w czasie } T_{1} \mathrm{i} T_{2}\end{array}$ & ha \\
\hline $\begin{array}{l}\text { 1.3. Powierzchnia zabudowy zajmowanej przez nieużytki poprzemy- } \\
\text { słowe lub funkcję produkcyjną w czasie } T_{1} \mathrm{i} T_{2}\end{array}$ & \\
\hline
\end{tabular}

Źródło: opracowanie autora.

W kontekście przyjętego problemu badawczego parametry muszą jednoznacznie wskazywać na wysoką $\left(\mathrm{W}_{\mathrm{p}}\right)$, umiarkowaną $\left(\mathrm{U}_{\mathrm{P}}\right)$ i niską $\left(\mathrm{N}_{\mathrm{p}}\right)$ intensywność zmian przestrzenno-funkcjonalnych na terenach poprzemysłowych. Ze względu na zróżnicowanie wielkości powierzchni analizowanych terenów poprzemysłowych oraz odmienny sposób ich zagospodarowania przed rozpoczęciem działań rewitalizacyjnych (w czasie $T_{1}$ ), jak też w celu umożliwienia porównania zakresu przekształceń przestrzenno-funkcjonalnych różnych obszarów zachodzi konieczność skonstruowania skali wyrażającej procentową zmianę (wzrost lub spadek) analizowanej cechy w okresie $T_{1} \mathrm{i} T_{2}$. W tym ujęciu porównywana jest zmiana wartości każdej cechy dla każdego obszaru w czasie $T_{2}$ (w 2013 r.) w stosunku do wartości parametru dla tej samej cechy na tym samym obszarze w czasie $T_{1}$ (przed rozpoczęciem rewitalizacji).

Stopień intensywności przekształceń terenów poprzemysłowych obliczono na podstawie wzoru:

$$
P=\frac{|x-y|}{x} 100 \%,
$$

gdzie:

$P$ - intensywność zmian przestrzenno-funkcjonalnych na terenach poprzemysłowych w czasie $T_{1}$ (przed rewitalizacją) i $T_{2}$ (po rewitalizacji);

$x$ - wartość dla parametru opisującego analizowany obszar w czasie $T_{1}$;

$y$ - wartość dla parametru opisującego analizowany obszar w czasie $T_{2}$.

Dla każdego z analizowanych parametrów przyjęto następującą skalę:

- wysoka intensywność zmian $\left(\mathrm{P}_{\mathrm{w}}\right)$, w której zidentyfikowano ponad 75\% zmianę wartości analizowanej cechy: $\mathrm{P}_{\mathrm{w}} \in\langle 76 ;+\infty\rangle$;

- umiarkowana intensywność zmian $\left(\mathrm{P}_{\mathrm{U}}\right)$, w której zidentyfikowano od 51 do $75 \%$ zmianę wartości analizowanej cechy: $\mathrm{P}_{\mathrm{U}} \in\langle 51 ; 75\rangle$;

- niska intensywność zmian $\left(\mathrm{P}_{\mathrm{N}}\right)$, w której zidentyfikowano maksymalnie $50 \%$ zmianę wartości analizowanej cechy: $\mathrm{P}_{\mathrm{N}} \in\langle 0 ; 50\rangle$. 
W sytuacji, gdy wartość parametru w czasie $T_{1}$ wynosiła $0(\mathrm{x}=0)$, a wartość tego samego parametru w czasie $T_{2}$ była większa od $0(\mathrm{y}>0)$, identyfikowano wysoki stopień intensywności zmian $\left(\mathrm{P}_{\mathrm{w}}\right)$. W sytuacji, gdy wartość parametru w czasie $T_{1}$ i $T_{2}$ wynosiła zero $(\mathrm{x}=0 \mathrm{i} \mathrm{y}=0)$, identyfikowano niski stopień intensywności zmian.

Dodatni lub ujemny znak przed wartością oznacza wzrost lub spadek wartości analizowanego parametru.

Im więcej parametrów wskazujących na wysoką intensywność zmian $\left(\mathrm{P}_{\mathrm{w}}\right)$ i im mniej parametrów umożliwiających identyfikację niskiej intensywności przekształceń $\left(\mathrm{P}_{\mathrm{N}}\right)$, tym wyższa intensywność procesu kształtowania przestrzeni centralnej na dawnych terenach przemysłowych. W celu identyfikacji zmian i możliwości ich porównania na wyższych poziomach agregacji (komponentu oraz miasta) skonstruowano skalę liniową, na której zaznaczono:

- wysoką intensywność zmian $\left(\mathrm{W}_{\mathrm{P}}\right)$, identyfikowaną na podstawie występowania więcej niż $75 \%$ analizowanych parametrów wskazujących na wysoką intensywność zmian (co najmniej 8 parametrów);

- umiarkowaną intensywność zmian $\left(\mathrm{U}_{\mathrm{p}}\right)$, identyfikowaną na podstawie występowania $51-75 \%$ analizowanych parametrów wskazujących na wysoką intensywność zmian (6-7 parametrów);

- niską intensywność zmian $\left(\mathrm{N}_{\mathrm{p}}\right)$, identyfikowaną na podstawie występowania maksymalnie $50 \%$ analizowanych parametrów wskazujących na wysoką intensywność zmian (5 lub mniej parametrów) i przewadze pozostałych parametrów wskazujących na niski stopień intensywności zmian.

$\mathrm{W}$ obu skalach identyfikacji intensywności zmian terenów poprzemysłowych wyróżniono przedziały o nierównej rozpiętości $(0-50 \%, 51-75 \%$, powyżej $75 \%$ ), co wynika z charakterystyki procesu rewitalizacji, którego celem, zgodnie z przyjętą definicją S. Kaczmarek (2010), jest szeroko rozumiane ożywienie zdegradowanego obszaru poprzez istotne przekształcenia w wymiarze przestrzennym i funkcjonalnym. Założono, że wskaźniki o wartości nieprzekraczającej 50\% zmiany wielkości analizowanej cechy, a następnie wszystkich analizowanych parametrów wskazujących na wysoką intensywność zmian, sugerowałyby jedynie modyfikacje struktury przestrzenno-funkcjonalnej przekształcanego obszaru. Tego typu przemiany mogą być typowe dla działań inwestycyjnych związanych z ekstensywnym charakterem użytkowania i procesu naprawczego, np. w ramach dzierżawy czy przebudowy pojedynczych elementów morfologicznych, a nie daleko idące działania łączone $\mathrm{z}$ faktycznym procesem rewitalizacji i wiążącego się z nim ożywienia zdegradowanego fragmentu przestrzeni miejskiej. Biorąc jedynie pod analizę przemiany morfologiczne (cechy z grupy 1, 2 i 3 - por. tab. 2.1), można wyróżnić działania o charakterze:

- rewitalizacji sensu largo, identyfikowaną na podstawie występowania co najmniej 50\% parametrów wskazujących na wysoką intensywność zmian $\left(\mathrm{W}_{\mathrm{P}}\right)$, 
natomiast wyróżnienie radykalnej lub historyzującej formy rewitalizacji sensu largo wymaga szczegółowej analizy fizjonomii nowej zabudowy oraz zgodności podziału działek miejskich, a także układu elementów liniowych (ulic) sprzed i po zakończeniu (względnie aktualnego dla czasu badań) procesu inwestycyjnego;

- rewitalizacji właściwej (sensu stricto), identyfikowaną na podstawie występowania mniej niż 50\% parametrów wskazujących na wysoką intensywność zmian $\left(\mathrm{W}_{\mathrm{p}}\right)$.

Proces identyfikacji relacji pomiędzy starą i nową przestrzenią centralną składa się z dwóch etapów. Pierwszy obejmuje analizę stopnia zróżnicowania starej i nowej przestrzeni centralnej. W tym celu wyróżniono 7 parametrów morfologicznych zgrupowanych w 3 komponentach (grupach cech) oraz 4 parametry $\mathrm{z}$ zakresu sposobu użytkowania starej i nowej przestrzeni centralnej w mieście, zgrupowane w 3 komponentach (grupach cech) (tab. 2.3 i 2.4 ).

Tabela 2.3. Zestawienie parametrów morfologicznych w ramach analizy drugiego stopnia

\begin{tabular}{|c|c|}
\hline Nazwa cechy i parametry & Jednostka miary \\
\hline $\begin{array}{l}\text { 1. Stopień zróżnicowania przestrzeni zamkniętych i otwartych w nowej i starej } \\
\text { przestrzeni centralnej }\end{array}$ & - \\
\hline 1.1. Powierzchnia nowej i starej przestrzeni centralnej & ha \\
\hline $\begin{array}{l}\text { 1.2. Powierzchnia przestrzeni zamkniętych w nowej i starej przestrzeni cen- } \\
\text { tralnej }\end{array}$ & ha \\
\hline $\begin{array}{l}\text { 1.3. Powierzchnia przestrzeni otwartych } \mathrm{w} \text { nowej i starej przestrzeni cen- } \\
\text { tralnej }\end{array}$ & ha \\
\hline $\begin{array}{l}\text { 2. Stopień zróżnicowania przestrzeni publicznej w starej i nowej przestrzeni } \\
\text { centralnej }\end{array}$ & - \\
\hline $\begin{array}{l}\text { 2.1. Powierzchnia przestrzeni publicznej integrującej (place miejskie) w no- } \\
\text { wej i starej przestrzeni centralnej }\end{array}$ & ha \\
\hline $\begin{array}{l}\text { 2.2. Powierzchnia terenów ruchu pieszego (inne strefy piesze bez placów) } \\
\text { w nowej i starej przestrzeni centralnej }\end{array}$ & ha \\
\hline 3. Stopień zróżnicowania w fizjonomii starej i nowej przestrzeni centralnej & - \\
\hline 3.1. Rozmieszczenie placów miejskich w starej i nowej przestrzeni centralnej & $\mathrm{L}$ \\
\hline $\begin{array}{l}\text { 3.2. Rozmieszczenie obiektów powyżej } 50 \mathrm{~m} \text { wysokości w starej i nowej } \\
\text { przestrzeni centralnej }\end{array}$ & $\mathrm{L}$ \\
\hline
\end{tabular}

Źródło: opracowanie autora.

W kontekście przyjętego problemu badawczego parametry muszą jednoznacznie wskazywać na wysoki $\left(\mathrm{W}_{\mathrm{Z}}\right)$, umiarkowany $\left(\mathrm{U}_{\mathrm{Z}}\right)$ lub niski $\left(\mathrm{N}_{\mathrm{Z}}\right)$ stopień zróżnicowania starej i nowej przestrzeni centralnej w każdym mieście. W celu umożliwienia porównania stopnia zróżnicowania starej i nowej przestrzeni centralnej $\mathrm{w}$ zbiorze analizowanych miast na poziomie konkretnej cechy oraz na wyższych poziomach agregacji (komponentu i miasta) za pomocą zestandaryzowanych wartości zastosowano skalę wyrażającą procentową wielkość analizowanej 
cechy nowej przestrzeni centralnej względem starej. Standaryzacja oznaczała zatem sprowadzenie wszystkich wartości analizowanych parametrów do wielkości procentowej. Konieczność zastosowania tak skonstruowanej skali wynika $\mathrm{z}$ odmiennych cech morfologicznych i instytucjonalnych przestrzeni centralnej, jakie może ona posiadać w każdym mieście. Oznacza to, że procedurę badawczą można powtórzyć w dowolnym zbiorze miast. Celem tej części analizy nie jest określenie poziomu jej rozwinięcia (do czego zastosowano analizę morfogenetyczną), a jedynie wskazanie zakresu jej zróżnicowania determinującą konkretne relacje przestrzenno-funkcjonalne.

Tabela 2.4. Zestawienie parametrów z zakresu sposobu użytkowania w ramach analizy drugiego stopnia

\begin{tabular}{|c|c|}
\hline \multicolumn{1}{|c|}{ Nazwa cechy i parametry } & Jednostka miary \\
\hline $\begin{array}{l}\text { 1. Stopień zróżnicowania w sposobie użytkowania ziemi w starej i nowej prze- } \\
\text { strzeni centralnej }\end{array}$ & - \\
\hline $\begin{array}{l}\text { 1.1. Powierzchnia zajmowanej przez funkcje wielkomiejskie w starej i nowej } \\
\text { przestrzeni centralnej }\end{array}$ & ha \\
\hline $\begin{array}{l}\text { 2. Stopień zróżnicowania rozmieszczenia instytucji centralnych w starej i nowej } \\
\text { przestrzeni centralnej }\end{array}$ & L \\
\hline $\begin{array}{l}\text { 2.1. Rozmieszczenie instytucji publicznych w starej i nowej przestrzeni cen- } \\
\text { tralnej }\end{array}$ & $\mathrm{L}$ \\
\hline $\begin{array}{l}\text { 2.2. Rozmieszczenie obiektów wybudowanych w ramach projektów wiodą- } \\
\text { cych w starej i nowej przestrzeni centralnej }\end{array}$ & - \\
\hline $\begin{array}{l}\text { 3. Stopień zróżnicowania w zakresie zewnętrznej dostępności komunikacyjnej } \\
\text { starej i nowej przestrzeni centralnej }\end{array}$ & $\mathrm{L}$ \\
\hline $\begin{array}{l}\text { 3.1. Liczba nowych instytucji centralnych i projektów wiodaccych w ekwidy- } \\
\text { stancie 15 minut od dworców kolejowych i autobusowych (punkty węzło- } \\
\text { we o randze ponadlokalnej) w starej i nowej przestrzeni centralnej }\end{array}$ & \\
\hline
\end{tabular}

Źródło: opracowanie autora.

Stopień zróżnicowania starej i nowej przestrzeni centralnej obliczono na podstawie wzoru:

$$
Z=\frac{|x-y|}{x+y} 100 \%,
$$

gdzie:

$Z$ - zróżnicowanie starej i nowej przestrzeni centralnej w czasie $T_{2}$;

$x$ - wartość dla parametru opisującego starą przestrzeń centralną w czasie $T_{2}$;

$y$ - wartość dla parametru opisującego nową przestrzeń centralną w czasie $T_{2}$.

Dla każdego z analizowanych parametrów przyjęto następującą skalę:

- wysoki stopień zróżnicowania $\left(\mathrm{Z}_{\mathrm{w}}\right)$, w której zidentyfikowano ponad $75 \%$ różnicę wartości analizowanej cechy: $Z_{\mathrm{w}} \in\langle 76 ;+\infty\rangle$; 
- umiarkowany stopień zróżnicowania $\left(\mathrm{Z}_{\mathrm{U}}\right)$, w której zidentyfikowano od 51 do $75 \%$ różnicę wartości analizowanej cechy: $Z_{U} \in\langle 51 ; 75\rangle$;

- niski stopień zróżnicowania $\left(Z_{\mathrm{N}}\right)$, w której zidentyfikowano maksymalnie $50 \%$ różnicę wartości analizowanej cechy: $Z_{N} \in\langle 0 ; 50\rangle$.

W celu identyfikacji stopnia zróżnicowania starej i nowej przestrzeni centralnej skonstruowano skalę prostoliniową, na której zaznaczono:

- wysoki stopień zróżnicowania $\left(\mathrm{W}_{\mathrm{z}}\right)$, identyfikowany na podstawie występowania co najmniej 51\% analizowanych parametrów (co najmniej 6 parametrów) wskazujących na wysoki $\left(\mathrm{Z}_{\mathrm{W}}\right)$ i umiarkowany $\left(\mathrm{Z}_{\mathrm{U}}\right)$ stopień zróżnicowania;

- umiarkowany stopień zróżnicowania $\left(\mathrm{U}_{\mathrm{Z}}\right)$, identyfikowany na podstawie występowania co najmniej 51\% analizowanych parametrów (co najmniej 5) wskazujących na umiarkowany $\left(Z_{U}\right)$ stopień zróżnicowania starej i nowej przestrzeni centralnej bądź mniej niż 51\% analizowanych parametrów (co najmniej 5 parametrów) wskazujących na wysoki $\left(\mathrm{Z}_{\mathrm{W}}\right)$ i umiarkowany $\left(\mathrm{Z}_{\mathrm{U}}\right)$ stopień zróżnicowania lub na niski $\left(Z_{N}\right)$ i umiarkowany $\left(Z_{U}\right)$ stopień zróżnicowania;

- niski stopień zróżnicowania $\left(\mathrm{N}_{\mathrm{Z}}\right)$, identyfikowany na podstawie występowania co najmniej 51\% analizowanych parametrów (co najmniej 6 parametrów) wskazujących na niski $\left(Z_{\mathrm{N}}\right)$ i umiarkowany $\left(Z_{\mathrm{U}}\right)$ stopień zróżnicowania.

W obu skalach identyfikacji stopnia zróżnicowania starej i nowej przestrzeni centralnej wyróżniono przedziały o nierównej rozpiętości $(0-50 \%, 51-75 \%$, powyżej 75\%). Podobnie jak w przypadku opracowania skali identyfikacji intensywności przemian morfologicznych i instytucjonalnych terenów poprzemysłowych, przyjęty podział skali wynika $\mathrm{z}$ właściwości procesu rewitalizacji. W celu ożywienia zdegradowanych terenów miejskich podejmowane są działania naprawcze, które w istotnym stopniu ingerują w zastaną strukturę morfologiczną i przede wszystkim funkcjonalną. Wychodząc $\mathrm{z}$ tego założenia, przyjęto, że wskaźniki o wartości poniżej 50\% wskazujące na zmiany wielkości analizowanej cechy, a następnie wszystkich analizowanych parametrów wskazujących na niski stopnień zróżnicowania, mogłyby sugerować zaledwie modyfikację struktury przestrzenno-funkcjonalnej przekształcanego obszaru. Oznaczałoby to tym samym, że wyposażenie nowej jednostki morfologicznej w układzie miejskim zachowałoby $\mathrm{w}$ daleko idącym stopniu cechy terenu (względnie ugoru) poprzemysłowego, co nie pozwalałoby utożsamiać tego obszaru z nową przestrzenią centralną miasta, charakteryzującego się znacznym udziałem terenów zajmowanych przez funkcje wielkomiejskie.

W drugim etapie identyfikacji relacji zachodzących pomiędzy starą i nową przestrzenią centralną w badanym mieście wyróżniono 6 cech (wskaźników cząstkowych) umożliwiających określenie poziomu rozwinięcia przestrzeni centralnej w czasie $T_{2}$ (tab. 2.5). Każdy z kolejnych wskaźników $\left(\mathrm{W}_{1}, \mathrm{~W}_{2}, \ldots, \mathrm{W}_{6}\right)$ stanowi iloraz parametru $a$ i $b$. 
Tabela 2.5. Wskaźniki cząstkowe do identyfikacji stopnia rozwinięcia przestrzeni centralnej w badanym mieście w czasie $T_{2}$

\begin{tabular}{|c|l|l|}
\hline $\mathrm{W}$ & \multicolumn{1}{|c|}{ Parametr $a$} & \multicolumn{1}{|c|}{ Parametr $b$} \\
\hline $\mathrm{W}_{1}$ & $\begin{array}{l}\text { Powierzchnia przestrzeni centralnej czasie } T_{2} \\
\text { (w ha) }\end{array}$ & Liczba ludności miasta w czasie $T_{2}$ \\
\hline $\mathrm{W}_{2}$ & $\begin{array}{l}\text { Liczba jednostek morfologicznych kształtują- } \\
\text { cych przestrzeń centralną miasta w czasie } T_{2}\end{array}$ & $\begin{array}{l}\text { Powierzchnia przestrzeni centralnej w cza- } \\
\text { sie } T_{2}(\mathrm{w} \text { ha) }\end{array}$ \\
\hline $\mathrm{W}_{3}$ & $\begin{array}{l}\text { Liczba instytucji publicznych w czasie } T_{2} \\
\mathrm{~W}_{4}\end{array}$ & $\begin{array}{l}\text { Powierzchnia przestrzeni centralnej w cza- } \\
\text { sie } T_{2}(\mathrm{w} \text { ha) }\end{array}$ \\
\hline $\mathrm{W}_{5}$ & $\begin{array}{l}\text { Liczba placów w przestrzeni centralnej w cza- } \\
\text { sie } T_{2}\end{array}$ & $\begin{array}{l}\text { Powierzchnia przestrzeni centralnej w cza- } \\
\text { sie } T_{2}(\mathrm{w} \text { ha) }\end{array}$ \\
\hline $\mathrm{W}_{6}$ & $\begin{array}{l}\text { Liczba instytucji publicznych w przestrzeni } \\
\text { centralnej w czasie } T_{2}\end{array}$ & \begin{tabular}{l} 
Liczba ludności miasta w czasie $T_{2}$ \\
\hline
\end{tabular}
\end{tabular}

Źródło: opracowanie autora.

W kolejnym etapie postępowania badawczego, w celu kompleksowego ujęcia poziomu rozwinięcia przestrzeni centralnej, skonstruowano syntetyczny wskaźnik poziomu rozwinięcia przestrzeni centralnej $\left(\mathrm{W}_{\mathrm{S}}\right) \mathrm{w}$ oparciu o metodę J. Perkala i zgodnie ze wzorem:

gdzie:

$$
\mathrm{Ws}=\frac{\sum_{j=1}^{p} y_{i j}}{p},
$$

Ws - wskaźnik syntetyczny;

$j-1,2, \ldots, p$;

$p$ - liczba uwzględnionych cech (wskaźników cząstkowych);

$y_{i j}$ - standaryzowana wartość $j$-tej cechy dla $i$-tego obiektu;

jeśli:

$$
y_{i j}=\frac{x_{i j}-\bar{x}_{j}}{\mathrm{~S}_{j}},
$$

$x_{i j}$ - wartość $j$-tej cechy dla $i$-tego obiektu;

$\bar{x}_{j}-$ średnia arytmetyczna wartości $j$-tej cechy;

$S_{j}$ - odchylenie standardowe wartości $j$-tej cechy.

Metoda J. Perkala umożliwiła otrzymanie jednego syntetycznego wskaźnika dla poziomu rozwoju przestrzeni centralnej $\left(\mathrm{W}_{\mathrm{S}}\right) \mathrm{w}$ badanym mieście w czasie $T_{2}$. Wskaźnik ten może przyjmować wartość $\mathrm{w}$ granicach od -3 do 3 , przy czym rozwinięta przestrzeń centralna będzie przyjmować wartości powyżej 0 , średnio rozwinięta - bliskie 0 , a słabo rozwinięta - poniżej 0 . Za podobne uznawane są przestrzenie o zbliżonej wartości wskaźnika $\mathrm{W}_{\mathrm{S}}$.

Identyfikacja charakteru relacji $\mathrm{w}$ przestrzeni centralnej badanych miast w czasie $T_{2}$ jest dokonywana w oparciu o analizę matrycy zależności pomiędzy 
stopniem zróżnicowania i rozwinięcia przestrzeni centralnej a występowaniem relacji konkurencyjnych, kooperacyjnych i konglomeracyjnych w przestrzeni centralnej miast (rys. 2.3). Na jej podstawie opracowano szczegółową typologię relacji zachodzących w przestrzeni centralnej oraz możliwości ich przekształcenia (konwersji planowanej lub nieplanowanej) w inny typ relacji (tab. 2.6).

\begin{tabular}{|c|c|c|c|c|}
\hline \multirow{2}{*}{\multicolumn{2}{|c|}{$\begin{array}{c}\text { RELACJE } \\
\text { W PRZESTRZENI } \\
\text { CENTRALNEJ }\end{array}$}} & \multicolumn{3}{|c|}{ Poziom rozwinięcia przestrzeni centralnej } \\
\hline & & wysoki & średni & niski \\
\hline \multirow{3}{*}{ 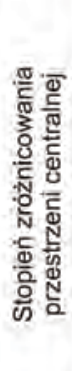 } & Wysoki & D & $\mathbf{E}$ & $\mathbf{G}$ \\
\hline & Umiarkowany & C & $F$ & H \\
\hline & Niski & B & A & 1 \\
\hline
\end{tabular}

\section{A, B, C - relacje konkurencyjne D, E, F-relacje kooperacyjne $\quad G, H, I$ - relacje konglomeracyjne}

Rys. 2.3. Matryca zależności pomiędzy stopniem zróżnicowania i rozwinięcia przestrzeni centralnej a występowaniem relacji konkurencyjnych, kooperacyjnych i konglomeracyjnych w przestrzeni centralnej miast europejskich

\section{Źródło: opracowanie autora}

Wyróżnić można pewne zależności decydujące o możliwości przekształceń relacji na inny typ. Im wyższy poziom rozwinięcia i zróżnicowania przestrzeni centralnej, tym trudniej dokonać konwersji relacji. Im słabiej rozwinięta i zróżnicowana przestrzeń centralna, tym proces ten jest trudniejszy. O możliwości przekształceń relacji w przestrzeni centralnej decyduje w pierwszej kolejności stopień zróżnicowania starej i nowej przestrzeni centralnej, a następnie poziom rozwoju przestrzeni jako całego układu. Zakres zróżnicowania starej i nowej przestrzeni centralnej jest możliwy do konwersji w wyniku intensywnych działań inwestycyjnych, np. w ramach rewitalizacji terenów poprzemysłowych. Poziom rozwinięcia przestrzeni centralnej jest natomiast procesem wynikowym $\mathrm{w}$ stosunku do działań podjętych w przestrzeni centralnej jako całości.

W oparciu o uzyskane wyniki studiów, zaproponowana typologia umożliwi realizację piątego cząstkowego celu badawczego pracy (patrz rys. W.1 i s. 21), jakim jest opracowanie katalogu rekomendacji dla rozwiązania problemów kształtowania centralnej przestrzeni w Łodzi, z wykorzystaniem doświadczeń Manchesteru i Lyonu. 
Tabela 2.6. Typologia relacji w przestrzeni centralnej miasta

\begin{tabular}{|c|c|}
\hline Typ relacji & Właściwości relacji przestrzenno-funkcjonalnych w przestrzeni centralnej \\
\hline \multicolumn{2}{|c|}{ Konkurencyjne } \\
\hline A & $\begin{array}{l}\text { Relacje słabo konkurencyjne, łatwe do przekształcenia na inny typ ze względu na } \\
\text { niski stopień zróżnicowania starej i nowej przestrzeni centralnej, która łącznie cha- } \\
\text { rakteryzuje się średnim poziomem rozwinięcia, co stwarza możliwość modyfikacji } \\
\text { struktury morfologicznej i funkcjonalnej. }\end{array}$ \\
\hline B & $\begin{array}{l}\text { Relacje silnie konkurencyjne, trudne do przekształcenia na innych typ relacji ze } \\
\text { względu na niski stopień zróżnicowania starej i nowej przestrzeni centralnej, która } \\
\text { łącznie charakteryzuje się wysokim poziomem rozwinięcia. }\end{array}$ \\
\hline $\mathrm{C}$ & $\begin{array}{l}\text { Relacje średnio konkurencyjne, możliwe do przekształcenia na inny typ relacji ze } \\
\text { względu na umiarkowany stopień zróżnicowania przestrzeni centralnej. Barierą kon- } \\
\text { wersji na inny typ relacji jest wysoki poziom rozwinięcia przestrzeni centralnej, który } \\
\text { ogranicza możliwość modyfikacji struktury morfologicznej i funkcjonalnej. }\end{array}$ \\
\hline \multicolumn{2}{|c|}{ Kooperacyjne } \\
\hline $\mathrm{D}$ & $\begin{array}{l}\text { Relacje silnie kooperacyjne, trudne do przekształcenia na inny typ relacji ze względu } \\
\text { na wysoki stopień zróżnicowania starej i nowej przestrzeni centralnej, która łącznie } \\
\text { charakteryzuje się wysokim poziomem rozwinięcia. }\end{array}$ \\
\hline $\mathrm{E}$ & $\begin{array}{l}\text { Relacje średnio kooperacyjne, możliwe do przekształcenia na inny typ relacji ze } \\
\text { względu na średni poziom rozwinięcia przestrzeni centralnej, który umożliwia mo- } \\
\text { dyfikację struktury morfologicznej i funkcjonalnej. Barierą konwersji na inny typ } \\
\text { relacji jest wysoki stopień zróżnicowania starej i nowej przestrzeni centralnej, który } \\
\text { wymaga intensywnych przekształceń przestrzenno-funkcjonalnych. }\end{array}$ \\
\hline F & $\begin{array}{l}\text { Relacje słabo kooperacyjne, łatwe do przekształcenia na inny typ relacji ze względu } \\
\text { na umiarkowany stopień zróżnicowania przestrzeni centralnej oraz średni poziom jej } \\
\text { rozwinięcia, który umożliwia modyfikację struktury morfologicznej i funkcjonalnej. }\end{array}$ \\
\hline \multicolumn{2}{|c|}{ Konglomeracyjne } \\
\hline G & $\begin{array}{l}\text { Relacje silnie konglomeracyjne, możliwe do przekształcenia na inny typ ze względu } \\
\text { na słaby poziom rozwinięcia przestrzeni centralnej, mimo wysokiego stopnia zróżni- } \\
\text { cowania starej i nowej przestrzeni centralnej. }\end{array}$ \\
\hline $\mathrm{H}$ & $\begin{array}{l}\text { Relacje średnio konglomeracyjne, łatwe do przekształcenia na inny typ relacji ze } \\
\text { względu na umiarkowany stopień zróżnicowania starej i nowej przestrzeni centralnej } \\
\text { oraz słaby poziom rozwoju całej przestrzeni centralnej. Działania te wymagają inten- } \\
\text { sywnych przekształceń przestrzenno-funkcjonalnych. }\end{array}$ \\
\hline I & $\begin{array}{l}\text { Relacje słabo konglomeracyjne, bardzo łatwe do przekształcenia na inny typ relacji } \\
\text { ze względu na słaby poziom rozwoju przestrzeni centralnej i niski stopień zróżnico- } \\
\text { wania jej starej i nowej części, umożliwiające daleko idącą modyfikację struktury } \\
\text { morfologicznej i funkcjonalnej. }\end{array}$ \\
\hline
\end{tabular}

Źródło: opracowanie autora. 
Wychodząc z założenia, że przestrzeń centralna to układ morfologiczny oraz sposób zagospodarowania wyrażający się w postaci występowania elementów programu instytucjonalnego i układów kompozycyjnych, przyjęto że:

- relacje o charakterze konkurencyjnym oznaczają, że użytkownik przestrzeni centralnej ma ułatwioną możliwość wyboru pomiędzy podobnie wyposażonymi przestrzeniami miejskimi o charakterze centralnym; im niższy stopień podobieństwa pomiędzy starą i nową przestrzenią centralną, tym bardziej rozwinięte relacje konkurencyjne;

- im większa dysproporcja w zagospodarowaniu starej i nowej przestrzeni centralnej, tym mniejsza możliwość dokonania takiego wyboru przez użytkownika; w tej sytuacji występują relacje kooperacyjne pomiędzy starą i nową przestrzenią centralną, polegające na ich wzajemnej komplementarności w zakresie programu morfologiczno-instytucjonalnego;

- w przypadku współistnienia co najmniej dwóch niezależnych od siebie przestrzeni centralnych w słabo rozwiniętej przestrzeni centralnej jako układzie morfologiczno-funkcjonalnym występują relacje konglomeracyjne rozumiane jako możliwość dokonania przez odbiorcę wyboru pomiędzy alternatywnymi względem siebie przestrzeniami wykazującymi niski stopień integracji; im niższy stopień rozwinięcia przestrzeni centralnej, tym bardziej rozwinięte relacje tego typu.

Współcześnie istniejące relacje w przestrzeni centralnej są zdeterminowane jej morfogenezą, stąd zachodzi konieczność dokonania zindywidualizowanej analizy procesu rozwojowego przestrzeni centralnej dla każdego miasta.

\subsection{Materiały źródłowe i ich ocena}

Materiały źródłowe pracy były bardzo zróżnicowane. Do wykonania badań posłużono się różnymi metodami i technikami, które umożliwiły zebranie informacji o charakterze obiektywnym i subiektywnym.

Część empiryczna pracy została poprzedzona wnikliwymi studiami literatury przedmiotu. Wykorzystano $\mathrm{w}$ niej opracowania $\mathrm{w}$ formie wydawnictw zwartych, czasopism oraz materiałów konferencyjnych i prac niepublikowanych z zakresu geografii miast, gospodarki przestrzennej, socjologii miast, ekonomiki miast, urbanistyki i architektury. W studiach literaturowych skoncentrowano się na zagadnieniu przekształceń przestrzenno-funkcjonalnych zdegradowanych terenów miejskich, w szczególności - terenów poprzemysłowych oraz ich roli w procesie kształtowania przestrzeni zurbanizowanej. W tym kontekście bardzo dużo uwagi poświęcono analizie prac na temat szeroko rozumianej przestrzeni publicznej i procesów jej transformacji. Niezwykle istotną część studiów literatury przedmiotu stanowiły opracowania podejmujące problematykę morfologii miast, szczególnie przemian morfologicznych. Odrębnym zagadnieniem było 
rozpoznanie niezwykle obszernej literatury naukowej dotyczącej trzech miast będących obszarem badań. Wśród prac poświęconych Manchesterowi, Lyonowi i Łodzi wyróżnić można literaturę związaną z historią i rozwojem przestrzennym, gospodarczym i społecznym tych miast, ze szczególnym uwzględnieniem problematyki rozwoju i przekształceń terenów przemysłowych oraz kształtowania centrum miejskiego.

Istotą procesu rewitalizacji są przemiany jakościowe, związane z podniesieniem statusu przekształcanego obszaru oraz zmianą roli, jaką pełni on w przestrzeni miejskiej (Kaczmarek 1999, 1999a, 2000, 2001). Zgodnie z tym twierdzeniem przeprowadzone studia miały przede wszystkim charakter jakościowy. Empiryczną podstawę rozważań stanowiły materiały i informacje zebrane $\mathrm{w}$ trakcie badań terenowych przeprowadzonych w trzech etapach:

- badania pilotażowe w Manchesterze, Lyonie i Łodzi w roku 2010;

- badania studialne w Łodzi w roku 2011;

- badania studialne w Manchesterze i Lyonie oraz badania uzupełniające w Manchesterze, Lyonie i Łodzi w roku 2012 i 2013.

Badania in situ obejmowały:

- inwentaryzację urbanistyczną, dokumentację fotograficzną, studia fizjonomiczne;

- studia analityczne krajobrazu miejskiego (studia fizjonomiczne i morfologiczne);

- kwerendę dokumentów i planów rewitalizacji terenów poprzemysłowych;

- kwerendę materiałów kartograficznych, umożliwiających studia nad przekształceniami przestrzennymi i funkcjonalnymi centrum wybranych miast w ujęciu historycznym;

- kwerendę opracowań planistycznych, ukazujących plany przekształceń przestrzeni centralnej wybranych miast.

Szczególne znaczenie w procesie badawczym miały materiały kartograficzne oraz opracowania planistyczne, wśród których za najważniejsze należy uznać plany i programy rewitalizacji wewnątrzmiejskich ugorów poprzemysłowych oraz strategie kompleksowego rozwoju miast, uwzględniające programy rozwoju obszarów centralnych. W kontekście opracowań planistycznych należy zwrócić uwagę na wyraźną dysproporcję pomiędzy Manchesterem i Lyonem a Łodzią w liczbie, jakości oraz dostępie, zarówno do materiałów publikowanych, jak i niepublikowanych.

Dynamiczne ujęcie badań wymagało wykorzystania materiałów archiwalnych, na które składały się przede wszystkim opracowania kartograficzne. Dla odtworzenia układu przestrzennego w analizowanych obszarach w Manchesterze wykorzystano plany miasta w skali 1:1760, wydane przez Alan Godfrey Maps, reprodukowane ze skali 1:1056 przez Old Ordnance Survey. Analizowany materiał kartograficzny podzielony był na sześć części prezentujących stan zagospodarowania z lat 1848-1849 dla rejonów: Manchester Victoria (mapa nr 23 
w serii), Manchester City Centre (28), Manchester Piccadilly (29), Castlefield (32), Oxford Street (33) i London Road (34). Do ilustracji stanu sprzed rozpoczęcia procesów rewitalizacyjnych $\mathrm{w}$ przestrzeni centralnej Manchesteru oraz w trakcie ich realizacji posłużyły plany i mapy użytkowania ziemi dla całego obszaru centralnego Manchesteru i poszczególnych jego rejonów w skali od 1:1000 do 1:10 000 wykonane w latach 1959-1960, 1980-1985, 1995-1996 i 2004-2008. Są to materiały dostępne w cyfrowej bazie Ordnance Survey Data. Do analizy współczesnego stanu zagospodarowania analizowanych obszarów posłużono się materiałami kartograficznymi w skali od 1:1500 do 1:10 000, które są dostępne w serii opracowań planistycznych publikowanych przez Manchester City Council i dostępnych w formie elektronicznej.

Studia nad przekształceniami przestrzennymi i funkcjonalnymi w ujęciu historycznym, obejmujące centrum Lyonu, ze szczególnym uwzględnieniem obszaru Confluence, umożliwił materiał kartograficzny w zwartej publikacji w formie atlasu historycznego autorstwa Ch. Delfante i J. Pelletier (2006). Opracowanie to zawiera szereg map i rycin wraz z opisem, ilustrujących rozwój przestrzenny Lyonu od roku 1350, włącznie z docelowym planem zagospodarowania przestrzennego Confluence w roku 2006. Do najważniejszych map i rycin wykorzystanych $\mathrm{w}$ studiach należy zaliczyć m.in. Plan géométral de la ville de Lyon par Joubert z roku 1773, Nouveau plan topographique de Lyon autorstwa Joséphine de Comberousse z roku 1816, Nouveau plan géométral de Lyon według Laurent Dignoscyo z 1822 r., Plan de Lyon et de ses environs J. M. Darmet z 1830 r., Nouveau plan topographique de Lyon wykonany przez J. B. Noellat z 1842 r., Plan de Lyon et de ses nouveaux quartiers autorstwa Jean-Baptiste Gadola z 1856 r., Plan de la ville de Lyon et des communes voisines z 1974 r., plan Lyonu z liniami tramwajowymi z 1880 r., wykonany przez Philippe Sapin oraz Carte industrielle z 1932 r. Do studiów przekształceń obszaru Confluence niezwykle przydatna okazała się także praca J.-P. Nouhaud i J. Damez (2008). Do najważniejszych współczesnych opracowań kartograficznych należy plan Lyonu z 1992 r. w skali 1:25 000 wydany przez Série Blue (3031 O), Plan Local d'Urbanisme de la comunnuate urbaine de Lyon dostępny w formie cyfrowej oraz liczne materiały kartograficzne i graficzne zawarte w planach rewitalizacji Confluence, także dostępne w formie cyfrowej.

Analiza przekształceń przestrzeni centralnej Łodzi ze szczególnym uwzględnieniem obszaru zawartego pomiędzy ulicami Narutowicza, Kopcińskiego, Tuwima i Kilińskiego, stanowiącego fragment historycznej Nowej Dzielnicy i będącego aktualnie terenem inwestycji związanej z budową tzw. Nowego Centrum Łodzi, została oparta o kwerendę publikowanych materiałów kartograficznych oraz publikowanych i niepublikowanych dokumentów oraz planów rewitalizacji. Do najważniejszych opracowań umożliwiających analizę przekształceń przestrzeni centralnej w ujęciu historycznym, obejmującej najstarsze planowo zakładane jednostki morfologiczne Lodzi (Nowego Miasta, osady 
Iniano-bawełnianej Łódka, posiadeł wodno-fabrycznych i Nowej Dzielnicy), należy uznać: rekonstrukcję rozplanowania Łodzi z 1840 r. w skali 1:20000, uwzględniającą projekt założenia Nowej Dzielnicy, opracowaną przez M. Kotera i J. Wesołowskiego ${ }^{1} \mathrm{w}$ oparciu o rozplanowanie osady sukienniczej Nowe Miasto według planu F. de Viebiga z 1823 r. i rozplanowanie osady lniano-bawełnianej Łódka według planu J. Leśniewskiego z 1825-1828, reprint planu Łodzi w skali 1:8400, wydanego około 1910 r. przez Rudolfa Fryderyka Luthera oraz reprint Planu Miasta Łodzi wydany w 1913 r. nakładem Alfreda Sieblera w Łodzi ulica Milsza 10 (obecnie Kopernika) (skala nieznana) ${ }^{2}$. Do analizy przemian przestrzenno-funkcjonalnych w obszarze planowanego Nowego Centrum Łodzi posłużono się niepublikowanymi planami rewitalizacji obszaru wokół dworca kolejowego Łódź Fabryczna, zawierającymi materiały kartograficzne (skala nieznana), i graficznymi uzyskanymi w siedzibie projektu „EC1 Łódź - Miasto Kultury” znajdującej się na ul. Tymienieckiego $5 \mathrm{w}$ Łodzi oraz opracowaniami graficznymi dostępnymi na stronie internetowej projektu ${ }^{3}$.

Pomocniczo w analizie wykorzystano inne dokumenty o charakterze planistycznym, m.in.: Uproszczony Lokalny Program Rewitalizacji wybranych terenów śródmiejskich oraz pofabrycznych Łodzi na lata 2004-2013 i Studium uwarunkowań $i$ kierunków zagospodarowania przestrzennego miasta Łodzi, oraz strategicznym, np. projekt Strategii Zintegrowanego Rozwoju Łodzi 2020+ i Uchwała nr LV/1146/13 Rady Miejskiej w Lodzi z dnia 16 stycznia 2013 roku w sprawie Strategii przestrzennego rozwoju Łodzi 2020+.

Dla analizy zmian przestrzennych we wszystkich miastach pomocne okazało się także narzędzie Google Earth umożliwiające analizę retrospektywną zdjęć satelitarnych. Dla Manchesteru są to zdjęcia pochodzące z okresu 20002013, dla Lyonu 2001-2012, a dla Łodzi 2007-2012. Do analizy zmian sposobu użytkowania ziemi we wszystkich miastach wykorzystano także cyfrowe dane kartograficzne GMES Urban Atlas, udostępnione przez European Environment Agency (EEA). Bezpłatne narzędzia internetowe, w tym Géoportail oraz Google Earth Pro, umożliwiły również uzyskanie danych liczbowych (z dokładnością do $1 \mathrm{~m} \mathrm{w}$ przypadku elementów liniowych oraz $1 \mathrm{~m}^{2}$ dla elementów powierzchniowych) uzupełniających materiał źródłowy skompletowany w trakcie badań terenowych. Był to proces czasochłonny i wymagający dużej precyzji. Udało się jednak uzyskać wiarygodne i dokładne dane liczbowe, które skonfrontowano z danymi liczbowymi pochodzącymi z badań in situ. Uzyskały one wysoką zbieżność (94\%) - w granicy błędu $1 \mathrm{~m}$ dla elementów liniowych oraz $1 \mathrm{~m}^{2} \mathrm{dla}$ elementów powierzchniowych.

\footnotetext{
${ }^{1}$ Dostępny m.in. w S. Liszewski (2009) oraz M. Koter (2002).

2 Materiały publikowane przez łódzki oddział „Gazety Wyborczej” w 2010 r.

${ }^{3}$ http://www.ec1lodz.pl/pl/ [dostęp10.10.2012].
} 
Końcowy materiał w zakresie zagospodarowania przestrzennego i funkcjonalnego analizowanych obszarów powstał w oparciu o inwentaryzację urbanistyczną przeprowadzoną in situ.

Do analizy zebranego materiału wykorzystano przede wszystkim metody analizy kartograficznej z opisem porządkującym i porównaniem. Rezultaty badań przedstawiono w postaci graficznej, kartograficznej, tabelarycznej oraz za pomocą opisu porządkującego. W tym celu wykorzystano metody techniki komputerowej, takie jak arkusz kalkulacyjny Microsoft Excel 10 oraz Corel Draw 12. W pracy stosowany jest ujednolicony opis map. Do opracowania map ukazujących proces rozwoju przestrzeni centralnej $\mathrm{w}$ ujęciu retrospektywnym korzystano $\mathrm{z}$ licznych materiałów historycznych, zarówno w formie opracowań kartograficznych, jak i źródeł pisanych. Informacja o źródłach nie znajduje się bezpośrednio pod mapami, lecz w treści kolejnych rozdziałów empirycznych. Ze względu na charakterystykę badań retrospektywnych jest to rozwiązanie często stosowane w pracach z zakresu geografii historycznej. W sytuacji, kiedy mapa powstała na podstawie jednego źródła, informacja o nim jest odpowiednio zaznaczona pod opracowaniem. 



\section{Rozdział 3 \\ EWOLUCJA PRZESTRZENI CENTRALNEJ W MIASTACH EUROPEJSKICH}

Przestrzeń centralna w mieście i jej organizacja jest wypadkową licznych uwarunkowań zewnętrznych i wewnętrznych oraz zbioru zmiennych w czasie czynników o charakterze antropogenicznym i przyrodniczym. Jak zauważa M. Kulesza (2011), czynniki kształtujące przestrzenną formę miast pozostają w ścisłym związku z oddziaływaniem różnych wzorców kulturowych, które ulegały ewolucji w kolejnych okresach w historii planowania i budowy miast. Mimo względnej trwałości form urbanistyczno-architektonicznych, podlegają one przekształceniom wraz z postępem cywilizacyjnym i zmianą w czasie głównych funkcji, które decydowały o rozwoju miasta. Szczególną rolę w historii budowy miast i kształtowania przestrzeni centralnej odegrał przemysł. Przyjmując $\mathrm{w}$ tym aspekcie założenie, że morfologia jest odzwierciedleniem struktury funkcjonalnej miasta, należy wyróżnić trzy etapy przekształceń przestrzeni centralnej w miastach europejskich obejmujące okres przed uprzemysłowieniem oraz $\mathrm{w}$ trakcie i po intensywnej industrializacji terenów wewnątrzmiejskich.

\subsection{Przestrzeń centralna $w$ miastach europejskich w okresie przedindustrialnym}

Miasta przedindustrialne rozwijały się w społeczeństwach gospodarki rolniczej jako ośrodki władzy, handlu i rzemiosła oraz centra religijne. Można wyróżnić trzy etapy formowania się miast w Europie przed uprzemysłowieniem: okres miast starożytnych do V w. n.e., okres miast średniowiecznych (przedlokacyjnych - V-X w. i lokacyjnych - XII-XIV w.) oraz okres miast ery nowożytnej (XVI-XVIII w.). Wyróżnia się także dwa okresy przejściowe (w XI i XV w.), kiedy kształtowały się warunki do tworzenia nowej formy miasta.

$\mathrm{W}$ historii rozwoju miast $\mathrm{w}$ europejskim kręgu kulturowym szczególne znaczenie miały starożytne cywilizacje Greków i Rzymian, które rozwinęły się w basenie Morza Śródziemnego. Decydujące znaczenie w procesie urbanizacyjnym 
tego regionu świata odegrał czynnik geograficzny: wąski pas nizinnych nabrzeży zamkniętych stromymi i stosunkowo wysokimi łańcuchami górskimi. Położenie to sprzyjało budowaniu miast obronnych i portowych, co umożliwiało handel morski, przyczyniając się do rozwoju starożytnych ośrodków miejskich.

Pierwsze miasta greckie związane z kulturą minojską i mykeńską (około 3000-1100 r. p.n.e.) charakteryzowały się nieregularnym układem przestrzennym. Ośrodki miejskie miały charakter grodów obronnych ${ }^{1}$ i podporządkowane były uwarunkowaniom topograficznym, które stwarzały naturalne walory obronne. Funkcję obronną wzmacniały mury miejskie, które z czasem stały się symbolem niepodległości polis (państw-miast) w starożytnej Grecji. Przestrzeń centralną $\mathrm{w}$ miastach minojskich tworzył pałac $\mathrm{z}$ dziedzińcem centralnym, który był ośrodkiem władzy politycznej, ale jednocześnie także centrum życia religijnego, artystycznego i produkcji rzemieślniczej (Słodczyk 2012). W mniejszych prowincjonalnych ośrodkach rozwinął się plac publiczny w bezpośrednim sąsiedztwie pałacu, który nie posiadał dziedzińca. Wokół dominanty architektonicznej powstało śródmieście z gęstą zabudową mieszkaniową i wąskimi ulicami. Kilka z głównych ulic o różnych kierunkach zbiegało się w pałacu.

W odróżnieniu od nieufortyfikowanych ośrodków minojskich, w warownych miastach mykeńskich przestrzeń centralna była związana $\mathrm{z}$ akropolem. Było to wzgórze, na którym znajdował się otoczony murami obronnymi zamek i/lub budowle pałacowe, domy mieszkalne, pomieszczenia gospodarcze i dziedzińce. Akropol stanowił reprezentacyjną część miasta, pełnił funkcję polityczno-religijną oraz pełnił funkcję miejsca schronienia dla mieszkańców dolnego miasta i okolic.

Kontynentalne miasta starożytnej Grecji w okresie archaicznym (X-VI w. p.n.e.) także miały nieregularny układ przestrzenny, dostosowany do warunków topograficznych, które sprzyjały ich obronności. Kolonie zakładane w tym okresie na wybrzeżach Morza Śródziemnego i Morza Czarnego od VIII w. p.n.e. oraz kontynentalne miasta $\mathrm{w}$ okresie klasycznym (V-IV w. p.n.e.) i hellenistycznym (od połowy IV w. p.n.e.) charakteryzowały się już w większości regularnym układem przestrzennym według tzw. systemu hippodamejskiego. System ten został opracowany prawdopodobnie przez Hippodamosa z Miletu i można go uznać za pierwszą opartą na naukowych podstawach koncepcję urbanistyczną (Słodczyk 2012). Stosowano go najpowszechniej w nowych miastach kolonizacji oraz przy odbudowie ośrodków lub ich dzielnic po zniszczeniach wojennych. Nowa koncepcja urbanistyczna odzwierciedlała postępującą demokratyzację i zakładała podział całej przestrzeni miejskiej na regularną siatkę ulic ${ }^{2}$. Wyznaczone zostały

${ }^{1}$ Za wyjątkiem miast cywilizacji minojskiej, wśród których nie odkryto śladów fortyfikacji (Müller i Vogel 2003).

2 Według P. Lavedana (1926, za: Jałowiecki i Szczepański 2010) szachownicowy układ ulic należy do archetypów kulturowych i wydaje się być związany z koncepcjami filozoficznymi i religijnymi, i w którym ogromną rolę odgrywa kwestia orientacji. Do tej ostatniej kwestii odnoszą się liczni klasycy XX-wiecznej urbanistyki, m.in. K. Lynch (1962) czy G. Cullen (2011). 
w ten sposób bloki (insule) - wszystkie zajmujące taką samą powierzchnię. Były one wypełnione zabudową na równej wielkości parcelach. Zróżnicowanie wielości bloków i działek występowało początkowo tylko pomiędzy poszczególnymi miastami. $Z$ czasem do systemu hippodamejskiego wprowadzono szereg modyfikacji, w których wielkość parceli mogła ulegać zmianie i wiązała się ze wzrostem i spadkiem zamożności miasta. Jednocześnie koncepcja urbanistyczna Hippodamosa poddana została krytyce ze względu na utrudnioną obronę w mieście z szachownicowym układem ulic oraz problemem $\mathrm{w}$ jego dostosowaniu do pionowego ukształtowania terenu (Słodczyk 2012).

Również koncepcje zagospodarowania przestrzeni centralnej w miastach greckich ulegały przekształceniom w kolejnych okresach historycznych. Pierwsze punkty krystalizujące przestrzeń centralną miasta greckiego tworzyły: akropol (akropolis) jako wzgórze z twierdzą (siedzibą władzy królewskiej i administracji), stanowiące miejsce schronienia, świątynie zlokalizowane na akropolu oraz niezabudowane place miejskie. Głównym placem miejskim była agora, która stanowiła centrum życia miejskiego. W ujęciu planistycznym te trzy części miasta antycznego nie zawsze stanowiły zintegrowaną całość. Poza przestrzenią centralną znajdowały się dzielnice mieszkalne.

Agora pierwotnie pełniła przede wszystkim funkcje polityczne. Odbywały się na niej zebrania wolnych mieszkańców. Ramę architektoniczną wokół niej stanowiły budynki użyteczności publicznej, m.in. buleuterion, czyli ratusz - miejsce posiedzeń rady, siedziba sądu (heliaja), stoy, arsenały, mennice i liczne portyki. Agora wraz z obiektami publicznymi (np. teatr, gimnazjon) stanowiła przestrzeń reprezentacyjną miasta. W późniejszych okresach zaczęła także pełnić funkcję handlową i usługową. Przejęła ona także część funkcji pełnionych początkowo przez akropol i zaczęła być miejscem ceremonii religijnych. W rezultacie wokół agory powstawały także liczne budynki sakralne. W okresie archaicznym agora miała najczęściej nieregularny kształt, natomiast od okresu klasycznego po hellenistyczny, pod wpływem koncepcji hippodamejskiej, budowana była na planie prostokąta i zajmowała kilka bloków. W wyniku wzrostu funkcji głównego placu miejskiego wydzielane były kolejne mniejsze i wyspecjalizowane agory, które rozszerzały ramy przestrzeni centralnej miasta.

W okresie hellenistycznym przestrzeń centralna, jako kluczowa część przestrzeni miejskiej, podlegała wyraźnie planowej organizacji. Podejmowane były w tym okresie próby wprowadzenia osi głównych i dominant. W tym celu wytyczano w układzie szachownicowym szerokie ulice główne i wąskie ulice boczne. Kompleksy pałacowe i świątynne rozmieszczane były na wielopoziomowych tarasach, połączonych systemem schodów i krużganków, co wzbogaciło architekturę placów (Słodczyk 2012). Pojawiły się także nowe budynki publiczne jak np. biblioteka, których ranga i obecność $\mathrm{w}$ mieście wymagały integracji z istniejącą przestrzenią centralną. Również teatry, które początkowo znajdowały się w pewnym oddaleniu od akropolu i agory, zaczęły być budowane w ich sąsiedztwie. 
Czynniki te świadczą o postępującej rozbudowie przestrzeni centralnej w miastach greckich w kolejnych okresach historycznych i jednocześnie o jej specjalizacji, przy zachowaniu spójności przestrzenno-funkcjonalnej.

W okresie starożytności najbardziej zaawansowana była urbanizacja rzymska. Ośrodki miejskie zakładane przez Rzymian rozwijane były początkowo na Półwyspie Apenińskim, a następnie w Europie Południowej i Zachodniej do Dunaju i Renu na północy, w Anglii, Walii i południowej Szkocji, Azji Mniejszej i na śródziemnomorskim wybrzeżu Afryki oraz w Egipcie. Stąd duża część współczesnych miast $\mathrm{w}$ tym regionie ma genezę rzymską i której wyraz w większym lub mniejszym stopniu zachował się do dziś w układzie przestrzennym. Miasta zakładane przez Rzymian miały regularny układ ulic, który odpowiadał schematowi obozu wojskowego castrum romanum. Były one wzorowane na ośrodkach greckich (od okresu klasycznego), czyli na planie hippodamejskim oraz na doświadczeniach planistycznych Etrusków oraz Italików ${ }^{3}$. Korzystające ze zbliżonych wzorców urbanistycznych miasta starożytnego Rzymu i Grecji charakteryzowały się więc podobną strukturą przestrzenno-funkcjonalną.

Rzymskie obozy wojskowe, stanowiące zalążek przyszłych miast, były orientowane, zakładane na planie prostokąta i otoczone murami obronnymi z wieżami. Wyróżnić w nich można dwie główne ulice: cardo, krótsza, która biegła z północy na południe i dzieliła obóz na dwie nierówne części (mniejszą - praetentura i większą - retentura) oraz decumanus, biegnąca ze wschodu na zachód i dzieląca obóz na dwie równe części ${ }^{4}$. Równolegle do cardo i decumanus biegły drugorzędne drogi, o mniejszej szerokości, które tworzyły regularną siatkę ulic. Osie dzieliły obóz na cztery części, które były przeznaczone dla różnych grup wojskowych i cywilnych. Przy skrzyżowaniu cardo i decumanus znajdowało się forum, czyli najważniejsze miejsce w obozie, przy którym zlokalizowana była siedziba komendanta i jego sztabu. Wraz z rozwojem i przejmowaniem nowych funkcji przez castrum zabudowa wojskowa była wypierana przez trwałe budynki, a obóz zamieniał się w regularne miasto (Wróbel 1971).

Przestrzeń centralna w miastach rzymskich była wyznaczana przez forum lub ich zespół oraz przez cadro i decumanus, wokół których koncentrowało się życie miejskie m.in. poprzez lokalizację wzdłuż nich kancelarii i sklepów. Obie ulice łączyły ze sobą cztery bramy wjazdowe i stanowiły one podstawowy element układu komunikacyjnego w mieście. Istotną rolę pełniły także obiekty użyteczności publicznej, do których należy zaliczyć: kurię, czyli miejsce posiedzeń senatu, bazylikę, czyli miejsce sprawowania sądów, termy, czyli obszerne łaźnie, teatry lub amfiteatry oraz inne urzędy. Duże znaczenie w kształtowaniu przestrzeni centralnej miały również reprezentacyjne budowle, takie jak: łuki

${ }^{3}$ Cywilizacje rozwijające się na Półwyspie Apenińskim od około 2000 r. p.n.e.

${ }^{4} \mathrm{~W}$ obozie wojskowym cardo nosiła nazwę via pretoria, a w mieście cywilnym - via cardinalis. Analogicznie decumanus nazywana była w obozie via principalis, a w mieście - via decumana. 
triumfalne, kolumny wotywne czy posągi. Najważniejszym jednak komponentem przestrzeni centralnej był główny plac publiczny - forum, które znajdowało się w środkowej części miasta. Miało ono regularny, prostokątny kształt i koncentrowały się na nim najważniejsze obiekty użyteczności publicznej oraz kultu religijnego (m.in. kapitol, czyli świątynia oficjalnej religii, oraz inne świątynie poświęcone rozmaitym bóstwom), podobnie jak miało to miejsce w przypadku greckiej agory. Forum miało charakter reprezentacyjnego placu władz miejskich, służyło także widowiskom i uroczystościom. W miastach, które zyskiwały nowe funkcje, budowano kolejne place sprzężone układem ulic. Szczególnie rozbudowany zespół forów występował w Rzymie ${ }^{5}$, mieście stołecznym rozwijającego się Imperium od 753 r. p.n.e. do momentu przeniesienia stolicy do Konstantynopola w 330 r. n.e. Tak zwane fora cesarskie powstały w celu odciążenia Forum Romanum i przejmowały zarówno funkcje reprezentacyjne, jak i komercyjne. Stanowiły one ciąg starannie zaprojektowanych placów, rozbudowywanych stopniowo przez kolejnych cesarzy, począwszy od Juliusza Cezara, który zbudował Forum Juliusza w 51 r. p.n.e. Następnie powstały: Forum Augusta, Forum Nerwy i Forum Trajana. W odróżnieniu od Forum Romanum, które zachowywało związek z otoczeniem, fora cesarskie zostały ściśle odgrodzone od siebie i od miasta (Müller i Vogel 2003). W pewnym sensie był to powrót do koncepcji minojskiego pałacu z dziedzińcem, jednocześnie było to całkowite novum w kształtowaniu przestrzeni centralnej w okresie urbanistyki rzymskiej.

Podobnie jak w miastach greckich, tak i w ośrodkach starożytnego Rzymu rozwój przestrzenny miast mógł spowodować przesunięcie się przestrzeni centralnej na skraj układu miejskiego. Przykładem takiego ośrodka były Pompeje. Rozwój nowych funkcji miejskich skutkował natomiast ekspansją przestrzeni centralnej i jej specjalizacją, przy jednocześnie silnej jej integracji przestrzenno-funkcjonalnej.

O ile w okresie antycznym w miastach na kontynencie europejskim można wskazać pewne wzorce kształtowania przestrzeni centralnej, o tyle w okresie rozwoju ośrodków średniowiecznych proces ten uległ dywersyfikacji. Po upadku Cesarstwa Zachodniorzymskiego w $476 \mathrm{r}$. miasta podlegały istotnym zmianom. Część z nich uległa całkowitej degradacji, inne natomiast przekształcono z wykorzystaniem wcześniejszego układu przestrzennego castrum romanum (Benevolo 1995). Ważnym czynnikiem decydującym o przetrwaniu wielu miast antycznych było zobowiązanie biskupów ${ }^{6}$ na soborze w Nicei w $325 \mathrm{r}$. do pozostania w siedzibach z czasów rzymskich. W okresie od V do X w. wyróżnia się trzy strefy urbanizacji europejskiej: pierwsza związana z basenem Morza Śródziemnego, gdzie miasta były stosunkowo mało zniszczone w okresie wędrówek ludów,

${ }^{5} \mathrm{~W}$ przeciwieństwie do osiedli rzymskich budowanych według koncepcji castrum romanum, Rzym jest przykładem układu rozwiniętego spontanicznie, ze względu na jego wielkość oraz ukształtowanie terenu (siedem wzgórz, na których został założony). Pomimo wielu prób miasto to nigdy nie osiągnęło planowego porządku charakterystycznego dla miast kolonialnych (Wróbel 1971).

${ }^{6}$ Biskupi są uważani za kontynuatorów administracji rzymskiej. 
strefa druga obejmująca obszary dawnego Imperium Rzymskiego, w której nowe ośrodki władzy feudalnej wykorzystywały istniejącą infrastrukturę miejską, oraz trzecia strefa, w której nie istniały miasta - była to środkowa, północna i wschodnia Europa (Liszewski i Maik 2000). W okresie wczesnego średniowiecza dominującą pozycję zdobył Kościół katolicki, który stanowił siłę zdolną zastąpić integrujące niegdyś Europę cesarstwo rzymskie. Ośrodkami cywilizacji stały się katedry, czyli siedziby biskupów, oraz klasztory. Wraz z zamkami, dworami królewskimi, innymi rzymskimi warowniami i osiedlami militarnymi oraz węzłami komunikacyjnymi w handlu dalekosiężnym były one zalążkami miast wczesnośredniowiecznych. Powszechne było także zakładanie nowych miast nienawiązujących do antycznych wzorców urbanistycznych.

W ośrodkach wczesnośredniowiecznych (przedlokacyjnych) dominował nieregularny układ przestrzenny. Miasta rozwijały się drogą ewolucyjną, w sposób organiczny (spontaniczny) według zasady geomorficznej, czyli dostosowując się do sytuacji topograficznej. Często wykorzystywane były naturalne walory obronne terenu. Rozwój ten odpowiadał staremu stylowi w urbanistyce greckiej. Oprócz funkcji militarnej (osada była otoczona murami obronnymi) ważnym czynnikiem miastotwórczym było oddzielenie się handlu i rzemiosła od gospodarki rolnej. Osiedle rzemieślniczo-targowe narastało wokół grodu (zamku), kościoła umocnionego lub klasztoru. Miasto tworzyło jeden zwarty organizm, otoczony murem miejskim, o nieregularnej sieci ulicznej, czasami o układzie promienisto-koncentrycznym bądź rozwijał się zespół osadniczy złożony z grodu, podgrodzia i placu targowego, który położony był przy szlakach komunikacyjnych. W miarę wznoszenia zajazdu, gospody, magazynów, kuźni itp. przekształcał się w osadę targową. W ośrodkach wczesnośredniowiecznych centralnym miejscem był nieregularny plac z kościołem, wokół którego koncentrowało się życie mieszkańców o coraz bardziej różnicującym się statusie społecznym. Przestrzeń centralną tworzył zatem prosty, czytelny układ.

W dojrzałym średniowieczu zmieniła się sytuacja prawna miast wraz z rozwojem produkcji, handlu, mieszczaństwa, kultury i architektury oraz wzrostem zamożności ośrodków. Miasta były zakładane na podstawie aktu prawnego, czyli lokacji, lub były one według niej przebudowywane. W akcie lokacyjnym określano m.in. przywileje miasta, prawa mieszczan, organizację władzy miejskiej, organizację gospodarki miejskiej, tereny, jakie należą do miasta oraz sposób organizacji przestrzennej. Ośrodki miejskie, odchodząc od funkcji militarnej z dominacją zamku, rozwijały się planowo, na regularnym planie, zgodnie z zasadą geometryczną, w której rządził regularny system miar. Były one bardziej niezależne od uwarunkowań topograficznych, jednak często następowała modyfikacja regularnego układu ulic i ich częściowe dostosowanie do ukształtowania terenu, biegu rzek etc. Przestrzeń miejska była dzielona na stosunkowo równe bloki uliczne (w środkowej części były one większe niż w obszarach zewnętrznych), zamknięte pomiędzy prostopadłymi ulicami. W zależności od funkcji pełnionych przez 
miasto następowała także modyfikacja układu ulic, stąd w miastach handlowych można dla przykładu wyróżnić: założenia o ulicach równoległych, typowe dla osiedli handlu zagranicznego; założenia o krzyżujących się osiach poprzecznych, z kilkoma bądź jedną główną ulicą i biegnącymi doń prostopadle ulicami bocznymi, osiedlami kupców i rzemieślników; założenia z kwadratową siatką ulic o jednakowej randze, preferowane w miastach targowych Europy Środkowej i Wschodniej (Müller i Vogel 2003a). W portowych miastach nadrzecznych ulice tworzyły natomiast układ grzebieniowy (Pancewicz 2004).

Centralnym miejscem w mieście był plac o zróżnicowanym kształcie, pełniący funkcję targową. Na rynku znajdowały się obiekty handlowe (kramy, jatki) i administracyjne (ratusz, urząd miar i wag). Ratusz mógł być zlokalizowany przy jednej z pierzei rynku lub usytuowany doń narożnikowo. Wraz z rozwojem funkcji handlowych w mieście budowano kolejne place targowe, które specjalizowały się np. w handlu solą, rybami czy płodami rolnymi. Czasami plac miejski ustępował miejsca szerokiej ulicy handlowej, która stanowiła główną oś miasta (Sumień 1992). Forma przestrzeni centralnej była kształtowana przez dwa ośrodki władzy: świecką, reprezentowaną przez ratusz oraz kościelną, której wyrazem architektonicznym była świątynia ${ }^{7}$ (kościól, katedra). Obiekty te początkowo były zlokalizowane przy innych rynkach, lecz z czasem dzieliły one przestrzeń wokół tego samego, głównego placu w mieście. Swoista rywalizacja władzy świeckiej i kościelnej znalazła swoje odzwierciedlenie w architekturze ratusza i świątyni. Kościoły farne i ratusze stały się dominantami krajobrazowymi, które kształtowały charakterystyczną sylwetę miast średniowiecznych. Były to najwyższe obiekty w mieście i jednoznacznie wskazywały one lokalizację przestrzeni centralnej.

Równie często w osiedlach średniowiecznych centralne funkcje zostały rozdzielone w strukturze przestrzennej miasta - na rejon katedry, który pełnił rolę centrum życia religijnego, centrum życia politycznego znajdującego się wokół placu przy ratuszu oraz obszar handlowy z głównym placem targowym. Jak zauważa L. Benelovo (1995), struktura przestrzeni publicznej w mieście średniowiecznym była wynikiem równowagi pomiędzy różnymi stanami: władzą kościelną, świecką, korporacjami i zakonami. Place zajmowały znaczny udział w powierzchni miast średniowiecznych.

Intensywny rozwój przestrzenny miast średniowiecznych wiązał się z dobudowywaniem nowych dzielnic o regularnym układzie ulic do starszych osiedli o nieregularnym (lub już regularnym w wyniku przebudowy zgodnie $\mathrm{z}$ aktem lokacyjnym) układzie przestrzennym. Początkowo funkcjonowały one oddzielnie, wykazując niewielki stopień integracji przestrzenno-funkcjonalnej. Czasami osiedla tworzące osobne jednostki morfologiczne i administracyjne były oddzielone murem obronnym. $\mathrm{Z}$ czasem sąsiadujące ośrodki łączono, wpisując je w rozbudowaną linię murów obronnych. Każde z nich zachowywało jednak swoją odrębną

\footnotetext{
${ }^{7}$ Przy rynku mogło się także znajdować palatium, które było również siedzibą biskupa.
} 
przestrzeń centralną, na którą składały się place reprezentacyjne i targowe, kościoły, obiekty handlowe oraz siedziby władz miejskich, które przenoszono po połączeniu dwóch ośrodków do jednego ratusza, adaptując drugi na inne cele. W pewnym sensie w miastach bipolarnych czy policentrycznych można wskazać na współistnienie „starej” $i$ „nowej” przestrzeni centralnej w ramach jednej jednostki administracyjnej.

W ostatniej fazie urbanizacji przedindustrialnej (XVI-XVIII w.) kształtowały się nowe uwarunkowania i czynniki rozwoju ośrodków miejskich, co było następstwem zwiększenia roli handlu i kupców oraz pojawienia się nowych funkcji miejskich. Ten etap w historii budowy i rozwoju miast wiąże się z powrotem do antycznych tradycji urbanistycznych, czego wyrazem było nawiązywanie do koncepcji miast idealnych Platona, Arystotelesa oraz Witruwiusza (Kostof 1991). Zmiany $\mathrm{w}$ urbanistyce wiązały się także $\mathrm{z}$ rozwojem broni palnej oraz rządów autorytarnych, które jednak starano się pogodzić z koncepcją mądrego i dobrego władcy, jak również z wizją idealnie funkcjonującego społeczeństwa (Słodczyk 2012) w doskonałej formie urbanistyczno-architektonicznej. Miasta renesansowe podporządkowane funkcjom militarnym podlegały daleko idącej geometryzacji, która wyrażała się w układzie promienisto-koncentrycznym (gwieździstym) bądź szachownicowym. W centrum układu zawsze znajdował się plac o znacznej powierzchni, którego kształt często zależał od przyjętej matrycy geometrycznej ${ }^{8}$. Plac centralny w układach gwieździstych ułatwiał koordynację działań obronnych w mieście-twierdzy, bowiem dzięki przyjętemu układowi przestrzennemu stanowił on punkt, z którego można kontrolować sytuacje na wszystkich bastionach. Analogicznie, budowla usytuowana na placu była widoczna z każdej ulicy w mieście, skierowanej do centrum. System promienisty utrudniał jednak integrację z prostokątnym placem, stąd często stosowane były nowe warianty łączenia się i przenikania układu promienisto-koncentrycznego i szachownicowego. Niezależenie od zastosowanego planu, w mieście renesansowym istniał hierarchiczny sposób organizacji przestrzeni centralnej, w której mniejsze place miejskie z kościołami lub obiektami użyteczności publicznej połączone były z głównym i największym placem w mieście, który pełnił funkcję reprezentacyjną. Znajdował się na nim pałac (często właściciela miasta) bądź obiekty administracji (ratusz, urząd wag i miar). Stanowiły one najważniejszy element układu miejskiego i jego dominantę. Podobnie jak w poprzednich epokach historycznych, stosowane było także zróżnicowanie rangi ulic, które wyrażało się najczęściej w jej szerokości.

Znacznie częściej od budowy nowych miast o zgeometryzowanych kształtach prowadzono projekty przebudowy średniowiecznych miast $\mathrm{z}$ gęsto zabudowanymi obszarami centralnymi. W renesansie nastąpiło przejście od średniowiecznej

${ }^{8}$ Z. Paszkowski (2011) w analizie rozwoju urbanistyki w kolejnych okresach historycznych wyróżnia szereg matryc geometrycznych, które odegrały znaczącą rolę w założeniach „idealnych”. Wskazał on na matryce: koncentryczną, osiową, gwieździstą, szachownicową, pasmową, sieciową, strefową, palczastą, policentryczną i dynamiczną. 
struktury o drobnych podziałach, z wieloma domami stojącymi obok siebie do wielkich bloków zabudowy z nielicznymi, lecz większymi budynkami stojącymi na oddzielnych działkach, nietworzącymi jednego ciągu fasad. Gęsta zabudowa miast średniowiecznych znalazła przeciwwagę jakościową i ilościową w przestrzeni niezabudowanej (Müller i Vogel 2003a). Przekształceniu uległy także centralne place miejskie, którym nadawano zgeometryzowane kształty. $\mathrm{W}$ ich projektowaniu w mniejszym stopniu kierowano się potrzebami praktycznymi, jak miało to miejsce w średniowieczu, bardziej zaś względami formalno-estetycznymi. Place umożliwiały ekspozycję monumentalnych budynków: ratusza, szpitali, teatrów, muzeów oraz pałaców miejskich. W okresie tym traciły na znaczeniu obiekty sakralne, choć ich ranga w kształtowaniu przestrzeni centralnej nadal była wysoka. Do miast renesansowych wprowadzona została także funkcja naukowa. Uniwersytety zajmowały reprezentacyjne obiekty, które rozszerzały przestrzeń centralną. W miastach wzrastała liczba placów, a ich funkcje rozrastały się. Wprowadzone zostały także osie łączące ważne place i budynki, czemu często towarzyszyły wyburzenia i budowa nowych ulic (Słodczyk 2012).

Założenia osiowe nabrały szczególnie istotnego znaczenia $\mathrm{w}$ barokowych i klasycystycznych koncepcjach urbanistycznych. Do głównych zasad w projektowaniu przestrzeni centralnej w tym okresie należało wprowadzenie prostej linii ulic, monumentalnej perspektywy oraz realizacja dużych i spójnych projektów urbanistyczno-przestrzennych. Stało się to możliwe dzięki koncentracji władzy w rękach monarchów. Miasta stały się powiązanym systemem, rozplanowanym według nadrzędnych osi - prostych szerokich ulic, w których place służyły jako węzły komunikacyjne i reprezentacyjne miejsca zgromadzeń, co jest rezultatem uwolnienia ich z części funkcji pełnionych w poprzednich epokach. Główny plac miejski stanowił punkt wyjścia dla reprezentacyjnych ulic. Zmiany $\mathrm{w}$ organizacji przestrzennej miast wiązały się z coraz powszechniejszym użyciem różnego rodzaju pojazdów kołowych, dla których szerokie i proste ulice stwarzały najlepsze i najszybsze możliwości dla przemieszczania się. Tego typu układ przestrzenny miast ułatwiał także manewry oddziałów wojskowych i poprawił skuteczność artylerii, co miało niebagatelne znaczenie w okresie licznych rewolucji o zróżnicowanym podłożu. Wielkie osie kompozycyjne integrowały dominanty architektoniczne, czyli punkty orientacyjne w mieście, a wśród nich: katedry, bazyliki, obiekty użyteczności publicznej oraz pałace monarsze, które rozwijane były na obrzeżach ówczesnych miast ze względu na możliwość kształtowania wielkich założeń ogrodowych według koncepcji otwarcia się miast na przyrodę. Powszechne dla tego okresu były miasta rezydencjonalne. Przed najważniejszymi obiektami w mieście znajdowały się place podkreślające ich monumentalną formę architektoniczną. W klasycyzmie nawiązywano chętnie do greckiej agory i rzymskiego forum, w powszechnym użyciu były kolumny oraz arkadowe podcienia.

Kształtowanie nowych placów, ich zróżnicowanych form i funkcji oraz rozproszenie obiektów użyteczności publicznej rozszerzało szkielet przestrzeni 
centralnej w mieście nowożytnym. Dzięki osiom nadal pozostawała ona jednak zintegrowana przestrzennie i funkcjonalnie. Ważnym elementem przestrzeni centralnej były place spacerowe oraz rzeźby i pomniki podnoszące ich rangę.

\subsection{Przestrzeń centralna w miastach europejskich w okresie industrialnym i przekształceń terenów przemysłowych}

Rewolucja przemysłowa, która miała miejsce w Anglii w połowie XVIII w., przyczyniła się do bardzo dynamicznej urbanizacji w XIX w., głównie na kontynencie europejskim i w Ameryce Północnej. Miasta przemysłowe powstawały w wyniku ewolucji wcześniejszych form osadniczych bądź też w konsekwencji wzrostu małych osad fabrycznych, które z czasem zyskiwały inne funkcje poza przemysłową. Industrializacja spowodowała bardzo duże przeobrażenia przestrzeni miejskiej szczególnie w tych ośrodkach, gdzie obiekty przemysłowe lokowano w strefach wewnętrznych.

Osobnym zagadnieniem są liczne miasta, które w tym okresie powstały na tzw. surowym korzeniu (in cruda radice), a ich struktura przestrzenno-funkcjonalna była niemal całkowicie podporządkowana działalności produkcyjnej. Wśród głównych czynników, które zadecydowały o intensywnym rozwoju przemysłu w XVIII i XIX w., a w następstwie o przekształceniach miast, wskazuje się na: przemiany technologii transportu i łączności wskutek wynalezienia maszyny parowej, silnika spalinowego, telegrafu i telefonu; postępy w produkcji i dystrybucji żywności, które umożliwiły przemieszczanie się ludności z gospodarstw rolnych do przemysłu w miastach, oraz przewóz nadwyżek żywności do powstających miast; eksplozję ludnościową wskutek obniżenia umieralności niemowląt i wydłużenia przeciętnej długości życia za sprawą rozwoju medycyny (m.in. Liszewski i Maik 2000, Majer 2010). M. Weber (2002) zwraca także uwagę na zróżnicowanie procesów uprzemysłowienia miast w zależności od czynnika społeczno-kulturowego. Niezależnie jednak od lokalnych zróżnicowań w rezultacie rewolucji przemysłowej nastąpił niespotykany dotąd wzrost zaludnienia miast ${ }^{9}$, a w konsekwencji ich ekspansja terytorialna. Szczególne znaczenie w tym ostatnim procesie miał rozwój kolei w drugiej połowie XIX w. Konieczność rozbudowy linii kolei pasażerskiej i towarowej w miastach przemysłowych wraz z wcześniejszymi zmianami w technice wojennej (rozwój artylerii i lotnictwa, które podważyło istnienie fortyfikacji miejskich) w istotnym stopniu zmieniła, przede wszystkim, wewnętrzne obszary miast.

Miasto przedindustrialne było tworzone w toku wymiany i dla potrzeb wymiany. Inne funkcje poza handlową były obecne w mieście, lecz odgrywały znaczenie

${ }^{9} \mathrm{Z}$ czym związane jest znacznie większe rozwarstwienie społeczeństwa w stosunku do miast przedindustrialnych. 
drugorzędne, co znalazło odbicie w ich stopniowym wypieraniu z przestrzeni centralnej, szczególnie w odniesieniu do działalności wytwórczej. Podporządkowanie się tej zasadzie czyniło plan miasta spójnym, harmonijnym i czytelnym (Jałowiecki i Szczepański 2010). W XIX w. przemysł stał się główną funkcją miastotwórczą, co zostało odzwierciedlone w strukturze przestrzenno-funkcjonalnej miast. Uległa ona przekształceniom $w$ kolejnych fazach industrializacji wraz ze zmianą technologii produkcji i transportu zależnych od dominującego rodzaju źródeł energii. Na ten fakt zwrócił uwagę L. Mumford (1961), który w rozwoju cywilizacji wyróżnił cztery okresy: eotechniczny (oparty na wykorzystaniu siły wody i wiatru - młyn, wiatrak, żaglowiec, manufaktura), paleotechniczny (pary wodnej - maszyna parowa, lokomotywa, parowiec), neotechniczny (gazów spalinowych - sinik spalinowy i elektryczny, samochód) i biotechniczny (substancje i procesy biotechniczne). Rozpatrując zaproponowany przez Mumforda podział, w aspekcie teorii modernizacji D. Bella, w której wyróżnia się okres przedindustrialny, industrialny i postindustrialny ${ }^{10}, \mathrm{~S}$. Liszewski i W. Maik (2000) powiązali koniec fazy eotechnicznej z początkami industrializacji, fazę paleotechniczną z XIX-wieczną industrializacją, natomiast fazę neotechniczną z przełomem ery industrialnej i postindustrialnej. Badacze ci twierdzą dalej, że każdą z tych faz cechują odmienne układy produkcyjne i transportowe, co w efekcie oddziałuje różnicująco na procesy urbanizacyjne i formy osadnictwa miejskiego. W tym ujęciu w początkowej fazie industrializacji zakłady przemysłowe lokowano nad rzekami, które wprowadzały w ruch koła napędowe manufaktur. W fazie paleotechnicznej w przemyśle wykorzystywano przede wszystkim maszynę parową, która uniezależniła zakłady produkcyjne od dolin rzecznych. Czynnik ten umożliwił dynamiczny rozwój terenów przemysłowych w przestrzeni miejskiej, co w istotny sposób zaburzyło regularną zabudowę części miast powstałych w erze przedindustrialnej. Powstał wówczas mozaikowy układ przestrzenny, charakteryzujący się przemieszaniem terenów produkcyjnych, składowo-magazynowych, komunikacyjnych ${ }^{11}$, mieszkaniowych oraz obszarów o dominacji obiektów użyteczności publicznej, budynków reprezentacyjnych $\mathrm{w}$ mieście, obiektów sakralnych z dużym udziałem przestrzeni publicznej. Zniekształcona została także tradycyjna przestrzeń wymiany. Innymi słowy rozwój przemysłu w strefie wewnętrznej zaburzył historycznie ukształtowaną przestrzeń centralną, która niezależnie od formy przestrzenno-funkcjonalnej, jaką przyjmowała w uprzednich etapach rozwoju miast europejskich, odznaczała się stosunkowo dużym stopniem integralności. Degradacji uległy także osie

${ }^{10} \mathrm{~W}$ studiach miejskich wyróżniane są także inne klasyfikacje, dla przykładu G. Sjöberg (1960) w kontekście zmian ustrojowych społeczeństwa (od społeczeństwa feudalnego do preindustrialnego, a następnie do miejskiego społeczeństwa przemysłowego) wskazuje na następującą kolejność zmian charakteru i form miejskich: miasto przedprzemysłowe, miasto fazy przejściowej w postaci miasta uprzemysławiającego się oraz miasto przemysłowe.

${ }^{11}$ Tereny przemysłowe (produkcyjne, magazynowe, składowe, komunikacyjne) były dostępne jedynie selektywnie. 
widokowe podkreślające dominanty architektoniczne w mieście. Poprzez wprowadzenie masywnych obiektów fabrycznych oraz kominów zatracony został krajobraz miast, w którym najwyższe obiekty nie umożliwiały już jednoznacznej identyfikacji przestrzeni centralnej.

Przemysł był lokowany także na terenach niezabudowanych w miastach o ukształtowanej strukturze przestrzennej. Prowadziło to w mniejszym stopniu do jej przekształceń, aczkolwiek wraz z rozwojem usług ${ }^{12}$ i funkcji metropolitalnych tereny przemysłowe tworzyły enklawy, głównie wokół dworców i linii kolejowych, dezintegrując $\mathrm{w}$ ten sposób przestrzeń centralną lub ograniczając jej ekspansję. Rozbudowa kolei w miastach w XIX i XX w. i jej miastotwórcza funkcja sprawiły, że wokół dworców kolejowych dynamicznie rozwijała się nowa dzielnica. Ulica, która ją łączyła z głównym rynkiem, stała się nową osią rozwojową miasta, wokół której koncentrowały się usługi centrotwórcze. Nastąpiła wówczas ekspansja bądź też przesunięcie przestrzeni centralnej z obszaru przyrynkowego w kierunku głównego dworca kolejowego, który często stawał się nową dominantą architektoniczną miasta. W XIX-wiecznym mieście przemysłowym do przestrzeni centralnej wprowadzone zostały również inne obiekty, które służyły rozwijającym się funkcjom. Są to przede wszystkim: urzędy pocztowe, giełdy, banki, towarzystwa kredytowe, hotele, domy towarowe, kryte pasaże handlowe oraz inne budynki związane m.in. z kulturą i oświatą, w tym uczelnie wyższe. Wyraźnie zaznaczyły się także w krajobrazie miejskim obiekty techniczne, jak np. wiadukty kolejowe, które były stosowane w gęstej zabudowie wewnątrzmiejskiej.

Wprowadzenie przemysłu do wewnętrznych stref miasta znacznie pogorszyło warunki życia w mieście, m.in. poprzez zanieczyszczenie powietrza, wód, rozdrobnienie systemu zieleni miejskiej, ale także w wyniku nadmiernej koncentracji ludności, rozwoju chorób (cholera, gruźlica, tyfus) i rosnących zjawisk patologii społecznych. Naprzeciw pogarszającym się warunkom życia w gęstej zabudowie śródmiejskich obszarów miast przemysłowych ${ }^{13}$ wychodzili fabrykanci, którzy w bezpośrednim sąsiedztwie swoich kompleksów fabrycznych budowali patriarchalne osiedla domów robotniczych. Pokłosiem pogarszających się warunków życia i funkcjonowania miast okresu intensywnej industrializacji XIX-wiecznej były licznie podejmowane próby przebudowy wewnętrznych stref miejskich. Poprawa złych warunków bytowych oraz zniwelowanie nierówności społecznych

12 Zdaniem J. Słodczyka (2012) koncentracja siły roboczej w miastach przemysłowych spowodowała także powstanie nowych miejsc pracy, które były związane z obsługą rozrastających się demograficznie i terytorialnie miast. W tym ujęciu dynamiczny rozwój funkcji produkcyjnej w miastach wywołał szybki rozwój wielu funkcji usługowych, co w rezultacie spowodowało dalsze napędzenie procesów urbanizacyjnych. Miasta przemysłowe pełniły też funkcje administracyjne, metropolitalne, komunikacyjne.

${ }^{13}$ Wpływ miał na to także niedostateczny rozwój komunikacji miejskiej, co w rezultacie powodowało, że mimo bardzo złych standardów życia mieszkańcy starali się mieszkać w pobliżu śródmieścia (Majer 2010, Słodczyk 2012). 
narosłych w miastach przemysłowych leżały u podstaw koncepcji nowej urbanistyki, promowanej m.in. przez Le Corbusiera, która znalazła swój wyraz w Karcie Ateńskiej ${ }^{14}$. Jej idee wpłynęły także na sposób kształtowania przestrzeni centralnej w miastach europejskich w XX w. Przełom XIX i XX w. to także liczne koncepcje miast ,idealnych" łączących funkcje przemysłowe i rezydencjonalne ${ }^{15}$.

W kolejnej fazie neotechnicznej zwiększyła się mobilność przemysłu ze względu na możliwość przesyłania energii na odległość. Był to okres eliminacji przemysłu z wewnętrznych stref miast, który był obserwowany od lat 50 . XX w. w najbardziej rozwiniętych krajach Europy Zachodniej, a w Europie Środkowo-Wschodniej od lat 90. XX w. Początkowo proces deindustrializacji miał charakter relokacji bliższej i związany był z postępującym rozwojem transportu, umożliwiającym szybsze i sprawniejsze przewożenie towarów z miejsca wytwarzania do miejsc dystrybucji. Tereny produkcyjne i składowo-magazynowe przenoszono do zewnętrznych stref miasta, co w konsekwencji prowadziło do dalszej ekspansji terytorialnej ośrodków miejskich. Wśród najważniejszych czynników deindustrializacji o charakterze relokacji dalszej wskazuje się na dążenie przedsiębiorstw do racjonalizacji i zwiększenia zysków poprzez przenoszenie produkcji do obszarów, gdzie dostępna była tania siła robocza (m.in. Domański 2000, Gasidło 1998, Kaczmarek 2010). W dobie kapitalizmu wolnorynkowego wpływ na proces deindustrializacji miała także renta gruntowa, różnicująca ceny ziemi w mieście w zależności od położenia, nasilenia ruchu budowlanego, rodzaju uzbrojenia, sąsiedztwa czy opinii (Liszewski i Maik 2000).

Eliminacja przemysłu z wewnętrznych części miasta stworzyła szansę na przywrócenie integralności przestrzeni centralnej w miastach, która została utracona $\mathrm{w}$ okresie uprzemysłowienia. Proces ten wiązał się $\mathrm{z}$ ponownym zagospodarowaniem opuszczonych terenów poprzemysłowych o zróżnicowanej wielkości i stopniu zwartości oraz z odnową dzielnic mieszkaniowych, które uległy dekapitalizacji w wyniku odpływu najzamożniejszych warstw społecznych na peryferia (z czym wiąże się faza dezurbanizacji) i napływu na ich miejsce ludności o znacznie niższych dochodach, często bezrobotnych. Istotny wpływ na charakter ewolucji przestrzeni centralnej w miastach europejskich po II wojnie światowej miały postulaty zawarte w Karcie Ateńskiej, dotyczące

${ }^{14}$ Karta Ateńska została opracowana na Międzynarodowym Kongresie Architektury Nowoczesnej (CIAM) w Atenach w 1933 r. pod przewodnictwem Le Corbusiera. Dokument ten zawierał zasady nowoczesnego wówczas projektowania urbanistycznego. Najważniejszymi postulatami tego opracowania było rozdzielenie obszarów funkcjonalnych miasta oraz stworzenie racjonalnej i zdrowej przestrzeni życia. Idea ta zyskała powszechne uznanie i była stosowana w większości krajów europejskich. Jej rezultatem jest m.in. struktura przestrzenno-funkcjonalna polskich miast, w których wokół historycznego śródmieścia powstały wielkie jednostki mieszkalne - osiedla budowane w systemie wielkiej płyty w okresie PRL.

15 Zostały one szczegółowo opisane m.in. w pracach: B. Jałowieckiego i M. S. Szczepańskiego (2010), A. Majera (2010), Z. Paszkowskiego (2011), J. Słodczyka (2012) i wielu innych. 
strefowania funkcjonalnego miast. Przestrzeń centralna w licznych ośrodkach w Europie kształtowana była według idei modernizmu, w którym podważone zostały tradycyjne zasady planowania przestrzeni w mieście, takie jak np. linia zabudowy i klasyczna ulica, która zostając zastąpiona „miejską drogą” (Jałowiecki i Szczepański 2010, s. 396), straciła społeczny charakter i wielkomiejską formę. W wyniku budowy dzielnic funkcjonalnych doszło do rozczłonkowania dotychczas zwartego miasta oraz rozdzielenia miejsca pracy i zamieszkania, co spowodowało intensyfikację ruchu wewnętrznego w obrębie miasta. Rozwój komunikacji kołowej sprawił, że przestrzeń w mieście podporządkowano wielkim arteriom samochodowym i licznym parkingom. Ruch pieszy w mieście zdominowany został przez komunikację kołową, z czym wiązało się wprowadzenie pionowej segregacji ruchu (Gehl 2009). Przestrzeń centralna zachowała wielofunkcyjny charakter, szczególnie jako miejsce dystrybucji dóbr i usług luksusowych (tzw. centralny ośrodek usługowy). Stopniowo jednak ograniczano jej kluczowe atrybuty przestrzenne i funkcjonalne, umożliwiające koncentrację użytkowników i mieszkańców miasta, którym zapewniano dostęp do dóbr i usług podstawowych $\mathrm{w}$ ramach dzielnicowych subcentrów. Również zróżnicowanie gospodarcze i polityczne Europy Zachodniej i Środkowo-Wschodniej determinowało odmienny charakter kształtowania przestrzeni centralnej. Ośrodki miejskie w ustroju socjalistycznym rozwijały się bez poszanowania zasad renty gruntowej i do lat 90 . XX w. pozostawały podporządkowane działalności przemysłowej, która niejednokrotnie zajmowała XIX-wieczne obiekty rozmieszczone w obszarach śródmiejskich. Historycznie ukształtowana przestrzeń centralna podlegała degradacji $\mathrm{w}$ wyniku luki remontowej. Wielkomiejska substancja materialna z XIX w., która z przyczyn ideologicznych była traktowana jako przejaw kapitalistycznego wyzysku klasy robotniczej, nie podlegała modernizacji. Bardzo często była ona także eliminowana z przestrzeni miejskiej i zastępowana modernistyczną architekturą. W tym samym okresie istotnej dekapitalizacji uległa historyczna zabudowa przemysłowa, która była intensywnie wykorzystywana na cele produkcyjne, niepoddawana jednocześnie działaniom renowacyjnym. Upadek przemysłu w latach 90. XX w. przyczynił się natomiast do dewastacji większości z zabytkowych, XIX-wiecznych obiektów przemysłowych.

Centralne obszary miast w Europie Środkowej i Wschodniej, podlegające silnym przekształceniom $\mathrm{w}$ okresie realnego socjalizmu, były przeznaczane głównie pod zabudowę mieszkaniową. Interwał gospodarki centralnie planowanej w Polsce, w której nie istniało zapotrzebowanie na funkcje zarządcze, pogłębił historycznie ukształtowany niedorozwój wyposażenia przestrzeni centralnej miast $\mathrm{w}$ instytucje centrotwórcze. Była to reperkusja rozwoju miast polskich przed II wojną światową w warunkach kapitalizmu peryferyjnego. W efekcie wskazanych uwarunkowań rozwojowych doszło do atrofii centrum miast polskich, rozumianych jako dzielnice staromiejskie. Były one zorientowane na obsługę mieszkańców, a współcześnie także turystów, pełniąc głównie funkcję turystyczną 
i symboliczną (Jałowiecki i Szczepański 2010). Natomiast obszary aktywności usługowej, handlowej i kulturowej o charakterze co najmniej ogólnomiejskim zostały wykształcone w innych, często rozproszonych lokalizacjach. Zagadnienie peryferyzacji przemysłowych miast polskich w dobie globalizacji podejmowane było m.in. przez A. Michalską-Żyłę (2010). W odróżnieniu od miast rozwijających się w ustroju socjalistycznym w drugiej połowie XX w. instytucje centrotwórcze były typowe dla większości dużych ośrodków Europy Zachodniej, wzrastających $\mathrm{w}$ gospodarce wolnorynkowej. Sposób wyposażenia instytucjonalnego w miastach polskich i innych w Europie Środkowo-Wschodniej uległ zmianie dopiero po transformacji gospodarczej i ustrojowej na przełomie lat 80. i 90. XX w.

Przestrzeń centralna $\mathrm{w}$ miastach zachodnioeuropejskich podlegała stopniowej przebudowie wraz z postępującym procesem deindustrializacji. Dominowały $\mathrm{w}$ niej funkcje administracyjne, usługowe, kulturowe, naukowe i rozrywkowe. Druga połowa XX w. w miastach Europy Zachodniej oraz przełom XX i XXI w. w ośrodkach Europy Środkowo-Wschodniej wiązał się z procesem metropolizacji i rozwoju funkcji III i IV sektora gospodarki. Miasta nabrały charakteru postindustrialnego, w których przewagę nad działalnością produkcyjną zyskały usługi. Współczesne instytucje centrotwórcze są znacznie bardziej złożonym zbiorem niż w poprzednich okresach w historii budowy i rozwoju miast. Wraz ze wzrostem ich liczby i zróżnicowania nastąpiła dyfuzja instytucji wielkomiejskich poza obszar centralny miast, a w rezultacie nastąpiła dyspersja wyspecjalizowanych form przestrzeni centralnej $\mathrm{w}$ mieście. Istotę przestrzeni centralnej jako przestrzeni wymiany zaburzył m.in. rozwój supermarketów i hipermarketów na peryferiach miast europejskich, co było konsekwencją nieustannie wzrastającego dostępu do samochodu osobowego, rozpraszania się miasta oraz postępującej suburbanizacji w drugiej połowie XX w. Znaczny wzrost galerii handlowych ${ }^{16}$, które stały się odzwierciedleniem nowoczesnej formy przestrzeni wymiany w centralnych obszarach miast europejskich obserwuje się od lat 60. XX w., natomiast jej najnowocześniejsze formy - tzw. galerie handlowe, trzeciej i czwartej generacji - łączące funkcję handlową z innymi usługami (np. kulturalną) oraz funkcją rezydencjonalną (tzw. galerie handlowe piątej generacji) - od lat 90. XX w. (w Polsce po roku 2000). Centra i galerie handlowe to przestrzeń publiczna o charakterze dośrodkowym, skoncentrowana wewnątrz obiektu, która stanowi zaprzeczenie idei tradycyjnej, otwartej przestrzeni publicznej. Specyficzną rolę w mieście pełnią galerie handlowe najnowszych generacji, które w dobie komercjalizacji licznych aspektów życia społecznego zastępują, poniekąd, dotychczasowe centra

${ }^{16}$ Galerie handlowe, a wcześniej domy towarowe, są specyficzną formą centrów handlowych, które rozwijają się w Europie Zachodniej od XIX w. Pierwszy dom towarowy w Europie otwarto w Paryżu w 1852 r. Do jednych z pierwszych należą także domy towarowe w Londynie oraz Mediolanie, które również powstały w XIX w. W przeciwieństwie do miast amerykańskich zapotrzebowanie na rozwój centrów handlowych w Europie był mniejszy ze względu na dynamikę rozwoju śródmieść miast europejskich (Dziedziuchowicz 2012). 
poprzez przejmowanie ich funkcji integrującej aktywność społeczności miejskiej. Stąd B. Jałowiecki i M. S. Szczepański (2010) różne formy koncentracji handlu i rozrywki w jednym obiekcie traktują jako swoiste ,,antycentrum”. Podobne zdanie wyraża M. Sepe (2007), która centrum handlowo-rozrywkowe określa mianem ,antymiasta” i ,antyprzestrzeni publicznej”, twierdząc, że jest to miejsce ucieczki do anonimowości, co stoi w opozycji do istoty przestrzeni publicznej miasta wyrażonej w formach jej użytkowania przez J. Gehla (2009). Część badaczy uważa, że powstanie przestrzeni publicznej o charakterze domkniętym jest przejawem kryzysu współczesnej domeny publicznej (m.in. Franta 2004; Kochanowska 2002, 2010; Maik 2011).

$\mathrm{U}$ podstaw kryzysu tożsamości przestrzeni centralnej $\mathrm{w}$ miastach europejskich w XX i na początku XXI w. leży XIX-wieczny rozwój przemysłu w wewnętrznych strefach miasta. W większości ośrodków miejskich w Europie został on pogłębiony przejściem gospodarki z industrialnej do postindustrialnej w drugiej połowie XX w., a w konsekwencji - procesami deindustrializacji i dezurbanizacji oraz forsowaniem przez znaczną część wieku XX modernistycznych postulatów strefowania miast i uprzywilejowania komunikacji kołowej w mieście. Współcześnie podejmowane działania odnowy zdegradowanych obszarów wewnątrzmiejskich splecione z intensyfikacją procesów metropolizacji również niejednoznacznie przyczyniają się do przywrócenia tożsamości przestrzeni centralnej w miastach, czego wyrazem może być dla przykładu budowa coraz wyższych obiektów, które z jednej strony odzwierciedlają prestiż instytucji i miasta, z drugiej - znacznie przewyższają tradycyjną skalę przestrzeni centralnej miasta europejskiego. Wśród pozytywnych zjawisk można natomiast wskazać działania zmierzające do ponownego uprzywilejowania ruchu pieszego i transportu zbiorowego kosztem indywidualnej komunikacji samochodowej, co przyczynia się do reintegracji przestrzeni centralnej w miastach.

Przestrzeń centralna $\mathrm{w}$ miastach europejskich podlegała istotnym przekształceniom morfologicznym i instytucjonalnym. Decydowały o tym zmiany historyczne, polityczne, technologiczne, gospodarcze, społeczne oraz kulturowe i religijne. Miały one różny wpływ na kształtowanie się przestrzeni centralnej w kolejnych okresach historycznych. Istotne znaczenie na etapie formowania się miast miały również uwarunkowania geograficzne, w tym topografia. Najbardziej trwałym elementem przestrzeni centralnej jest układ przestrzenny. Można przyjąć, że w mieście przedindustrialnym przestrzeń centralna stanowiła prostą formę morfologiczno-instytucjonalną, o dużym stopniu koncentracji i integracji przestrzenno-funkcjonalnej i tym samym czytelnie określała lokalizację centrum miasta. Od XIX w. przestrzeń centralna w miastach europejskich podlegała jednak ciągłym procesom dezintegracyjnym i dywersyfikacyjnym. Jest ona rozmieszczona w różnych częściach miasta, nie tylko w ścisłym obszarze śródmieścia. 


\section{Rozdział 4}

\section{REWITALIZACJA JAKO ELEMENT KSZTAŁTOWANIA PRZESTRZENI CENTRALNEJ WE WSPÓŁCZESNYCH MIASTACH EUROPEJSKICH}

Proces rewitalizacji terenów poprzemysłowych jest obecny w miastach Europy Zachodniej od lat 60. XX w. Ze względu na interwał gospodarki centralnie planowanej w krajach Europy Środkowej i Wschodniej, które zorientowane były na działalność produkcyjną, zjawisko to zostało przesunięte w czasie do ostatniej dekady XX w. Wówczas to nastąpił gwałtowny i brzemienny w skutkach kryzys i upadek różnych branż przemysłu, który zajmował także strefy śródmiejskie. Niezależnie od rejonu geograficznego, genezy i przebiegu procesu deindustrializacji, spowodował on degradację miast w wymiarze gospodarczym, społeczno-kulturowym i przestrzennym. Podejmowane działania naprawcze w ramach rewitalizacji wewnątrzmiejskich terenów poprzemysłowych przyczyniły się do istotnych przekształceń przestrzeni centralnej.

\subsection{Istota rewitalizacji w procesie kształtowania przestrzeni centralnej w miastach europejskich}

Kryzys i upadek przemysłu w miastach próbuje tłumaczyć wiele teorii. Współcześni badacze miast, m.in.: B. Jałowiecki i M. S. Szczepański (2010), A. Majer (2010), I. Sagan (2000), A. Wojnarowska (2011), wskazują na wyraźną zależność zachodzącą między rewitalizacją śródmiejskich obszarów zdegradowanych a koncepcją cyklu życia miejskiego zaproponowaną przez L. von Klassena (1965). P. Lorens i J. Martyniuk-Pęczek (2009) zauważają, że w wyniku dokonujących się transformacji gospodarczych następuje dekapitalizacja i degradacja wielu terenów przemysłowych w zabudowie miejskiej. Z procesami deindustrializacji wiążą są także dramatyczne konsekwencje społeczne w postaci bardzo wysokich wskaźników bezrobocia, ogromnego wzrostu przestępczości i fizycznej degradacji znacznej wielkości przestrzeni miejskiej. Mimo pojawienia się tak licznych efektów o charakterze pejoratywnym, proces eliminacji działalności 
przemysłowej z centralnych dzielnic miast stwarza równocześnie szansę na ich reurbanizację, co ma szczególne znaczenie dla przekształceń istniejącej oraz kształtowania nowej przestrzeni centralnej. Rewitalizację wewnątrzmiejskich terenów poprzemysłowych traktuje się także jako pewnego rodzaju panaceum na zjawisko niekontrolowanego rozlewania się miast (ang. urban sprawl), a tym samym możliwość realizacji koncepcji miasta spójnego (zwartego, kompaktowego, ang. compact city), zaznaczonej bardzo wyraźnie w wizji rozwoju miast XXI w. w tzw. Nowej Karcie Ateńskiej ${ }^{1}$ opracowanej w 2003 r. Stwarza ona jednocześnie możliwość kształtowania zwartej przestrzeni centralnej.

Proces rewitalizacji wewnątrzmiejskich terenów poprzemysłowych wiąże się z ponownym zagospodarowaniem zdegradowanych terenów poprzemysłowych, które ze względu na swoje położenie w układzie miejskim są uważane za atrakcyjny obszar lokalizacji nowych funkcji miastotwórczych, także o charakterze metropolitalnym. Ma to niebagatelne znaczenie w kontekście braku możliwości przebudowy istniejących dzielnic centralnych współczesnych miast europejskich, które często posiadają wybitne wartości historyczne i kulturowe oraz podlegają ochronie konserwatorskiej. Zagadnienie lokalizacji funkcji wielkomiejskich na terenach poprzemysłowych było już przedmiotem rozważań w dotychczasowych studiach miejskich. Zdaniem I. Mironowicz i T. Ossowicza (2005) na potencjał metropolitalny składają się takie cechy miejsca, jak np.: położenie, wartości kulturowe i przyrodnicze, dotychczasowe zagospodarowanie, uroda miejsca oraz pełnienie już funkcji metropolitalnych w minionym okresie rozwoju miasta. P. Lorens (2005) wskazuje dodatkowo na wielkość obszaru, który w sposób naturalny wyznacza możliwości uzyskania przez niego funkcji o znaczeniu metropolitalnym. W kontekście wskazanych cech badacz ten dokonał analizy potencjału możliwości lokowania funkcji metropolitalnych na terenach poprzemysłowych, uwzględniając ich pierwotne przeznaczenie. Wyróżnił w ten sposób: tereny produkcyjne wraz z terenami magazynowymi i składowymi oraz towarzyszące im tereny pokolejowe (dzieląc je dalej na: tereny towarzyszące działającym dworcom kolejowym, tereny stacji postojowych, towarowych i rozrządowych oraz infrastruktury kolejowej i tereny likwidowanych linii i dworców kolejowych) oraz tereny poportowe (o genezie średniowiecznej oraz o genezie XIX-wiecznej

1 W 2003 r. Europejska Rada Planistów Przestrzennych przyjęła Nową Kartę Ateńską, która przedstawia wizje spójnych pod względem społecznym, ekonomicznym, ekologicznym i przestrzennym miast przyszłości. Nowa Karta Ateńska jest odpowiedzią na Kartę Ateńską opracowaną w 1933 r., która determinowała planowanie przestrzenne w miastach europejskich przez znaczną część XX w., według tzw. urbanistyki modernistycznej. Odrzucała ona wielowiekowe wzorce projektowania miast $\mathrm{w}$ wyniku pogarszających się warunków mieszkaniowych, jakie pojawiły się w miastach europejskich na przełomie XIX i XX w. W krajach Europy Zachodniej urbanistyka modernistyczna została skrytykowana już w latach 60. XX w., natomiast w Polsce znacznie później, przede wszystkim ze względu na system polityczno-gospodarczy w II poł. XX w. czerpiący z tej doktryny w planowaniu miast. 
i wczesno-XX-wiecznej). W wymiarze morfologicznym i funkcjonalnym ${ }^{2}$ najwyższą podatnością na lokalizację funkcji metropolitalnych odznaczały się tereny pokolejowe, w mniejszym stopniu - tereny poprodukcyjne, a w najmniejszym tereny poportowe. Głównym czynnikiem decydującym o tej kolejności jest nie tylko wielkość terenów poprzemysłowych, co zaznacza P. Lorens (2005), ale także ich zwartość, która umożliwia kształtowanie nowej jednostki morfologiczno-funkcjonalnej w przestrzeni miejskiej.

W aspekcie kształtowania funkcji wielkomiejskich na zdegradowanych terenach miejskich istnieje także pojęcie podatności na rewitalizację, którą wprowadzili do literatury przedmiotu S. Kaczmarek i J. Kaczmarek (2010). Badacze ci definiują ją jako ,zespół cech materialnych i niematerialnych, uwarunkowań ekonomicznych i społecznych właściwych dla każdego obszaru poprzemysłowego, charakteryzujących go i jednocześnie będących determinantami planowanych dlań przemian" (s. 70). Autorzy opracowali trzystopniowy podział podatności terenu na rewitalizację, wyróżniając: stopień silny, średni i słaby. W procesie delimitacji zdegradowanych terenów miejskich uwzględnili kontekst urbanistyczny, architektoniczny, ekonomiczny i społeczny. Wyniki studiów przeprowadzonych na przykładzie Łodzi wskazują, że najwyższą podatnością na rewitalizację charakteryzują się obiekty (tereny) położone w obszarze śródmiejskim ze względu na dobrą dostępność komunikacyjną oraz na sąsiedztwo innych instytucji wielkomiejskich. W świetle pracy P. Lorensa (2005) oznacza to, że kluczowym czynnikiem decydującym o podatności terenów poprzemysłowych na rewitalizację, czyli również na możliwość rozwoju funkcji metropolitalnych, nie jest ich wielkość, geneza i pierwotne przeznaczenie, lecz położenie w układzie miejskim (lokalizacja). W mniejszym natomiast stopniu była to m.in. powierzchnia działek, stosunki własnościowe, stan zachowania obiektów i walory architektoniczne obiektów pofabrycznych.

Wyniki dotychczasowych badań wskazują na zasadniczą rolę czynnika morfologicznego (sensu stricto i sensu largo) i instytucjonalnego w procesie przekształceń przestrzeni centralnej w miastach europejskich. Pozwalają one również wnioskować, że wewnątrzmiejskie tereny poprzemysłowe stanowią atrakcyjny obszar do kształtowania nowej przestrzeni centralnej w mieście. Sprzyja temu oryginalna forma urbanistyczno-architektoniczna, która stwarza ramy dla interesującej aranżacji przestrzeni publicznej oraz wzrastające na świecie zainteresowanie okresem industrializacji jako ważnym etapem $\mathrm{w}$ rozwoju cywilizacji (Stott 2012). Trend ten przekłada się również na rosnącą atrakcyjność inwestycyjną przestrzeni postindustrialnej w miastach, mimo istotnych komplikacji

${ }^{2}$ Wyróżniono cztery kryteria badania degradacji obszarów metropolitalnych: materialną, funkcjonalną oraz moralną, związaną przede wszystkim z wizerunkiem miejsca (ocena bezpieczeństwa, miejsce eleganckie, niezwykłe czy przeciwnie), i kompozycyjną, obejmującą stopień wykształcenia struktur kompozycyjnych, zwanych zespołami kompozycyjnymi, oraz realizację funkcji kompozycji. 
prawnych, przestrzennych i społecznych wiążących się z procesem rewitalizacyjnym, realizowanym $\mathrm{w}$ zgodzie $\mathrm{z}$ poszanowaniem dziedzictwa kulturowego (Franger 2012, Preite 2012). Istotną rolę w tym procesie pełnią wówczas władze miejskie oraz inni lokalni aktorzy sceny miejskiej, tacy jak: przedsiębiorcy, mieszkańcy, społecznicy (Falconer 2012, Jones i Evans 2009, Sagan 2000). Interesująca, unikatowa kompozycja urbanistyczna oraz wyposażenie instytucjonalne nowej przestrzeni centralnej na terenach poprzemysłowych przyciąga znaczną liczbę użytkowników przestrzeni miejskiej, często kosztem istniejącej wcześniej przestrzeni centralnej. Ranga instytucji centrotwórczych, jakość i wielkość przestrzeni publicznej, indywidualność i oryginalność formy architektonicznej oraz przede wszystkim zainteresowanie ze strony użytkowników decydują o relacjach zachodzących pomiędzy starą i nową przestrzenią centralną w mieście.

Zdaniem B. Jałowieckiego i M. S. Szczepańskiego (2010) miastotwórczymi czynnikami w erze postindustrialnej, oprócz informacji, są kultura i rozrywka. Instytucje kultury bardzo często uczestniczą w procesie rewitalizacji zdegradowanych fragmentów przestrzeni miejskiej, jako dopełnienie programu komercyjnego. B. Sułkowski (2010) zwraca uwagę na swoistą symbiozę kultury i funkcji usługowo-rozrywkowych na przekształconych terenach pofabrycznych. Na znaczącą rolę kultury i rozrywki w transformacji dawnych miast przemysłowych i rozwoju miast postmodernistycznych zwracają uwagę m.in. A. Hommouche (2004), T. Markowski i D. Stawasz (2007) oraz B. Sułkowski (2004). S. Zukin (1995) stwierdził, że lokalizacja instytucji wysokiej kultury jest także elementem budowy marki miasta. Wpływ ten dostrzegają władze miejskie i deweloperzy odpowiedzialni za przekształcenia terenów poprzemysłowych. Rezultat ich działań wyrażany jest bardzo często $\mathrm{w}$ formie projektów wiodących ${ }^{3}$ (ang. flagship projects). Odgrywają one kluczową rolę w procesie rewitalizacji zdegradowanych terenów miejskich i przekształcania przestrzeni centralnej ze względu na wysoką rangę instytucji, które zajmują nowy obiekt, zazwyczaj o oryginalnej formie architektonicznej. Projekty wiodące są najczęściej elementem szerzej zakrojonych działań, związanych z procesem odnowy większych fragmentów zdegradowanych dzielnic centralnych, które obejmują też ugory poprzemysłowe. Do ich realizacji bardzo często zapraszani są światowej sławy architekci, którzy swoim nazwiskiem w bezpośredni sposób firmują dzieła architektoniczne, a pośrednio miasta, w których one powstają (Jałowiecki i Szczepański 2010). Podstawowym celem tworzenia projektów wiodących $\mathrm{w}$ ramach procesu rewitalizacji jest podniesienie prestiżu miasta i zwiększenie atrakcyjności inwestycyjnej konkretnego fragmentu przestrzeni miejskiej. P. Lornes (2002) określa te projekty jako „przedsięwzięcia o znaczeniu kluczowym, mające w wyniku realizacji w sposób skoordynowany i kompleksowy przyspieszać w sposób skokowy procesy rozwojowe danego

${ }^{3} \mathrm{~W}$ literaturze przedmiotu funkcjonują one także pod pojęciem: projekty flagowe i demonstracyjne (m.in. Gibson 2003; Jałowiecki i Szczepański 2010; Lorens 2002, 2009, 2010; Wesołowski 2006). 
obszaru" (s. 197). Procesy te polegają na zachęceniu do inwestycji kolejnych deweloperów i lokalizacji instytucji centrotwórczych w pierwotnie zdegradowanym przestrzennie i funkcjonalnie rejonie, a w którym znajduje się tenże projekt wiodący. Są to najczęściej instytucje, których profil jest zbliżony do charakteru projektu wiodącego (Peck i Ward 2002, Jones i Evans 2008, Roberts i Sykes 2008). Ch. Gibson (2003) uważa, że obiekty wiodące mogą przyczyniać się do znacznie lepszego postrzegania miasta, co jest jednym z celów rewitalizacji. Bardzo często obiekty stają się dodatkowo znakami, symbolami miasta. W tym kontekście architektura projektów wiodących pełni funkcję prestiżową. Powstawanie tego typu obiektów w konkretnych lokalizacjach jest wynikiem przemyślanej polityki planistycznej oraz próbą budowania marki miasta.

Procesowi generowania nowej przestrzeni centralnej na terenach poprzemysłowych często towarzyszy kształtowanie nowych „obiektów-znaków rozpoznawczych" (ang. landmarks) miasta, z wykorzystaniem obiektów postindustrialnych adaptowanych do potrzeb współczesnych instytucji centrotwórczych. W tym rozumieniu istotę rewitalizacji ugorów poprzemysłowych można porównać do palimpsestu ${ }^{4}$, w którym przestrzeń miejska jest zestawiana z kartą wielokrotnego zapisu i odczytu (m.in. Rewers 2005, Jaroszewska-Brudnicka 2011, Wójcik 2008). Obiekty i dzielnice przemysłowe stanowiły ,wizytówki” miast w okresie dynamicznej industrializacji w XIX w. Były one wówczas utożsamiane z największym postępem cywilizacyjnym i potęgą danego miasta przemysłowego. Następnie w okresie upadku przemysłu obiekty pofabryczne utożsamiały negatywne wartości, takie jak ubóstwo, patologie społeczne oraz degradację krajobrazu zurbanizowanego (kulturowego). Po upadku przemysłu tereny poprzemysłowe są zajmowane przez współczesne funkcje wielkomiejskie. W literaturze z zakresu urbanistyki i architektury pojawia się pojęcie dualności postmodernistycznej architektury, której podstawową cechą jest podwójne kodowanie w dziele architektonicznym (Jencks 1987, 1993). Architektura postmodernistyczna współtworząca oryginalny i niepowtarzalny image współczesnych miast jest wykorzystywana również w walce konkurencyjnej ośrodków miejskich o przyciągnięcie kapitału, nowych festiwali, artystów, mieszkańców etc. w celu zwiększenia wzrostu dochodów do budżetu z tytułu podatków (Majer 2010). W tym ujęciu wtórne zagospodarowanie wewnątrzmiejskich terenów postindustrialnych na funkcje centrotwórcze stwarza możliwość kształtowania przestrzeni centralnej adekwatnej do wizerunku nowoczesnego miasta, rozwijającego się w poszanowaniu tożsamości mieszkańców miasta. Przestrzeń centralna wykształcona na terenie postindustrialnym stanowi w tym świetle przeciwwagę dla historycznej przestrzeni centralnej, niejednokrotnie zyskując dominującą pozycję w hierarchii terenów miejskich.

${ }^{4}$ Nazwa palimpsest wywodzi się z języka starogreckiego palimpeston. Jest to rękopis spisany na używanym już wcześniej materiale piśmiennym (często była to skóra zwierzęca, najczęściej jagnięca, ze względu na większą jej trwałość niż papirusu i papieru), z którego usunięto poprzedni tekst, najczęściej w celu zmniejszenia kosztów zakupu nowego materiału. 
Wygenerowanie nowej przestrzeni centralnej niezależnie od jej wielkości i sposobu wyposażenia prowadzi do zmian w organizacji przestrzeni centralnej $\mathrm{w}$ mieście jako całości. Jest to proces permanentny w historii budowy i rozwoju miast, a rewitalizacja ugorów poprzemysłowych jest jednym z czynników, które wpływają na reorganizację przestrzeni centralnej we współczesnych miastach. Można w tym kontekście wskazać na proces kształtowania nowej przestrzeni centralnej sensu stricto na terenach poprzemysłowych (w mezoskali) oraz na proces tworzenia nowej przestrzeni centralnej sensu largo, ze względu na wpływ, jaki wywiera nowa przestrzeń centralna sensu stricto na istniejącą wcześniej przestrzeń centralną (w makroskali).

\subsection{Formy przekształceń przestrzeni centralnej w miastach europejskich pod wpływem rewitalizacji wewnątrzmiejskich terenów poprzemysłowych}

W procesie rewitalizacji terenów poprzemysłowych można wyróżnić dwa typy działań przestrzenno-funkcjonalnych, mających wpływ na sposób reorganizacji przestrzeni centralnej w makroskali:

- projekty o charakterze punktowym, które obejmują podstawowe elementy morfologiczne oraz jednostki morfologiczne (bloki, kwartały miejskie);

- projekty o charakterze wielkoobszarowym, które wiążą się z przekształceniami dzielnic, czyli prostych układów morfologicznych.

Rewitalizacja o charakterze punktowym i wieloobszarowym różni się odmiennym przebiegiem procesu inwestycyjnego, który jest determinowany czynnikiem morfologicznym. W przypadku kwartałów miejskich za działania wystarczające do kompleksowej realizacji procesu rewitalizacji są uważane interwencje pojedynczych inwestorów, którzy są zainteresowani poszczególnymi inwestycjami kubaturowymi na konkretnych działkach (parcelach) bądź w jednym bloku urbanistycznym. W przypadku dzielnic miejskich zazwyczaj niezbędna jest obecność dewelopera terenu (zwanego też gruntowym), którego zadaniem jest przygotowanie procesu restrukturyzacji całej dzielnicy. W krajach wysoko rozwiniętych i posiadających duże doświadczenie w zakresie rewitalizacji terenów miejskich typu brownfields (m.in. Niemcy, Francja i Wielka Brytania) przygotowaniem terenu pod nowe zagospodarowanie zajmują się wyspecjalizowane instytucje publiczne oraz prywatne firmy. Ich podstawowym celem jest m.in. wykup ugorów poprzemysłowych, scalanie terenu należącego do różnych właścicieli, eliminacja z przestrzeni poprzemysłowej bezwartościowej zabudowy i zabezpieczenie obiektów historycznych, oczyszczenie terenu ze skażonej ziemi bądź budynków z chemikaliów (jeśli zaistnieje taka konieczność) oraz ponowna parcelacja terenu pod kątem nowych inwestycji (por. m.in. Bryx 2009, Evans i Jones 2008, Guzik 2009, Imrie i Thomas 1993, Lorens 2005, Skalski 2009, Tölle 2006, Wojnarowska 
2011). W polskich uwarunkowaniach prawnych i finansowych występują znaczne ograniczenia $\mathrm{w}$ możliwościach funkcjonowania tego typu instytucji i przedsiębiorstw, co komplikuje sprawną realizację procesu rewitalizacji. Utrudnione jest również wykupienie własności terenu przez miasto w celu jego ponownej parcelacji, gdyż rewitalizacja nie posiada statusu zadania publicznego (Ziobrowski i Domański 2010).

Rewitalizacja o charakterze punktowym podejmowana jest w konsekwencji rozdrobnienia i rozproszenia terenów poprzemysłowych w przestrzeni miejskiej bądź w wyniku braku zainteresowania ze strony inwestora terenem poprzemysłowym o dużej powierzchni. Ze względu na skalę działań naprawczych punktowe przekształcenia przestrzenno-funkcjonalne mają ograniczony zasięg oddziaływania na reorganizację przestrzeni centralnej. Zasięg ten zależy od specyfiki nowego wyposażenia instytucjonalnego i oryginalności formy architektonicznej na przekształcanej działce lub kwartale. Na formę tę mogą się składać nowe obiekty bądź zaadaptowane do nowych funkcji i zrewaloryzowane budynki postindustrialne.

Rewitalizacja o charakterze wielkoobszarowym obejmuje zazwyczaj wewnątrzmiejskie ugory poprzemysłowe o znacznej powierzchni bądź zbiór mniejszych terenów poprzemysłowych o dużym stopniu koncentracji. W zależności od stopnia rozproszenia zdegradowanych obszarów postindustrialnych działania naprawcze $w$ ramach projektów wielkoskalowych mogą obejmować nie tylko przestrzeń poprzemysłową, lecz także tereny o innym sposobie użytkowania i stopniu dekapitalizacji substancji miejskiej. Ze względu na spójność działań w wymiarze przestrzennym i funkcjonalnym projekty wielkoskalowe, mimo możliwego zróżnicowania morfologicznego terenów objętych procesem, stwarzają możliwość wygenerowania nowej, zwartej jednostki morfologiczno-funkcjonalnej. Centralne położenie w układzie miejskim zwiększa jej podatność na lokalizację funkcji metropolitalnych. Dodatkowo, koncentracja oryginalnych obiektów architektonicznych, które zajmują instytucje centrotwórcze, adaptacja interesującego układu przestrzennego i wysoka jakość urządzenia przestrzeni publicznej sprzyjają wygenerowaniu nowej przestrzeni centralnej w mieście ${ }^{5}$. W tym kontekście przestrzeń publiczna jest wyróżniana na podstawie kryterium dostępności dla użytkowników, co oznacza, że jej właścicielem może być również inwestor prywatny.

${ }^{5}$ Może ona być również rozwijana jako złożony projekt wiodący. Realizacja przedsięwzięć wielkoskalowych stanowi jednak istotne zagrożenie dla integracji struktury przestrzennej, na co zwrócił uwagę m.in. Z. Zuziak (1998). Jego zdaniem projekty, które są uznane przez władze lokalne za priorytetowe dla przyjętej strategii rozwoju miasta i nazywane przez badacza - sztandarowymi lub specjalnymi, mogą prowadzić do odwrócenia logicznej relacji plan-projekt. W warunkach podporządkowania polityki przestrzennej gospodarce liberalnej, plan rozwoju wybranego fragmentu miasta jest podporządkowany realizacji projektu rewitalizacyjnego. Zaburzenie tych relacji, przy braku odpowiednich powiązań strukturalnych, może przyczynić się do osłabienia integracji przestrzeni miejskiej (Zuziak 1998). 
Camillo Sitte ${ }^{6}$ stwierdził, że każdy nowy fragment miasta nie tylko buduje swój własny byt, ale uczestniczy w budowaniu miasta jako całości (Paszkowski 2011). Ma to szczególne znaczenie w procesie kształtowania nowej bądź przekształcenia już istniejącej przestrzeni centralnej, która jest kluczowa dla egzystencji miasta i decyduje o jego dalszym rozwoju. W złożonym układzie morfologicznym, identyfikowanym $\mathrm{z}$ dużym miastem istotną rolę ma wygenerowanie nowej przestrzeni centralnej w wyniku realizacji projektów o charakterze wielkoskalowym bądź znacznej koncentracji, skoordynowanych działań o charakterze punktowym, w rezultacie którego dochodzi do efektu synergii. Znaczenie ma również stopień rozwinięcia starej przestrzeni centralnej w mieście, który zależy od jej morfogenezy.

Proces rewitalizacji wewnątrzmiejskich terenów poprzemysłowych, który prowadzi do wykształcenia nowej przestrzeni centralnej (sensu stricto, w mezoskali) w mieście odznacza się całkowitą zmianą programu funkcjonalnego oraz dwoistym charakterem przemian w wymiarze morfologicznym. W tym aspekcie można wyróżnić rewitalizację sensu largo, która ma charakter procesu historyzującego lub radykalnego oraz rewitalizację właściwą - sensu stricto. Rewitalizacja sensu largo charakteryzuje się eliminacją i wymianą zastanych podstawowych elementów morfologicznych, w tym elementów liniowych, które M. Koter (1974) uznaje za najbardziej trwały element struktury przestrzennej miasta, oraz kształtowaniem nowych bloków urbanistycznych w nowym układzie komunikacyjnym (układzie ulic). W nawiązaniu do cyklu zagospodarowania terenów miejskich Conzena, cykl wtórny, z którym związana jest rewitalizacja miejskich ugorów poprzemysłowych, jest powtórzeniem cyklu pierwotnego i obejmuje wszystkie cztery fazy. Pierwsza z nich - wstępna (inicjalna) wiąże się z ponowną parcelacją nowo wygenerowanych kwartałów (w nowym układzie ulic) oraz intensywnym narastaniem tkanki miejskiej na działkach wolnych od pierwotnej zabudowy (rys. 4.1). Radykalna forma rewitalizacji sensu largo wiąże się ostatecznie z wygenerowaniem nowych dzielnic (jednostek przestrzenno-funkcjonalnych), których wtórne właściwości przestrzenne w znaczący sposób różnią się od pierwotnych cech morfologicznych przekształconego obszaru. Rewitalizacja sensu largo o charakterze historyzującym wyróżnia się budową nowych obiektów, których fizjonomia nawiązuje do pierwotnej zabudowy przemysłowej (mimo jej całkowitej eliminacji) i dodatkowo może się ona wiązać z częściowym odtworzeniem pierwotnego podziału działek miejskich oraz układu elementów liniowych (ulic).

W rewitalizacji właściwej (sensu stricto) dominuje natomiast: adaptacja istniejących elementów morfologicznych do nowych funkcji i uzupełnienie ich nowymi elementami przestrzennymi o architekturze współczesnej lub stylizowanej na industrialną, modyfikacja bloków urbanistycznych poprzez dostosowanie ich do nieznacznie zmienionego pierwotnego układu komunikacyjnego oraz znaczny

${ }^{6}$ Camillo Sitte (1843-1903) - austriacki teoretyk urbanistyki końca XIX w. 
stopień zachowania pozostałych pierwotnych właściwości morfologicznych układów prostych. We wtórnym cyklu zagospodarowania nie wyróżnia się inicjalnej fazy, gdyż przemiany przestrzenne wykorzystują pierwotny układ przestrzenny, poddany jedynie adaptacji (rys. 4.1). Można w nim jednak wskazać na działania związane z wtórną parcelacją części działek, które uprzednio przeszły komasację.

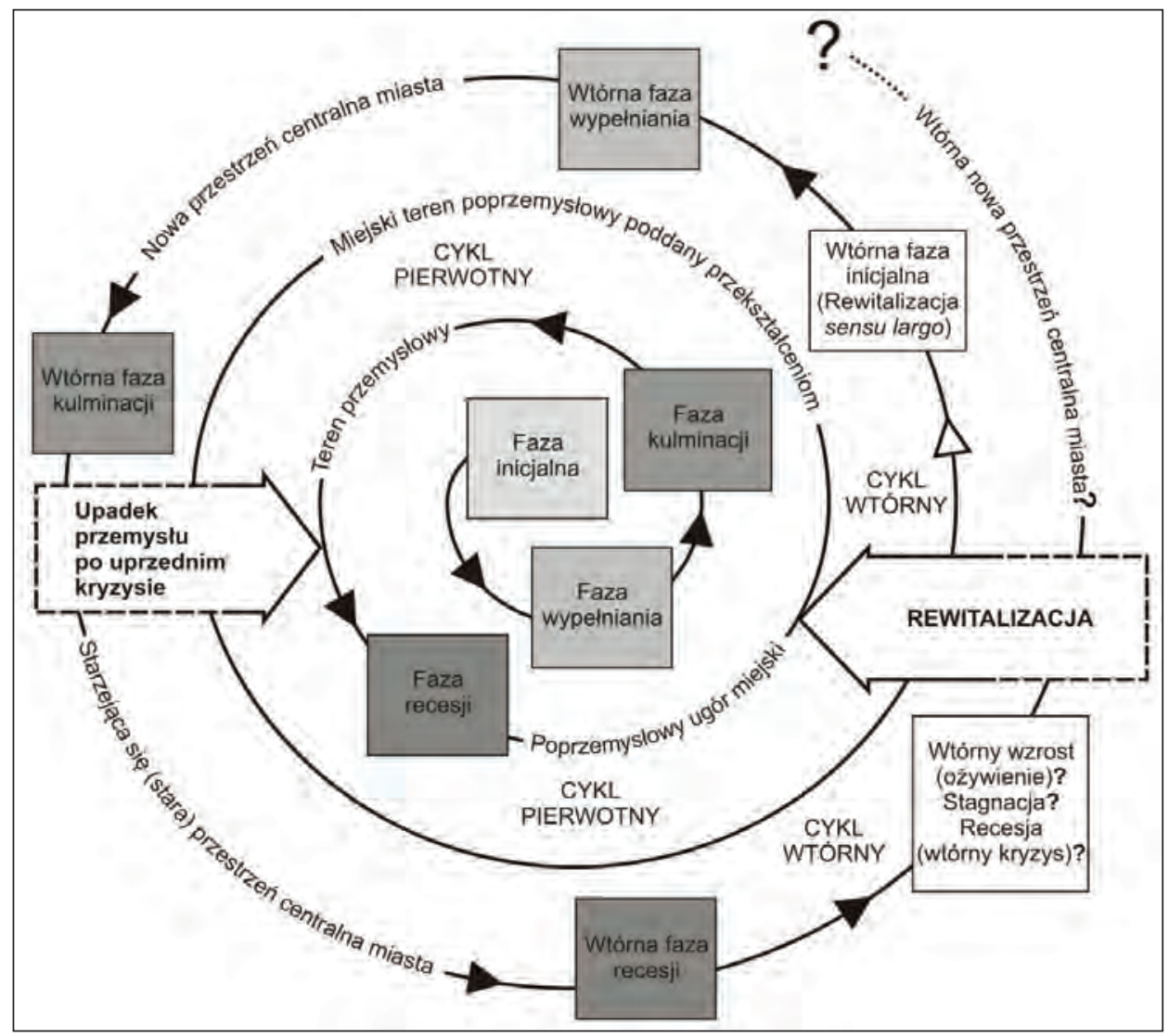

Rys. 4.1. Pierwotny i wtórny cykl zagospodarowania terenu (po)przemysłowego wobec procesu rewitalizacji i kształtowania nowej przestrzeni centralnej w mieście

Źródło: badania własne autora

Podział procesu rewitalizacji na działania o charakterze rewitalizacji właściwej i sensu largo (historyzującej i radyklanej) odpowiada po części typom procesu rewitalizacji, który został zidentyfikowany przez S. Kaczmarek (2001). Uwzględniał on dodatkowo wymiar gospodarczy, społeczny i kulturowy restrukturyzacji terytorialnej. W tym kontekście rewitalizacji sensu largo można przypisać pewne właściwości rewitalizacji implantacyjnej, natomiast rewitalizacji właściwej - część cech procesu przekształceń przestrzennych w ramach rewitalizacji integracyjnej (por. Kaczmarek 2001). 
M. Koter (1994) stwierdził, że przemiany morfologiczne można sprowadzić do trzech podstawowych procesów: wypełnienia, uzupełnienia i przekształcenia. Pierwszy znich polega na wypełnieniu dodatkowymi elementami wcześniej powstałych jednostek bądź układów morfologicznych i który prowadzi do poziomego i pionowego zintensyfikowania zabudowy. W procesie tym dochodzi do subpodziałów elementów powierzchniowych planu miasta, jednak jego pierwotny układ pozostaje bez zmian. Proces uzupełniania polega na tworzeniu nowych jednostek obok już istniejących. W rezultacie intensywność przemian w starszych jednostkach jest znacznie mniejsza, o charakterze addytywnym, ekstensywnym. Proces przekształceń wiąże się natomiast z przebudową istniejących struktur przestrzennych w celu stworzenia nowych, sprawniejszych funkcjonalnie i modniejszych estetycznie form. Proces przekształceń ma bardzo często charakter radykalnej transformacji, również o charakterze jakościowym. Jest on podejmowany wówczas, gdy dwa poprzednie procesy, których istotą były przemiany ilościowe, osiągnęły pewną wartość progową, przy jakiej dalszy kierunek zmian był już niemożliwy (Koter 1994). Rewitalizacja terenów poprzemysłowych w wymiarze morfologicznym odpowiada procesom przekształceń istniejących struktur przestrzennych i ma charakter jakościowy. Intensywność przekształceń ilościowych jest jednak zróżnicowana, począwszy od zmian w niewielkim stopniu ingerujących w pierwotną strukturę urządzeń trwałych, której odpowiada rewitalizacja sensu stricto, aż po przekształcenia $\mathrm{w}$ formie radykalnej, właściwe rewitalizacji sensu largo. Zmiany fizjonomiczne tkanki miejskiej oraz intensywności zagospodarowania $\mathrm{w}$ obu obszarach zidentyfikowanych typów przemian morfologicznych w ramach rewitalizacji terenów poprzemysłowych obejmują wszystkie z wyodrębnionych przez J. W. R. Whitehand (1979) oraz J. W. R. Whitehand i S. M. Whitehand (1983) typów przemian fizycznych budynków: dużą przebudowę, dobudowę, przemianę połączoną z dobudową i zmiany fasad. Przekształcenia te mają zatem zawsze charakter ilościowy i jakościowy.

Niezależnie od charakteru przemian morfologicznych, proces rewitalizacji wewnątrzmiejskich terenów poprzemysłowych prowadzi do wykształcenia ,nowej” przestrzeni centralnej w mieście, która jest w opozycji do „starej”. O jej „,nowości" decyduje: inna (nowa) lokalizacja, późniejszy okres powstania, nowoczesny charakter zabudowy, wśród której mogą się znaleźć obiekty historyczne poddane rewaloryzacji oraz nowe instytucje centrotwórcze, odpowiadające współczesnym funkcjom miasta oraz aktualnym potrzebom mieszkańców i użytkowników miasta.

Zdaniem M. Kotera (1994) rozpoznanie sił oraz procesów tworzących, a zarazem przekształcających formy krajobrazu kulturowego, w tym miejskiego, stanowi istotę $\mathrm{w}$ pełni naukowych badań morfogenetycznych, w których chodzi nie tylko o określenie czasu, ale i sposobu, w jaki powstały dane formy, następnie rozwijały się i podlegały ewolucji. W kontekście morfogenezy przestrzeni centralnej w mieście, czyli procesie jej rozwoju i transformacji w ujęciu ewaluacyjnym, industrializację wewnętrznych stref miasta należy łączyć z procesem 
zewnętrznym o charakterze destruktywnym, podobnie jak kryzys, a następnie upadek przemysłu. W tym aspekcie rewitalizacja wewnątrzmiejskich terenów poprzemysłowych (rewitalizacja wyspowa, wielkoobszarowa, sensu largo i sensu stricto) jest jednym z zewnętrznych procesów o charakterze konstruktywnym, który ma wpływ na przekształcenia formy architektonicznej i urbanistycznej przestrzeni centralnej w jej cyklu rozwojowym (por. rys. 4.1). W założeniu proces rewitalizacji jest uniwersalny, bowiem zawsze łączy się z przekształceniami przestrzennymi i funkcjonalnymi, mającymi na celu ożywienie zdegradowanych terenów miejskich. Jednak jego konsekwencje dla kształtowania przestrzeni centralnej są różne w zależności od miejsca i czasu realizacji.

Nowa przestrzeń centralna wygenerowana $\mathrm{w}$ ramach rewitalizacji na terenach poprzemysłowych tak jak inne tereny miejskie jest również wrażliwa na siły i procesy zewnętrzne i wewnętrzne o charakterze destruktywnym i konstruktywnym. W rezultacie mogą one prowadzić do stagnacji, upadku lub dalszego rozwoju przestrzeni centralnej w wymiarze morfologicznym $\mathrm{i}$ instytucjonalnym. Sposób jej transformacji jest także uzależniony od kontekstu rozwoju przestrzeni centralnej w mieście jako jednego układu, w którym może pozostać najnowszym genetycznie elementem lub podlegać degradacji i procesom naprawczym wraz z wykształceniem nowocześniejszych jednostek przestrzenno-funkcjonalnych. 



\section{Rozdział 5}

\section{PRZEKSZTAŁCENIA ORGANIZACJI PRZESTRZENI CENTRALNEJ W MANCHESTERZE}

Manchester leży w północno-zachodniej Anglii, na południowy zachód od Gór Pennińskich, w miejscu, gdzie rzeki Irk i Medlock uchodzą do rzeki Irwell. Miasto znajduje się na pograniczu trzech hrabstw: Lancashire, Cheshire i Yorkshire. Współcześnie Manchester to trzeci co do liczby ludności zespół miejski ${ }^{1} \mathrm{w}$ Wielkiej Brytanii. Zamieszkuje go 2682500 osób, z czego 502900 osób w centralnej części - City of Manchester². Jest on utożsamiany z pierwszym przemysłowym miastem świata (Hall 1998; Kidd 1993, 1997), które w latach swej największej świetności, czyli około r. 1850, określane było w Wielkiej Brytanii mianem ,przemysłowego klejnotu korony brytyjskiej” (Kaczmarek 2001, Kidd 1997). Złożony rozwój Manchesteru ma swoje odzwierciedlenie w morfologii przestrzeni centralnej miasta.

\subsection{Geneza przestrzeni centralnej w Manchesterze}

Studia w zakresie rozwoju przestrzenno-funkcjonalnego Manchesteru prowadzili m.in. A. Briggs (1968), C. F. Carter (1962), N. J. Frangopulo (1962), C. Hartwell (2010), A. Kidd (1993, 1997), M. Kennedy (1970), D. Kenyon (1991), Ch. Makepeace (2013), M. Nevell (2012), S. Tylor i J. Holder (2008), S. T. Willan (1980). W polskiej literaturze tematykę tę podejmowali m.in. S. Kaczmarek (2001), S. Liszewski i C. Young (1997) oraz A. Majer (2010). W ujęciu morfologicznym można wyróżnić pewien cykl rozwojowy przestrzeni centralnej, który został przedstawiony poniżej.

Manchester to miasto o rodowodzie rzymskim. Jego geneza sięga 79 r. n.e., kiedy w widłach rzek Irwell i Medlock założono castrum o nazwie Mancunium

${ }^{1}$ Określany jako obszar metropolitalny Greater Manchester (Wielki Manchester), w którego skład wchodzą oprócz Manchesteru: Salford, Stockport, Tameside, Trafford, Bolton, Bury, Oldham, Rochdale i Wigan.

2 Office of National Statistics 2011. 
bądź Mamucium³ ${ }^{3}$ Był to graniczny fort Imperium Rzymskiego zlokalizowany na przecięciu szlaków ze wschodu na zachód, łączących Eboracum (współczesny York) i Deva (Chester), wraz z kolejnym szlakiem biegnącym z południa z Buxton, wzdłuż zachodniego skraju Pennin do Luguvlium (Caslisle) i Ribchester na północy. Pierwszy fort założony został na planie prostokąta o powierzchni około 1,2 ha i przeznaczony był dla 480 żołnierzy jednostki piechoty. Przestrzeń centralną kształtowały decumanus, cardo i forum, które było zlokalizowane w miejscu ich przecięcia. Forma przestrzenna osady miała zatem charakter typowy dla rzymskich obozów wojskowych. Mamucium nie było wyposażone w żadne instytucje publiczne. W sąsiedztwie forum znajdował się obiekt zajmowany przez dowódcę obozu. W castrum dominowała funkcja militarna. W III w. n.e. fort został rozbudowany, a pierwotne obwarowania $\mathrm{z}$ darni i drewna zastąpione kamiennym murem. Na północ od castrum rozwinęła się niewielka osada pełniąca funkcje usługowe i rzemieślnicze na rzecz stacjonującego tu wojska (rys. 5.1). Łącznie Mamucium zajmowało około 2 ha i zamieszkiwało je około 2000 osób.

Castrum wraz z przyległą do niej osadą upadły w V w., gdy wojska rzymskie wycofały się z Brytanii. Pozostałością po obozie były kamienne obwarowania fortu, które w X-XII w. zostały rozebrane i wykorzystane powtórnie do budowy domów średniowiecznej osady. Do tego okresu obszar ten posiadał wiejski charakter użytkowania (Kidd 1993).

Po upadku osady rzymskiej nastąpił około pięćsetletni interwał w procesie rozwoju miasta. Od X do początku XXI w. można wyróżnić pięć etapów kształtowania przestrzeni centralnej Manchesteru:

Etap I - okres rozwoju miasta średniowiecznego od X w. do połowy XVII w.;

Etap II - okres rozwoju miasta handlowo-rękodzielniczego od połowy XVII w. do około $1780 \mathrm{r}$.;

Etap III - okres rozwoju miasta wielkoprzemysłowego i kryzysu od około 1780 do około 1950 r.;

Etap IV - okres degradacji miasta po upadku przemysłu od około 1950 do 1988 r.;

Etap V - okres kształtowania miasta metropolitalnego od $1988 \mathrm{r}$.

Średniowieczna osada powstała w X w., około $1,2 \mathrm{~km}$ na północ od ruin rzymskiego fortu. Jej rozwój wiązał się z miejscem ujścia rzeki Irk do Irwell. Manchester był wówczas małą handlową osadą z prawem do rocznego targu (zostało ono uzyskane w 1223 r.). Prawdopodobnie na lewym brzegu Irwell, $\mathrm{w}$ miejscu, gdzie rzeka zmienia bieg $\mathrm{z}$ południowo-wschodniego na południowo-zachodni, wzniesiony został mały drewniany zamek, który następnie został zastąpiony murowanym dworem. Wokół dworu oraz kościoła, położonego w jego bezpośrednim sąsiedztwie, narastał średniowieczny Manchester. Miasto rozwijało się południkowo od przeprawy na rzece Irk na północy, wzdłuż ulicy Long

${ }^{3}$ Historycy używają obu wersji. Założycielem osady był namiestnik Rzymu w Brytanii - Juliusz Agrykola (Kidd 1993). 


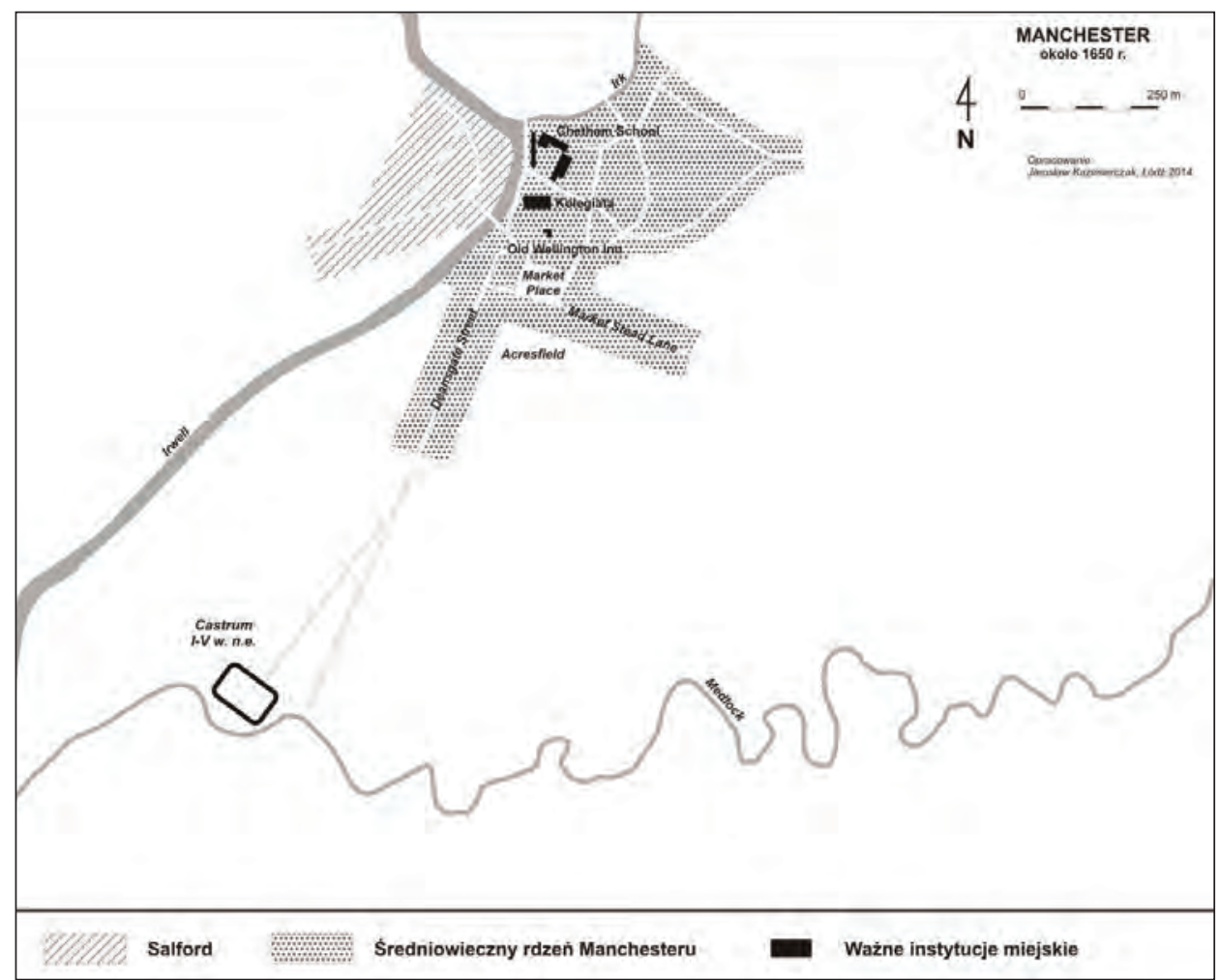

Rys. 5.1. Obszar Manchesteru około 1650 r.

Źródło: badania własne autora

Millingate, po nieistniejący już rynek (Market Place), z którego wykształciła się Market Stead Lane - dzisiejsza Market Street, a od XIV w. dalej na południe wzdłuż Deansgate Street. Stanowi ona relikt dawnego rzymskiego traktu handlowego przebiegającego z północy na południe (rys. 5.1). Przestrzeń centralną średniowiecznego miasta tworzyły główne osie komunikacyjne oraz rynek (Market Place) położony w nieznacznej odległości na południe od istniejącego wówczas kościoła. Targi organizowane były na terenach przyłączonych do miasta, na południu w tzw. Acresfield. W 1421 r. kościół w Manchesterze został podniesiony do rangi kolegiaty. Wydarzenie to zaowocowało powstaniem seminarium. W $1653 \mathrm{r}$. budynek nabył Humprey Chetham, który przekształcił go w szkołę (Chetham's School) oraz publiczną bibliotekę - Chetham's Library. W 1550 r. przy Shambles Square, na południe od katedry, zbudowano sklep Old Wellington Inn, który przetrwał do czasów współczesnych. Proces kształtowania przestrzeni centralnej w analizowanym okresie wykazywał się wyraźnym konserwatyzmem przestrzennym, związanym z obszarem przykościelnym oraz ulicą Deansgate (rys. 5.1). Od XVI do XVIII w. Manchester rozwijał się jako ośrodek produkcji tkanin, zyskując 
coraz ważniejszą pozycję w sieci osadniczej Lancashire i Cheshire. Miasto stało się także najważniejszym w regionie ośrodkiem handlu wełną i lnem, które były sprowadzane m.in. z Irlandii i dystrybuowane do manufaktur w całym regionie, jak również na rynek w Londynie. Dynamiczny rozwój Manchesteru jako ośrodka produkcyjno-handlowego przyczynił się do osiedlenia się w mieście nowych mieszkańców, wśród których przeważali kupcy i robotnicy (Tylor i Holder 2008). W latach 1543-1773 ludność Manchesteru wzrosła z 2300 do 43 000. Największy przyrost został odnotowany w latach 1660-1773, kiedy liczba mieszkańców miasta zwiększyła się czterokrotnie (Willan 1980). W połowie XVIII w. Manchester był głównym centrum handlowym w Lancashire i Cheshire.

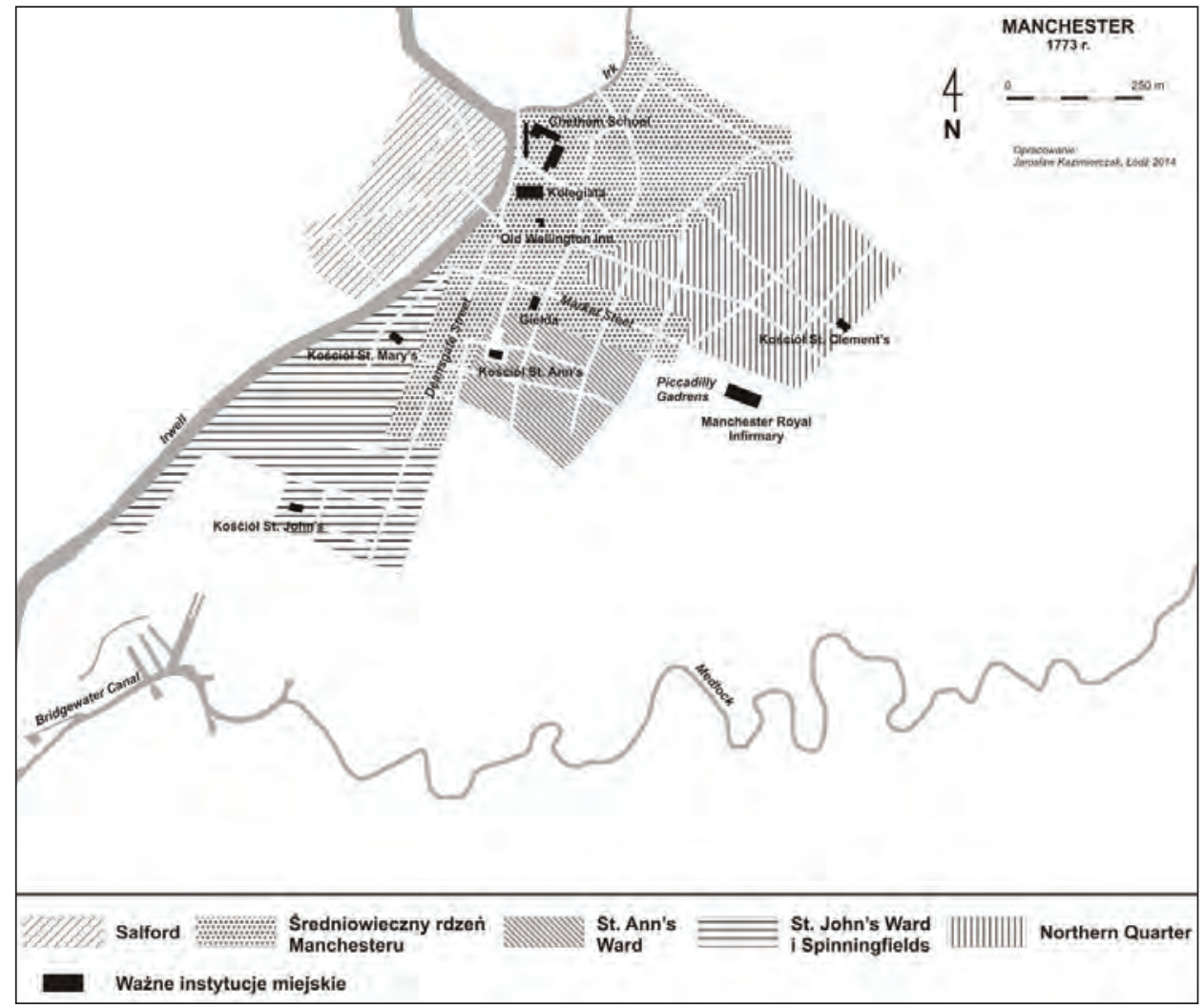

Rys. 5.2. Jednostki morfogenetyczne w przestrzeni centralnej Manchesteru w $1773 \mathrm{r}$.

Źródło: badania własne autora

Rosnąca ranga Manchesteru jako miasta handlowo-przemysłowego odzwierciedlona została w sposobie organizacji przestrzeni centralnej. W drugim etapie jej kształtowania, czyli od połowy XVII w. do około 1780 r., postępowała stopniowa intensyfikacja zabudowy miejskiej oraz nastąpiła inkorporacja nowych terenów 
zlokalizowanych na południe od średniowiecznego centrum (rys. 5.2). Na przyłączonym obszarze dawnego Acresfield w latach 1709-1712 wybudowano kościół St. Ann, a w 1720 r. wokół świątyni utworzono plac miejski. Nowa jednostka przestrzenna stała się najbardziej prestiżową dzielnicą rezydencjalną w mieście, co spowodowało przesunięcie centrum Manchesteru na południe od średniowiecznego rdzenia (Taylor i Holder 2008). Na jej obszarze wybudowano m.in. pierwszą w mieście giełdę (w 1729 r.). W analizowanym okresie Deansgate Street pozostała główną osią rozwojową, wzdłuż której postępowała ekspansja przestrzenna miasta na południe. W jej sąsiedztwie wytyczono nowe place miejskie - wokół kościoła St. Mary, położonego pomiędzy Deansgate Street i rzeką Irwell oraz przy kościele St. John's dalej na południe (rys. 5.2). Szczególnie istotnym elementem kształtowanej przestrzeni centralnej miasta był obszar Piccadilly Gardens utworzony w $1752 \mathrm{r}$. wraz z budową szpitala Manchester Royal Infirmary na wschodnich peryferiach miasta. W związku z likwidacją Market Place rolę głównej ulicy handlowej zyskała Market Street prowadząca od Deansgate Street na zachodzie do Piccadilly Gardens (rys. 5.2). Obszar Northern Quarter miał natomiast charakter peryferyjnej dzielnicy robotniczej, w której łączona była funkcja produkcyjna i mieszkaniowa.

Rozwój produkcji włókienniczej w Manchesterze spowodował wzrost zapotrzebowania na surowce energetyczne, głównie drewno i węgiel kamienny, który był sprowadzany z Worsley. W celu obniżenia kosztów transportu w latach 50. i 60 . XVIII w. rozpoczęto budowę kanału Bridgewater, który oddano do użytku w 1764 r. (rys. 5.2). Ze względu na bliskość dróg wodnych oraz handlowego centrum miasta w południowej części St. John's Ward powstały liczne magazyny. Budowa dróg wodnych oraz rozwój obiektów składowych w ich sąsiedztwie zdeterminował późniejszy sposób użytkowania tych terenów na szeroko rozumianą działalność przemysłową.

Trzeci etap kształtowania przestrzeni centralnej w Manchesterze przypada na czas najbardziej intensywnej industrializacji miasta rozpoczynającej się około 1780 r., trwającej przez cały XIX w. oraz na okres kryzysu miasta przemysłowego w pierwszej połowie XX w. W analizowanym okresie można wyróżnić trzy fazy:

1) kształtowania przestrzeni centralnej miasta wielkoprzemysłowego od około 1780 do 1829 r.;

2) dojrzałości przestrzeni centralnej miasta wielkoprzemysłowego od 1830 do $1918 \mathrm{r}$.;

3) kryzysu przestrzeni centralnej miasta wielkoprzemysłowego od $1918 \mathrm{r}$. do lat 50. XX w.

Pierwsza faza analizowanego okresu charakteryzowała się intensywnym zagospodarowaniem południowych przedmieść Manchesteru, położonych wzdłuż rzeki Medlock, i nowych dróg wodnych zapewniających transport surowców energetycznych do fabryk, jak również umożliwiających import materiałów do produkcji włókienniczej oraz eksport gotowych wyrobów do portu w Liverpoolu. Na wschód od kanału Bridgewater, w roku 1797 oddano do użytku Ashton Canal, a w roku 1804 - Rochdale Canal. Obszar, który do końca XVIII w. zajmowały lasy, pola uprawne 
i nieliczne gospodarstwa został przekształcony w tereny przemysłowe oraz składowe. Wzdłuż rzeki Medlock oraz kanałów powstały liczne nabrzeża, które przeznaczono na cele składowe, m.in. węgla kamiennego i drewna, liczne młyny, magazyny oraz obiekty produkcyjne. Najstarszymi jednostkami morfologicznymi, których geneza wiąże się z pierwszą fazą kształtowania przestrzeni centralnej wielkoprzemysłowego Manchesteru są Castlefield oraz Whitworth (rys. 5.3). Do lat 30. XIX w. dominował w nich ekstensywny sposób użytkowania przestrzeni, szczególnie w Castlefield zdominowanym przez tereny składowe nad kanałem Bridgewater. W widłach Rochdale i Ashton Canal wykształciła się natomiast jednostka przestrzenno-funkcjonalna o nazwie Ancoats, w której w późniejszym okresie rozwoju miasta zlokalizowane były największe w Manchesterze obiekty składowe, magazynowe i produkcyjne, związane z przemysłem włókienniczym, chemicznym i maszynowym.

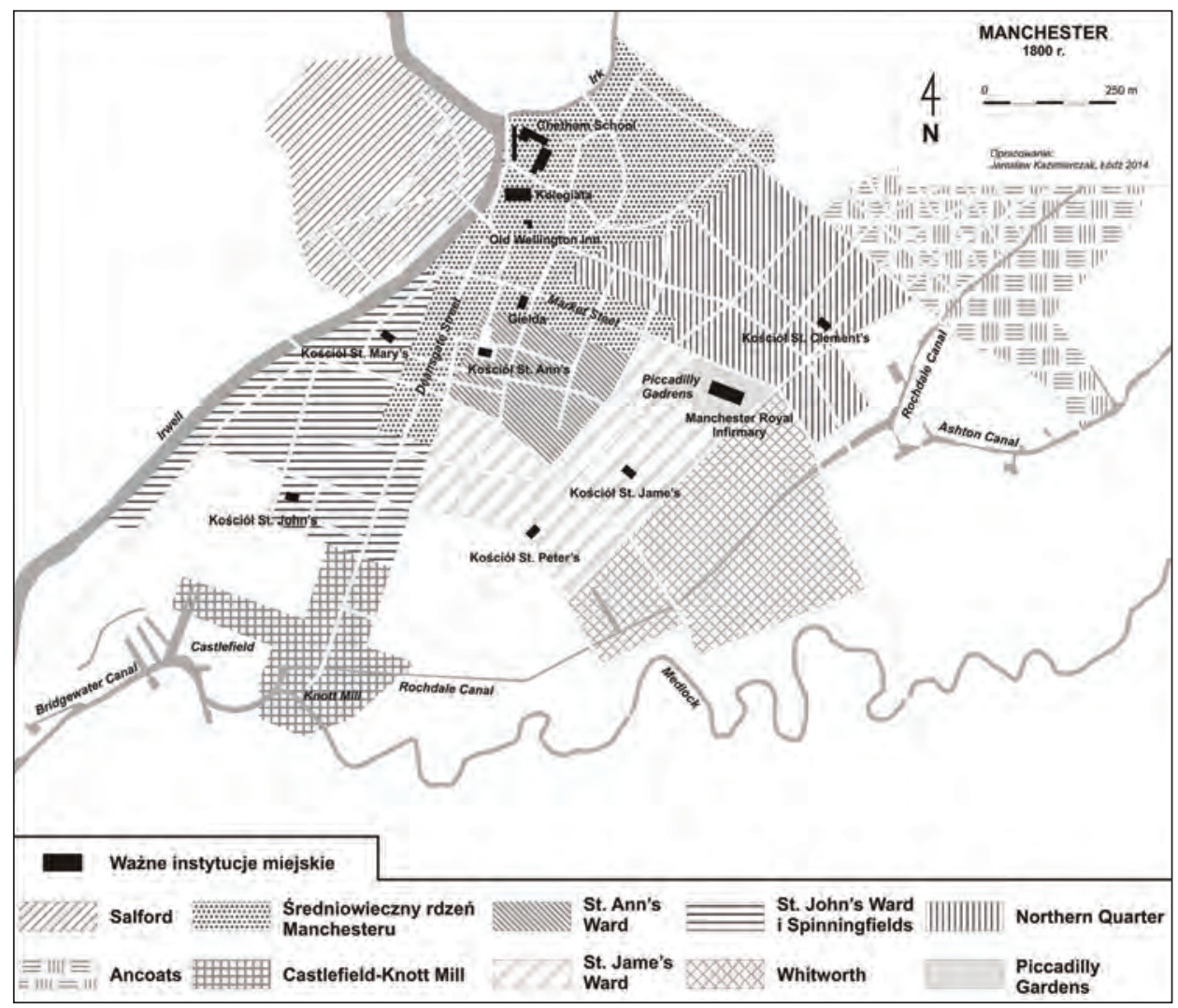

Rys. 5.3. Jednostki morfogenetyczne w przestrzeni centralnej Manchesteru w $1800 \mathrm{r}$.

Źródło: badania własne autora

$\mathrm{W}$ aspekcie kształtowania przestrzeni centralnej, w analizowanym okresie kluczowym obszarem przyłączonym do Manchesteru był teren St. James Ward położony 
na południe od historycznego rdzenia miasta. Głównymi osiami rozwojowymi nowej jednostki przestrzennej były ulice: Portland Street, Mosley Street o przebiegu z północnego wschodu na południowy zachód oraz Princess Street i Oxford Street z północnego zachodu na południowy wschód. Podobnie jak w pozostałych fragmentach przestrzeni centralnej Manchesteru z początku XIX w., dominującymi obiektami były świątynie, w tym przypadku kościół St. James i St. Peter, wokół których wyznaczono nowe place miejskie (rys. 5.3). Oprócz świątyń najważniejszymi instytucjami publicznymi w tym okresie pozostawały giełda oraz szpital, a następnie liczne obiekty hotelowe w sąsiedztwie Piccadilly Gardens.

Druga i trzecia faza przekształceń przestrzeni centralnej wielkoprzemysłowego Manchesteru charakteryzowała się największą w dziejach miasta ekspansją terytorialną oraz zmianami morfologicznymi. W $1845 \mathrm{r}$. w północnej części miasta, na przedłużeniu Cross Street wybudowano nową ulicę - Corporation Street, dzięki czemu uregulowano układ przestrzenny średniowiecznego rdzenia miasta (por. rys. 5.3 i 5.4). W środkowej części miasta również nastąpiły przekształcenia, które polegały na budowie licznych obiektów bankowych wzdłuż Kings Street i Spring Gardens. Transformacji uległ także Piccadilly Gardens. Na początku XX w. przeniesiony został stąd szpital (Royal Infirmary), na miejscu którego powstała pierwotnie miejska biblioteka, a następnie największy otwarty obszar publiczny w mieście, w formie ogólnodostępnego ogrodu. Na południu wraz z inkorporacją niezagospodarowanych dotychczas terenów miejskich położonych na północ od kanału Rochdale, w latach 80. XIX w. wytyczono nową arterię komunikacyjną w postaci Whitworth Street. Stanowiła ona strefę przejściową pomiędzy obszarem handlowym i industrialnym. Umożliwiła także rozwój dzielnicy biznesowej zlokalizowanej na północ w okolicach Princess Street i Portland Street.

Zmiany morfologiczne w południowej części śródmieścia wynikały przede wszystkim z rozwoju kolei. W roku 1830 pomiędzy Liverpoolem i Manchesterem oddano do użytku pierwszą na świecie pasażerską linię kolejową, której końcową stacją w Manchesterze i jednocześnie pierwszą wewnątrzmiejską stacją dla podróżnych była Liverpool Road Station w rejonie Castlefield (rys. 5.4). Do lat 60. XIX w. rozwój kolei zdominował proces transformacji przestrzeni centralnej miasta, a dworce kolejowe stały się wyraźnymi akcentami architektonicznymi w krajobrazie Manchesteru. Największymi były London Road Station (współcześnie Piccadilly Station) oddany do użytku w 1840 r. i Victoria Station otwarty w 1844 r., które zostały połączone bezpośrednią drogą żelazną w 1849 r. W $1880 \mathrm{r}$. do istniejącego systemu kolejowego włączono Central Station, z budową którego wiązały się przekształcenia morfologicznie na obszarze około 4 ha (rys. 5.4). Linia kolejowa biegnąca ze wschodu na zachód przez południową część śródmieścia poprowadzona była na wiaduktach, co przyczyniło się do nieznacznej ingerencji w istniejący układ ulic oraz bieg kanałów i rzeki Medlock. Rozwój kolei spowodował degradację dominującej pozycji dróg wodnych w systemie transportowym, pozostawały one jednak jego ważnym ogniwem. Ich znaczenie potwierdziła 
budowa Manchester \& Salford Junction Canal w 1839 r. (rys. 5.4) oraz Manchester Ship Canal w 1894 r. W ramach tego drugiego projektu powstał śródlądowy port, który uniezależnił Manchester od portu w Liverpoolu. W wyniku rozwoju linii kolejowej wokół historycznego centrum miasta stworzono pierścień terenów komunikacyjnych, wzdłuż których wybudowano liczne obiekty przemysłowe i składowo-magazynowe, dominujące w zabudowie rejonu Ancoats, Northern Quarter, Piccadilly, Whitworht, Gaythorn (znajdowała się w nim także gazownia miejska), Central (City Centre) oraz Castlefield (rys. 5.4 i 5.5). Na południe od nich rozwinęły się robotnicze dzielnice mieszkaniowe w Hulme.



Rys. 5.4. Jednostki morfogenetyczne w przestrzeni centralnej Manchesteru w $1916 \mathrm{r}$.

Źródło: badania własne autora

Proces uprzemysłowienia niósł ze sobą wiele niekorzystnych skutków widocznych w fizycznej przestrzeni miasta. W pierwszej połowie XIX w. Manchester był jednym z najbardziej zatłoczonych miast w Anglii, w których panowały bardzo złe warunki sanitarne (Kidd 1993). Duża gęstość zabudowy i jej skrajnie utylitarna 
forma, zdawały się być rodzajem wynaturzenia, co sprawiło, że od początku rozwoju industrialnego Manchester zyskał złą sławę w oczach współczesnych. Zagospodarowanie Manchesteru odbiegało znacznie od pejzażu, uporządkowanych przez tradycję starych miast angielskich (Majer 2010). W latach 60. XIX w. podjęto próby uporządkowania skutków wcześniejszego, niekontrolowanego rozwoju miasta, co wiązało się z przebudową centrum ze względów sanitarnych. Rozwój systemu komunikacji publicznej w drugiej połowie XIX w. (kolei i tramwajów, początkowo konnych, następnie elektrycznych) zainicjował proces powolnego odśrodkowego rozwoju miasta, który wiązał się z odpływem mieszkańców oraz inwestycji przemysłowych do strefy zewnętrznej. Ówczesne władze miejskie starały się zmienić jednostronny przemysłowy wizerunek miasta poprzez rozwój instytucji naukowych i kulturalnych w dzielnicy śródmiejskiej. W okresie wielkoprzemysłowego Manchesteru powstały nowe instytucje, które rozszerzały istniejącą przestrzeń centralną, m.in. biblioteki John Ryland's (1899 r.) i The Portico Library (1806 r.), The Royal Manchester Institution (1823 r.) przekształcona następnie w Manchester City Art Gallery (1882 r.), Museum of Natural History (1835 r.), The Theatre Royal (1845 r.), Prince's Theatre (1864 r.), St. James's Theatre (1884 r.), Queen's Theatre (1891 r., współcześnie Opera House), Palace Theatre (1891 r.), Free Trade Hall (1856 r.), który był wykorzystywany m.in. przez The Hallé Orchestra, People's Concert Hall (1852 r., który został wyburzony w latach 80. XIX w. i w jego miejscu w 1903 r. oddano do użytku potężny Midland Hotel, którego lokalizacja została zdeterminowana powstaniem Central Station) oraz uniwersytet - School of Technology, późniejszy University of Manchester Institute of Science and Technology (UMIST), który powołano do życia w 1824 r. (rys. 5.4). Powstanie instytucji kultury, sztuki i nauki ilustrowało zmiany, jakie zachodziły w przestrzeni centralnej Manchesteru w XIX w.

Rosnąca rola wymiany handlowej w strukturze ekonomicznej Manchesteru i związana z tym wzrastająca ranga miasta, które w połowie XIX w. można już uznać za światowe, zostały odzwierciedlone w jego fizjonomii. Oprócz nowych masywnych dworców kolejowych powstawały liczne reprezentacyjne obiekty użyteczności publicznej, w tym potężny neoromański ratusz (Town Hall) wybudowany w 1877 r. wraz z placem o nazwie Albert Square, hotele, banki, sklepy, znaczna liczba biur, agencji handlowych oraz liczne hurtownie, obiekty magazynowe i składowe. W mieście powstały także dwie giełdy: Royal Exchange (w 1903 r.) i Corn Exchange, której budynek, jako jeden z największych wówczas w Europie, był dumą i ozdobą miasta. Corn Exchange, czyli giełda zbożowa, przeznaczona była tylko dla handlu zagranicznego, podczas gdy Royal Exchange (giełda królewska) do obsługi handlu bawełną w Lancashire.

Wwyniku dynamicznego rozwoju Manchesteru wokresie wielkoprzemysłowym przestrzeń centralna miasta charakteryzowała się mozaikowym rozmieszczeniem terenów produkcyjno-magazynowych, składowych, mieszkaniowych, użyteczności publicznej, komercyjnych oraz licznych urządzeń komunikacyjnych. Kształtowaniu 
nowych, monumentalnych obiektów w formie eklektycznej okresu wiktoriańskiego towarzyszyło generowanie nowych przestrzeni handlowych. W drugiej połowie XIX w. w północnej części dzielnicy śródmiejskiej wiele $\mathrm{z}$ mieszkalnych ulic zostało przekształconych w pasaże firmowych składów i magazynów oraz siedziby wielkich handlowych przedsiębiorstw. Początkowo mieścily się one przede wszystkim wzdłuż Kings Street, Cannon Street, Hight Street, Market Street oraz St. Ann Square, a następnie $\mathrm{w}$ jednostkach przestrzennych położonych na południe, $\mathrm{w}$ rejonach: Mosley Street, Portland Street oraz Princess Street (rys. 5.5). Wzdłuż tych ulic zlokalizowane były najbardziej reprezentacyjne obiekty w mieście. W końcu XIX w. stanowiły one komercyjne serce miasta. Centrum handlu detalicznego rozwinęło się w okolicach Market Street, przy której otworzono w 1880 r. dom towarowy Lewis, oraz Cross Street, gdzie znajdował się dom towarowy Kendal, Milne \& Faulkner. Ekskluzywne sklepy z odzieżą, jubilerzy, antykwariaty i księgarnie zlokalizowane były wówczas wzdłuż Kings Street, Exchange Street oraz pasażu St. Ann (5.5).

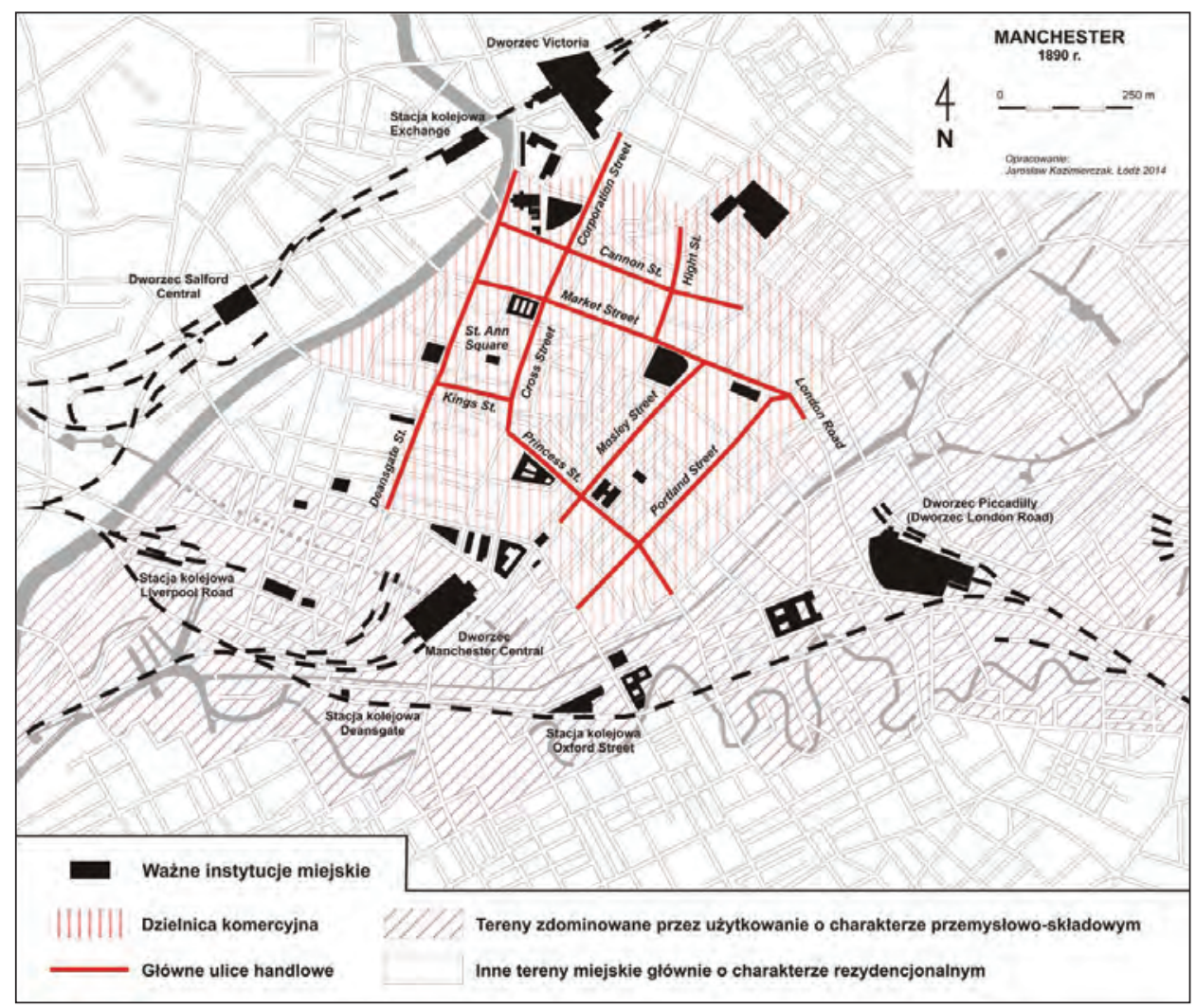

Rys. 5.5. Rozmieszczenie terenów przemysłowo-składowych i komercyjnych w dzielnicy śródmiejskiej Manchesteru w 1890 r.

Źródło: badania własne autora 
Trzecia faza transformacji przestrzeni centralnej wielkoprzemysłowego Manchesteru przypada na okres narastania kryzysu w przemyśle włókienniczym i innych branżach z nim powiązanych (m.in. maszynowym, chemicznym). Wiązała się ona ze stopniowym zamykaniem i odpływem zakładów przemysłowych do zewnętrznych stref miasta, a tym samym spadkiem liczby ludności w śródmieściu. Od 1918 do końca lat 30. XX w. przeprowadzone zostały wyburzenia starej i niskiej jakości zabudowy robotniczej w centrum Manchesteru oraz w Hulme. Działania te objęły także południową część współczesnego Gaythorn i Castlefield. Zabudowa śródmiejska $\mathrm{w}$ Manchesterze została także poddana renowacji i modernizacji po powstałych zniszczeniach z okresu II wojny światowej. W analizowanym okresie wyburzono kościoły St. Jame's, St. John's, St. Matthew's, a wcześniej także St. Peter's, na którego miejscu powstał plac. W latach 20. i 30. XX w., nastąpiła m.in. rozbudowa ratusza i budowa teatru oraz biblioteki centralnej przy placu St. Peter (patrz rys. 5.4), likwidacja gazowni miejskiej w Gaythorn (w 1937 r.) oraz powstanie ogólnodostępnych ogrodów w Piccadilly Gardens.

\subsection{Przestrzeń centralna w Manchesterze przed rewitalizacją}

Stan, w jakim znajdowała się dzielnica śródmiejska Manchesteru w latach 60., 70. i 80. XX w., był synonimem upadku potężnego XIX-wiecznego miasta wielkoprzemysłowego. Bezpośrednią przyczyną degradacji przestrzeni centralnej miasta był kryzys przemysłu włókienniczego zapoczątkowany już w latach 20. XX w. Związany był on m.in. z utratą części rynku zbytu w koloniach brytyjskich, głównie w Indiach, a w latach 30. XX w. na rynku krajowym, ze światowym kryzysem lat 20. XX w., obiema wojnami światowymi, zmianami technologicznymi oraz rozwojem transportu, który umożliwił relokację produkcji przemysłowej do regionów świata, w których znajdowała się tańsza siła robocza. Kolejne lata załamania produkcji doprowadziły ostatecznie do upadku przemysłu włókienniczego i innych powiązanych z nim działalności gospodarczych w mieście i w całym regionie (przemysł maszynowy, elektrotechniczny, chemiczny i górniczy) w latach 50. XX w.

Czwarty etap transformacji przestrzeni centralnej w Manchesterze charakteryzował się istotnymi zmianami morfologicznymi i instytucjonalnymi. W historycznej przestrzeni centralnej pozostały obecne imponujące pod względem architektonicznym obiekty zajmowane wcześniej przez giełdy, sklepy, banki i inne firmy finansowe, a także ubezpieczeniowe, które swoją świetność zawdzięczały dobrze rozwiniętemu regionowi przemysłowemu. W rezultacie upadku przemysłu przestrzeń centralna Manchesteru została pozbawiona instytucji, które w XIX w. kształtowały prestiż miasta. Wśród nich należy wymienić, przede wszystkim Corn Exchange i Royal Exchange, Refuge Assuarance, Watt's Warehouse, Great Northern Railway Company's Goods Warehouse i wiele innych. W ich miejsce 
pojawiały się niekiedy nowe instytucje. W budynku dawnej Royal Exchange, zamkniętej w 1968 r., powstał teatr (The Royal Exchange Theatre), który zainaugurował swoją działalność w 1976 r., oraz centrum handlowe. Również Corn Exchange przekształcono w obiekt handlowy oraz biurowy. W budynku Watt's Warehouse, który utracił swoją pierwotną funkcję, w 1982 r. otworzono Britannia Hotel. Dawny budynek Refuge Assurance, którego siedziba została przeniesiona do Wilmslow, zaadaptowano natomiast na Palace Hotel. Podobnym przekształceniom podlegało także wiele innych obiektów w rejonie Piccadilly Gardens i Market Street. Konsekwencją spadku liczby ludności w Manchesterze (rys. 5.6) było także zmniejszenie się liczby instytucji kultury i sztuki. W latach 50. i 60 . XX w. kontynuowany był proces wyburzenia niskiej jakości domów robotniczych wybudowanych w XIX w., które znajdowały się w centralnej części Manchesteru oraz w Hulme. Radykalne przekształcenia przestrzenno-funkcjonalne objęły w głównej mierze południową część śródmieścia, przez którą przeprowadzono południową obwodnicę miasta tzw. Mancunian Way (rys. 5.7).

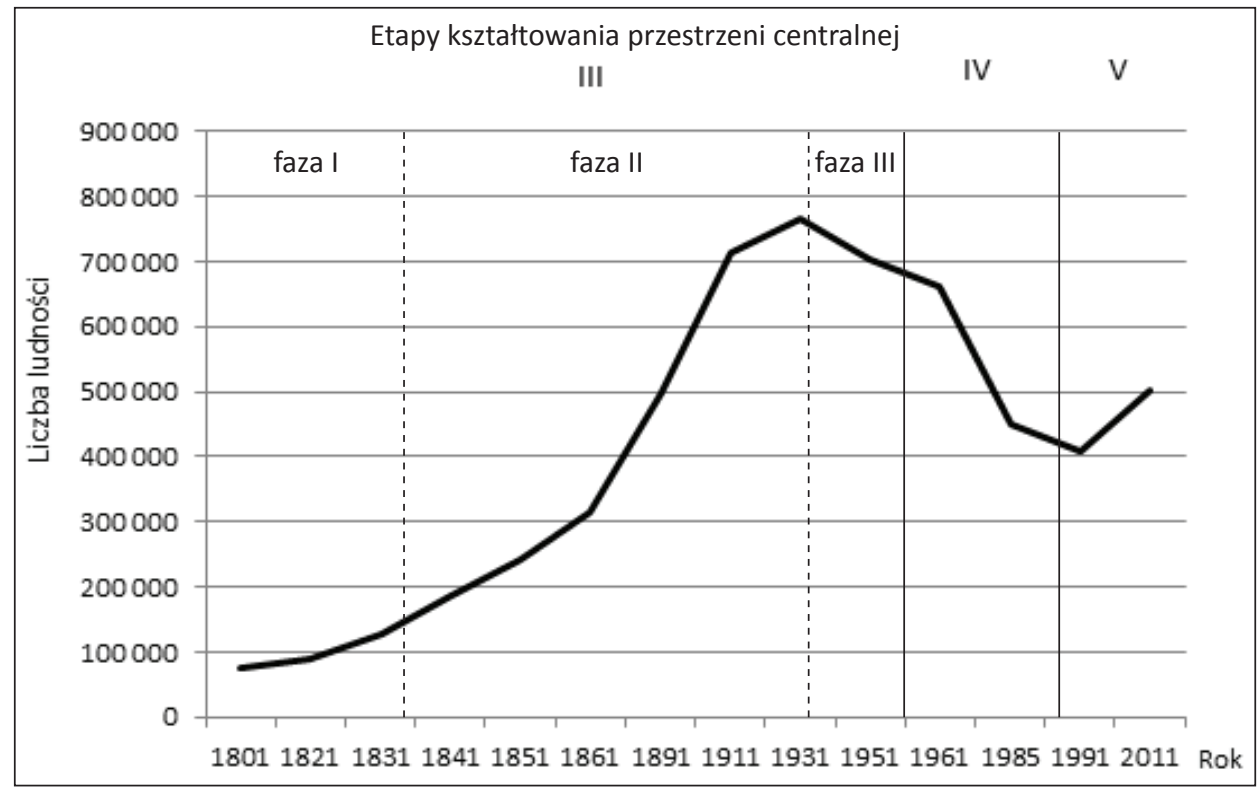

Rys. 5.6. Zmiany liczby ludności wobec etapów kształtowania przestrzeni centralnej w Manchesterze w latach 1801-2011

Źródło: opracowanie autora na podstawie A. Kidd $(1993,1997)$ i Office of National Statistics 2011

Daleko idącym przemianom przestrzenno-funkcjonalnym poddany został obszar nazywany Exchange Market, na wschód od katedry (rys. 5.7). W wyniku przeprowadzonych przekształceń wyburzono zabudowę czynszową pomiędzy 
ulicami Shudenhill, High Street, Corporation Street i Market Street i na obszarze o powierzchni 7,2 ha wybudowano centrum handlowe Arndale (rys. 5.7). Jego budowa wpisywała się w rewolucję nawyków konsumenckich klientów w Wielkiej Brytanii, którzy wraz ze zmianą stylu życia zaczęli preferować częstsze zakupy w hipermarketach i dużych centrach handlowych. Arndale Centre wraz w historycznymi ulicami handlowymi, takimi jak: Market Street, Kings Street, północna część Deansgate Street, rejon St. Ann's Square, a następnie Portland Street i Peter Street kształtowały komercyjną przestrzeń centralną Manchesteru $\mathrm{w}$ drugiej połowie XX w.

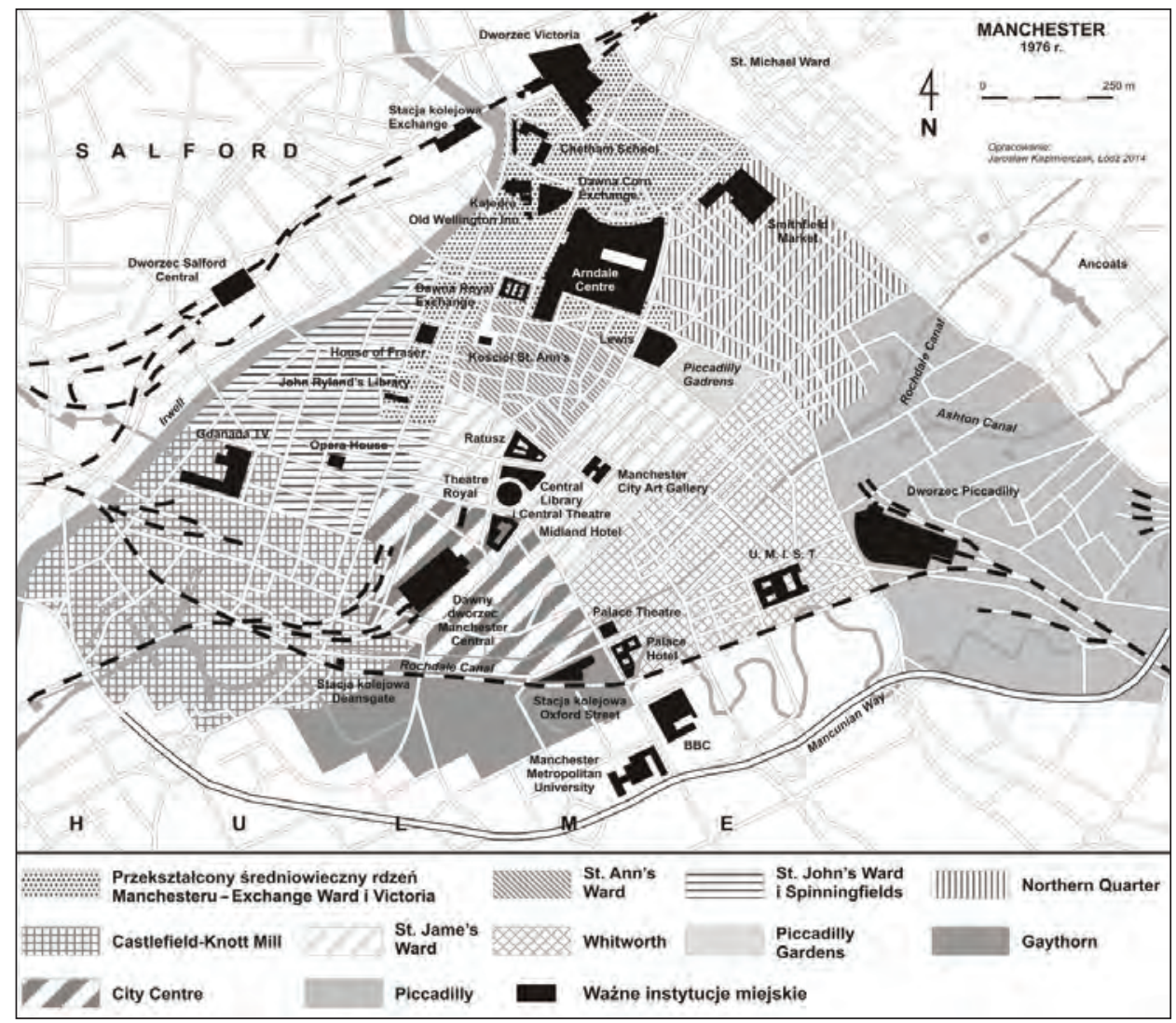

Rys. 5.7. Jednostki morfogenetyczne w przestrzeni centralnej Manchesteru w $1976 \mathrm{r}$.

Źródło: badania własne autora

Lata 60. i 70. XX w. to okres intensywnej budowy licznych obiektów wysokościowych, które stały się siedzibami instytucji o zasięgu ponadregionalnym, takich jak m.in. Co-operative Bank, Marchant Bank Davenham, The Bank of England oraz Co-operative Insurance Service (C.I.S.). Wyznaczały one biznesową 
przestrzeń centralną miasta, która znajdowała się w północnej części śródmieścia, w okolicy publicznych ogrodów Piccadilly Gardens oraz Mosley Street i Portland Street. Wzniesione wówczas budynki o wysokości co najmniej $50 \mathrm{~m}$ zmieniły historycznie ukształtowaną sylwetę śródmieścia Manchesteru, w której dotychczas dominował ratusz oraz wieża katedry (rys. 5.8). W okresie tym wybudowano m.in.: CIS Tower o wysokości $118 \mathrm{~m}$, City Tower $(107 \mathrm{~m})$, Portland Tower, aktualnie Manchester One ( $80 \mathrm{~m}), 111$ Piccadilly (64 m) oraz Ramada Renaissance Hotel $(56 \mathrm{~m})$. Wśród jednych z najwyższych budynków w mieście znajduje się także biurowiec Arndale House o wysokości 90 m, ukończony w 1979 r. w ramach kompleksu handlowego. Nowoczesna forma architektoniczna licznych obiektów wysokościowych ilustrowała konsekwentny rozwój sektora usług w Manchesterze od połowy XX w. i dążenie do zmiany wizerunku miasta pogrążonego w kryzysie. Jednocześnie kontrastowała ona z coraz bardziej zdegradowaną XIX-wieczną zabudową industrialną i wielkomiejską.

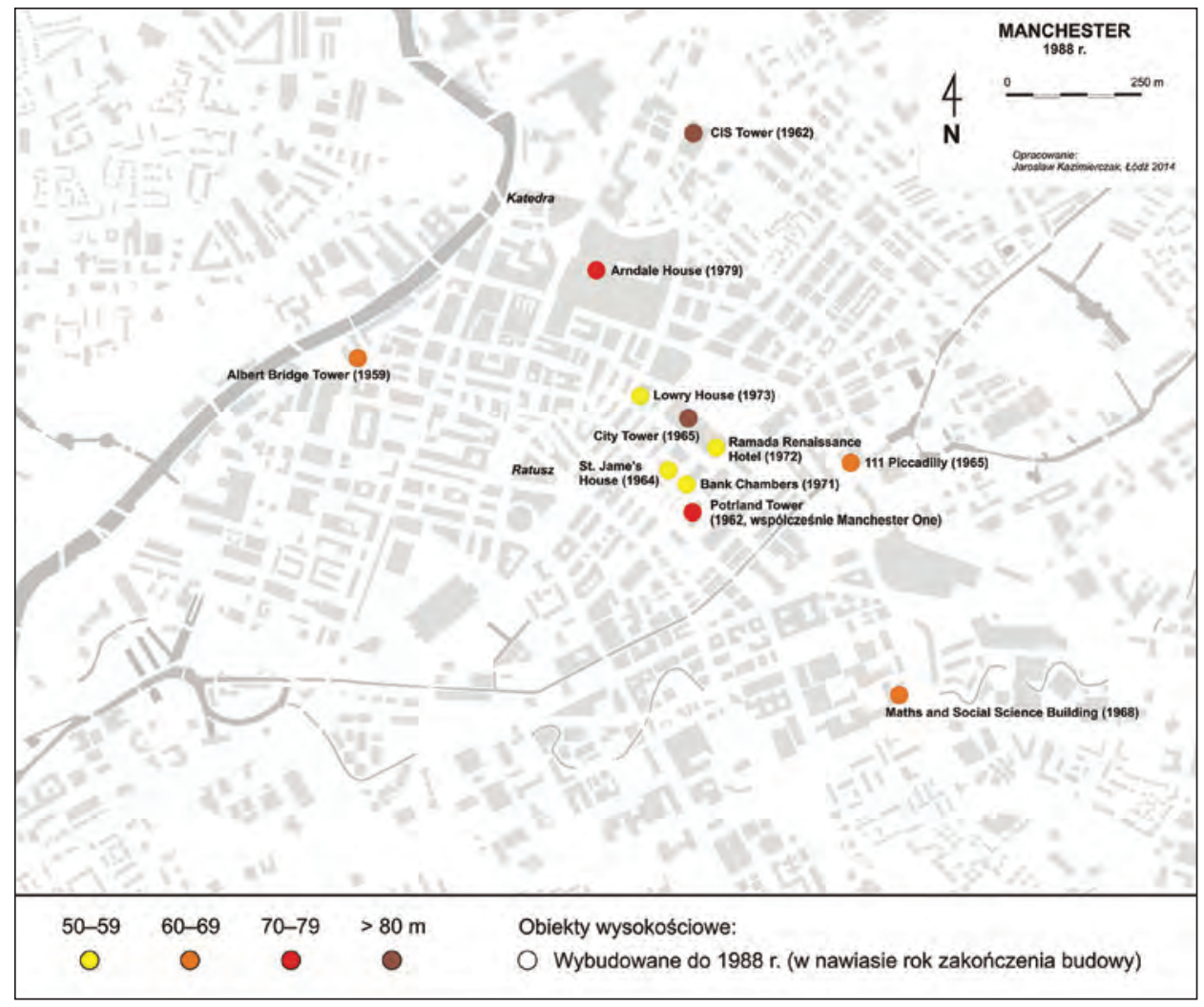

Rys. 5.8. Obiekty wysokościowe w Manchesterze wybudowane w latach 1959-1988

Źródło: badania własne autora 
Pomimo nowych inwestycji skoncentrowanych w północnej części śródmieścia przestrzeń centralna Manchesteru od lat 50. do końca lat 80. XX w. ulegała stopniowej recesji. Świadczył o tym ubytek liczby instytucji, które kształtowały wizerunek Manchesteru jako światowej metropolii, zaniedbanie reprezentacyjnych fragmentów przestrzeni publicznej - placów i głównych ulic handlowych, dekapitalizacja historycznej zabudowy wielkomiejskiej i jej częściowa eliminacja, szczególnie w przypadku substancji postindustrialnej w południowej części dzielnicy śródmiejskiej. Proces kształtowania przestrzeni centralnej w analizowanym okresie był skoncentrowany w północnej części dzielnicy śródmiejskiej Manchesteru, podczas gdy jej południowe fragmenty, zdominowane przez zabudowę przemysłową, kolejową i mieszkaniową, uległy daleko idącej degradacji. Dawne tereny industrialne w Central, Castlefield, Gaythorn i w mniejszym stopniu w Whitworth i Piccadilly charakteryzowały się obecnością zamkniętych i zdewastowanych dworców kolejowych (w tym Central Station, który zamknięto w 1969 r.) wraz z opuszczonymi bocznicami i obiektami pomocniczymi, fabryk i innych magazynów, składów, hurtowni. Oprócz nieużytkowanych terenów, zajętych uprzednio przez kolej, daleko posuniętej degradacji uległy także drogi wodne wraz z nabrzeżami i obiektami inżynieryjnymi. Nieużytkowane kanały zamieniono w składowiska odpadów. Część z obiektów poprzemysłowych zlokalizowanych w okolicach Rochdale Canal, meandrującej rzeki Medlock, Whitworth Street, Great Bridgewater Street i Portland Street została wyburzona i zagospodarowana na wielkopowierzchniowe parkingi. Działania te były podyktowane bardzo złym stanem technicznym budynków oraz rozwijającą się komunikacją samochodową, która powodowała coraz większe zatłoczenie ulic w historycznym śródmieściu Manchesteru, co wynikało też z całkowitej eliminacji linii tramwajowych ze śródmieścia. Budowa parkingów miała także zachęcić do nowych inwestycji na zdegradowanych terenach poprzemysłowych (Lever 1997). W celu ochrony kolejnych obiektów świadczących o przemysłowej przeszłości miasta utworzono w rejonie Castlefield obszar ochrony (Conservation Area), a w 1982 r. pierwszy w Wielkiej Brytanii Park Dziedzictwa Miejskiego, tzw. Urban Heritage Park. Realizację tego projektu należy uznać za jedno z niewielu pozytywnych przedsięwzięć obejmujących dawne tereny przemysłowe w Manchesterze w analizowanym okresie, obok budowy siedziby Granada TV (aktualnie ITV) w Castlefield oraz siedziby British

Broadcasting Company (B.B.C.) i rozbudowy kampusu Manchester Metropolitan University wzdłuż Oxford Street (patrz rys. 5.7).

\subsection{Cechy współczesnej przestrzeni centralnej w Manchesterze}

Odpowiedzią na wielowymiarową degradację miasta w latach 50 . XX w. były podjęte przez władze lokalne działania naprawcze już w połowie lat 70 . XX w. Wiązały się one $\mathrm{z}$ opracowaniem strategicznego planu działania, którego celem było 
przekształcenie struktury ekonomicznej miasta $\mathrm{w}$ długim horyzoncie czasowym, a w rezultacie wygenerowanie nowych miejsc pracy w sektorach III i IV przy jednoczesnym wykorzystaniu istniejącego w mieście potencjału wykształconych ludzi (Kaczmarek 2001). Drugim kluczowym zadaniem było podniesienie jakości życia przez zmianę organizacji przestrzeni miejskiej i uzyskanie nowego kształtu przestrzennego oraz funkcjonalnego centrum miasta, który miał być symbolem nowej wizji Manchesteru jako dynamicznego miasta, nowoczesnych, wysoko wyspecjalizowanych usług właściwych dla XXI w. (Bartenshaw 1991, za: Kaczmarek 2001).

Cele te zostały sformułowane w planie przekształceń gospodarczych i śródmieścia Manchesteru w 1976 r. pod nazwą „City Centre Local Plan”. W 1988 r. została powołana instytucja rządowa o nazwie Korporacja Rozwoju Centralnego Manchester (Central Manchester Development Corporation - C.M.D.C. ${ }^{4}$ ), której powierzono rewitalizację zdegradowanych terenów miejskich, w tym obszarów poprzemysłowych. Wyróżniono w nim sześć obszarów, które ze sobą sąsiadowały w linii wschód-zachód, wzdłuż dawnych kanałów transportowych Bridgewater, Rochdale i Ashton, ograniczone od południa Mancunian Way, od wschodu Great Ancoats Road i od zachodu dawnymi dokami w Pomonie. Były to od zachodu jednostki: Pomona, Castlefield, Gaythorn, Central, Whitworth i Piccadilly (rys. 5.9). W latach 80 . i na początku lat 90 . XX w. były to obszary charakteryzujące się największym stopniem degradacji przestrzeni miejskiej. Zgodnie z „City Centre Local Plan" rejon Piccadilly miał być przeznaczony na lokalizację biur, urzędów oraz terenów mieszkaniowych i wypoczynkowych. Obszar Whitworth został przeznaczony na zespoły budynków mieszkalnych o wysokim standardzie (apartamenty, m.in. w obiektach postindustrialnych, w tym lofty) wraz z terenami rekreacyjnymi im towarzyszącymi oraz na miejsce lokalizacji funkcji biurowej. Teren wokół dawnego dworca centralnego został nazwany City Centre i przeznaczony na miejsce lokalizacji instytucji międzynarodowych, firm finansowych, ubezpieczeniowych oraz obiektów kultury, turystyki i wypoczynku. Ze względu na szczególne walory architektoniczne oraz koncentrację obiektów postindustrialnych i licznie zachowanych urządzeń technicznych w rejonie Castlefield planowano rozwój funkcji turystycznej, rekreacyjnej, handlowej i mieszkaniowej. W Gaythorn przewidziano zabudowę mieszkaniową i usługową oraz galerie sztuki, biura i budynki dla szkolnictwa wyższego. Ze względu na peryferyjne położenie w stosunku do pozostałych obszarów, jak też brak terenów zielonych w śródmieściu Manchesteru, obszar Pomony przeznaczono na rozległe tereny wypoczynkowo-rekreacyjne. Nowy plan rozwoju Manchesteru opracowany przez C.M.D.C. w latach 1989-1990 kontynuował założenia strategiczne wskazane w „City Centre Local Plan”. Do kluczowych celów należało wzbogacenie istniejących i dodanie nowych wartości funkcjonalno-przestrzennych w śródmieściu,

${ }^{4}$ C.M.D.C. powołana była na czas realizacji zadań w wyznaczonych obszarach w latach 1988-1996. 
które w wyniku przekształceń miało stać się ważnym ośrodkiem koncentracji działalności finansowej, biznesowej i handlowej.

W roku 1996 rozpoczęto realizację modernizacji północnej części śródmieścia w okolicach Arndale Centre, katedry i dworca kolejowego Victoria w ramach tzw. Millenium Quarter (rys. 5.9). Była to konsekwencja zamachu bombowego przeprowadzonego przez Irlandzką Armię Republikańską (IRA) w dniu 15 czerwca 1996 r., w rezultacie którego zniszczeniu uległo centrum handlowe Arndale oraz jego najbliższe okolice. Projekt odnowy tego obszaru wiązał się z odbudową historycznych obiektów, takich jak Corn Exchange i Royal Exchange, jak również budową nowych obiektów. W analizowanym okresie, związanym z piątym etapem kształtowania przestrzeni centralnej metropolitalnego Manchesteru, przekształcenia przestrzenno-funkcjonalne objęły także obszar historycznej dzielnicy Spinningfields, w wyniku których powstała dzielnica finansowa (Central Business District), druga największa w Wielkiej Brytanii po City of London (rys. 5.9).

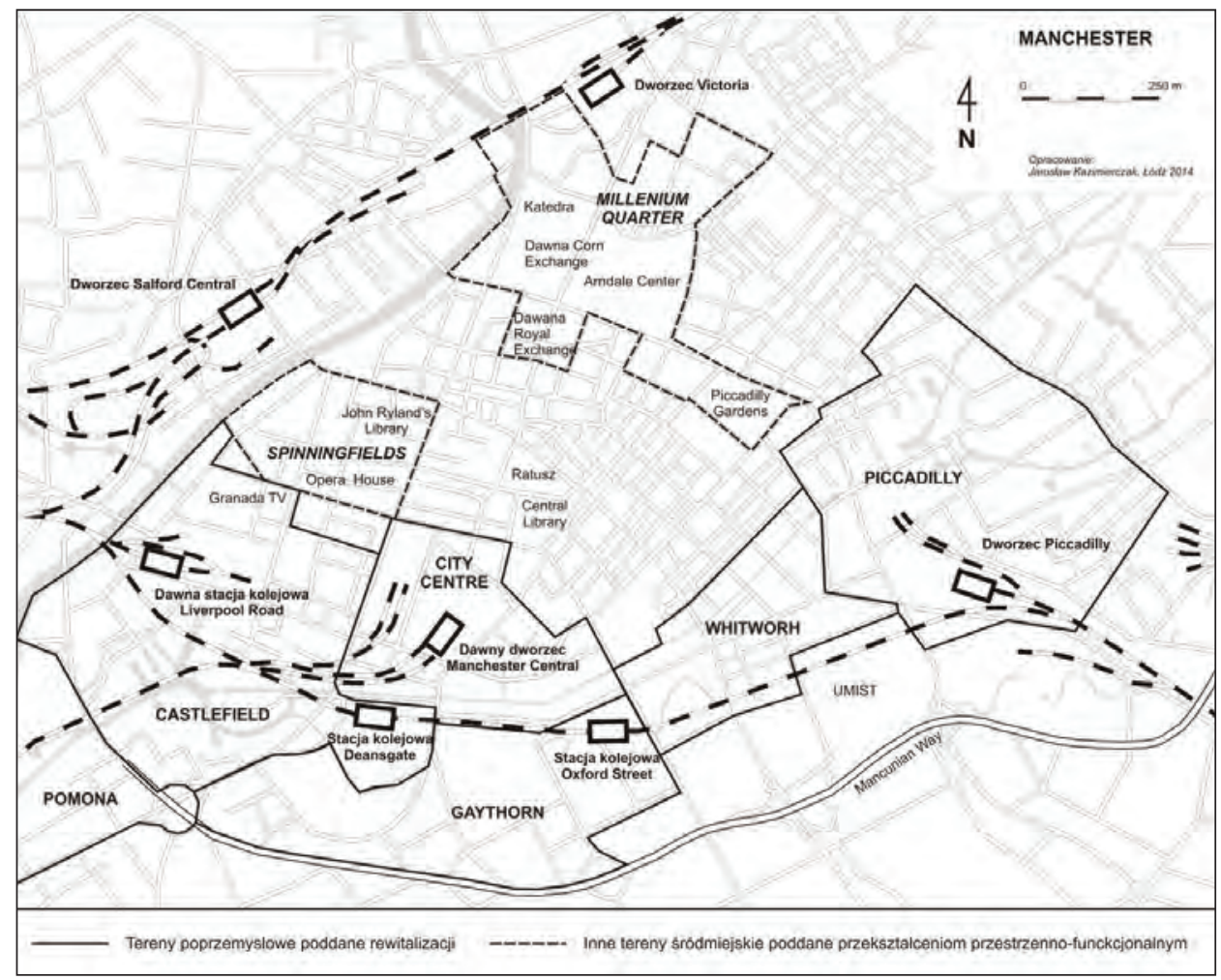

Rys. 5.9. Obszary poddane przekształceniom przestrzenno-funkcjonalnym w Manchesterze w latach 1988-2002

Źródło: opracowanie autora na podstawie S. Kaczmarek (2001) oraz J. Peck i K. Ward (2002) 
W niniejszym opracowaniu skoncentrowano się na analizie reperkusji przemian morfologiczno-funkcjonalnych $\mathrm{w}$ trzech jednostkach przestrzennych objętych programem naprawczym C.M.D.C. Są to rejony City Centre, Castlefield oraz Gaythorn (rys. 5.9), które w momencie podjęcia działań rewitalizacyjnych charakteryzowały się zróżnicowanym położeniem w stosunku do historycznej przestrzeni centralnej Manchesteru, morfologią, przeznaczeniem funkcjonalnym i skalą degradacji, a w wyniku rewitalizacji odmienną intensywnością zmian morfologicznych. Zajmują one łącznie powierzchnię 101,2 ha.

Tabela 5.1. Przekształcenia morfologii i sposobu użytkowania terenów poprzemysłowych w Manchesterze w latach 1988-2013

\begin{tabular}{|l|c|c|c|}
\hline \multicolumn{1}{|c|}{ Cecha } & \multirow{2}{*}{$\begin{array}{c}\text { Jednostka } \\
\text { miary }\end{array}$} & \multicolumn{2}{c|}{ Stan w roku } \\
\cline { 3 - 4 } & $\mathrm{m}$ & 1988 & 2013 \\
\hline Długość dróg kołowych & $\mathrm{m}$ & 11456 & 17689 \\
\hline Długość naziemnych linii kolejowych & $\mathrm{m}$ & 0 & 2290 \\
\hline Długość nowych linii tramwajowych & ha & 22,5 & 28,8 \\
\hline Powierzchnia zabudowy & ha & 0 & 12,9 \\
\hline $\begin{array}{l}\text { Powierzchnia nowo wzniesionej zabudowy (wybudowanej } \\
\text { w ramach rewitalizacji) }\end{array}$ & ha & 15,7 & 9,0 \\
\hline $\begin{array}{l}\text { Powierzchnia zachowanej dawnej zabudowy użytkowanej } \\
\text { przez przemysł }\end{array}$ & ha & 0 & 6,9 \\
\hline $\begin{array}{l}\text { Powierzchnia dawnej zabudowy użytkowanej przez prze- } \\
\text { mysł, która została poddana renowacji i adaptacji na nowe } \\
\text { funkcje w ramach procesu rewitalizacji }\end{array}$ & m & 0 & 4485 \\
\hline $\begin{array}{l}\text { Długość ogólnodostępnej linii dostępu do wody (rzeki, kana- } \\
\text { ły, zbiorniki wodne) - od rozpoczęcia procesu rewitalizacji }\end{array}$ & ha & 2,8 & 16,1 \\
\hline $\begin{array}{l}\text { Powierzchnia zabudowy zajmowanej przez funkcję usłu- } \\
\text { gową }\end{array}$ & ha & 4,0 & 11,0 \\
\hline $\begin{array}{l}\text { Powierzchnia zabudowy zajmowanej przez funkcję miesz- } \\
\text { kaniową }\end{array}$ & ha & 15,7 & 1,7 \\
\hline $\begin{array}{l}\text { Powierzchnia zabudowy zajmowanej przez nieużytki po- } \\
\text { przemysłowe lub funkcję produkcyjną }\end{array}$ & & & \\
\hline
\end{tabular}

Źródło: badania własne autora.

Rewitalizacja wewnątrzmiejskich terenów poprzemysłowych w Manchesterze wiązała się z istotnymi przekształceniami morfologicznymi i funkcjonalnymi. Wśród linowych elementów morfologicznych największe zmiany objęły likwidację naziemnych i nieużytkowanych linii kolejowych wraz z bocznicami (tab. 5.1). Wynikała ona przede wszystkim z wycofania funkcji przemysłowej, składowej i magazynowej z analizowanego obszaru, a tym samym z utraty znaczenia linii kolejowych jako dróg zaopatrzenia w surowce niezbędne do produkcji (włókienniczej, chemicznej, maszynowej oraz elektromaszynowej) oraz jako elementów infrastruktury komunikacyjnej umożliwiającej dostawę gotowych wyrobów do magazynów bądź ich eksport. Drugim czynnikiem wpływającym na eliminację linii kolejowych z rejonu 
Central (City Centre) było zamknięcie dworca centralnego dla ruchu pasażerskiego w 1969 r. Współcześnie w południowej części śródmieścia dostępność komunikacyjną do miasta zapewniają Piccadilly Station, Oxford Station i Deansgate Station (rys. 5.10). Na terenach uwolnionych od infrastruktury kolejowej w Castlefield, City Centre oraz Gaythorn powstały liczne parkingi naziemne umożliwiające pozostawienie samochodu oraz skorzystanie z komunikacji tramwajowej i autobusowej w ramach systemu ,park \& ride”. Budowa aglomeracyjnej linii tramwajowej Metrolink, przebiegającej m.in. przez dawne tereny industrialne, stanowiła istotny element przekształceń przestrzenno-funkcjonalnych i wiązała się z lokalizacją nowych instytucji publicznych w tej części miasta (rys. 5.10). Tereny dawnej komunikacji kołowej w znacznym stopniu przeznaczono natomiast na strefy ruchu pieszego, których ważnym elementem są waterfronty wzdłuż kanałów oczyszczonych ze śmieci.

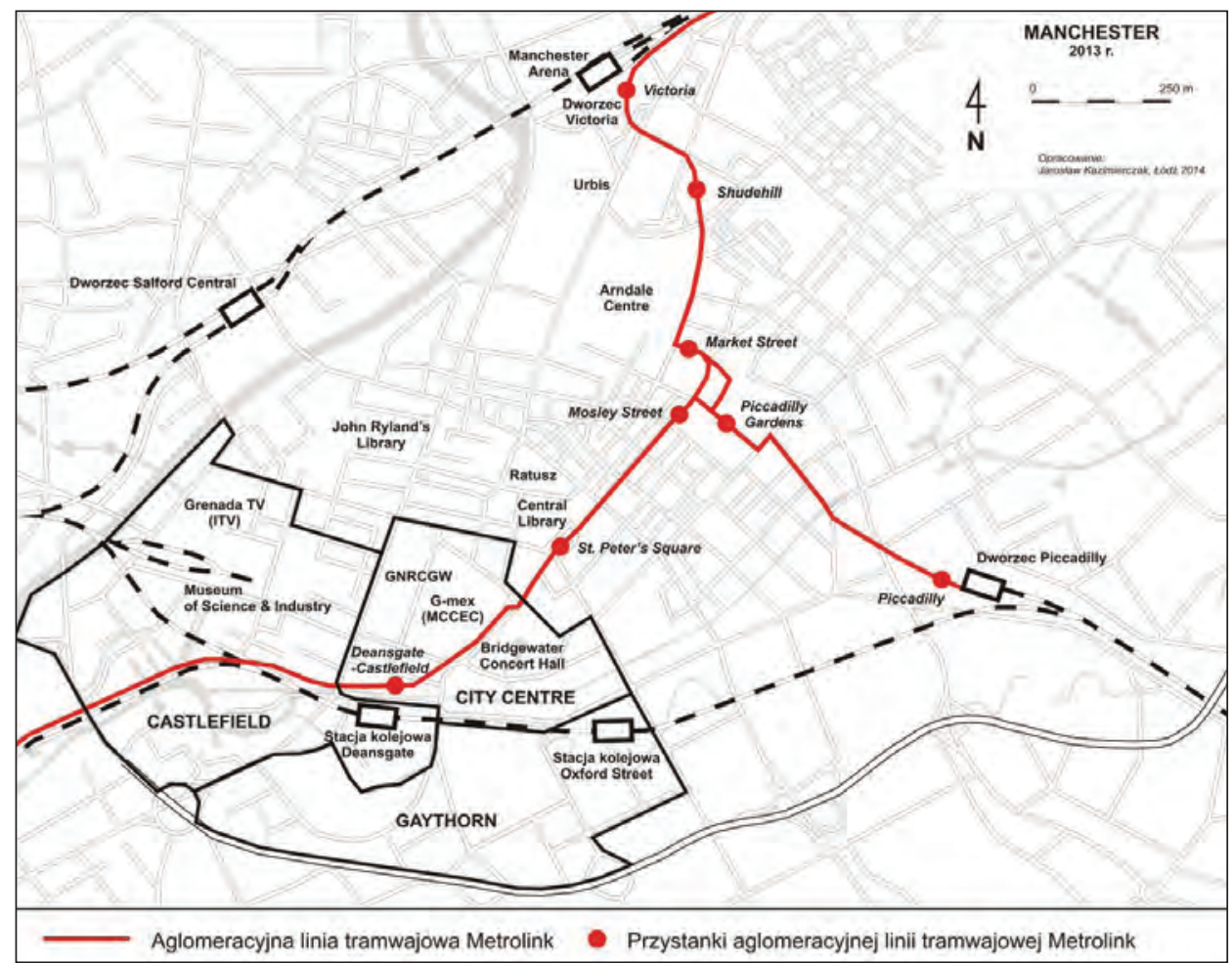

Rys. 5.10. Przebieg Metrolink w śródmieściu Manchesteru (2013 r.)

Źródło: badania własne autora

Proces rewitalizacji terenów poprzemysłowych w rejonie Castlefield, City Centre i Gaythorn był związany z istotnym zwiększeniem powierzchni zabudowy. Znaczny jej udział stanowią obiekty nowo wzniesione w okresie 1988-2013. Przekształcenia morfologiczne objęły także proces adaptacji historycznej zabudowy 


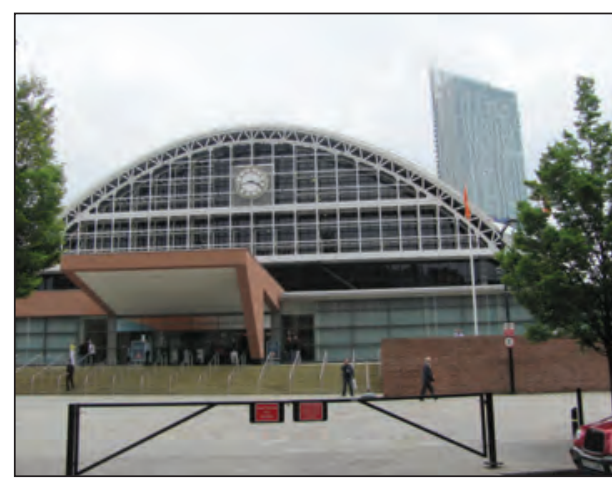

Fot. 5.1. Manchester Central Convention and Exhibition Centre w hali dawnego dworca kolejowego Central Station

Źródło: fotografia autora

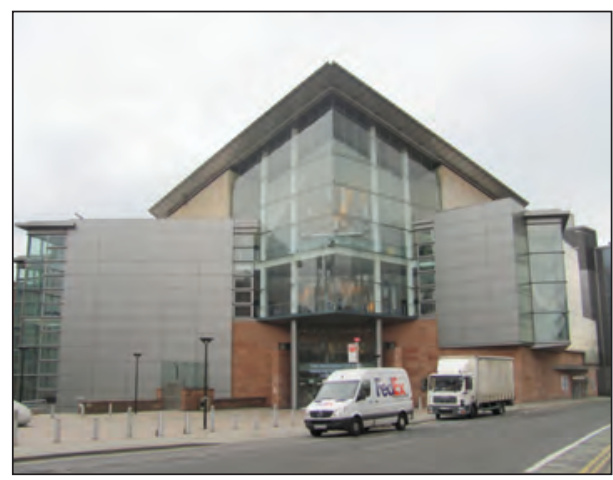

Fot. 5.3. Bridgewater Concert Hall

Źródło: fotografia autora

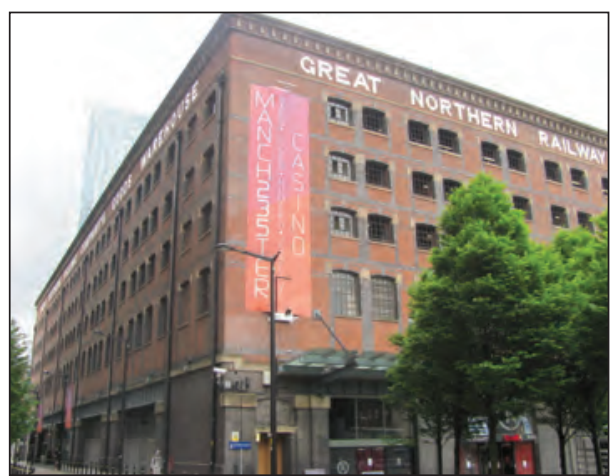

Fot. 5.2. Centrum rozrywkowe w dawnym GNRCGW

Źródło: fotografia autora

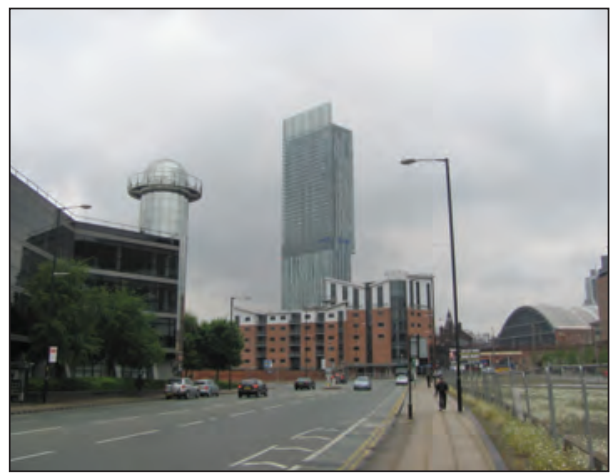

Fot. 5.4. Beetham Tower widziany z Gaythorn

Źródło: fotografia autora

na nowe funkcje, dostosowane do współczesnych potrzeb mieszkańców miasta i kształtowanej metropolitalnej pozycji Manchesteru (tab. 5.1). W roku 1986 halę dawnego dworca centralnego (Central Station) zaadaptowano na centrum wystawiennicze G-mex (pierwotna nazwa), czyli Greater Manchester Central Convention and Exhibition Centre (wcześniej Greater Manchester Exhibition and Events Centre) (fot. 5.1). Jest to jeden $\mathrm{z}$ projektów wiodących zrealizowanych w ramach rewitalizacji tego obszaru. Towarzyszyło mu przekształcenie dawnego obiektu Great Northern Railway Company’s Goods Warehouse (GNRCGW), w którym współcześnie mieści się centrum rozrywkowe oraz wielopoziomowy parking (fot. 5.2). W sąsiedztwie Manchester Central Convention and Exhibition Centre (MCCEC) znajduje się koncentracja nowych obiektów, w tym nowej filharmonii Bridgewater Concert Hall (fot. 5.3), będącej kolejnym z projektów wiodących, zrealizowanych w ramach rewitalizacji obszaru wokół dawnego dworca centralnego. Filharmonię 
otwarto w 1996 r., natomiast Free Trade Hall, który do tej pory zajmowała The Hallé Orchestra, przekształcono na luksusowy hotel. W City Centre zlokalizowany jest także najwyższy wysokościowiec w mieście - Beetham Tower o wysokości 169 metrów (fot. 5.4). Obiekt oddany do użytku w 2006 r. jest najwyższym budynkiem rezydencjonalnym w Wielkiej Brytanii, zlokalizowanym poza Londynem. Oprócz apartamentów, znajduje się tu hotel Hilton. Beetham Tower stał się symbolem przemian gospodarczych Manchesteru i jego współczesną wizytówką.

Wśród analizowanych obszarów poprzemysłowych największy udział nowej zabudowy względem ogólnej powierzchni zabudowy charakteryzuje rejon City Centre - 65\%, następnie Gaythorn - 44\% i Castlefield - 33\%. Ze względu na utworzenie Parku Dziedzictwa Miejskiego (Urban Heritage Park) w Castelfield, stopień zachowania historycznej zabudowy poprzemysłowej w $2013 \mathrm{r}$. wynosił w tym rejonie $25 \%$ ogólu powierzchni zabudowy, w porównaniu do $45 \% \mathrm{w}$ roku 1988, czyli przed rewitalizacją. Znacznie większy spadek udziału dawnej zabudowy przemysłowej w okresie 1988-2013 jest właściwy dla rejonu City Centre - z 77\% w 1988 do 27\% w 2013 r. oraz dla Gaythorn - z 95\% w 1988 do 38\% w 2013 r. Najwyższym stopniem wykorzystania zachowanej zabudowy poprzemysłowej na nowe funkcje w $2013 \mathrm{r}$. odznaczał się City Centre, gdzie adaptacji podlegał każdy z zachowanych obiektów. W przypadku Castlefield udział ten wynosi $74 \%$, a w Gaythorn - 70\%. Zmiany morfologiczne na analizowanym obszarze przedstawiają rysunki 5.11, 5.12 i 5.13.

W wyniku rewitalizacji terenów poprzemysłowych w Castlefield, City Centre i Gaythorn zostały wygenerowane nowe jednostki morfologiczno-funkcjonalne o cechach fizycznych i z zakresu sposobu użytkowania znacznie różniące się od pierwotnych. Według przyjętej skali najbardziej intensywne przekształcenia przestrzenno-funkcjonalne objęły obszar City Centre, gdzie zidentyfikowano wysoki stopień przekształceń. W Castlefield i Gaythorn proces rewitalizacji wiązał się natomiast ze stopniem umiarkowanym. Rejon Castlefield charakteryzuje się najmniej przekształconym krajobrazem industrialnym w ramach nowej przestrzeni centralnej Manchesteru. W tzw. Castle Quays dominantami krajobrazowymi są XIX-wieczne wiadukty kolejowe, które wraz z zielenią miejską, kanałami, zachowanymi urządzeniami technicznymi oraz dużą powierzchnią terenów ruchu pieszego kształtują atrakcyjną przestrzeń publiczną. Generowanie ogólnodostępnej strefy kontaktu miasta z wodą (tzw. waterfrontów) jest jednym z kluczowych elementów procesu rewitalizacji zdegradowanych fragmentów przestrzeni miejskiej $\mathrm{i}$ był to jeden $\mathrm{z}$ priorytetów przekształceń przestrzenno-funkcjonalnych terenów poprzemysłowych w Manchesterze (tab. 5.1). Nowe nadwodne przestrzenie publiczne stały się obszarem chętnie odwiedzanym przez mieszkańców miasta, zapewniającym miejsce do wypoczynku i rekreacji. W ramach przemian przestrzennych w waterfrontach wybudowano także liczne kładki oraz zamontowano oświetlenie, co zwiększyło poczucie bezpieczeństwa. Tereny spacerowe nad kanałami zostały utworzone także w rejonie City Centre. Brakuje ich wciąż w Gaythorn, który nadal poddawany jest przekształceniom morfologicznym. 



Rys. 5.11. Struktura morfologiczna w Castlefield w roku 1988 i 2013 Źródło: badania własne autora 

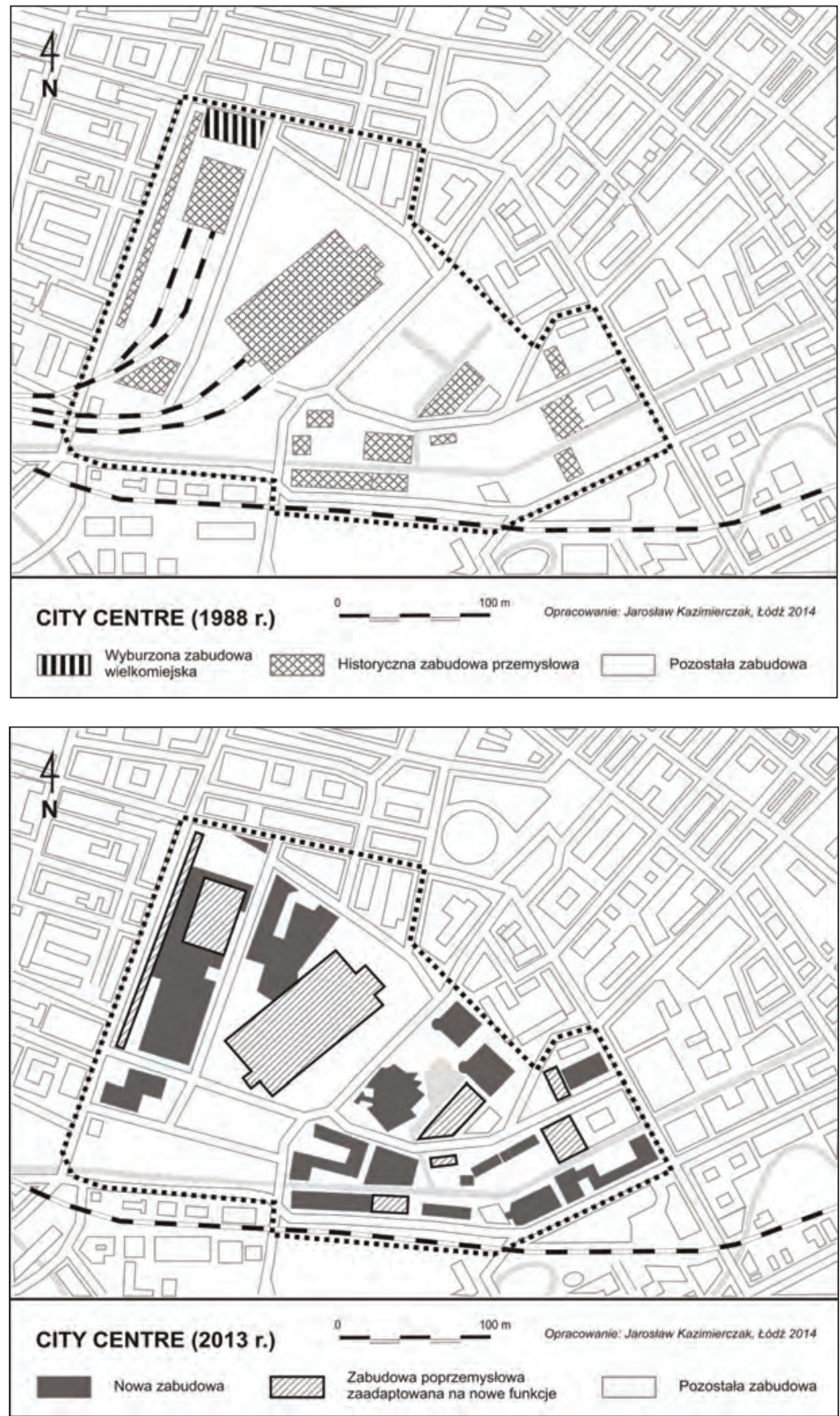

Rys. 5.12. Struktura morfologiczna w City Centre w roku 1988 i 2013 Źródło: badania własne autora 

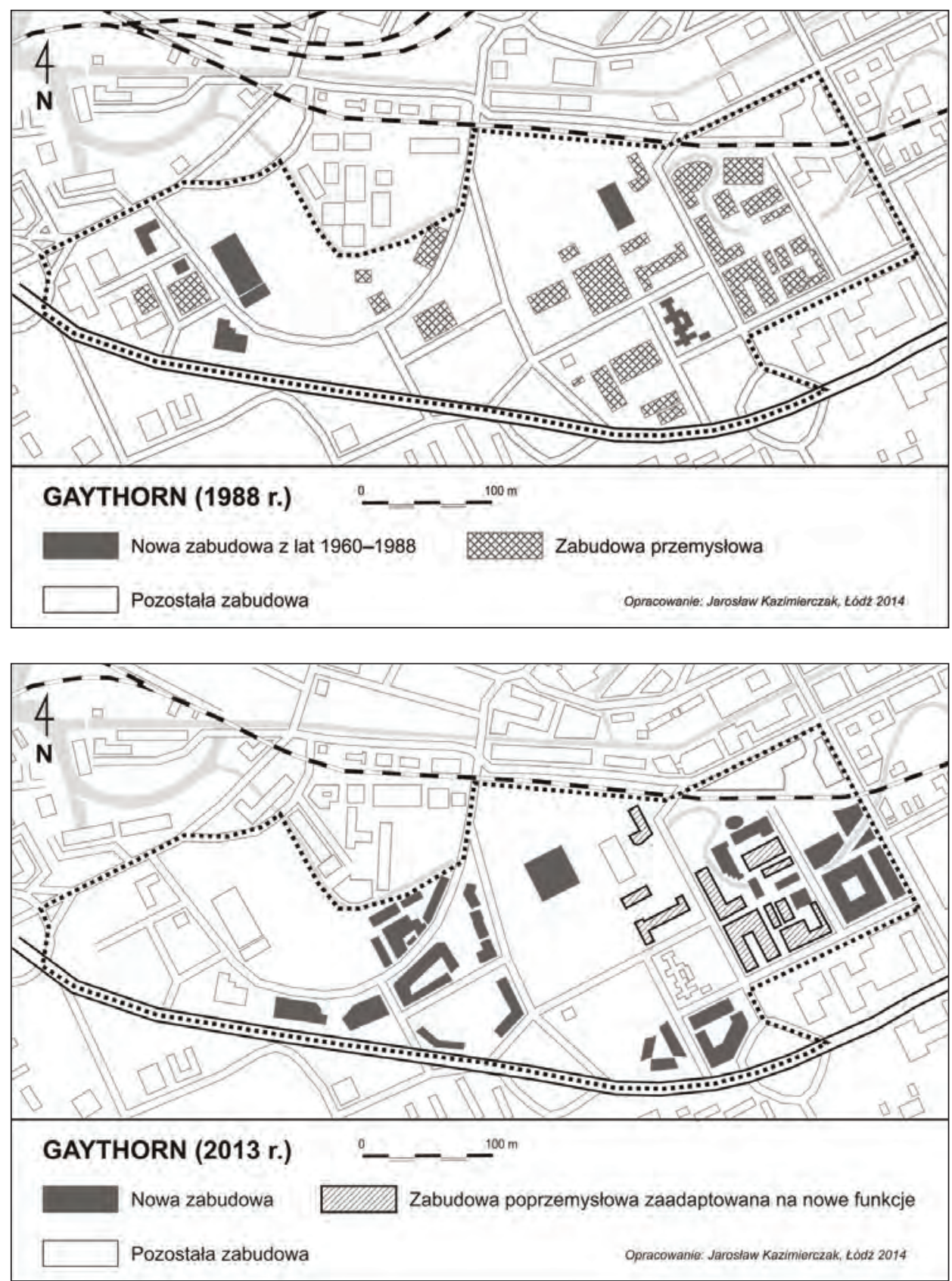

Rys. 5.13. Struktura morfologiczna w Gaythorn w roku 1988 i 2013 Źródło: badania własne autora 
W wyniku przeprowadzonej analizy w mezoskali i przyjętej skali (patrz rozdz. 2) stwierdzono, że proces rewitalizacji terenów poprzemysłowych w Manchesterze, w wyniku którego została wygenerowana nowa przestrzeń centralna, wiązał się $\mathrm{z}$ umiarkowanym $\left(\mathrm{U}_{\mathrm{P}}\right)$ stopniem intensywności przekształceń przestrzenno-funkcjonalnych. W wymiarze morfologicznym zidentyfikowano natomiast radykalny charakter rewitalizacji terenów postindustrialnych (tab. 5.2).

Tabela 5.2. Intensywność przekształceń morfologii i sposobu użytkowania terenów poprzemysłowych w Manchesterze w latach 1988-2013

\begin{tabular}{|l|c|c|}
\hline \multicolumn{1}{|c|}{ Cecha } & $\mathrm{P}(\mathrm{w} \%)$ & $\begin{array}{c}\text { Intensywność } \\
\text { zmian }\end{array}$ \\
\hline Długość dróg kołowych & $-2,2$ & Niski $\left(\mathrm{P}_{\mathrm{N}}\right)$ \\
\hline Długość naziemnych linii kolejowych & $-49,0$ & Niski $\left(\mathrm{P}_{\mathrm{N}}\right)$ \\
\hline Długość nowych linii tramwajowych & 27,9 & Niski $\left(\mathrm{P}_{\mathrm{N}}\right)$ \\
\hline Powierzchnia zabudowy & $\mathrm{x}$ & Wysoki $\left(\mathrm{P}_{\mathrm{W}}\right)$ \\
\hline $\begin{array}{l}\text { Powierzchnia nowo wzniesionej zabudowy (wybudowanej w ra- } \\
\text { mach rewitalizacji) }\end{array}$ & $-42,9$ & Niski $\left(\mathrm{P}_{\mathrm{N}}\right)$ \\
\hline $\begin{array}{l}\text { Powierzchnia zachowanej dawnej zabudowy użytkowanej przez } \\
\text { przemysł }\end{array}$ & $\mathrm{x}$ & Wysoki $\left(\mathrm{P}_{\mathrm{W}}\right)$ \\
\hline $\begin{array}{l}\text { Powierzchnia dawnej zabudowy użytkowanej przez przemysł, } \\
\text { która została poddana renowacji i adaptacji na nowe funkcje w ra- } \\
\text { mach procesu rewitalizacji }\end{array}$ & $\mathrm{x}$ & Wysoki $\left(\mathrm{P}_{\mathrm{W}}\right)$ \\
\hline $\begin{array}{l}\text { Długość ogólnodostępnej linii dostępu do wody (rzeki, kanały, } \\
\text { zbiorniki wodne) - od rozpoczęcia procesu rewitalizacji }\end{array}$ & 456,5 & Wysoki $\left(\mathrm{P}_{\mathrm{W}}\right)$ \\
\hline Powierzchnia zabudowy zajmowanej przez funkcję usługową & 178,0 & Wysoki $\left(\mathrm{P}_{\mathrm{W}}\right)$ \\
\hline Powierzchnia zabudowy zajmowanej przez funkcję mieszkaniową & $-89,0$ & Wysoki $\left(\mathrm{P}_{\mathrm{W}}\right)$ \\
\hline $\begin{array}{l}\text { Powierzchnia zabudowy zajmowanej przez nieużytki poprzemy- } \\
\text { słowe lub funkcję produkcyjną }\end{array}$ & & \\
\hline
\end{tabular}

Źródło: badania własne autora.

Nowa przestrzeń centralna w Manchesterze zajmuje powierzchnię 165 ha. Składają się na nią tereny poprzemysłowe w Castlefield, City Centre i Gaythorn oraz dawne tereny industrialne i mieszkaniowe w Whitworth, Piccadilly i Spinningfields. Proces przekształceń tych obszarów był analogiczny do analizowanych w mezoskali i obejmował lata 1988-2013. Stara przestrzeń centralna w Manchesterze zajmuje północną część śródmieścia o powierzchni 107,5 ha (rys. 5.14). Kształtują ją jednostki przestrzenne najstarsze pod względem morfogenetycznym. $\mathrm{O}$ charakterze relacji pomiędzy starą i nową przestrzenią centralną w istotnym stopniu decyduje zakres podobieństwa (zróżnicowania) sposobu ich organizacji w wymiarze morfologicznym i instytucjonalnym. Im stopień zróżnicowania jest mniejszy, tym bardziej prawdopodobne jest zaburzenie historycznie ukształtowanej hierarchii terenów miejskich, co prowadzi do rywalizacji pomiędzy starą 
i nową przestrzenią centralną o użytkownika przestrzeni publicznej. W tabeli 5.3 zestawiono analizowane cechy morfologiczno-funkcjonalne starej i nowej przestrzeni centralnej w Manchesterze.

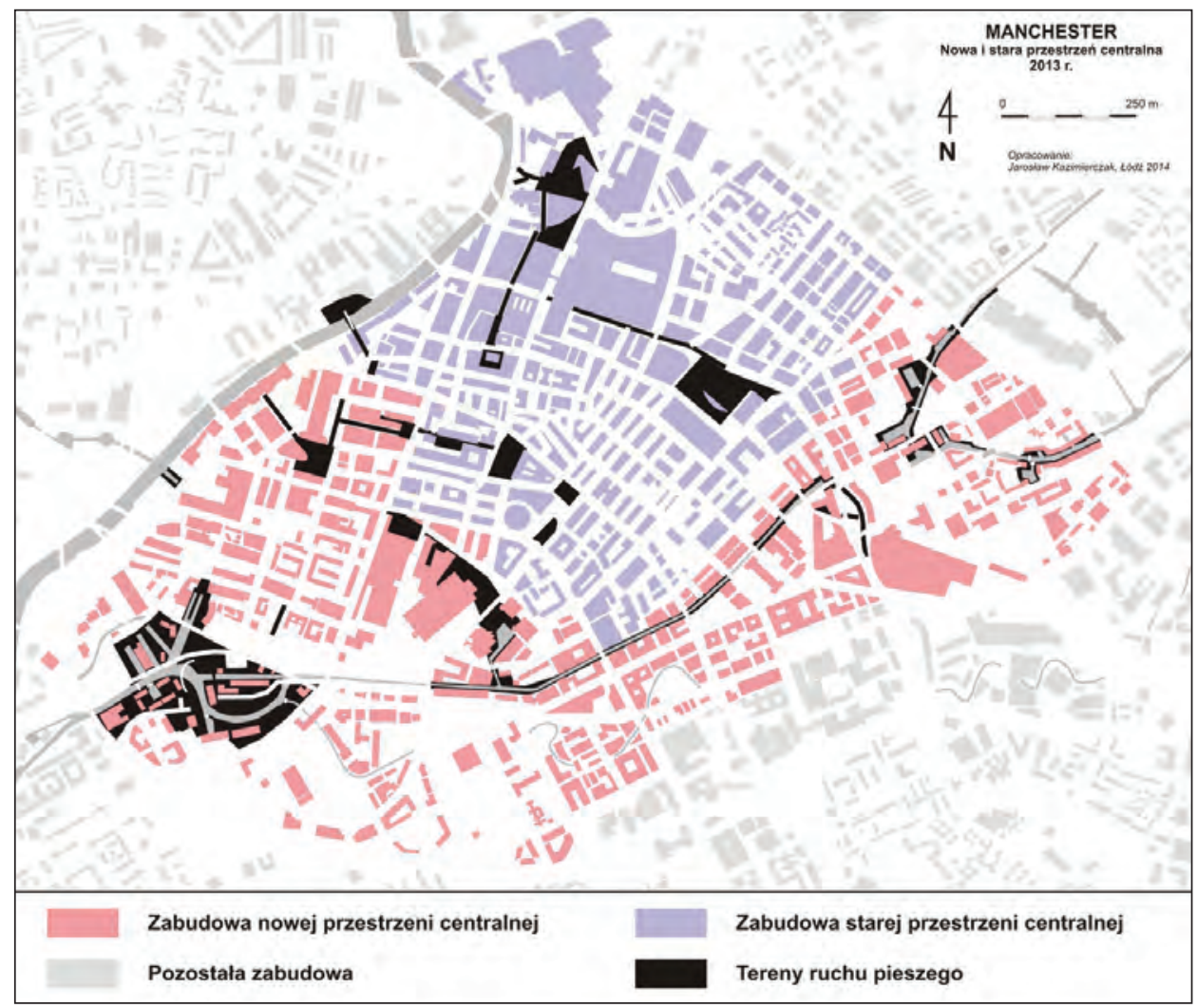

Rys. 5.14. Obszar zajmowany przez starą i nową przestrzeń centralną w Manchesterze w roku 2013

Źródło: opracowanie autora

W przestrzeni centralnej można wyróżnić tereny zamknięte (zabudowane) i otwarte. Stosunek przestrzeni zamkniętych do ogólnej powierzchni przestrzeni centralnej informuje o intensywności poziomej zabudowy. Jej uśredniona wartość dla przestrzeni centralnej w Manchesterze wynosi $61 \%$. W przypadku starej przestrzeni centralnej wzrasta ona do $76 \%$, podczas gdy w nowej wynosi zaledwie 44\%. Według klasyfikacji intensywności poziomej terenów miejskich opracowanej przez S. Liszewskiego (1978), rozumianej jako stopień pokrycia terenów budynkami i budowlami, określono, że:

- intensywność pozioma zabudowy w starej przestrzeni centralnej Manchesteru ma charakter intensywności wielkiej (powyżej 75\%) i odpowiada zabudowie zwartej; 
- intensywność pozioma zabudowy w nowej przestrzeni centralnej ma charakter intensywności niskiej (poniżej 50\%), odpowiadającej zabudowie rozproszonej;

- natomiast uśredniona intensywność zabudowy w przestrzeni centralnej Manchesteru (nowej i starej) ma charakter intensywności dużej (50-75\%) i odpowiada zabudowie luźnej.

Tabela 5.3. Wybrane cechy morfologii i sposobu użytkowania starej i nowej przestrzeni centralnej w Manchesterze w 2013 r.

\begin{tabular}{|c|c|c|c|c|}
\hline \multirow[b]{2}{*}{ Cecha } & \multirow[b]{2}{*}{$\begin{array}{c}\text { Jednostka } \\
\text { miary }\end{array}$} & \multirow[b]{2}{*}{$\begin{array}{l}\text { Stara } \\
\text { przestrzeń } \\
\text { centralna }\end{array}$} & \multicolumn{2}{|c|}{$\begin{array}{l}\text { Nowa przestrzeń } \\
\text { centralna }\end{array}$} \\
\hline & & & całość & $\begin{array}{l}\text { w tym na } \\
\text { terenach } \\
\text { poprzemy- } \\
\text { słowych }\end{array}$ \\
\hline Powierzchnia przestrzeni centralnej & ha & 107,5 & 165,0 & 101,2 \\
\hline $\begin{array}{l}\text { Powierzchnia przestrzeni zamkniętych } \\
\text { w przestrzeni centralnej }\end{array}$ & ha & 81,5 & 73,2 & 28,8 \\
\hline $\begin{array}{l}\text { Powierzchnia przestrzeni otwartych w prze- } \\
\text { strzeni centralnej }\end{array}$ & ha & 26,0 & 91,8 & 71,2 \\
\hline $\begin{array}{l}\text { Powierzchnia przestrzeni publicznej integru- } \\
\text { jącej (place miejskie) w przestrzeni centralnej }\end{array}$ & ha & 7,2 & 3,2 & 1,7 \\
\hline $\begin{array}{l}\text { Powierzchnia terenów ruchu pieszego (inne } \\
\text { strefy piesze bez placów) przestrzeni centralnej }\end{array}$ & ha & 4,5 & 11,1 & 7,7 \\
\hline $\begin{array}{l}\text { Rozmieszczenie placów miejskich w prze- } \\
\text { strzeni centralnej }\end{array}$ & $\mathrm{L}$ & 11 & 8 & 4 \\
\hline $\begin{array}{l}\text { Rozmieszczenie obiektów powyżej } 50 \mathrm{~m} \\
\text { wysokości w przestrzeni centralnej }\end{array}$ & $\mathrm{L}$ & 17 & 12 & 5 \\
\hline $\begin{array}{l}\text { Powierzchnia zajmowana przez funkcje } \\
\text { wielkomiejskie w przestrzeni centralnej }\end{array}$ & ha & 95,8 & 77,1 & 63,7 \\
\hline $\begin{array}{l}\text { Rozmieszczenie instytucji publicznych } \\
\text { w przestrzeni centralnej }\end{array}$ & $\mathrm{L}$ & 25 & 28 & 12 \\
\hline $\begin{array}{l}\text { Rozmieszczenie obiektów wybudowanych } \\
\text { w ramach projektów wiodących w przestrze- } \\
\text { ni centralnej }\end{array}$ & $\mathrm{L}$ & 2 & 5 & 3 \\
\hline $\begin{array}{l}\text { Liczba nowych instytucji centralnych i pro- } \\
\text { jektów wiodących w ekwidystancie } 15 \text { mi- } \\
\text { nut drogi pieszej od dworców kolejowych } \\
\text { i autobusowych (punkty węzłowe o randze } \\
\text { ponadlokalnej) w przestrzeni centralnej }\end{array}$ & $\mathrm{L}$ & 7 & 6 & 6 \\
\hline
\end{tabular}

Źródło: badania własne autora. 
Niska średnia intensywność pozioma zabudowy w nowej przestrzeni centralnej w Manchesterze wynika $\mathrm{z}$ topografii dawnych terenów przemysłowych. Ich pierwotny i wtórny układ zabudowy został zdeterminowany przebiegiem rzeki Medlock i kanałów, wzdłuż których w ramach rewitalizacji wygenerowano waterfronty i otwarte tereny ruchu pieszego. Nowa przestrzeń centralna wykazuje wewnętrzne zróżnicowanie w zakresie analizowanej cechy morfologicznej. Najniższa intensywność pozioma zabudowy (26\%) charakteryzuje rejon Castlefield, który w ramach przekształceń przestrzenno-funkcjonalnych został przeznaczony na funkcję turystyczną i rekreacyjną. W rezultacie w tzw. Castle Quays dominują tereny spacerowe i wypoczynkowe nad kanałem Bridgewater, przeznaczone dla mieszkańców śródmieścia oraz turystów. Ze względu na wielkomiejski program instytucjonalny najintensywniej zagospodarowany został obszar City Centre. Niemniej i w tym przypadku intensywność pozioma jest znacznie niższa od tej, która występuje w starej przestrzeni centralnej i wynosi zaledwie 44\%. Istotnym czynnikiem decydującym o tej wartości jest zajęcie znacznej części terenów położonych na południe od Manchester Central Convention and Exhibition Centre na tereny kolejowe oraz parkingi, które stanowią ważne ogniwo w systemie ,park \& ride" w śródmieściu Manchesteru. Najwyższą intensywnością poziomą wśród obszarów kształtujących nową przestrzeń centralną odznacza się Spinningfields, które jest identyfikowane ze współczesnym CBD (Central Business District) Manchesteru. Wynosi ona w tym rejonie 78\%.

Wysoka intensywność pozioma zabudowy w starej przestrzeni centralnej wynika z historycznej rangi tego obszaru, który w okresie wielkoprzemysłowym w XIX w. był identyfikowany z komercyjnym centrum miasta (patrz rys. 5.5). Charakterystyczna dla niego zabudowa wielkomiejska została zachowana i odnowiona, a liczne monumentalne budynki zajmowane przez instytucje centralne stanowią do dziś szczególnie mocno widoczny element w krajobrazie śródmiejskim (fot. 5.5-5.8). W drugiej połowie XX w. nastąpiła intensyfikacja procesów inwestycyjnych, podjętych $\mathrm{w}$ celu zabudowy terenów zniszczonych w czasie nalotów bombowych z II wojny światowej. Zachowana historyczna substancja miejska była konsekwentnie uzupełniana nową zabudową, która wypełniła wolne działki, w tym również parcele po wyburzonych, zdekapitalizowanych obiektach postindustrialnych i rezydencjonalnych. Działania te zostały nasilone w ostatniej dekadzie XX w. W wyniku zamachów bombowych w 1996 r. oraz procesu metropolizacji Manchesteru realizowanego od przełomu lat 80. i 90. $\mathrm{XX}$ w. stara przestrzeń centralna została $\mathrm{w}$ istotnej części poddana modernizacji, przede wszystkim w ramach projektu Millenium Quarter (patrz rys. 5.9) Wiązała się ona z rewaloryzacją istniejącej zabudowy wielkomiejskiej, dalszymi wyburzeniami niskiej jakości zabudowy i budową na ich miejscu nowych obiektów o współczesnej formie architektonicznej przeznaczonej na usługi. W rezultacie historyczna (genetycznie najstarsza w mieście) przestrzeń centralna charakteryzuje się współcześnie wysoką intensywnością poziomą zabudowy, mozaikowym 


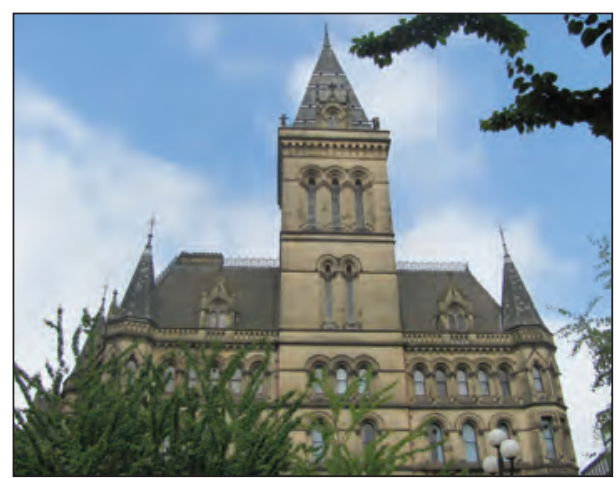

Fot. 5.5. Ratusz w Manchesterze jako przykład architektury eklektycznej z XIX w.

Źródło: fotografia autora

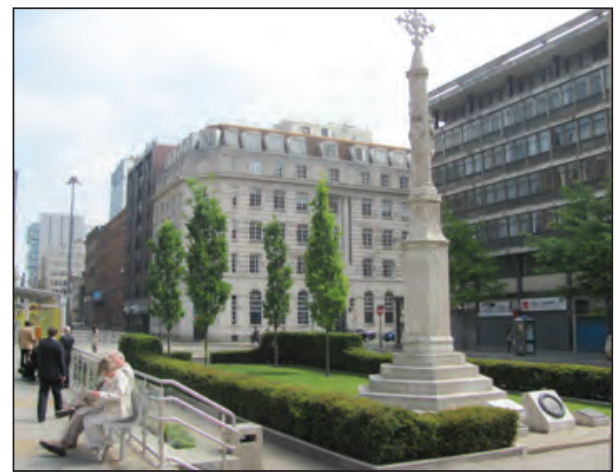

Fot. 5.7. Zabudowa wielkomiejska z XIX i XX w. wokół placu Peter's Square

Źródło: fotografia autora

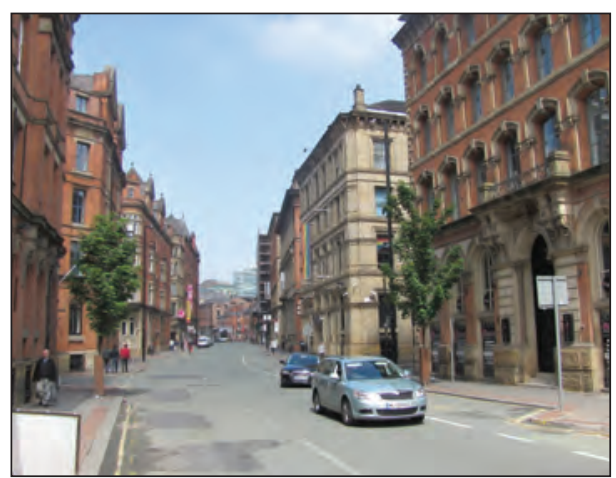

Fot. 5.6. Wielkomiejska zabudowa handlowej Portland Street

Źródło: fotografia autora

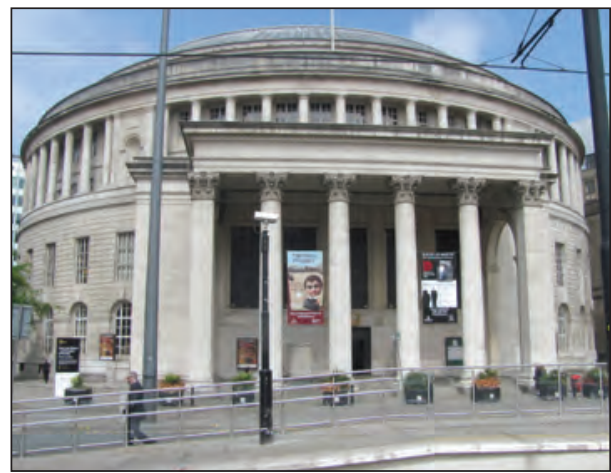

Fot. 5.8. Budynek biblioteki centralnej jako przykład zabudowy z I połowy XX w.

Źródło: fotografia autora

rozmieszczeniem kamienic wielkomiejskich z XIX i pierwszej połowy XX w., wybudowanych najczęściej w stylu eklektycznym, oraz licznych nowoczesnych budynków wykończonych materiałami typowymi dla architektury drugiej połowy XX w. i początku XXI w. (fot. 5.9-5.12).

We współczesnym krajobrazie przestrzeni centralnej Manchesteru szczególnie widoczne są obiekty wysokościowe, których budowę rozpoczęto w latach 50 . XX w. Proces ich powstawania można podzielić na dwa okresy charakteryzujące się odmiennym rozmieszczeniem tego typu budynków w dzielnicy śródmiejskiej. Pierwszy z nich, związany z czwartym etapem kształtowania przestrzeni centralnej w Manchesterze od lat 50. do drugiej połowy lat 80 . XX w., objął tereny miejskie położone na południe od Piccadilly Gardens (rys. 5.15, por. też z rys. 5.8). Drugi etap budowy zabudowy wysokościowej rozpoczął się w $1996 \mathrm{r}$. od powstania biurowca 


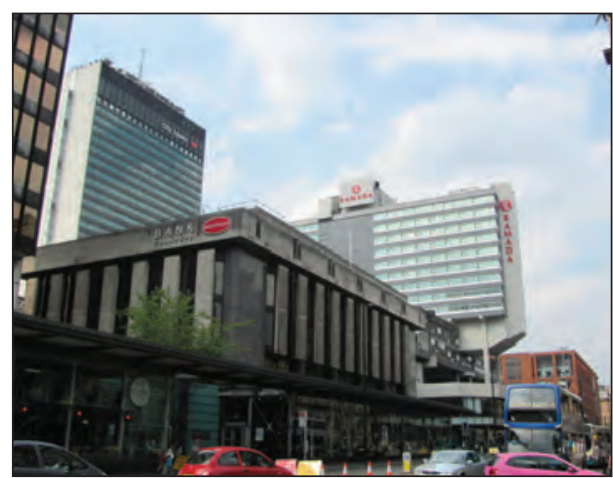

Fot. 5.9. City Tower i Ramada Renaissance Hotel jako przykład zabudowy wysokościowej w Manchesterze z lat 60. i 70. XX w.

Źródło: fotografia autora

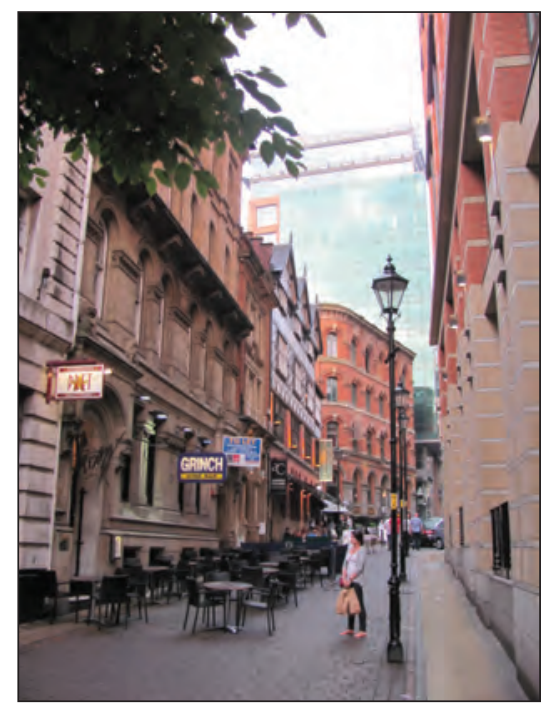

Fot. 5.11. Przykład połączenia XIX-wiecznej i XX-wiecznej zabudowy w starej przestrzeni centralnej Manchesteru - Chapel Street

Źródło: fotografia autora

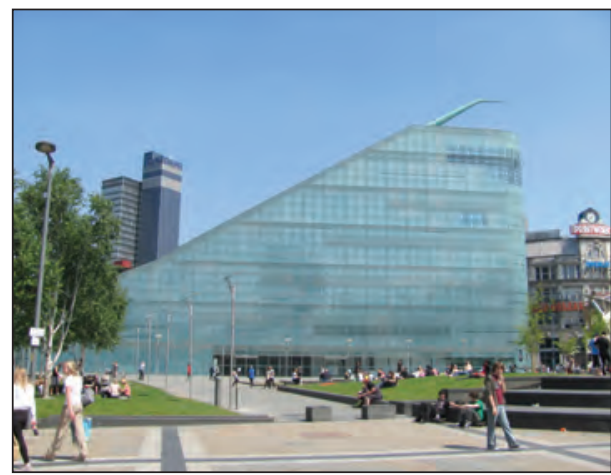

Fot. 5.10. Urbis i CIS Tower (na drugim planie) jako przykład nowej zabudowy w historycznej przestrzeni centralnej Manchesteru

Źródło: fotografia autora

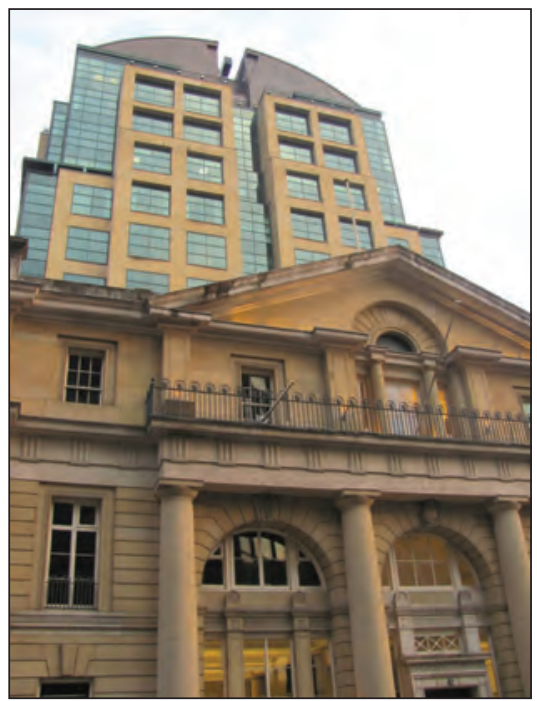

Fot. 5.12. Przykład połączenia historycznej i współczesnej zabudowy w Manchesterze przy Kings Street

Źródło: fotografia autora

82 King Street (fot. 5.12). W 2013 r. nie można uznać tego etapu za ukończony, gdyż planowana jest budowa kolejnych obiektów wysokościowych, m.in. w okolicach dworca Piccadilly i w Gaythorn w ramach projektu dzielnicy biznesowej First Street, na południe od Beetham Tower. Zauważyć można, że analizowany proces do roku 2013 wiązał się z dyspersją zabudowy wysokościowej, zarówno w starej, jak i nowej przestrzeni centralnej, z czym związane były działania w ramach 
rewitalizacji terenów poprzemysłowych (rys. 5.15). Niewątpliwie budowa nowych obiektów wysokościowych przekształciła zarówno historyczną przestrzeń centralną miasta jak również krajobraz dawnych terenów przemysłowych.

W okresie przedindustrialnym w Manchesterze dominantą architektoniczną miasta była wieża katedralna. W okresie wielkoprzemysłowym była nią 85-metrowa wieża neoromańskiego ratusza (fot. 5.5). We współczesnym Manchesterze znajduje się 29 budynków liczących powyżej 50 metrów wysokości. W starej przestrzeni centralnej zlokalizowanych jest 17 obiektów, a w nowej - 12 (tab. 5.3 i rys. 5.15). Większość nowych obiektów wysokościowych wybudowanych od połowy lat 90 . XX w. znajduje się na dawnych terenach poprzemysłowych oraz w Spinningfields (rys. 5.15). Beetham Tower - najwyższy budynek w mieście i jego współczesna dominanta o wysokości 169 metrów powstał w rejonie City Centre (rys. 5.15, patrz też fot. 5.1 i 5.4). Rozmieszczenie analizowanej zabudowy

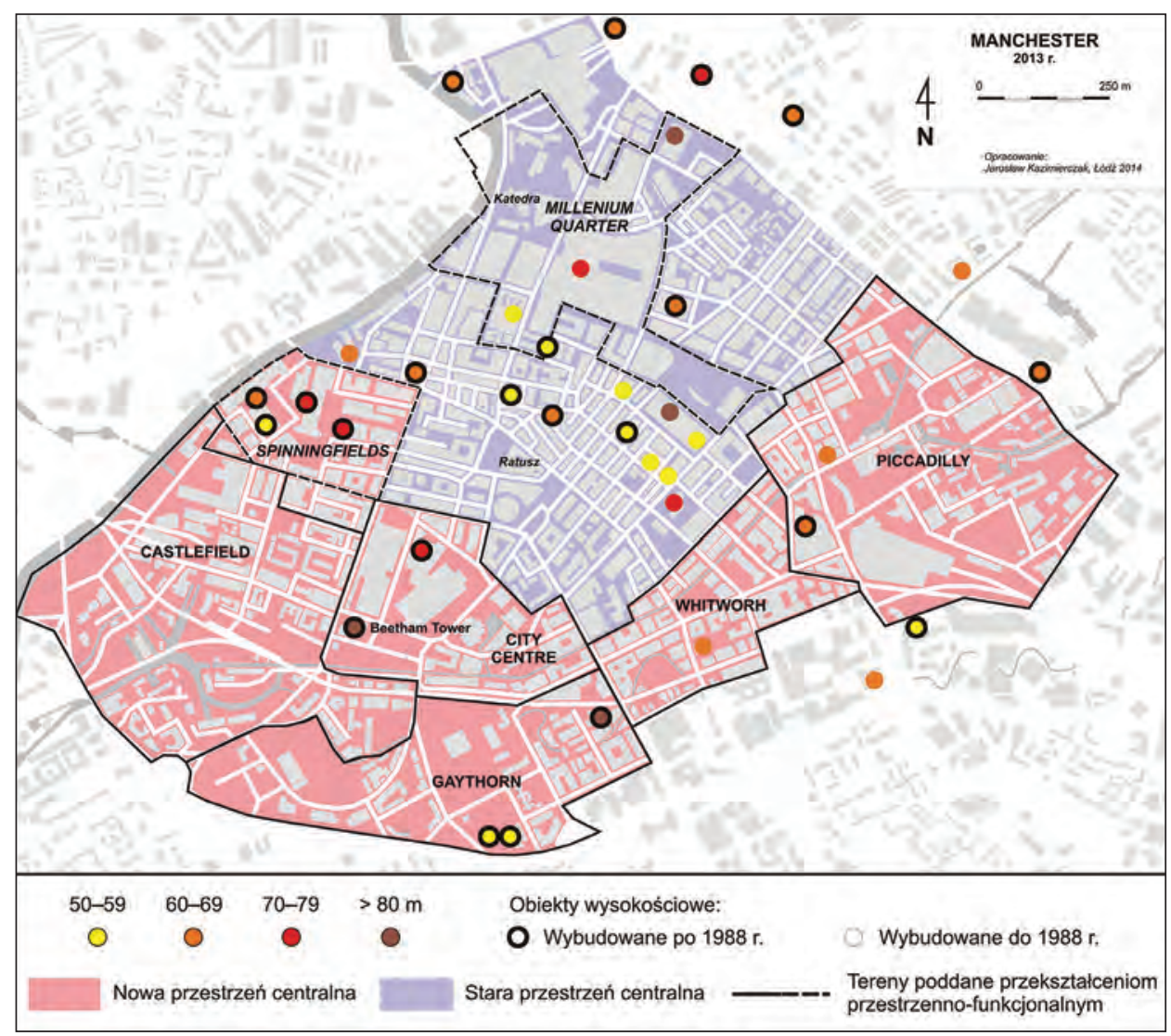

Rys. 5.15. Rozmieszczenie obiektów wysokościowych w przestrzeni centralnej Manchesteru w 2013 r.

Źródło: badania własne autora 
w starej i nowej przestrzeni centralnej Manchesteru wykazuje nieznaczne zróżnicowanie, co może świadczyć o ich porównywalnej atrakcyjności inwestycyjnej. Jest ono także wyrazem metropolizacji miasta oraz globalizacji (unifikacji) sylwety jego przestrzeni centralnej (starej i nowej).

Największą koncentracją współczesnej zabudowy wielkomiejskiej w Manchesterze charakteryzuje się obszar Spinningfields (fot. 5.13-5.16). Jest to pierwsze co do wielkości i ważności centrum finansowe w Wielkiej Brytanii, zlokalizowane poza Londynem. Sukcesja tego typu zabudowy objęła także rejony

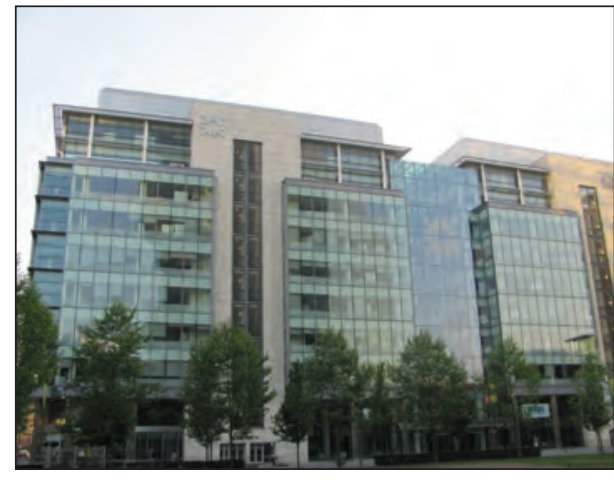

Fot. 5.13. Siedziba Royal Bank of Scotland w Spinningfields

Źródło: fotografia autora

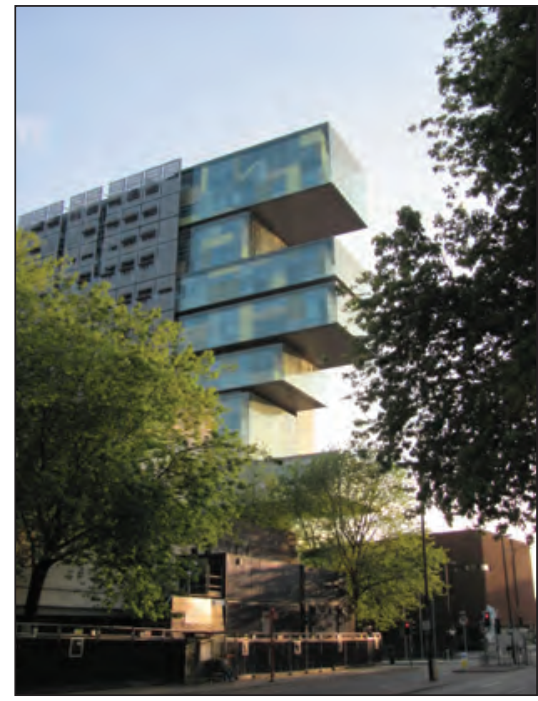

Fot. 5.15. Budynek Civil Justice Centre w Spienningfields

Źródło: fotografia autora

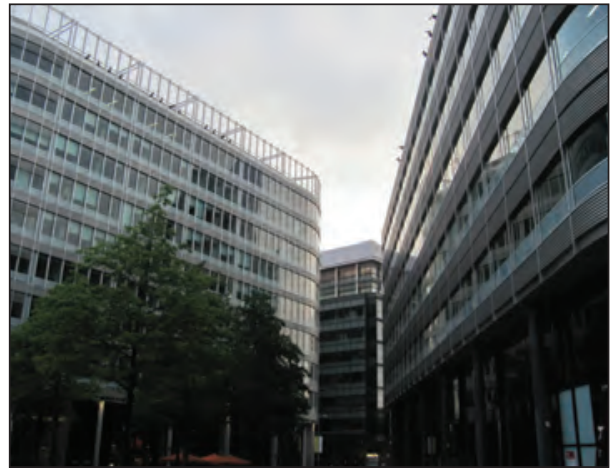

Fot. 5.14. Obiekty biurowe w Spinningfields Źródło: fotografia autora

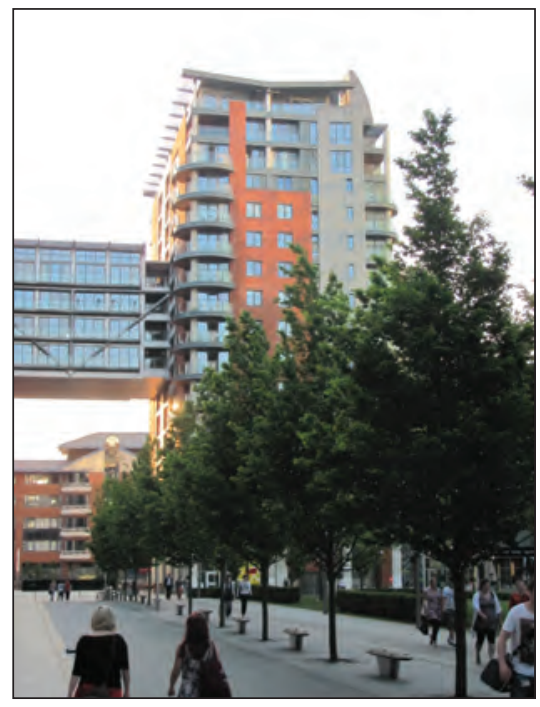

Fot. 5.16. Zabudowa apartamentowa w Spinningfields

Źródło: fotografia autora 
Castlefield, City Centre i Gaythorn, sąsiadujące ze Spinningfields. Nastąpiła ona w wyniku rozwoju funkcji wielkomiejskich w ramach rewitalizacji obszarów postindustrialnych. Nowoczesna architektura wraz z zachowanymi i zrewaloryzowanymi budynkami poprzemysłowymi, znacznym udziałem terenów zieleni oraz waterfrontów decyduje o interesującej kompozycji urbanistycznej nowej przestrzeni centralnej w Manchesterze (fot. 5.17-5.20).

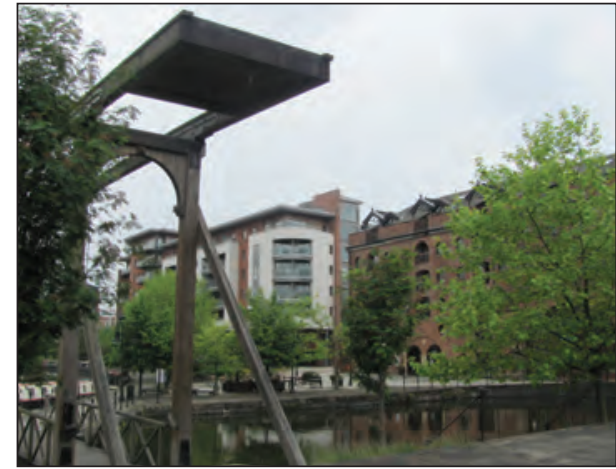

Fot. 5.17. Połączenie elementów zabudowy historycznej i współczesnej oraz wody i zieleni miejskiej w Castlefield

Źródło: fotografia autora

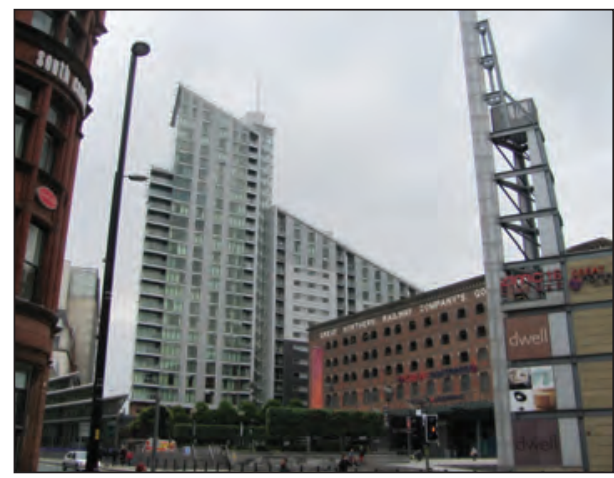

Fot. 5.19. Zabudowa wysokościowa i budynek dawnego GNRCGW przekształcony na centrum rozrywkowe w City Centre

Źródło: fotografia autora

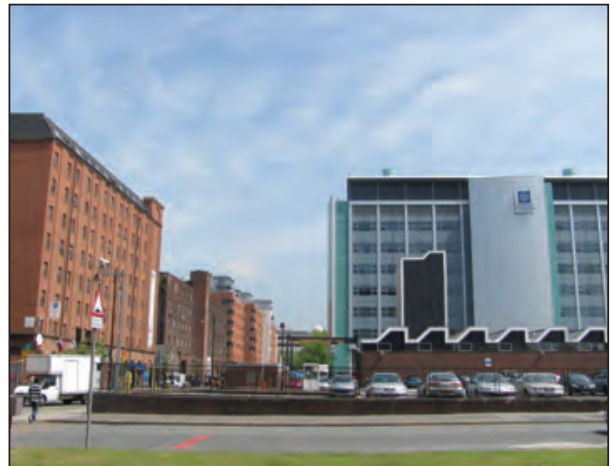

Fot. 5.18. Integracja zabudowy poprzemysłowej i współczesnej w Gaythorn Źródło: fotografia autora

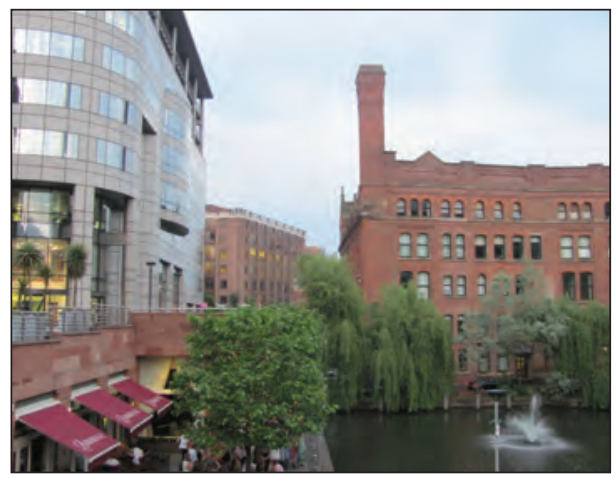

Fot. 5.20. Połączenie XIX-wiecznej architektury przemysłowej i współczesnej w City Centre Źródło: fotografia autora

Proces rewitalizacji terenów poprzemysłowych, z którym wiązały się przekształcenia fizjonomiczne zabudowy śródmiejskiej, stanowił jeden z czynników prowadzących do wykształcenia współczesnego, metropolitalnego krajobrazu przestrzeni centralnej (starej i nowej) w Manchesterze. Jego istotnym elementem są obiekty o oryginalnej formie architektonicznej, takie jak np. Bridgewater 
Concert Hall (fot. 5.3), Urbis (fot. 5.10) czy Civil Justice Centre (fot. 5.15), i które stanowią symbole zmian przestrzennych i ekonomicznych w Manchesterze. Powszechne występowanie nowoczesnej zabudowy w obszarze śródmiejskim unifikuje fizjonomię starej i nowej przestrzeni centralnej, przy czym na terenach poprzemysłowych stałym elementem morfologicznym jest zabudowa pofabryczna z nieotynkowanej cegły oraz liczne urządzenia techniczne, w tym śluzy kanałów. Rzadziej natomiast wstępują kamienice wielkomiejskie z XIX w., typowe dla historycznej przestrzeni centralnej.

Proces przekształceń przestrzennych w starej i nowej przestrzeni centralnej od końca lat 80 . XX w. doprowadził do znaczącego podniesienia estetyki przestrzeni publicznej. Wiązał się on z wyburzeniem bądź modernizacją zdekapitalizowanej zabudowy, budową nowych obiektów o oryginalnej fizjonomii oraz powszechnym zastosowaniem wody, zieleni miejskiej i elementów małej architektury. W efekcie działań naprawczych na terenach poprzemysłowych i w obszarze śródmiejskim powstało 7 nowych placów miejskich i odnowiono 7 kolejnych, w tym największy współcześnie plac miejski w Manchesterze o powierzchni 3 ha, zlokalizowany w miejscu historycznych ogrodów Piccadilly Gardens (rys. 5.16 i fot. 5.21).

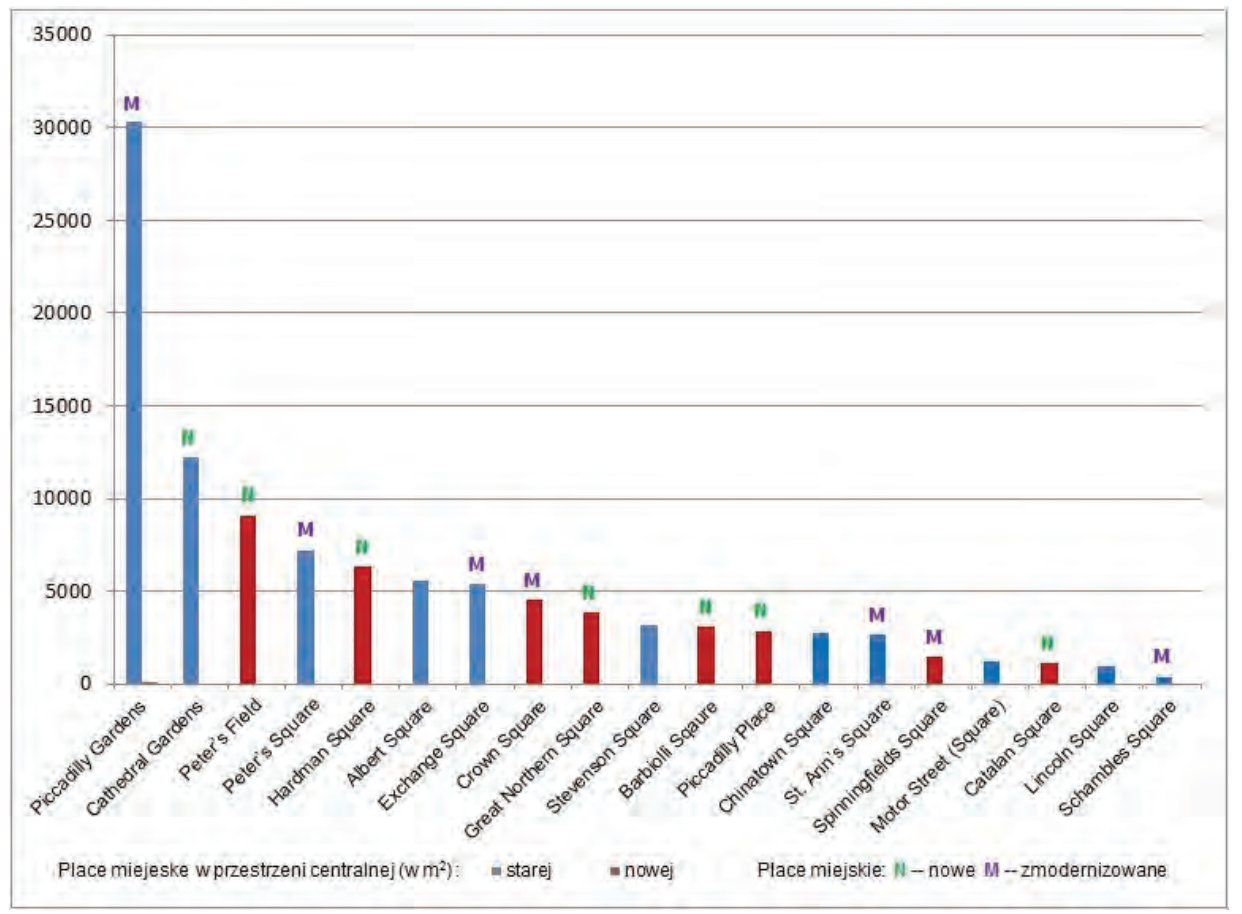

Rys. 5.16. Struktura placów miejskich w przestrzeni centralnej Manchesteru w 2013 r.

Źródło: badania własne autora 
W wyniku procesu rewitalizacji terenów poprzemysłowych powstały 4 nowe place miejskie: Calatan Square w Castlefield oraz Great Northern Square, Peter's Field Square i Barbilli Square w City Centre w sąsiedztwie Manchester Central Convention and Exhibition Centre oraz centrum rozrywkowego w dawnym GNRCGW (rys. 5.17 i fot. 5.22). Specyfiką nowej przestrzeni centralnej w Manchesterze jest powszechne występowanie waterfrontów wzdłuż kanałów: Bridgewater w Castle Quays (fot. 5.23), Rochdale i Ashton. Łączna powierzchnia waterfrontów w nowej przestrzeni centralnej to 6,8 ha, z czego 4,6 ha w Castlefield i 0,7 ha w City Centre. Całość powstała w wyniku rewitalizacji terenów poprzemysłowych. Znaczenie stref kontaktu „miasta z wodą” w przestrzeni publicznej współczesnych miast wyraźnie wzrasta, a ich obecność podnosi walory użytkowe obszarów śródmiejskich jako terenów wypoczynkowych i komunikacyjnych. Łączna powierzchnia terenów pieszych (bez placów) w nowej przestrzeni centralnej wynosi 11,1 ha i jest znacznie większa niż w jej historycznej (starej) części (4,5ha), w której dominują place miejskie (rys. 5.17).

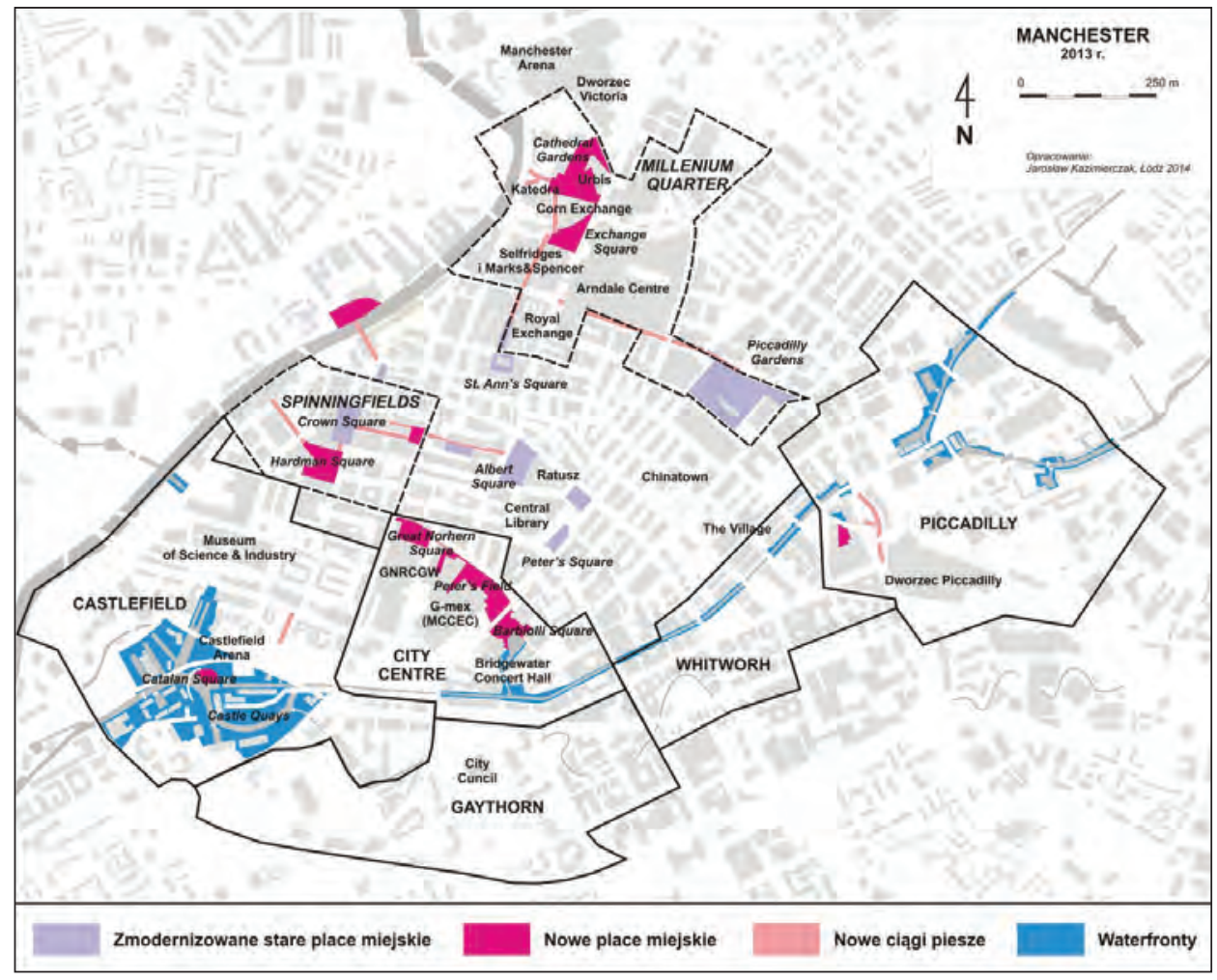

Rys. 5.17. Rozmieszczenie terenów pieszych w przestrzeni centralnej Manchesteru w $2013 \mathrm{r}$. względem zrealizowanych projektów naprawczych

Źródło: badania własne autora 


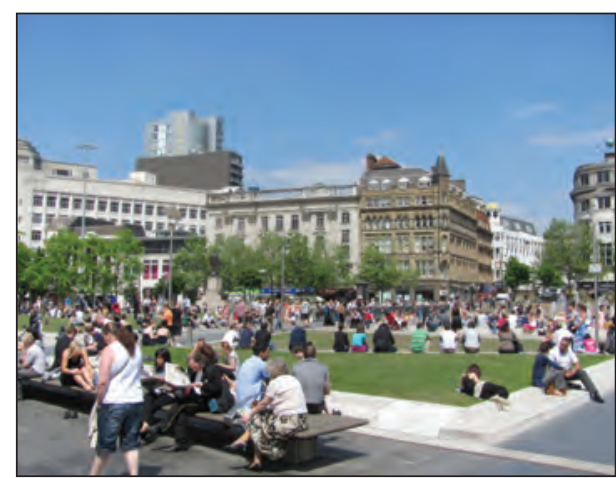

Fot. 5.21. Piccadilly Gardens jako główny plac miejski w Manchesterze

Źródło: fotografia autora

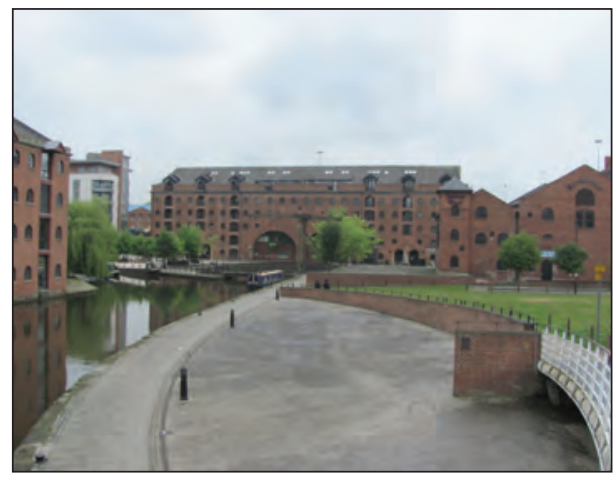

Fot. 5.23. Przykład waterfrontu w Castle Quays Źródło: fotografia autora

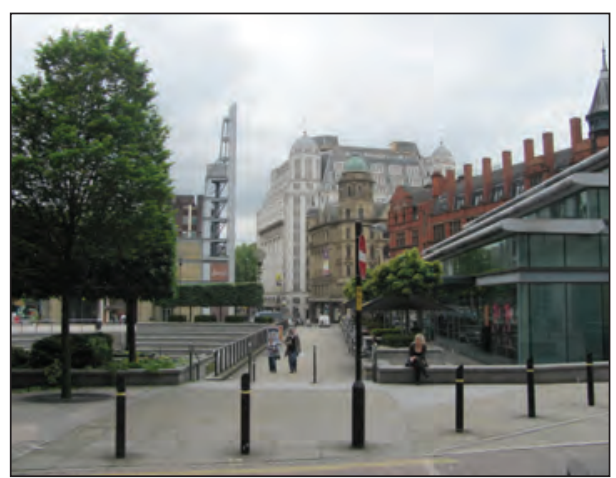

Fot. 5.22. Great Northern Square - rezultat rewitalizacji terenów poprzemysłowych

Źródło: fotografia autora

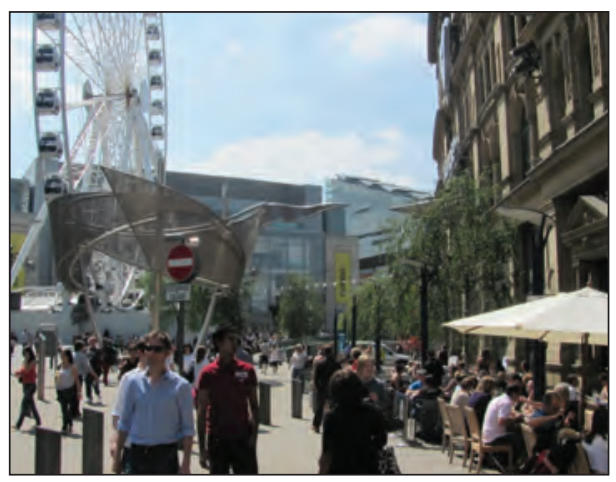

Fot. 5.24. Exchange Square, na którym ustawione zostało koło widokowe

Źródło: fotografia autora

Nowe place w północnej części śródmieścia zostały wygenerowane w ramach projektu Millenium Quarter, którego celem było wykształcenie atrakcyjnej pod względem użytkowym i estetycznym przestrzeni śródmiejskiej (rys. 5.17, patrz też fot. 5.10 i 5.24). W ramach projektu wygenerowano 2,2 ha nowych stref ruchu pieszego oraz nowy plac miejski Cathedral Gardens o powierzchni 1,2 ha. W ramach tego samego projektu modernizacji zostały poddane dwa historyczne place miejskie Exchange Square (fot. 5.24) i Schambles Square, o łącznej powierzchni 0,9 ha (rys. 5.16 i 5.17). Najbardziej reprezentacyjnym placem współczesnego Manchesteru jest Piccadilly Gardens. Ze względu na brak innych otwartych terenów zielonych w gęsto zabudowanej północnej części śródmieścia jest on także ważnym miejscem spotkań i wypoczynku użytkowników przestrzeni miejskiej (fot. 5.21). Ruch na Piccadilly Gardens generuje też główny węzeł aglomeracyjnych linii tramwajowych Metrolink i miejskich linii autobusowych 
oraz liczne obiekty handlowe i gastronomiczne znajdujące się w jego otoczeniu (Arndale Centre, Primark i Debenhams). Ciągi piesze stanowią istotny element integrujący przestrzeń publiczną w starej i nowej przestrzeni centralnej. Wielkość powierzchni przestrzeni publicznej jest odzwierciedleniem rangi konkretnego obszaru w hierarchii terenów centralnych, stąd jej koncentracja w starej lub nowej przestrzeni centralnej świadczy o wyraźnej dominacji jednej nad drugą. W Manchesterze przestrzeń publiczna zarówno o charakterze integrującym, jak i w formie innych terenów pieszych wykazuje niski stopień zróżnicowania.

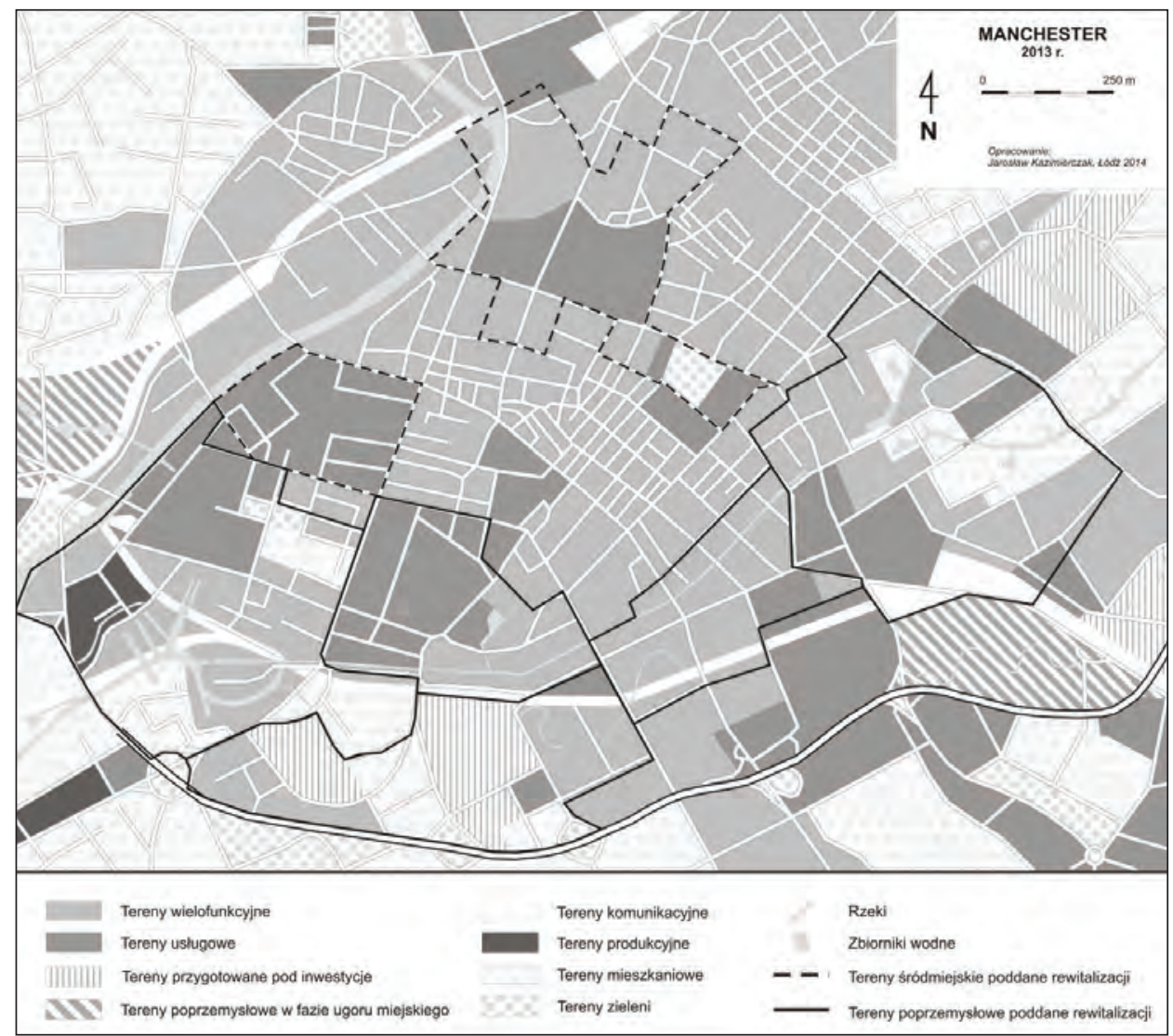

Rys. 5.18. Użytkowanie ziemi w starej i nowej przestrzeni centralnej w Manchesterze w 2013 r.

Źródło: badania własne autora

Stara i nowa przestrzeń centralna w Manchesterze charakteryzuje się zbliżonym udziałem powierzchni zajmowanej przez funkcje wielkomiejskie. Jest ona obliczana na podstawie stosunku powierzchni terenów wielofunkcyjnych i usługowych do powierzchni zajmowanej przez starą i nową przestrzeń centralną (rys. 5.18). Nietypowy dla przestrzeni centralnej sposób użytkowania ziemi 
występuje w zachodniej części Castlefield, którą zajmują tereny produkcyjne. Niemniej rejon ten został przeznaczony przede wszystkim na funkcje wielkomiejskie w $63 \%$, podczas gdy w Gaythorn zajmują one zaledwie $34 \%$ powierzchni obszaru. Jest to konsekwencja nadal niezakończonego procesu naprawczego i dużego udziału terenów inwestycyjnych, m.in. w ramach projektu First Street (nowego centrum biznesu i administracji Manchesteru). Istotną część nowej przestrzeni centralnej zajmują także tereny mieszkaniowe, zlokalizowane w peryferyjnej części Castlefield, Gaythorn i Piccadilly. Największy udział terenów o wielkomiejskim sposobie użytkowania występuje w rejonie City Centre i wynosi aż 98\% (rys. 5.18).

Egzemplifikacją przekształceń przestrzenno-funkcjonalnych terenów poprzemysłowych na wielkomiejski sposób użytkowania oraz modernizacji historycznej przestrzeni centralnej w Manchesterze jest rozmieszczenie nowych instytucji III i IV sektora, w tym zrealizowanych w ramach projektów wiodących. Wyróżnić można dwa obszary ich koncentracji. W przestrzeni centralnej wygenerowanej na dawnych terenach industrialnych są one zlokalizowane głównie w rejonie City Centre, który wraz ze Spinningfields tworzy dzielnicę biznesową współczesnego Manchesteru (rys. 5.19). Drugim rejonem koncentracji instytucji centralnych jest obszar w okolicach Arndale Centre, katedry i dworca kolejowego Victoria. Ich powstanie było rezultatem działań naprawczych na obszarze zdewastowanych kwartałów miejskich, realizowanych w ramach Millenium Quarter, podjętych po zamachu bombowym przeprowadzonym przez IRA w 1996 r. Objęły one rewaloryzację historycznych budynków Corn Exchange i Royal Exchange, które adaptowano na obiekty handlowe i pełniące funkcje kulturalne, oraz najstarszy zachowany do dziś obiekt w mieście - The Old Wellington Inn. W ramach realizacji projektów wiodących wybudowano budynek Urbis, w którym mieści się National Football Museum. Natomiast na północ od dworca kolejowego Victoria powstała hala sportowo-widowiskowa Manchester Arena ${ }^{5}$, która przejęła część imprez organizowanych do czasu jej powstania w 1995 r. w Manchester Central Convention and Exhibition Centre (rys. 5.19). Przekształcenia historycznej przestrzeni centralnej w okolicach katedry i Arndale Centre, dokonane w ramach projektu Millenium Quarter, były także związane z budową luksusowego domu towarowego Selfridges, który w Wielkiej Brytanii poza Manchesterem mieści się jedynie w Londynie i Birmingham. W jego sąsiedztwie znajduje się inny dom towarowy - Marks \& Spencer, którego marka jest rozpoznawana na całym świecie. Projekt Millenium Quarter zakładał także modernizację Market Street i Piccadilly Gardens, którą ukończono w 2000 r. Obiektem rozpoznawczym dla tego fragmentu przestrzeni centralnej jest koło widokowe, znajdujące się na Exchange Square (fot. 5.24).

${ }^{5} \mathrm{~W}$ pracy używana jest nazwa Manchester Arena jako powszechnie stosowana przez mieszkańców Manchesteru. Od oddania do użytku nazwa hali zmieniała się wielokrotnie, przyjmując nazwę głównego sponsora. W latach 1995-1997 nosiła nazwę NYNEX Arena, następnie Manchester Evening News Arena, w skrócie MEN Arena (w latach 1998-2011), Manchester Arena (w 2012 r.) i Phones 4u Arena (od lipca 2013 r.). 
Przebudowa zespołu zdegradowanych kwartałów w północnej części śródmieścia w latach 90. XX w. poprawiła jakość fizyczną i użytkową przestrzeni publicznej obszaru, który identyfikowany jest ze starą przestrzenią centralną Manchesteru. Mimo że przekształcenia tego fragmentu śródmieścia rozpoczęly się po zainicjowaniu pierwszych zinstytucjonalizowanych działań rewitalizacyjnych na terenach poprzemysłowych w latach 80. XX w., to rejon Millenium Quarter nie może być traktowany jako nowa przestrzeń centralna. Wynika to z przyjętych założeń teoretycznych, według których kwartały kształtujące istniejące centrum miasta permanentnie podlegają transformacji zróżnicowanej w zależności od skali i intensywności. W przypadku Millenium Quarter doszło do modernizacji fragmentu starej przestrzeni centralnej zbieżnej $\mathrm{w}$ czasie $\mathrm{z}$ przekształceniami przestrzenno-funkcjonalnymi terenów poprzemysłowych, które wcześniej takiej roli w układzie miejskim nie pełniły. Wygenerowana w procesie rewitalizacji przestrzeń centralna

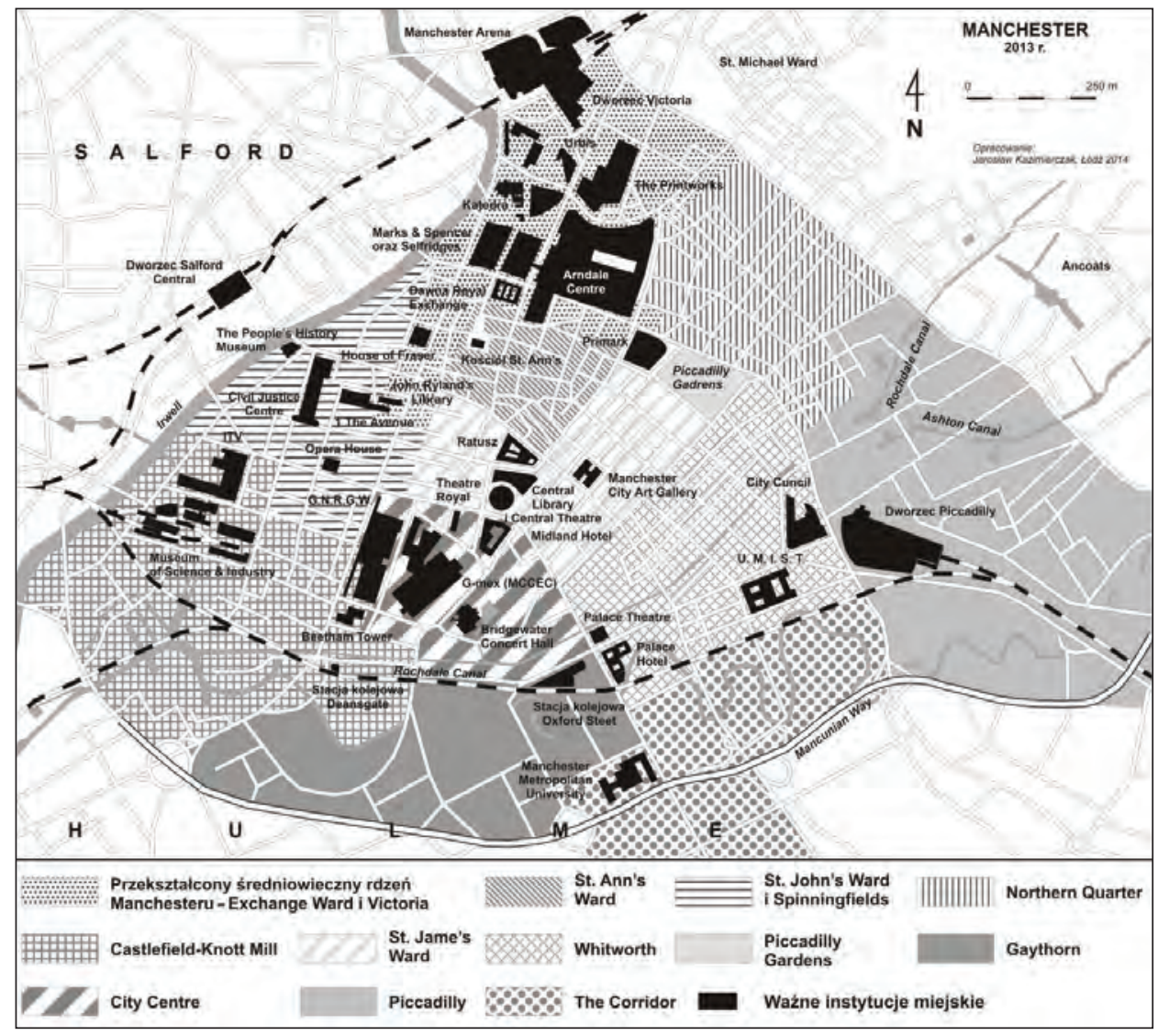

Rys. 5.19. Jednostki morfogenetyczne w przestrzeni centralnej Manchesteru w $2013 \mathrm{r}$.

Źródło: badania własne autora 
spełnia w tym ujęciu trzy znaczenia: nowej jako młodej, nowej w innej lokalizacji i nowej jako nowoczesnej (patrz rozdz. 1, s. 8 i s. 37-38).

Wyposażenie starej i nowej przestrzeni centralnej wykazuje umiarkowany stopień zróżnicowania $\mathrm{w}$ zakresie rozmieszczenia projektów wiodących oraz niski stopień zróżnicowania $\mathrm{w}$ zakresie rozmieszczenia instytucji publicznych. Również lokalizacja instytucji centralnych oraz projektów wiodących w ekwidystancie 15 minut pieszego dojścia od dworców kolejowych i autobusowych oraz węzła przesiadkowego Metrolink wykazuje niski stopień zróżnicowania pomiędzy starą i nową przestrzenią centralną (tab. 5.3). Sąsiedztwo ponadlokalnych węzłów komunikacji zbiorowej ma bardzo duże znaczenie dla rozmieszczenia instytucji III i IV sektora, szczególnie instytucji publicznych, które generują ruch użytkowników przestrzeni miejskiej - mieszkańców oraz przybyszów do miasta. Wśród tych instytucji należy wskazać głównie Muzeum Nauki i Techniki (MOSI) i Air \& Space Gallery w Castlefield, centrum rozrywkowe GNRGC, Manchester Central Convention and Exhibition Centre, Bridgewater Concert Hall w City Centre, Operę (Opera House), The People's History Museum (Pump House Museum) w Spinningfields, Dancehouse w Gaythorn oraz Urbis, Manchester Arena, The Prinworks, The Triangle at Corn Exchange, Royal Exchange Theatre \& Shopping Centre i Manchester City Art Gallery w historycznej przestrzeni centralnej. Uzupełniają ją obiekty handlowe, które generują największy ruch użytkowników przestrzeni w północnej części dzielnicy śródmiejskiej, takie jak Selfridges, Marks \& Spencer, Debenhams, Primark, Kendals House of Fraser i Arndale Centre (rys. 5.19). W wyniku budowy kompleksu medialnego MediaCity UK w Salford Quays siedziba BBC North, która do tej pory znajdowała się przy Oxford Street, została przeniesiona do Salford ${ }^{6}$ (por. rys. 5.7 i rys. 5.19).

Piąty etap kształtowania przestrzeni centralnej w Manchesterze był związany z przekształceniami morfologicznymi i instytucjonalnymi w najstarszych jednostkach morfogenetycznych, położonych w północnej części dzielnicy śródmiejskiej, oraz z rewitalizacją terenów poprzemysłowych w jej południowym fragmencie. W wyniku podjętych działań naprawczych nastąpiła intensywna ekspansja przestrzeni centralnej zarówno w ujęciu odśrodkowym - związana z sukcesją nowych terenów miejskich (w tym postindustrialnych), jak i w ujęciu dośrodkowym polegająca na sanacji i częściowej transformacji jednostek morfogenetycznych tworzących starą przestrzeń centralną (rys. 5.19). Efektem działań naprawczych zdegradowanych fragmentów historycznej i nowej przestrzeni centralnej w Manchesterze jest de facto brak klasycznej starej, nieprzekształconej przestrzeni.

${ }^{6}$ Salford Quays to nowe centrum biznesowe aglomeracji Wielkiego Manchesteru. Jest ono zlokalizowane w Salford i Trafford na obszarze dawnych doków - Manchester Docks, które zostały poddane przekształceniom przestrzenno-funkcjonalnym, począwszy od lat 80 . XX w. MediaCity UK jest największym zespołem instytucji metropolitalnych, jakie lokują się w Salford Quays. Oprócz niego w Salford Quays znajdują się m.in. The Lowry Centre, Imperial War Museum North (IMNW) oraz University of Salford. W roku 2014 planowane jest otwarcie nowego kompleksu ITV (dawnej Granada TV), który zostanie przeniesiony z Castlefield. 
Tabela 5.4. Stopień zróżnicowania wybranych cech morfologii i sposobu użytkowania starej i nowej przestrzeni centralnej w Manchesterze w 2013 r.

\begin{tabular}{|l|c|c|}
\hline \multicolumn{1}{|c|}{ Cecha } & $\mathrm{Z}(\mathrm{W} \%)$ & $\begin{array}{c}\text { Stopień } \\
\text { zróżnicowania }\end{array}$ \\
\hline Powierzchnia przestrzeni centralnej & 21 & Niski $\left(Z_{\mathrm{N}}\right)$ \\
\hline Powierzchnia przestrzeni zamkniętych w przestrzeni centralnej & 5 & Niski $\left(Z_{\mathrm{N}}\right)$ \\
\hline Powierzchnia przestrzeni otwartych w przestrzeni centralnej & 56 & Umiarkowany $\left(Z_{\mathrm{U}}\right)$ \\
\hline $\begin{array}{l}\text { Powierzchnia przestrzeni publicznej integrującej (place miej- } \\
\text { skie) w przestrzeni centralnej }\end{array}$ & 38 & Niski $\left(Z_{\mathrm{N}}\right)$ \\
\hline $\begin{array}{l}\text { Powierzchnia terenów ruchu pieszego (inne strefy piesze bez } \\
\text { placów) przestrzeni centralnej }\end{array}$ & 42 & Niski $\left(Z_{\mathrm{N}}\right)$ \\
\hline Rozmieszczenie placów miejskich w przestrzeni centralnej & 16 & Niski $\left(Z_{\mathrm{N}}\right)$ \\
\hline $\begin{array}{l}\text { Rozmieszczenie obiektów powyżej 50 m wysokości w prze- } \\
\text { strzeni centralnej }\end{array}$ & 17 & Niski $\left(Z_{\mathrm{N}}\right)$ \\
\hline $\begin{array}{l}\text { Powierzchnia zajmowana przez funkcje wielkomiejskie w prze- } \\
\text { strzeni centralnej }\end{array}$ & 11 & Niski $\left(Z_{\mathrm{N}}\right)$ \\
\hline Rozmieszczenie instytucji publicznych w przestrzeni centralnej & 6 & Niski $\left(Z_{\mathrm{N}}\right)$ \\
\hline $\begin{array}{l}\text { Rozmieszczenie obiektów wybudowanych w ramach projektów } \\
\text { wiodących w przestrzeni centralnej }\end{array}$ & 43 & Niski $\left(Z_{\mathrm{N}}\right)$ \\
\hline $\begin{array}{l}\text { Liczba nowych instytucji centralnych i projektów wiodących } \\
\text { w ekwidystancie 15 minut drogi pieszej od dworców kolejo- } \\
\text { wych i autobusowych (punkty węzłowe o randze ponadlokalnej) } \\
\text { w przestrzeni centralnej }\end{array}$ & 8 & Niski $\left(Z_{\mathrm{N}}\right)$ \\
\hline
\end{tabular}

Źródło: badania własne autora.

Tabela 5.5. Wartości wskaźnika syntetycznego (Ws) i wartości standaryzowane cech opisujących poziom rozwinięcia przestrzeni centralnej w Manchesterze w 2013 r.

\begin{tabular}{|c|l|c|}
\hline $\mathrm{W}$ & \multicolumn{1}{|c|}{ Cecha (wskaźnik cząstkowy) } & $\begin{array}{c}\text { Wartość } \\
\text { zestandaryzowana }\end{array}$ \\
\hline $\mathrm{W}_{1}$ & Powierzchnia przestrzeni centralnej (w ha) / Liczba ludności miasta & 1,36461 \\
\hline $\mathrm{W}_{2}$ & $\begin{array}{l}\text { Liczba jednostek morfologicznych kształtujących przestrzeń centralną } \\
\text { / Powierzchnia przestrzeni centralnej (w ha) }\end{array}$ & 1,41357 \\
\hline $\mathrm{W}_{3}$ & $\begin{array}{l}\text { Liczba instytucji publicznych w przestrzeni centralnej / Powierzchnia } \\
\text { przestrzeni centralnej (w ha) }\end{array}$ & $-1,08723$ \\
\hline $\mathrm{W}_{4}$ & $\begin{array}{l}\text { Powierzchnia przestrzeni centralnej (w ha) / Powierzchnia śródmie- } \\
\text { ścia (w ha) }\end{array}$ & 1,40203 \\
\hline $\mathrm{W}_{5}$ & $\begin{array}{l}\text { Liczba placów w przestrzeni centralnej / Powierzchnia przestrzeni } \\
\text { centralnej (w ha) }\end{array}$ & $-0,41960$ \\
\hline $\mathrm{W}_{6}$ & $\begin{array}{l}\text { Liczba instytucji publicznych w przestrzeni centralnej / Liczba lud- } \\
\text { ności miasta }\end{array}$ & $-0,72749$ \\
\hline $\mathrm{Ws}$ & Wskaźnik poziomu rozwinięcia przestrzeni centralnej & $\mathbf{0 , 3 2 4 3 2}$ \\
\hline
\end{tabular}

Źródło: badania własne autora. 
Na podstawie przeprowadzonej analizy wybranych cech morfologicznych i sposobu użytkowania przestrzeni centralnej oraz przyjętej skali oceny (patrz rozdz. 2) w Manchesterze zidentyfikowano niski stopień zróżnicowania starej i nowej przestrzeni centralnej $\left(\mathrm{N}_{\mathrm{Z}}\right)$ (tab. 5.4).

W celu identyfikacji relacji zachodzących pomiędzy starą i nową przestrzenią centralną w Manchesterze w 2013 r. przeprowadzono także analizę poziomu rozwinięcia przestrzeni centralnej. Wartości wskaźnika syntetycznego Ws wraz z wartościami standaryzowanymi cech (wskaźników cząstkowych) opisujących poszczególne aspekty poziomu rozwinięcia przestrzeni centralnej w Manchesterze zawiera tabela 5.5.

Wskaźnik poziomu rozwinięcia przestrzeni centralnej w Manchesterze w 2013 r. (Ws) wynosi 0,32432. Zgodnie z przyjętymi założeniami oznacza to średni poziom rozwinięcia przestrzeni centralnej (wskaźnik dodatni, zbliżony do wartości 0). W oparciu o założenia metodologiczne pracy, kompilacja wyników analizy stopnia zróżnicowania starej i nowej przestrzeni centralnej w wyniku rewitalizacji terenów poprzemysłowych oraz analizy poziomu rozwinięcia przestrzeni centralnej umożliwiła identyfikację relacji we współczesnej przestrzeni centralnej w Manchesterze. W oparciu o matrycę zależności pomiędzy stopniem zróżnicowania i rozwinięcia przestrzeni centralnej a występowaniem relacji w przestrzeni centralnej miast (patrz rys. $2.3 \mathrm{w}$ rozdz. 2) w Manchesterze zidentyfikowano relacje słabo konkurencyjne (typu A). Charakteryzują się one możliwością przekształcenia na inny typ relacji ze względu na niski stopień zróżnicowania przestrzeni centralnej oraz średni poziom rozwinięcia przestrzeni centralnej, co umożliwia modyfikację aktualnej struktury morfologicznej i funkcjonalnej.

Relacje konkurencyjne w przestrzeni centralnej Manchesteru mają stymulujący wpływ na rozwój zwartego i wielofunkcyjnego centrum miasta, w którym użytkownicy przestrzeni miejskiej posiadają możliwość wyboru pomiędzy podobnie wyposażonymi fragmentami, położonymi w niewielkiej odległości od siebie.

\subsection{Wnioski}

W procesie kształtowania przestrzeni centralnej w Manchesterze wyróżniono pięć etapów. Pierwszy z nich obejmował przedindustrialny okres rozwoju miasta. Przestrzeń centralna Manchesteru wykazywała wówczas silne powiązanie ze średniowiecznym rdzeniem miasta. Do połowy XVIII w. była słabo rozwinięta i wyznaczona głównie rozmieszczeniem kościołów. Kolejne trzy etapy kształtowania przestrzeni centralnej miasta miały miejsce w okresie industrialnym. Rozwój przemysłu od początku XIX w. stał się czynnikiem determinującym intensywny proces ekspansji przestrzeni centralnej Manchesteru. W efekcie szybko rosnącej pozycji ekonomicznej miasta zostało ono wyposażone w liczne instytucje typowe dla XIX-wiecznej metropolii. Kryzys i upadek przemysłu włókienniczego 
$\mathrm{w}$ drugiej połowie XX w. spowodowały natomiast recesję przestrzeni centralnej, która odzwierciedlała się $\mathrm{w}$ degradacji substancji materialnej i instytucjonalnej miasta. Reasumując, proces kształtowania przestrzeni centralnej w drugim, trzecim i czwartym etapie wykazywał wyraźny związek z koniunkturą terenów przemysłowych (rys. 5.20).

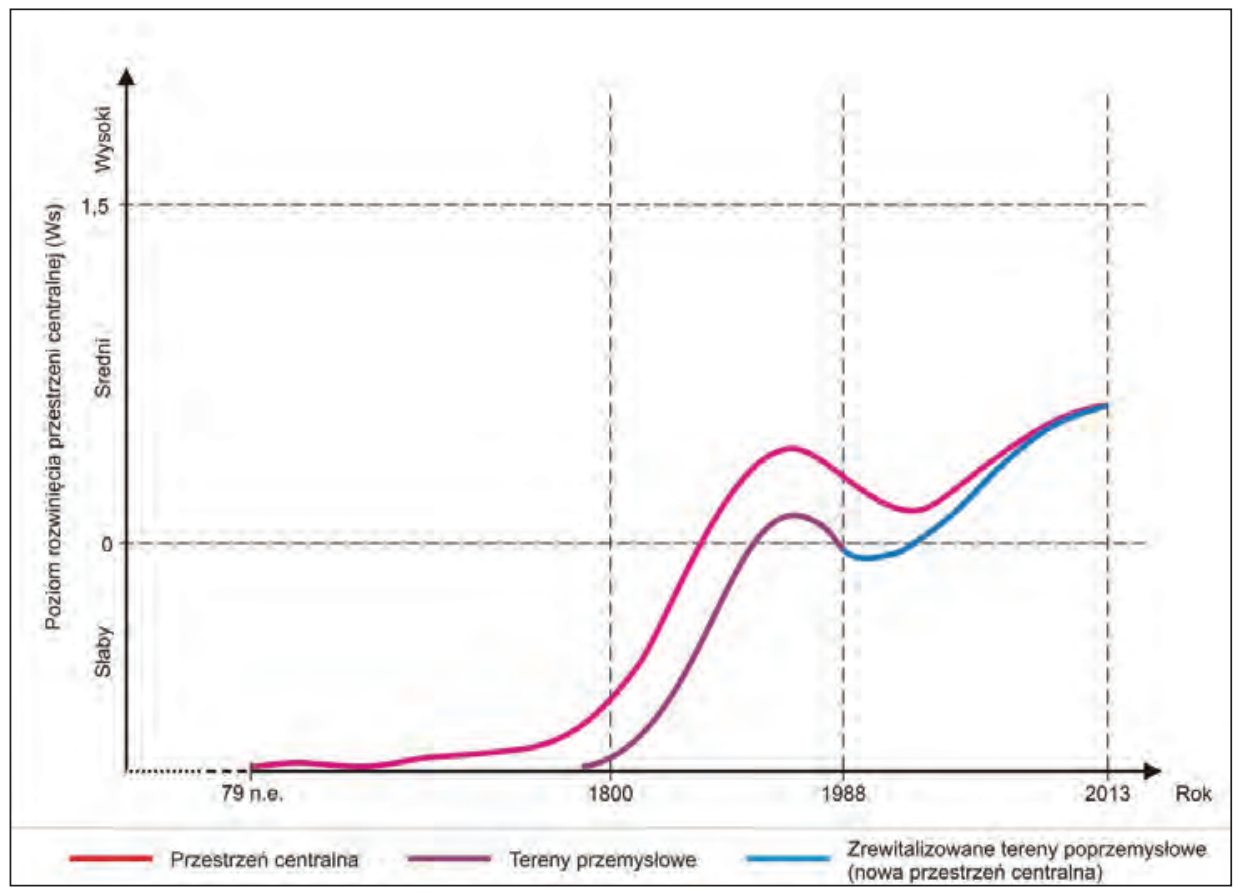

Rys. 5.20. Model sposobu rozwoju przestrzeni centralnej i terenów przemysłowych w Manchesterze

Źródło: badania własne autora

W konsekwencji upadku przemysłu pozycja Manchesteru w krajowej i międzynarodowej sieci osadniczej znacząco zmalała. Piąty etap kształtowania przestrzeni centralnej w Manchesterze w okresie po upadku przemysłu wiąże się z rewitalizacją wewnątrzmiejskich terenów postindustrialnych. Działania naprawcze podjęte $\mathrm{w}$ jej ramach miały intensywny charakter i są identyfikowane z umiarkowanym stopniem intensywności przekształceń przestrzenno-funkcjonalnych i radykalnym typem rewitalizacji w wymiarze morfologicznym. $\mathrm{W}$ ich rezultacie została wykształcona nowa przestrzeń centralna, której poziom rozwinięcia jest bardzo zbliżony do starej (lecz zmodernizowanej) przestrzeni centralnej miasta (rys. 5.20). W wyniku rewitalizacji terenów poprzemysłowych nastąpiła wtórna metropolizacja Manchesteru zbliżona do poziomu z drugiej połowy XIX w., kiedy to miasto miało rangę światową. 
Proces rewitalizacji terenów poprzemysłowych w istotnym stopniu zmienił organizację przestrzeni centralnej w Manchesterze, przyczyniając się do jej usprawnienia i ożywienia, czyli wtórnego wzrostu (rys. 5.20). Współczesna przestrzeń centralna miasta zajmuje zwarty obszar. Jej stara i nowa część wykazują nieznaczne zróżnicowanie w zakresie morfologii i sposobu użytkowania. Na podstawie przeprowadzonego postępowania badawczego w Manchesterze zidentyfikowano nieciągły (skokowy) sposób rozwoju przestrzeni centralnej. Morfogeneza terenów śródmiejskich w Manchesterze zadecydowała o rewolucyjnym charakterze przekształceń przestrzenno-funkcjonalnych, który doprowadził do wykształcenia relacji konkurencyjnych pomiędzy starą i nową przestrzenią centralną. 


\section{Rozdział 6}

\section{PRZEKSZTAŁCENIA ORGANIZACJI PRZESTRZENI CENTRALNEJ W LYONIE}

Lyon leży w środkowo-wschodniej Francji pomiędzy Alpami i Masywem Centralnym, u ujścia Saony do Rodanu. Jest stolicą regionu Rodan-Alpy i departamentu Rodan. W 2011 r. miasto zamieszkiwało 472300 osób. Wraz z sąsiednimi gminami tworzy zespół miejski Wielkiego Lyonu, liczący 1281971 mieszkańców (2009 r.). Jest to współcześnie trzecia co do wielkości aglomeracja we Francji, po Paryżu i Marsylii. Lyon odegrał ważną rolę w historii rewolucji przemysłowej we Francji, podobnie jak Manchester w Wielkiej Brytanii. Jednak w odróżnieniu od miasta angielskiego Lyon uzyskał status miasta liczącego się w sieci osadniczej Europy przed okresem industrializacji, co zostało odzwierciedlone w morfologii jego przestrzeni centralnej.

\subsection{Geneza przestrzeni centralnej w Lyonie}

Studia w zakresie rozwoju przestrzennego i funkcjonalnego Lyonu prowadziło wielu badaczy, m.in. A. Audin (1959), B. Mabrouk i B. Jouve (1999), D. Bertin (2012), J. Bonnet (1982), M. Bonneville (1997), P. Cayez (1980), M. Garden (1975), S. Hochart (2013), M. Laferrère (1960), A. Kleinclausz (1978), R. Payre (2013), D. Questney (2007), R. Racine (2013) i J. Rossiaud (2013). Podobnie jak w przypadku Manchesteru, w ujęciu morfologicznym można wyróżnić pewien cykl rozwojowy przestrzeni centralnej, który został przedstawiony poniżej.

Lyon z Manchesterem łączy rzymska geneza. Zanim Rzymianie osiedlili się w Lugdunum w 43 r. p.n.e., podstawą rozwoju miasta był obszar położony pomiędzy Rodanem i Saoną (Coudroy de Lille 2003). Lugdunum zostało założone na wzgórzu Fourvière, około 100 m powyżej prawego (zachodniego) brzegu Saony, który został zagospodarowany jako port rzeczny. Rzymianie zajęli także obszar międzyrzecza Rodanu i Saony, gdzie znajdowała się dzielnica handlowa o nazwie Condate, czyli widły. Osada składała się także z jeszcze jednej jednostki przestrzennej (być może osobnego miasta) o nazwie Canabae i położonego na lewym 
(północnym) brzegu Saony na wzgórzu La Croix-Rousse (rys. 6.1). Po podboju Galii przez Rzymian Lyon stał się stolicą wszystkich posiadłości znajdujących się na północny-zachód od Alp. Wyposażenie przestrzeni centralnej świadczyło o wysokim znaczeniu miasta w sieci osadniczej Imperium Rzymskiego. W różnych jednostkach przestrzennych osady znajdowały się liczne instytucje publiczne, takie jak: teatr, odeon, cyrk. Ponadto, na wzgórzu Fourvière znajdowała się świątynia Sybilii, a w Canabae - amfiteatr. Część Lugdunum położona na wzgórzu Fourvière, nabrzeża Saony i Canabae miały nieregularny układ przestrzenny, co było zdeterminowane warunkami topograficznymi. Najwyżej położone osiedle było otoczone murem obronnym. Szachownicowy układ ulic zastosowany był natomiast w Condate, w którym mieściły się koszary. Jednostki przestrzenne na lewym i prawym brzegu Saony połączone były dwoma mostami. W Fourvière znajdowało się stare i nowe forum.



Rys. 6.1. Schemat przedstawiający obszar zajmowany

przez Lugdunum w II w. n.e.

Źródło: badania własne autora

Szczyt rozkwitu Lugdunum przypada na II w. n.e. W III w. n.e. liczne najazdy barbarzyńców spowodowały upadek miasta. Zniszczenie akweduktów było prawdopodobną przyczyną opuszczenia osady na wzgórzu. W IV w. n.e. istniało już tylko dolne miasto, które zachowało swój pierwotny układ urbanistyczny. W kolejnych stuleciach Lyon stał się głównym ośrodkiem rozwoju kultu chrześcijańskiego w cesarstwie rzymskim po zachodniej stronie Alp (Straszewicz 1987). 
Podobnie jak w przypadku Manchesteru, geneza przestrzeni centralnej Lyonu $\mathrm{W}$ niewielkim stopniu wykazuje związek $\mathrm{z}$ antycznym rozwojem miasta. W procesie kształtowania współczesnej przestrzeni centralnej miasta można wyróżnić cztery etapy:

Etap I - okres rozwoju miasta średniowiecznego od V do końca XIII w.

Etap II - okres rozwoju miasta handlowo-rękodzielniczego od XIII w. do lat 20. XIX w.

Etap III - okres rozwoju miasta wielkoprzemysłowego od lat 20. XIX w. do $1969 \mathrm{r}$.

Etap IV - okres metropolizacji miasta (rozwoju Wielkiego Lyonu) od 1969 r.

Średniowieczny Lyon rozwinął się u podnóża Fourvière na prawym brzegu Saony w oparciu o kościoły chrześcijańskie St. Irenée, St. Just, St. Etienne, Ste Marie oraz St. Paul, wokół których narasta zabudowa. Wraz z rozwojem społecznym, ekonomicznym i politycznym mniejsze świątynie zastępowane były bardziej okazałymi budowlami. W drugiej połowie XIII w. w Lyonie dwukrotnie zwoływano sobory ekumeniczne, co wskazuje na bardzo wysoką rangę miasta w ówczesnym świecie chrześcijańskim. W tzw. Starym Lyonie (Vieux Lyon), który dziś zajmuje powierzchnię bliską 49 ha, wyróżnia się trzy jednostki morfologiczne. Ich rdzeniem był kościół St. Paul na północy, St. Jean w środkowej części oraz St. Georges - w części południowej (rys. 6.2). Vieux Lyon charakteryzuje się nieregularnym układem, wąskimi ulicami oraz gęstą zabudową. Do XIX w. obszar ten zamieszkiwała arystokracja ziemska i miejska.

Katedra St. Jean została wybudowana w latach 1180-1480 w stylu romańskim i gotyckim. Dzielnica, która rozwinęła się wokół świątyni była w średniowieczu politycznym i religijnym centrum miasta, co odzwierciedlał duży plac o powierzchni około 0,2 ha zlokalizowany przed katedrą. Wraz z rue de Gadagne i rue de St. Jean, które łączyły kościoły St. Paul, St. Jean i St. Georges tworzył on przestrzeń centralną Starego Lyonu. W późniejszym okresie wzdłuż wymienionych ulic powstały mniejsze place, takie jak: Place du Change, Place du Petit Collège oraz Place de la Baleine. W okresie średniowiecznym wszystkie jednostki przestrzenne Starego Lyonu były podporządkowane funkcjom sakralnym, a świątynie jako najważniejsze instytucje w mieście wyznaczały przestrzeń centralną miasta (rys. 6.2).

W okresie od XIV do XVII w. Lyon zyskał funkcję handlową dzięki położeniu blisko granicy włoskiej oraz Avignionu. Okres ten wiąże się z intensywnym napływem do miasta kupców włoskich i niemieckich. Wraz z rozwojem miasta analizowane jednostki przestrzenne Starego Lyonu zyskiwały nowe przeznaczenie. W XVII w. w St. Paul powstała m.in. giełda Temple du Change, a wraz z rozwojem kolei w XIX w. wybudowano dworzec kolejowy Gare de LyonSt. Paul. Oba obiekty pełniły istotną rolę w tej części miasta, stąd w ich pobliżu powstały nowe place miejskie, które rozszerzały wcześniej istniejącą przestrzeń centralną. W rejonie St. Georges w XVI w. osiedlili się tkacze jedwabiu, którzy następnie w XIX w. przenieśli się do La Croix-Rousse. 
W okresie późnego średniowiecza, w XIII w., nastąpiła ekspansja Lyonu na obszar międzyrzecza (nazywanego Presqu'île) Rodanu i Saony, z którym wiązał się drugi i trzeci etap kształtowania przestrzeni centralnej miasta. Pierwotnie znaczną część półwyspu zajmowało opactwo Ainay z romańskim kościołem

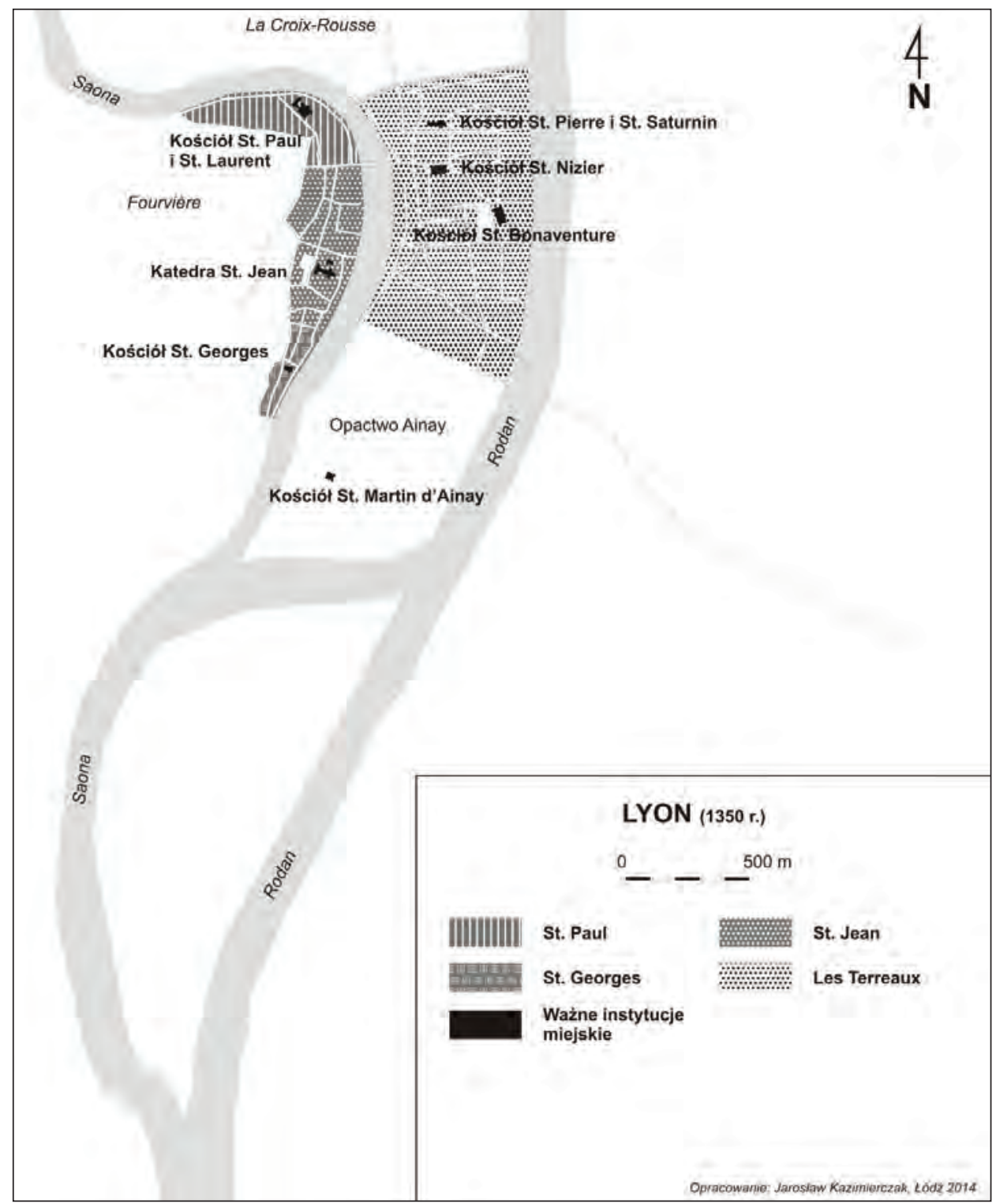

Rys. 6.2. Jednostki morfogenetyczne w przestrzeni centralnej Lyonu w $1350 \mathrm{r}$.

Źródło: badania własne autora, opracowanie na podkładzie Plan topographique de Lyon en 1350 - Vermorel - XIXe siècle 
Saint-Martin d'Ainay (rys. 6.2 i rys. 6.3). W następstwie rewolucji 1789 r. opactwo Ainay zostało zsekularyzowane. Świątynia została zachowana do dziś. W połowie XVIII w. większość z 364 ha Lyonu zajmowały tereny kościelne (około 75\%) oraz ogrody, co powodowało stłoczenie mieszkańców miasta na pozostałych

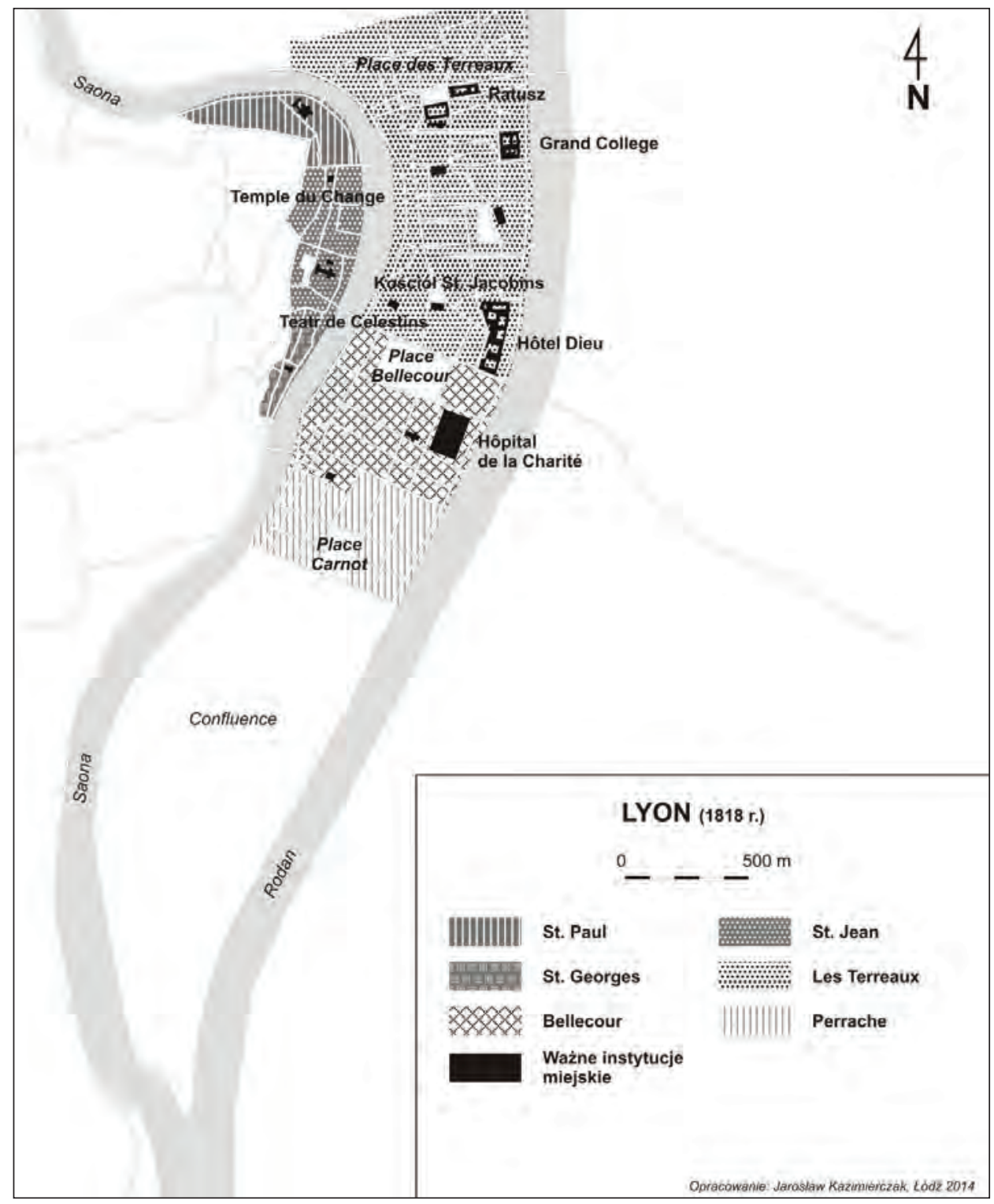

Rys. 6.3. Jednostki morfogenetyczne w przestrzeni centralnej Lyonu w $1818 \mathrm{r}$.

Źródło: badania własne autora, opracowanie na podkładzie

Plan de Lyon en $1818-$ L. B. Coillet 
90 ha (Straszewicz 1987), w rejonie Les Terreaux, Bellecour i Vieux Lyon. Obszar Presqu'île na początku XIX w. zajmował obszar około 370 ha i rozciągał się na długości około 4,5 km od wzgórza Croix-Rousse na północy po dzielnicę Perrache na południu, utworzoną w pierwszych dwóch dekadach XIX w. w celu powiększenia obszaru miasta wraz ze wzrastającą liczbą ludności.

W analizowanym okresie obszar międzyrzecza został bardzo gęsto zabudowany. Składał się on z kilku mniejszych jednostek morfogenetycznych, w których wraz z rozwojem miasta powstawały nowe przestrzenie publiczne, głównie w sąsiedztwie ważnych instytucji publicznych. Najstarszą jednostką przestrzenną na Presqu'île jest Les Terreaux. Jego głównym placem jest Place des Terreaux, przy którym w XVII w. wzniesiono ratusz miejski (l'Hôtel de ville de Lyon). Do XVII w. teren ten zajęty był przez północną część obwarowań miejskich, które rozciągały się pomiędzy Saoną i Rodanem. W sąsiedztwie ratusza wybudowano klasztor St. Pierre. Stanowi on do dziś południową pierzeję Place des Terreaux. W 1803 r. w obiekcie tym utworzono Muzeum Sztuk Pięknych (Musée des Beaux-Arts de Lyon), które jest jedną z najważniejszych instytucji kulturalnych we współczesnym Lyonie.

Na południe od Les Terreaux wytyczona została w XVII w. nowa jednostka przestrzenna - Bellecour, która zajęła częściowo obszar opactwa Ainay. Jej centralnym elementem morfologicznym jest plac Bellecour wytyczony na planie zbliżonym do prostokąta (rys. 6.3). Zajmuje on powierzchnię 6,2 ha i jest to do dziś największy plac miejski w Lyonie. Od początku swojego istnienia stanowi najbardziej reprezentacyjną przestrzeń publiczną miasta. Ze względu na zajmowaną powierzchnię oraz swoje centralne położenie w układzie komunikacyjnym obszaru Presqu'île zyskał on szczególnie wysoką rangę. Stąd wychodzą ulice prowadzące na północ do ratusza, opery i giełdy oraz na zachód w stronę katedry St. Jean w Starym Lyonie. W pierwszej połowie XX w., na wschód od Bellecour i na zachód od Rodanu powstał plac Antoine Poncet. Zajął on miejsce dawnego szpitala (hôpital de la Charité) wybudowanego w 1622 r. i zburzonego w 1934 r. Był to drugi co do wielkości szpital w Lyonie po Hôtel Dieu, położonym kilkaset metrów na północ od niego w południowej części Les Terreaux (rys. 6.3). Świadectwem pierwotnego sposobu użytkowania tego miejsca jest zachowana do dziś dzwonnica szpitalna. Na południe od Placu Poncet w latach 30. XX w. wybudowano główny urząd pocztowy w Lyonie.

W drugim etapie kształtowania przestrzeni centralnej Lyonu wytyczono jeszcze jedną jednostkę morfologiczną położoną na południe od Bellecour. Nowa przestrzeń miejska - Confluence, która została zajęta w północnej części przez dzielnicę mieszkalną Perrache, powstała dopiero w latach 70. XVIII w. w wyniku uregulowania brzegów Rodanu i Saony (por. rys. 6.2 i 6.3). Powstanie nowego, niezabudowanego terenu $\mathrm{w}$ atrakcyjnym położeniu pomiędzy dwoma rzekami było wyzwaniem dla kolejnych urbanistów. Na początku XIX w. podjęto decyzję o zagospodarowaniu tego obszaru na nową dzielnicę mieszkalną ze względu 
na konieczność pozyskiwania nowych terenów miejskich dla wzrastającej liczby ludności Lyonu. Dzielnica wzięła swoją nazwę od Antoine'a Michela Perrache'a, który w 1772 r. przedstawił projekt zagospodarowania południowej części Presqu'île wykorzystujący pewne elementy wcześniej istniejącej koncepcji autorstwa Jean-Antoine'a Moranda. Oprócz budowy dzielnicy mieszkalnej wiązał się on z budową drogi na południe, uregulowaniem biegu Rodanu oraz powstaniem portu rzecznego. Ze względu na brak środków finansowych projekt ten nie został zrealizowany, za wyjątkiem obiektów mieszkalnych na północy. Zagospodarowanie terenów położonych na południe od dzielnicy Perrache nastąpiło dopiero $\mathrm{w}$ okresie industrializacji Lyonu, z którym wiąże się trzeci etap kształtowania przestrzeni centralnej miasta.

Pomiędzy XIV i początkiem XIX w. nastąpiła sukcesja nowych terenów miejskich na Presqu'île, na których rozwinęła się przestrzeń centralna Lyonu. Dominującą rolę pełniły w niej nadal świątynie, lecz program instytucjonalny został rozszerzony o nowe instytucje publiczne - ratusz, szpitale, giełdę oraz instytucje kultury. W analizowanym okresie nastąpiła marginalizacja terenów miejskich położonych na prawym brzegu Saony w Starym Lyonie.

Rozwój przestrzeni centralnej w Lyonie od XIX w. do połowy XX w. związany był z rosnącą pozycją miasta jako ośrodka przemysłowego, komunikacyjnego, handlowego, kulturalnego i akademickiego. Lyon charakteryzował się w tym okresie znaczną ekspansją terytorialną, głównie na lewym brzegu Rodanu. Proces przekształceń przestrzenno-funkcjonalnych objął także wewnętrzną część historycznego obszaru położonego w międzyrzeczu Saony i Rodanu. Ze względu na złe warunki sanitarne, wynikające z nieregularnego układu wąskich ulic ukształtowanych jeszcze w średniowieczu, w latach 50. i 60. XIX w. przebudowany został obszar Les Terreaux. Z inicjatywy prefekta Claude-Mariusa Vaïsse'a w rejonie tym oraz częściowo w Bellecour powstały długie, proste i szerokie bulwary o południkowym przebiegu oraz nowe ulice łączące wschodnią i zachodnią część półwyspu (por. rys. 3.3 i rys. 3.4). Na nabrzeżu Saony i Rodanu zbudowano bulwary spacerowe, m.in. Jeana Jauresa, Marcheala de Saxe'a oraz Gambetta. W roku 1855 została otwarta giełda lyońska w Palais de la Bourse. Na północ od niej wybudowano nowy plac miejski. Oprócz giełdy w Presqu’île powstał nowy rynek (Halle des Cordeliers, współcześnie znajduje się w tym miejscu parking wielopoziomowy), le Grand Bazar (zniszczony w drugiej połowie XX w. i ponownie oddany w nowej formie architektonicznej w 2007 r.), Galeria Laffayette oraz siedziba Banque de France przy rue de la Republique, wzdłuż której znajdowała się liczna grupa instytucji finansowych (rys. 6.4). W rejonie Les Cordeliers w południowej części Les Terreaux rozwinęły się prestiżowe ulice handlowe: rue Tupin, rue Ferrandière, rue Grenette, rue Édouard-Herriot, rue Mercière oraz Place des Jacobins. Na wschód od ratusza w 1831 r. oddano do użytku operę. Pomiędzy nią a ratuszem utworzono niewielki plac (współcześnie Place de la Comédie). Ostateczna forma organizacji przestrzennej północnej 
części międzyrzecza została ukształtowana w latach 90. XX w. wraz z modernizacją gmachu opery oraz budową nowego placu miejskiego na północ od niego i który dziś nosi nazwę Place Louis Pradel (rys. 6.4). Dzięki nowym inwestycjom w drugiej połowie XIX w. obszar Les Terreaux i Bellecour zachował dominującą pozycję $\mathrm{w}$ hierarchii terenów miejskich mimo ekspansji przestrzennej miasta na lewym brzegu Rodanu oraz rozwoju kolei i dworców kolejowych jako nowych instytucji centralnych poza historycznym śródmieściem.

W połowie XIX w. nastąpił rozwój Lyonu na lewym brzegu Rodanu. Był to teren płaski i podmokły, lecz po ogroblowaniu i zdrenowaniu nadawał się bardzo dobrze pod lokalizację wkraczającego do miasta przemysłu, na co miały wpływ niskie ceny ziemi. Kiedy w wieku XIX Lyon przekształcił się w wielki ośrodek przemysłowy, posiadał ukształtowane tradycje przemysłowe, bowiem już w 1536 r. miasto uzyskało przywilej królewski uprawniający do wyrobu tkanin jedwabnych (Leferrère 1960, Straszewicz 1987). W okresie intensywnej industrializacji miasta jedwabnictwo lyońskie osiągnęło szczytowy okres rozwoju. Warsztaty produkcyjne rozmieszczone były w różnych częściach miasta, także w Starym Lyonie (głównie w St. Geogres), w Presqu'île i przede wszystkim w La Croix-Rousse, które w XIX w. znajdowało się jeszcze poza granicami miasta. Struktura przemysłu włókienniczego była rozproszona w przestrzeni miejskiej w postaci domów-warsztatów tzw. canuts, czyli tkaczy jedwabiu. System produkcji, zarządzania i dystrybucji jedwabiu przyjął formę organizacji o nazwie La Grande Fabrique. Funkcjonowała ona od XVI do XIX w. Tworzyli ją ściśle ze sobą powiązani dostawcy, wykonawcy, projektanci, tkacze i kupcy (Pellatier 2012). Istota funkcjonowania La Grande Fabrique wyjaśnia rozproszoną strukturę przestrzenną przemysłu włókienniczego w Lyonie i jej wpływ na przekształcenia przestrzeni centralnej miasta do XX w.

W okresie industrializacji Lyonu w XIX i XX w. oprócz przemysłu włókienniczego i masowej produkcji odzieży rozwinął się także przemysł chemiczny, farmaceutyczny i metalowo-mechaniczny. Zakłady produkujące maszyny na potrzeby miejscowego przemysłu włókienniczego, transportu rzecznego, kolei, zakłady zbrojeniowe, maszyn budowlanych i drogowych i produkcji samochodów zlokalizowane były głównie na obrzeżach ówczesnego miasta oraz w gminach ościennych. W granicach Lyonu przemysł rozwijał się w dzielnicach peryferyjnych, takich jak Vaise na północy, Brotteaux na wschodzie oraz Gerland i Perrache (Confluence) na południu (rys. 6.4). W rezultacie proces uprzemysłowienia miasta nie doprowadził do zaburzenia historycznie ukształtowanej przestrzeni centralnej Lyonu.

Rozmieszczenie terenów przemysłowych w Lyonie wykazywało silny związek z przebiegiem linii kolejowych (rys. 6.4). Transport szynowy odegrał istotną rolę w procesie rozwoju miasta wielkoprzemysłowego, gdyż dostarczano nim węgiel kamienny z St. Etienne stanowiący surowiec energetyczny dla lyońskich fabryk. Infrastruktura kolejowa stała się wyraźnym elementem w krajobrazie nowych jednostek morfogenetycznych Lyonu, które rozwinęły się w XIX w. Wraz 


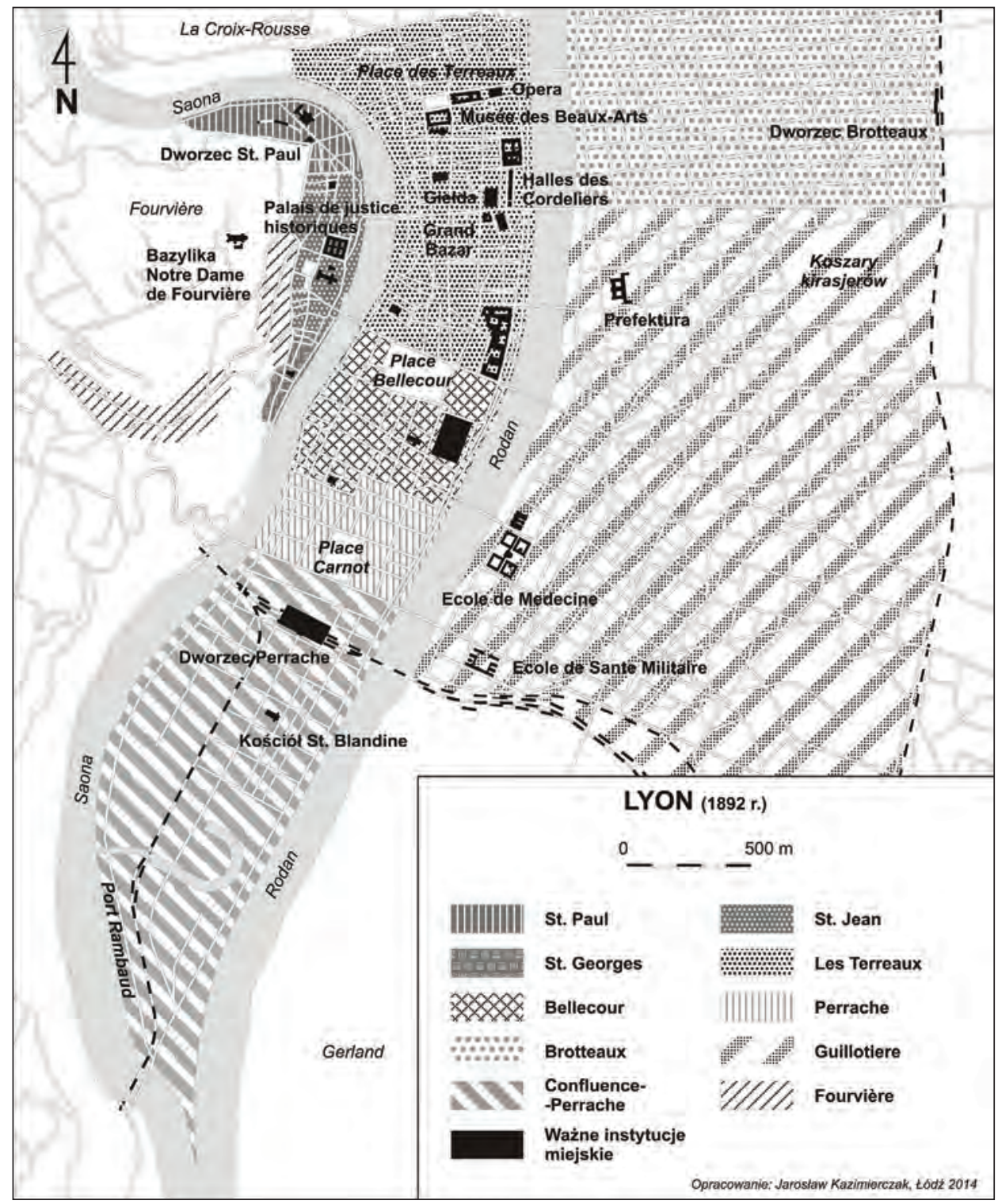

Rys. 6.4. Jednostki morfogenetyczne w przestrzeni centralnej Lyonu w 1892 r.

Źródło: badania własne autora, opracowanie na podkładzie

Plan de Lyon pittoresque et monumental en 1892 - P. J. Reithofer

z rozwojem kolei we Francji oraz potrzebą przeprowadzenia przez centralną część Lyonu trasy wiodącej z Paryża nad Morze Śródziemne powrócono do koncepcji inżyniera Antoine’a Michela Perrache'a. Wzbogacono ją jednak o budowę dworca kolejowego (Gare de Lyon-Perrache), który oddano do użytku 1857 r. (rys. 6.4). 
Ze względu na bardzo trudne uwarunkowania topograficzne linię kolejową z północnego-zachodu na wschód przeprowadzono tunelem pod wzgórzem Fourvière, a następnie wiaduktem nad Saoną. Zróżnicowanie poziomów wysokości między tunelem a międzyrzeczem zdeterminowało budowę dworca kolejowego na wiaduktach o wysokości 6 metrów. Dworzec z wiaduktami zajął całą szerokość półwyspu, „odcinając” jego południową część od pozostałej części miasta. Nowy dworzec stanowił barierę morfologiczną oraz w wyobrażeniach przestrzennych mieszkańców miasta (Coudroy de Lille 2003).

Od północnej strony Gare de Lyon-Perrache, czyli od placu Carnot, rozwijała się infrastruktura pełniąca nowe funkcje usługowe: hotele, restauracje, browar, jarmarki. Wykształcona elegancka i estetyczna przestrzeń publiczna cieszyła się bardzo dużą popularnością (Coudroy de Lille 2003) i rozszerzała w ten sposób istniejącą wcześniej przestrzeń centralną Lyonu na dzielnicę Perrache. Tereny położone na południe od dworca, połączone $\mathrm{z}$ resztą miasta ciemnymi tunelami pod wiaduktem kolejowym, zostały natomiast zdegradowane do roli przemysłowego przedmieścia. W Confluence znajdował się kościół St. Blandine oraz secesyjna dzielnica mieszkalna o tej samej nazwie. Zajmowała ona obszar 40 ha. W północnej części półwyspu wybudowano więzienie St. Joseph w 1830 r. oraz St. Paul w 1860 r. Choć obszar Confluence nie był zajęty przez przemysł włókienniczy, miał kluczowy wpływ na jego rozwój, bowiem od lat 30. XIX w. stworzono tu multimodalny obszar komunikacyjny, na który składały się port rzeczny Rambaud, linia kolejowa i stacja rozładunkowa dla węgla importowanego znad Loary. Stanowił on główny surowiec energetyczny dla lyońskich fabryk. Budowa linii kolejowej pozwoliła obniżyć koszt importu węgla z odleglejszych regionów Francji, co przełożyło się na obniżenie kosztów produkcji i zwiększyło konkurencyjność lyońskich wyrobów przemysłu włókienniczego. Oprócz składów węgla teren Confluence zajmowały zakłady produkujące lokomotywy, zakłady tytoniowe i energetyczne oraz zakłady chemiczne, w których Lyon wyspecjalizował się do końca XIX w. Do 1928 r. funkcjonowała na tym obszarze rzeźnia miejska. W okresie międzywojennym we wschodniej części Confluence wybudowano pierwsze w Lyonie osiedle typu HMB, czyli mieszkania komunalne i spółdzielcze, oraz osiedle przeznaczone dla kolejarzy. Po II wojnie światowej powstały nowe obiekty składowe, hurtowy targ artykułów spożywczych oraz sortownia listów. Przez cały okres przemysłowego użytkowania znaczną część obszaru Confluence zajmowały tereny komunikacyjne, głównie kolejowe.

Teren ten był praktycznie pozbawiony przestrzeni publicznej i mimo że $\mathrm{w}$ wyniku rozwoju przestrzennego Lyonu znalazł się on niemal w centrum aglomeracji, sposób jego użytkowania oraz morfologia wskazywały na jego peryferyjny charakter.

Rozwój przemysłu w Lyonie spowodował powstanie regionu produkcyjnego, podobnie jak miało to miejsce w przypadku Manchesteru. W odróżnieniu od miasta angielskiego przestrzeń centralna Lyonu rozwijała się w sposób zrównoważony, 
bowiem przemysł tylko w nieznacznym stopniu zajął tereny wewnątrzmiejskie i nie spowodował degradacji przestrzeni śródmiejskiej. Wyposażenie instytucjonalne przestrzeni centralnej było zróżnicowane, a obecność części z tych instytucji związanych z rozwijającym się przemysłem, m.in. giełd i licznych banków, była sankcjonowana także innymi funkcjami pełnionymi przez miasto. Ekspansja terytorialna miasta w Guilloriere, Brotteaux i Confluence-Perrache spowodowała rozszerzenie istniejącej przestrzeni centralnej zajmującej obszar Presqu'île o nowe elementy morfologiczno-instytucjonalne, mające charakter enklawowy. W nowy układ wpisywało się także rozmieszczenie dworców kolejowych jako obiektów generujących ruch użytkowników przestrzeni miejskiej, które zostały zlokalizowane na peryferiach historycznego śródmieścia. Kluczowym czynnikiem, mającym wpływ na charakter przestrzeni centralnej złożonej z jednostek morfogenetycznych pomiędzy Rodanem i Saoną oraz częściowo na prawym brzegu Saony - w Starym Lyonie - oraz na lewym brzegu Rodanu była topografia.

\subsection{Przestrzeń centralna w Lyonie przed rewitalizacją}

W drugiej połowie XX w. Lyon sukcesywnie tracił rolę ośrodka przemysłowego' ${ }^{1}$. Według danych ze spisu powszechnego w 1975 r. podstawą utrzymania większości mieszkańców był sektor trzeci, a zatrudnienie w przemyśle dotyczyło około $30 \%$ zawodowo czynnych mieszkańców. Dla porównania w roku 1861 udział ten wynosił 55\%, w tym w przemyśle włókienniczym - 26\% (Straszewicz 1987). W ostatnim etapie kształtowania przestrzeni centralnej miasta, od roku 1969, Lyon rozwijał się jako silny ośrodek administracyjny, finansowy, targowy i akademicki. Lyon zyskał także pozycję jednego z najważniejszych francuskich miast kongresowych, dlatego znajduje się tam potężna baza hotelowa i gastronomiczna (Tölle 2009). W 1969 r. rząd francuski utworzył Wspólnotę Miejską Lyonu, czyli Wielki Lyon². Składa się on z Lyonu i Villeurbanne oraz 53 mniejszych jednostek administracyjnych. Jego administracja mieści się w Lyonie jako największym ośrodku wchodzącym w skład Wspólnoty. Rozwijająca się funkcja administracyjna miasta (stolicy regionu Rodan-Alpy i departamentu Rodan) oraz zwiększające się znaczenie usług finansowych w gospodarce stały się motywem do budowy dzielnicy dyspozycyjno-handlowej na wzór amerykańskiego CBD (Central Business District, który we Francji nosi nazwę centre d'affaires) - Part-Dieu. Jest to największa poza Paryżem dzielnica biznesowa we Francji.

${ }^{1}$ W skali regionalnej i krajowej Lyon nadal jest ważnym ośrodkiem przemysłowym (m.in. chemicznym, petrochemicznym, farmaceutycznym itd.), bowiem nastąpiła bliska relokacja przemysłu do sąsiednich gmin, jak np. Venissieux i Saint-Fons, wchodzących w skład Wielkiego Lyonu.

${ }^{2}$ W języku francuskim Wielki Lyon to Grand Lyon. Inną francuską nazwą tej jednostki administracyjnej jest Communauté urbaine de Lyon, w skrócie COURLY. 
Trzeci etap kształtowania przestrzeni centralnej w Lyonie można podzielić na dwie fazy. Pierwsza z nich obejmuje budowę dzielnicy finansowej Part-Dieu na lewym brzegu Rodanu, którą rozpoczęto w latach 70. XX w. Projekt ten nie został jak dotąd zakończony. W rezultacie realizacji tej inwestycji przestrzeń centralna miasta została rozszerzona o nowy element, stanowiący enklawę we wschodniej części

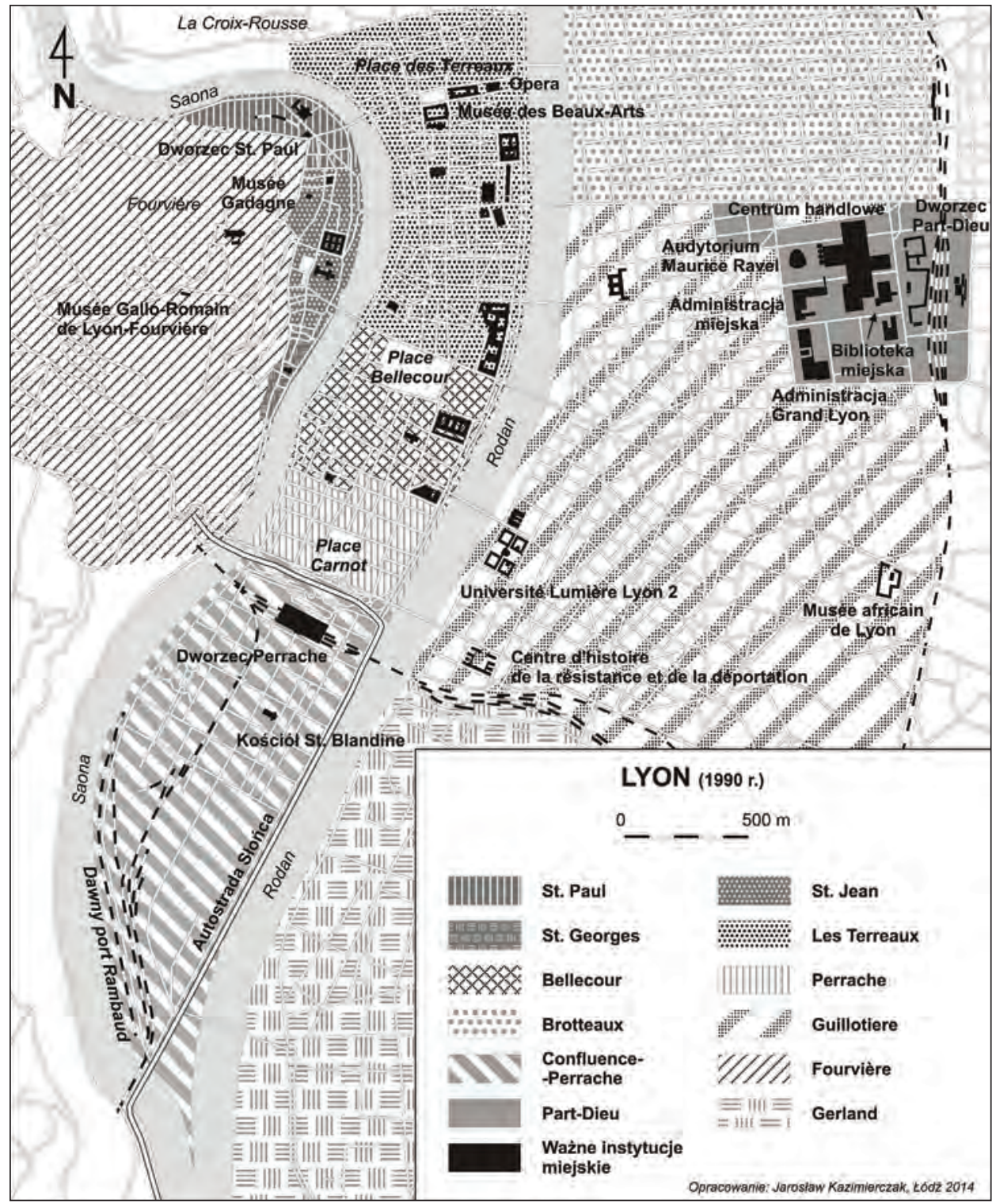

Rys. 6.5. Jednostki morfogenetyczne w przestrzeni centralnej Lyonu w $1990 \mathrm{r}$.

Źródło: badania własne autora 
Lyonu. Sposób jej wyposażenia instytucjonalnego i układ morfologiczny znacznie różnią się od historycznej przestrzeni centralnej w Presqu'île i Vieux Lyon. Druga faza rozpoczęła się w latach 90 . XX w. i jest związana z procesem uzupełniania istniejącej wówczas przestrzeni centralnej i kształtowaniem nowych jednostek morfologiczno-funkcjonalnych Cité Internationale oraz Confluence. Obie fazy wiążą się z procesami transformacyjnymi jednostek przestrzennych, które utraciły swoje pierwotne przeznaczenie funkcjonalne, oraz z rozwojem instytucji metropolitalnych na terenach peryferyjnych w stosunku do historycznej przestrzeni centralnej.

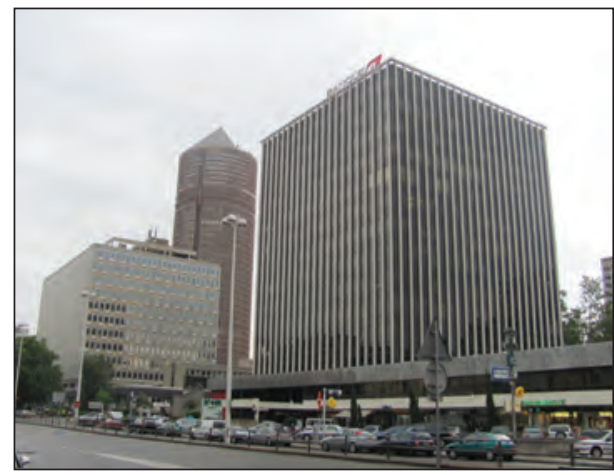

Fot. 6.1. Zabudowa wysokościowa w Part-Dieu Źródło: fotografia autora

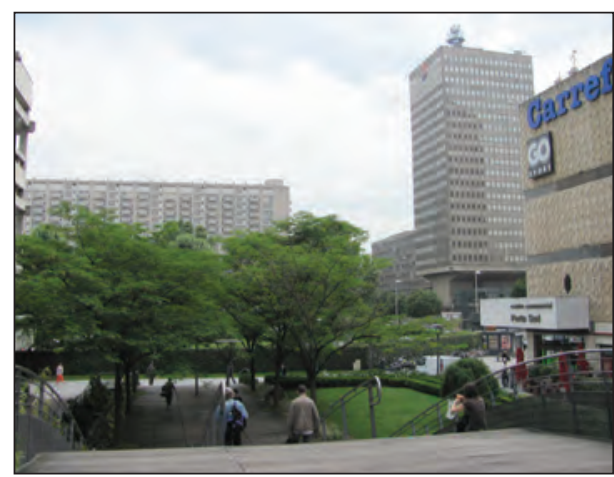

Fot. 6.3. Centrum handlowe w Part-Dieu i wieżowiec EDF

Źródło: fotografia autora

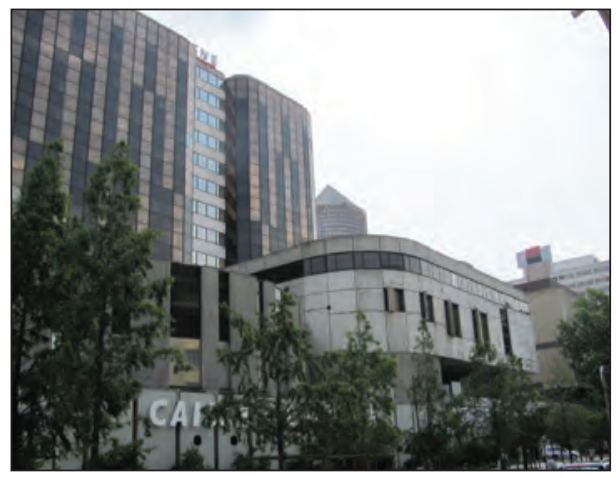

Fot. 6.2. Zróżnicowana fizjonomia zabudowy w Part-Dieu

Źródło: fotografia autora

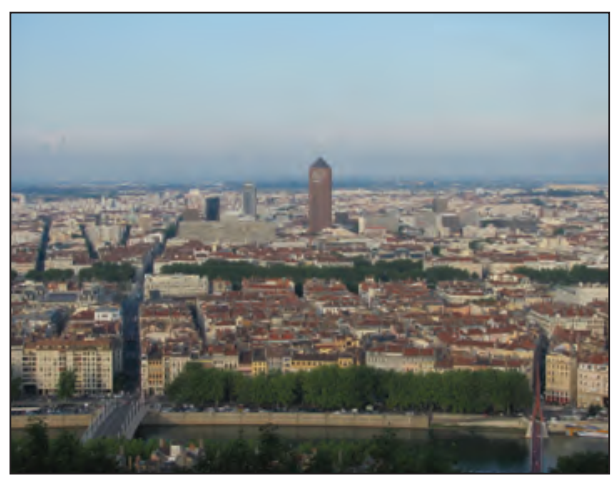

Fot. 6.4. Widok na Tour Part-Dieu ze wzgórza Fourvière

Źródło: fotografia autora

Centrum Part-Dieu zostało zbudowane w Guillotiere na terenie dawnych koszarów kirasjerów, które utworzono w 1844 r. na obszarze 22 ha (rys. 6.4 i 6.5). Od zakończenia II wojny światowej były one nieużytkowane, stąd w latach 60 . $\mathrm{XX}$ w. miasto nabyło te tereny od wojska z przeznaczeniem na dzielnicę usługową. Jej budowa wiązała się z transformacją morfologiczną terenów po dawnych 
koszarach oraz sąsiadujących z nimi od południa terenów, na których mieściła się wcześniej zabudowa typowa dla przedmieść. Centrum Part-Dieu zajęło obszar o powierzchni 55,2 ha (rys. 6.5). Charakteryzuje się zabudową wysokościową, uzupełnioną niższymi obiektami o współczesnej formie architektonicznej (fot. 6.1-6.3). Jego dominantą jest wieżowiec tour Part-Dieu o wysokości $165 \mathrm{~m}$ (fot. 6.4). Został on oddany do użytku w 1977 r. W dzielnicy zlokalizowane są także pozostałe najwyższe budynki w mieście: Tour Oxygène o wysokości $116 \mathrm{~m}$ (ukończony w 2010 r.), Tour Swiss Life o wysokości 82 m (1990 r.) oraz Tour EDF o wysokości 80 m (1975 r.). Planowane są także kolejne budynki wysokościowe, z których cztery przekraczać będą $200 \mathrm{~m}$.

W dzielnicy finansowej Lyonu znajdują się liczne urzędy administracji publicznej zajmującej około $90000 \mathrm{~m}^{2}$, znaczna powierzchnia biurowa (około $150000 \mathrm{~m}^{2}$ ) oraz siedziby koncernów medialnych, banków i towarzystw ubezpieczeniowych. W Part-Dieu zostały także zaplanowane funkcje społeczne i kulturalne. Znajduje się

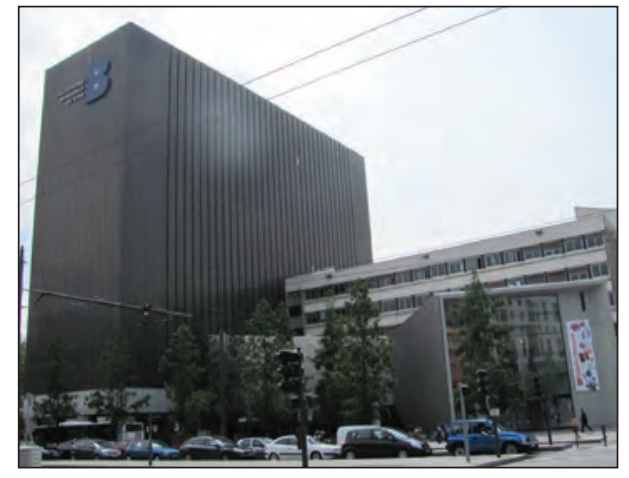

Fot. 6.5. Biblioteka miejska w dzielnicy Part-Dieu Źródło: fotografia autora

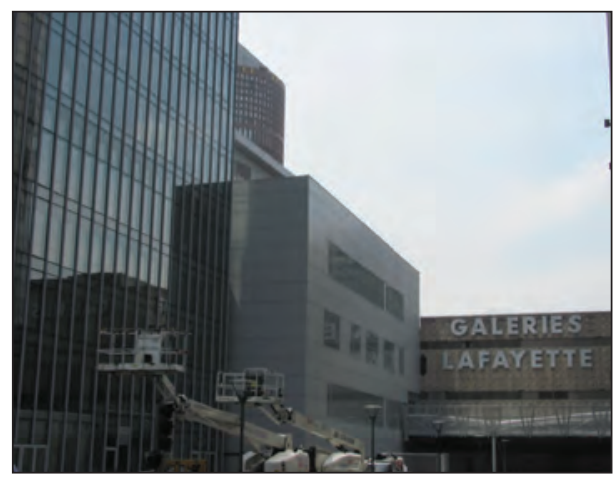

Fot. 6.7. Budynek Galerii Lafayette w centrum handlowym w Part-Dieu Źródło: fotografia autora

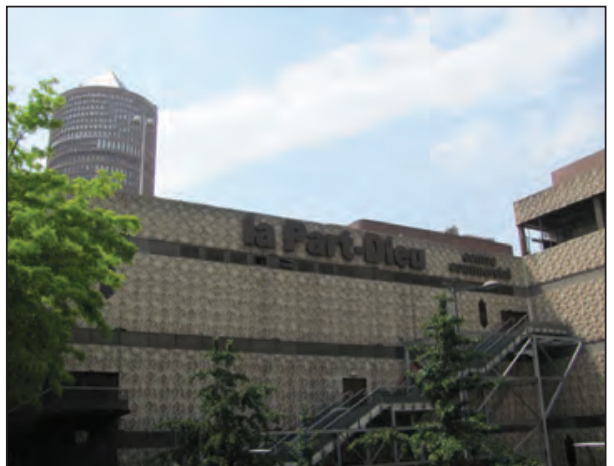

Fot. 6.6. Centrum handlowe w dzielnicy Part-Dieu Źródło: fotografia autora

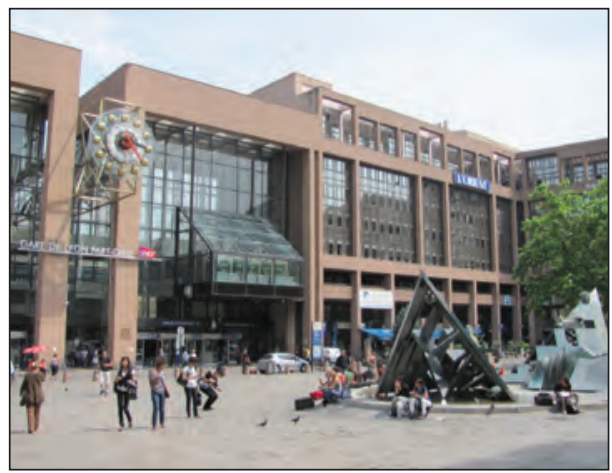

Fot. 6.8. Plac Ch. Beraudier przed wejściem do dworca SNCF Part-Dieu Źródło: fotografia autora 
tu m.in. główna biblioteka miejska (rys. 6.5 i fot. 6.5), sala kongresowa oraz teatr. Znaczną część obszaru zajmuje centrum handlowe (rys. 6.5 i fot. 6.6) o powierzchni $120000 \mathrm{~m}^{2}$, w którym w połowie lat 70. XX w. swój sklep otworzył m.in. Marks $\&$ Spencer (jedyny wówczas oddział we Francji poza Paryżem). W Part-Dieu otworzono także ekskluzywną Galerię Laffayette (fot. 6.7).

Budowa Part-Dieu rozszerzyła historycznie ukształtowaną przestrzeń centralną Lyonu na wschodnią część miasta, która dotychczas pozbawiona była zwartej przestrzeni tego typu. W nowej dzielnicy finansowo-usługowej powstała znaczna powierzchnia przestrzeni publicznych w postaci pasaży, skwerów i terenów zielonych. Główny, reprezentacyjny plac nowej jednostki morfologicznej został wybudowany przed dworcem kolejowym Part-Dieu. Nowy dworzec powstał w wyniku budowy kolei szybkich prędkości TGV i zapewnił dogodną dostępność komunikacyjną do centrum o znaczeniu regionalnym (rys. 6.5 i fot. 6.8). W konsekwencji jego powstania podstawy swojej egzystencji stracił dworzec Brotteaux położony na północ od Part-Dieu (patrz rys. 6.4). Współcześnie jest on przeznaczony na działalność usługową i kulturalną, a budynek został gruntownie zmodernizowany i przystosowany do nowych funkcji w latach 2002-2006. Dzielnica finansowa Part-Dieu w latach 70. $\mathrm{XX}$ w. została lepiej połączona z innymi częściami miasta dzięki rozbudowie metra. Lyon był drugim miastem we Francji posiadającym ten typ transportu publicznego.

Pierwsza faza czwartego etapu kształtowania przestrzeni centralnej w Lyonie wiązała się z wielkimi inwestycjami mieszkaniowymi i komunikacyjnymi. Przyczyniły się one do przekształceń morfologicznych w dzielnicy śródmiejskiej. Zgodnie z modernistyczną myślą urbanistyczną, w celu usprawnienia ruchu samochodowego w centrum od lat 60 . XX w. podejmowano liczne wyburzenia historycznej zabudowy mieszkaniowej. Przekształcenia nie objęły jednak najbardziej wartościowych pod względem urbanistycznym i architektonicznym obszarów miasta w Presqu'île na północ od Placu Carnot oraz w Starym Lyonie.

Jednym z kluczowych projektów komunikacyjnych zrealizowanych w latach 70. XX w. była budowa autostrady śródmiejskiej na wzór miast amerykańskich. Przebiegała ona z północnego zachodu, tunelem pod wzgórzem Fourvière, mostem nad Saoną i dalej na południe w kierunku Marsylii i St. Etienne wzdłuż prawego brzegu Rodanu i jednocześnie wschodniego nabrzeża Confluence (rys. 6.5 i rys. 6.6). Budowa Autostrady Słońca (Autoroute du Soleil) związana była z radykalnymi przekształceniami przestrzennymi w okolicach dworca Perrache, w wyniku których wyburzona została część zabudowy śródmiejskiej. Nowa arteria komunikacyjna poprowadzona została na północ od torów kolejowych, pogłębiając izolację obszarów położonych na południe od dworca kolejowego oraz od Centrum Transferowego (Centre d'échanges), które zostało ukończone w 1976 r. Oprócz dworca TGV i autostrady, wchodził w jego skład dworzec autobusowy dla linii miejskich, krajowych i międzynarodowych oraz stacja metra, a współcześnie także przystanek komunikacji tramwajowej (rys. 6.6). Centrum Transferowe obejmuje także parkingi oraz pasaż handlowy. Ideą projektu autorstwa René Gagèsa 


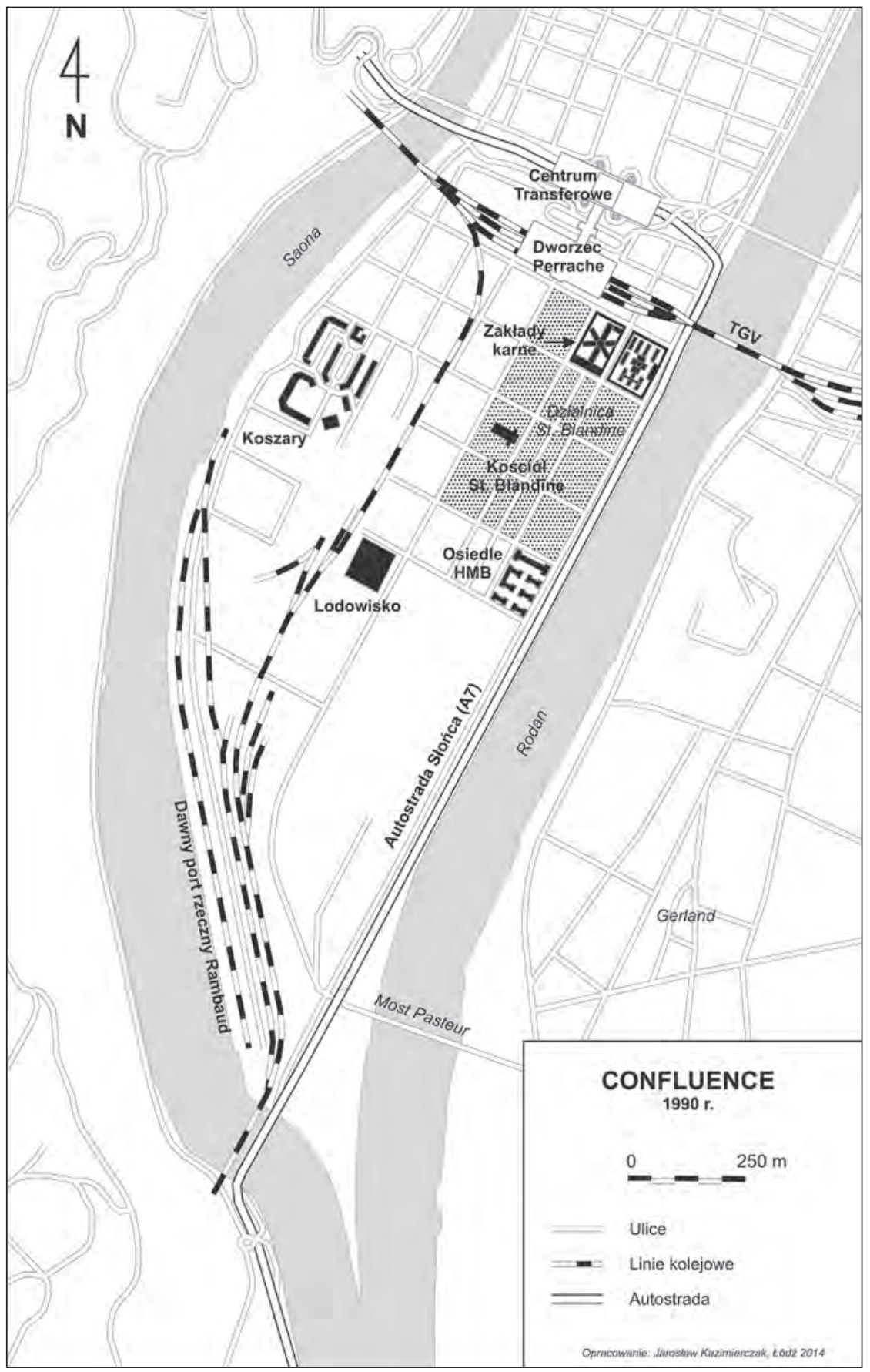

Rys. 6.6. Infrastruktura komunikacyjna w Confluence w 1990 r. Źródło: badania własne autora 
było utworzenie tzw. „generatora miasta” w miejscu, w którym łączyły się dwie autostrady - z Paryża i Marsylii. Nowa inwestycja komunikacyjna miała pobudzić miasto do rozkwitu, szczególnie południową część Presqu'île. W efekcie osiągnięto jednak przeciwne skutki.

Przed rozpoczęciem działań rewitalizacyjnych w Confluence w latach 90. XX w. przekształcenia przestrzeni centralnej Lyonu miały dwojaki charakter. Pierwotnie wynikały one ze stopniowej ekspansji terytorialnej miasta oraz sukcesji wielkomiejskiego użytkowania nowych jednostek morfogenetycznych. Proces ten dotyczył pierwszych trzech etapów kształtowania przestrzeni centralnej na obszarze Vieux Lyon i Presqu'île. W początkowej fazie ostatniego etapu kształtowania przestrzeni centralnej Lyonu proces ten przyjął formę radykalnych przekształceń morfologii i sposobu użytkowania w rejonie Part-Dieu. W rezultacie rozwoju nowych funkcji wielkomiejskich przestrzeń centralna Lyonu wykazywała coraz większy stopień złożoności. Brak wykształcenia terenów przemysłowych w obszarze śródmiejskim (m.in. w formie La Grande Fabrique) wpłynął korzystnie na spójność przestrzeni centralnej, głównie w Presqu'île. Z tej samej przyczyny proces deindustrializacji miasta, który miał miejsce w drugiej połowie XX w., nie spowodował degradacji starej przestrzeni centralnej Lyonu. Kluczowym czynnikiem wstrzymującym ekspansję przestrzeni miejskiej o charakterze centralnym na południową część obszaru międzyrzecza Saony i Rodanu było powstanie bariery komunikacyjno-infrastrukturalnej pomiędzy Perrache i Confluence.

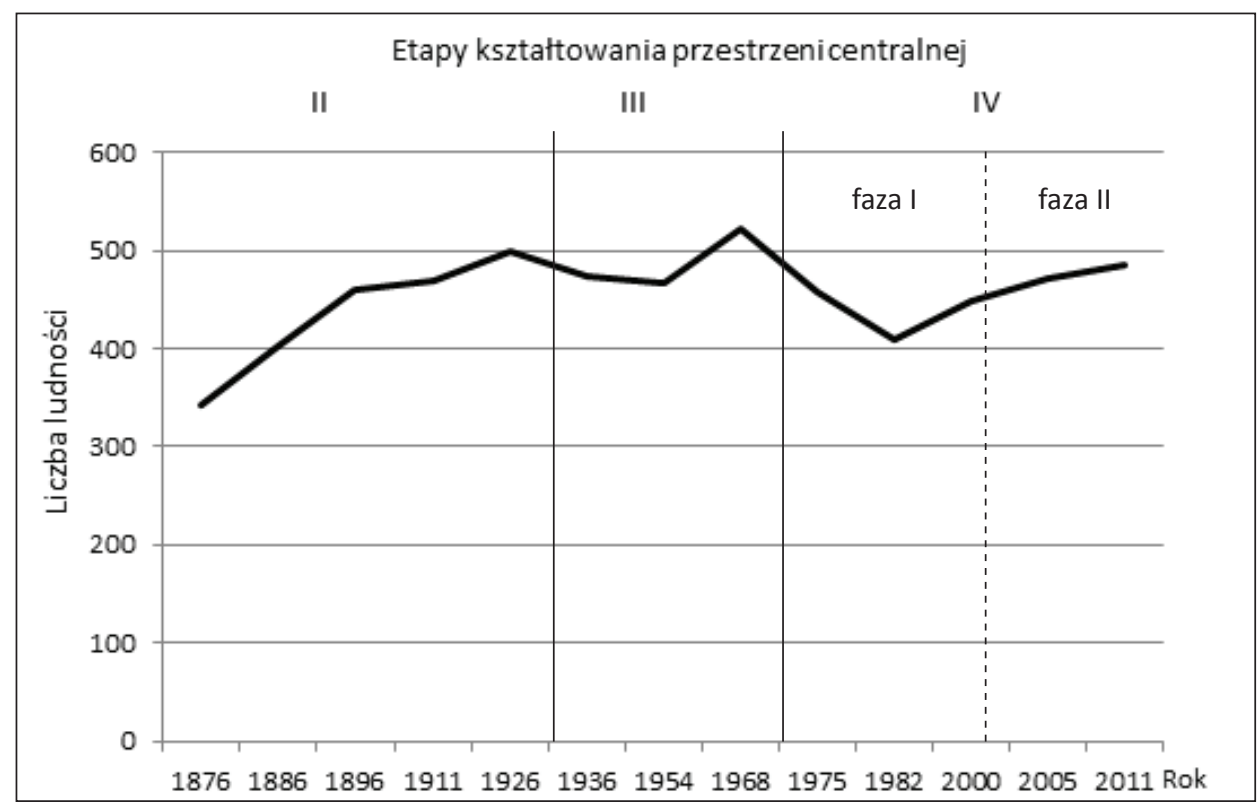

Rys. 6.7. Zmiany liczby ludności wobec etapów kształtowania przestrzeni centralnej w Lyonie w latach 1876-2011

Źródło: opracowanie autora na podstawie L. Straszewicz (1987) 
W analizowanym okresie, do połowy lat 90 . XX w., liczba mieszkańców Lyonu ulegała nieznacznym wahaniom, co potwierdza stabilność rozwoju miasta (rys. 6.7). Największy spadek liczby ludności miasta odnotowano w pierwszej fazie czwartego etapu rozwoju przestrzeni centralnej Lyonu, na co mógł mieć wpływ upadek przemysłu. Od drugiej połowy lat 70. XX w. nastąpił jednak wzrost liczby mieszkańców związany z rozpoczęciem metropolizacji przestrzeni centralnej Lyonu. Proces rozwoju wielkiego Lyonu jest aktualnie kontynuowany, m.in. w ramach projektów Cité Internationale oraz Lyon Confluence.

\subsection{Cechy współczesnej przestrzeni centralnej w Lyonie}

Druga faza czwartego etapu kształtowania przestrzeni centralnej w Lyonie rozpoczęła się przed podjęciem działań rewitalizacyjnych w Confluence i wiązała się $\mathrm{z}$ budową tzw. Miasteczka Międzynarodowego (Cité Internationale). Zostało ono utworzone w 1996 r. na północ od Part-Dieu i parku de la Tête d'Or, bezpośrednio nad brzegiem Rodanu. Zajęło ono dawne tereny targowe. Mieści się w nim Pałac Kongresowy, Muzeum Sztuki Współczesnej, hotele i biura. Program funkcjonalny uzupełniają mieszkania oraz multikino (rys. 6.8).

$\mathrm{Na}$ początku XXI w. rozpoczęto także przekształcenia w innych obszarach poprzemysłowych w tym realizację projektów rewitalizacyjnych w dzielnicy Gerland na południu śródmieścia Lyonu. Gerland charakteryzuje się zbliżonym do Confluence kontekstem urbanistycznym, gdyż także znajduje się w izolowanej terenami kolejowymi części miasta. Od południa jego rozwój ogranicza natomiast port rzeczny Édouard Herriot o powierzchni 140 ha (na Rodanie). W wyniku przekształceń przestrzenno-funkcjonalnych w Gerland powstaje dzielnica nauki oraz duży park technologiczny z pomieszczeniami dla firm i instytucji badawczych. $\mathrm{W}$ celu przyciągnięcia zagranicznych instytucji badawczych powstało $\mathrm{W}$ tym rejonie liceum międzynarodowe, w którym można uczyć się w różnych językach (m.in. po polsku). Wybudowano tu także gmach elitarnej wyższej szkoły państwowej ENTP oraz adaptowano halę dawnej rzeźni miejskiej autorstwa znanego architekta Tony Garniera na centrum artystyczno-wystawowe. Na północy, przykładem przekształceń przestrzenno-funkcjonalnych na terenach poprzemysłowych jest dzielnica Vaise, która stała się obszarem koncentracji firm technologii informacyjno-komunikacyjnych i kilku inwestycji publicznych.

Budowa terenów komunikacyjnych w XIX i XX w., z czym wiązały się liczne wyburzenia historycznej tkanki miejskiej, powstanie bariery przestrzenno-funkcjonalnej pomiędzy dzielnicą St. Blandine i Perrache, niemal całkowity brak infrastruktury komunikacyjnej łączącej Confluence $\mathrm{z}$ innymi częściami miasta ${ }^{3}$

${ }^{3}$ Współcześnie istnieje jeden most (Pont Pasteur) przez Rodan łączący Confluence z dzielnicą Gerland. 




Rys. 6.8. Organizacja przestrzenno-funkcjonalna Cité Internationale w Lyonie w 2013 r.

Źródło: badania własne autora

doprowadziły do skrajnej marginalizacji tego rejonu miasta. Jedyna przeprawa mostowa na południe od dworca kolejowego, czyli Pont Pasteur, znajduje się w południowej części półwyspu, łącząc Confluence z innym przemysłowym rejonem miasta w Gerland (rys. 6.6). Stopniowa utrata funkcji przemysłowej i portowej w XX w. przyczyniła się do dalszej degradacji pozycji Confluence w hierarchii terenów miejskich Lyonu. Władze miejskie, zdając sobie sprawę z problemów przestrzennych, społecznych i kulturowych, jakie zostały wygenerowane w rejonie Confluence w wyniku niewłaściwej polityki przestrzennej oraz potencjału, jaki jednak posiada ten rejon w kontekście rozwoju metropolitalnych ambicji Lyonu, podjęły w latach 90. XX w. działania zmierzające do nowego zagospodarowania obszaru. Celem projektu Lyon Confluence było rozszerzenie funkcji handlowych i kulturalnych obszaru Presqu'île. W nowej dzielnicy przewidziano także tereny rekreacyjno-wypoczynkowe. Docelowo w Confluence mają powstać mieszkania 
dla 25000 mieszkańców i 16000 nowych miejsc pracy. W ramach nowego zagospodarowania terenów poprzemysłowych do roku 2020 ma powstać łącznie $1200000 \mathrm{~m}^{2}$ powierzchni użytkowej. Istotnym elementem rewitalizacji terenów poprzemysłowych w Confluence jest idea ,powrotu” tego obszaru do rzek, poprzez zagospodarowanie na cele rekreacyjne terenów nabrzeżnych Saony i ewentualnie Rodanu po wyprowadzeniu autostrady poza miasto.

Największą przeszkodą w procesie integracji nowej dzielnicy z Bellecour stanowi Centrum Transferowe (Centre d'échanges de Perrache) wraz z autostradą, położone na północ od dworca kolejowego Perrache (rys. 6.6). Początkowo projekt rewitalizacji Confluence zakładał likwidację węzła komunikacyjnego dzięki budowie zachodniej obwodnicy Lyonu ${ }^{4}$. W rezultacie pojawiła się potrzeba opracowania nowej koncepcji zagospodarowania Confluence. Realizację procesu rewitalizacji podzielono w nim na dwa etapy ${ }^{5}-$ ZAC 1 i ZAC 2 (rys. 6.9). W porównaniu z założeniami pierwszego planu przekształceń przestrzenno-funkcjonalnych, w nowym projekcie problem węzła komunikacyjnego nie stanowił punktu wyjścia dla działań naprawczych. Aktualnie wydaje się, że wyprowadzenie całego ruchu tranzytowego prowadzonego przez śródmiejską autostradę jest niemożliwe w najbliższym czasie. Uniemożliwi to pełną realizację drugiego etapu przekształceń (ZAC 2), związanego z zagospodarowaniem wschodniej część rejonu na funkcję biurową i mieszkaniową, i którego istotnym zadaniem miała być budowa bulwaru spacerowego na miejscu dawnej autostrady (rys. 6.9).

Przeprowadzone studia empiryczne związane z identyfikacją stopnia intensywności przekształceń morfologii i sposobu użytkowania Confluence objęły obszar działań rewitalizacyjnych podjętych w ramach pierwszego etapu przemian przestrzenno-funkcjonalnych (ZAC 1) oraz teren, na którym budowane jest Muzeum Confluence. Zakres czasowy analizy obejmuje okres od roku 1998, w którym rozpoczęto działania naprawcze, do roku 2013. Obszar poddany analizie w mezoskali zajmuje powierzchnię 56 ha, natomiast cały projekt Lyon Confluence obejmuje obszar 151 ha, w tym ZAC $2-35$ ha. W przypadku obszaru ZAC 2, który będzie poddany rewitalizacji w drugim etapie realizacji projektu, ocenie podlegały jedynie plany przyszłego programu zagospodarowania. W $2010 \mathrm{r}$. opracowano także nową koncepcję zagospodarowania terenów położonych pomiędzy obszarami ZAC 1 i ZAC 2 oraz dworcem Perrache, obejmującą także dzielnicę mieszkaniową St. Blandine (rys. 6.9).

${ }^{4}$ Szacuje się, że po zakończeniu budowy obwodnicy jej przepustowość okaże się niewystarczająca, by odciążyć śródmiejską autostradę. Uniemożliwi to de facto likwidację tej bariery przestrzenno-funkcjonalnej w Confluence, a to w konsekwencji przyczyni się do niepełnej realizacji koncepcji przebudowy nabrzeża Rodanu w tej części półwyspu.

${ }^{5}$ ZAC, czyli zone d'aménagement concerté. Jak podaje A. Tölle (2009) jest to instrument urbanistyki operacyjnej powołany do życia w latach 60. XX w., przede wszystkim w celu realizacji wielkich projektów urbanistycznych. W Lyonie, podobnie jak w innych francuskich aglomeracjach, są one głównym sposobem przystosowania większych obszarów śródmiejskich do nowoczesnych funkcji mieszkaniowych, handlowych oraz usługowych (Mabrouk i Jouve 1999, Bourdin i Petitet 2002). 


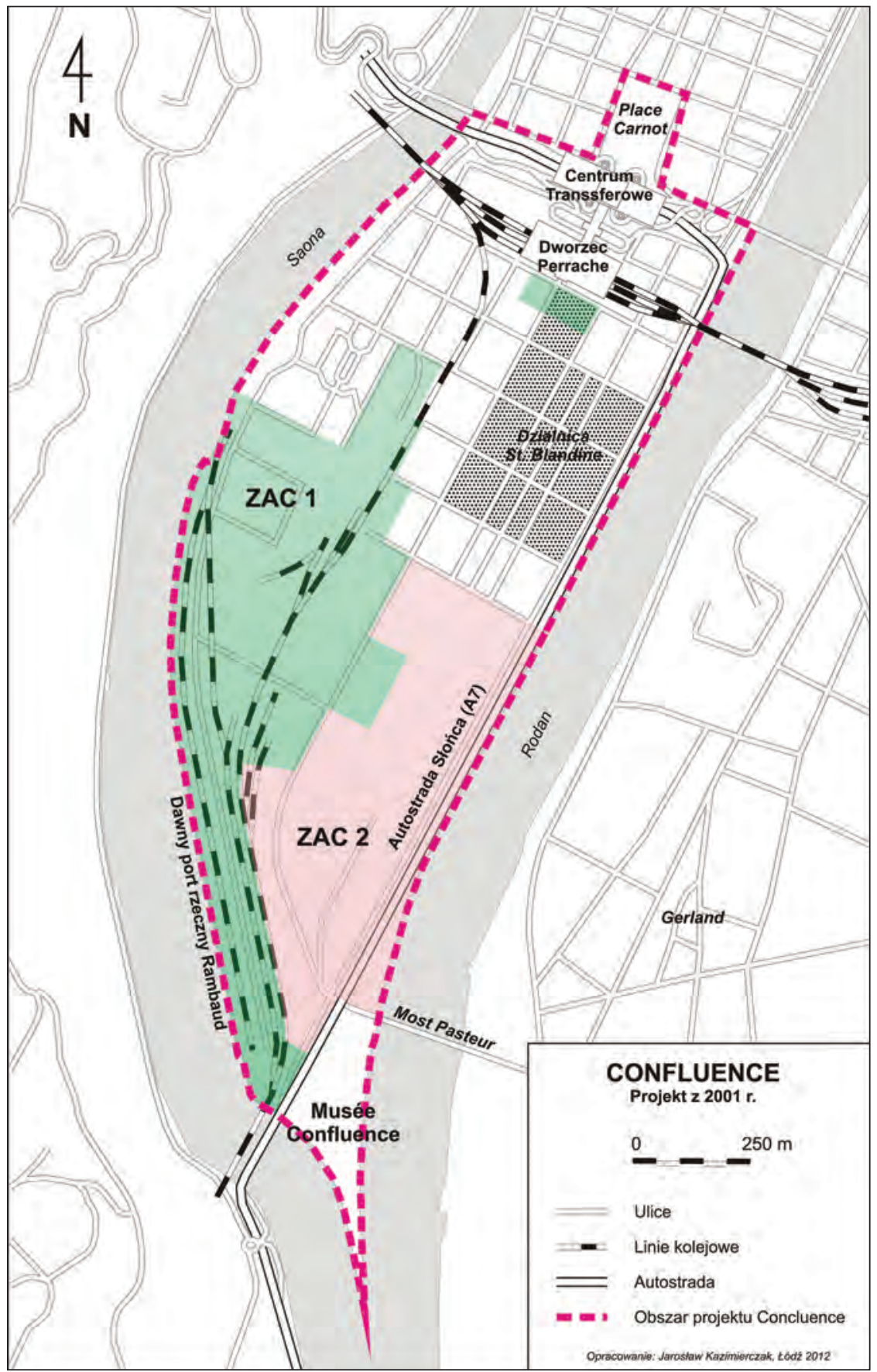

Rys. 6.9. Zakres przestrzenny projektu Confluence i etapów jego realizacji Źródło: badania własne autora 
Realizacja projektu Lyon Confluence rozpoczęła się w 1998 r. Jego celem było wygenerowanie nowej przestrzeni centralnej w mieście. Jak twierdzi L. Coudroy de Lille (2003) projekt zakładał wzmocnienie ambicji metropolitalnych Lyonu nie poprzez skupienie działalności gospodarczej, jaką pełnią współcześnie inne dzielnice Lyonu - Part-Dieu i Cité Internationale, lecz poprzez skalę i nowoczesną formę architektoniczną budynków. W wyniku rewitalizacji zdegradowanych terenów miejskich, położonych na południe od dworca kolejowego Perrache, miała zostać rozszerzona przestrzeń centralna rejonu Bellecour.

Istotnym elementem projektu było stworzenie atrakcyjnej i wielofunkcyjnej przestrzeni publicznej w oparciu o unikatowe walory przyrodnicze, które zadecydowały o współczesnej topografii Confluence. Kluczowym zadaniem w wymiarze przestrzenno-funkcjonalnym procesu rewitalizacji analizowanego obszaru było silne powiązanie nowego programu zagospodarowania z Saoną. W tym celu na dawnych terenach portowo-magazynowych, na których zlokalizowany był port rzeczny Rambaud, wybudowano nowy akwen z mariną, który jest położony w centralnej części przekształcanego obszaru (rys. 6.10). Koncepcja budowy tego akwenu nawiązuje do genezy i wcześniejszych planów zagospodarowania obszaru Confluence, które kładły nacisk na silne powiązanie tego rejonu $\mathrm{z}$ wodą. Nowy sztuczny zbiornik wodny wraz z terenami pieszymi wokół niego został nazwany Place nautique (fot. 6.9). Całe nabrzeże Saony zostało zamienione na przestrzeń spacerową. Jego północna część, pomiędzy wiaduktami kolejowymi a granicą obszaru ZAC 1, jest nadal przekształcana. Część południowa, objęta projektem ZAC 1, została wyposażona w liczne tereny zieleni miejskiej, z roślinnością wodną, która występowała w obszarze Confluence przed rozwojem szeroko rozumianych funkcji przemysłowo-składowo-komunikacyjnych w XIX w. Na południe od mariny zielone tereny piesze zostały wydłużone o bulwar nadrzeczny Quai Rambaud - którego nazwa nawiązuje do portowej przeszłości tego obszaru (rys. 6.10). $\mathrm{O}$ industrialnym dziedzictwie omawianego fragmentu nabrzeża Saony informują także zachowane elementy bocznicy kolejowej i budynki poprzemysłowe.

Działania związane $\mathrm{z}$ budową akwenu, parków, ogrodów i waterfrontów wiązały się z ideą kształtowania ekologicznej dzielnicy mieszkaniowo-usługowej. Nowy program zagospodarowania Confluence wymusił daleko idące przekształcenia, które objęły istotne zmniejszenie długości linii kolejowych - głównie w południowej części półwyspu, gdzie znajdowały się znaczne tereny zajęte przez bocznice kolejowe prowadzące do portu rzecznego (tab. 6.1 i rys. 6.11). Współcześnie istnieje jedynie linia kolejowa przebiegająca przez całą długość półwyspu, z jego południowej nasady do dworca Perrache. Jest ona wykorzystywana zarówno przez pociągi pasażerskie, jak i towarowe. Mniej radykalne zmiany były związane z modyfikacją układu ulic, który dostosowano do wtórnego sposobu użytkowania przestrzeni miejskiej. Długość dróg kołowych uległa zmniejszeniu, głównie ze względu na rozwój na ich miejscu stref ruchu pieszego (tab. 6.1). Jednocześnie nastąpiła budowa nowych odcinków ulic w celu zwiększenia dostępności 


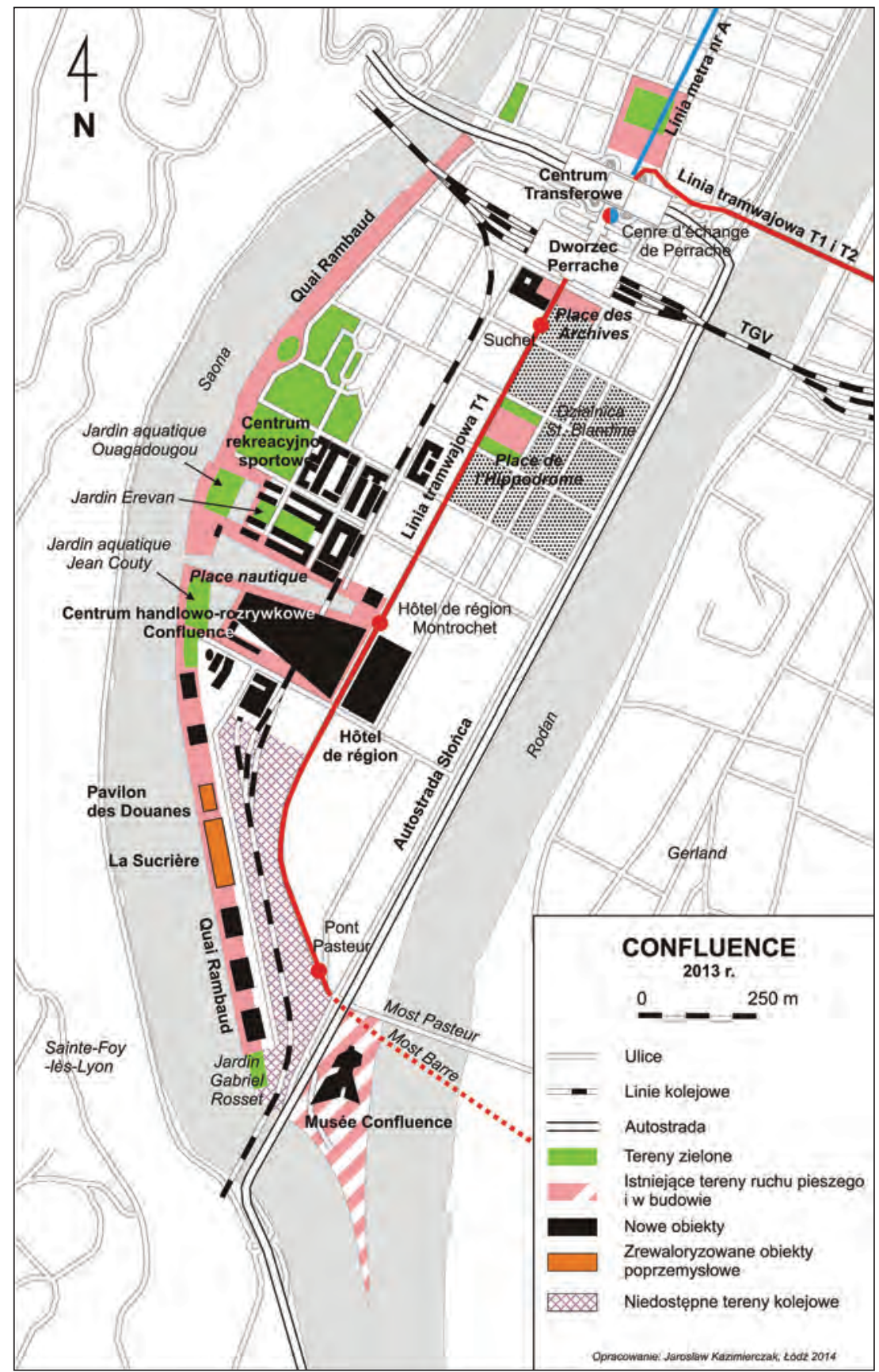

Rys. 6.10. Nowy program przestrzeni publicznych i komunikacji miejskiej w Confluence (stan na 2013 r.)

Źródło: badania własne autora 
komunikacyjnej do nowo zabudowanych terenów mieszkaniowo-usługowych. W tym kontekście analizowany obszar (ZAC 1) można podzielić na trzy fragmenty, które ulegały odmiennym transformacjom. W części północnej nastąpił proces uzupełniania liniowych elementów morfologicznych. Nowa regularna siatka ulic, zbliżona do szachownicowej, nawiązuje do układu komunikacyjnego w dzielnicy St. Blandine oraz terenów położonych na południowy zachód od dworca Perrache. Przekształcenia $\mathrm{w}$ środkowej części terenu ZAC 1 wiązały się przede wszystkim z eliminacją dróg dojazdowych do dawnych terenów magazynowo-składowych i portu rzecznego Rambaud. W ich miejsce powstał akwen $z$ mariną, strefy ruchu pieszego oraz nowe tereny zielone. W południowej części obszaru także nastąpiła eliminacja części dróg, głównie w porcie Rambaud (rys. 6.11).

Tabela 6.1. Przekształcenia morfologii i sposobu użytkowania terenów poprzemysłowych

(ZAC 1 i w rejonie budowanego Muzeum Confluence) w Lyonie w latach 1998-2013

\begin{tabular}{|l|c|c|r|}
\hline \multicolumn{1}{|c|}{ Cecha } & \multirow{2}{*}{$\begin{array}{c}\text { Jednostka } \\
\text { miary }\end{array}$} & \multicolumn{2}{c|}{ Stan w roku } \\
\cline { 3 - 4 } & $\mathrm{m}$ & 16908 & 2013 \\
\hline Długość dróg kołowych $^{a}$ & $\mathrm{~m}$ & 20279 & 87569 \\
\hline Długość naziemnych linii kolejowych $^{a}$ & $\mathrm{~m}$ & 0 & 1685 \\
\hline Długość nowych linii tramwajowych $^{a}$ & ha & 14,0 & 12,9 \\
\hline Powierzchnia zabudowy & ha & 0 & 11,5 \\
\hline $\begin{array}{l}\text { Powierzchnia nowo wzniesionej zabudowy (wybudowanej } \\
\text { w ramach rewitalizacji) }\end{array}$ & ha & 113,0 & 5,1 \\
\hline $\begin{array}{l}\text { Powierzchnia zachowanej dawnej zabudowy użytkowanej } \\
\text { przez przemysł }\end{array}$ & ha & 0 & 5,1 \\
\hline $\begin{array}{l}\text { Powierzchnia dawnej zabudowy użytkowanej przez przemysł, } \\
\text { która została poddana renowacji i adaptacji na nowe funkcje } \\
\text { w ramach procesu rewitalizacji }\end{array}$ & & 1012 & 3514 \\
\hline $\begin{array}{l}\text { Długość ogólnodostępnej linii dostępu do wody (rzeki, kanały, } \\
\text { zbiorniki wodne) - od rozpoczęcia procesu rewitalizacjia }\end{array}$ & $\mathrm{m}$ & 1,5 & 8,3 \\
\hline Powierzchnia zabudowy zajmowanej przez funkcję usługową & ha & 1,2 & 4,6 \\
\hline $\begin{array}{l}\text { Powierzchnia zabudowy zajmowanej przez funkcję mieszka- } \\
\text { niową }\end{array}$ & ha & 11,3 & 0 \\
\hline $\begin{array}{l}\text { Powierzchnia zabudowy zajmowanej przez nieużytki poprze- } \\
\text { mysłowe lub funkcję produkcyjną }\end{array}$ & ha & & \\
\hline
\end{tabular}

${ }^{a}$ Parametry obejmują cały obszar Confluence.

Źródło: badania własne autora.

W wyniku przeprowadzonych działań naprawczych analizowany teren zyskał charakter ogólnodostępnego (publicznego), za wyjątkiem terenów wykorzystywanych przez kolej w południowej części półwyspu (rys. 6.10). Długość ulic oraz ich układ w dzielnicy St. Blandine nie uległy modyfikacji poza terenem przylegającym od południa do dworca Perrache, przy którym powstał Plac Archiwów (Place des 


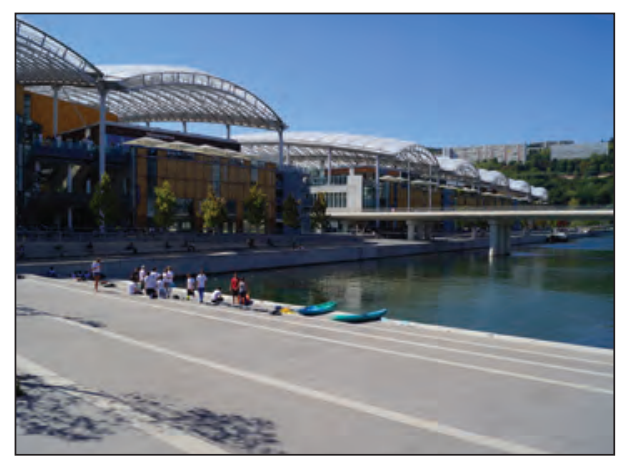

Fot. 6.9. Place nautique jako nowa przestrzeń publiczna w Confluence

Źródło: fotografia autora

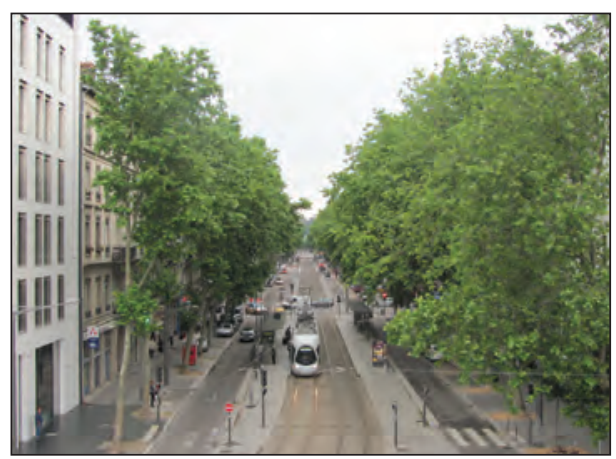

Fot. 6.10. Główna oś komunikacyjna w Confluence - Cours Charlemange

Źródło: fotografia autora

Archives). Główną osią komunikacyjną w Confluence pozostała Cours Charlemagne, która pełni tę rolę nieprzerwanie od XIX w. (rys. 6.10 i fot. 6.10).

Istotną część przekształceń przestrzenno-funkcjonalnych w Confluence, których celem była integracja tego rejonu $\mathrm{z}$ innymi fragmentami miasta, stanowiła budowa nowej linii tramwajowej (tab. $6.1 \mathrm{i}$ rys. 6.10). Została ona poprowadzona wzdłuż Cours Charlemagne i aktualnie (2013 r.) kończy się na przystanku Pont Pasteur w południowej części półwyspu. Docelowo, w 2014 r., ma ona połączyć Confluence z dzielnicą Gerland na lewym brzegu Rodanu i stacją metra Debourg (linia B). W tym celu wybudowany zostanie nowy most na Rodanie - Pont Raymond Barre, przeznaczony do komunikacji tramwajowej i ruchu pieszo-rowerowego (rys. 6.10). Interesującym, nowym elementem infrastruktury komunikacyjnej łączącej Confluence z Bellecour jest tramwaj rzeczny „Vaporetto”. Miejscem, z którego zaczyna i kończy trasę jest marina. System ekologicznej komunikacji ogólnomiejskiej w Confluence uzupełnia komunikacja rowerowa - velo'v. W celu zwiększenia dostępności pieszej do Confluence w drugiej fazie przekształceń planowane jest wybudowanie przepraw nad Rodanem łączących nową przestrzeń miejską z Gerland.

W wyniku przekształceń przestrzenno-funkcjonalnych w Confluence w latach 1998-2013 nastąpił nieznaczny spadek powierzchni zabudowanej (tab. 6.1). Wynika on z wygenerowania znacznej wielkości terenów otwartych, które zostały przeznaczone na akwen z mariną, bulwary nadrzeczne i pozostałe strefy piesze, w tym tereny rekreacyjne (Jardin Erevan i Jardin Gabriel Rosset) oraz ogrody z odtworzoną roślinnością nadrzeczną: Jardin aquatique Oaugadougaou i Jardin aquatique Jean Couty (rys. 6.10). Dodatkowo nowe budynki mieszkaniowo-usługowe zajmują znacznie mniejszą powierzchnię w porównaniu z wcześniejszym zagospodarowaniem, w którym dominowały wielkopowierzchniowe obiekty składowe i magazynowe. Wśród nowej tkanki materialnej, w której przeważają budynki o niewielkiej powierzchni, wyjątek stanowi zabudowa centralnej części przekształcanego obszaru, czyli centrum handlowo-rozrywkowe (Pôle de 
Commerces et Loisirs Confluence) oraz Hôtel de region (rys. 6.10 i 6.11). Są to współczesne dominanty architektoniczne w rejonie Confluence (kolejnym będzie Muzeum Confluence - aktualnie w budowie).

Proces rewitalizacji zdegradowanych terenów miejskich w Confluence przyczynił się do radykalnej zmiany krajobrazu tego rejonu miasta. Współcześnie dominuje w nim nowa zabudowa, która nie nawiązuje do uprzedniego, przemysłowego sposobu użytkowania Confluence. Wygenerowaniu znacznej powierzchni współczesnej zabudowy, przy niskim stopniu zachowania zabudowy postindustrialnej, sprzyjała niska wartość historyczna i estetyczna obiektów składowo-magazynowych. W rezultacie została ona niemal całkowicie wyeliminowana z nowego programu zagospodarowania analizowanego obszaru. Wyjątek stanowią dwa obiekty - Pavilon des Douanes oraz La Sucrière, który w okresie industrialnym pełnił funkcję magazynu cukru w portcie Rambaud, a w wyniku przekształceń przestrzenno-funkcjonalnych został zaadaptowany na cele kulturalne i mieści się w nim centrum wystawiennicze (rys. 6.10 i 6.11). Budynek stanowi interesujący przykład działań adaptacyjnych. Został on częściowo wzbogacony o nowe elementy architektoniczne (m.in. zewnętrzne schody i nową elewację) i jednocześnie fragmentarycznie zachowany w surowej, industrialnej formie (fot. 6.11). W ten sposób symbolizuje stan, w jakim znajdowała się ta część miasta przed rewitalizacją oraz zakres zmian, jakie w nim zaszły - zarówno w ujęciu przestrzennym, jak i instytucjonalnym. Innymi reliktami uprzedniego sposobu użytkowania nabrzeża Saony w południowej części półwyspu jest suwnica portowa oraz tory kolejowe wkomponowane w posadzkę bulwaru nadrzecznego Quai Rambaud.

W następstwie niemal całkowitej eliminacji pierwotnej zabudowy postindustrialnej nowa przestrzeń publiczna zyskała charakter typowy dla obszarów miejskich, w której wyróżnia się pierzeję, linię zabudowy, narożnik, dominantę. Nowy układ zabudowy w północnej części przekształcanych terenów ma charakter regularny, wpisany w szachownicową siatkę ulic, charakterystyczną dla sposobu rozplanowania dzielnicy St. Blandine. W części południowej zabudowane zostało jedynie nabrzeże rzeki Saony (rys. 6.11). Część wschodnia obszaru jest planowana do transformacji.

Nowe obiekty, stanowiące zdecydowaną większość współczesnej zabudowy południowej części Confluence (rys. 6.11), charakteryzują się nowoczesną i oryginalną formą. Do najciekawszych budynków pod względem architektonicznym należą m.in. Lyon Islands - Block B, Le Monolithe - Block C oraz Le Cube (fot. 6.12-6.14). Również Muzeum Confluence odznaczać się będzie unikatową bryłą. Nowa zabudowa obszaru wyraźnie kontrastuje z charakterem zagospodarowania secesyjnej dzielnicy St. Blandine oraz Cours Charlemange, która stanowiła główny element przestrzeni publicznej w tej części miasta przed rozpoczęciem działań naprawczych (fot. 6.15). W ten sposób zrealizowany został jeden z podstawowych celów projektu Confluence, czyli wykształcenie dzielnicy wyróżniającej się w krajobrazie Lyonu nowoczesną i oryginalną formą architektoniczną. 


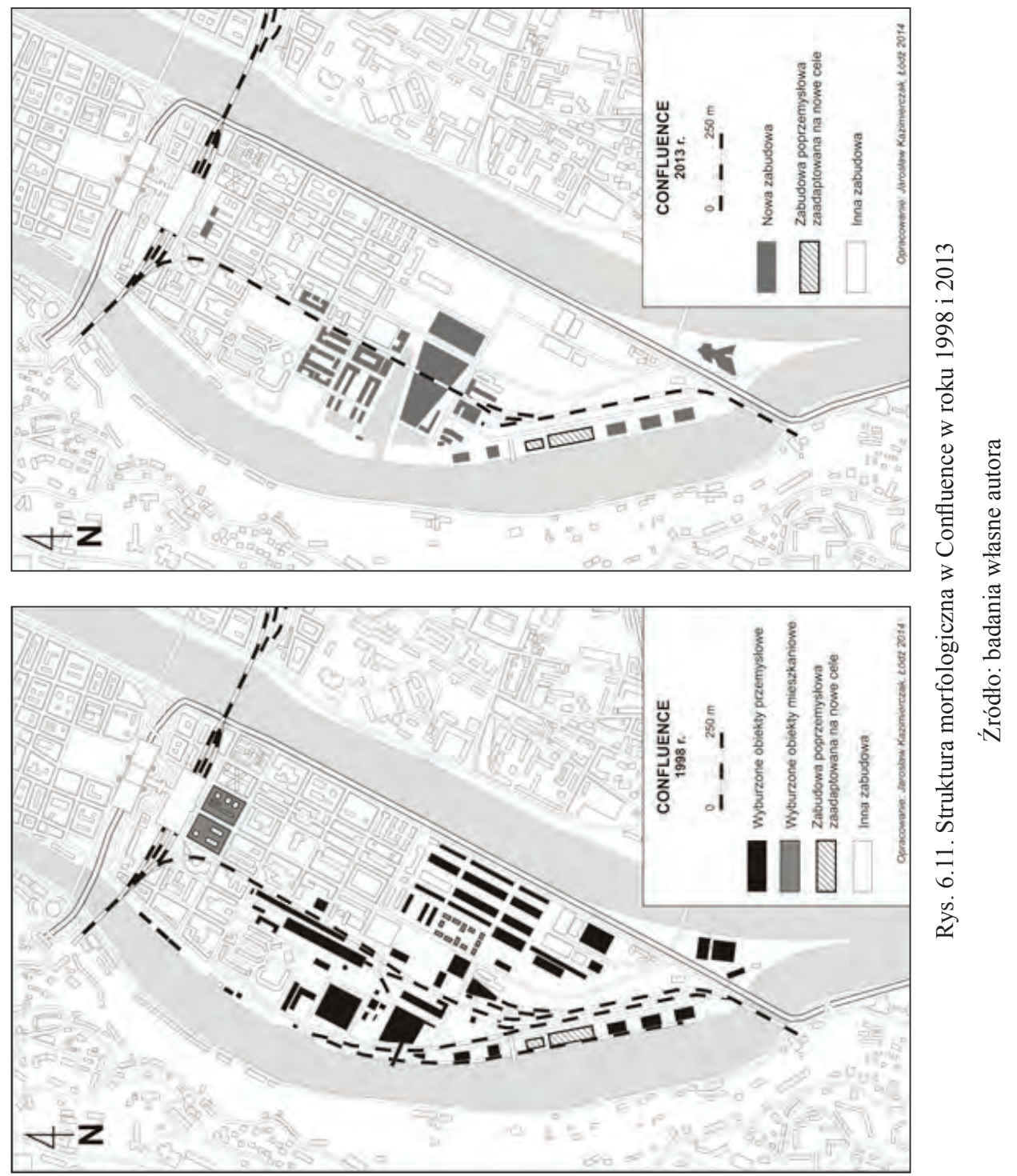




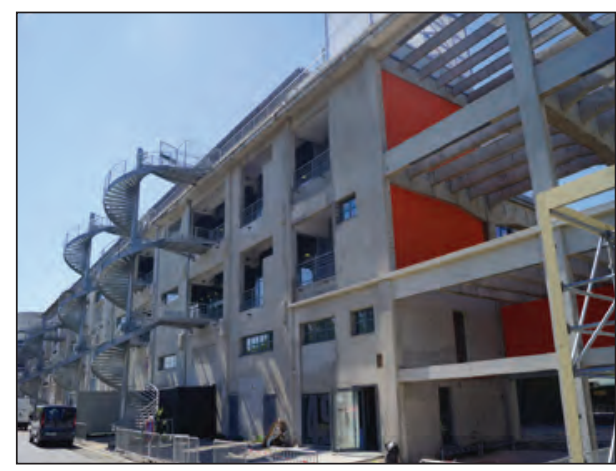

Fot. 6.11. La Sucrière jako przykład zachowanej zabudowy postindustrialnej

w Confluence (Quai Rambaud)

Źródło: fotografia autora

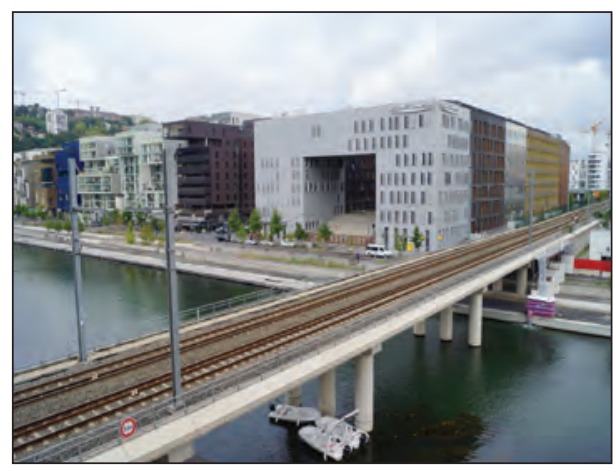

Fot. 6.13. Le Monolithe i nowa zabudowa mieszkaniowo-usługowa przy Place nautique

Źródło: fotografia autora

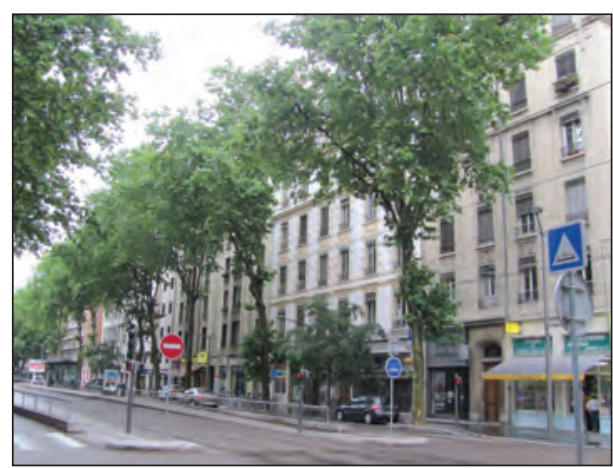

Fot. 6.15. Cours Charlemange i historyczna zabudowa w dzielnicy St. Blandine

Źródło: fotografia autora

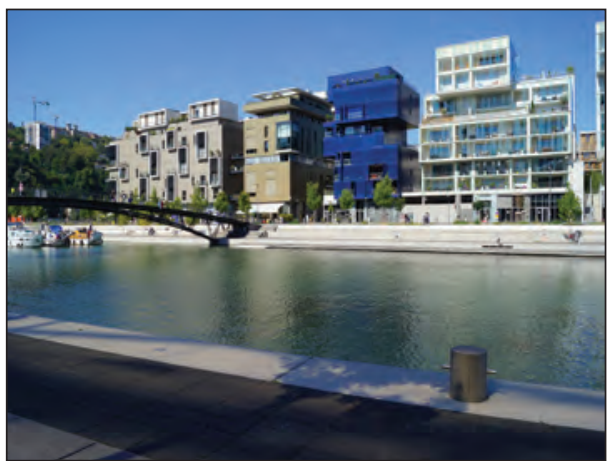

Fot. 6.12. Współczesna architektura zabudowy mieszkaniowo-usługowej przy Place nautique - budynki Lyon Islands

Źródło: fotografia autora

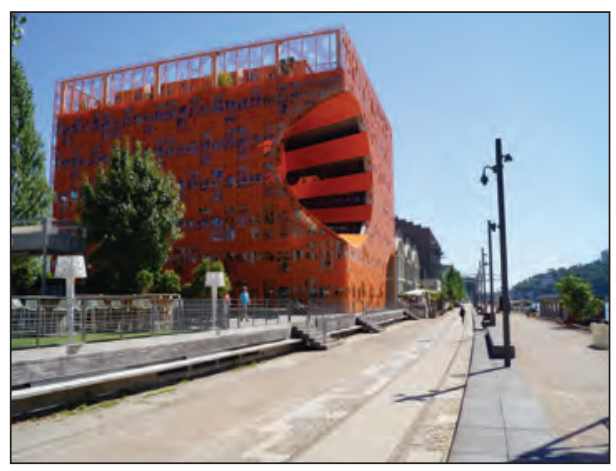

Fot. 6.14. Oryginalna forma architektoniczna Le Cube w Quai Rambaud

Źródło: fotografia autora

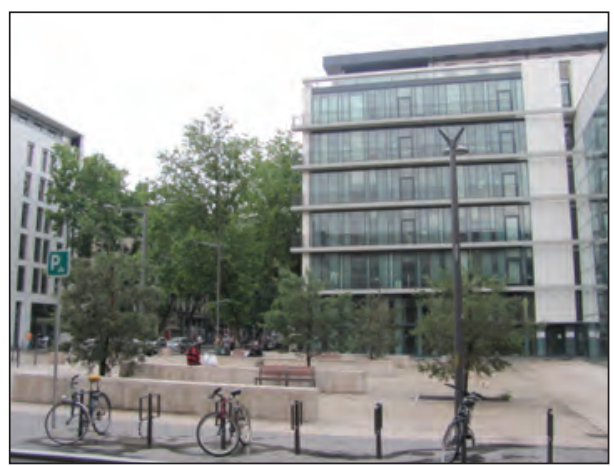

Fot. 6.16. Place des Archives i budynek Archiwów miejskich

Źródło: fotografia autora 
Ważny element procesu przekształceń przestrzeni publicznej w Confluence stanowiła budowa placu Archiwów (Place des Archives) zlokalizowanego przy południowym wejściu do dworca Perrache. W tym celu wyburzone zostały dwie kamienice na skrajnych północnych działkach przy Cours Charlemange (rys. 6.11). W ich miejsce zbudowano jeden nowy obiekt, w którym zlokalizowano miejskie archiwum (fot. 6.16). Znajduje się on w zachodniej części placu. Wschodnia część nie została zabudowana i stanowi otwartą przestrzeń z licznymi elementami zieleni i małej architektury, które umożliwiają spontaniczne przebywanie w przestrzeni publicznej. Pod placem Archiwów wybudowano parking, ułatwiający dostęp do dworca. Wschodnią pierzeję placu będzie stanowić budynek Uniwersytetu Katolickiego, na który są adaptowane dane obiekty więzienia St. Paul (rys. 6.12).

Przed rozpoczęciem procesów naprawczych na terenach zdegradowanych działalność usługowa w Confluence skoncentrowana była wzdłuż Cours Charlemange jako głównej przestrzeni publicznej tego rejonu miasta. Po zakończeniu pierwszego etapu rewitalizacji ulica ta zachowała swój charakter, jednak równocześnie nastąpił proces sukcesji funkcji wielkomiejskich na tereny dotychczas mieszkaniowe oraz przemysłowe. Zrównoważony wzrost powierzchni terenów mieszkaniowych i usługowych, wygenerowanych w ramach rewitalizacji w latach 1998-2013, świadczy o harmonijnej kompozycji programu nowego użytkowania Confluence, na który składa się wyposażenie dzielnicy w usługi podstawowe, ogólnomiejskie i metropolitalne.

W wyniku przeprowadzonej analizy stwierdzono, że proces kształtowania nowej przestrzeni centralnej w Confluence charakteryzował się wysokim $\left(\mathrm{W}_{\mathrm{P}}\right)$ stopniem intensywności przekształceń przestrzenno-funkcjonalnych i radykalnym charakterem rewitalizacji zdegradowanych terenów miejskich w wymiarze morfologicznym (tab. 6.2, por. rozdz. 2).

Studia nad programem przekształceń przestrzenno-funkcjonalnych związanych z drugim etapem procesu naprawczego Confluence (ZAC 2) pozwalają stwierdzić, że będzie on odznaczać się podobnymi parametrami w zakresie zmian morfologicznych i sposobu użytkowania. Działania w ramach ZAC 2 związane będą jednak w większym stopniu z zachowaniem historycznych obiektów wchodzących w skład sortowni poczty Montrochet i wkomponowaniem ich w nową strukturę urbanistyczno-architektoniczną. Drugi etap przekształceń przestrzenno-funkcjonalnych w Confluence ma wiązać się z dalszym rozwojem terenów usługowo-rezydencjonalnych. Szczegółowy program instytucjonalny oraz w zakresie planowanego sposobu użytkowania historycznych i nowo wybudowanych obiektów nie jest jednak dotychczas sprecyzowany. Ważnym zadaniem w ramach realizacji projektu ZAC 2 jest budowa dwóch nowych mostów pieszych nad Rodanem na północ od mostu Pasteur (rys. 6.12). W istotnym stopniu zwiększą one dostępność tej części miasta i przyczynią się do łatwego „przepływu” użytkowników przestrzeni miejskiej dwóch postindustrialnych jednostek morfologicznych Lyonu - Condlunce i Gerland na wschodnim brzegu Rodanu. 
Tabela 6.2. Intensywność przekształceń morfologii i sposobu użytkowania terenów poprzemysłowych w Lyonie w latach 1998-2013

\begin{tabular}{|l|c|c|}
\hline \multicolumn{1}{|c|}{ Cecha } & $\mathrm{P}(\mathrm{w} \%)$ & $\begin{array}{c}\text { Intensywność } \\
\text { zmian }\end{array}$ \\
\hline Długość dróg kołowych & 9,8 & Niski $\left(\mathrm{P}_{\mathrm{N}}\right)$ \\
\hline Długość naziemnych linii kolejowych & $-56,4$ & $\begin{array}{c}\text { Umiarkowany } \\
\left(\mathrm{P}_{\mathrm{U}}\right)\end{array}$ \\
\hline Długość nowych linii tramwajowych & $\mathrm{x}$ & Wysoki $\left(\mathrm{P}_{\mathrm{W}}\right)$ \\
\hline Powierzchnia zabudowy & $-8,2$ & Niski $\left(\mathrm{P}_{\mathrm{N}}\right)$ \\
\hline $\begin{array}{l}\text { Powierzchnia nowo wzniesionej zabudowy (wybudowanej w ra- } \\
\text { mach rewitalizacji) }\end{array}$ & $\mathrm{x}$ & Wysoki $\left(\mathrm{P}_{\mathrm{W}}\right)$ \\
\hline $\begin{array}{l}\text { Powierzchnia zachowanej dawnej zabudowy użytkowanej przez } \\
\text { przemysł }\end{array}$ & $-95,4$ & Wysoki $\left(\mathrm{P}_{\mathrm{W}}\right)$ \\
\hline $\begin{array}{l}\text { Powierzchnia dawnej zabudowy użytkowanej przez przemysł, która } \\
\text { została poddana renowacji i adaptacji na nowe funkcje w ramach } \\
\text { procesu rewitalizacji }\end{array}$ & $\mathrm{x}$ & Wysoki $\left(\mathrm{P}_{\mathrm{W}}\right)$ \\
\hline $\begin{array}{l}\text { Długość ogólnodostępnej linii dostępu do wody (rzeki, kanały, } \\
\text { zbiorniki wodne) - od rozpoczęcia procesu rewitalizacji }\end{array}$ & 247,2 & Wysoki $\left(\mathrm{P}_{\mathrm{W}}\right)$ \\
\hline Powierzchnia zabudowy zajmowanej przez funkcję usługową & 440,2 & Wysoki $\left(\mathrm{P}_{\mathrm{W}}\right)$ \\
\hline Powierzchnia zabudowy zajmowanej przez funkcję mieszkaniową & $-281,2$ & Wysoki $\left(\mathrm{P}_{\mathrm{W}}\right)$ \\
\hline $\begin{array}{l}\text { Powierzchnia zabudowy zajmowanej przez nieużytki poprzemysło- } \\
\text { we lub funkcję produkcyjną }\end{array}$ & $-100,0$ & Wysoki $\left(\mathrm{P}_{\mathrm{W}}\right)$ \\
\hline
\end{tabular}

Źródło: badania własne autora.

W 2013 r. intensywne prace naprawcze w Confluence obejmowały obszar o powierzchni 32,1 ha w rejonie działania ZAC 2 o powierzchni 18,6 ha, w północnej części ZAC 1 na wschód od koszarów policji - 3,1 ha, oraz na terenie wokół Muzeum Confluence - 4,5 ha. Działania związane z przebudową dawnych zakładów karnych St. Joseph i St. Paul i ich adaptacją na Uniwersytet Katolicki oraz obiekty mieszkaniowe i biurowe $(2,1 \mathrm{ha})$ mają zostać zakończone do końca 2015 r. Do projektu przekształceń przestrzenno-funkcjonalnych w Confluence została włączona także modernizacja Placu de l'Hippodrome o powierzchni 0,9 ha oraz Placu Carnot o powierzchni 2,7 ha, który jest zlokalizowany przy północnym wejściu do dworca Perrache (rys. 6.12).

Nowa przestrzeń centralna w Lyonie zajmuje powierzchnię 166 ha (rys. 6.13). Obejmuje ona najmłodsze jednostki morfologiczne, które powstały w wyniku przekształceń przestrzenno-funkcjonalnych od lat 90 . XX w. Składa się na nią obszar Confluence położony na południe od dworca kolejowego Perrache, w tym przekształcone tereny użytkowane na szeroko rozumianą działalność przemysłową. Zajmuje on powierzchnię 151,3 ha. Do nowej przestrzeni centralnej zaliczono także Cité Internationale, które zajmuje 14,7 ha. 


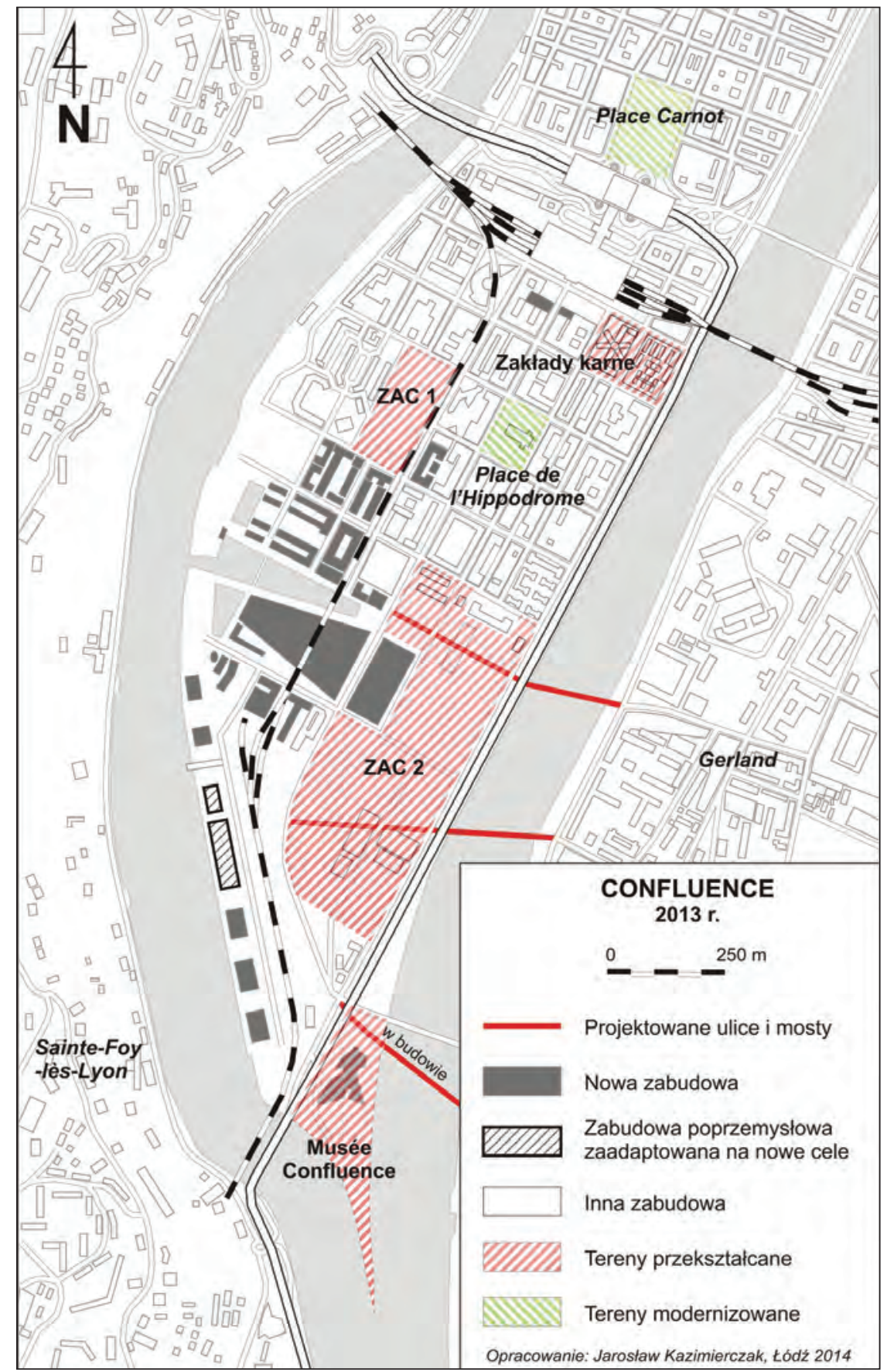

Rys. 6.12. Obszary działań naprawczych w Confluence w roku 2013

Źródło: badania własne autora 
Starą przestrzeń centralną w Lyonie tworzą najstarsze jednostki morfogenetyczne: Vieux Lyon o powierzchni 30,1 ha, obszar Presqu'île, czyli rejon Les Terreaux, Bellecour oraz Perrache zajmujący 162,4 ha, oraz Part-Dieu o powierzchni 56,5 ha (rys. 6.13). Stara przestrzeń centralna w Lyonie zajmuje 249,9 ha, co stanowi $66,5 \%$ z łącznych 415,9 ha przestrzeni centralnej we współczesnym Lyonie.

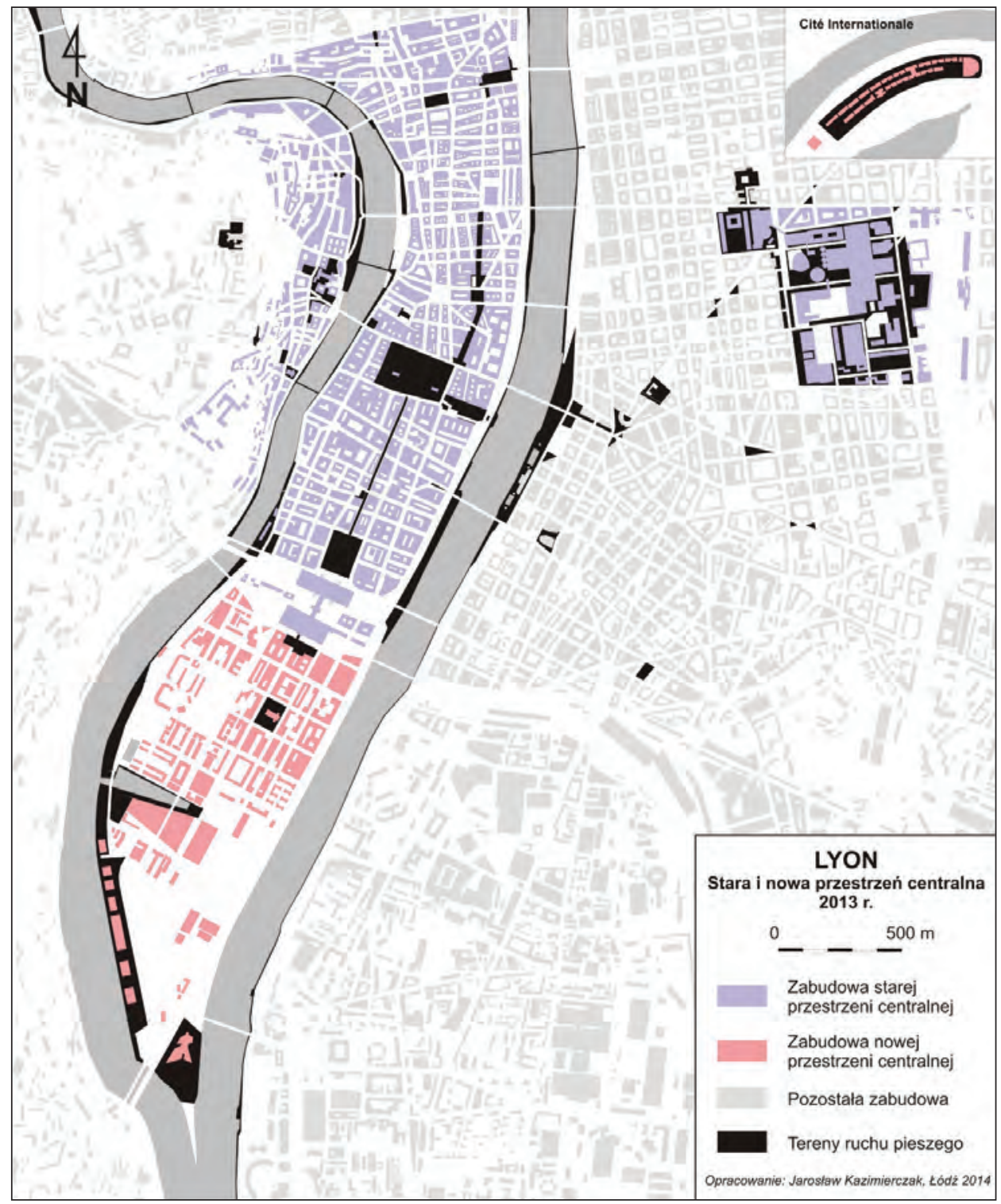

Rys. 6.13. Obszar zajmowany przez starą i nową przestrzeń centralną w Lyonie w roku 2013 Źródło: badania własne autora 
Tabela 6.3. Wybrane cechy morfologii i sposobu użytkowania starej i nowej przestrzeni centralnej w Lyonie w 2013 r.

\begin{tabular}{|l|c|c|c|c|}
\hline \multicolumn{1}{|c|}{ Cecha } & Jednostka & \multicolumn{2}{|c|}{$\begin{array}{c}\text { Stara } \\
\text { mrzestrzeń } \\
\text { centralna }\end{array}$} & \multicolumn{2}{|c|}{$\begin{array}{c}\text { Nowa przestrzeń } \\
\text { centralna }\end{array}$} \\
\cline { 4 - 6 } całość & $\begin{array}{c}\text { w tym } \\
\text { w Confluence }\end{array}$ \\
\hline Powierzchnia przestrzeni centralnej & ha & 249,9 & 166,0 & 151,3 \\
\hline $\begin{array}{l}\text { Powierzchnia przestrzeni zamkniętych w prze- } \\
\text { strzeni centralnej }\end{array}$ & ha & 170,2 & 74,1 & 65,6 \\
\hline $\begin{array}{l}\text { Powierzchnia przestrzeni otwartych w prze- } \\
\text { strzeni centralnej }\end{array}$ & ha & 79,7 & 91,9 & 85,7 \\
\hline $\begin{array}{l}\text { Powierzchnia przestrzeni publicznej integru- } \\
\text { jącej (place miejskie) w przestrzeni centralnej }\end{array}$ & ha & 19,4 & 3,2 & 3,2 \\
\hline $\begin{array}{l}\text { Powierzchnia terenów ruchu pieszego (inne } \\
\text { strefy piesze bez placów) przestrzeni centralnej }\end{array}$ & ha & 18,7 & 17,0 & 14,1 \\
\hline $\begin{array}{l}\text { Rozmieszczenie placów miejskich w prze- } \\
\text { strzeni centralnej }\end{array}$ & L & 64 & 8 & 8 \\
\hline $\begin{array}{l}\text { Rozmieszczenie obiektów powyżej 50 m wy- } \\
\text { sokości w przestrzeni centralnej }\end{array}$ & L & 5 & 0 & 0 \\
\hline $\begin{array}{l}\text { Powierzchnia zajmowana przez funkcje wiel- } \\
\text { komiejskie w przestrzeni centralnej }\end{array}$ & ha & 200,0 & 63,0 & 42,1 \\
\hline $\begin{array}{l}\text { Rozmieszczenie instytucji publicznych w prze- } \\
\text { strzeni centralnej }\end{array}$ & L & 80 & 12 & 7 \\
\hline $\begin{array}{l}\text { Rozmieszczenie obiektów wybudowanych } \\
\text { w ramach projektów wiodących w przestrzeni } \\
\text { centralnej }\end{array}$ & L & 0 & 4 & 3 \\
\hline $\begin{array}{l}\text { Liczba nowych instytucji centralnych i projek- } \\
\text { tów wiodących w ekwidystancie 15 minut drogi } \\
\text { pieszej od dworców kolejowych i autobuso- } \\
\text { wych (punkty węzłowe o randze ponadlokalnej) } \\
\text { w przestrzeni centralnej }\end{array}$ & L & 0 & 3 & 3 \\
\hline
\end{tabular}

Źródło: badania własne autora.

Zgodnie z przyjętym założeniem, charakter relacji pomiędzy starą i nową przestrzenią centralną $\mathrm{w}$ każdym $\mathrm{z}$ miast jest $\mathrm{w}$ daleko idącym stopniu determinowany zakresem podobieństwa (zróżnicowania) sposobu ich organizacji w ujęciu morfologiczno-instytucjonalnym. Im stopień zróżnicowania jest wyższy, tym mniej prawdopodobne jest zaburzenie historycznie ukształtowanej hierarchii terenów miejskich. W przypadku wysokiego lub średniego poziomu rozwinięcia przestrzeni centralnej sytuacja taka sprzyja wytworzeniu relacji kooperacyjnych pomiędzy jej starą i nową częścią, bowiem sposób wyposażenia jednostek morfologicznych umożliwia użytkownikowi przestrzeni miejskiej identyfikację obszaru dominującego oraz komplementarnych względem niego. $\mathrm{W}$ tabeli 6.3 dokonano zestawienia analizowanych cech morfologicznych i z zakresu sposobu 
użytkowania starej i nowej przestrzeni centralnej w Lyonie w 2013 r. Posłużyły one do identyfikacji wpływu rewitalizacji zdegradowanych terenów wewnątrzmiejskich w Confluence na organizację współczesnej przestrzeni centralnej Lyonu.

Średnia intensywność pozioma zabudowy dla starej i nowej przestrzeni centralnej w Lyonie, będąca stosunkiem powierzchni zajmowanej przez przestrzeń zamkniętą względem ogólnej wielkości powierzchni analizowanego obszaru, wynosi 60\%. Pomiędzy starą i nową częścią zaznacza się wyraźne zróżnicowanie. Wartość intensywności poziomej zabudowy dla rejonów w Presqu'île to $74 \%$, dla Vieux Lyon - 58\%, a dla Part-Dieu - 69\%, co daje średnią dla starej przestrzeni centralnej-68\%. Analizowana wartość dla rejonu Cité Internationalne wynosi 52\%, a w Confluence $-43 \%$, co daje w rezultacie średnią intensywność poziomą zabudowy dla nowej przestrzeni centralnej równą $45 \%$. Biorąc pod uwagę jedynie obszar poddany najbardziej intensywnym przekształceniom przestrzennym w ZAC 1 oraz wokół Muzeum Confluence - wartość ta maleje do $21 \%$. Wynika to z przeznaczenia znacznej części zrewitalizowanej przestrzeni miejskiej na tereny ruchu pieszego oraz infrastrukturę rekreacyjno-wypoczynkową, np. na place zabaw dla dzieci mieszkających w nowych obiektach rezydencjonalnych wokół Jardin Erevan na północ od akwenu i mariny. Na niską intensywność poziomą zabudowy w Confluence mają także wpływ niezakończone jak dotąd działania naprawcze, obejmujące łącznie 32,1 ha (patrz rys. 6.12). Zgodnie ze skalą S. Liszewskiego intensywność pozioma zabudowy nowej przestrzeni centralnej w Lyonie jest niska (poniżej 50\%) i odpowiada zabudowie luźnej (rys. 6.13). W starej przestrzeni centralnej zidentyfikowano natomiast zabudowę rozproszoną, co wynika przede wszystkim ze znacznego udziału otwartych terenów zajętych przez strefy ruchu pieszego i tereny kolejowe w Part-Dieu, duże place miejskie oraz tereny komunikacyjne (dworzec Perrache i Centrum Transferowe) w Presqu'île i tereny zielone w Vieux Lyon. Zabudowa w Bellecour, Les Terreaux, Perrache i Vieux Lyon ma charakter zabudowy zwartej (rys. 6.13).

W przestrzeni centralnej w Presqu'île i w Starym Lyonie dominuje zabudowa wielkomiejska z XVIII i XIX w. z charakterystyczną czerwoną dachówką (fot. 6.17-6.20) oraz średniowieczne kościoły wybudowane w stylu romańskim i gotyckim, a niektóre $\mathrm{z}$ nich następnie przebudowane według nowych wzorców architektonicznych w kolejnych epokach (fot. 6.21 i 6.22). Wśród historycznej zabudowy znajdują się liczne reprezentacyjne budynki zajmowane przez ważne instytucje publiczne, takie jak ratusz przy placu Terreaux czy giełda - Palais de la Bourse (fot. 6.23-6.24). Nowe obiekty z drugiej połowy XX w. bądź z XXI w. są zlokalizowane punktowo i nie wpływają $\mathrm{w}$ istotny sposób na zmiany historycznego krajobrazu tej części śródmieścia. Wśród nich można wskazać m.in. budynek poczty głównej przy placu Poncet, budynek Centrum Transferowego przy Gare de Perrache-Lyon bądź dom towarowy le Nouveau Grand Bazar w miejscu historycznego budynku le Grand Bazar (fot. 6.25). Innym przykładem historycznego budynku, który w drugiej połowie XX w. został zastąpiony nowym obiektem, jest rynek Halle des Cordeliers. Współcześnie na jego miejscu znajduje się parking 
wielopoziomowy. Część z historycznej zabudowy zyskała nową formę w wyniku działań rewaloryzacyjnych. Za przykład może posłużyć rozbudowa opery lyońskiej (L'opéra national de Lyon) zrealizowana w latach 1986-1993 pod kierunkiem Jeana Nouvela (fot. 6.26).

Fizjonomia Presqu'île i Starego Lyonu zdecydowanie różni się od zabudowy Part-Dieu, w której przeważają nowe obiekty, a wśród nich także wysokościowce (patrz fot. 6.1-6.8). Wszystkie obiekty w mieście o wysokości przekraczającej $50 \mathrm{~m}$ zlokalizowane są na lewym (wschodnim) brzegu Rodanu (tab. 6.3). Znaczne oddalenie nowoczesnej dzielnicy finansowej od Bellecour, Les Terreaux, Perrache i Vieux Lyon umożliwiło zachowanie historycznej sylwety najstarszej części miasta. Dominantą krajobrazową oraz symbolem nowoczesnego Lyonu jest Tour Part-Dieu (patrz fot. 6.4 i fot. 6.17). Wieżowiec ma wysokość $165 \mathrm{~m}$ i liczy 42 piętra, z których 10 położonych najwyżej zajętych jest przez Radisson Blu Hotel Lyon. Koncepcja budowy dzielnicy finansowej w Lyonie wpisuje się w ideę amerykańskiego Central Business District,

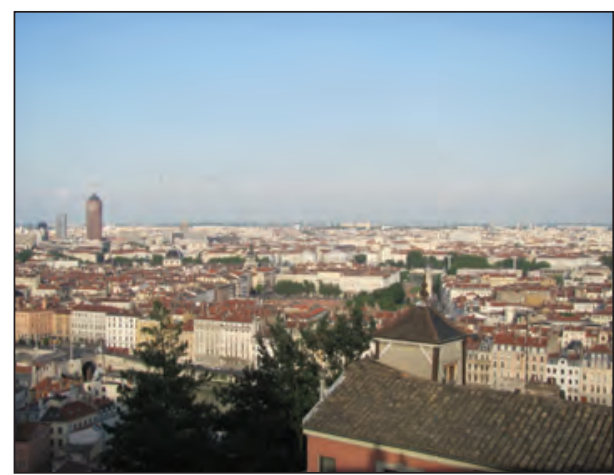

Fot. 6.17. Widok na zabudowę Presqu'île ze wzgórza Fourvière, po lewej Tour Part-Dieu

Źródło: fotografia autora



Fot. 6.19. Zabudowa wokół placu Terreaux Źródło: fotografia autora

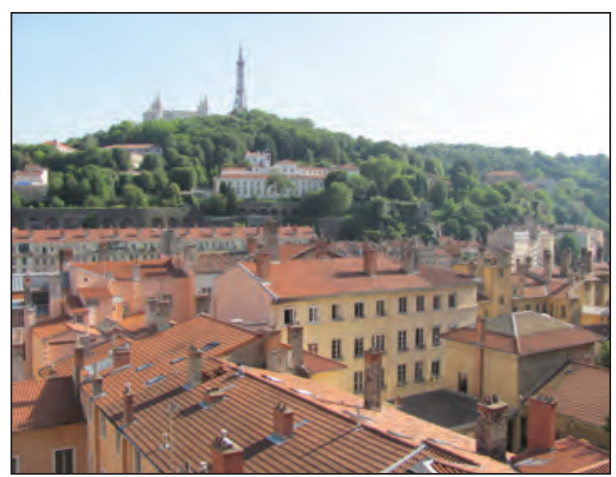

Fot. 6.18. Widok na zabudowę Presqu'île i na wzgórze Fourvière z La Croix-Rousse

Źródło: fotografia autora

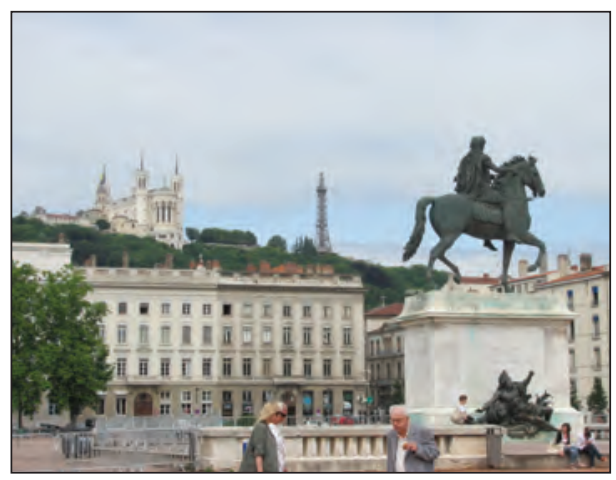

Fot. 6.20. Zabudowa przy placu Bellecour Źródło: fotografia autora 


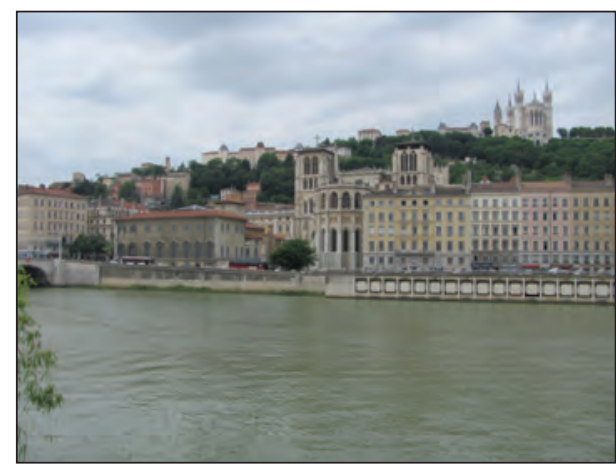

Fot. 6.21. Widok z Presqu'île na katedrę St. Jean, Vieux Lyon i bazylikę Notre Dame de Fourvière

Źródło: fotografia autora

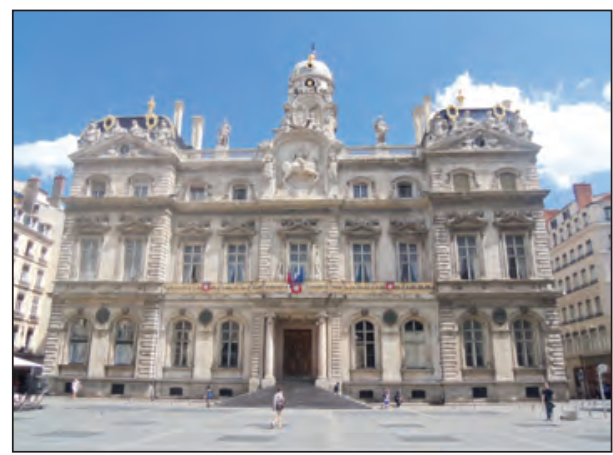

Fot. 6.23. Reprezentacyjny budynek Lyonu ratusz z XVII w.

Źródło: fotografia autora

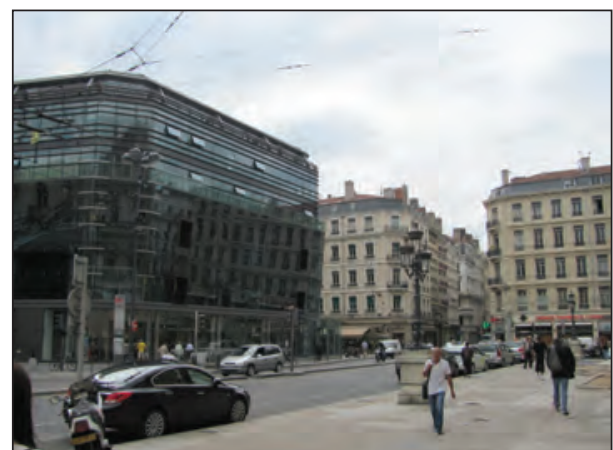

Fot. 6.25. Dom towarowy le Nouveau Grand Bazar w sąsiedztwie giełdy

Źródło: fotografia autora

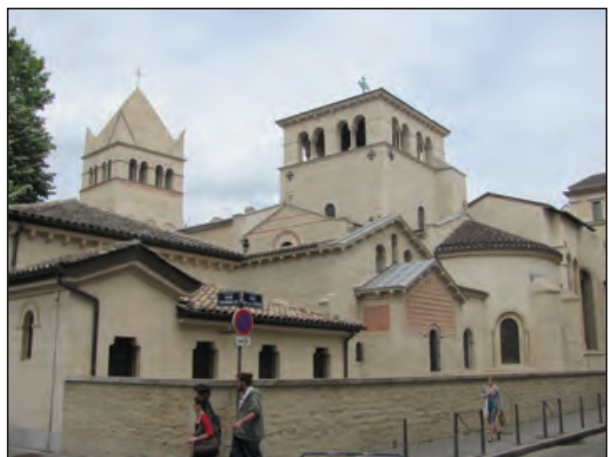

Fot. 6.22. Jeden z najstarszych obiektów sakralnych w Lyonie - kościół St. Marie d’Ainay

Źródło: fotografia autora

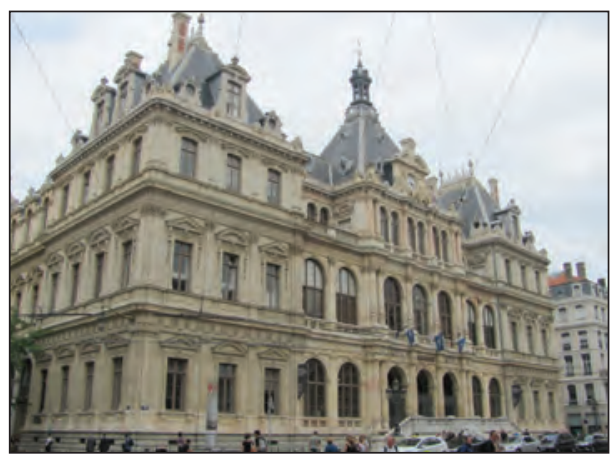

Fot. 6.24. Budynek Palais de la Bourse - symbol ekonomicznej potęgi XIX-wiecznego Lyonu

Źródło: fotografia autora

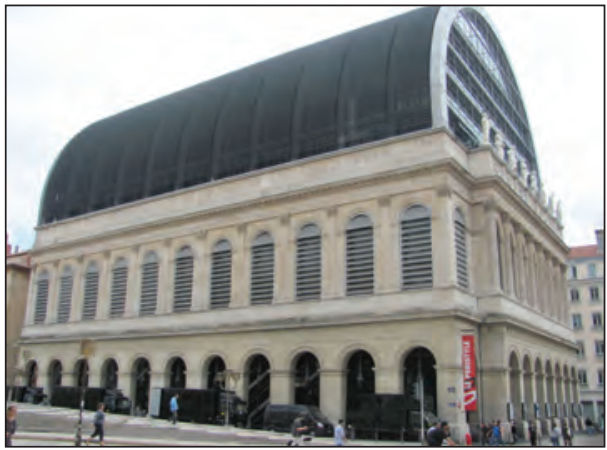

Fot. 6.26. Współczesna bryła opery lyońskiej Źródło: fotografia autora 
w której skoncentrowane są najwyższe budynki w mieście. W Part-Dieu do roku 2020 zlokalizowanych będzie 13 obiektów o wysokości przekraczającej $80 \mathrm{~m}$, w tym 4 planowane budynki będą mierzyły co najmniej $200 \mathrm{~m}$. Wybudowane wysokościowce zajmą wolne działki na zachód i wschód od dworca kolejowego, tym samym znacznie wzrośnie intensywność zagospodarowania tego obszaru (pozioma jak i pionowa).

Nowa przestrzeń centralna w Lyonie wykazuje także znaczne zróżnicowanie w zakresie fizjonomii zabudowy. Poza eklektyczną dzielnicą St. Blandine (fot. 6.27 i 6.28 ) i pojedynczymi obiektami poprzemysłowymi zaadaptowanymi do nowych funkcji, w Confluence i Cité Internationale zdecydowanie przeważają

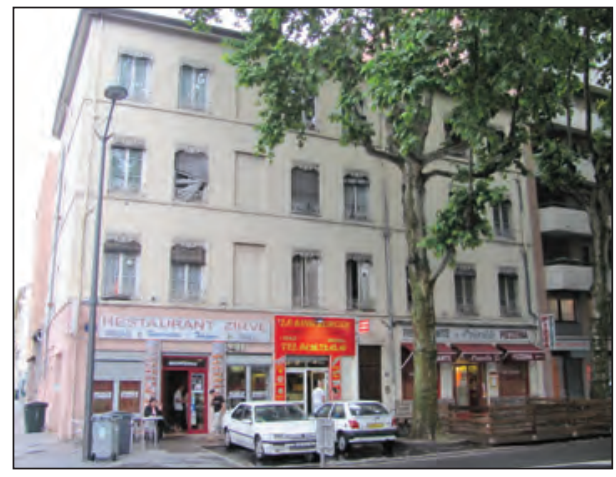

Fot. 6.27. Zabudowa w dzielnicy St. Blandine Źródło: fotografia autora

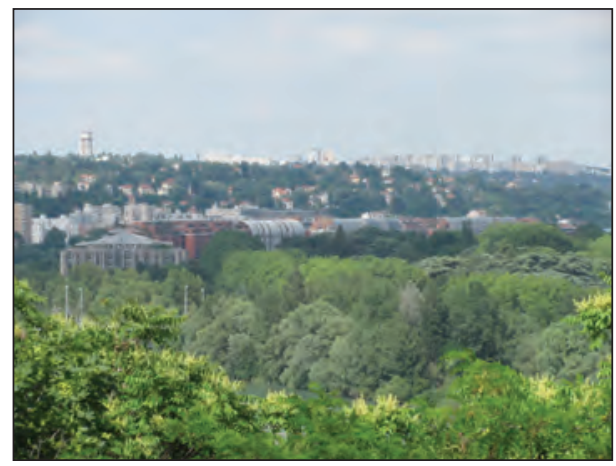

Fot. 6.29. Widok na Cité Internationale ze wzgórza Fourvière

Źródło: fotografia autora

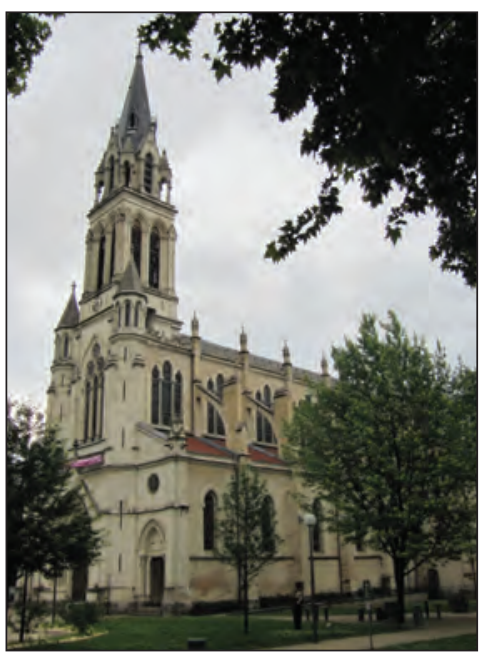

Fot. 6.28. Jedyny obiekt sakralny w Confluence - kościół St. Blandine

Źródło: fotografia autora

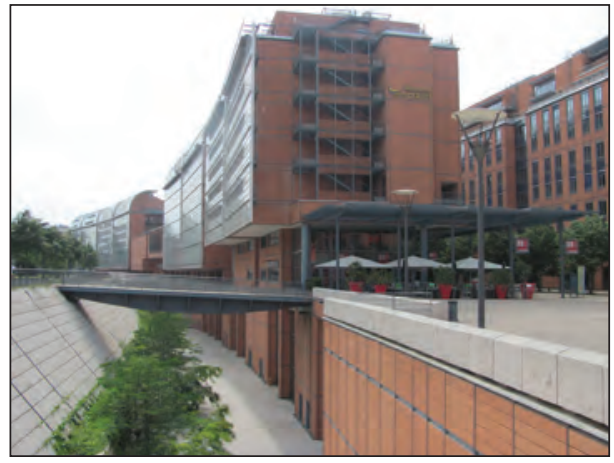

Fot. 6.30. Charakterystyczna dla Cité Internationale zabudowa ze szklaną i pomarańczową elewacją Źródło: fotografia autora 
budynki o współczesnej formie architektonicznej (fot. 6.29 i 6.30, patrz też fot. 6.9 i 6.12-6.14). Jej powierzchnia wzrośnie w istotny sposób po zakończeniu realizacji projektu ZAC 2. Inną istotną cechą szerzej rozumianej fizjonomii nowej przestrzeni centralnej jest znaczny udział terenów zajętych przez zieleń miejską. W Presqu'île i Vieux Lyon są to przede wszystkim parki i skwery oraz

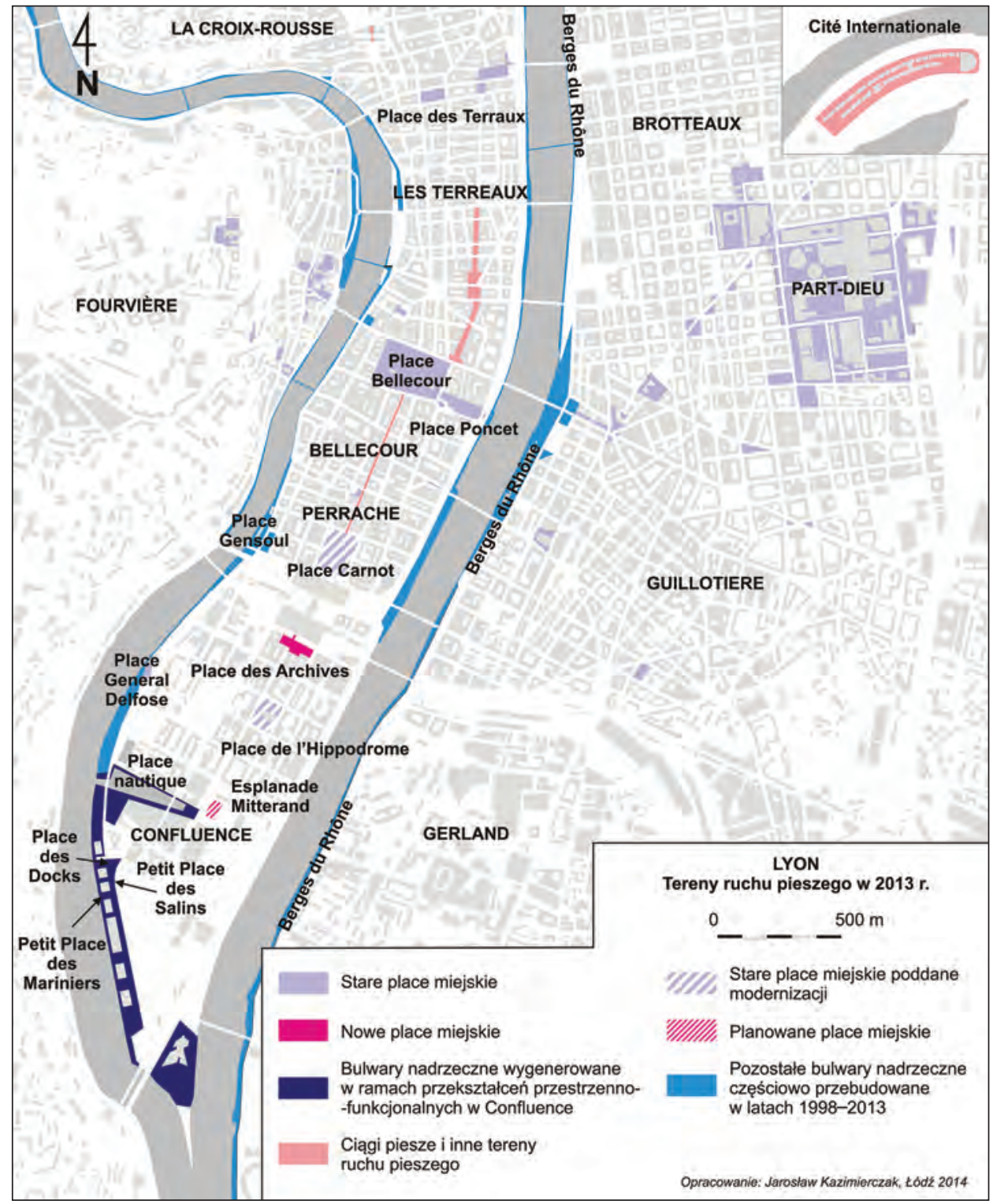

Rys. 6.14. Rozmieszczenie terenów ruchu pieszego w przestrzeni centralnej Lyonu w $2013 \mathrm{r}$. Źródło: badania własne autora 
bulwary nad rzekami Saoną i Rodanem. W Confluence i Cité Internationale kluczowym elementem systemu terenów zielonych są głównie bulwary nadrzeczne. Ze względu na znaczną wielkość powierzchni terenów otwartych (tab. 6.3) oraz realizowaną od lat 90 . XX w. koncepcję kształtowania ekologicznych dzielnic (przykładem są właśnie Confluence i Cité Internationale), w nowej przestrzeni centralnej zieleń miejska zajmuje także tereny oddalone od nabrzeży. Obejmuje ona nie tylko parki, ale także obszary aktywne biologicznie na dachach nowych budynków, co w znaczący sposób poprawia warunki zamieszkania i pracy.

Proces przekształceń przestrzenno-funkcjonalnych zrealizowany w Confluence oraz Cité Internationale i prowadzący do rozszerzenia istniejącej wcześniej przestrzeni centralnej miasta wiązał się $\mathrm{z}$ wygenerowaniem nowych przestrzeni publicznych (rys. 6.14). W ramach procesów naprawczych w Confluence nastąpiło uzupełnienie systemu bulwarów na lewym brzegu Saony. Ze względu na współczesny przebieg śródmiejskiej części „Autostrady Słońca” (A7), nadal nie istnieje możliwość zagospodarowania prawego brzegu Rodanu na przestrzeń publiczną atrakcyjną dla pieszych użytkowników miasta. W założeniach projektu ZAC 2 pozostaje jednak likwidacja autostrady i jej adaptacja na strefę uspokojonego ruchu. Dotychczas zakończone inwestycje związane z budową nowych terenów z uprzywilejowanym ruchem pieszym obejmowały przede wszystkim kształtowanie stref spacerowych na nabrzeżu Saony - Qui Rambaud, od Place nautique na północy docelowo do Muzeum Confluence u południowej nasady półwyspu (rys. 6.14). Obszar ten obejmuje powierzchnię aż 12,3 ha, co stanowi 76\% wszystkich stref pieszych w Confluence bez placów miejskich. Północna część bulwaru nad Saoną (od mariny do Placu Gensoul) zostanie zmodernizowana w ramach rehabilitacji północnej części Confluence do roku 2020. Przekształcenia układu przestrzeni publicznej były również powiązane z budową nowych placów miejskich (rys. 6.14). Na obszarze objętym projektem ZAC 1 do 2013 r. wygenerowano 6 placów miejskich, w ujęciu morfologicznym. Są to kolejno od północy: Place des Archives, Place nautique, Esplanade François Mitterrand, Place des Docks, Petit Place des Salins i Petit Place des Mariniers (rys. 6.14). Zajmują one łączną powierzchnię 2 ha, co stanowi $62 \%$ powierzchni wszystkich placów w Confluence (rys. 6.15). Dwa pozostałe - Place Generale Delfose i Place de l'Hippodrome, planowane są do modernizacji.

W ramach przekształceń układu przestrzeni publicznej w Cité Internationale wybudowano 2,9 ha stref ruchu pieszego. Na obszarze tym nie ma żadnego placu miejskiego.

Bardzo ważną inwestycją, w wyniku której śródmiejski układ przestrzeni publicznej Lyonu uległ istotnej transformacji, była budowa tzw. Berges du Rhône. Działania inwestycyjne realizowane były w latach 2004-2007 na wschodnim nabrzeżu Rodanu na odcinku $5 \mathrm{~km}$ od parku de la Tête d'Or na północy ${ }^{6}$ do parku

${ }^{6}$ Jest to największy park w Lyonie o powierzchni 116 ha, nazywany także ,zielonymi płucami metropolii lyońskiej" (Jażdżewska, Coudroy de Lille i Lavot 2011, s. 56). Jest on zlokalizowany pomiędzy dzielnicą Brotteaux oraz Cité Internationale. 
Gerland na południu (rys. 6.14). Obejmowały one budowę nadrzecznych terenów rekreacyjno-wypoczynkowych, na obszarach przeznaczonych wcześniej głównie na parkingi. W ramach projektu powstało m.in. kilka placów zabaw dla dzieci, siłownia na wolnym powietrzu, skate park i ścieżki rowerowe. Jednym z wiodących zadań było także częściowe przywrócenie pierwotnej roślinności nabrzeża Rodanu, w tym przede wszystkim lasów łęgowych.

Mimo podjęcia intensywnych działań w ramach rewitalizacji zdegradowanych terenów miejskich w Confluence oraz dawnych terenów targowych w Cité Internationale, nowa i stara przestrzeń centralna odznaczają się znacznym stopniem zróżnicowania w zakresie wyposażenia w przestrzenie publiczne (tab. 6.3). Szczególnie duża dysproporcja na korzyść starej przestrzeni centralnej występuje w liczbie placów miejskich oraz jej powierzchni (patrz tab. 6.3).

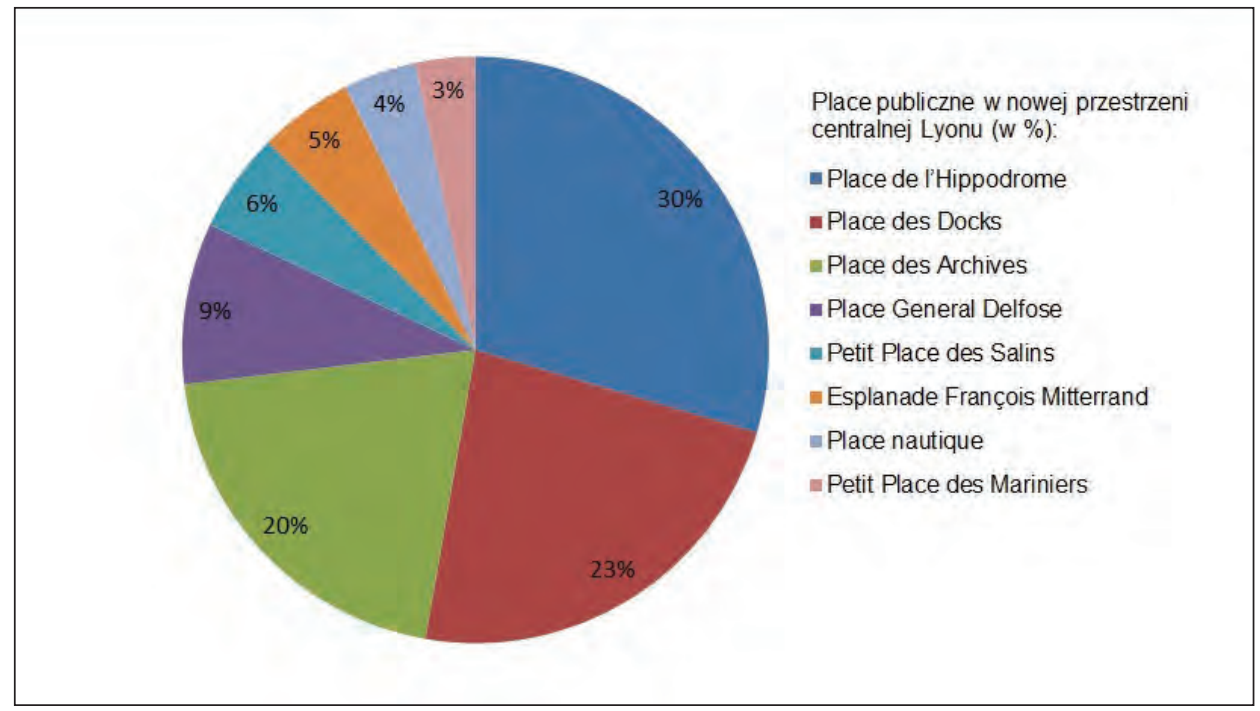

Rys. 6.15. Struktura procentowa powierzchni placów w Confluence w 2013 r.

Źródło: badania własne autora

Nawiązując do koncepcji dośrodkowej przestrzeni publicznej rozumianej jako przestrzeń ogólnodostępna znajdująca się wewnątrz obiektów, które mogą mieć charakter publiczny bądź prywatny, należy stwierdzić, że jest ona integralnym elementem nowo wygenerowanej przestrzeni centralnej w Confluence i Cité Internationale (fot. 6.31 i 6.32), a która w starej przestrzeni centralnej praktycznie nie występuje poza zbudowanym w latach 70 . XX w. centrum handlowym w Part-Dieu. Dośrodkowej przestrzeni publicznej w nowych jednostkach morfologicznych towarzyszy jednak zawsze klasyczna, otwarta przestrzeń publiczna. Integracja obu typów może wyrażać powrót do klasycznej koncepcji budowy miast, w których łączono funkcje zamieszkania, handlu i rozrywki w jednym miejscu (placu). 


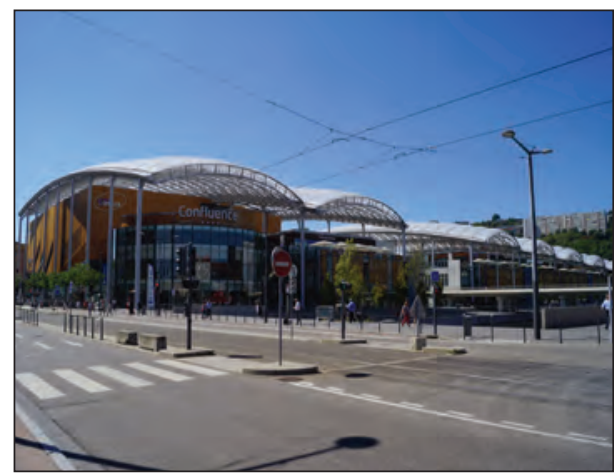

Fot. 6.31. Centrum handlowo-rozrywkowe w Confluence jako najnowsza dośrodkowa przestrzeń publiczna w Lyonie

Źródło: fotografia autora



Fot. 6.32. Dośrodkowa przestrzeń publiczna w kompleksie biznesowo-kongresowym Cité Internationale

Źródło: fotografia autora

Przestrzeń publiczna w starej i nowej przestrzeni centralnej wykazuje także istotne zróżnicowanie w zakresie fizjonomii. W Confluence i Cité Internationale powszechnie zastosowano zieleń miejską w postaci drzew, gazonów, klombów bądź nawierzchni trawiastej oraz elementy wody i małej architektury, często posiadającej oryginalną formę. W historycznej przestrzeni centralnej, głównie w Presqu'île, punktowe elementy morfologiczne mają przede wszystkim charakter rzeźb lub pomników.

Determinantami procesu rozwoju przestrzeni publicznej w nowej przestrzeni centralnej Lyonu są zarówno uwarunkowania przyrodnicze, jak i antropogeniczne. Brak przepraw pieszych nad Rodanem i Saoną oraz lokalizacja dworca Perrache, wiaduktów kolejowych, Centrum Transferowego wraz z zagłębieniem, w którym została poprowadzona autostrada, stanowią współcześnie największe bariery umożliwiające pełną integrację rejonu Confluence z sąsiednimi fragmentami miasta. O ile podjęte zostały już działania w celu budowy nowych mostów (w tym tramwajowego, pieszych i pieszo-rowerowych) nad rzekami (patrz rys. 6.12), to problem wymienionych terenów komunikacyjnych z pewnością będzie istotną przeszkodą w dalszych działaniach zmierzających do wykształcenia zwartej przestrzeni centralnej w ,widłach" Saony i Rodanu. Cité Internationale natomiast od najbliższej przestrzeni centralnej w Part-Dieu oddziela park de la Tête d'Or, w którym zlokalizowano ogród zoologiczny i botaniczny. Niemniej, to właśnie lokalizacja parku zapewniająca dogodne warunki do wypoczynku i relaksu dla rezydentów i pracowników „Miasteczka międzynarodowego” była jednym z kluczowych czynników wpływających na decyzję o jego budowie w peryferyjnej części śródmieścia Lyonu.

Kształtowanie nowej przestrzeni centralnej w Lyonie wiązało się z powstaniem atrakcyjnych przestrzeni publicznych. Uzupełniła ona dobrze rozwiniętą przestrzeń publiczną w starej przestrzeni centralnej, przede wszystkim w Presqu'île, 
gdzie znajdują się reprezentacyjne place miejskie. Niezmiennie głównym placem publicznym w Lyonie pozostał Bellecour, na którym odbywają się liczne imprezy plenerowe, głównie ze względu na jego wielkość i centralne położenie w układzie komunikacyjnym miasta. Istotne jest także jego historyczne znaczenie jako głównego placu w Lyonie.

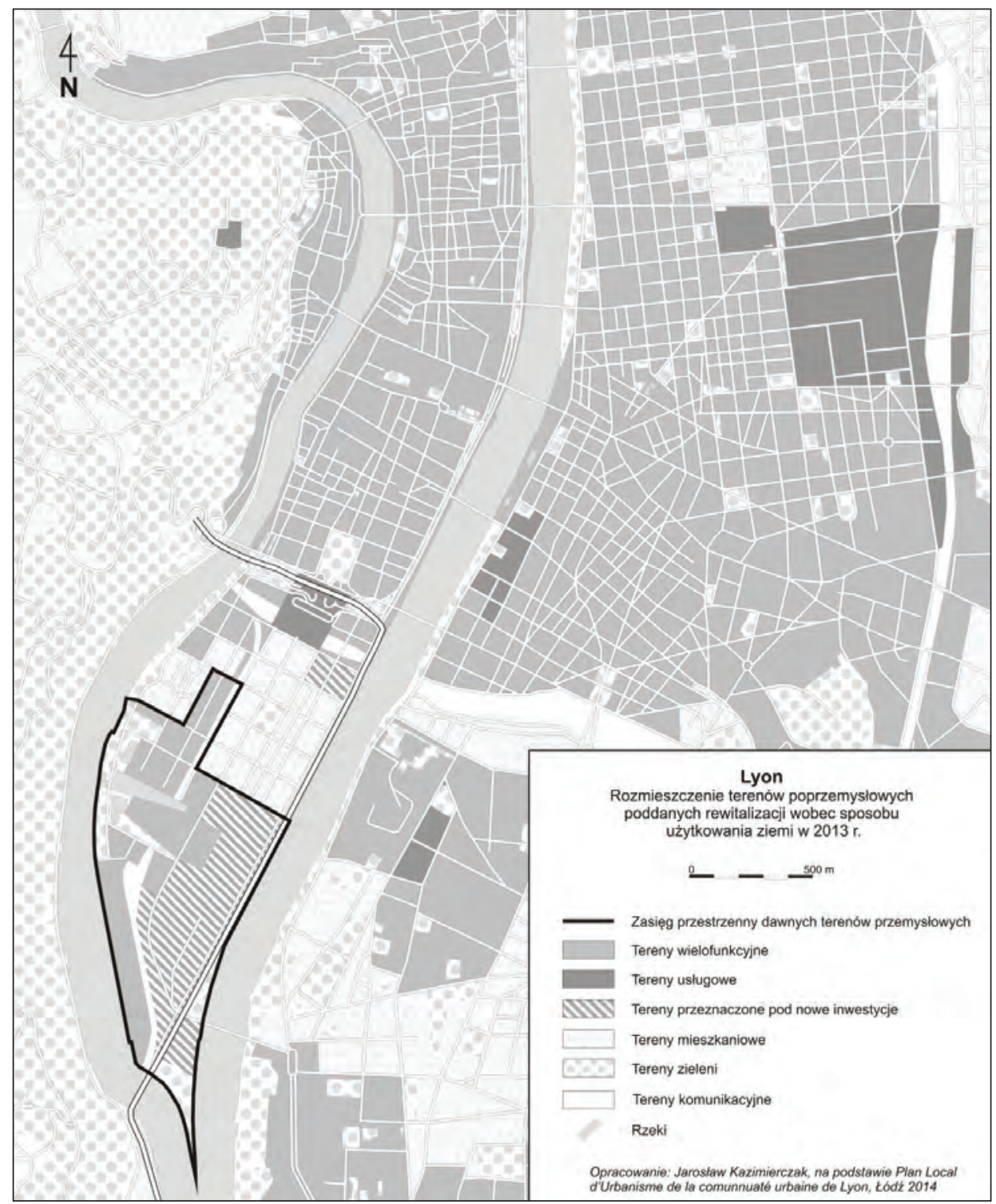

Rys. 6.16. Użytkowanie ziemi w starej i nowej przestrzeni centralnej w Lyonie w 2013 r. Źródło: badania własne autora 
Przeprowadzona analiza sposobu użytkowania ziemi w starej i nowej przestrzeni centralnej Lyonu wykazała znaczne ich zróżnicowanie w zakresie wielkości powierzchni wykorzystywanej przez funkcje wielkomiejskie (tab. 6.3). Rejony Vieux Lyon, Les Terreaux, Bellecour, Perrache i Part-Dieu niemal w całości stanowią tereny wielofunkcyjne bądź usługowe, uzupełnione o nieznacznej powierzchni tereny zieleni śródmiejskiej (rys. 6.16). Dla porównania w Confluence tylko $28 \%$ powierzchni zajmują tereny wielofunkcyjne i usługowe, a dla całej nowej przestrzeni centralnej udział ten wynosi 38\%. Pozostałą część Confluence zajmują głównie tereny mieszkaniowe, tereny zieleni miejskiej bądź obszary przeznaczone pod nowe inwestycje - głównie w ZAC 2 (rys. 6.16). Mimo wygenerowania nowych funkcji wielkomiejskich w Confluence, najbardziej reprezentacyjną ulicą zlokalizowaną na południe od dworca Perrache pozostała Cours Charlemange.

Na podstawie przeprowadzonych studiów nad etapami kształtowania przestrzeni centralnej Lyonu stwierdzono, że jej stara część wykazywała się stabilnym rozwojem, który wiązał się z ekspansją terytorialną. Wraz z transformacją przestrzeni centralnej następowała sukcesja wyposażenia instytucjonalnego na nowe tereny miejskie. Chronologicznie, w pierwszym etapie kształtowania przestrzeni centralnej instytucje budujące prestiż średniowiecznego Lyonu skoncentrowane były na prawym brzegu Saony - w Vieux Lyonie. W okresie XV-XIX w. zaczęły się one rozwijać w widłach Saony i Rodanu, w Les Terreaux, Bellecour i Perrache. Ze względu na morfologię oraz historyczne wyposażenie instytucjonalne jednostki te stanowią do dziś najbardziej reprezentacyjną część przestrzeni centralnej Lyonu. W wymienionych jednostkach przestrzennych zlokalizowane są m.in. ratusz, opera i Muzeum Sztuk Pięknych (patrz rys. 6.5). W drugiej połowie XX w. w wyniku decyzji politycznych przestrzeń centralna miasta została rozwinięta w Part-Dieu, gdzie swoje siedziby mają najważniejsze instytucje związane ze współczesnym funkcjonowaniem miasta i regionu metropolitalnego Lyonu. Od lat 90. XX w. nowe instytucje III i IV sektora lokowane są w nowej przestrzeni centralnej w Cité Internationale oraz w Confluence (rys. $6.17 \mathrm{i}$ tab. 6.3). Prestiż nowych dzielnic podnoszą przede wszystkim: siedziba władz regionalnych Rodan-Alpy - Hôtel de région, siedziba dziennika Le Progrès, europejska siedziba Euronews, Muzeum Confluence w Confluence oraz Muzeum Sztuki Współczesnej (Musée d'Art Contenporain), Centrum Kongresowe (Palais de Congres i Salle 3000) i światowa siedziba Interpolu w Cité Internationale. Za najważniejsze instytucje centralne (III i IV sektora), które generują ruch w nowej przestrzeni miejskiej, należy uznać przede wszystkim centrum handlowo-rozrywkowe w Confluence.

Trzy spośród nowych instytucji metropolitalnych, które powstały w Confluence, mają charakter projektów wiodących, nazywanych we Francji ,projektami latarniami" (projet phares): Hôtel de région Rhône-Alpes, Muzeum Confluence i centrum handlowo-rozrywkowe Confluence. Warto zauważyć, że tego typu inwestycje nie były rozwijane w innych fragmentach miasta, za wyjątkiem Cité Internationale, który należy uznać za jeden wielkoskalowy projekt wiodący 
(tab. 6.3). Jednocześnie jednak cele projektu rewitalizacji jasno precyzowały, że Confluence będzie obszarem lokalizacji instytucji niższej rangi niż te, które są zlokalizowane w Presqu'île i Part-Dieu. Poprzez tak przemyślaną politykę planistyczną w znaczący sposób utrudniono rozwój relacji konkurencyjnych pomiędzy starą i nową przestrzenią centralną w Lyonie w zakresie sposobu ich użytkowania. W Lyonie lokalizacja ponadlokalnych węzłów komunikacji zbiorowej nie ma znaczenia dla rozmieszczenia instytucji III i IV sektora.

Druga faza ostatniego (czwartego) etapu kształtowania przestrzeni centralnej w Lyonie, obejmująca rewitalizację zdegradowanych terenów postindustrialnych w Confluence oraz budowę „Miasteczka międzynarodowego" na obrzeżach współczesnego śródmieścia, sprowadzona została do procesu uzupełnienia istniejącej wcześniej przestrzeni centralnej w Vieux Lyon, Les Terreaux, Bellecour, Perrache i Part-Dieu. Proces ten miał charakter odśrodkowy, w którym dokonano jedynie nieznacznej modyfikacji starej przestrzeni centralnej. W wyniku przekształceń przestrzenno-funkcjonalnych wygenerowano nowe jednostki w układzie miejskim, o zbliżonych cechach morfologicznych i użytkowych. Zrewitalizowane tereny w Confluence stanowią wyraźnie odmienną przestrzeń pod względem krajobrazowym i instytucjonalnym w porównaniu z pozostałą częścią obszaru położonego w widłach Saony i Rodanu (rys. 6.17).

Tabela 6.4. Stopień zróżnicowania wybranych cech morfologii i sposobu użytkowania starej i nowej przestrzeni centralnej w Lyonie w $2013 \mathrm{r}$.

\begin{tabular}{|l|c|c|}
\hline \multicolumn{1}{|c|}{ Cecha } & $\mathrm{Z}(\mathrm{w} \%)$ & $\begin{array}{c}\text { Stopień } \\
\text { zróżnicowania }\end{array}$ \\
\hline Powierzchnia przestrzeni centralnej & 20 & Niski $\left(\mathrm{Z}_{\mathrm{N}}\right)$ \\
\hline Powierzchnia przestrzeni zamkniętych w przestrzeni centralnej & 39 & Niski $\left(\mathrm{Z}_{\mathrm{N}}\right)$ \\
\hline Powierzchnia przestrzeni otwartych w przestrzeni centralnej & 7 & Niski $\left(\mathrm{Z}_{\mathrm{N}}\right)$ \\
\hline $\begin{array}{l}\text { Powierzchnia przestrzeni publicznej integrującej (place miejskie) } \\
\text { w przestrzeni centralnej }\end{array}$ & 72 & Umiarkowany $\left(\mathrm{Z}_{\mathrm{U}}\right)$ \\
\hline $\begin{array}{l}\text { Powierzchnia terenów ruchu pieszego (inne strefy piesze bez pla- } \\
\text { ców) przestrzeni centralnej }\end{array}$ & 5 & Niski $\left(\mathrm{Z}_{\mathrm{N}}\right)$ \\
\hline Rozmieszczenie placów miejskich w przestrzeni centralnej & 78 & Wysoki $\left(\mathrm{Z}_{\mathrm{W}}\right)$ \\
\hline $\begin{array}{l}\text { Rozmieszczenie obiektów powyżej 50 m wysokości w przestrzeni } \\
\text { centralnej }\end{array}$ & 100 & Wysoki $\left(\mathrm{Z}_{\mathrm{w}}\right)$ \\
\hline $\begin{array}{l}\text { Powierzchnia zajmowana przez funkcje wielkomiejskie w prze- } \\
\text { strzeni centralnej }\end{array}$ & 52 & Umiarkowany $\left(\mathrm{Z}_{\mathrm{U}}\right)$ \\
\hline Rozmieszczenie instytucji publicznych w przestrzeni centralnej & 74 & Umiarkowany $\left(\mathrm{Z}_{\mathrm{U}}\right)$ \\
\hline $\begin{array}{l}\text { Rozmieszczenie obiektów wybudowanych w ramach projektów } \\
\text { wiodących w przestrzeni centralnej }\end{array}$ & 100 & Wysoki $\left(\mathrm{Z}_{\mathrm{w}}\right)$ \\
\hline $\begin{array}{l}\text { Liczba nowych instytucji centralnych i projektów wiodących } \\
\text { w ekwidystancie 15 minut drogi pieszej od dworców kolejowych } \\
\text { i autobusowych (punkty węzłowe o randze ponadlokalnej) w prze- } \\
\text { strzeni centralnej }\end{array}$ & 100 & Wysoki $\left(\mathrm{Z}_{\mathrm{w}}\right)$ \\
\hline
\end{tabular}

Źródło: badania własne autora. 


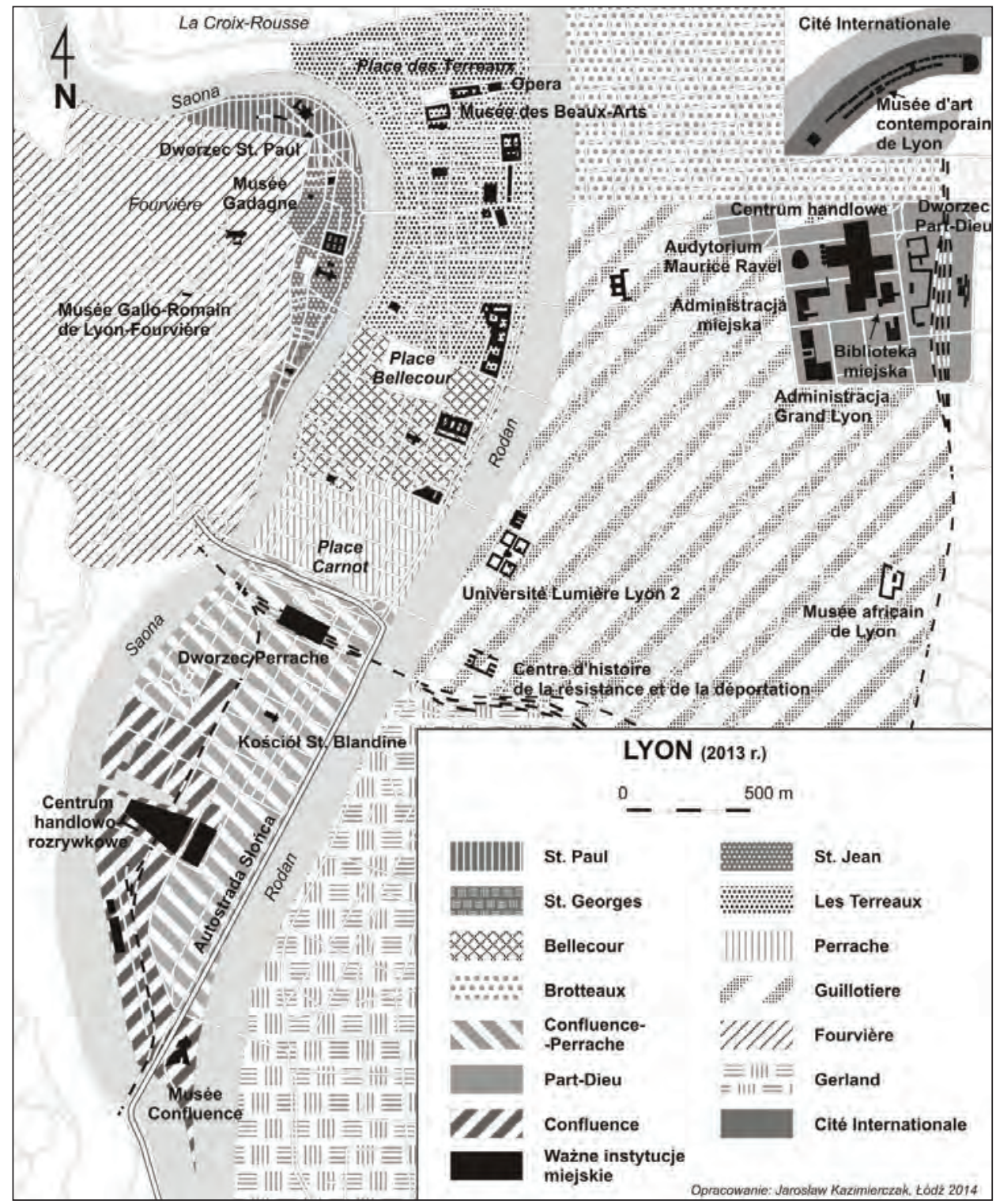

Rys. 6.17. Jednostki morfogenetyczne w przestrzeni centralnej Lyonu w 2013 r.

Źródło: badania własne autora

Rezultatem rewitalizacji zdegradowanych terenów poprzemysłowych w Confluence oraz budowy Cité Internationale jest wyraźne zróżnicowanie jednostek morfogenetycznych współkształtujących współczesną przestrzeń centralną Lyonu w zakresie morfologii oraz sposobu użytkowania. W większości analizowanych cech zidentyfikowano wysoki $\left(\mathrm{Z}_{\mathrm{W}}\right)$ lub umiarkowany $\left(\mathrm{Z}_{\mathrm{U}}\right)$ stopień zróżnicowania 
starej i nowej przestrzeni centralnej miasta (tab. 6.4). Na tej podstawie można zidentyfikować wysoki stopień zróżnicowania $\left(\mathrm{W}_{\mathrm{Z}}\right)$ starej i nowej przestrzeni centralnej w Lyonie.

W celu identyfikacji relacji zachodzących pomiędzy starą i nową przestrzenią centralną w Lyonie w 2013 r. dokonano analizy poziomu rozwinięcia przestrzeni centralnej. Posłużył do tego wskaźnik syntetyczny Ws obliczony w oparciu o metodę Perkala na podstawie zestandaryzowanych wartości cech (wskaźników cząstkowych), które opisują poszczególne aspekty poziomu rozwinięcia przestrzeni centralnej. Zestandaryzowane wartości analizowanych cech oraz wartość wskaźnika syntetycznego dla poziomu rozwinięcia współczesnej przestrzeni centralnej w Lyonie zawiera tabela 6.5.

Tabela 6.5. Wartości wskaźnika syntetycznego (Ws) i wartości standaryzowane cech opisujących poziom rozwinięcia przestrzeni centralnej w Lyonie w $2013 \mathrm{r}$.

\begin{tabular}{|c|l|c|}
\hline $\mathrm{W}$ & \multicolumn{1}{|c|}{ Cecha (wskaźnik cząstkowy) } & $\begin{array}{c}\text { Wartość } \\
\text { zestandaryzowana }\end{array}$ \\
\hline $\mathrm{W}_{1}$ & Powierzchnia przestrzeni centralnej (w ha) / Liczba ludności miasta & $-1,00382$ \\
\hline $\mathrm{W}_{2}$ & $\begin{array}{l}\text { Liczba jednostek morfologicznych kształtujących przestrzeń centralną / } \\
\text { Powierzchnia przestrzeni centralnej (w ha) }\end{array}$ & $-0,74373$ \\
\hline $\mathrm{W}_{3}$ & $\begin{array}{l}\text { Liczba instytucji publicznych w przestrzeni centralnej / Powierzchnia } \\
\text { przestrzeni centralnej (w ha) }\end{array}$ & $-0,23961$ \\
\hline $\mathrm{W}_{4}$ & $\begin{array}{l}\text { Powierzchnia przestrzeni centralnej (w ha) / Powierzchnia śródmieścia } \\
\text { (w ha) }\end{array}$ & $-0,54061$ \\
\hline $\mathrm{W}_{5}$ & $\begin{array}{l}\text { Liczba placów w przestrzeni centralnej / Powierzchnia przestrzeni cen- } \\
\text { tralnej (w ha) }\end{array}$ & 1,37939 \\
\hline $\mathrm{W}_{6}$ & $\begin{array}{l}\text { Liczba instytucji publicznych w przestrzeni centralnej / Liczba ludności } \\
\text { miasta }\end{array}$ & 1,41402 \\
\hline $\mathrm{W}_{\mathrm{s}}$ & Wskaźnik poziomu rozwinięcia przestrzeni centralnej & $\mathbf{0 , 0 4 4 2 7}$ \\
\hline
\end{tabular}

Źródło: badania własne autora.

Wskaźnik poziomu rozwinięcia przestrzeni centralnej w Lyonie w $2013 \mathrm{r}$. (Ws) wynosi 0,04427 , co zgodnie z przyjętymi założeniami oznacza średni poziom rozwinięcia przestrzeni centralnej (wskaźnik dodatni, zbliżony do wartości 0). Identyfikacja relacji we współczesnej przestrzeni centralnej Lyonu opiera się o analizę stopnia zróżnicowania jej starej i nowej przestrzeni centralnej oraz poziomu jej rozwinięcia jako całego układu morfologiczno-funkcjonalnego. $\mathrm{Na}$ podstawie analizy matrycy zależności pomiędzy stopniem zróżnicowania i rozwinięcia przestrzeni centralnej a występowaniem relacji w przestrzeni centralnej miast (patrz rys. $2.3 \mathrm{w}$ rozdz. 2) w Lyonie zidentyfikowano relacje średnio kooperacyjne (typu E). Są one możliwe do przekształcenia na inny typ relacji ze względu na średni poziom rozwinięcia przestrzeni centralnej, który umożliwia modyfikację struktury morfologicznej i funkcjonalnej. Barierą konwersji na inny typ relacji jest wysoki stopień zróżnicowania starej i nowej przestrzeni centralnej, który wymaga intensywnych przekształceń przestrzenno-funkcjonalnych. 
Jednostki morfogenetyczne starej i nowej przestrzeni centralnej Lyonu są względem siebie komplementarne. Czynnik ten ma istotny wpływ na zrównoważony rozwój przestrzenno-funkcjonalny miasta, nieprowadzący do radykalnych zmian w hierarchii terenów miejskich.

\subsection{Wnioski}

Proces kształtowania przestrzeni centralnej w Lyonie obejmuje cztery etapy. Pierwsze dwa wystąpiły w przedindustrialnym okresie rozwoju miasta. Transformacja przestrzeni centralnej w Lyonie od wczesnego średniowiecza odznaczała się stopniową sukcesją i integracją kolejnych jednostek morfologicznych, przyłączanych w wyniku ekspansji terytorialnej i funkcjonalnej miasta. Intensywna industrializacja $\mathrm{w}$ trzecim etapie kształtowania przestrzeni centralnej, rozpoczęta w latach 20. XIX w., objęła tereny peryferyjne Lyonu względem ówczesnej przestrzeni centralnej, tym samym nie wpłynęła na przekształcenia jej morfologii. Proces uprzemysłowienia nie spowodował także zmian $\mathrm{w}$ hierarchii terenów miejskich Lyonu (rys. 6.18).

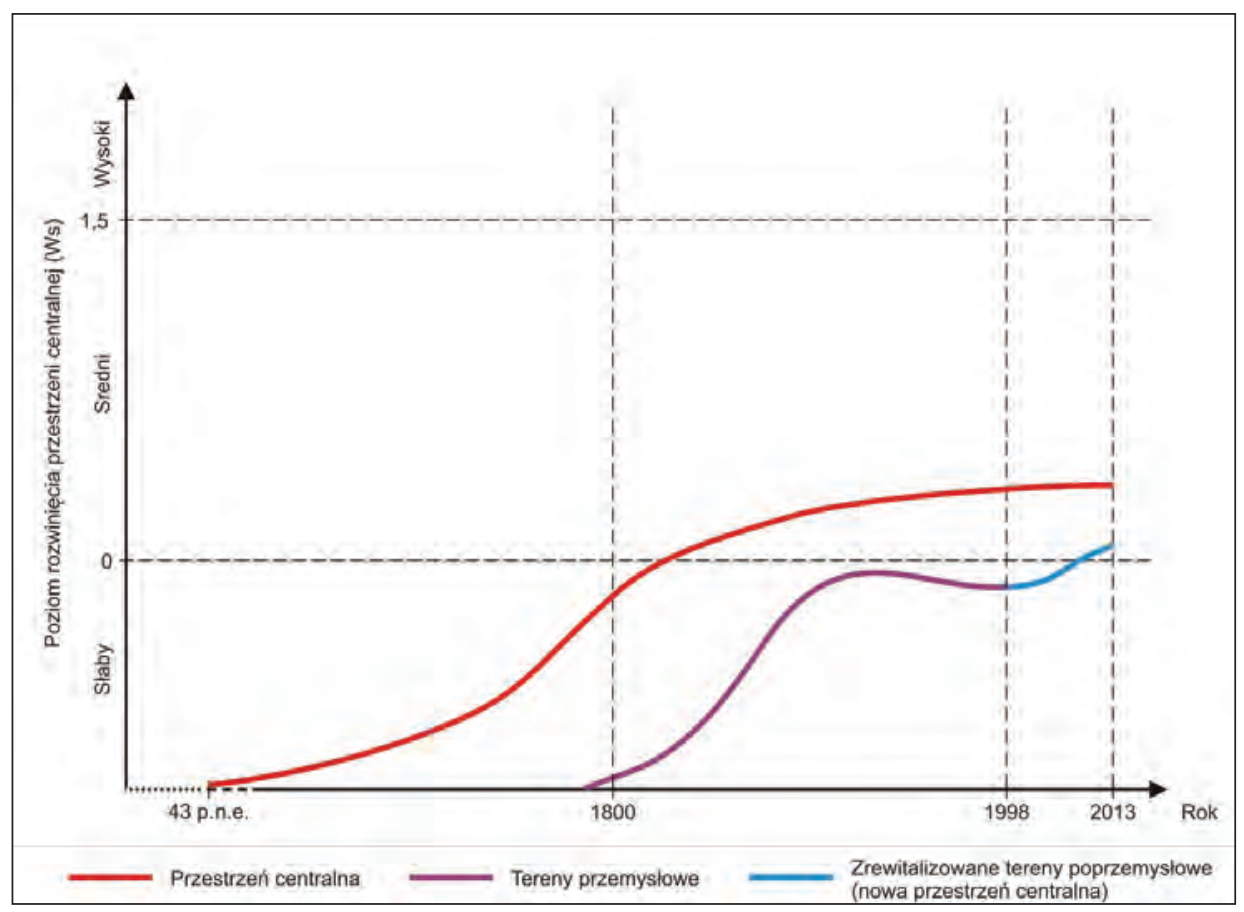

Rys. 6.18. Model sposobu rozwoju przestrzeni centralnej i terenów przemysłowych w Lyonie Źródło: badania własne autora 
Czwarty etap kształtowania przestrzeni centralnej w Lyonie wiązał się początkowo z budową dzielnicy finansowej w Part-Dieu. Upadek, a następnie wycofanie działalności przemysłowej z Confluence umożliwiło sanację tego obszaru i rozszerzenie ukształtowanej do lat 90 . XX w. przestrzeni centralnej Lyonu. Proces rewitalizacji terenów poprzemysłowych w Confluence charakteryzował się wysoką intensywnością przekształceń przestrzenno-funkcjonalnych i radykalną formą rewitalizacji w wymiarze morfologicznym. Nowa przestrzeń centralna miasta została wygenerowana także w wyniku realizacji projektu Cité Internationale. Ze względu na mniejszą powierzchnię i peryferyjną lokalizację nowe jednostki morfologiczno-funkcjonalne nie spowodowały przewartościowania struktury hierarchicznej przestrzeni centralnej w mieście (rys. 6.17).

Istotną rolę w procesie kształtowania przestrzeni centralnej w Lyonie odegrały uwarunkowania topograficzne, co ma swój wyraz w rozmieszczeniu jednostek morfologiczno-funkcjonalnych, które ją współtworzą. Proces kształtowania wieloośrodkowej przestrzeni centralnej w Lyonie miał ciągły charakter. Na podstawie przeprowadzonych studiów zidentyfikowano zatem ewolucyjny sposób rozwoju przestrzeni centralnej w Lyonie, który zadecydował również o wygenerowaniu kooperacyjnych relacji pomiędzy jej współczesną starą i nową częścią. Relacje tego typu wynikają z odmiennej morfologii oraz ze specjalizacji sposobu użytkowania poszczególnych elementów przestrzeni centralnej miasta.

Zgodnie z przyjętymi założeniami teoretycznymi organizacja przestrzeni centralnej jest zmienna, co oznacza, że współcześnie występujące relacje kooperacyjne w Lyonie mogą ulec zmianie w wyniku dalszych przekształceń morfologicznych i instytucjonalnych. Wydaje się jednak, że mimo niezakończonego dotychczas procesu rewitalizacji terenów poprzemysłowych w południowej części Confluence, przede wszystkim w ramach projektu ZAC 2 (patrz rys. 6.12), nie nastąpi konwersja zidentyfikowanych relacji kooperacyjnych na inny rodzaj ze względu na zbyt duże zróżnicowanie morfologiczne i instytucjonalne starej i nowej, wciąż kształtowanej, przestrzeni centralnej miasta. 


\section{Rozdział 7}

\section{PRZEKSZTAŁCENIA ORGANIZACJI PRZESTRZENI CENTRALNEJ W ŁODZI}

Łódź jest położona w środkowej części Polski. Jest stolicą województwa łódzkiego i największym ośrodkiem w aglomeracji liczącej około 1,1 mln mieszkańców. W 2013 r. Łódź w granicach administracyjnych zamieszkiwało 718960 osób ${ }^{1}$. Dynamiczny wzrost przestrzenny i demograficzny miasta w XIX w. związany był z rozwojem przemysłu włókienniczego. W rezultacie, w zaledwie 100 lat Łódź urosła do rangi drugiego po Warszawie największego ośrodka miejskiego w Polsce. Podobnie jak Lyon, Łódź w literaturze często jest porównywana do Manchesteru. Porównanie to wydaje się być na wyrost, szczególnie ze względu zróżnicowaną strukturę przestrzenno-funkcjonalną obu miast oraz uwarunkowania geopolityczne i ekonomiczno-społeczne ich rozwoju. Niemniej, Łódź w XIX i w pierwszej połowie XX w. stanowiła szczególny przykład ośrodka przemysłowego w Europie Środkowo-Wschodniej, który odegrał istotną rolę w rozwoju gospodarczym Polski.

\subsection{Geneza przestrzeni centralnej w Łodzi}

Badania $\mathrm{w}$ zakresie przemian przestrzenno-funkcjonalnych $\mathrm{w}$ Łodzi zostały obszernie przedstawione w literaturze geograficznej. Prowadzili je m.in. M. Koter (1976, 1979, 1990, 2002, 2009, 2009a), M. Koter i D. Wiktorowska $(1974,1976)$, J. Kotlicka (2009), M. Piech (2004) i inni. Przeprowadzone studia morfologiczne pozwoliły wyróżnić cykl rozwojowy przestrzeni centralnej w Łodzi, który został przedstawiony poniżej.

Łódź uzyskała prawa miejskie w 1414 r. z inicjatywy kapituły włocławskiej. Nosiła wówczas nazwę Ostroga od nazwy rzeki, nad którą powstała. Jednak formalnoprawnej lokacji miasta dokonał dopiero król Władysław Jagiełło w roku 1423. W przywileju lokacyjnym miasto nosiło nazwę Łódź, która funkcjonuje

\footnotetext{
${ }^{1}$ Według stanu na 31.12.2012, Powierzchnia i ludność $w$ przekroju terytorialnym $w 2013 \mathrm{r}$,
} GUS. 
do dziś. Centralnym punktem średniowiecznej osady był kościół wzniesiony na tzw. Górce Plebejskiej. Świątynia i dobra proboszcza znajdowały się na rynku o kształcie zbliżonym do trapezu. Podobnie jak układ przestrzenny ówczesnego miasta, jego rozplanowanie wynikało z przebiegających przez osadę dróg o kierunku równoleżnikowym i południkowym. W XV w. szlak z Łęczycy do Krakowa poprowadzono przez wybudowany wówczas młyn na rzece Łódce. W późniejszym okresie przeprawa przez rzekę stanowiła istotny element nowego traktu piotrkowskiego wytyczonego na początku XIX w., i który następnie dał początek ulicy Piotrkowskiej. Wiejski charakter przedindustrialnej osady odzwierciedlała drewniana zabudowa. Jedynymi obiektami o publicznym charakterze w ówczesnym mieście były: szkoła parafialna, przytułek, nazywany szpitalem, oraz XVI-wieczny ratusz, również drewniany. Przestrzeń centralną ówczesnego miasta, a w zasadzie jej zalążek, można ograniczyć do obszaru przykościelnego, przy którym skoncentrowane były wymienione obiekty.

Geneza współczesnej przestrzeni centralnej Łodzi wiąże się z procesem uprzemysłowienia miasta w XIX w. Pomimo niespełna 200 lat obejmujących rozwój Łodzi jako dużego ośrodka miejskiego, proces kształtowania przestrzeni centralnej do 2013 r. można podzielić na cztery etapy:

Etap I - okres rozwoju miasta wczesnoprzemysłowego w latach 1818-1863;

Etap II - okres rozwoju miasta wielkoprzemysłowego od 1864 do zakończenia II wojny światowej w 1945 r.;

Etap III - okres rozwoju miasta socjalistycznego w latach 1946-1989;

Etap IV - okres miasta postsocjalistycznego, po upadku przemysłu włókienniczego od $1990 \mathrm{r}$.

Łódź, jako miasto wielkoprzemysłowe, rozwinęła się w uwarunkowaniach gospodarczych zdeterminowanych sytuacją geopolityczną Polski w XIX i na początku XX w. Od końca XVIII w. do zakończenia I wojny światowej dawne terytorium Rzeczpospolitej zostało podzielone pomiędzy trzy kraje ościenne: Prusy, Austrię i Rosję. Łódź znalazła się w granicach słabo rozwiniętego gospodarczo Cesarstwa Rosyjskiego. Władze zaborcze umożliwiły kształtowanie miasta przemysłowego, lecz ograniczały rozwój funkcji wielkomiejskich, co w istotny sposób determinowało sposób transformacji przestrzeni centralnej miasta. W tym kontekście XIX-wieczna industrializacja Łodzi odbiega znacząco od warunków, w jakich wzrastały przemysłowy Manchester w silnym ekonomicznie Imperium Brytyjskim oraz Lyon - w równie potężnej gospodarczo Francji.

Pierwszy etap kształtowania przestrzeni centralnej w Łodzi wiązał się z wytyczeniem traktu piotrkowskiego w latach 1818-1821. Stanowił on główną oś rozwojową miasta wczesnoprzemysłowego i z czasem połączył jego trzy niezależne jednostki przestrzenno-funkcjonalne: Stare i Nowe Miasto na północy, osadę Łódkę oraz osadę Nową Łódkę na południu. W północnej części ówczesnej Łodzi, czyli w tzw. Starym Mieście o średniowiecznej genezie, trakt został poprowadzony po zachodniej stronie rynku i kościoła wcześniejszej osady 
(pierwotnie przebiegał on od strony wschodniej), dalej na południe przez most na rzece Łódce w miejscu dawnego Młyna Grobelnego, następnie w linii prostej do mostu na rzece Jasień we wsi Wólka (rys. 7.1). Wzdłuż traktu, który w $1823 \mathrm{r}$. został przemianowany na ulicę Piotrkowską, zostały założone nowe jednostki morfogenetyczne, przeznaczone przede wszystkim na działalność przemysłową. Pierwszą z nich było Nowe Miasto. Prace związane z jego budową rozpoczęły się w roku 1823. Osadę zlokalizowano na wzniesieniu pomiędzy doliną Łódki oraz jej lewobrzeżnym dopływem. Nowe Miasto zostało wyznaczone na planie regularnego prostokąta, z prostokątną siatką ulic zawartą pomiędzy ulicami Północną, Zachodnią, Południową i Wschodnią. W jego centralnej części, na przecięciu traktu piotrkowskiego (ulicy Piotrkowskiej) oraz ulicy Średniej (współcześnie Legionów i Pomorskiej), wyznaczono ośmiokątny rynek. W jego południowej części wybudowano dwa bliźniacze w formie architektonicznej (w stylu klasycystycznym) obiekty, pełniące funkcje publiczne: ratusz i kościół ewangelicki

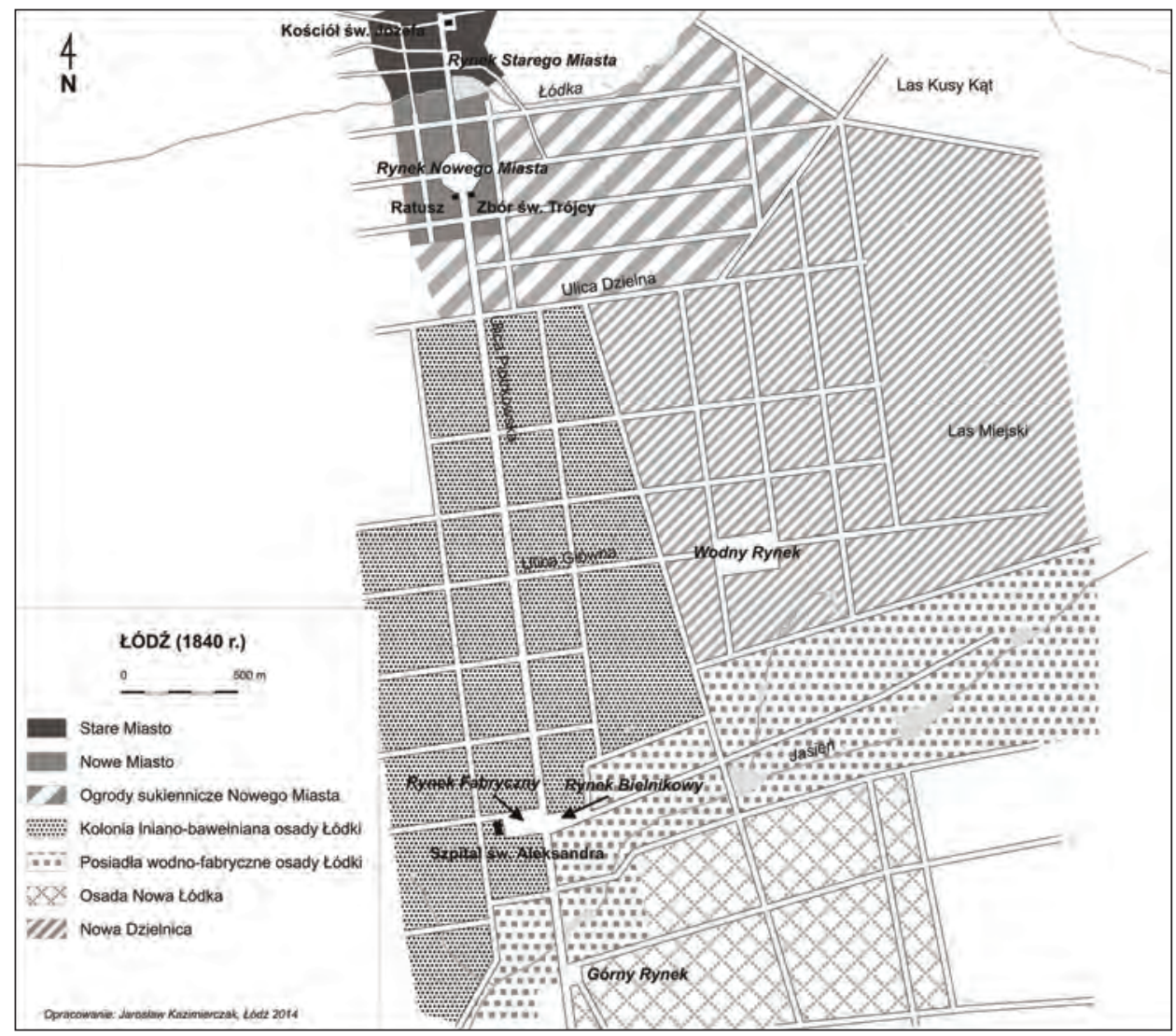

Rys. 7.1. Jednostki morfogenetyczne w przestrzeni centralnej Łodzi w $1840 \mathrm{r}$.

Źródło: opracowanie autora na podstawie M. Koter (2002) 
pw. św. Trójcy, przeznaczony dla osadników z krajów protestanckich. Stanowiły one swoistą bramę do miasta (rys. 7.1). W nowej przestrzeni centralnej rozwijającego się miasta powstały domy murowane, w odróżnieniu od drewnianej zabudowy w bocznych ulicach Nowego Miasta.

W roku 1824 rozpoczęto budowę nowej rękodzielniczo-manufakturowej osady lniano-bawełnianej o nazwie Łódka (rys. 7.1). Jej trzon był związany z rzeką Jasień, która stwarzała dogodne warunki do rozwoju zmechanizowanej wytwórczości lnianej i bawełnianej. Dodatkowo znajdował się na niej szereg młynów, których urządzenia spiętrzające i koła wodne były z powodzeniem adaptowane na potrzeby przemysłowe. Wzdłuż rzeki Jasień wytyczono obszerną strefę produkcyjną, tzw. posiadła wodno-fabryczne, które rozciągały się od wsi Widzew na wschodzie po ulicę Wólczańską na zachodzie (rys. 7.1). Strefa posiadeł wodno-fabrycznych pozostawała jednak niezintegrowana z osadą sukienniczą Nowego Miasta i ze Starym Miastem. W celu ich połączenia w jeden organizm urbanistyczny, pomiędzy ulicą Dzielną (współcześnie Narutowicza) na północy i doliną Jasienia na południu, wyznaczono w 1825 r. kolonię rękodzielniczą dla tkaczy wyrobów lnianych i bawełnianych oraz osadę prządniczą (rys. 7.1).

Trzecią jednostkę morfogenetyczną wczesnoprzemysłowej Łodzi tworzyła kolonia prządnicza przeznaczona dla osadników czeskich i niemieckich - Nowa Łódka. Jej osią była ulica Zarzewska (współcześnie Przybyszewskiego), którą w środkowej części przecinała ulica Widzewska (aktualnie Kilińskiego). U zbiegu ulicy Zarzewskiej z traktem piotrkowskim wyznaczono centralny plac nowej jednostki przestrzennej, tzw. Górny Rynek (dziś plac Reymonta). Układ pozostałych ulic w Nowej Łódce został dostosowany do przebiegu dwóch głównych, czyli Zarzewskiej i Widzewskiej, co w rezultacie spowodowało ich odchylenie w odniesieniu do traktu piotrkowskiego (rys. 7.1). W 1827 r. nastąpiło powiększenie zagospodarowanych terenów miasta o kolonię Ślązaki (Szlezyng).

W wyniku dynamicznego rozwoju miasta w 1840 r. powiększono obszar Łodzi o 534 ha poprzez utworzenie tzw. Nowej Dzielnicy (rys. 7.1). Nowa jednostka morfologiczna zająła obszar lasu rządowego, wypełniając lukę pomiędzy Nowym Miastem i jego ogrodami sukienniczymi na północy oraz osadą Łódką (posiadłami wodno-fabrycznymi) na południu. Układ przestrzenny Nowej Dzielnicy był dostosowany do prostokątnego układu ulic Nowego Miasta oraz kolonii lniano-bawełnianej wzdłuż ulicy Piotrkowskiej. Centralnym elementem morfologicznym nowej jednostki przestrzenno-funkcjonalnej był Wodny Rynek, zlokalizowany na przecięciu dwóch najważniejszych ulic dzielnicy - Głównej i Targowej. Był to największy plac miejski ówczesnej Łodzi o powierzchni 5,6 ha. Ze względu na swoją powierzchnię stał się dogodnym miejscem do rozwoju handlu i miejscem licznych zgromadzeń. Wodny Rynek wraz z pierwszym w Łodzi publicznym parkiem (Źródliska) stał się jedną z najważniejszych przestrzeni publicznych miasta. Ze względu jednak na peryferyjne położenie, brak lokalizacji 
instytucji wielkomiejskich i słabe zintegrowanie z ulicą Piotrkowską nie rozszerzył istniejącej przestrzeni centralnej wczesnoprzemysłowej Łodzi.

Kluczowym elementem przestrzeni centralnej w Łodzi w pierwszym okresie jej kształtowania była ulica Piotrkowska. Mimo że łączyła ona trzy najstarsze jednostki przestrzenno-funkcjonalne Łodzi, nie przyczyniła się do ich integracji. Skutkowało to ich niezależnym względem siebie rozwojem. Wzdłuż ulicy Piotrkowskiej zlokalizowane były wszystkie place miejskie wczesnoprzemysłowej Łodzi, za wyjątkiem Wodnego Rynku (rys. 7.1). Najbardziej reprezentacyjnym był rynek nowomiejski o oryginalnym ośmiobocznym kształcie, przy którym znajdował się ratusz i kościół ewangelicki. Poza tymi obiektami fizjonomia przestrzeni centralnej w Łodzi wczesnoprzemysłowej miała małomiasteczkowy charakter. Na północ od rynku Nowego Miasta zlokalizowany był rynek staromiejski. Na południu, w Łódce były to natomiast Rynek Bielnikowy, o powierzchni 1,3 ha, Rynek Fabryczny - największy przy ulicy Piotrkowskiej o powierzchni 2,74 ha, oraz Rynek Górny o powierzchni 0,66 ha (rys. 7.1). W późniejszym okresie na południowym krańcu ulicy Piotrkowskiej wyznaczono plac Niepodlegości, którego powierzchnia wynosi 3,83 ha.

W przeciwieństwie do pierwszego etapu kształtowania przestrzeni centralnej, który miał charakter procesu odśrodkowego, drugi etap w okresie rozwoju wielkoprzemysłowej Łodzi odznaczał się rozwojem dośrodkowym. Związany był on przede wszystkim z gwałtownie wzrastającą liczbą ludności miasta (rys. 7.2). Istotnym czynnikiem miastotwórczym była także budowa kolei warszawsko-wiedeńskiej, do której w 1865 r. przyłączono „łódzką kolej fabryczną” poprzez stację w Koluszkach. Umożliwiła ona usprawnienie oraz obniżenie kosztów transportu surowców i gotowych wyrobów, co w konsekwencji spowodowało dalszy rozwój przemysłu włókienniczego w Łodzi. Negatywnym skutkiem wytyczenia linii kolejowej przez środek Nowej Dzielnicy, wykazującej pierwotnie spójność przestrzenno-funkcjonalną, było natomiast stworzenie kolejnej, obok doliny Łódki na północy i Jasienia na południu, bariery przestrzenno-funkcjonalnej ograniczającej rozwój miasta (rys. 7.3). Szeroki pas zajęty przez tereny kolejowe przeznaczony był na funkcje nietypowe dla obszaru śródmiejskiego, głównie ekstensywnie użytkowane tereny składowe i magazynowe. Budowa linii kolejowej w środkowej części miasta wiązała się z radykalnymi przekształceniami morfologicznymi, niekorzystnymi z punktu widzenia rozwoju przestrzeni centralnej w późniejszych okresach wzrostu Łodzi.

Wybudowanie dworca kolejowego Łódź Fabryczna w 1868 r. spowodowało rozwój terenów położonych w północnej części Nowej Dzielnicy, która zyskała wielkomiejski charakter zabudowy. Na północ od dworca powstał Rynek Targowy (nazywany także Cegielnianym, współcześnie jest to plac Dąbrowskiego o powierzchni 3,19 ha), który pierwotnie miał zostać połączony z Wodnym Rynkiem na południu ulicami Targową i Wodną. W konsekwencji budowy linii kolejowej nie nastąpiła jednak ich planowana integracja przestrzenna (rys. 7.3). Bliskie położenie Dworca Fabrycznego względem obu rynków predestynowało 


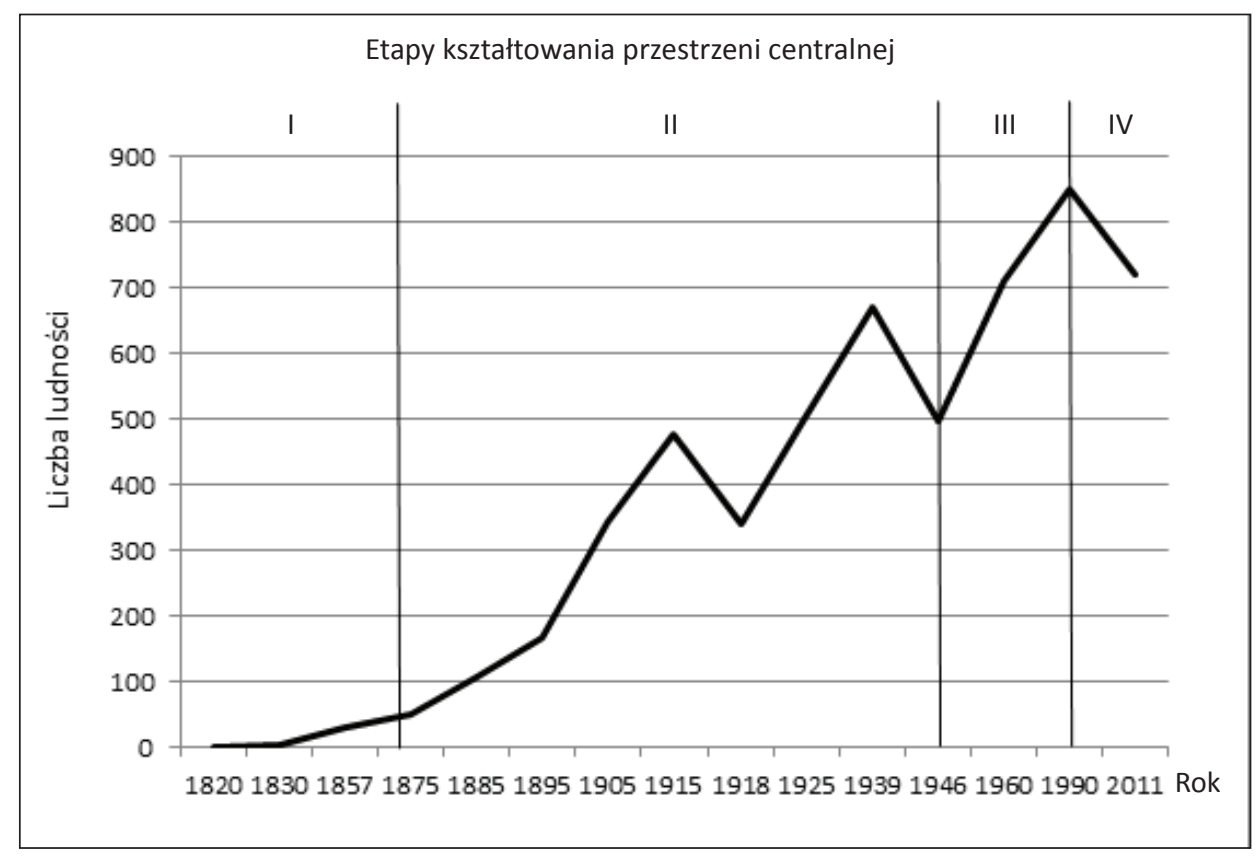

Rys. 7.2. Zmiany liczby ludności wobec etapów kształtowania przestrzeni centralnej w Łodzi w latach 1820-2011

Źródło: opracowanie autora na podstawie S. Liszewski (1992)

ten rejon Łodzi do ekspansji przestrzeni centralnej. Decydowało o tym sąsiedztwo ulicy Piotrkowskiej, która stopniowo nabierała charakteru reprezentacyjnej ulicy wielkomiejskiej, mimo lokalizacji wzdłuż niej (w podwórzach) zakładów produkcyjnych. W latach 90. XIX w. przy ulicy Piotrkowskiej znajdowały się najbardziej okazałe budynki w Łodzi. W 1907 r. na terenach położonych na południe od Dworca Fabrycznego wybudowano pierwszą miejską elektrownię, na co wpływ miała łatwość dowozu węgla przebiegającą obok linią kolejową. Inwestycja ta ostatecznie zahamowała sukcesję funkcji wielkomiejskich w tej części miasta i zadecydowała o jej ekstensywnym sposobie użytkowania aż do początku XXI w.

Oprócz ulicy Piotrkowskiej w okresie Łodzi wielkoprzemysłowej istniały trzy reprezentacyjne ulice. Pierwszą z nich była ulica Spacerowa (współcześnie jest to północna część alei Kościuszki), która powstała w latach 70. XIX w. wraz z wytyczeniem Dzielnicy Wiązowej (rys. 7.3). Była to szeroka ulica z zadrzewionymi terenami spacerowymi po środku. Wzdłuż niej wznosiły się okazałe kamienice i obiekty użyteczności publicznej (rys. 7.3). Ulica Dzielna (współcześnie Narutowicza) to druga ulica charakteryzująca się wielkomiejską zabudową w okresie Łodzi wielkoprzemysłowej. W jej sąsiedztwie znajdowały się instytucje kultury, hotel Palast oraz dwie z trzech łódzkich cerkwi. Łączyła ona ulicę Piotrkowską z Rynkiem Targowym (rys. 7.3). Trzecią reprezentacyjną ulicą XIX-wiecznej Łodzi był tzw. Pasaż Mayera 
(współcześnie ulica Moniuszki). Była to prywatna ulica śródmiejska o ujednoliconej zabudowie willowej wybudowana w latach 1883-1885 przez łódzkiego fabrykanta Ludwika Mayera. Jako pierwsza w Łodzi zyskała oświetlenie. Przeznaczona była dla grupy nowych urzędników, która miała pojawić się w Łodzi wraz z przeniesieniem siedziby władz guberni z Piotrkowa Trybunalskiego. Nigdy nie doszło do tego transferu, jednak wybudowanie Pasażu przyczyniło się do pozytywnych przemian przestrzenno-funkcjonalnych $\mathrm{w}$ jego bezpośrednim sąsiedztwie, związanych m.in. $\mathrm{z}$ budową w $1888 \mathrm{r}$. najbardziej luksusowego łódzkiego hotelu - Grand Hotelu.

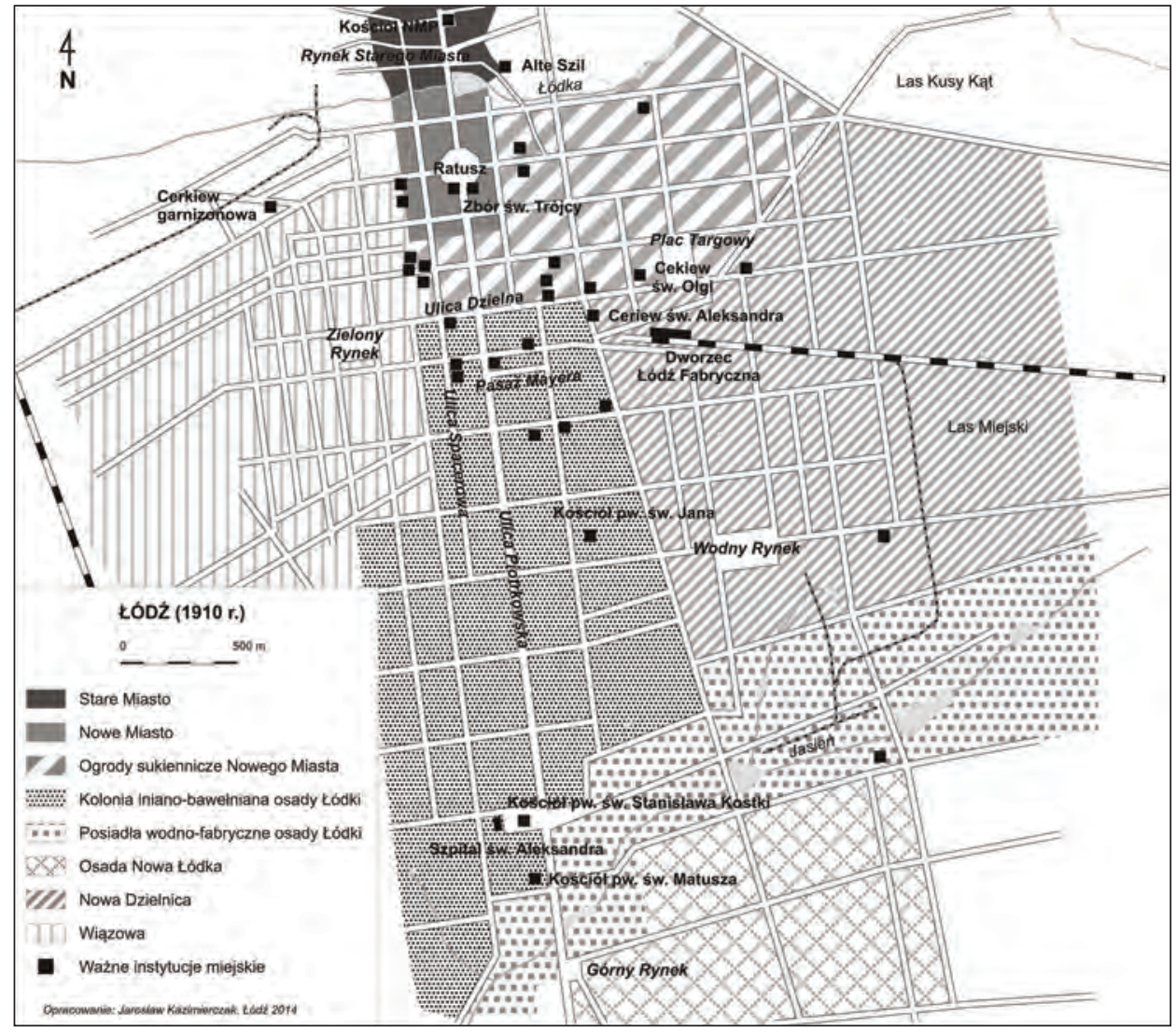

Rys. 7.3. Jednostki morfogenetyczne w przestrzeni centralnej Łodzi w $1910 \mathrm{r}$.

Źródło: opracowanie autora na podstawie M. Koter (2002) i J. Wesołowski (2002)

Przed zakończeniem I wojny światowej Łódź charakteryzowała się bardzo ubogim życiem kulturalnym, co wynikało z bardzo spolaryzowanego społeczeństwa $^{2}$ i braku wykształconych tradycji kulturalnych mieszkańców miasta.

${ }^{2}$ Na początku XX w. $60 \%$ mieszkańców Łodzi było analfabetami (Jewtuchowicz i Suliborski 2009). 
Tworzeniu instytucji kultury nie sprzyjała także izolacja grup narodowościowych zamieszkujących ówczesną Łódź. Wśród ważniejszych instytucji można wskazać kilka mniejszych teatrów żydowskich i niemieckich (np. Thalia przy ulicy Dzielnej) oraz polski teatr Victoria (przy ulicy Piotrkowskiej). W 1915 r. powstała Filharmonia Łódzka, a koncerty odbywały się w sali przy ulicy Dzielnej (w roku 1948 Filharmonia zyskała stałą siedzibę). W okresie międzywojennym działały w Łodzi cztery muzea i trzy galerie sztuki. Najsłynniejsze z nich było Muzeum Historii i Sztuki im. J. i K. Bartoszewiczów utworzone w 1930 r. (późniejsze Muzeum Sztuki), w którego zbiorach znajdowały się jedne z najcenniejszych światowych dzieł sztuki XIX w. i sztuki modernistycznej. Jego siedziba mieściła się początkowo w dawnym ratuszu przy Placu Wolności (Rynku Nowego Miasta).

Mimo dynamicznego rozwoju przestrzennego i ludnościowego, Łódź do czasu zakończenia I wojny światowej nie pełniła funkcji administracyjnych. Brak nowych instytucji centrotwórczych przyczynił się do stagnacji rozwoju przestrzeni centralnej. Ograniczała się ona do kwartałów przylegających do ulicy Piotrkowskiej, głównie w jej północnej części (pomiędzy ulicą Główną i Rynkiem Nowego Miasta), oraz do mniejszych enklaw lokalizacji instytucji publicznych wzdłużulicy Spacerowej i Dzielnej (rys. 7.3). Drugi etap kształtowania przestrzeni centralnej w Łodzi był silnie związany z rozmieszczeniem świątyń katolickich, ewangelickich i w mniejszym stopniu także cerkwi oraz synagog (rys. 7.3). W 1912 r. zakończono budowę największego łódzkiego kościoła pw. św. Stanisława Kostki znajdującego się na dawnym Placu Fabrycznym ${ }^{3}$ (por. rys. 7.1 i 7.3).

W okresie międzywojennym Łódź uzyskała nowe funkcje miastotwórcze, przede wszystkim administracyjne, co wiązało się z odzyskaniem przez Polskę niepodległości. W 1919 r. utworzono województwo łódzkie, w 1920 r. powstała diecezja łódzka, a w roku 1921 utworzono garnizon łódzki Wojska Polskiego. W efekcie uzyskania statusu stolicy województwa oraz rosnących ambicji metropolitalnych w okresie międzywojennym wzniesiono w Łodzi około 20 reprezentacyjnych obiektów publicznych, które były skoncentrowane w trzech strefach. Pierwszą z nich był Plac Dąbrowskiego (dawny Rynek Targowy), przy którym w latach 1927-1932 powstał monumentalny budynek Sądu Okręgowego. W jego sąsiedztwie, przy ulicy Narutowicza zlokalizowano Dom Związków, Pocztową Kasę Oszczędności, gmach Sądu Grodzkiego i biurowiec Dyrekcji Wodociągów i Kanalizacji (obecnie zajmowany przez Rektorat Uniwersytetu Łódzkiego). Drugim rejonem lokalizacji instytucji centralnych było zachodnie otoczenie Dworca Fabrycznego. Przy ulicy Sienkiewicza w latach 1924-1926 powstał gmach Banku Związków Spółek Zarobkowych, natomiast przy ulicy Moniuszki (dawnym Pasażu Mayera) w latach 1934-1939 wybudowano obiekt

${ }^{3}$ Wieża kościoła została ukończona w 1927 r. i tym samym świątynia stała się najwyższym obiektem w Łodzi (do dziś). W 1989 r. kościół został podniesiony do rangi bazyliki mniejszej, a w roku 1992 - po utworzeniu archidiecezji łódzkiej - do rangi archikatedry. 
Polskiego Chrześcijańskiego Stowarzyszenia Młodzieży Męskiej (YMCA). W roku 1935, przy ulicy Strzeleckiej (współcześnie Traugutta) rozpoczęto budowę reprezentacyjnego obiektu kulturalnego, tzw. Domu Pomnika Marszałka Józefa Piłsudskiego (od 1953 r. mieści się w nim Łódzki Dom Kultury). Trzecim obszarem koncentracji nowych instytucji publicznych była aleja Kościuszki (dawniej ulica Spacerowa). W latach 1923-1928 wybudowano przy niej budynek Banku Gospodarstwa Krajowego, w latach 1927-1929 - gmach Łódzkiej Izby Skarbowej oraz Polskiej Akcyjnej Spółki Telefonicznej, w latach 1929-1932 wzniesiono natomiast budynek Powszechnego Zakładu Ubezpieczeń Społecznych. W dwudziestoleciu międzywojennym utrwalony został zatem sposób organizacji przestrzeni centralnej ukształtowany w okresie Łodzi wielkoprzemysłowej, obejmując ulicę Piotrkowską z ulicą Moniuszki (dawnym Pasażem Mayera), aleję Kościuszki oraz ulicę Narutowicza wraz z Placem Dąbrowskiego (dawnym Placem Targowym).

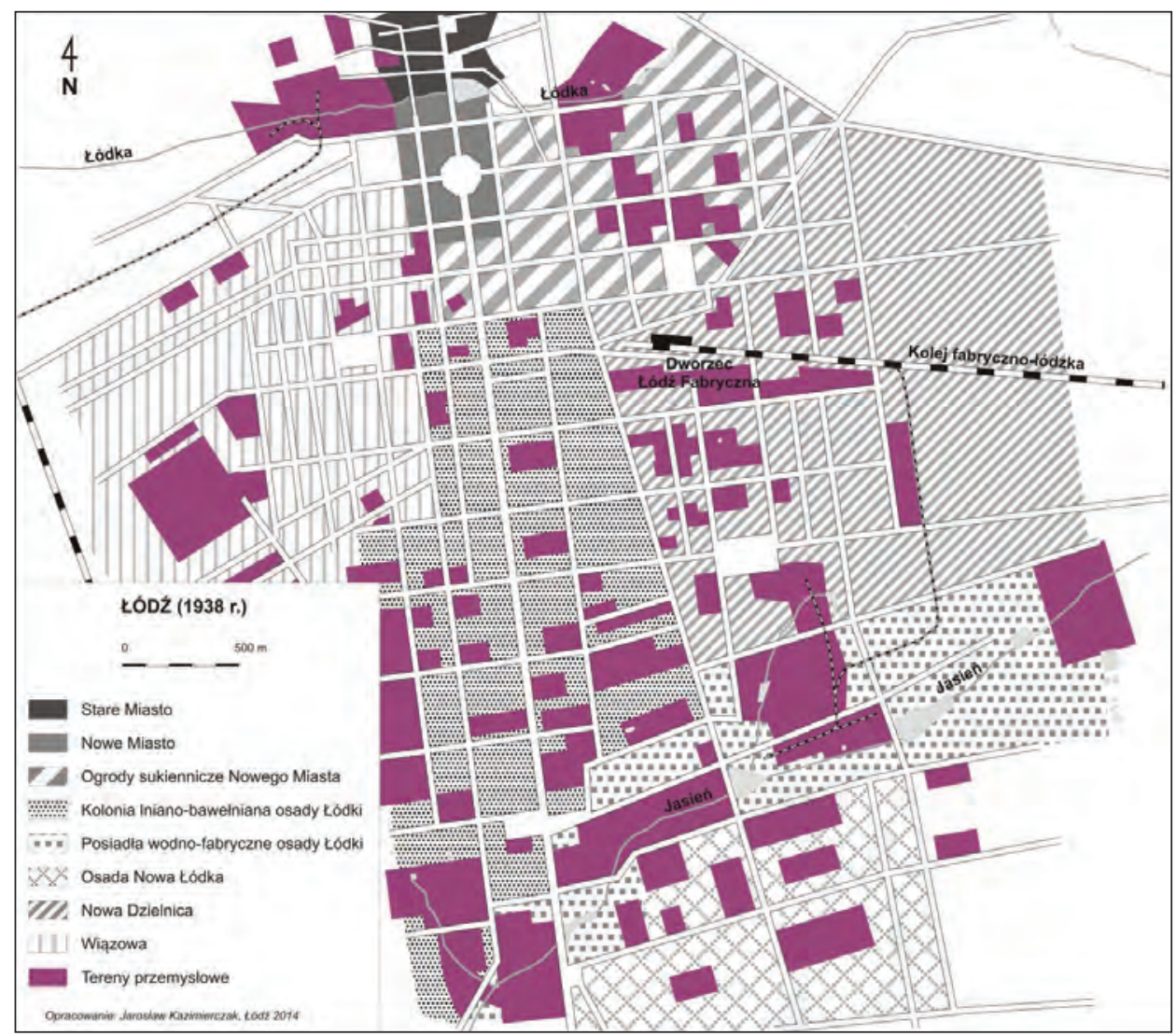

Rys. 7.4. Rozmieszczenie terenów przemysłowych w dzielnicy śródmiejskiej w Łodzi w $1938 \mathrm{r}$.

Źródło: opracowanie autora na podstawie M. Piech (2002) 
W latach 30. XX w. został ostatecznie wyznaczony zasięg współczesnej dzielnicy śródmiejskiej, który obejmuje tereny znajdujące się wewnątrz kolei obwodowej. Ukształtowany do tego czasu mozaikowy charakter rozmieszczenia obiektów usługowych, mieszkaniowych, przemysłowych, komunikacyjnych i rekreacyjnych $\mathrm{w}$ śródmieściu Łodzi był konsekwencją niekontrolowanego rozwoju miasta od lat 60. XIX w. do końca lat 30. XX w. W roku 1938 tereny przemysłowe były skoncentrowane głównie $\mathrm{w}$ trzech rejonach śródmiejskich: przy dworcach kolejowych (Fabrycznym i Kaliskim), na posiadłach wodno-fabrycznych oraz na terenach dawnych ogrodów sukienniczych Nowego Miasta (rys. 7.4). Ponadto, poszczególne jednostki morfogenetyczne bądź ich mniejsze części były od siebie odizolowane w wyniku przebiegu barier przestrzenno-funkcjonalnych w postaci doliny rzeki Łódki i Jasieni oraz przez linię kolei fabrycznej. Tak ukształtowana struktura morfologiczna miasta nie sprzyjała rozwojowi przestrzeni centralnej w pierwszych dwóch etapach procesu jej kształtowania.

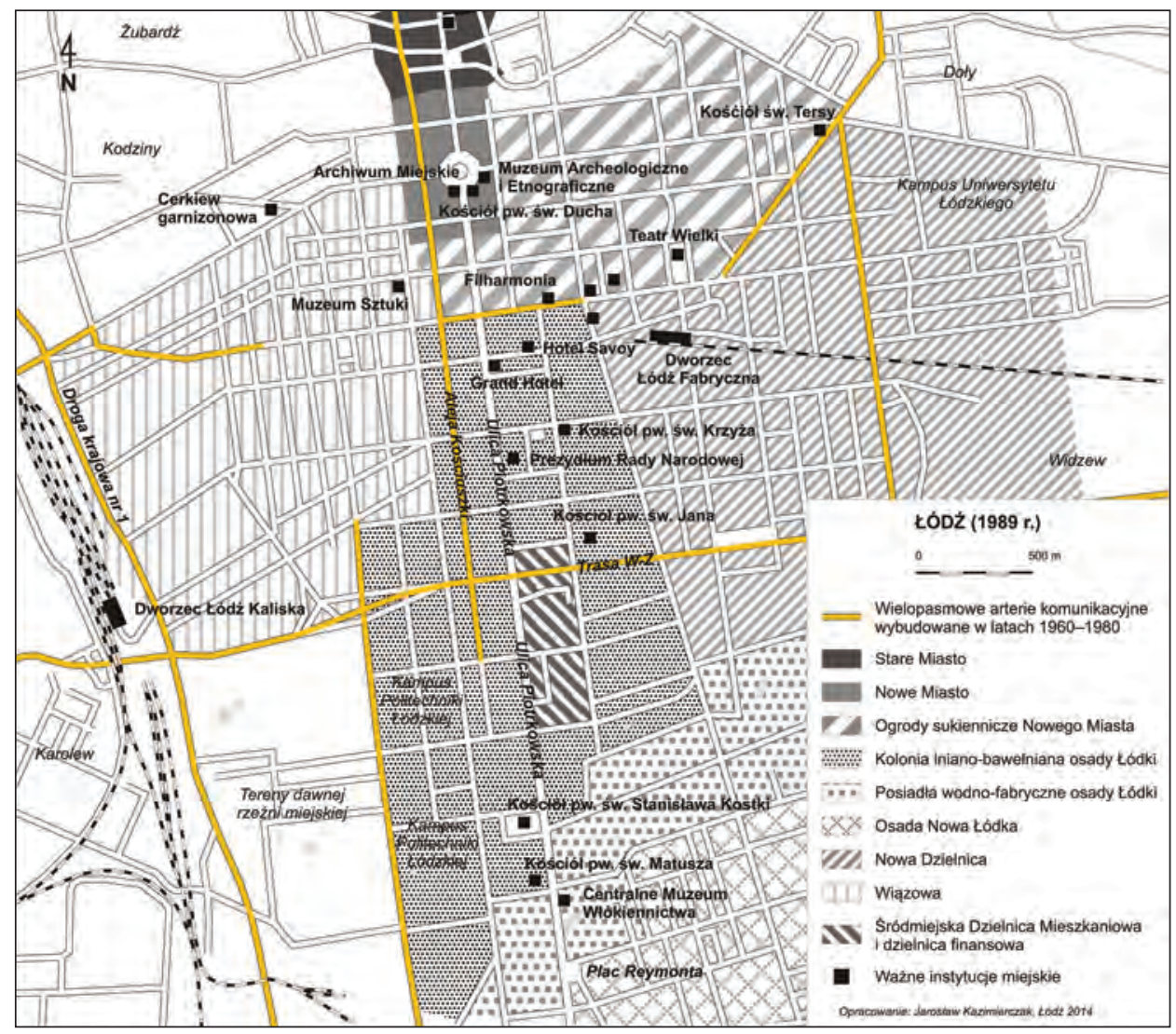

Rys. 7.5. Jednostki morfogenetyczne w przestrzeni centralnej Łodzi w 1989 r.

Źródło: badania własne autora 
W okresie powojennym, w latach 1946-1989, słabo rozwinięta przestrzeń centralna w Łodzi, która posiadała charakter liniowo-enklawowy, została przekształcona przez nowe władze socjalistyczne według modernistycznych koncepcji budowy miast z uprzywilejowaną komunikacją indywidualną. Budowa wielkich arterii komunikacyjnych zwiększyła istniejącą dezintegrację śródmiejskich jednostek morfogenetycznych, w których rozwijała się przestrzeń centralna przed wybuchem II wojny światowej. W latach 70 . XX w. aleja Kościuszki i ulica Narutowicza zostały podporządkowane transportowi samochodowemu oraz rozbudowywanej komunikacji tramwajowej. Ulica Piotrkowska została natomiast wyraźnie podzielona na odmiennie użytkowaną część północną i południową w wyniku budowy Trasy Wschód-Zachód (rys. 7.5). Inwestycji towarzyszyła transformacja kwartałów położonych pomiędzy współczesnymi ulicami Piotrkowską, Roosvelta, Sienkiewicza i Brzeźną, w wyniku której powstała Śródmiejska Dzielnica Mieszkaniowa oraz łódzka dzielnica biznesu (rys. 7.5). Odznaczają się one zdecydowanie odmienną fizjonomią w stosunku do zabudowy historycznej dzielnicy śródmiejskiej (fot. 7.1 i 7.2). W rezultacie przekształceń przestrzenno-funkcjonalnych w okresie powojennym do roku 1989 nastąpiła recesja przestrzeni centralnej w Łodzi oraz jej rozproszenie, które utrudniło identyfikację wielkomiejskiego centrum.

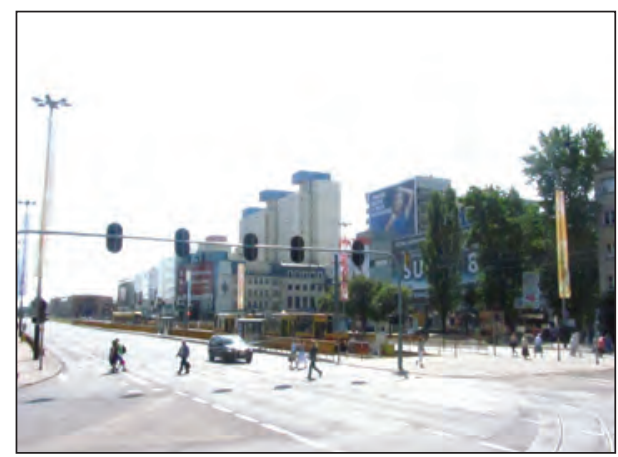

Fot. 7.1. Zabudowa Śródmiejskiej Dzielnicy Mieszkaniowej w Łodzi

Źródło: fotografia autora

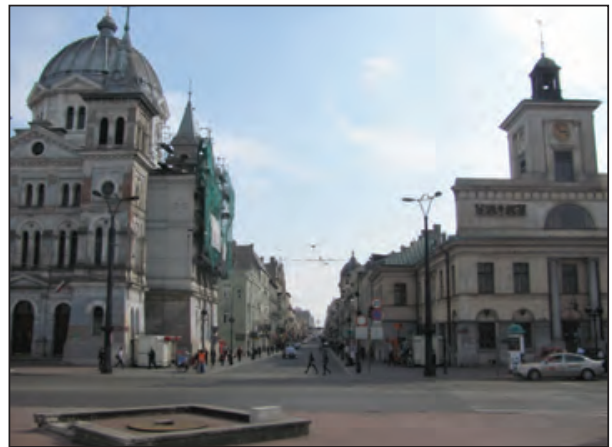

Fot. 7.2. Historyczna zabudowa placu Wolności i ulicy Piotrkowskiej

Źródło: fotografia autora

W odróżnieniu od wielu innych polskich miast, Łódź nie została zniszczona w trakcie II wojny światowej, co paradoksalnie miało pejoratywny wpływ na zachowanie substancji materialnej historycznie ukształtowanej przestrzeni centralnej miasta. W innych polskich miastach zniszczenia wojenne stały się czynnikiem determinującym odbudowę zabytkowych centrów zgodnie z tzw. „polską szkołą konserwatorską". W Łodzi natomiast XIX-wieczne kamienice wielkomiejskie były sukcesywnie wyburzane i zastępowane obiektami modernistycznymi. Historyczna zabudowa śródmiejska została także objęta tzw. „luką remontową", co w rezultacie doprowadziło m.in. jej degradacji. 
W okresie powojennym dzielnica śródmiejska Łodzi nie została wzbogacona o istotną liczbę reprezentacyjnych obiektów użyteczności publicznej. W latach 1953-1955 przy ulicy Sienkiewicza i Narutowicza wybudowano w stylu socrealistycznym najwyższy łódzki wieżowiec Centrali Tekstylnej liczący szesnaście kondygnacji. Znalazł w nim również swoją siedzibę pierwszy regionalny oddział Telewizji Polskiej. Wśród innych ważniejszych obiektów administracyjnych można wskazać przede wszystkim budynek Wojewódzkiej Rady Narodowej, który stanowił przedłużenie (w stronę północną) pałacu Izraela Poznańskiego oraz nowe zabudowania Prezydium Rady Narodowej miasta Łodzi, które powstały na wschód od pałacu Juliusza Heinzla przy ulicy Piotrkowskiej. Ich budowa wiązała się z powstaniem placu Komuny Paryskiej, od wschodniej strony budynków Prezydium (współcześnie Rady Miejskiej), który miał pełnić rolę reprezentacyjnej przestrzeni publicznej miasta. W rzeczywistości jednak nigdy takiej rangi nie zyskał.

Wśród instytucji publicznych związanych z kulturą i sztuką, funkcjonujących w Łodzi w okresie socjalistycznym obok Muzeum Sztuki (które zlokalizowano w nowej siedzibie przy ulicy Więckowskiego, w dawnym pałacu Maurycego Poznańskiego) wymienić należy: Muzeum Archeologiczne i Etnograficzne, Muzeum Przyrodnicze, Centralne Muzeum Włókiennictwa, które powstało w dawnej fabryce Ludwika Geyera (tzw. „białej fabryce”) przy ulicy Piotrkowskiej, Muzeum Miasta Łodzi w pałacu Izraela Poznańskiego (współcześnie Muzeum Historii Miasta Łodzi), filharmonię łódzką oraz Teatr Wielki, którego gmach powstał $1967 \mathrm{r}$. na placu Dąbrowskiego, po 18 latach budowy (rys. 7.5). Wskazane instytucje zlokalizowane zostały przede wszystkim w kwartałach przylegających do ulicy Piotrkowskiej oraz ulicy Narutowicza, co odpowiadało ukształtowanemu wcześniej liniowo-enklawowemu charakterowi przestrzeni centralnej w Łodzi.

Nowym elementem w przestrzeni centralnej Łodzi, wprowadzonym w okresie rozwoju miasta socjalistycznego, były domy handlowe: „Central”, „Uniwersal” oraz „Magda”. Od lat 60. do końca lat 80. XX w. były to obiekty o ponadlokalnym zasięgu. Wszystkie zostały zlokalizowane w bezpośrednim sąsiedztwie ulicy Piotrkowskiej, zarówno w jej północnej, jak i południowej części.

$\mathrm{W}$ pierwszych trzech etapach rozwoju przestrzeni centralnej w Łodzi nie zostało ukształtowane czytelne centrum miasta. Śródmieście było zdegradowane i podporządkowane funkcji mieszkaniowej, produkcyjnej i komunikacyjnej. Stanowiło ono konglomerat terenów zabudowy usługowej, mieszkaniowej i przemysłowo-składowej. Brakowało w niej atrakcyjnej przestrzeni publicznej. Powszechnie występowały także niezagospodarowane działki, będące m.in. efektem rozbudowy nowych szerokich arterii komunikacyjnych bądź innych niedokończonych inwestycji, związanych z wyburzeniami XIX-wiecznej zabudowy śródmiejskiej. W wyniku kształtowania przestrzeni centralnej w latach 18181989 nie nastąpiła integracja najstarszych śródmiejskich jednostek osadniczych. Dodatkowo rozwój terenów komunikacyjnych spowodował dezintegrację ulicy Piotrkowskiej stanowiącej rdzeń rozwojowy przestrzeni centralnej w Łodzi. 


\subsection{Przestrzeń centralna w Łodzi przed rewitalizacją}

Na przełomie lat 80. i 90. XX w. nastąpił proces transformacji ustrojowej i gospodarczej w Polsce. Przejście z gospodarki centralnie planowanej do wolnorynkowej przyniosło daleko idące konsekwencje dla łódzkiej monokultury włókienniczej, której egzystencja od roku 1945 opierała się głównie na eksporcie gotowych wyrobów do Związku Radzieckiego. W wyniku utraty wschodniego rynku zbytu łódzki przemysł włókienniczy w szybkim tempie podlegał recesji, aż ostatecznie upadł jeszcze w latach 90 . XX w. Dawne obiekty przemysłowe zajmujące znaczną część obszaru śródmiejskiego w Łodzi (rys. 7.6) zostały opuszczone i ulegały degradacji. Część z nich została wyburzona, kolejne natomiast były dzierżawione przez mniejsze zakłady usługowe lub produkcyjne. Towarzyszyła im zdekapitalizowana XIX-wieczna zabudowa śródmiejska przeznaczona w istotnej części

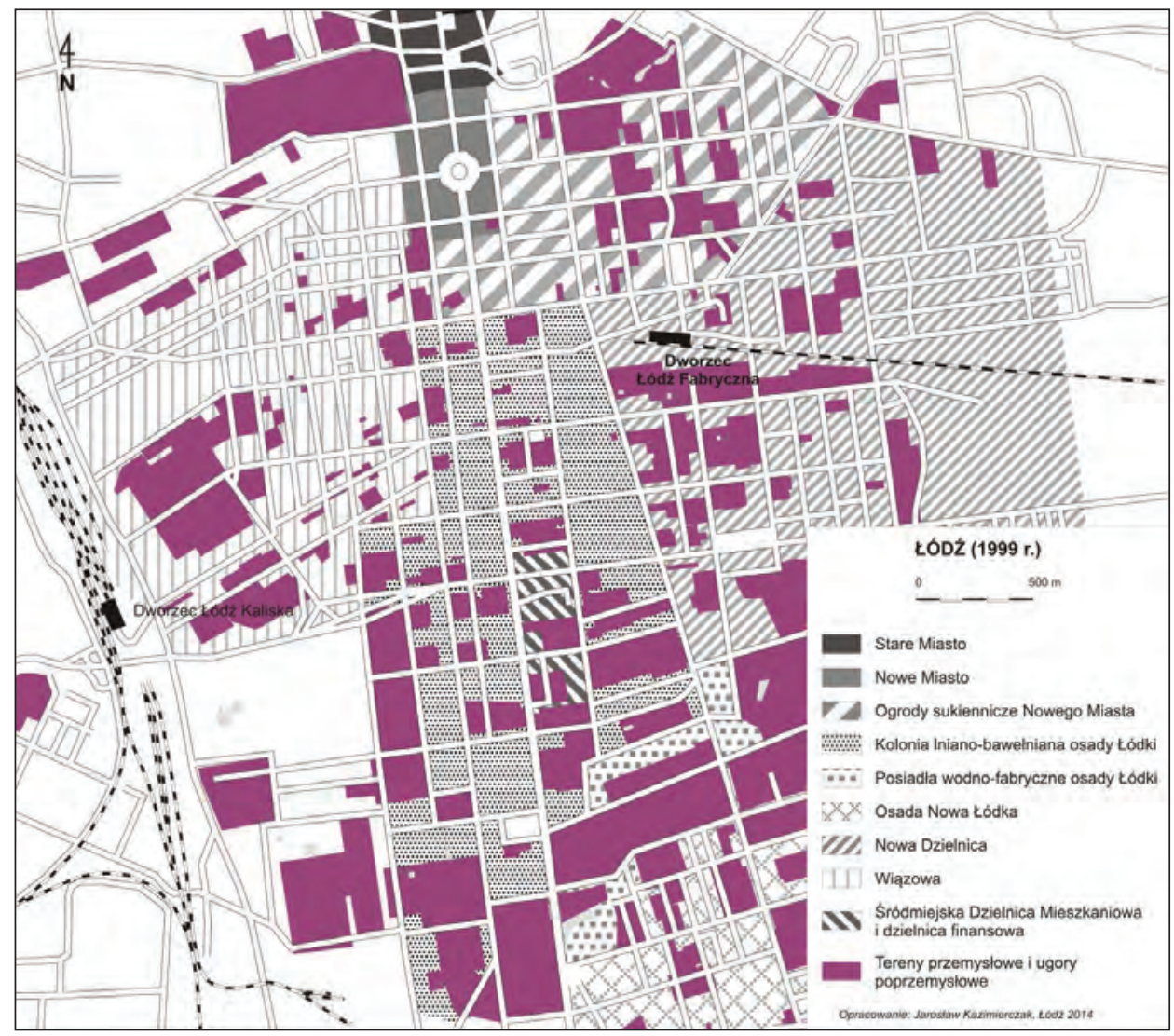

Rys. 7.6. Rozmieszczenie terenów przemysłowych i poprzemysłowych względem jednostek morfogenetycznych w śródmieściu Łodzi (stan na 1999 r.)

Źródło: badania własne autora 
na mieszkania komunalne. Dzielnica śródmiejska w latach 90. XX w. stanowiła synonim upadku wielkiego miasta przemysłowego, podobnie jak miało to miejsce w Manchesterze w latach 60. i 70. XX w.

Przestrzeń centralna w Łodzi w latach 90. XX w. i na początku XXI w. nadal pozostawała ograniczona do ulicy Piotrkowskiej, wzdhuż której zlokalizowanych było większość instytucji publicznych w mieście. W połowie lat 90 . XX w. północny fragment ulicy Piotrkowskiej, położony pomiędzy Placem Wolności i alejami Mickiewicza i Piłsudskiego (czyli Trasą W-Z), poddano modernizacji, przekształcając ją w reprezentacyjny ciąg pieszo-kołowy (fot. 7.3). Mieściły się przy niej najbardziej prestiżowe sklepy w mieście, liczne restauracje, puby i kluby nocne, dzięki czemu stała się ona miejscem koncentrującym społeczne życie miasta w ciągu dnia i w nocy, szczególnie w weekendy. Ze względu na lokalizację wielu z najcenniejszych łódzkich zabytków, ulica Piotrkowska była uważana za wizytówkę miasta, rozpoznawaną w całej Polsce jako główna atrakcja turystyczna Łodzi. Liniowa forma przestrzeni centralnej Łodzi została na początku XXI w. wzbogacona o nowy element morfologiczno-funkcjonalny w postaci galerii handlowej („Galeria Łódzka”) zlokalizowanej na dawnych terenach przemysłowych przy skrzyżowaniu ulicy Sienkiewicza i alei Piłsudskiego (por. rys. 7.6 i 7.7).

Szczególnie istotną cechą odzwierciedlającą charakter przestrzeni centralnej Łodzi na przełomie XX i XXI w. był brak reprezentacyjnego placu miejskiego. W okresie socjalistycznym władze miasta próbowały taką przestrzeń stworzyć poprzez budowę placu Komuny Paryskiej. Jednak wzrastające zapotrzebowanie na miejsca parkingowe $\mathrm{w}$ mieście spowodowało przeznaczenie tego placu na parking. W pewnym stopniu funkcję przestrzeni reprezentacyjnej spełniała ulica Piotrkowska, szczególnie po przeprowadzonej modernizacji. Za namiastkę tego typu przestrzeni miejskiej w Łodzi można także uznać plac Katedralny, noszący aktualnie imię Jana Pawła II, zlokalizowany przed archikatedrą łódzką (fot. 7.4). O jego reprezentacyjnym charakterze świadczy ranga świątyni oraz lokalizacja Grobu Nieznanego Żołnierza, który wybudowano w latach 20. XX w. Pozostałe place miejskie, które ze względu na położenie w układzie morfologicznym miasta oraz fizjonomię mogłyby pełnić rolę reprezentacyjnej przestrzeni miasta, w latach 90. XX w. zostały w znakomitej większości podporządkowane potrzebom komunikacyjnym mieszkańców Łodzi. Przykład mógł stanowić przekształcony w parking Plac Dąbrowskiego, przy którym znajduje się Teatr Wielki oraz gmach Sądu Apelacyjnego (fot. 7.5). Innym placem, który ze względu na zajmowaną powierzchnię oraz położenie w układzie miejskim mógłby pełnić funkcje reprezentacyjną miasta, jest Plac Wolności (fot. 7.6). Jednak od momentu jego wybudowania w roku $1823 \mathrm{w}$ ramach Nowego Miasta (jako rynek nowomiejski) pełni on przede wszystkim funkcję komunikacyjną, a pierwotnie także handlową.

Przestrzeń centralna w Łodzi od początku XIX do końca XX w. cechowała się okresami transgresji i regresji w zależności od pojawiających się nowych czynników zewnętrznych i wewnętrznych o charakterze konstruktywnym lub destruktywnym. 


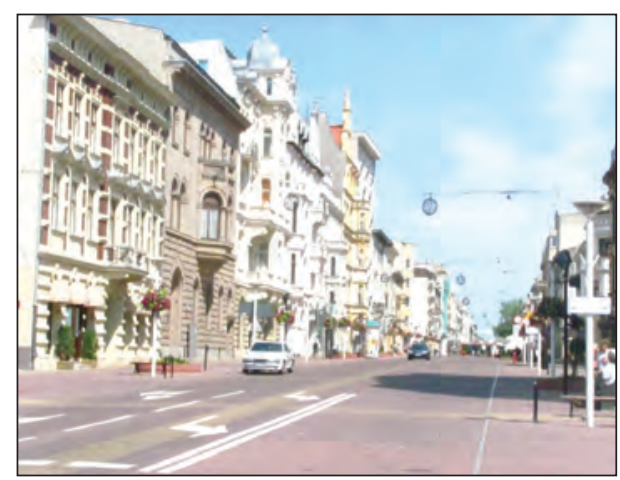

Fot. 7.3. Ulica Piotrkowska po renowacji przeprowadzonej w latach $90 . \mathrm{XX}$ w.

Źródło: fotografia autora

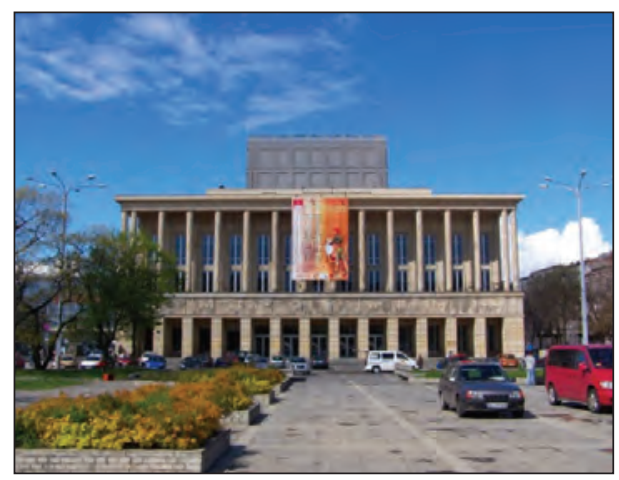

Fot. 7.5. Parking na Placu Dąbrowskiego w $2002 \mathrm{r}$

Źródło: fotografia autora

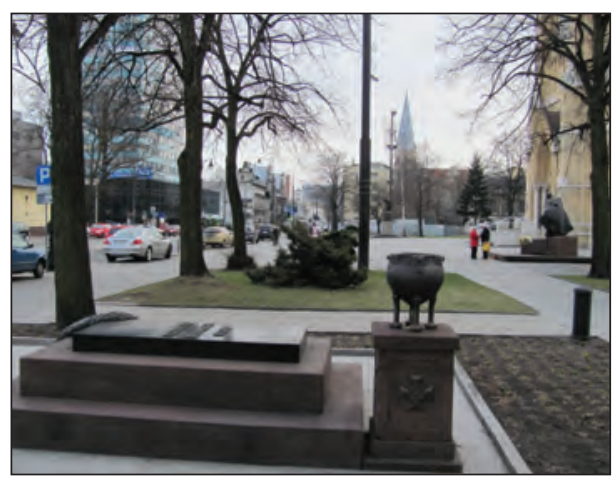

Fot. 7.4. Grób Nieznanego Żołnierza na Placu Katedralnym im. Jana Pawła II

Źródło: fotografia autora



Fot. 7.6. Plac Wolności z pomnikiem Tadeusza Kościuszki pełniący funkcję komunikacyjną

Źródło: fotografia autora

W tym kontekście należy do takich zaliczyć rozwój przemysłu i kolei oraz uzyskanie funkcji administracyjnej w pierwszym, drugim i trzecim etapie kształtowania przestrzeni centralnej oraz dekapitalizację obszaru śródmiejskiego związaną z działalnością władz socjalistycznych w latach 1946-1989, a następnie z upadkiem przemysłu włókienniczego w Łodzi po 1990 r. W wyniku przekształceń w okresie od 1818 do około 2005 r. przestrzeń centralna w Łodzi odznaczała się zalążkowym charakterem rozwoju i ograniczała się do ulicy Piotrkowskiej i kwartałów do niej przyległych. Stopniowa deindustrializacja obszaru śródmiejskiego w Łodzi, rozpoczęta w latach 90 . XX w., stworzyła szansę na ekspansję przestrzeni centralnej i integrację jednostek morfogenetycznych dzielnicy śródmiejskiej.

$\mathrm{O}$ zalążkowym stopniu wykształcenia przestrzeni centralnej w Łodzi na przełomie XX i XXI w. zadecydował rozwój miasta w dwóch odmiennych systemach polityczno-gospodarczych, które miały negatywny wpływ na proces kształtowania 
centrum wielkomiejskiego. Pierwszy z nich to XIX-wieczny kapitalizm, w którym śródmieście zostało podporządkowane funkcji produkcyjnej. Rozwój instytucji centrotwórczych był celowo ograniczany przez władze carskiej Rosji, której celem było zachowanie przemysłowego charakteru miasta. W krótkim okresie międzywojennym Łódź zyskała funkcje metropolitalne, które stwarzały szansę na sukcesję instytucji wielkomiejskich poza ulicę Piotrkowską. Proces ten zatrzymała II wojna światowa, po której nastał interwał gospodarki centralnie planowanej. Władza socjalistyczna w latach 1945-1989 podtrzymała wcześniejszy sposób użytkowania przestrzeni śródmiejskiej. Podobnie jak w pierwszych dwóch etapach kształtowania przestrzeni centralnej w Łodzi, w analizowanym okresie również nie nastąpiło znaczące $\mathrm{w}$ randze i wielkości wyposażenie śródmieścia w nowe instytucje centrotwórcze, które odpowiadałyby miejscu miasta w strukturze osadniczej kraju. W konsekwencji zaistnienia interwału gospodarki centralnie planowanej w Łodzi nie wystąpiły sprzyjające uwarunkowania ekonomiczne, ani przesłanki polityczne do wykształcenia centrum wielkomiejskiego, w odróżnieniu od miast zachodnioeuropejskich, rozwijających się nieprzerwanie w warunkach ekonomii wolnorynkowej. Mimo że Łódź w XIX i XX w. urosła do rangi wielkiego miasta przemysłowego, zachowała ona jednak prowincjonalny charakter w porównaniu z Lyonem i Manchesterem. Wpływ na ten stan rzeczy miało położenie Łodzi w granicach upośledzonej gospodarczo Rosji do 1918 r., a następnie transformacja przestrzeni centralnej w zgodzie z ideologią socjalistyczną.

\subsection{Cechy współczesnej przestrzeni centralnej w Łodzi}

Proces rewitalizacji łódzkich obiektów pofabrycznych na nowe cele rozpoczął się w drugiej połowie XX w. od adaptacji dawnej fabryki Ludwika Geyera na Centralne Muzeum Włókiennictwa w 1956 r. Działania tego typu na terenach poprzemysłowych były realizowane sporadycznie, miały charakter punktowy i nie prowadziły do rozwoju przestrzeni centralnej miasta. Rewitalizacja łódzkich obiektów poprzemysłowych nabrała przyspieszenia w pierwszej dekadzie XXI w. Ze względu na znaczne rozdrobnienie terenów postindustrialnych i ich rozproszenie na obszarze śródmiejskim proces przekształceń przestrzenno-funkcjonalnych nadal miał jednak charakter enklawowy. Inwestycje na terenach poprzemysłowych nie były wspierane działaniami naprawczymi, realizowanymi na obszarach z nimi sąsiadującymi. W rezultacie spowodowało to, że odnowione obiekty, głównie o przeznaczeniu biurowym i charakteryzujące się interesującą fizjonomią, stanowiły „wyspy” wśród zdegradowanej zabudowy śródmiejskiej.

Pierwsze dziesięciolecie XXI w. związane było z rozpoczęciem działań rewitalizacyjnych na terenie dwóch największych kompleksów pofabrycznych w śródmieściu Łodzi, zlokalizowanych na biegunach ulicy Piotrkowskiej (rys. 7.7). Pierwszy z nich to dawny zespół fabryczny należący do Karola Scheiblera, który znajduje się w dolinie rzeki Jasień w środkowej części posiadeł wodno-fabrycznych. 
W wyniku procesu adaptacyjnego obiekty poprzemysłowe kompleksu zostały przeznaczone na funkcję mieszkaniową (fot. 7.7). Inwestycja pod nazwą „U Scheiblera” (z racji pierwotnego właściciela jurydyki) objęła także stworzenie nowej zabudowy rezydencjonalnej, która uzupełniła postindustrialną substancję materialną zabytkowego zespołu. Nieprzekształcona została natomiast część zajęta przez dawne domy robotnicze na Księżym Młynie, które władze miasta objęły osobnym projektem rewitalizacji, zakładającym rozwój na tym obszarze funkcji kulturalnych. W ramach projektu na osiedlu zostanie zlokalizowany m.in. Instytut Designu Akademii Sztuk Pięknych. Północna i najstarsza część kompleksu Karola Scheiblera, tzw. „Centrala" przy alei Piłsudskiego oraz Parku Źródliska I i II, nadal nie została poddana kompleksowym przekształceniom, za wyjątkiem pałacu rodziny Scheiblerów, który od lat 80. XX w. pełni funkcję Muzeum Kinematografii (fot. 7.8 i rys. 7.7). Działania naprawcze w tej części doliny Jasienia nie zostały jak dotąd zakończone.

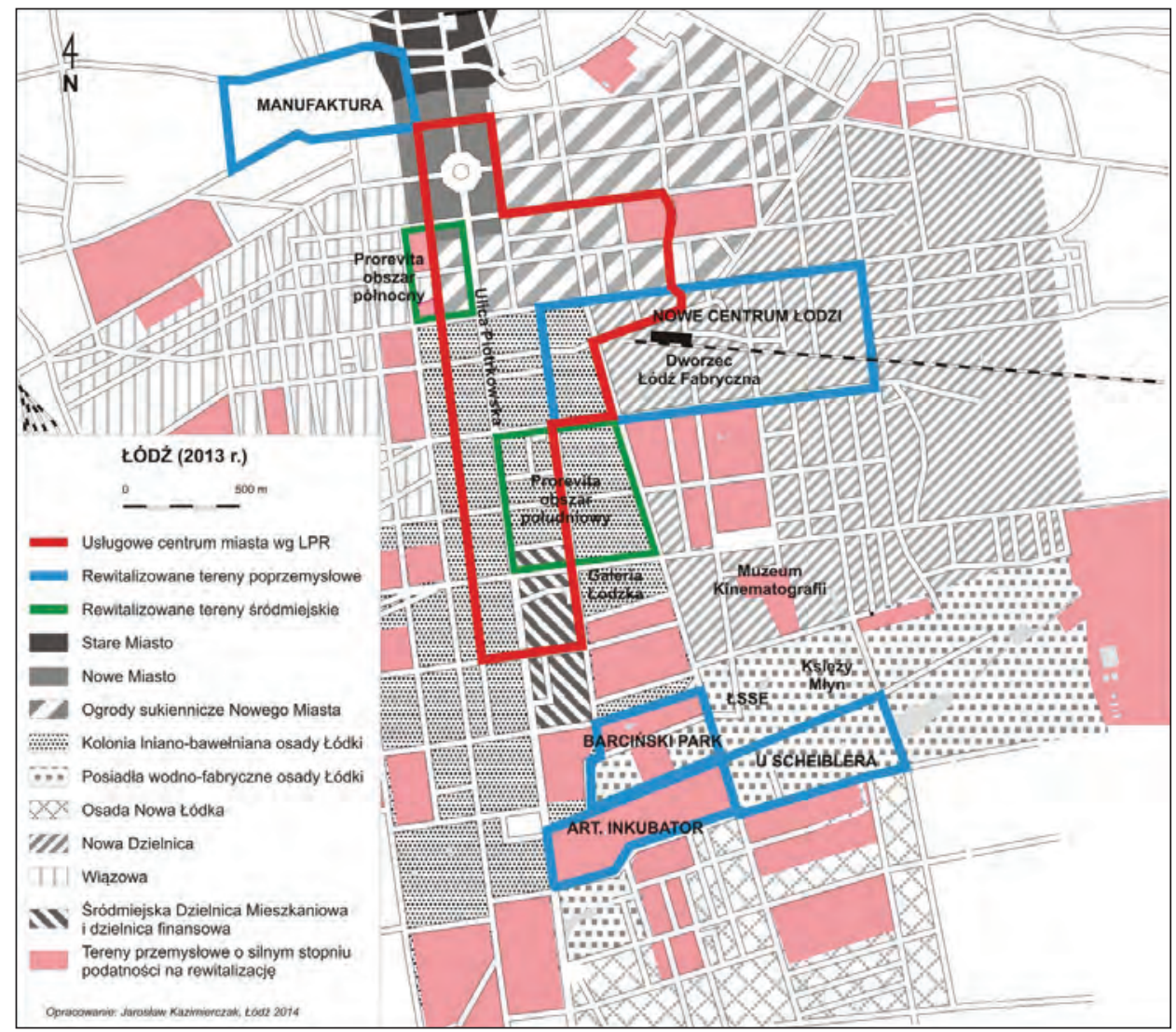

Rys. 7.7. Rozmieszczenie przekształcanych lub przeznaczonych do przekształcenia terenów poprzemysłowch względem usługowego centrum Łodzi (stan na 2013 r.)

Źródło: badania własne autora, opracowanie na podstawie LPR 
Większość terenów poprzemysłowych w zachodniej części dawnych posiadeł wodno-fabrycznych osady Łódki pozostaje współcześnie w fazie ugoru. Wśród nielicznych inwestycji podjętych w pierwszej dekadzie XXI w. była budowa zamkniętych osiedli mieszkaniowych (m.in. „Barciński Park”) w kwartale ulic - Tymienieckiego, Kilińskiego, Abramowskiego, Sienkiewicza (rys. 7.7). Na południe od ulicy Tymienieckiego w zachodniej części zespołu fabrycznego rodziny Scheiblerów, na tzw. posiadłach bielnikowych, w roku 2012 rozpoczęto budowę „Art_Inkubatora” (rys. 7.7). Dawne budynki poprzemysłowe, które zachowają swoją fizjonomię, mają stać się siedzibami różnego typu organizacji, stowarzyszeń i fundacji kulturalno-edukacyjno-społecznych promujących rozwój przedsiębiorczości związanej z kulturą i sztuką w Łodzi. W kompleksie zlokalizowane będzie centrum festiwalowe oraz pracownie artystyczne, galeria sztuki, obiekty biurowe przeznaczone głównie dla młodych artystów i przedsiębiorców. Ze względu na program funkcjonalny jest to jedyna aktualnie realizowana inwestycja na posiadłach wodno-fabrycznych, która stwarza szansę na rozszerzenie współczesnej przestrzeni centralnej w Łodzi. Istotny wpływ na ten stan rzeczy ma także morfologia kompleksu i bezpośrednie sąsiedztwo ulicy Piotrkowskiej (rys. 7.7). Niemniej, według Uproszczonego Lokalnego Programu Rewitalizacji wybranych terenów śródmiejskich i oraz pofabrycznych Łodzi na lata 2004-2013 (w skrócie LPR) posiadła wodno-fabryczne znajdują się znacznie poza „usługowym centrum miasta". W celu zintegrowania zrewitalizowanych terenów poprzemysłowych jako potencjalnej nowej przestrzeni centralnej powinno dążyć się do podjęcia działań zmierzających do kształtowania nowych funkcji wielkomiejskich pomiędzy tymi dwoma obszarami (rys. 7.7).

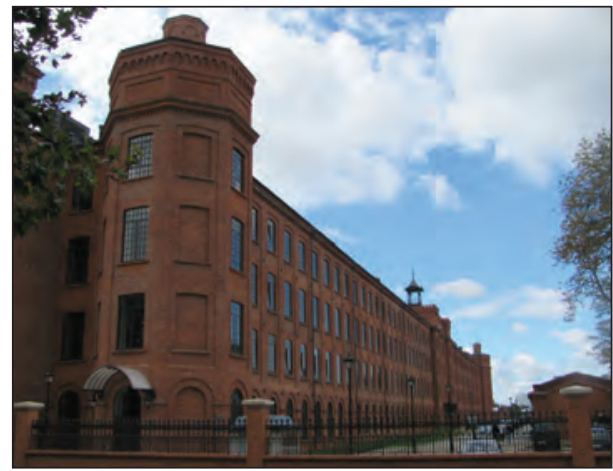

Fot. 7.7. Przędzalnia Karola Scheiblera wybudowana w latach 1870-1878 adaptowana na obiekt mieszkalny w latach 2005-2010

Źródło: fotografia autora

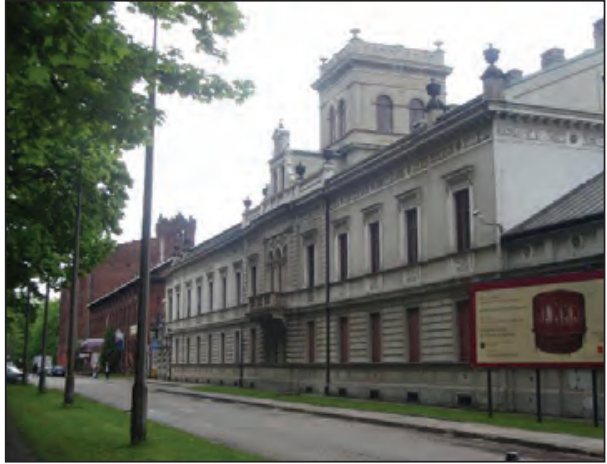

Fot. 7.8. Pałac Scheiblerów przy Placu

Zwycięstwa jest współcześnie siedzibą Muzeum Kinematografii w Łodzi

Źródło: fotografia autora

Morfologia posiadeł wodno-fabrycznych nie uległa istotnym przekształceniom w wyniku procesu rewitalizacji. Zachowana została niemal w całości substancja 
postindustrialna, którą uzupełniono nowymi obiektami rezydencjonalnymi, głównie na wcześniej niezabudowanych obszarach. Środkowa część posiadeł (dawne tereny fabryczne rodziny Grohmanów) nadal wykorzystywana jest przez przemysł w ramach Łódzkiej Specjalnej Strefy Ekonomicznej (ŁSSE, rys. 7.7). Czynnik ten ma negatywny wpływ na kształtowanie przestrzeni centralnej w południowym fragmencie dzielnicy śródmiejskiej.

Drugim co do wielkości powierzchni kompleksem postindustrialnym w śródmieściu Łodzi poddanym procesom naprawczym w pierwszej dekadzie XXI w. był zespół kwartałów fabrycznych Izraela Poznańskiego. Jest on położony w dolinie rzeki Łódki na północny-zachód od Nowego Miasta (rys. 7.7). W wyniku przekształceń przestrzenno-funkcjonalnych w roku 2006 otwarto nowe centrum handlowo-rozrywkowo-kulturalne Łodzi. W tzw. „Manufakturze” znajduje się m.in. galeria handlowa, liczne obiekty gastronomiczne, kino, teatr, dyskoteka oraz pierwszy łódzki hotel o standardzie czterech gwiazdek - andel's Hotel. W ramach kompleksu powstały także dwa muzea - Muzeum Fabryki, prezentujące historię łódzkiego przemysłu włókienniczego i kompleksu fabrycznego wybudowanego przez rodzinę Poznańskich, oraz filia Muzeum Sztuki w Łodzi, czyli ms², w którym znajdują się światowej rangi dzieła sztuki współczesnej (rys. 7.8).

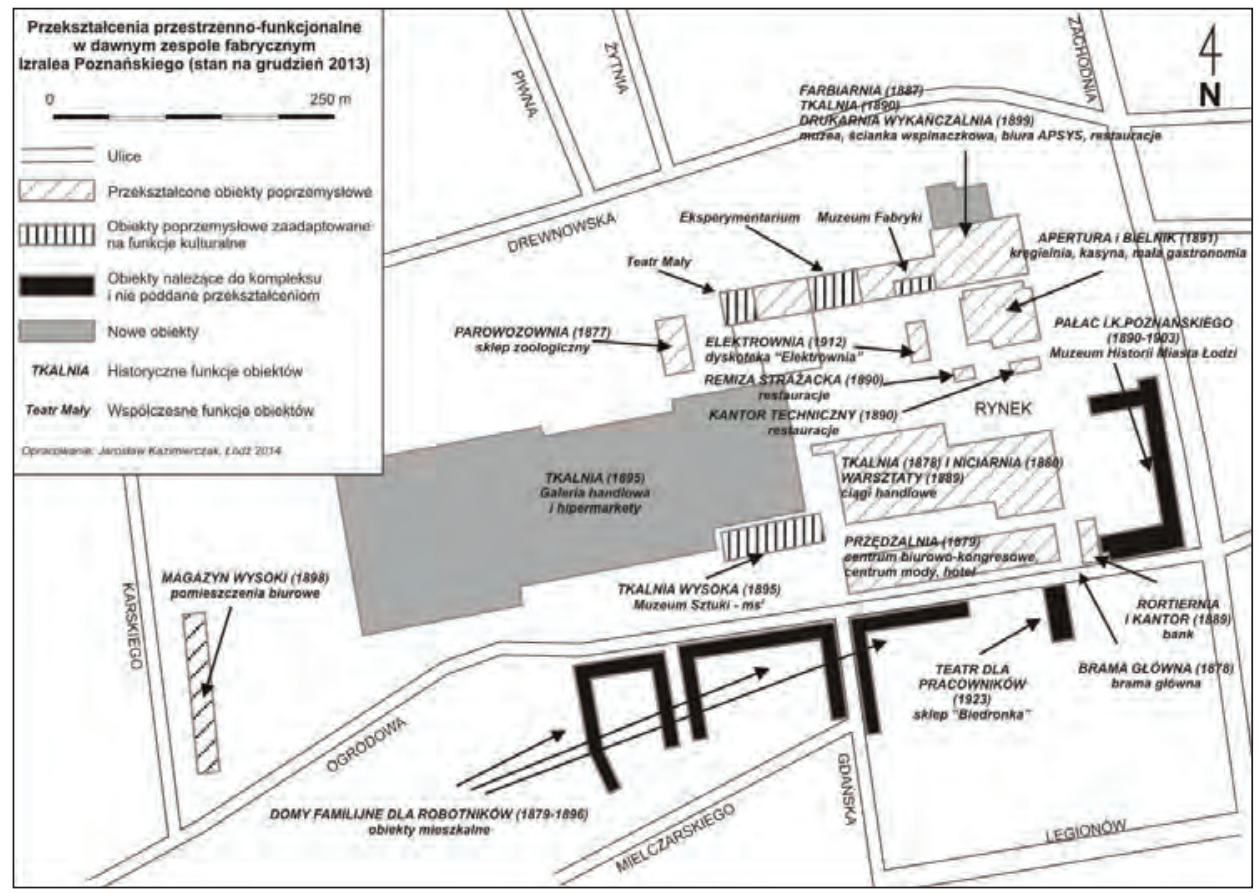

Rys. 7.8. Zakres przekształceń przestrzenno-funkcjonalnych dawnego kompleksu fabrycznego Izraela Poznańskiego (stan na 2013 r.)

Źródło: badania własne autora 
Na podstawie przyjętej skali (patrz rozdz. 2) stwierdzono, że proces kształtowania nowej przestrzeni centralnej na terenie dawnego kompleksu fabrycznego Izraela Poznańskiego wiązał się z umiarkowanym $\left(\mathrm{U}_{\mathrm{p}}\right)$ stopniem intensywności przekształceń przestrzenno-funkcjonalnych oraz radykalnym charakterem rewitalizacji terenów postindustrialnych w wymiarze morfologicznym. Najintensywniejsze zmiany morfologiczne objęły zmianę długości ulic i dróg kołowych, zmianę długości linii kolejowych oraz wielkości powierzchni nowej zabudowy wzniesionej w ramach rewitalizacji (tab. 7.1). Zachowana zabudowa poprzemysłowa została w całości zaadaptowana na potrzeby nowej działalności usługowej, głównie kulturalnej oraz rozrywkowej. Nowe obiekty zostały natomiast przeznaczone na handel, w tym wielkopowierzchniowy (rys. 7.8).

Tabela 7.1. Przekształcenia morfologii i sposobu użytkowania terenów poprzemysłowych („Manufaktura”) w Łodzi i stopień ich intensywności w latach 2000-2013

\begin{tabular}{|c|c|c|c|c|c|}
\hline \multirow{2}{*}{ Cecha } & \multirow{2}{*}{$\begin{array}{l}\text { Jednostka } \\
\text { miary }\end{array}$} & \multicolumn{2}{|c|}{ Stan $\mathrm{w}$ roku } & \multirow{2}{*}{$\mathrm{P}(\mathrm{w} \%)$} & \multirow{2}{*}{$\begin{array}{l}\text { Intensywność } \\
\text { zmian }\end{array}$} \\
\hline & & 2000 & 2013 & & \\
\hline Długość dróg kołowych & $\mathrm{m}$ & 2853 & 7500 & 163 & Wysoki $\left(\mathrm{P}_{\mathrm{w}}\right)$ \\
\hline $\begin{array}{l}\text { Długość naziemnych linii kolejo- } \\
\text { wych }\end{array}$ & $\mathrm{m}$ & 1284 & 0 & -100 & Wysoki $\left(\mathrm{P}_{\mathrm{W}}\right)$ \\
\hline $\begin{array}{l}\text { Długość nowych linii tramwajo- } \\
\text { wych }\end{array}$ & $\mathrm{m}$ & 0 & 0 & $\mathrm{x}$ & $\operatorname{Niski}\left(\mathrm{P}_{\mathrm{N}}\right)$ \\
\hline Powierzchnia zabudowy & ha & 7,7 & 9,5 & 23 & Niski $\left(\mathrm{P}_{\mathrm{N}}\right)$ \\
\hline $\begin{array}{l}\text { Powierzchnia nowo wzniesionej za- } \\
\text { budowy (wybudowanej w ramach } \\
\text { rewitalizacji) }\end{array}$ & ha & 0 & 5,9 & $\mathrm{x}$ & Wysoki $\left(\mathrm{P}_{\mathrm{w}}\right)$ \\
\hline $\begin{array}{l}\text { Powierzchnia zachowanej dawnej } \\
\text { zabudowy użytkowanej przez prze- } \\
\text { mysł }\end{array}$ & ha & 7,7 & 3,6 & 54 & $\begin{array}{l}\text { Umiarkowany } \\
\qquad\left(\mathrm{P}_{\mathrm{U}}\right)\end{array}$ \\
\hline $\begin{array}{l}\text { Powierzchnia dawnej zabudowy } \\
\text { użytkowanej przez przemysł, która } \\
\text { została poddana renowacji i adapta- } \\
\text { cji na nowe funkcje w ramach pro- } \\
\text { cesu rewitalizacji }\end{array}$ & ha & 0 & 3,6 & $\mathrm{x}$ & Wysoki $\left(\mathrm{P}_{\mathrm{w}}\right)$ \\
\hline $\begin{array}{l}\text { Długość ogólnodostępnej linii } \\
\text { dostępu do wody (rzeki, kanały, } \\
\text { zbiorniki wodne) - od rozpoczęcia } \\
\text { procesu rewitalizacji }\end{array}$ & $\mathrm{m}$ & 0 & 0 & $\mathrm{x}$ & $\operatorname{Niski}\left(\mathrm{P}_{\mathrm{N}}\right)$ \\
\hline $\begin{array}{l}\text { Powierzchnia zabudowy zajmowa- } \\
\text { nej przez funkcję usługową }\end{array}$ & ha & 0,8 & 9,5 & 1166 & Wysoki $\left(\mathrm{P}_{\mathrm{w}}\right)$ \\
\hline $\begin{array}{l}\text { Powierzchnia zabudowy zajmowa- } \\
\text { nej przez funkcję mieszkaniową }\end{array}$ & ha & 0 & 0 & $\mathrm{x}$ & $\operatorname{Niski}\left(\mathrm{P}_{\mathrm{N}}\right)$ \\
\hline $\begin{array}{l}\text { Powierzchnia zabudowy zajmowa- } \\
\text { nej przez nieużytki poprzemysłowe } \\
\text { lub funkcję produkcyjną }\end{array}$ & ha & 7,0 & 0 & -100 & Wysoki $\left(\mathrm{P}_{\mathrm{w}}\right)$ \\
\hline
\end{tabular}

Źródło: badania własne autora. 
W wyniku rewitalizacji zespołu kwartałów poprzemysłowych ograniczonych ulicami Ogrodową, Zachodnią, Drewnowską i Karskiego przestrzeń centralna w Łodzi związana przede wszystkim z ulicą Piotrkowską i w mniejszym stopniu z „Galerią Łódzką” została wzbogacona o nowy element morfologiczny. Wykształcony $\mathrm{w}$ ten sposób układ przestrzeni centralnej składa się $\mathrm{z}$ trzech niezintegrowanych przestrzennie enklaw (rys. 7.7). Budowa dużego centrum handlowego w „Manufakturze” wraz z atrakcyjną pod względem estetycznym i fizjonomicznym przestrzenią publiczną, która zdecydowanie wyróżnia się na tle zaniedbanej dzielnicy śródmiejskiej (fot. 7.9-7.12), oraz powstanie „Galerii Łódzkiej”, która ma charakter dośrodkowej, komercyjnej przestrzeni publicznej, spowodowało obniżenie rangi ulicy Piotrkowskiej jako głównej ulicy handlowej

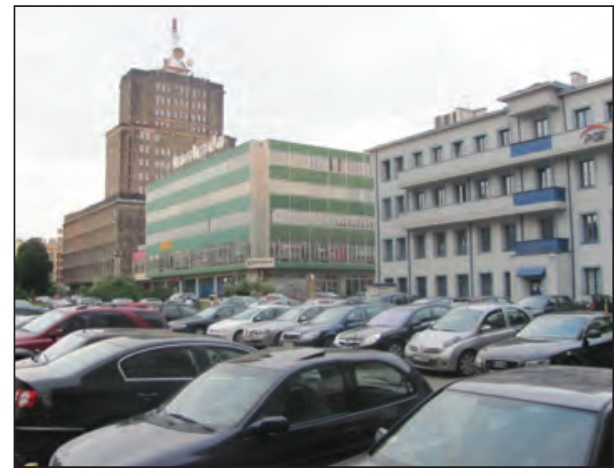

Fot. 7.9. Zabudowa śródmiejska Łodzi z drugiej połowy XX w. i jeden $\mathrm{z}$ wielu parkingów powstałych na terenach po wyburzonych kamienicach

Źródło: fotografia autora

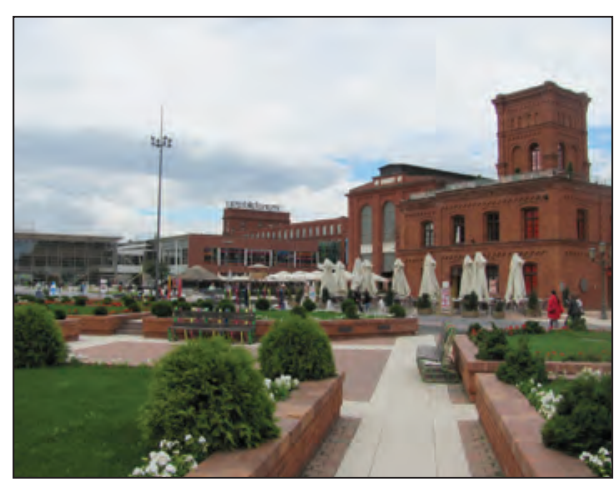

Fot. 7.11. Zadbana przestrzeń publiczna w „Manufakturze”

Źródło: fotografia autora

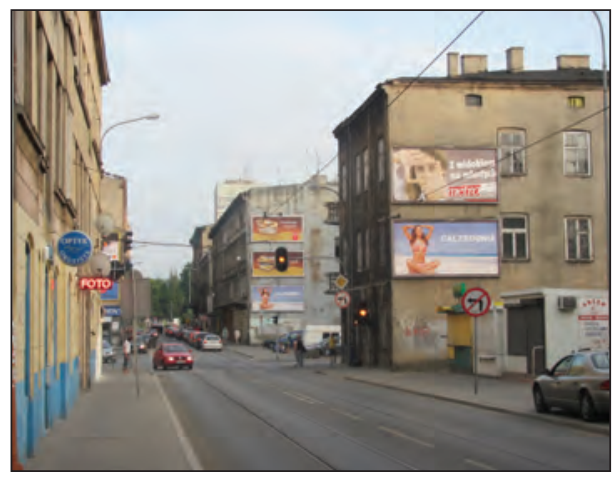

Fot. 7.10. Ulica Kilińskiego jako przykład ulicy śródmiejskiej odznaczającej się niską jakością estetyczną krajobrazu

Źródło: fotografia autora

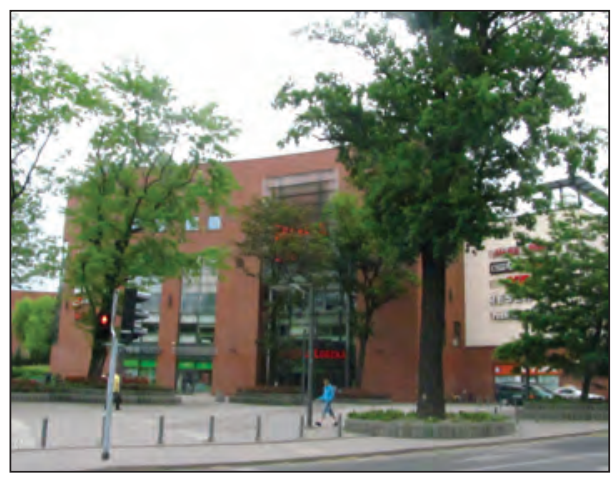

Fot. 7.12. Estetyczna przestrzeń publiczna przed wejściem do „Galerii Łódzkiej”

Źródło: fotografia autora 
miasta. Zaburzona została $\mathrm{w}$ ten sposób historycznie ukształtowana hierarchia terenów miejskich w Łodzi, co może mieć negatywny wpływ na dalszą transformację przestrzeni centralnej miasta w oparciu o ulicę Piotrkowską jako główną oś urbanistyczną integrującą najstarsze jednostki morfologiczne śródmieścia. Paradoksem zaistniałej sytuacji jest to, że koncepcja powstania „Manufaktury” wiązała się z dalszym ożywianiem i wzmacnianiem handlowo-rozrywkowych funkcji ulicy Piotrkowskiej stanowiącej najważniejsze miejsce spotkań mieszkańców miasta.

Zgodnie z opinią S. Kaczmarek i J. Kaczmarka (2010) wszystkie tereny poprzemysłowe zlokalizowane w obszarze śródmiejskim Łodzi odznaczają się wysoką podatnością na rewitalizację ze względu na ich kontekst urbanistyczny, rozumiany jako układ morfologiczny oraz wyposażenie instytucjonalne terenów z nimi sąsiadujących. Jednak rozdrobnienie tych terenów nie sprzyja realizacji wielkoskalowych projektów rewitalizacyjnych, które umożliwiłyby wykształcenie spójnej przestrzeni centralnej miasta (rys. 7.7). Działania takie wymagałyby kompleksowego ujęcia i koordynacji w celu jasno sprecyzowanej wizji rozwoju centrum wielkomiejskiego. W tym aspekcie rozpoczęte w XXI w. procesy przekształceń przestrzenno-funkcjonalnych w dolinie Łódki, na obszarze współczesnej „Manufaktury” oraz w dolinie Jasienia - na posiadłach wodno-fabrycznych należy uznać za kluczowe dla osiągnięcia efektu synergii w zakresie sukcesji przestrzeni centralnej. Oba projekty, ze względu na lokalizację, skalę inwestycji oraz program wyposażenia nowych przestrzeni miejskich, stwarzają możliwość zintegrowania za pośrednictwem osi ulicy Piotrkowskiej - po raz pierwszy w dziejach miasta niezależnie jak dotąd rozwijających się jednostek morfogenetycznych Łodzi - Nowego Miasta na północy oraz osad Łódki i Nowej Łódki na południu (patrz rys. 7.7).

Jednym z kluczowych projektów w procesie kształtowania współczesnej przestrzeni centralnej Łodzi jest budowa tzw. NCŁ, czyli Nowego Centrum Łodzi (rys. 7.7). Obszar inwestycji zajmuje środkowy fragment historycznej Nowej Dzielnicy, która została podzielona na dwie, niezależne od siebie, rozwijające się części w wyniku budowy „łódzkiej kolei fabrycznej” w drugiej połowie XIX w. Koncepcja projektu NCŁ powstała w latach 2005-2007. Radni Rady Miasta Łodzi przyjęli Program Nowego Centrum Łodzi uchwałą nr XVII/279/07 z dnia 28 sierpnia 2007 r. Zgodnie z tą decyzją projekt NCŁ obejmował prawie 90 ha i był ograniczony ulicami: Tuwima, Narutowicza, Sienkiewicza i Kopcińskiego. Uchwała ta została zmieniona 4 lipca 2012 r., kiedy Radni zdecydowali m.in. o zwiększeniu obszaru objętego Programem o dodatkowe 10 ha położone między ulicami Piotrkowską, Sienkiewicza, Tuwima i Narutowicza. Punktem wyjściowym dla inwestycji była budowa podziemnego dworca kolejowego, który ma zostać w przyszłości połączony 11-kilometrowym tunelem średnicowym z linią kolejową nr 15 (na odcinku pomiędzy stacjami Łódź Kaliska-Łódź Żabieniec) i dworcem Łódź Kaliska. Tym sposobem dwa największe łódzkie dworce kolejowe uzyskają bezpośrednie połączenie. 




Rys. 7.9. Planowany program przestrzenno-funkcjonalny

zagospodarowania zachodniej części Nowego Centrum Łodzi (plany z 2013 r.)

Źródło: badania własne autora

Rejon działań rewitalizacyjnych na dawnych terenach kolejowych, produkcyjnych i składowo-magazynowych zajmuje 100 ha i jest ograniczony ulicami: Sienkiewicza od zachodu, Narutowicza od północy, Kopcińskiego od wschodu i Tuwima od południa. Teren inwestycji został podzielony na trzy strefy urbanistyczne. Pierwsza obejmuje obszar około 40 ha w okolicach elektrociepłowni EC-1 wybudowanej na przełomie XIX i XX w. i obejmuje kwartały na południe od ulicy Narutowicza, na wschód od ulicy Kilińskiego, na północ od ulicy Tuwima i na zachód od nowej ulicy - Nowotargowej. Został on przeznaczony przede wszystkim na cele kulturalne, co prezentuje rysunek 7.9. Strefa II przekształceń przestrzenno-funkcjonalnych jest położona na wschód od ulicy Nowotargowej i zajmuje powierzchnię około 30 ha zlokalizowanych na wschód od ulicy Nowotargowej aż do 
ulicy Kopcińskiego (rys. 7.9 i 7.10). Zostanie ona zagospodarowana na funkcje usługowe, mieszkaniowe i rekreacyjne (nowy park miejski). Trzecia strefa o powierzchni 30 ha obejmuje tereny śródmiejskie pomiędzy ulicą Kilińskiego na wschodzie i ulicą Piotrkowską na zachodzie. Działania naprawcze w tej części inwestycji będą obejmować renowację istniejącej zabudowy oraz jej uzupełnienie nowymi obiektami (patrz rys. $7.9 \mathrm{i} 7.10$ ). W sumie $\mathrm{w}$ ramach programu NCŁ prowadzone jest 51 projektów o łącznej wartości około 4,4 mld zł (stan na grudzień 2013 r.).

Pierwszy etap inwestycji wiąże się z zagłębieniem dworca kolejowego na około 16,5 $\mathrm{m}$ i doprowadzeniem do niego tunelu ze stacji Łódź Widzew położonej we
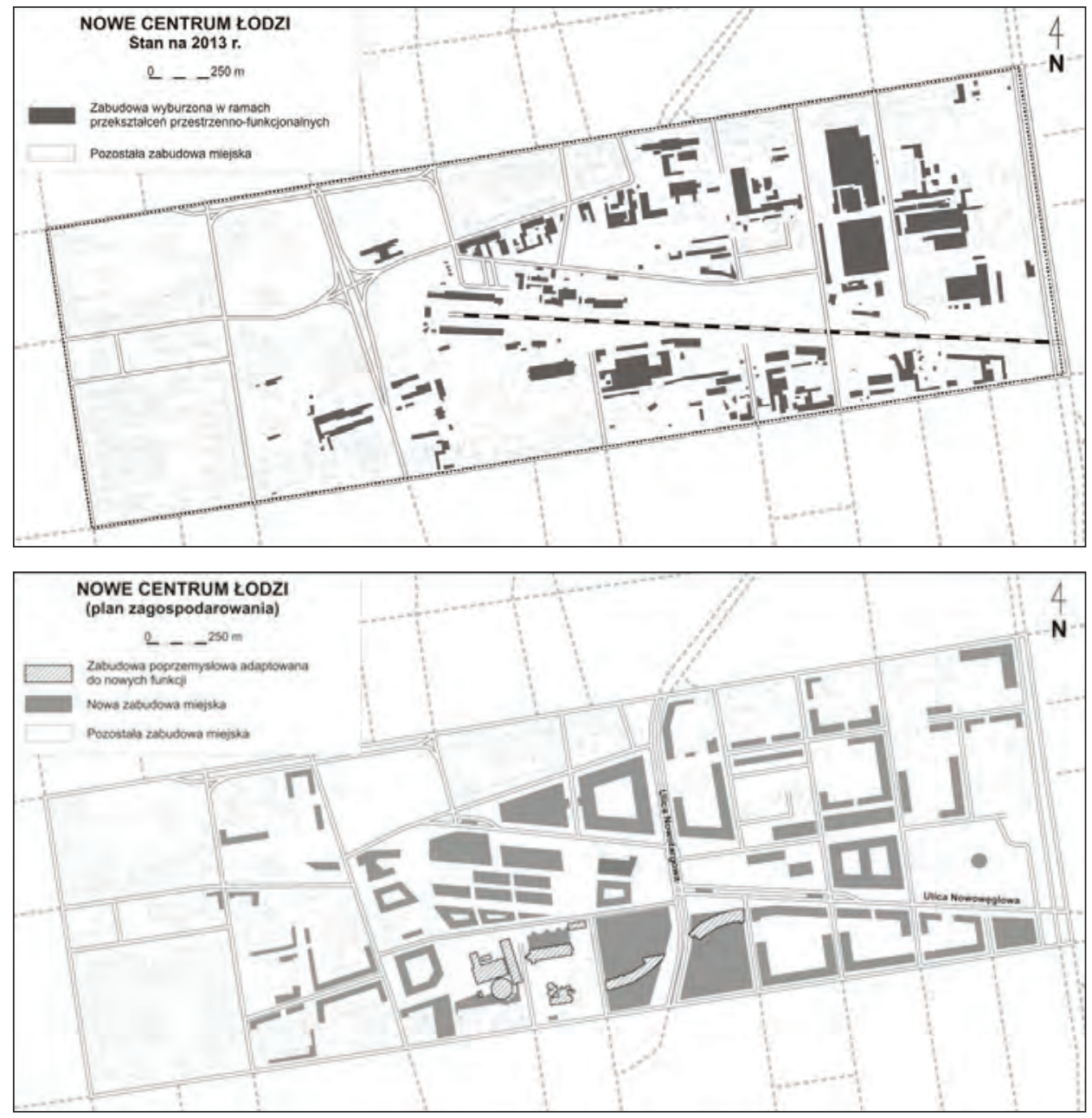

Rys. 7.10. Struktura morfologiczna Nowego Centrum Łodzi w 2013 r. i zgodnie z planami jego zagospodarowania do $2030 \mathrm{r}$.

Źródło: badania własne autora 
wschodniej części miasta. Dworzec ${ }^{4}$ o długości 400 m i szerokości 90 m będzie się składać z czterech peronów i ośmiu torów. Po dwa perony zostaną przeznaczone dla kolei konwencjonalnej, w tym dla Łódzkiej Kolei Aglomeracyjnej (ŁKA), oraz dla planowanej Kolei Dużych Prędkości (KDP). Na nowym tzw. dworcu multimodalnym powstanie także podziemny, trzypoziomowy parking dla 1000 samochodów. Oprócz budowy dworca kolejowego, na różnych poziomach pod powierzchnią ziemi powstanie także węzeł lokalnej, regionalnej i międzynarodowej komunikacji autobusowej oraz węzeł dla miejskiego transportu publicznego (autobusowego i tramwajowego). W tym celu przebudowane zostaną istniejące linie tramwajowe. Zostaną one także uzupełnione o nową trasę wzdłuż ulicy Nowowęglowej, łączącą ulicę Kopcińskiego na wschodzie z dworcem kolejowym oraz z ulicą Kilińskiego i Narutowicza na zachodzie i północy Nowego Centrum Łodzi. Przekształcenia obejmą łącznie około $2,5 \mathrm{~km}$ torowisk.

Rysunek 7.10 ukazuje zakres planowanych zmian struktury przestrzennej na terenie poddanym działaniom rewitalizacyjnym. Na jego podstawie można stwierdzić, że będzie się on wiązał z działaniami o charakterze radykalnym w wymiarze morfologicznym. W ramach przekształceń przestrzenno-funkcjonalnych Nowego Centrum Łodzi znacznej modyfikacji ulegnie istniejący aktualnie układ komunikacyjny. Ze względu na zagłębienie dworca kolejowego pod ziemią $\mathrm{z}$ analizowanego obszaru całkowicie usunięta zostanie naziemna infrastruktura kolejowa (około $11 \mathrm{~km}$ torów kolejowych). Przebudowany zostanie system ulic (około $9 \mathrm{~km}$ ), z czym będzie się wiązać eliminacja części starych dróg kołowych, głównie w części zachodniej, oraz budowa nowych odcinków ulic na całym obszarze Nowego Centrum Łodzi (rys. 7.10). Celem inwestycji drogowych jest zwiększenie wewnętrznej i zewnętrznej dostępności komunikacyjnej rejonu. W pierwszej kolejności modernizacji zostanie poddana ulica Kilińskiego od ulicy Narutowicza do Tuwima. Po przebudowie ma być ona przeznaczona wyłącznie dla komunikacji zbiorowej i docelowych wjazdów gospodarczych. Główną arterią komunikacyjną będą nowo wytyczone ulice - Nowowęglowa (w linii dawnych torów kolejowych, rys. 7.10) i Nowotargowa, która po części nawiązuje do XIX-wiecznej koncepcji połączenia Rynku Wodnego (współcześnie Placu Zwycięstwa przy alei Piłsudskiego) oraz Rynku Targowego (aktualnie Placu Dąbrowskiego). Będzie to wielopasmowa ulica łączącą aleję Piłsudskiego (część Trasy Wschód-Zachód) na południu z ulicą Uniwersytecką na północy, która prowadzi do węzła autostradowego w Strykowie. Budowa wielopasmowej ulicy Nowotargowej w planowanej formie może jednak spowodować utratę spójności kształtowanej przestrzeni miejskiej i de facto skutkować marginalizacją terenów we wschodniej części Nowego Centrum Łodzi (rys. 7. 9 i 7.10).

W celu zwiększenia powierzchni terenów pieszych wybudowane zostaną parkingi podziemne, natomiast zachodni fragment ulicy Nowowęglowej pomiędzy ulicą Nowotargową i ulicą Kilińskiego zostanie poprowadzony tunelem. W Nowym

${ }^{4}$ Inwestorami są: Miasto Łódź, PKP PLK S.A. i PKP S.A. Całkowity koszt inwestycji wynosi $1,7 \mathrm{mld}$ zł. Koszt ponoszony przez Miasto Łódź to prawie $413 \mathrm{mln}$ zł. 
Centrum Łodzi powstaną cztery place miejskie. Będą to przede wszystkim: Rynek Katarzyny Kobro i Rynek Władysława Strzemińskiego jako główna przestrzeń publiczna w nowej jednostce morfologicznej miasta (rys. 7.9). Na wschód od Rynku Władysława Strzemińskiego rozciągać się będzie nowy park i pas zieleni miejskiej, który wzdłuż ulicy Nowowęglowej zostanie połączony z Parkiem 3-go Maja i Parkiem Generała Baden-Powella zlokalizowanych na wschód od ulicy Kopcińskiego (poza obszarem Nowego Centrum Łodzi). Układ przestrzeni publicznej zostanie uzupełniony o tzw. Pasaż Knychalskiego - bulwar pieszo-rowerowy, zlokalizowany na północ od Rynku Katarzyny Kobro (rys. 7.9). W ten sposób stworzone zostanie otwarcie architektoniczne na Plac Dąbrowskiego, którego dominantą jest gmach Teatru Wielkiego. Pomiędzy zabudową Specjalnej Strefy Kultury wytyczone zostaną ulice Polska, Niemiecka, Żydowska i Rosyjska, których nazwy nawiązują do wielonarodowego dziedzictwa kulturowego Łodzi. Dla integracji Nowego Centrum Łodzi z ulicą Piotrkowską niezbędne będą przekształcenia przestrzenno-funkcjonalne w kwartale ulic Sienkiewicza-Narutowicza-Piotrkowska-Tuwima, polegające m.in. na budowie nowych ciągów pieszo-kołowych.

W projekcie Nowego Centrum Łodzi planowane jest wyburzenie znacznej części istniejącej współcześnie zabudowy i zastąpienie jej nowymi obiektami (rys. 7.10). Zagęszczanie tkanki miejskiej na obszarze Nowego Centrum Łodzi prowadzone będzie w myśl zasady odtwarzania historycznej pierzei ulicy Narutowicza, narożników ulic: Narutowicza-Kilińskiego, Kilińskiego-Traugutta, oraz kształtowania nowych pierzei na odcinkach ulic: Traugutta, Kilińskiego, Tuwima, Składowej, Tramwajowej, Lindleya, Wierzbowej i Kopcińskiego. W programie zagospodarowania analizowanego obszaru nowo powstałe budynki będą stanowić około 64\% ogółu zabudowy, podczas gdy obiekty poprzemysłowe - około $2 \%$. Będzie to przede wszystkim zrewitalizowany zespół historycznej elektrociepłowni EC-1 (rys. 7.9). Na pozostałe 24\% zabudowy Nowego Centrum Łodzi będą się składać istniejące współcześnie budynki o zróżnicowanej fizjonomii i przeznaczeniu - budynki sakralne, mieszkaniowe, usługowe, w tym obiekty handlu wielkopowierzchniowego. Kwartały zachodniej części NCŁ wypełnione są zabytkową zabudową. Ze względu na dużą powierzchnię kwartałów planowane jest ich przebicie w postaci pasaży dla pieszych oraz drogami wewnętrznymi zapewniającymi komunikację wewnętrzną. Natomiast wschodnia część NCŁ (na wschód od ulicy Nowotargowej, rys. 7.10) to tereny zdegradowane bez gęstej zabudowy śródmiejskiej. Daje to możliwość kształtowania zupełnie nowej zabudowy.

Pod inwestycje przeznaczono przede wszystkim tereny położone na południe od dworca oraz dawne tereny kolejowe, przemysłowe i składowo-magazynowe (rys. 7.10). Zgodnie z zapisami opracowywanego Miejscowego Planu Zagospodarowania Przestrzennego ${ }^{5}$ wysokość nowej zabudowy będzie zbliżona do wysokości

${ }^{5}$ Przed głosowaniem o jego przyjęciu na Radzie Miasta Łodzi, które jest planowane na pierwszy kwartał 2014 r., zostanie poddany on konsultacjom społecznym w celu zebrania uwag i ocen mieszkańców miasta. 
istniejących obiektów zlokalizowanych w śródmieściu, czyli 5 kondygnacji. Do 12 kondygnacji będą mogły mieć budynki zlokalizowane wokół dworca. Osiem kondygnacji przewidziano dla pierzei ulicy Nowowęglowej oraz dla obiektów w Specjalnej Strefie Kultury. Zachowanie odpowiednich gabarytów nowej zabudowy podporządkowane jest idei „budowy przestrzeni publicznej o ludzkiej skali”.

Projektem wiodącym dla Nowego Centrum Łodzi jest Centrum Nauki i Techniki znajdujące się w budynku dawnej elektrociepłowni EC-1. Jej rewitalizację rozpoczęto w 2011 r. Projekt został podzielony na trzy części. Budynek EC-1 Wschód spełniać będzie głównie funkcje kulturalno-artystyczne z przestrzeniami udostępnionymi na warsztaty, seminaria oraz twórcze projekty młodych artystów. Dla celów filmowych stworzony zostanie m.in. teatr dźwięków umożliwiający nagrywanie i montowanie muzyki filmowej. Ponadto w tej części zabytkowego zespołu elektrociepłowni powstanie także planetarium, galeria sztuki, studia seminaryjno-konferencyjne, klub muzyczny, kino 3D dla 140 osób oraz wieża widokowa. EC-1 Zachód zostanie zaadaptowana na siedzibę interaktywnego Centrum Nauki i Techniki, którego powierzchnia przewyższy Centrum Nauki „Kopernik” w Warszawie i które rocznie odwiedza około 250 tys. gości. Budynek EC-1 Południowy-Wschód od roku 2008 jest siedzibą studia animacji Se-Ma-For oraz Muzeum Bajki (rys. 7.9).

Drugim projektem wiodącym, który dopiero zostanie zrealizowany w ramach Nowego Centrum Łodzi jest budynek biurowo-rezydencjonalno-usługowy, nazwany „Bramą miasta”. Będzie on zlokalizowany na działce o powierzchni $8000 \mathrm{~m}^{2}$ przy skrzyżowaniu ulicy Kilińskiego z Traugutta (rys. 7.9). Jego autorem jest Daniel Libeskind ${ }^{6}$. Poprzez nazwisko twórcy i oryginalną architekturę, obiekt ma pełnić funkcję informacyjną o znaczeniu projektu NCŁ i zachęcać do kolejnych inwestycji w przekształcanym rejonie. Program funkcjonalny „Bramy miasta" nie został jak dotąd ściśle sprecyzowany, jednak pożądanym jest lokalizacja instytucji co najmniej o ponadregionalnym zasięgu oddziaływania. Nowy budynek o wysokości 13 kondygnacji (maksymalnie 64 metrów) będzie dominantą architektoniczną zachodniej części NCŁ. Ma się on także stać współczesną wizytówką miasta i symboliczną „bramą” łączącą ulicę Piotrkowską z Nowym Centrum Łodzi oraz dworcem kolejowym.

W ostatnich latach przez władze Łodzi podejmowane są także działania związane z przekształceniem ulicy Narutowicza w wielkomiejski bulwar. W ramach tych przekształceń zmodernizowano również Plac Dąbrowskiego w 2009 r., a w latach 2012-2013 dokonano generalnego remontu Teatru Wielkiego. Budowa bulwaru Narutowicza wpisuje się w koncepcję Nowego Centrum Łodzi. Jednocześnie jest jedną z nielicznych i dotychczas realizowanych inicjatyw władz miejskich w celu integracji nowej przestrzeni centralnej Łodzi z ulicą

${ }^{6}$ Daniel Libeskind to amerykański architekt polsko-żydowskiego pochodzenia, przedstawiciel modernizmu, postmodernizmu, neomodernizmu, teoretyk architektury, scenograf. Jednymi z jego najsłynniejszych projektów są m.in. Muzeum Żydowskie w Berlinie i projekt zagospodarowania Ground Zero po World Trade Center w Nowym Jorku. Urodził się 12 maja 1946 r. w Łodzi. 
Piotrkowską. W rezultacie podjętych przekształceń przestrzenno-funkcjonalnych na analizowanej części obszaru historycznej Nowej Dzielnicy istnieje realistyczna perspektywa rozszerzenia zalążka współczesnej przestrzeni centralnej w Łodzi. W kontekście rewitalizacji terenów poprzemysłowych w dolinie Łódki i Jasienia tworzy się także możliwość wykształcenia zintegrowanego centrum wielkomiejskiego obejmującego wszystkie śródmiejskie jednostki morfogenetyczne.

Charakter relacji, jakie zajdą pomiędzy starą i nową przestrzenią centralną w Łodzi po zakończeniu kompleksowej rewitalizacji terenów poprzemysłowych w śródmieściu, określono na podstawie badań terenowych w latach 2010-2013, a w przypadku Nowego Centrum Łodzi w oparciu o dokumentację projektową z 2013 r. W analizie założono, że działania rewitalizacyjne w istotnym stopniu będą korespondować z planami przyjętymi do realizacji w 2013 r. przez spółkę miejską „EC-1 Łódź - Miasto Kultury” oraz Zarząd Nowego Centrum Łodzi, które są odpowiedzialne za realizację projektu. Treść materiałów źródłowych (tzw. Koncepcja miejscowych planów zagospodarowania przestrzennego dla obszaru Nowego Centrum Łodzi, w skali 1 : 2000) określała również preferowane ramowe formy użytkowania Nowego Centrum Łodzi, które posłużyły do pogłębionych studiów analitycznych. W tabeli 7.2 zestawiono analizowane cechy morfologiczno-funkcjonalne starej i nowej (będącej częściowo w fazie realizacji) przestrzeni centralnej w Łodzi.

Stara przestrzeń centralna w Łodzi jest identyfikowana z kwartałami przyległymi do ulicy Piotrkowskiej i Nowomiejskiej, zlokalizowanymi pomiędzy ulicą Północną w historycznym Nowym Mieście w północnej części tzw. strefy wielkomiejskiej Łodzi oraz Placem Niepodległości na południu w jednostce osadniczej Nowa Łódka (patrz rozdz. 7.1). Tak wyznaczony obszar zajmuje powierzchnię 171,7 ha. Nowa przestrzeń centralna obejmuje powierzchnię 112,9 ha, w tym Nowe Centrum Łodzi $-86 \mathrm{ha}^{7}$, natomiast Manufaktura - 26,9 ha (tab. 7.2 i rys. 7.11). Nie stanowią one zwartego obszaru i złożone są z dwóch niezintegrowanych jednostek przestrzennych, zlokalizowanych w odległości około $1 \mathrm{~km}$.

Intensywność pozioma zabudowy $\mathrm{w}$ starej przestrzeni centralnej Łodzi i w kształtowanej nowej przestrzeni centralnej wygenerowanej na śródmiejskich terenach poprzemysłowych wykazuje niewielki stopień zróżnicowania. Wskaźnik intensywności poziomej zabudowy w starej przestrzeni centralnej wynosi $68 \%$. Pomiędzy jej północną i południową częścią (na północ i na południe od alei Mickiewicza i Piłsudskiego) zaznacza się jednak wyraźne zróżnicowanie (rys. 7.11). W kwartałach w północnym fragmencie ulicy Piotrkowskiej intensywność pozioma zabudowy jest równa $76 \%$. Według klasyfikacji S. Liszewskiego

${ }^{7}$ Ze względu na przyjęty zakres przestrzenny starej przestrzeni centralnej Łodzi, który obejmuje także część projektu NCŁ, obszar nowej przestrzeni centralnej kształtowanej w ramach NCŁ został pomniejszony o wielkość powierzchni kwartałów zlokalizowanych pomiędzy ulicami: Narutowicza na północy, Sienkiewicza na wschodzie, Tuwima na południu i Piotrkowską na zachodzie. Powierzchnia wskazanego obszaru zajmuje 14 ha. 
Tabela 7.2. Wybrane cechy morfologii i sposobu użytkowania starej i nowej przestrzeni centralnej w Łodzi w 2013 r. (z uwzględnieniem planów Nowego Centrum Łodzi - NCŁ)

\begin{tabular}{|l|c|c|c|c|}
\hline \multicolumn{1}{|c|}{ Cecha } & \multirow{2}{*}{$\begin{array}{c}\text { Jednostka } \\
\text { miary }\end{array}$} & \multicolumn{2}{|c|}{$\begin{array}{c}\text { Stara } \\
\text { przestrzeń } \\
\text { centralna }\end{array}$} & \multicolumn{2}{|c|}{$\begin{array}{c}\text { Nowa przestrzeń } \\
\text { centralna }\end{array}$} \\
\cline { 4 - 5 } & & hałość & NCŁ \\
\hline Powierzchnia przestrzeni centralnej & 171,7 & 112,9 & 86,0 \\
\hline $\begin{array}{l}\text { Powierzchnia przestrzeni zamkniętych w przestrzeni } \\
\text { centralnej }\end{array}$ & ha & 116,7 & 72,0 & 62,5 \\
\hline $\begin{array}{l}\text { Powierzchnia przestrzeni otwartych w przestrzeni } \\
\text { centralnej }\end{array}$ & ha & 55,0 & 40,9 & 23,5 \\
\hline $\begin{array}{l}\text { Powierzchnia przestrzeni publicznej integrującej } \\
\text { (place miejskie) w przestrzeni centralnej }\end{array}$ & ha & 4,8 & 7,8 & 5,0 \\
\hline $\begin{array}{l}\text { Powierzchnia terenów ruchu pieszego (inne strefy } \\
\text { piesze bez placów) przestrzeni centralnej }\end{array}$ & ha & 5,8 & 5,5 & 5,5 \\
\hline $\begin{array}{l}\text { Rozmieszczenie placów miejskich w przestrzeni } \\
\text { centralnej }\end{array}$ & L & 5 & 6 & 5 \\
\hline $\begin{array}{l}\text { Rozmieszczenie obiektów powyżej 50 m wysokości } \\
\text { w przestrzeni centralnej }\end{array}$ & L & 13 & 4 & 4 \\
\hline $\begin{array}{l}\text { Powierzchnia zajmowana przez funkcje wielkomiej- } \\
\text { skie w przestrzeni centralnej }\end{array}$ & ha & 148,3 & 82,0 & 66,4 \\
\hline $\begin{array}{l}\text { Rozmieszczenie instytucji publicznych w przestrze- } \\
\text { ni centralnej }\end{array}$ & L & 55 & 22 & 17 \\
\hline $\begin{array}{l}\text { Rozmieszczenie obiektów wybudowanych w ra- } \\
\text { mach projektów wiodących w przestrzeni centralnej }\end{array}$ & L & 0 & 4 & 4 \\
\hline $\begin{array}{l}\text { Liczba nowych instytucji centralnych i projektów } \\
\text { wiodących w ekwidystancie 15 minut drogi pieszej od } \\
\text { dworców kolejowych i autobusowych (punkty węzło- } \\
\text { we o randze ponadlokalnej) w przestrzeni centralnej }\end{array}$ & L & 0 & 4 & 4 \\
\hline
\end{tabular}

Źródło: badania własne autora.

zabudowa analizowanych kwartałów ma charakter zwarty. W południowym fragmencie ulicy Piotrkowskiej omawiana wartość maleje do 61\%, co według tej samej klasyfikacji odpowiada zabudowie rozproszonej. O niższej intensywności poziomej zabudowy w południowym odcinku ulicy Piotrkowskiej zadecydowała lokalizacja ekstensywnie użytkowanych terenów przemysłowych w osadzie Łódka oraz przekształcenia przestrzenne, wiążące się z budową Śródmiejskiej Dzielnicy Mieszkaniowej w latach 70. XX w. Składa się ona z wieżowców mieszkalnych zbudowanych w systemie płyt prefabrykowanych, pomiędzy którymi znajdują się znaczne obszary otwartej przestrzeni o charakterze osiedlowym, zapewniającej jednocześnie dostęp światła dziennego do mieszkań.

W zgodzie z istniejącymi planami przekształceń morfologicznych terenów poprzemysłowych w Nowym Centrum Łodzi, po zakończeniu inwestycji intensywność pozioma zabudowy w całej nowej przestrzeni centralnej Łodzi będzie 


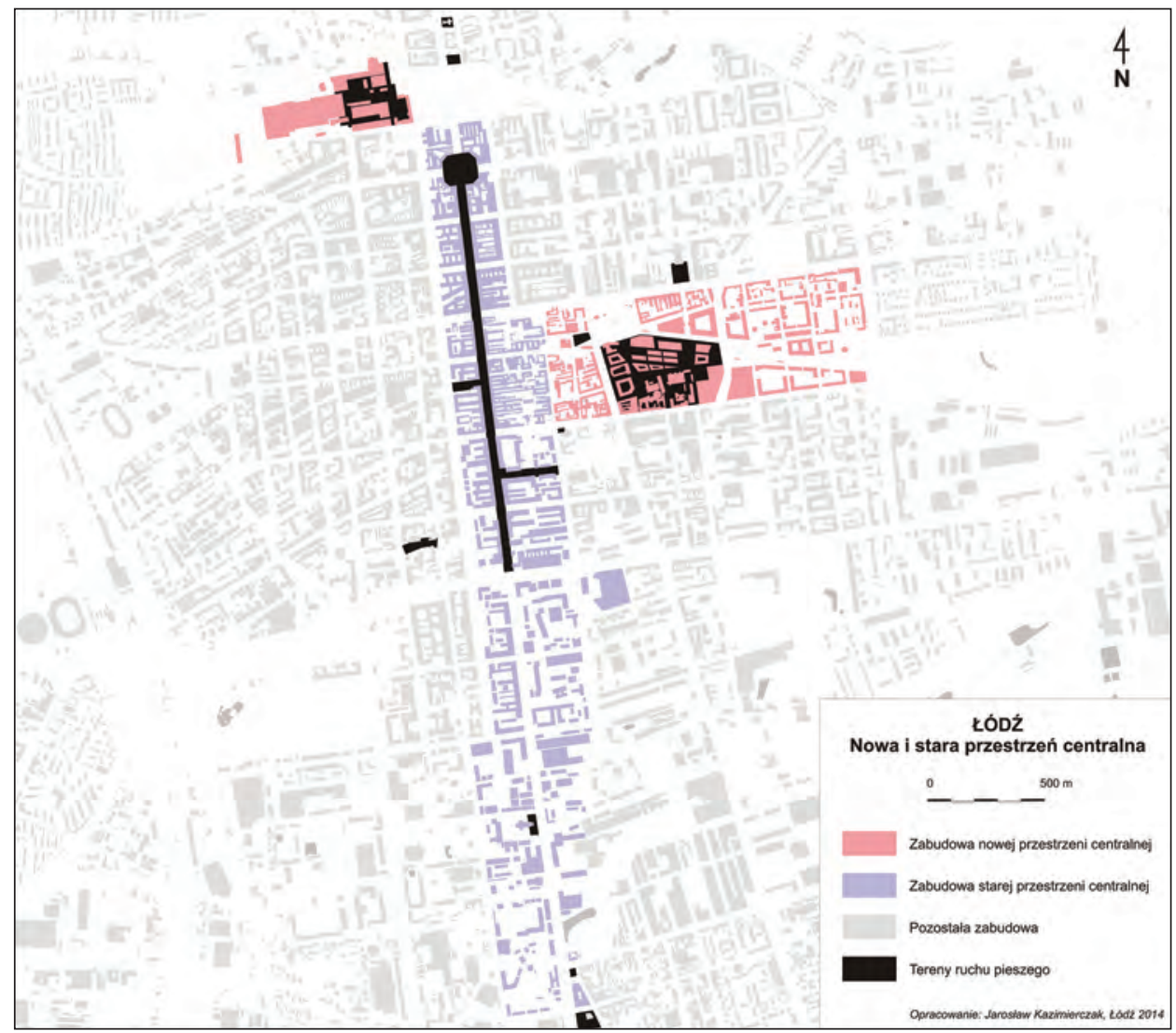

Rys. 7.11. Obszar zajmowany przez starą i nową przestrzeń centralną w Łodzi w roku 2013 ( $\mathrm{z}$ uwzględnieniem planów budowy Nowego Centrum Łodzi)

Źródło: badania własne autora

wynosić około 64\%. Aktualnie w „Manufakturze” analizowana wartość jest równa 35\%, co oznacza, że na obszarze tym występuje zabudowa luźna. W przypadku Nowego Centrum Łodzi intensywność pozioma zabudowy będzie zbliżona do 73\%. Przyszła struktura materialna tej części śródmieścia będzie zatem mieć charakter rozproszonej. Zróżnicowanie pomiędzy analizowanymi fragmentami nowej przestrzeni centralnej wynika z podporządkowania obszaru „Manufaktury” funkcji handlowej i przeznaczenia istotnej części terenów wokół galerii handlowej na parkingi naziemne. Na obszarze wytyczonego Nowego Centrum Łodzi, znajdują się natomiast fragmenty gęsto zabudowanych działek miejskich, szczególnie wzdłuż ulicy Sienkiewicza, Narutowicza i Tuwima (głównie w strefie III). O charakterze zabudowy rozproszonej, a nie typowej dla centrów miast europejskich zabudowie zwartej, decyduje przeznaczenie znacznej części NCŁ na tereny otwarte - place miejskie, zieleńca, szerokie ulice. Niemniej, po zakończeniu 
inwestycji Nowe Centrum Łodzi będzie stanowić jeden z najintensywniej zagospodarowanych terenów śródmiejskich.

Uśredniona intensywność przestrzeni centralnej w Łodzi po zakończeniu planowanych przekształceń przestrzenno-funkcjonalnych będzie wynosić około $66 \%$. Tym samym będzie jej odpowiadać zabudowa rozproszona, przy czym według klasyfikacji S. Liszewskiego (1978) za intensywność poziomą zabudowy typowej dla śródmieść miast europejskich przyjmuje się minimum $75 \%$. Na niską wartość analizowanego parametru ma wpływ przede wszystkim występowanie znacznej liczby niezagospodarowanych działek w kwartałach przylegających do ulicy Piotrkowskiej, co może świadczyć o niskiej atrakcyjności inwestycyjnej Łodzi. Kolejnym czynnikiem jest specyfika zagospodarowania nowej przestrzeni centralnej w miastach europejskich (w Łodzi, a także w Manchesterze i Lyonie), w której istotna część obszaru ma charakter otwarty, przeznaczony na funkcje rekreacyjne, wypoczynkowe oraz na nowe place miejskie, jako kluczowej integrującej przestrzeni publicznej miasta.

Znaczna część zabudowy śródmieścia Łodzi odznacza się niską bądź bardzo niską estetyką. W krajobrazie miejskim powszechnie występują niezabudowane narożniki, nieciągłości w pierzei ulic, odsłonięte oficyny zabudowy oraz XIX i XX-wieczne kamienice czynszowe, które w wyniku występowania „luki remontowej" pozbawione zostały detalu architektonicznego, niejednokrotnie także tynku. Część z historycznych obiektów jest w złym lub bardzo złym stanie technicznym (fot. 7.13). Dopełnieniem wizualnej dekapitalizacji zabudowy śródmiejskiej jest wandalizm, którego przejawem są liczne zabrudzenia elewacji budynków mieszkalnych, gospodarczych i usługowych (fot. 7.14). Stan, w jakim znajduje się współcześnie zabudowa obszaru śródmiejskiego, można uznać za najbardziej wyrazisty przejaw upadku miasta oraz niedostatecznych inwestycji w podnoszenie jakości przestrzeni publicznej Łodzi od zakończenia II wojny światowej. Jakość krajobrazu dzielnicy śródmiejskiej powoli, lecz konsekwentnie ulega poprawie w efekcie działań naprawczych podjętych m.in. w ramach dwóch obszarów pilotażowych Zintegrowanego Programu Rewitalizacji Prorevita (patrz rys. 7.7) oraz programu „Mia100 kamienic” (czytaj „Miasto kamienic”), zakładającym odnowę w latach 2012-2014 około 100 kamienic wielkomiejskich zlokalizowanych w historycznym śródmieściu Łodzi. W latach 2014-2020 planowana jest tzw. rewitalizacja obszarowa centrum Łodzi, finansowana z funduszy Unii Europejskiej. W tym celu tzw. strefa wielkomiejska Łodzi została podzielona na 55 obszarów przewidzianych w planach rewitalizacji. Są one zlokalizowane w północnej części śródmieścia pomiędzy ulicami Północną i Legionów na północy oraz aleją

${ }^{8}$ W nowym budżecie Unii Europejskiej na latach 2014-2020 szeroko rozumiana odnowa miast jest jednym z priorytetów. Szacuje się, że projekty rewitalizacji śródmieścia Łodzi mogą w tym okresie zostać dofinansowane w wysokości 2 mld złotych. Zgodnie z polskim prawem publiczne środki finansowe mogą być przeznaczone jedynie na inwestycje, które obejmują budynki i działki będące w posiadaniu gminy Łódź. 
Mickiewicza i Piłsudskiego na południu. Wyróżniono także 8 obszarów priorytetowych, które mają podlegać przekształceniom w pierwszym etapie i 12 kolejnych obszarów przewidzianych do realizacji w drugim etapie rewitalizacji obszarowej (rys. 7.12). Obejmować ona będzie zarówno inwestycje o charakterze „twardym”, ukierunkowane na naprawę warstwy materialnej śródmieścia, jak i działania o charakterze „miękkim” - w wymiarze społecznym. Na rok 2014 planowane są konsultacje społeczne w ramach wskazanych projektów priorytetowych (łącznie 20), natomiast sam proces inwestycyjny ma się rozpocząć w roku 2015.

Działania w ramach rewitalizacji obszarowej w Łodzi w rzeczywisty sposób mogą znacząco poprawić jakość przestrzeni publicznej śródmieścia Łodzi, co wynika $\mathrm{z}$ właściwości rewitalizacji wielkoobszarowej. Mankamentem

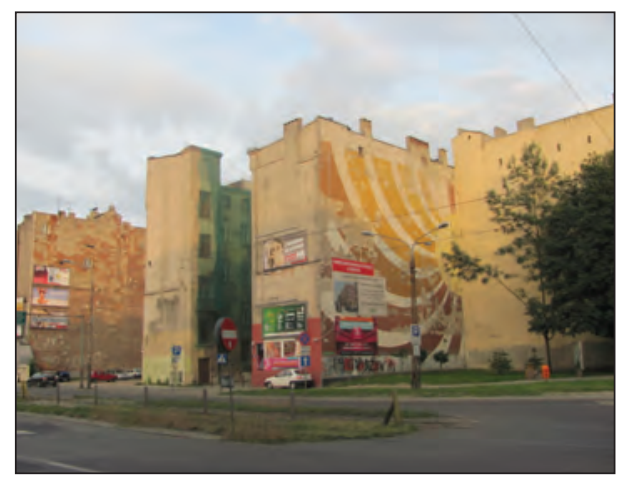

Fot. 7.13. Odsłonięte oficyny zabudowy przy ulicy Narutowicza

Źródło: fotografia autora



Fot. 7.15. Dom handlowy „Magda” wybudowany w latach 60 . XX w. w pierzei XIX-wiecznej zabudowy ulicy Piotrkowskiej

Źródło: fotografia autora

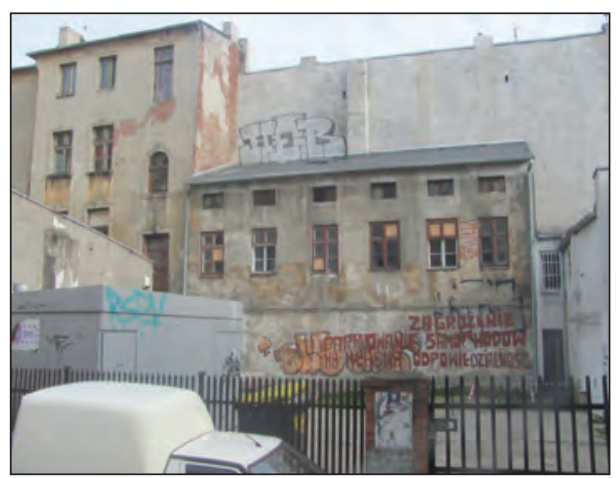

Fot. 7.14. Zdegradowana zabudowa przy skrzyżowaniu ulic Piotrkowskiej i Narutowicza

Źródło: fotografia autora

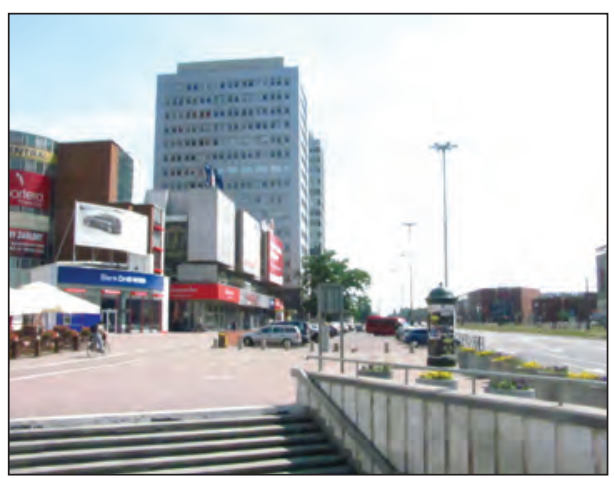

Fot. 7.16. Fragment łódzkiej dzielnicy biznesowo-administracyjnej z lat 70. XX w. Źródło: fotografia autora 
planowanych przekształceń jest brak ujęcia w planach rewitalizacji południowej części śródmieścia, położonej na południe od Trasy W-Z (aleja Mickiewicza-Piłsudskiego), co może prowadzić do stopniowej marginalizacji tej części przestrzeni centralnej. Wydaje się jednak, że podział ten wynika z ograniczonych środków finansowych $\mathrm{w}$ stosunku do potrzeb inwestycyjnych i wskazuje na kierunek planowanych zmian w centrum Łodzi.

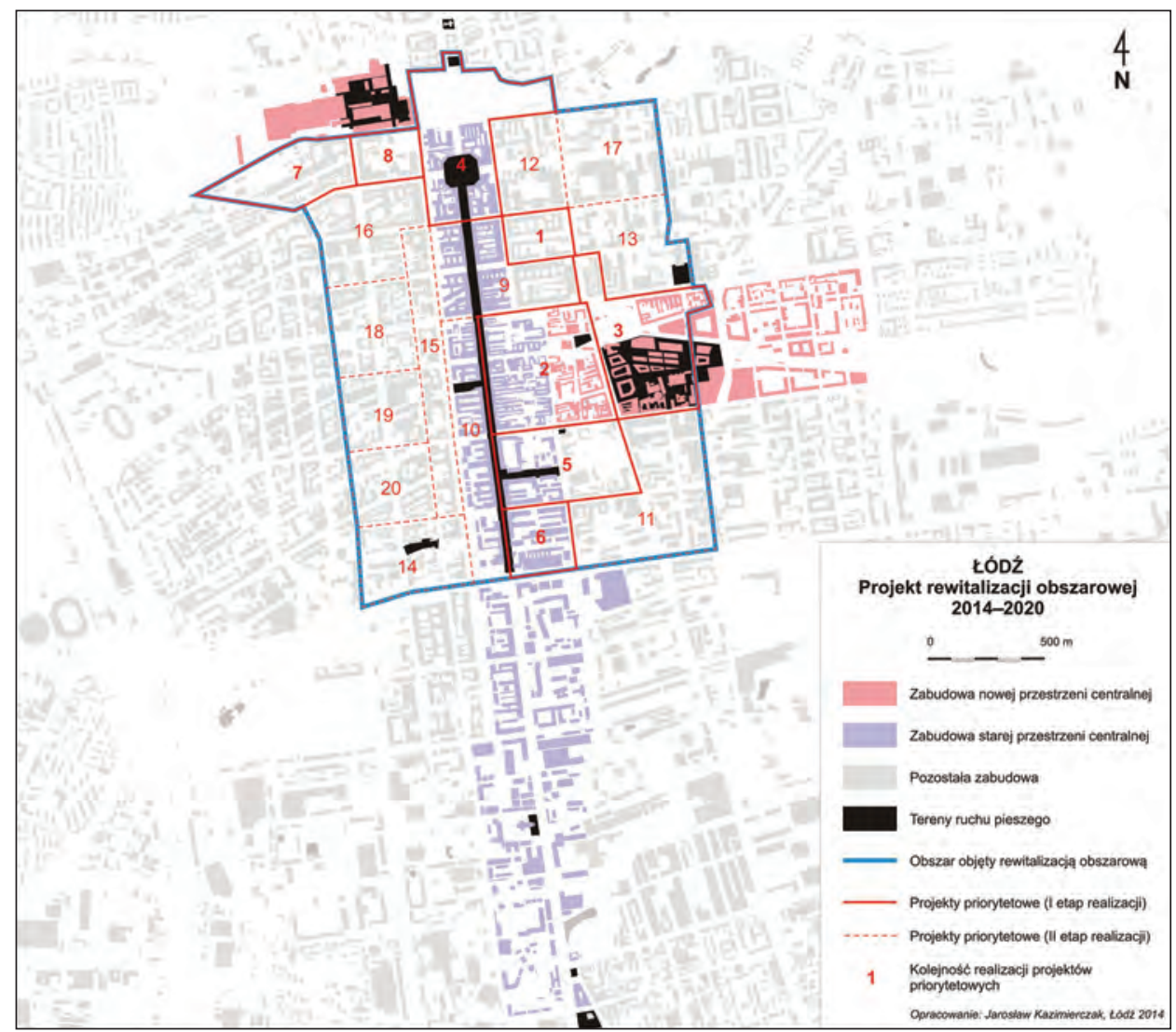

Rys. 7.12. Obszar strefy wielkomiejskiej Łodzi objęty programem rewitalizacji obszarowej w latach 2014-2020 z uwzględnieniem projektów priorytetowych

Źródło: Biuro Rewitalizacji i Rozwoju Zabudowy Miasta, Urząd Miasta Łodzi

Specyfiką śródmieścia Łodzi jest występowanie bardzo dużych kontrastów krajobrazowych. Polegają one na mozaikowym rozmieszczeniu obiektów o zróżnicowanej architekturze, wśród których szczególne miejsce zajmują budynki wybudowane w okresie socjalistycznym, które towarzyszą obiektom fabrycznym, wielkomiejskim kamienicom czynszowym bądź willom oraz pałacom miejskim (fot. 7.15 i 7.16). Szczególnie jaskrawym przykładem ingerencji w strukturę 
przestrzenną historycznej części Łodzi była budowa tzw. Śródmiejskiej Dzielnicy Mieszkaniowej w latach 70. XX w. wraz z „,dzielnicą biznesowo-administracyjną”. Znaczne kontrasty w krajobrazie śródmieścia Łodzi wiążą się także z przemiennym występowaniem enklaw odnowionej i zdegradowanej zabudowy bądź też częściej - pojedynczych budynków poddanych renowacji wewnątrz obszarów zdekapitalizowanej tkanki urbanistycznej. Wśród najbardziej zadbanych fragmentów dzielnicy śródmiejskiej należy wymienić ulicę Narutowicza i przede wszystkim ulicę Piotrkowską, która od XIX w. rozwijała się jako reprezentacyjna przestrzeń publiczna miasta, zastępując w ten sposób poniekąd rolę głównego placu miejskiego w Łodzi. Ze względu na rangę ulicy w kwartałach do niej przyległych zlokalizowana jest znaczna część najbardziej okazałych budynków w mieście. Są to głównie eklektyczne kamienice wielkomiejskie oraz obiekty sakralne z przełomu XIX i XX w. (fot. 7.17 i 7.18). Działania renowacyjne budynków przy ulicy Piotrkowskiej, podobnie jak w większości innych fragmentów przestrzeni śródmiejskiej, ograniczyły się głównie do odnowy elewacji z pominięciem gruntowej modernizacji obiektu, co w literaturze przedmiotu często określane jest pojęciem „fasadyzmu”.

Współczesna fizjonomia zabudowy w starej i nowej przestrzeni centralnej wykazuje znaczne zróżnicowanie. W krajobrazie przekształconych kwartałów pofabrycznych Izraela Poznańskiego dominuje odnowiona architektura industrialna, która została uzupełniona nowymi elementami architektonicznymi (patrz rys. $7.8 \mathrm{i}$ fot. 7.19-7.20). Powszechne jest połączenie ceglanych i szklanych elementów elewacji. Wśród nowych obiektów wyraźnie widoczna jest galeria handlowa, której fizjonomia jest jednak całkowicie podporządkowana funkcjom komercyjnym i nie wzbogaca walorów krajobrazowych tego rejonu miasta (fot. 7.20). Ze względu na znaczną kubaturę obiekty poprzemysłowe będą także stanowić wyraźny akcent w fizjonomii Nowego Centrum Łodzi, mimo nieznacznego jej udziału w ogólnej powierzchni przyszłej zabudowy (patrz rys. 7.10). Oprócz budynku „Bramy miasta”, który według przyjętych planów zagospodarowania będzie mógł mieć do 13 kondygnacji (do 64 metrów wysokości), dominantę zachodniej części Nowego Centrum Łodzi będzie stanowić zrewitalizowana elektrociepłownia EC-1 wraz z kominem zaadaptowanym na wieżę widokową (fot. 7.21). Obiekty wybudowane w ramach przekształceń przestrzenno-funkcjonalnych Nowego Centrum Łodzi będą mieć współczesną formę architektoniczną, typową dla nowoczesnych ośrodków europejskich początku XXI w. Wśród nich znajdą się budynki o oryginalnej fizjonomii, które będą współtworzyć wyróżniającą się w śródmieściu przestrzeń wielkomiejską (fot. 7.22).

Architektura nowych elementów przestrzeni centralnej Łodzi wyraźnie kontrastuje z historyczną zabudową ulicy Piotrkowskiej, a w szczególności z pozostałymi rejonami dzielnicy śródmiejskiej, w których przeważa zdekapitalizowana substancja mieszkaniowa i usługowa. Rewitalizacja terenów poprzemysłowych wprowadza zatem kolejne enklawy estetycznej przestrzeni publicznej, które prawdopodobnie spowodują odpływ użytkowników z zaniedbanej przestrzeni do nowej. Zjawisko 




Fot. 7.17. Neogotycka bazylika archikatedralna ze 102-metrową wieżą jest najwyższym budynkiem w Łodzi

Źródło: fotografia autora

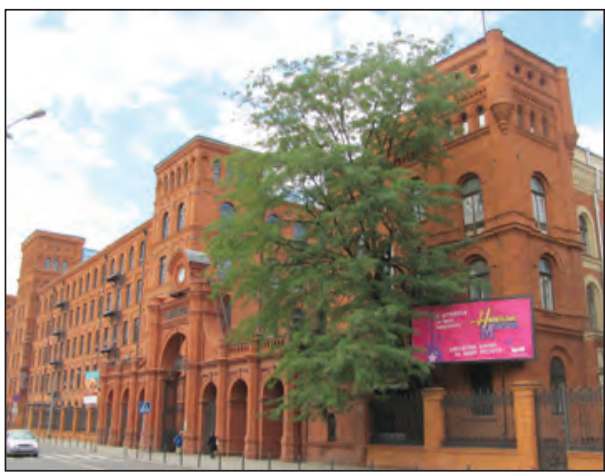

Fot. 7.19. Monumentalna zabudowa poprzemysłowa w południowej części kompleksu „Manufaktury”

Źródło: fotografia autora

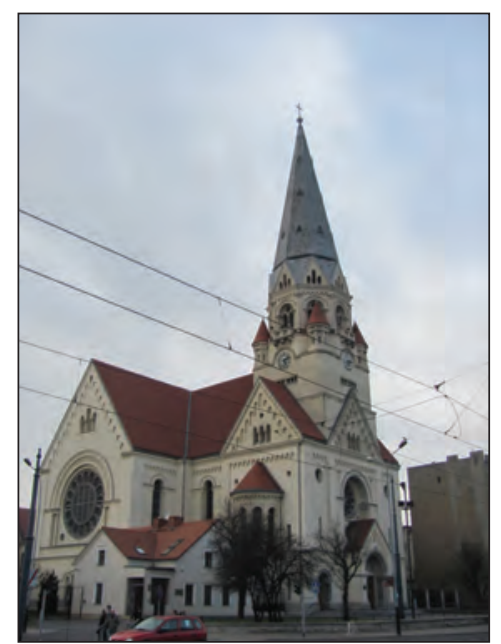

Fot. 7.18. Neoromański kościół ewangelicki pw. św. Mateusza przy ulicy Piotrkowskiej

Źródło: fotografia autora

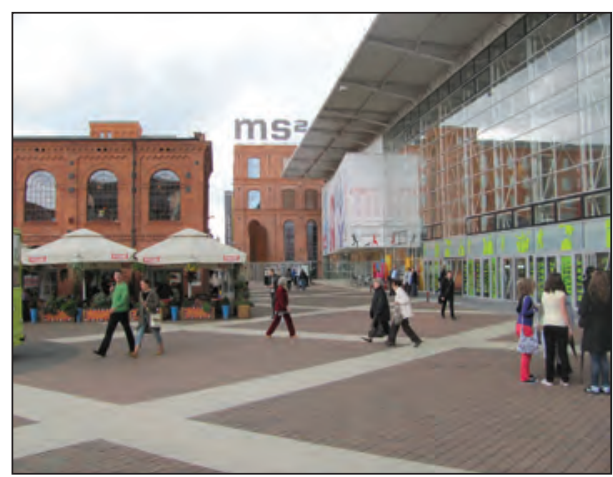

Fot. 7.20. Galeria handlowa wkomponowana w zabudowę postindustrialną „Manufaktury”

Źródło: fotografia autora

tego typu miało już miejsce w Łodzi na początku XXI w., kiedy część najemców lokali przy ulicy Piotrkowskiej przeniosła się nowych i bardziej estetycznych przestrzeni publicznych w nowo powstałej „Galerii Łódzkiej” (przestrzeni publicznej o charakterze dośrodkowym) i w „Manufakturze” (przestrzeni publicznej zarówno o charakterze dośrodkowym, jak i klasycznej, otwartej).

Do końca lat 90. XX w. najważniejszymi instytucjami publicznymi w przestrzeni centralnej Łodzi były świątynie, co widocznie zaznaczało się w sylwecie miasta. We współczesnej Łodzi najwyższym obiektem (poza obiektami 




Fot. 7.21. Budynek EC-1 Południowy-Wschód zajęty przez Muzeum Bajki oraz komin EC-1 Wschód, który zostanie przekształcony na wieżę widokową

Źródło: fotografia autora

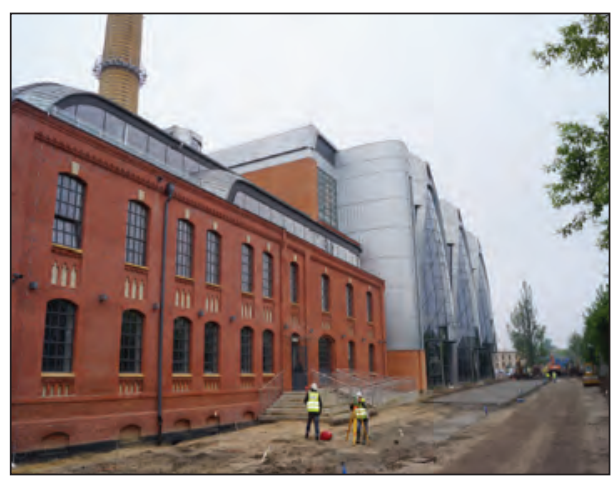

Fot. 7.22. Integracja nowoczesnej i postindustrialnej formy architektonicznej w kompleksie EC-1 Wschód Źródło: fotografia autora

technicznymi takimi jak kominy elektrociepłowni) jest 102-metrowa wieża archikatedry pw. św. Stanisława Kostki w południowej części ulicy Piotrkowskiej (patrz fot. 7.17). Wśród pozostałych najwyższych obiektów w mieście wskazać można inne wieże kościelne (m.in. kościoła pw. św. Mateusza, patrz fot. 7.18) oraz budynki wysokościowe wybudowane w okresie socjalistycznym. W zdecydowanej większości forma architektoniczna obiektów biurowo-administracyjnych z lat 60., 70. i 80. XX w. nie wzbogaca krajobrazu miasta, stwarza jednak namiastkę wielkomiejskiego charakteru Łodzi. W starej przestrzeni centralnej miasta zlokalizowanych jest 13 obiektów niesakralnych przekraczających 50 metrów wysokości, podczas gdy w nowej zaledwie 3 (tab. 7.2 i rys. 7.13). Jedynymi nowymi obiektami wysokościowymi, które zostały wybudowane w Łodzi po 1990 r., czyli w okresie gospodarki wolnorynkowej, są budynki hotelu Novotel przy alei Piłsudskiego oraz hotelu Double Tree by Hilton przy alei Mickiewicza oddane do użytkowania w 2013 r. Są to jednak budynki o wysokości nieprzekraczającej 50 m (rys. 7.13). Brak większej liczby nowych inwestycji w „łódzkiej dzielnicy biznesowej” ma ambiwalentny wydźwięk. Z jednej strony świadczy on bowiem o niskiej atrakcyjności Łodzi, szczególnie w kontekście wzmożonego zainteresowania inwestorów budową tego typu budynków w innych dużych polskich miastach w latach 90 . XX w. i na początku XXI w. Liczba obiektów wysokościowych we współczesnych miastach jest pewnego typu informacją o metropolitalnym charakterze miasta, jest też symbolem prestiżu miasta. W tym aspekcie Łódź można uznać za miasto o prowincjonalnym charakterze w skali europejskiej. Z drugiej strony, dzięki brakowi popytu na tego typu obiekty zachowana została istota krajobrazu XIX-wiecznej Łodzi, a współcześnie można mówić o kształtowaniu przestrzeni publicznej w „ludzkiej skali”. 


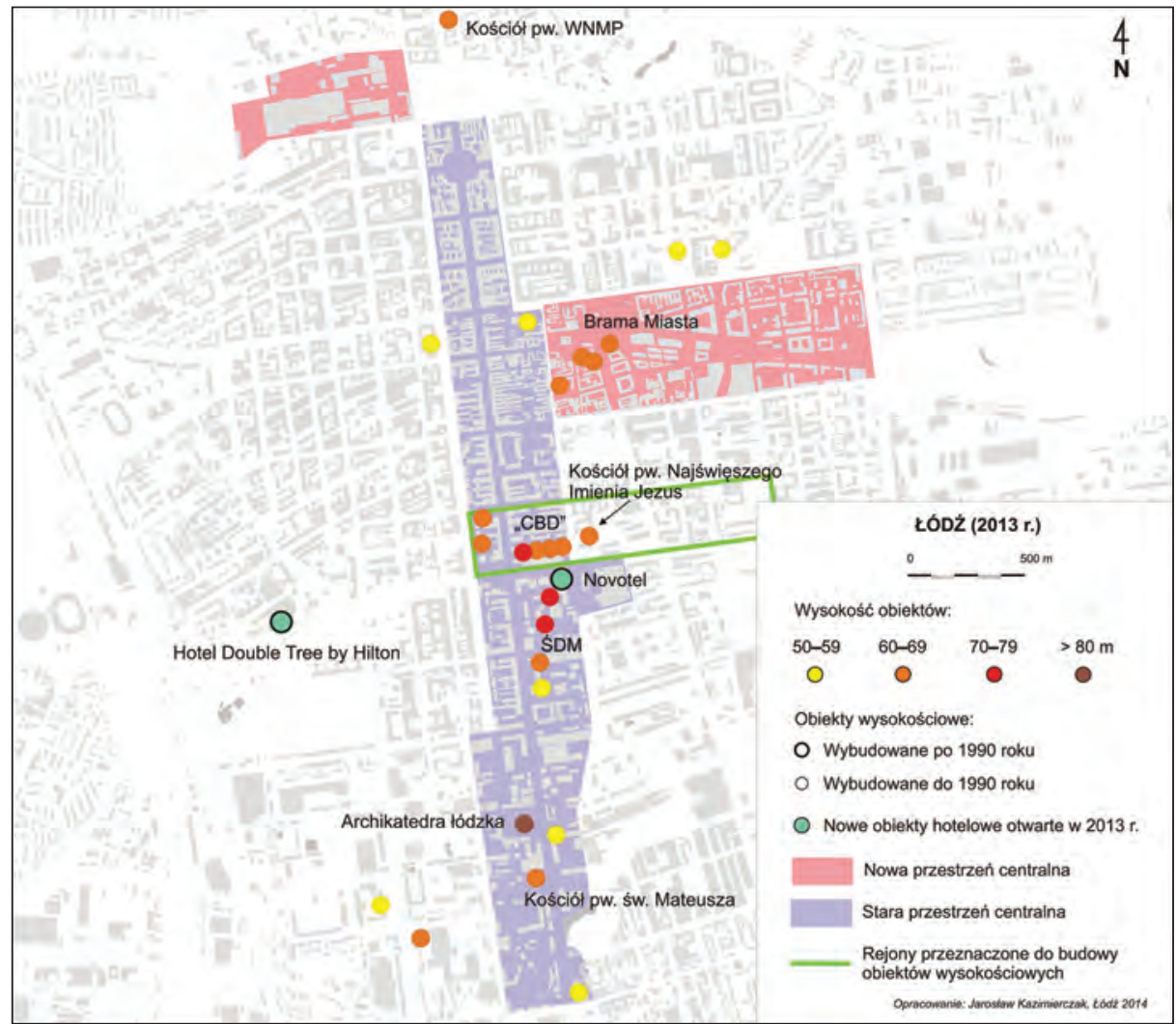

Rys. 7.13. Rozmieszczenie obiektów wysokościowych w śródmieściu Łodzi w 2013 r. (wykorzystano planowany układ zabudowy)

Źródło: badania własne autora

W celu poprawy estetyki „dzielnicy biznesowo-administracyjnej” Łodzi część $\mathrm{z}$ biurowców wybudowanych $\mathrm{w}$ okresie socjalistycznym została $\mathrm{w}$ latach 90. XX w. i na początku XXI w. poddana modernizacji. Przykład mogą stanowić obiekty biurowe przy alei Piłsudskiego - tzw. Orion i Red Tower (najwyższy obiekt biurowy w Łodzi o wysokości 76 metrów) oraz jedna z wież dawnej Centrali Handlu Zagranicznego przy ulicy Traugutta. Według współczesnych planów zagospodarowania przestrzennego Łodzi tereny położone przy Trasie WschódZachód, pomiędzy ulicą Piotrkowską i ulicą Targową, są przeznaczone pod zabudowę wysokościową (rys. 7.13.). Ze względu na sąsiedztwo ponadlokalnego węzła komunikacyjnego (nowego Dworca Fabrycznego), wybudowane obiekty zostaną przeznaczone na siedziby międzynarodowych firm oraz na wysokiej klasy mieszkania oraz hotele. Lokalizacja stref zabudowy wysokościowej w Łodzi oraz sama wysokość obiektów nieprzekraczająca $80 \mathrm{~m}$ jest determinowana położeniem lotniska i przebiegiem ścieżki lądowania samolotów nad obszarem śródmiejskim. 
Wielkość powierzchni placów oraz innych stref ruchu pieszego jest odzwierciedleniem rangi fragmentów przestrzeni centralnej w mieście. $Z$ uwzględnieniem planu przekształceń morfologicznych w NCŁ w Łodzi można zidentyfikować niski stopień zróżnicowania $\mathrm{w}$ tym zakresie pomiędzy ulicą Piotrkowską oraz nową przestrzenią centralną na terenach zrewitalizowanych (tab. 7.2 i rys. 7.14). W wyniku przemian przestrzenno-funkcjonalnych terenów poprzemysłowych powstał tzw. „Rynek Manufaktury” o powierzchni 2,1 ha. W Nowym Centrum Miasta planowana jest budowa Rynku Katarzyny Kobro o powierzchni około 1,6 ha, Rynku Władysława Strzemińskiego o powierzchni około 0,9 ha oraz dwóch innych placów (roboczo na potrzeby pracy nazwane „A” i „B”) o łącznej powierzchni 2,2 ha (rys. 7.14 , patrz też rys. $7.9 \mathrm{i} 7.15$ ).

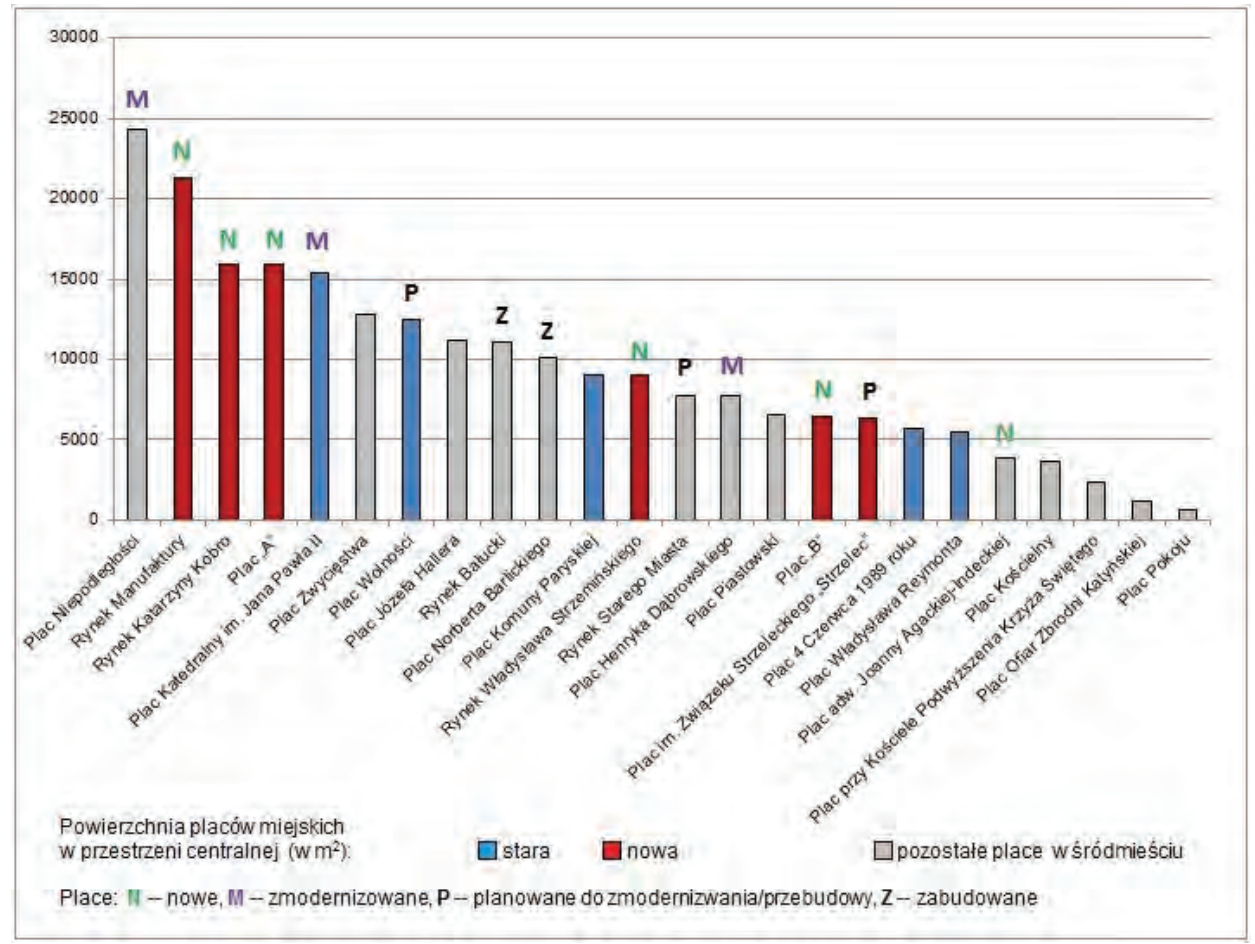

Rys. 7.14. Wielkość placów miejskich zlokalizowanych w obszarze śródmiejskim Łodzi w 2013 r. z uwzględnieniem projektu Nowego Centrum Łodzi (NCE)

Źródło: badania własne autora

Wraz z istniejącym placem im. Związku Strzeleckiego „Strzelec” oraz 5,5 ha pozostałych stref ruchu pieszego i pieszo-rowerowego NCŁ stanie się obszarem największej koncentracji otwartej przestrzeni publicznej w Łodzi. Zostanie ona uzupełniona także o elementy dośrodkowej przestrzeni publicznej „multimodalnego" dworca kolejowego i autobusowego. Budowa Rynku Kobro i Strzemińskiego 
wpisuje się koncepcję stworzenia nowego głównego placu w Łodzi. Przed podjęciem decyzji o rozbudowie Nowego Centrum Łodzi rolę taką miał pełnić rynek w „Manufakturze”, który jednak jest przestrzenią zarządzaną przez prywatnego inwestora. Nowa przestrzeń publiczna w Nowym Centrum Łodzi będzie natomiast w pełni nadzorowana przez władze miejskie.

Przeprowadzona analiza $\mathrm{z}$ łatwością pozwala stwierdzić, że tereny ruchu pieszego w śródmieściu Łodzi tworzą niezintegrowane ze sobą enklawy. Zaznacza się także zróżnicowanie w sposobie ich rozmieszczenia w północnej i południowej części śródmieścia (rys. 7.15).

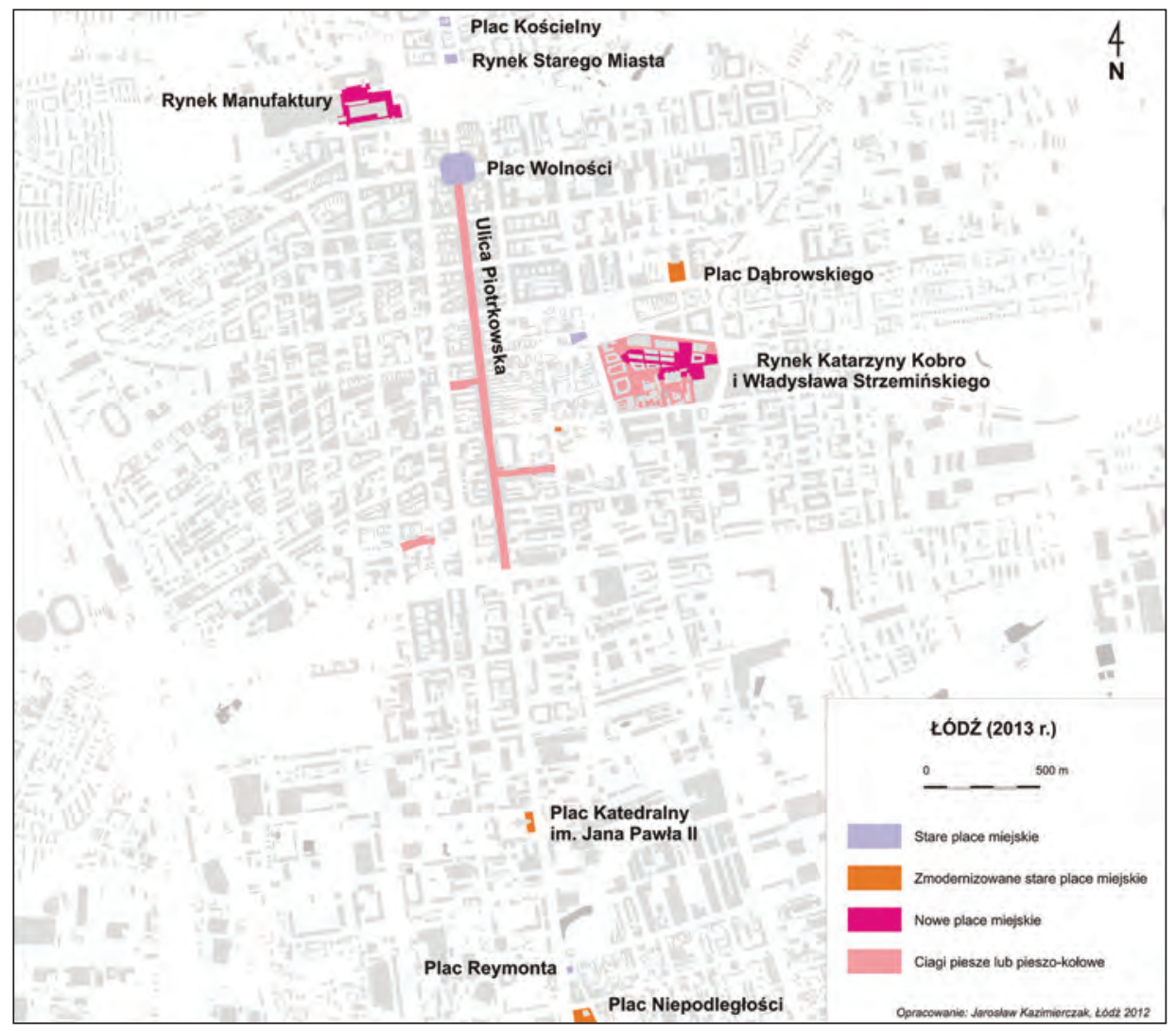

Rys. 7.15. Rozmieszczenie terenów pieszych w śródmieściu Łodzi w 2013 r. ( $\mathrm{z}$ uwzględnieniem planów budowy przestrzeni publicznej w Nowym Centrum Łodzi)

Źródło: badania własne autora

W roku 2013 opracowany został dokument strategiczny Urzędu Miasta Łodzi pt. „Atrakcyjne przestrzenie miejskie, czyli program działań mających na celu poprawę jakości przestrzeni publicznych w Łodzi”. Zgodnie z tym opracowaniem do roku 2020 układ przestrzeni publicznych w Łodzi ma ulec znaczącej 
modyfikacji, przede wszystkim poprzez wprowadzenie nowych ulic, placów, skwerów i pasaży do wnętrz kwartałów przylegających do ulicy Piotrkowskiej (rys. 7.16). Zasada ta ma także być implikowana w ramach planowanej rewitalizacji obszarowej centrum Łodzi. Pozostałe działania ujęte w programie koncentrują się na remoncie istniejących elementów liniowych i powierzchniowych struktury morfologicznej przestrzeni publicznej w starej przestrzeni centralnej, która została objęta planami miejscowymi (rys. 7.16). Jako generalną zasadę kształtowania nowych elementów przestrzeni publicznej w programie „Atrakcyjne przestrzenie...” przyjęto „konieczność realizacji usług w parterach nowych budynków, które będą nawiązywać dialog z przestrzenią, którą wykreują" (s. 12).

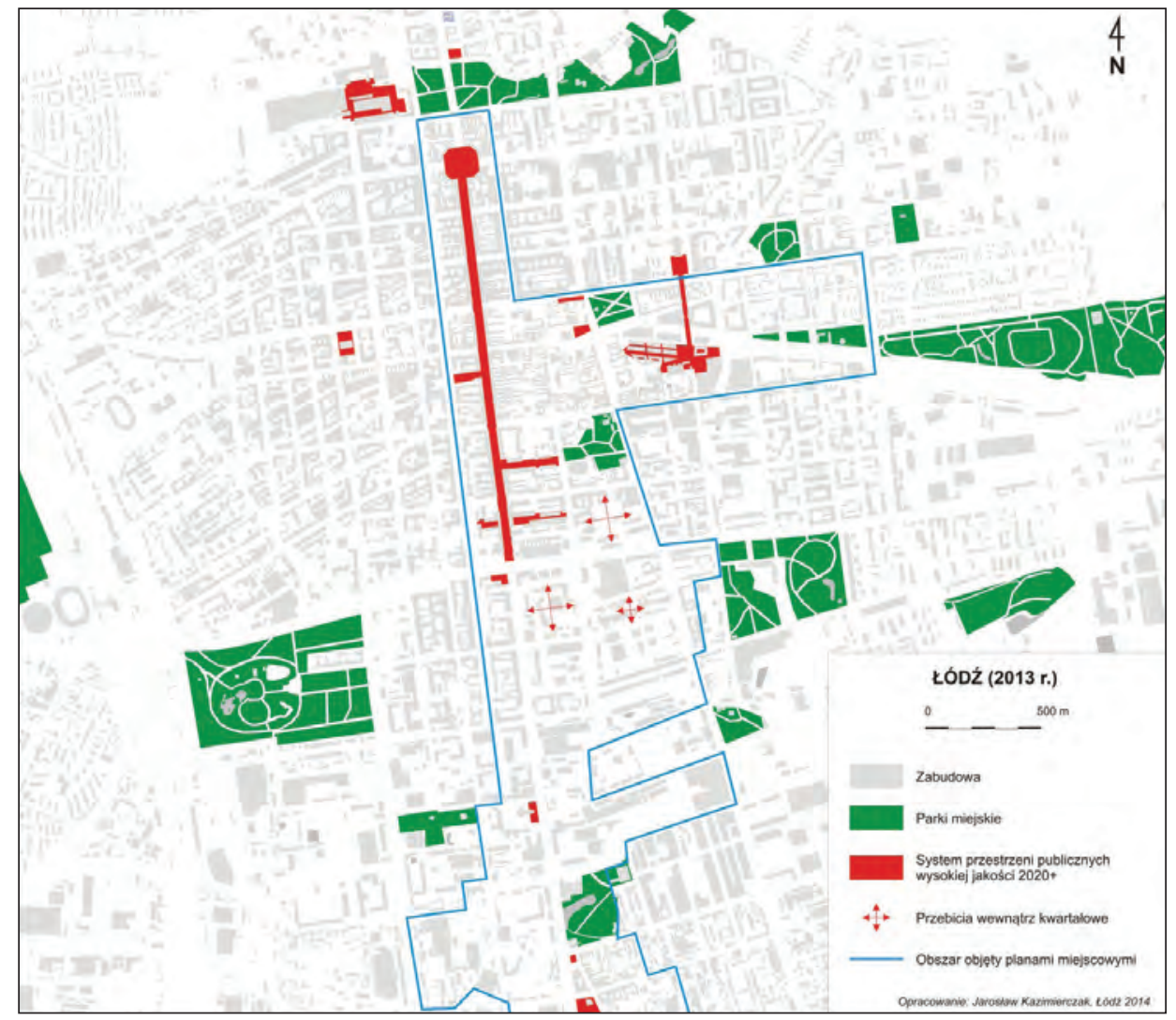

Rys. 7.16. Projekt rozwoju tzw. systemu przestrzeni publicznych wysokiej jakości 2020+ w śródmieściu Łodzi

Źródło: opracowanie autora na podstawie „Atrakcyjne przestrzenie...”

Jako jeden z podstawowych celów programu „Atrakcyjne przestrzenie...” wskazuje się na poprawę jakości przestrzeni publicznej. W dokumencie tym miara jakości przestrzeni publicznej jest rozumiana jako sposób jej użytkowania, 
wyrażona liczbą i jakością aktywności ludzi w niej się pojawiających oraz szeroko rozumianymi uwarunkowaniami estetycznymi będącymi narzędziem uatrakcyjniania przestrzeni. W przeważającej części współczesna przestrzeń publiczna w śródmieściu Łodzi jest zaniedbana. Składają się na nią nierówne chodniki, zanieczyszczone trawniki, skwery i parki, rzadko występujące klomby oraz inne elementy małej architektury poza licznymi pomnikami (Kazimierczak 2010). W rezultacie przyczynia się ona do sporadycznej, okazjonalnej aktywności mieszkańców miasta w przestrzeni publicznej. Pomiędzy starą i istniejącą współcześnie nową przestrzenią centralną zaznacza się wyraźna różnica $\mathrm{w}$ zakresie estetyki, fizjonomii i sposobu użytkowania placów miejskich oraz innych stref ruchu pieszego i pieszo-kołowego. Przestrzeń publiczna w zrewitalizowanym kompleksie Izraela Poznańskiego jest zadbana i wyposażona w meble miejskie

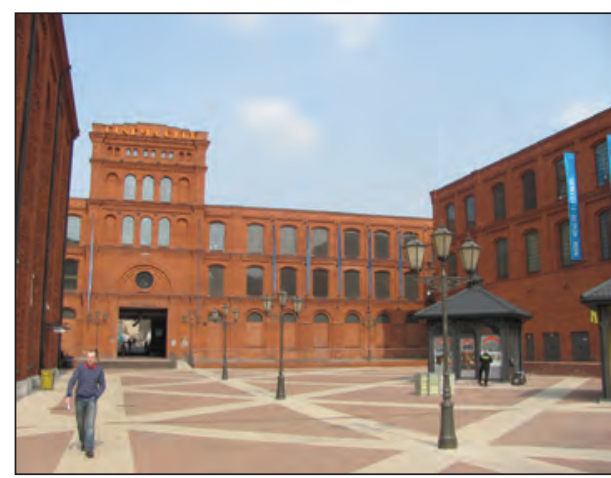

Fot. 7.23. Stylizowane latarnie i kioski jako element małej architektury w „Manufakturze”

Źródło: fotografia autora

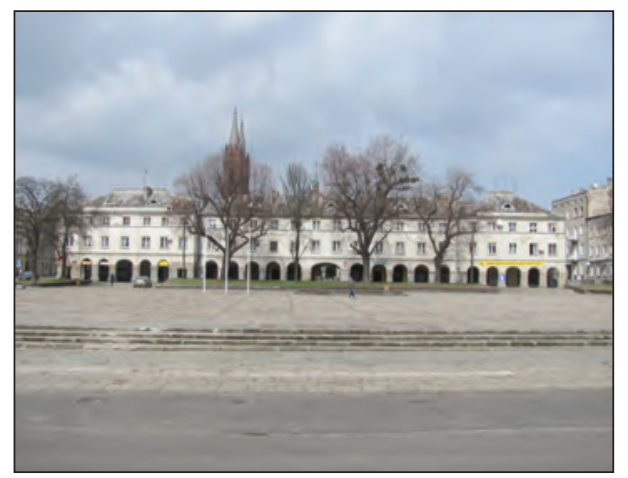

Fot. 7.25. Rynek staromiejski - zaniedbana przestrzeń publiczna w sąsiedztwie „Manufaktury"

Źródło: fotografia autora

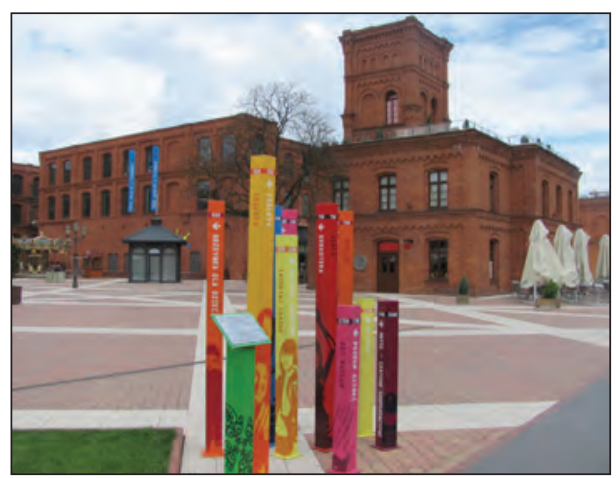

Fot. 7.24. Szata informacyjna jako element małej architektury w „Manufakturze”

Źródło: fotografia autora



Fot. 7.26. Szata informacyjna w „centrum” Łodzi przy skrzyżowaniu ulicy Piotrkowskiej $\mathrm{z}$ aleją Mickiewicza i Piłsudskiego (2012 r.)

Źródło: fotografia autora 
o oryginalnej formie, które nadają tej części miasta wyraźnego kontrastu w stosunku do innych przestrzeni publicznych w Łodzi (por. fot. 7.23-7.26). Na małą architekturę w „Manufakturze” składają się m.in. ławki i innego typu siedziska, klomby, stylizowane latarnie, zunifikowany system informacyjny oraz fontanna, której wydłużony kształt nawiązuje do przebiegu rzeki Łódki, biegnącej aktualnie w kanale pod powierzchnią rynku. Wyróżniająca się w kontekście innych placów w śródmieściu jest także posadzka rynku „Manufaktury”. Forma zastosowanych mebli miejskich wraz z postindustrialną zabudową uzupełnioną współczesnymi elementami architektonicznymi tworzą interesującą kompozycję przestrzenną.

Wybudowane w XIX w. place miejskie, zlokalizowane wzdłuż ulicy Piotrkowskiej, charakteryzują się znacznie niższą estetyką w porównaniu z rynkiem „Manufaktury”, co ma istotny wpływ na odmienny sposób ich użytkowania. Place wraz ze skwerami i innymi elementami przestrzeni publicznej w starej przestrzeni centralnej Łodzi są sporadycznie wykorzystywane jako miejsce spotkań i wypoczynku mieszkańców miasta oraz turystów. Funkcję takiego miejsca w śródmieściu pełni aktualnie przestrzeń publiczna (otwarta i zamknięta - dośrodkowa) „Manufaktury”, która ma charakter komercyjny. Z końcem 2012 r. rozpoczęto modernizację ulicy Piotrkowskiej, na której zostanie wymieniona nawierzchnia oraz elementy małej architektury. Zakończenie inwestycji jest planowane w połowie 2014 r. Planowana jest także przebudowa Placu Wolności, której celem będzie ograniczenie jego funkcji komunikacyjnej oraz przekształcenie placu w strefę ruchu pieszego (z torowiskiem dla tramwajów w północnej części). Obie inwestycje w istotny sposób poprawią walory estetyczne i użytkowe ulicy Piotrkowskiej.

Intersującym nowym miejscem w przestrzeni publicznej Łodzi jest obszar tzw. „OFF Piotrkowska Center”, rozwijany w dawnym kompleksie fabrycznym Franciszka Remischa, pomiędzy ulicami Piotrkowską i Sienkiewicza. Proces adaptacji przestrzeni poprzemysłowej obejmuje w tym przypadku głównie przekształcenia funkcjonalne. Obiekty o surowej industrialnej architekturze stały się dogodnym miejscem lokalizacji licznych obiektów gastronomicznych, klubów, barów oraz pracowni artystycznych i biur.

Mimo podjętych działań związanych z remontem ulicy Piotrkowskiej pomiędzy Placem Wolności oraz aleją Mickiewicza i Piłsudskiego, brakuje współcześnie klarownej wizji kształtowania wielkomiejskiego centrum Łodzi jako układu integrującego poszczególne enklawy (,zalążki”) rozwijanej przestrzeni centralnej. Szczególnie mocno zaznacza się to $\mathrm{w}$ marginalizacji południowego fragmentu ulicy Piotrkowskiej, która po wybudowaniu Trasy Wschód-Zachód w latach 70. $\mathrm{XX}$ w. systematycznie traci znaczenie w hierarchii terenów miejskich. Ponadto, w roku 2013 rozpoczęto przebudowę wspomnianej Trasy (rys. 7.17). Środkowy fragment przebudowywanej Trasy $\mathrm{W}-\mathrm{Z}$ (pomiędzy aleją Kościuszki i ulicą Piotrkowską) zostanie poprowadzony tunelem, co należy uznać za działanie pozytywne, które umożliwiłoby wygenerowanie nowej przestrzeni publicznej 
w formie strefy ruchu pieszego. Do realizacji przyjęta została natomiast koncepcja budowy centrum przesiadkowego dla linii tramwajowych łączących wschodnią i zachodnią oraz północną i południową część miasta9. Oznacza to, że wygenerowana $\mathrm{w}$ ramach budowy tunelu otwarta przestrzeń miejska zagospodarowana zostanie na tereny komunikacyjne z nieznaczną ilością zieleni miejskiej i nowych elementów małej architektury. Pozostała część Trasy $\mathrm{W}-\mathrm{Z}$, pomiędzy ulicą Żeromskiego i aleją Kościuszki (w zachodniej części), oraz pomiędzy ulicą Piotrkowską i Kilińskiego (w części wschodniej) zostanie poprowadzona w otwartym zagłębieniu, nad którym na wsporniku zostanie wybudowana linia tramwajowa. Inwestycja w zaproponowanym kształcie nie przyczyni się do przestrzennej i funkcjonalnej integracji północnej i południowej części śródmieścia Łodzi. Dodatkowo, budowa drogi w odkrytym zagłębieniu uniemożliwi tego typu działania naprawcze na kolejne dekady, co w konsekwencji spowoduje trwałą dezintegrację przestrzeni centralnej oraz marginalizację południowej części śródmieścia (na południe od Trasy $\mathrm{W}-\mathrm{Z}$ ).

W kontekście kształtowania zintegrowanej przestrzeni centralnej w północnej części dzielnicy śródmiejskiej Łodzi istotne wydaje się być także rozmieszczenie stacji kolejowych wzdłuż planowanego tunelu średnicowego. Według przeprowadzonego studium wykonalności inwestycji pomiędzy dworcami Łódź Fabryczna i Łódź Kaliska rozważane są dwie stacje pośrednie - w „Manufakturze” oraz przy skrzyżowaniu ulicy Zielonej oraz Zachodniej-Kościuszki w sąsiedztwie ulicy Piotrkowskiej (rys. 7.17). Realizacja tunelu średnicowego w tej formie wpłynęłaby korzystnie na ożywienie ulicy Piotrkowskiej (szczególnie po zakończeniu jej modernizacji) jako ważnego elementu integrującego użytkowników przestrzeni miejskiej w nowej strukturze przestrzeni centralnej Łodzi. Ze względu jednak na wysoki koszt inwestycji stacja przy ulicy Piotrkowskiej prawdopodobnie nie zostanie wybudowana. W sytuacji, kiedy inwestycja kolejowa obejmie budowę przystanku w „Manufakturze”, nastąpić może dalsze obniżenie pozycji ulicy Piotrkowskiej w hierarchii terenów miejskich w Łodzi.

Od otwarcia „Manufaktury” w 2006 r. nadal nie zostały podjęte działania prowadzące do integracji tego obszaru z Placem Wolności, a tym samym z ulicą

${ }^{9}$ Tunel Trasy W-Z powstanie jedynie na odcinku pomiędzy ulicą Wólczańską na zachodzie do ulicy Sienkiewicza na wschodzie. Nad tunelem znajdować się będzie tramwajowe centrum przesiadkowe, składające się z czterech torów. Pozostała część Trasy W-Z będzie miała kształt zagłębienia, nad którym będą przebiegać ulice biegnące do niej prostopadle. Inwestycję tę można łączyć de facto z budową wschodniej obwodnicy Łodzi, którą stanowić będzie odcinek autostrady A1 z Trójmiasta na północy do granicy polsko-czeskiej w Gorzyczkach na południu. Zasadność budowy śródmiejskiej Trasy W-Z w realizowanej formule wydaje się być jednak wątpliwa, szczególnie w kontekście kształtowanego ringu drogowego wokół Łodzi, który, oprócz wspomnianego odcinka autostrady A1, tworzyć będą autostrada A2 na północy, droga ekspresowa S8 na południu (z Wrocławia do Białegostoku) i planowana droga ekspresowa S14 na zachodzie. W przygotowaniu jest także studium transportowe Łodzi, w którym sugerowane jest uzupełnienie obwodnicy śródmieścia m.in. poprzez budowę tzw. ulicy Nowokonstytucyjnej. 
Piotrkowską. W ramach planowanej modernizacji ulicy Piotrkowskiej zadanie tego typu także zostało pominięte. Również projekt Nowego Centrum Łodzi jest realizowany jako kolejna inwestycja w dzielnicy śródmiejskiej, która nie wykazuje realnego powiązania przestrzenno-funkcjonalnego z ulicą Piotrkowską i „Manufakturą”. W rezultacie budowa Nowego Centrum Łodzi, która niewątpliwie jest bardzo ważna w kontekście przyszłego rozwoju miasta, może de facto przyczynić się do utrwalenia liniowo-enklawowej struktury przestrzeni centralnej w Łodzi, przy trwałej marginalizacji jednostek morfologicznych znajdujących się w południowej części śródmieścia (Łódka i Nowa Łódka).

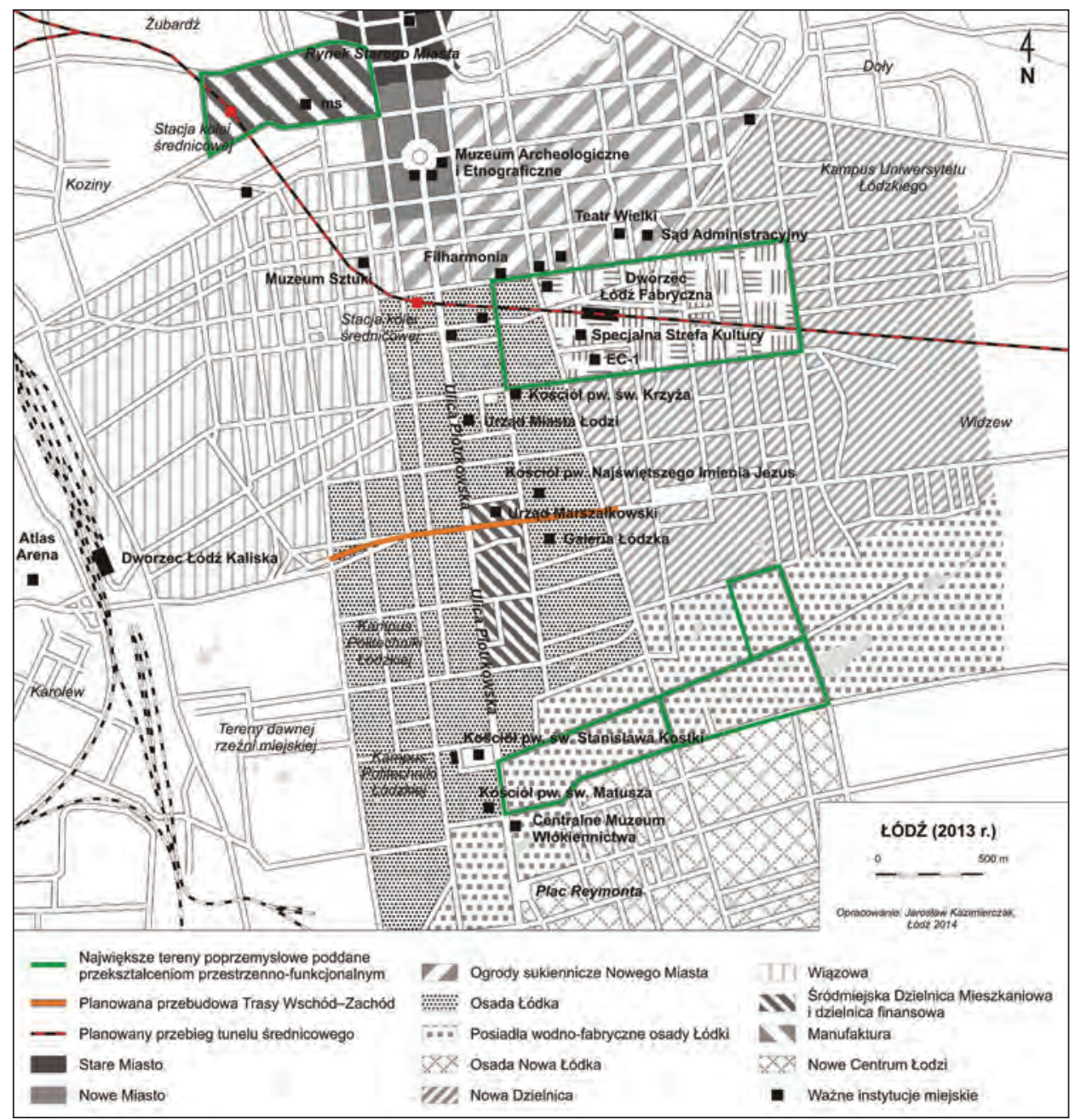

Rys. 7.17. Współczesne przekształcenia w dzielnicy śródmiejskiej Łodzi (stan na 2013 r.) Źródło: badania własne autora 
Stara i kształtowana nowa przestrzeń centralna w Łodzi charakteryzują się znacznym podobieństwem $\mathrm{w}$ zakresie udziału powierzchni zajmowanej przez funkcje wielkomiejskie w stosunku do ogólnej powierzchni przestrzeni centralnej (tab. 7.2). W aspekcie rozmieszczenia nowych instytucji centralnych, projektów wiodących i ich lokalizacji względem węzłów komunikacji ponadlokalnej ulica Piotrkowska i nowa przestrzeń centralna, głównie w ramach Nowego Centrum Łodzi, wykazywać się będą natomiast wysokim stopniem zróżnicowania (tab. 7.2).

Proces transformacji przestrzeni centralnej w Łodzi do roku 2013 składał się z czterech etapów i nie doprowadził do wygenerowania obszaru identyfikowanego $\mathrm{z}$ centrum miasta. Jednostki morfogenetyczne tworzące dzielnicę śródmiejską na przestrzeni niespełna 200 lat rozwoju wielkiego ośrodka miejskiego stanowiły odrębnie funkcjonujące części miasta zarówno w ujęciu przestrzennym, jak i instytucjonalnym. Czynnik ten zadecydował o wykształceniu się przestrzeni centralnej o zalążkowym charakterze i jedynie w kwartałach przylegających do ulicy Piotrkowskiej. Podjęte na początku XXI w. działania rewitalizacyjne na terenach poprzemysłowych, które miały formę przekształceń punktowych jak i wielkoobszarowych, również nie przyczyniły się do ukształtowania wielkomiejskiego centrum. Inne przekształcenia morfologiczne w dzielnicy śródmiejskiej realizowane od połowy XX w. i skoncentrowane na przebudowie układu komunikacyjnego śródmieścia Łodzi spowodowały dodatkowo marginalizację najstarszych jednostek morfogenetycznych miasta położonych na południe od Trasy Wschód-Zachód. Istniejąca bariera przestrzenno-funkcjonalna, rozmieszczenie współczesnego ,usługowego centrum miasta” wzdłuż ulicy Piotrkowskiej pomiędzy Placem Wolności i Trasą Wschód-Zachód oraz koncentracja działań zmierzających do wygenerowania nowej przestrzeni centralnej w północnej części śródmieścia (rys. 7.17) mogą stanowić czynnik determinujący zasięg przestrzenny przyszłego centrum Łodzi.

Pomiędzy starą i nową przestrzenią centralną w Lodzi ( $w$ tym z uwzględnieniem planów budowanego Nowego Centrum Łodzi) można wskazać kierunek rozwoju przestrzeni centralnej charakteryzującej się niskim stopniem zróżnicowania $\left(\mathrm{N}_{\mathrm{Z}}\right)$ starej i nowej części (tab. 7.3).

W celu identyfikacji relacji zachodzących pomiędzy starą i nową przestrzenią centralną w Łodzi przeprowadzono także analizę poziomu rozwinięcia przestrzeni centralnej uwzględniającą programy rewitalizacji terenów poprzemysłowych. Wartości wskaźnika syntetycznego Ws wraz z wartościami standaryzowanymi cech, czyli wskaźników cząstkowych, opisujących poszczególne aspekty poziomu rozwinięcia przestrzeni centralnej w Łodzi zawiera tabela 7.4.

Wskaźnik poziomu rozwinięcia przestrzeni centralnej (Ws) w Łodzi po zakończeniu rewitalizacji terenów poprzemysłowych w NC€ i wykształceniu nowej przestrzeni centralnej będzie wynosić $-0,36859$. Zgodnie z przyjętymi założeniami oznacza to niski poziom rozwinięcia przestrzeni centralnej (wskaźnik ujemny). 
Tabela 7.3. Stopień zróżnicowania wybranych cech morfologii i sposobu użytkowania starej i nowej przestrzeni centralnej w Łodzi w 2013 r.

(z uwzględnieniem planów Nowego Centrum Łodzi)

\begin{tabular}{|l|c|c|}
\hline \multicolumn{1}{|c|}{ Cecha } & $Z(w \%)$ & $\begin{array}{c}\text { Stopień } \\
\text { zróżnicowania }\end{array}$ \\
\hline Powierzchnia przestrzeni centralnej & 21 & Niski $\left(Z_{N}\right)$ \\
\hline Powierzchnia przestrzeni zamkniętych w przestrzeni centralnej & 24 & Niski $\left(Z_{N}\right)$ \\
\hline Powierzchnia przestrzeni otwartych w przestrzeni centralnej & 15 & Niski $\left(Z_{N}\right)$ \\
\hline $\begin{array}{l}\text { Powierzchnia przestrzeni publicznej integrującej (place miejskie) } \\
\text { w przestrzeni centralnej }\end{array}$ & 24 & Niski $\left(Z_{N}\right)$ \\
\hline $\begin{array}{l}\text { Powierzchnia terenów ruchu pieszego (inne strefy piesze bez placów) } \\
\text { przestrzeni centralnej }\end{array}$ & 3 & Niski $\left(Z_{N}\right)$ \\
\hline Rozmieszczenie placów miejskich w przestrzeni centralnej & 9 & Niski $\left(Z_{N}\right)$ \\
\hline $\begin{array}{l}\text { Rozmieszczenie obiektów powyżej 50 m wysokości w przestrzeni cen- } \\
\text { tralnej }\end{array}$ & 53 & $\begin{array}{c}\text { Umiarkowany } \\
\left(Z_{\mathrm{U}}\right)\end{array}$ \\
\hline $\begin{array}{l}\text { Powierzchnia zajmowana przez funkcje wielkomiejskie w przestrzeni } \\
\text { centralnej }\end{array}$ & 29 & Niski $\left(Z_{N}\right)$ \\
\hline Rozmieszczenie instytucji publicznych w przestrzeni centralnej & 43 & Niski $\left(Z_{N}\right)$ \\
\hline $\begin{array}{l}\text { Rozmieszczenie obiektów wybudowanych w ramach projektów wio- } \\
\text { dących w przestrzeni centralnej }\end{array}$ & 100 & Wysoki $\left(Z_{\mathrm{W}}\right)$ \\
\hline $\begin{array}{l}\text { Liczba nowych instytucji centralnych i projektów wiodących w ekwidy- } \\
\text { stancie 15 minut dojścia pieszego od dworców kolejowych i autobuso- } \\
\text { wych (punkty węzłowe o randze ponadlokalnej) w przestrzeni centralnej }\end{array}$ & 100 & Wysoki $\left(Z_{\mathrm{W}}\right)$ \\
\hline
\end{tabular}

Źródło: badania własne autora.

Tabela 7.4. Wartości wskaźnika syntetycznego (Ws) i wartości standaryzowane cech opisujących poziom rozwinięcia przestrzeni centralnej w Łodzi z uwzględnieniem projektu NCŁ

\begin{tabular}{|c|l|c|}
\hline $\mathrm{W}$ & \multicolumn{1}{|c|}{ Cecha (wskaźnik cząstkowy) } & $\begin{array}{c}|c| \\
\text { Wartość } \\
\text { zestandaryzowana }\end{array}$ \\
\hline $\mathrm{W}_{1}$ & Powierzchnia przestrzeni centralnej (w ha) / Liczba ludności miasta & $-0,36079$ \\
\hline $\mathrm{W}_{2}$ & $\begin{array}{l}\text { Liczba jednostek morfologicznych kształtujących przestrzeń centralną } \\
\text { / Powierzchnia przestrzeni centralnej (w ha) }\end{array}$ & $-0,66984$ \\
\hline $\mathrm{W}_{3}$ & $\begin{array}{l}\text { Liczba instytucji publicznych w przestrzeni centralnej / Powierzchnia } \\
\text { przestrzeni centralnej (w ha) }\end{array}$ & 1,32684 \\
\hline $\mathrm{W}_{4}$ & $\begin{array}{l}\text { Powierzchnia przestrzeni centralnej (w ha) / Powierzchnia śródmieścia } \\
\text { (w ha) }\end{array}$ & $-0,86142$ \\
\hline $\mathrm{W}_{5}$ & $\begin{array}{l}\text { Liczba placów w przestrzeni centralnej / Powierzchnia przestrzeni cen- } \\
\text { tralnej (w ha) }\end{array}$ & $-0,95980$ \\
\hline $\mathrm{W}_{6}$ & $\begin{array}{l}\text { Liczba instytucji publicznych w przestrzeni centralnej / Liczba ludno- } \\
\text { ści miasta }\end{array}$ & $-0,68652$ \\
\hline $\mathrm{Ws}$ & Wskaźnik poziomu rozwinięcia przestrzeni centralnej & $\mathbf{- 0 , 3 6 8 5 9}$ \\
\hline
\end{tabular}

Źródło: badania własne autora. 
W oparciu o matrycę zależności pomiędzy stopniem zróżnicowania i rozwinięcia przestrzeni centralnej a występowaniem relacji konkurencyjnych, kooperacyjnych i konglomeracyjnych w przestrzeni centralnej miast (patrz rys. $2.3 \mathrm{w}$ rozdz. 2) w Łodzi zidentyfikowano relacje slabo konglomeracyjne (typu I). Charakteryzują się one możliwością bardzo łatwej konwersji na inny typ relacji ze względu na słaby poziom rozwoju przestrzeni centralnej i niski stopień zróżnicowania jej starej i nowej części, umożliwiające daleko idącą modyfikację struktury morfologicznej i funkcjonalnej. Kierunek rozwoju przestrzeni centralnej w Łodzi o charakterze konglomeracji potwierdza historyczna i współczesna struktura morfologiczna przestrzeni centralnej, którą współtworzą niezintegrowane ze sobą enklawy. Relacje tego typu mają negatywny wpływ na proces kształtowania spójnego centrum wielkomiejskiego.

\subsection{Wnioski}

Łódź jest jedynym miastem w przeprowadzonych studiach przypadku, w ramach którego analizie zostały poddane projekty przekształceń przestrzenno-funkcjonalnych terenów poprzemysłowych będące we wstępnej fazie realizacji. Studia retrospektywne pozwoliły wyróżnić cztery etapy kształtowania przestrzeni centralnej w Łodzi. Dynamika jej rozwoju była niska i w kolejnych okresach rozwoju miasta cechowała się zalążkowym charakterem oraz liniowo-enklawową strukturą przestrzenną. Na podstawie przeprowadzonych badań stwierdzono, że proces transformacji przestrzeni centralnej odbywał się w warunkach dominacji działalności przemysłowej (rys. 7.18). Od XIX w. dzielnica śródmiejska Łodzi wykazuje się znacznymi kontrastami w zakresie rozplanowania oraz fizjonomii, co wynika z mozaikowego rozmieszczenia terenów produkcyjnych, składowych, komunikacyjnych, usługowych i rezydencjonalnych. W wyniku transformacji gospodarczej w Polsce na początku lat 90 . XX w. powszechnym i istotnym elementem współkształtującym morfologię dzielnicy śródmiejskiej Łodzi stały się zdegradowane tereny poprzemysłowe.

Peryferyjne położenie Łodzi w słabo rozwiniętej gospodarczo Rosji w XIX w., a następnie rozwój w warunkach gospodarki centralnie planowanej stanowiły istotny czynnik ograniczający rozwój instytucji centralnych. Struktura morfologiczna śródmieścia kształtowana od początku XIX do przełomu XX i XXI w. również nie sprzyjała ekspansji urządzonej przestrzeni publicznej poza ulicę Piotrkowską.

Pierwsze cztery etapy kształtowania przestrzeni centralnej warunkują współcześnie podejmowane działania w dzielnicy śródmiejskiej, które prowadzić mają do wykształcenia wielkomiejskiego centrum Łodzi. Obejmują one m.in. przekształcenia przestrzenno-funkcjonalne wewnątrzmiejskich zdegradowanych terenów poprzemysłowych o zróżnicowanej powierzchni i wartości zachowanej substancji materialnej. 
W świetle rezultatów inwestycji zakończonych do 2013 r. oraz założeń aktualnie realizowanych projektów rewitalizacji obszarów postindustrialnych i transformacji innych elementów struktury morfologicznej miasta istnieje zagrożenie utrwalenia niekorzystnego, liniowo-enklawowego układu przestrzeni centralnej w Łodzi.

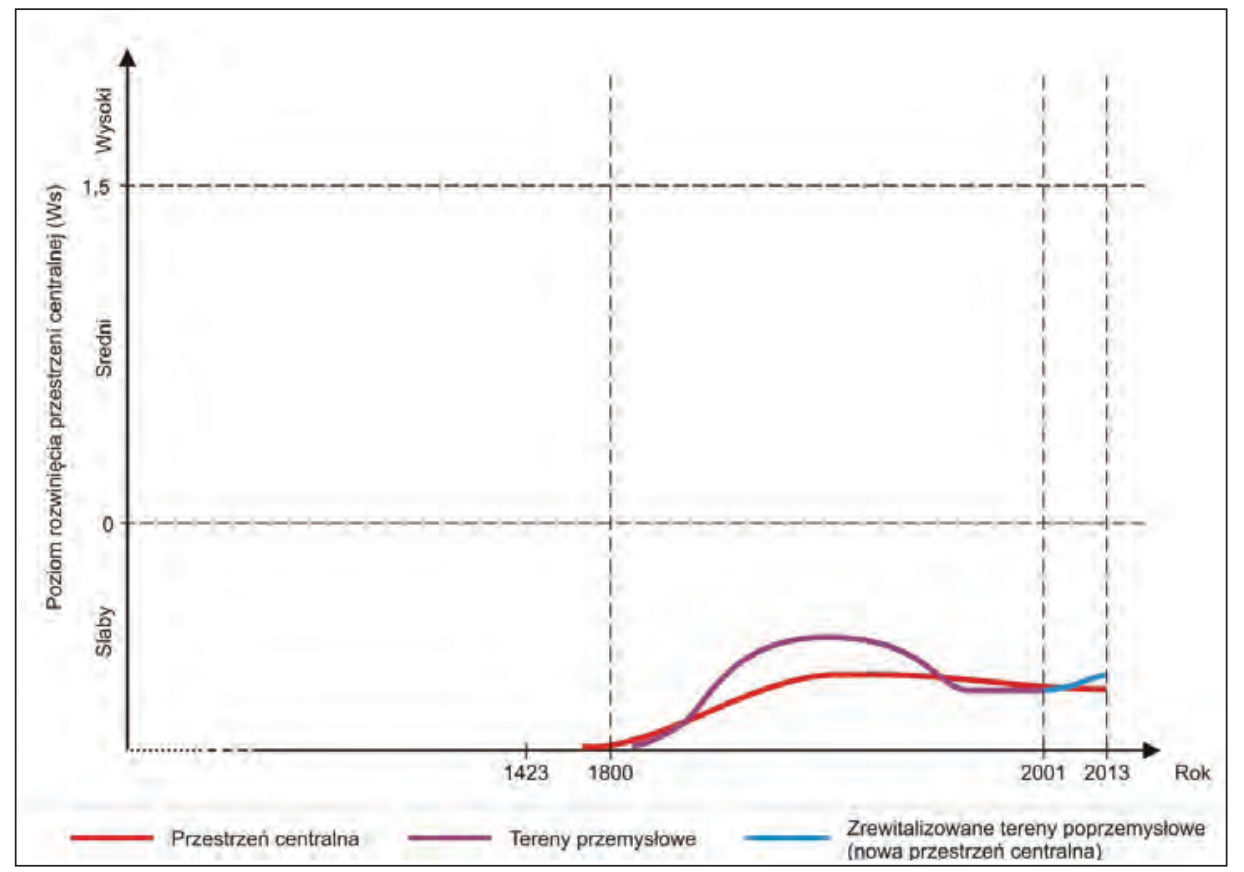

Rys. 7.18. Model sposobu rozwoju przestrzeni centralnej i terenów przemysłowych w Łodzi

Źródło: badania własne autora

Reasumując, proces kształtowania przestrzeni centralnej w Łodzi odznaczał się niewielką dynamiką. Uwarunkowania polityczno-gospodarcze, w jakich rozwijało się miasto w XIX i XX w., zadecydowały o znacznym powiększeniu terenów industrialnych, które zdominowały strukturę morfologiczną śródmieścia (rys. 7.18). Rewitalizacja terenów poprzemysłowych stanowi kluczowy czynnik zmieniający morfologię przestrzeni centralnej w Łodzi na początku XXI w. Rezultaty podjętych przekształceń przestrzenno-funkcjonalnych nie przyniosły dotychczas pozytywnych zmian, które przyczyniłyby się do zainicjowania synergicznego procesu kształtowania spójnego centrum miasta. Realizowane współcześnie projekty generowania nowej przestrzeni centralnej miasta także nie przyczyniają się do ożywienia apatycznego sposobu rozwoju zintegrowanego centrum wielkomiejskiego. Brak prawidłowości w procesie rozwojowym oraz w wyposażeniu modyfikowanej struktury przestrzeni centralnej w Łodzi jak również zmieniająca się hierarchia terenów śródmiejskich determinują w istotnym stopniu wykształcenie relacji konglomeracyjnych pomiędzy starą i nową przestrzenią centralną miasta. 


\section{Rozdział 8}

\section{KONKLUZJA}

Przeprowadzone w pracy postępowanie analityczne objęło przemiany morfologiczne obszarów śródmiejskich w trzech dużych miastach europejskich, w których w wyniku rewitalizacji terenów poprzemysłowych została wygenerowana nowa przestrzeń centralna. $\mathrm{W}$ celu weryfikacji implikowanej tezy procedura badawcza wiązała się:

- ze studiami morfologicznymi w mezoskali, które umożliwiły identyfikację intensywności przekształceń przestrzenno-funkcjonalnych terenów poprzemysłowych;

- ze studiami morfologicznymi i morfogenetycznymi w makroskali, na podstawie których określono sposób kształtowania przestrzeni centralnej oraz charakter relacji zachodzących pomiędzy starą i nową przestrzenią centralną w każdym z badanych miast.

$\mathrm{Na}$ podstawie przeprowadzonych badań rozwoju przestrzeni centralnej w Manchesterze, Lyonie i Łodzi stwierdzono, że proces ten odbywał się etapami i miał zindywidualizowany charakter w każdym z tych miast. Liczba wyróżnionych etapów kształtowania przestrzeni centralnej i długość ich trwania wykazywały zróżnicowanie spowodowane odmiennymi czynnikami gospodarczymi, technologicznymi i geopolitycznymi, w jakich rozwijały się analizowane miasta. Wykonane studia morfogenetyczne umożliwiły jednocześnie zidentyfikowanie prawidłowości procesu przekształceń przestrzeni centralnej w Manchesterze, Lyonie i Łodzi.

\subsection{Rewitalizacja a rozwój przestrzeni centralnej w mieście europejskim w świetle wyników badań}

Transformację przestrzeni centralnej w badanych ośrodkach rozpatrywano w kontekście trzech okresów w historii budowy miast: przedindustrialnym, industrialnym i postindustrialnym (rys. 8.1). Podział ten został odzwierciedlony w strukturze empirycznych rozdziałów pracy. Na przedindustrialnym etapie rozwoju miast nadrzędna była rola przestrzeni wymiany, która przyczyniała się do powolnego, 
lecz konsekwentnego przyrostu przestrzeni centralnej. Wśród badanych miast w omawianym okresie najwyższym tempem wzrostu charakteryzował się Lyon. Pomiędzy okresem rzymskim i XIX-wiecznym uprzemysłowieniem w Lyonie mamy do czynienia z ciągłością rozwojową oraz stopniową ekspansją terytorialną i funkcjonalną miasta. Przyczyniała się ona do generowania nowej przestrzeni centralnej, która pierwotnie uzupełniała ówcześnie istniejącą strukturę przestrzeni centralnej, a następnie zyskiwała dominującą pozycję w hierarchii terenów miejskich. Proces ten nie powodował jednak materialnej i instytucjonalnej degradacji starej przestrzeni centralnej. Ze względu na uwarunkowania topograficzne przestrzeń centralna w Lyonie rozwijała się jako obszar wieloczęściowy. W okresie przedindustrialnym Lyon zyskał znaczącą pozycję w krajowej i międzynarodowej sieci osadniczej, co wynikało z dogodnego położenia geopolitycznego miasta. Ranga Lyonu została odzwierciedlona we wzrastającym poziomie rozwinięcia przestrzeni centralnej (rys. 8.1). Składa się na niego wielkość przestrzeni centralnej, złożoność morfologiczna (liczba jednostek przestrzennych narastających w kolejnych okresach wzrostu miasta) oraz intensywność jego wyposażenia instytucjonalnego ${ }^{1}$.

Do przełomu XVIII i XIX w. przestrzeń centralna w Manchesterze wykazywała niższe tempo wzrostu niż w Lyonie. Wynikało to $\mathrm{z}$ braku czasowej i przestrzennej ciągłości rozwojowej pomiędzy rzymskim i średniowiecznym rdzeniem miasta. W okresie przedindustrialnym Manchester był małym handlowo-rękodzielniczym miastem o prowincjonalnym charakterze, co zostało odzwierciedlone w morfologii kształtowanej wówczas przestrzeni centralnej. Odznaczała się ona znacznie niższą wielkością, złożonością i intensywnością w porównaniu z Lyonem (rys. 8.1).

Spośród trzech badanych miast, w przededniu XIX-wiecznej industrializacji najsłabiej rozwinięta była przestrzeń centralna w Łodzi, która znajdowała się we wczesnej fazie inicjalnej (rys. 8.1). Była to konsekwencja zdominowania ówczesnej struktury przestrzenno-funkcjonalnej miasta przez działalność rolniczą i brak lokalizacji instytucji o ponadlokalnym zasięgu oddziaływania.

W XIX i w pierwszej połowie XX w. struktura morfologiczna Manchesteru, Lyonu i Łodzi, a przede wszystkim ich obszarów śródmiejskich, została w różnym stopniu podporządkowana potrzebom nowej działalności miastotwórczej,

${ }^{1}$ Patrz także cechy - wskaźniki cząstkowe do identyfikacji stopnia rozwinięcia przestrzeni centralnej w tabeli 2.5 na stronie 49 (rozdz. 2). Model przedstawiony na rys. 8.1 przedstawia rozwój miast w okresie przedindustrialnym, industrialnym i postindustrialnym. Autor ma świadomość, że funkcja przemysłowa w Łodzi była sztuczne utrzymywana w drugiej połowie XX w., więc wymienione okresy nie są tożsame dla Manchesteru, Lyonu i Łodzi. W tym kontekście czynnik czasu (długość okresu postindustrialnego) ma istotne znaczenie dla sposobu rewitalizacji terenów poprzemysłowych i jej wpływu na organizację współczesnej przestrzeni centralnej. Niemniej w celu ukazania przekształceń rozwoju przestrzeni centralnej we wszystkich analizowanych miastach forma graficzna modelu wymagała pewnego uproszczenia. 
jaką był przemysł, w szczególności włókienniczy. Industrializacja w istotny sposób przekształciła organizację przestrzeni centralnej ówczesnych miast europejskich, zaburzając klasyczną przestrzeń wymiany oraz domenę publiczną. Wpływ ten zaznaczał się tym mocniej, im słabiej rozwinięta była przestrzeń centralna w zakresie wielkości, złożoności oraz intensywności. W Lyonie rozwój terenów przemysłowych w pierwszej połowie XIX w. zwiększył dynamikę wzrostu przestrzeni centralnej, która jednak nadal rozwijała się w sposób ciągły. Również kryzys i upadek przemysłu w drugiej połowie XX w. nie zaburzył zrównoważonego procesu transformacji przestrzeni centralnej (rys. 8.1), co wynikało z podrzędnej roli terenów industrialnych względem innych funkcji wielkomiejskich, które wpływały na formowanie ówczesnej przestrzeni centralnej miasta.

W przeciwieństwie do Lyonu zmiany morfologii przestrzeni centralnej w Manchesterze wykazywały znaczną zbieżność z procesem generowania nowych terenów przemysłowych. Industrializacja w XIX w. zadecydowała o dynamicznym wzroście powierzchni, złożoności oraz intensywności przestrzeni centralnej, natomiast kryzys i upadek przemysłu w XX w. spowodował jej recesję. W okresie industrialnego rozwoju Manchesteru przestrzeń centralna była zatem kształtowana w sposób skokowy, podobnie jak miało to miejsce w erze przedindustrialnej (rys. 8.1).

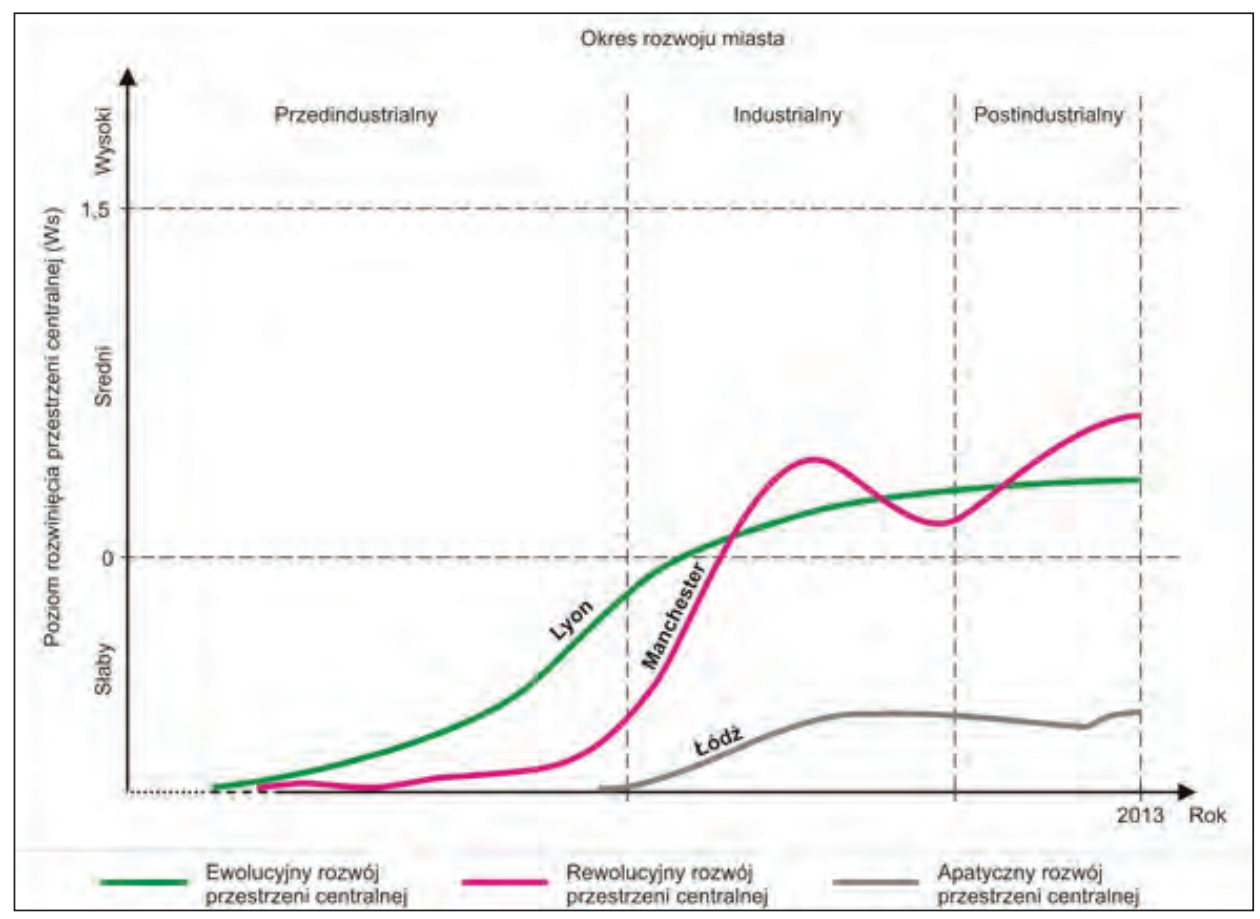

Rys. 8.1. Model sposobu rozwoju przestrzeni centralnej w Manchesterze, Lyonie i Łodzi Źródło: badania własne autora 
Lyon i Manchester w XIX i w XX w. zyskały rangę miast światowych. Morfogeneza przestrzeni centralnej Lyonu zadecydowała o tym, że deindustrializacja miasta nie wpłynęła negatywnie na jego pozycję w międzynarodowej sieci osadniczej w przeciwieństwie do Manchesteru, który w wyniku upadku przemysłu stracił metropolitalny charakter przestrzeni centralnej. Oba miasta w analizowanym okresie rozwijały się $\mathrm{w}$ silnych ekonomicznie krajach, posiadających liczne terytoria zamorskie. W odróżnieniu od nich wielkoprzemysłowa Łódź wzrastała w zacofanym pod względem gospodarczym Cesarstwie Rosyjskim, co zadecydowało o słabej dynamice rozwoju przestrzeni centralnej miasta. Okres gospodarki centralnie planowanej w drugiej połowie XX w. utrwalił peryferyjną pozycję Łodzi w europejskiej sieci osadniczej. Czynnik ten oraz zdominowanie struktury przestrzenno-funkcjonalnej śródmieścia przez tereny przemysłowe ograniczyły w znaczącym stopniu ekspansję przestrzeni centralnej, która obejmowała jedynie kwartały położone wzdłuż ulicy Piotrkowskiej i kilka mniejszych enklaw w śródmieściu. Podobnie jak w przypadku Lyonu i Manchesteru, największy wzrost przestrzeni centralnej w Lodzi identyfikowano w okresie XIX-wiecznej industrializacji. Ze względu jednak na uwarunkowania geopolityczne jej poziom rozwinięcia był zdecydowanie niższy niż w analizowanych ośrodkach zachodnioeuropejskich (rys. 8.1). Upadek przemysłu na przełomie lat 80. i 90. XX w. w Łodzi nie miał więc tak negatywnego wpływu na morfologię przestrzeni centralnej, jak miało to miejsce w Manchesterze (rys. 8.1). Wynikało to z podrzędnej pozycji przestrzeni centralnej w Łodzi w stosunku do śródmiejskich terenów przemysłowych (patrz rys. $7.18 \mathrm{w}$ rozdz. 7).

Okres postindustrialny w rozwoju wszystkich analizowanych miast wiązał się z kształtowaniem nowej przestrzeni centralnej w rezultacie rewitalizacji terenów poprzemysłowych. Badania wykonane in situ wykazały, że proces przekształceń przestrzenno-funkcjonalnych odznaczał się wysokim lub umiarkowanym stopniem intensywności. Proces wtórnego zagospodarowania terenów poprzemysłowych w wymiarze morfologicznym przyjął formę rewitalizacji radykalnej. W rezultacie wykształcone zostały nowe jednostki przestrzenno-funkcjonalne, których wtórne właściwości przestrzenne w znaczący sposób różnią się od pierwotnych cech morfologicznych przekształconego obszaru. Należy wnioskować, że przyjęcie do realizacji radykalnej formy rewitalizacji wynika z konieczności daleko idących przekształceń struktury przestrzenno-funkcjonalnej w celu wygenerowania nowej przestrzeni miejskiej posiadającej atrybuty typowe dla centrum miasta. Ich nowy program przestrzenny i instytucjonalny jest ponadto adekwatny do aktualnych potrzeb użytkowników przestrzeni miejskiej.

$\mathrm{Na}$ podstawie przeprowadzonych studiów przypadku Manchesteru, Lyonu i Łodzi można wskazać na prawidłowości w zakresie procesu kształtowania nowej przestrzeni centralnej na terenach poprzemysłowych. Wiązał się on z:

1) rozwojem jednostek morfologicznych o niskiej intensywności poziomej zabudowy, który w analizowanych miastach przyjmował wartości poniżej 50\%, co odpowiada zabudowie luźnej według klasyfikacji intensywności poziomej terenów miejskich zaproponowanej przez S. Liszewskiego (1978); 
2) zróżnicowanym stopniem zachowania pierwotnych elementów morfologicznych: liniowych, kubaturowych, przestrzennych i punktowych w nowych jednostkach morfologicznych;

3) sukcesją zabudowy wielkomiejskiej ze zróżnicowanym programem funkcjonalnym i która tylko w sporadycznych przypadkach jest związana z powstaniem obiektów wysokościowych;

4) powstaniem obiektów o oryginalnej formie architektonicznej, które stają się nowymi „znakami” miasta, a nie tylko zrewitalizowanych terenów poprzemysłowych - tym samym oddziałują na organizację przestrzeni centralnej w wymiarze społeczno-kulturowym;

5) znacznym stopniem wtórnego wykorzystania (adaptacji) zachowanej zabudowy poprzemysłowej z przeznaczeniem jej na nowe funkcje, głównie wielkomiejskie i rezydencjonalne;

6) ekstensywną formą organizacji przestrzeni publicznej, poprzez kształtowanie otwartych terenów spacerowych o znacznej powierzchni, w tym bulwarów nadrzecznych i/lub zabudowanych nabrzeży - waterfrontów, rzadziej natomiast kształtowane są place miejskie, typowe dla starej przestrzeni centralnej.

W oparciu o przeprowadzone studia należy stwierdzić, że sposób organizacji przestrzeni centralnej w analizowanych miastach w istotnym stopniu zależy od transformacji jakościowej i ilościowej w przestrzeni publicznej, m.in. w wyniku rewitalizacji terenów poprzemysłowych. Wyróżnić można kilka czynników determinujących odmienny sposób kształtowania przestrzeni publicznej w Łodzi - mieście postsocjalistycznym Europy Środkowo-Wschodniej - w stosunku do Manchesteru i Lyonu rozpatrywanych jako przykłady miast zachodnioeuropejskich:

- wydłużony okres sztucznie utrzymywanego uprzemysłowienia w obszarze śródmiejskim Łodzi, który uniemożliwił przekształcenia przestrzenno-funkcjonalne przestrzeni centralnej w drugiej połowie XX w.;

- dyspersja terenów poprzemysłowych w śródmieściu Łodzi, oraz znacząco mniejsza powierzchnia kompleksów pofabrycznych niż w Manchesterze i Lyonie, która utrudnia realizację procesu rewitalizacji w formie wielkoobszarowej, co stanowi przeszkodę dla koordynacji działań w celu rozwoju zintegrowanej przestrzeni centralnej - brak kompleksowych inwestycji w strefie wielkomiejskiej Łodzi w celu osiągnięcia efektu synergii;

- słabo rozwinięta przestrzeń centralna w Łodzi w porównaniu do średniego poziomu rozwinięcia przestrzeni centralnej w Manchesterze i Lyonie - wyraża się ona m.in. historycznie ukształtowanym brakiem ciągłości przestrzeni publicznej o wysokiej jakości;

- brak rzek i kanałów w Łodzi², których zagospodarowane nabrzeża stanowiłyby liniowe elementy morfologiczne miasta, umożliwiające w naturalny sposób

${ }^{2}$ Przez Łódź przepływa 18 rzek, lecz zdecydowana większość z nich została skanalizowana w okresie budowy infrastruktury wodno-kanalizacyjnej w Łodzi na początku XX w. Nielicznie zachowane odkryte odcinki rzek, przebiegające przez śródmieście, są krótkie i zlokalizowane głównie 
integrację istniejących lub planowanych elementów struktury przestrzeni publicznej w postaci placów miejskich, parków i pasaży pieszo-rowerowych;

- znaczny udział terenów poprzemysłowych w śródmieściu Łodzi oraz daleko posunięty stopień degradacji terenów śródmiejskich wymagających natychmiastowych działań naprawczych, w których istotna część substancji mieszkaniowej przeznaczona jest na lokale komunalne lub socjalne;

- niekorzystna struktura przestrzenno-społeczna śródmieścia Łodzi, utrudniająca rozszerzenie i integrację przestrzeni centralnej (szczególnie w porównaniu z Manchesterem, gdzie obszar śródmiejski przed rozpoczęciem działań rewitalizacyjnych był niemal pozbawiony mieszkańców (ok. 200 osób w 1983 r.), tymczasem w Łodzi liczbę stałych mieszkańców śródmieścia szacowano na ok. 73 000), ogranicza proces transformacji morfologicznej i funkcjonalnej kwartałów śródmiejskich o wielofunkcyjnej strukturze użytkowania oraz rozdrobnionych w obszarze śródmiejskim terenów poprzemysłowych;

- ograniczony zasób środków finansowych do momentu przystąpienia Polski do Unii Europejskiej (w 2004 r.), co spowodowało stagnację rozwoju przestrzeni centralnej Łodzi we wczesnym okresie gospodarki wolnorynkowej lat 90. XX w. - miało to istotny wpływ na opóźnienie procesów rewitalizacji terenów poprzemysłowych w Łodzi;

- znacznie słabsza siła nabywcza użytkowników przestrzeni miejskiej Łodzi w porównaniu z mieszkańcami miast w wysoko rozwiniętych krajach Europy Zachodniej, co ograniczało dynamikę rozwoju usług w przestrzeni publicznej, czynnik ten ogranicza także liczbę nowych inwestycji w przestrzeni publicznej Łodzi, w tym także na dawnych terenach przemysłowych, co w rezultacie prowadzi do utrzymania zaawansowanego stanu dekapitalizacji śródmieścia w wymiarze materialnym i społecznym.

W wyniku rewitalizacji wewnątrzmiejskich terenów poprzemysłowych zmieniona została organizacja przestrzeni centralnej w Manchesterze, Lyonie i Łodzi. Konsekwencje procesu przekształceń morfologicznych były odmienne w każdym ze wskazanych miast. Zależały one od morfogenezy starej przestrzeni centralnej oraz stopnia jej rozwinięcia, czyli wielkości, złożoności i intensywności. W Manchesterze zidentyfikowano rewolucyjny sposób kształtowania przestrzeni centralnej odznaczający się skokowym procesem rozwojowym, determinowanym koniunkturą terenów przemysłowych w okresie industrialnym, a współcześnie - terenów poprzemysłowych (rys. 8.1). Zrewitalizowane obszary postindustrialne wykazują niski stopień zróżnicowania morfologii i sposobu użytkowania w porównaniu ze starą (lecz zmodernizowaną) przestrzenią centralną, co wraz ze średnim poziomem rozwinięcia przestrzeni centralnej zadecydowało o wykształceniu pomiędzy nimi relacji konkurencyjnych (typu A). Proces kształtowania przestrzeni centralnej

w parkach. Ze względu na duże koszty oraz znaczne przekształcenia w morfologii miasta, jakie związane byłyby z ich rewitalizacją, nie posiadają one potencjału dla integracji elementów przestrzeni publicznej w Łodzi. 
w Lyonie miał ewolucyjny charakter (rys. 8.1). W wyniku rewitalizacji terenów poprzemysłowych w Confluence stara przestrzeń centralna miasta została uzupełniona o nowy fragment, który jest w stosunku do niej komplementarny, zarówno w ujęciu przestrzennym, jak i instytucjonalnym. Współczesna przestrzeń centralna Lyonu charakteryzuje się także średnim poziomem rozwinięcia i jest wysoko zróżnicowana. Na podstawie przeprowadzonej procedury badawczej zidentyfikowano relacje kooperacyjne (typu E) pomiędzy jej starą i nową częścią. W przypadku Łodzi zidentyfikowano natomiast niski poziom rozwinięcia i zróżnicowania kształtowanej przestrzeni centralnej. Składa się ona z niezależnie funkcjonujących jednostek morfologicznych. Dotychczas zakończone bądź współcześnie realizowane projekty rewitalizacji terenów poprzemysłowych prowadzą do powstania nowych fragmentów przestrzeni centralnej, które nie tworzą zintegrowanej struktury morfologicznej. Zalążkowy, liniowo-enklawowy charakter przestrzeni centralnej oraz brak prawidłowości w procesie rozwojowym pozwalają stwierdzić, że pomiędzy starymi i nowymi fragmentami przestrzeni centralnej w Łodzi kształtowane są relacje konglomeracyjne (typu I). Tym samym wyniki przeprowadzonych studiów pozwalają pozytywnie zweryfikować przyjętą hipotezę badawczą.

Ponadto, wyniki postępowania analitycznego przeprowadzonego na przykładzie Manchesteru, Lyonu i Łodzi pozwoliły stwierdzić, że:

- relacje kooperacyjne i konkurencyjne mają pozytywny wpływ na organizację przestrzeni centralnej, przyczyniając się do stabilizacji lub jej dalszego rozwoju;

- relacje o charakterze konglomeracyjnym mają negatywny skutek na przestrzeń centralną, przyczyniając się do jej stagnacji bądź nawet regresu.

W związku z powyższym można stwierdzić, że rewitalizacja wewnątrzmiejskich terenów poprzemysłowych przyczyniła się do przywrócenia sprawności przestrzeni centralnej w Manchesterze iutrwalenia tej sprawności w Lyonie. W Łodzi natomiast zakończone i realizowane współcześnie procesy rewitalizacyjne na dawnych obszarach industrialnych stwarzają zagrożenie wzmocnienia braku sprawności przestrzeni centralnej, utrudniającej jej dalszy zrównoważony rozwój w przyszłości (tab. 8.1). Rewitalizacja terenów poprzemysłowych w Lyonie skutkuje kontynuacją stabilnego, lecz uspokojonego wzrostu przestrzeni centralnej, podczas gdy w Manchesterze spowodowała jej wtórny wzrost (rys. 8.1).

Przedindustrialny etap kształtowania przestrzeni centralnej $\mathrm{w}$ badanych miastach europejskich miał charakter odśrodkowy, związany z sukcesją i ekspansją na nowe tereny miejskie. W industrialnym okresie rozwoju Manchesteru, Lyonu i Łodzi zidentyfikowano zarówno proces odśrodkowy, jak i dośrodkowy, który łączył się z intensyfikacją struktury morfologicznej (czasem przebudową obszarów śródmiejskich) i sukcesją funkcji wielkomiejskich na obszarach wewnątrzmiejskich. Kluczowym czynnikiem determinującym te transformacje był dynamicznie rozwijający się przemysł w strefie śródmiejskiej ${ }^{3}$ Poprzez

${ }^{3} \mathrm{Na}$ ten sam okres przypada także dynamiczny rozwój kolei, który zintensyfikował industrializację miast. 
aneksję terenów wewnątrzmiejskich w sposób bezpośredni zmieniał on przestrzeń centralną i przestrzeń publiczną. W sposób pośredni natomiast przyczyniał się on do przekształceń morfologicznych i funkcjonalnych w wyniku rozwoju nowych instytucji obsługujących przemysł (banki, towarzystwa ubezpieczeniowe, towarzystwa kredytowe, giełdy etc.), zmieniających krajobraz miasta. Wśród negatywnych czynników, które spowodowały konieczność transformacji struktury morfologicznej przedindustrialnej przestrzeni centralnej, należy wymienić m.in. bardzo szybki przyrost liczby mieszkańców miasta i pogorszenie się jakości życia, np. poprzez zwiększenie zatłoczenia obszarów śródmiejskich, zagęszczenie zabudowy czy zanieczyszczenie środowiska.

Tabela 8.1. Zależności pomiędzy sposobem rozwoju przestrzeni centralnej, relacjami pomiędzy jej nowymi i starymi fragmentami, a współczesnymi cechami i skutkami dla organizacji

\begin{tabular}{|l|c|c|l|c|}
\hline Miasto & $\begin{array}{c}\text { Sposób } \\
\text { rozwoju } \\
\text { przestrzeni } \\
\text { centralnej }\end{array}$ & $\begin{array}{c}\text { Relacje pomiędzy } \\
\text { starą i nową } \\
\text { przestrzenią } \\
\text { centralną }\end{array}$ & $\begin{array}{c}\text { Cechy morfologiczne } \\
\text { współczesnej przestrzeni } \\
\text { centralnej miasta }\end{array}$ & $\begin{array}{c}\text { Skutki } \\
\text { dla organizacji } \\
\text { przestrzeni } \\
\text { centralnej }\end{array}$ \\
\hline Manchester & Rewolucyjny & Konkurencyjne & $\begin{array}{l}\text { Złożoność, podobieństwo, } \\
\text { substytucyjność programowa, } \\
\text { integracja terytorialna (inte- } \\
\text { gralność, zwartość) }\end{array}$ & $\begin{array}{l}\text { Pozytywne } \\
\text { - rozwój zrów- } \\
\text { noważony }\end{array}$ \\
\hline Lyon & Ewolucyjny & Kooperacyjne & $\begin{array}{l}\text { Złożoność, różnorodność, } \\
\text { komplementarność programo- } \\
\text { wa, częściowa integracja tery- } \\
\text { torialna (wieloośrodkowość) }\end{array}$ & $\begin{array}{l}\text { Pozytywne } \\
\text { rozwój zrów- } \\
\text { noważony }\end{array}$ \\
\hline Aódź & Konglomeracyjne & $\begin{array}{l}\text { Dyspersja, mozaikowość, od- } \\
\text { mienność programowa, dezin- } \\
\text { tegracja terytorialna (enkla- } \\
\text { wowość) }\end{array}$ & $\begin{array}{l}\text { Negatywne } \\
\text { trozwój nie- } \\
\text { zrównoważony }\end{array}$ \\
\hline
\end{tabular}

Źródło: badania własne autora.

Rewitalizacja wewnątrzmiejskich terenów poprzemysłowych prowadzi do wtórnego dośrodkowego procesu rozwojowego, związanego z generowaniem nowej (młodej i nowoczesnej) przestrzeni centralnej w nowych lokalizacjach. Jak wykazały wyniki przeprowadzonych badań, rewitalizacja przyczyniająca się do wykreowania nowych terenów o programie instytucjonalnym, typowym dla centrum miasta, jest także bodźcem do przekształcenia morfologii i sposobu wyposażenia funkcjonalnego istniejącej wcześniej przestrzeni centralnej i jej dostosowania do współczesnych potrzeb mieszkańców i innych użytkowników miasta. W rezultacie można stwierdzić, że zarówno rewitalizacja terenów poprzemysłowych, jak i transformacje starej przestrzeni centralnej ograniczyły w pewnym stopniu proces rozlewania się miasta (ang. urban sprawl) poprzez zwrócenie części procesów inwestycyjnych na tereny śródmiejskie. 


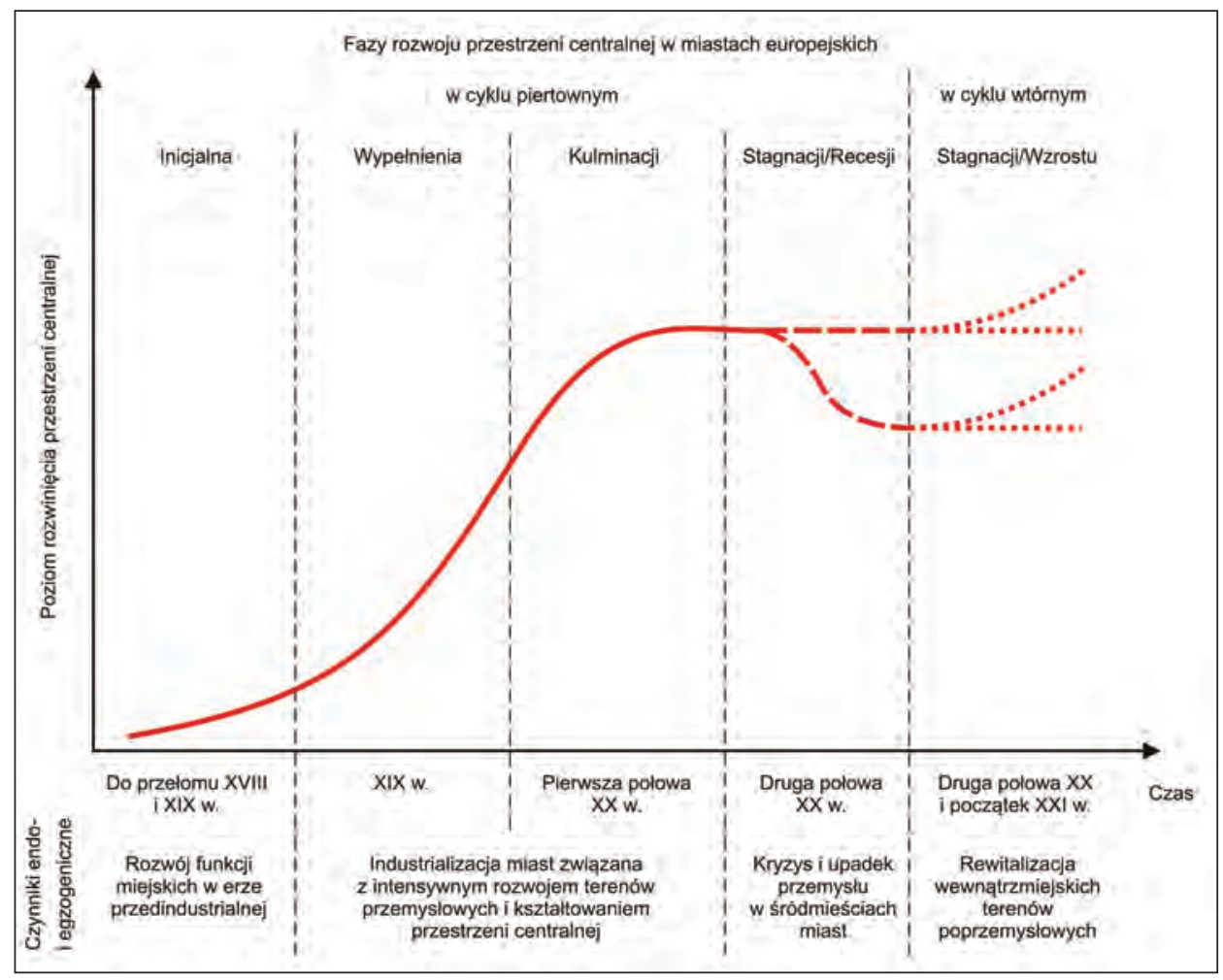

Rys. 8.2. Model cyklu rozwojowego przestrzeni centralnej w badanych miastach europejskich

Źródło: badania własne autora

Przeprowadzone studia morfogenetyczne i morfologiczne w trzech miastach europejskich, zróżnicowanych pod względem struktury przestrzenno-funkcjonalnej i wzrastających w odmiennych uwarunkowaniach gospodarczych i geopolitycznych, pozwoliły na wykrycie istniejących prawidłowości w cyklu rozwojowym przestrzeni centralnej. Prezentuje go rys. 8.2.

Rewitalizacja wewnątrzmiejskich terenów poprzemysłowych wiąże się z transformacją i częściową adaptacją zastanej morfologii na potrzeby współczesnych mieszkańców miasta. Proces ten jest kolejnym czynnikiem w cyklu rozwojowym przestrzeni centralnej w miastach europejskich (rys. 8.2). Wyniki przeprowadzonych badań potwierdzają conzenowską koncepcję cykliczności zagospodarowania terenów miejskich, którą w warunkach miasta przemysłowego pozytywnie zweryfikował M. Koter $(1974,1976,1990)$. Cyk1 życia obszaru przemysłowego był natomiast przedmiotem rozważań S. Kaczmarek (2001), według której rewitalizacja przyczynia się do stabilizacji jego rozwoju. Faza użytkowania terenów poprzemysłowych przez instytucje III i IV sektora prowadzi do zidentyfikowanego przez autora niniejszej pracy: 
- wtórnego wzrostu przestrzeni centralnej, na co wskazuje przykład Manchesteru, gdzie ów wtórny wzrost przyczynił się do odzyskania przez miasto pozycji metropolii światowej, którą posiadało w drugiej połowie XIX w.;

- stabilizacji wykształconej przestrzeni centralnej, którą stwierdzono w przypadku Lyonu, co umocniło metropolitalną pozycję miasta;

- stagnacji słabo rozwiniętej przestrzeni centralnej w przypadku Łodzi, która utrwala prowincjonalną pozycję miasta $\mathrm{w}$ europejskiej sieci osadniczej.

W świetle rozważań koncepcyjno-teoretycznych podjętych w niniejszym opracowaniu wydaje się, że rewitalizacja terenów poprzemysłowych może również przyczynić się do dynamicznego wtórnego rozwój przestrzeni centralnej charakteryzującej się ustabilizowaną koniunkturą (rys. 8.2). Nie zidentyfikowano jednak tego typu przekształceń wśród badanych miast.

\subsection{Rekomendacje dla sposobu kształtowania przestrzeni centralnej w Łodzi}

Przeprowadzona charakterystyka procesu rozwojowego przestrzeni centralnej w Manchesterze, Lyonie i Łodzi obejmuje okres od powstania wskazanych ośrodków miejskich do roku 2013, na którym zakończone zostały studia empiryczne. Rewitalizacja terenów poprzemysłowych, w wyniku której kształtowana jest nowa przestrzeń centralna, stanowi aktualnie ostatni etap analizowanego procesu rozwojowego. Dalsze przekształcenia przestrzeni centralnej, wykraczające poza zakres czasowy niniejszego opracowania (po 2013 r.), mogą jednakże spowodować zmianę właściwości sposobu przekształceń przestrzeni centralnej oraz jej organizacji i koniunktury, co wynika z przyjętych założeń teoretycznych o ich zmienności. Decydują o tym zależności pomiędzy stopniem zróżnicowania starej i nowej przestrzeni centralnej oraz ogólnym poziomem rozwoju przestrzeni centralnej jako całego układu przestrzenno-funkcjonalnego. Wydaje się, że w przypadku Manchesteru transformacja organizacji przestrzeni centralnej jest możliwa w kontekście dalej postępujących działań rewitalizacyjnych skoncentrowanych na terenach postindustrialnych w rejonie Piccadilly. Ze względu jednak na użytkowanie znacznej części tego obszaru przez kolej i przedsiębiorstwa logistyczno-transportowe i tym samym ograniczony zakres przestrzenny dla nowych inwestycji wielkomiejskich, działania te nie przyczynią się do istotnych przekształceń morfologicznych i funkcjonalnych, a w konsekwencji - zidentyfikowanych relacji konkurencyjnych. Niemniej, nastąpić powinien dalszy wtórny wzrost w cyklu koniunkturalnym przestrzeni centralnej, a następnie jego stabilizacja. Zgodnie z matrycą zależności pomiędzy stopniem zróżnicowania i rozwinięcia przestrzeni centralnej a występowaniem relacji konkurencyjnych, kooperacyjnych i konglomeracyjnych $\mathrm{w}$ przestrzeni centralnej miast europejskich współcześnie zidentyfikowane relacje typu A mogą potencjalnie zostać przekształcone na typ 
B - relacje średnio konkurencyjne, wraz ze wzrostem poziomu rozwinięcia przestrzeni centralnej.

W Lyonie, gdzie przestrzeń centralna wykazuje średni poziom rozwinięcia i wysoki stopień zróżnicowania, zmiana relacji morfologiczno-instytucjonalnych także może zajść jedynie $\mathrm{w}$ dłuższej perspektywie czasowej i raczej nie nastąpi ona w wyniku dalszych przekształceń w Confluence. Rewitalizacja terenów poprzemysłowych, przede wszystkim w ramach ZAC 2, spowoduje dalszy wzrost intensywności przestrzeni centralnej i jej dalszą stabilizację w cyklu koniunkturalnym. Potencjalna zmiana relacji może wynikać z ogólnego wzrostu poziomu rozwinięcia przestrzeni centralnej i przyjąć charakter relacji typu D - silnie kooperacyjnych.

Inna sytuacja występuje natomiast w przypadku Łodzi, gdzie przestrzeń centralna jest najsłabiej rozwinięta spośród analizowanych ośrodków miejskich. Zmiana organizacji przestrzeni centralnej może nastąpić stosunkowo gwałtownie w wyniku szeroko zakrojonych działań inwestycyjnych, obejmujących przekształcenia morfologiczne obszaru śródmiejskiego, w tym także rewitalizację terenów poprzemysłowych. W tym kontekście szczególnie istotne znaczenie wydaje się mieć projekt rewitalizacji obszarowej tzw. strefy wielkomiejskiej Łodzi współfinansowany ze środków Unii Europejskiej i realizowany począwszy od $2014 \mathrm{r}$. Potencjalnymi kierunkami zmian jest konwersja relacji:

- na typ H - średnio konglomeracyjne wraz ze wzrostem zróżnicowania pomiędzy starą i nową przestrzenią centralną, przy stagnacji poziomu rozwinięcia przestrzeni centralnej jako całości;

- na typ A - słabo konkurencyjny, wraz ze wzrostem poziomu rozwinięcia przestrzeni centralnej jako całości i jednoczesnym zachowaniem niskiego stopnia zróżnicowania starej i nowej przestrzeni centralnej;

- na typ F - słabo kooperacyjny, wraz ze wzrostem zróżnicowania starej i nowej przestrzeni centralnej i towarzyszącym mu wzrostem poziomu rozwinięcia przestrzeni centralnej jako całości.

W związku z powyższym uzasadnione było opracowanie rekomendacji dla dalszego sposobu kształtowania przestrzeni centralnej w Łodzi ${ }^{4}$. Punkt wyjścia do przygotowania katalogu rekomendacji stanowią wnioski sformułowane na podstawie teoretycznej i empirycznej części pracy. Ze względu na rangę przestrzeni centralnej opracowany katalog musi uwzględniać istniejący kontekst historyczny i morfologiczny Łodzi. Celem rekomendacji jest:

1) ożywienie zidentyfikowanego apatycznego sposobu kształtowania przestrzeni centralnej, który wpływa negatywnie na jej dalszy rozwój (koniunkturę) (por. rys. 8.1 i 8.2 oraz tab. 8.1);

2) zatrzymanie procesu formowania relacji konglomeracyjnych w rezultacie mozaikowego kształtowania niezintegrowanej przestrzeni centralnej, charakteryzującej się niskim stopniem zróżnicowania (por. tab. 8.1);

\footnotetext{
${ }^{4}$ Jest to piąty cel szczegółowy pracy (patrz rozdz. 1, por. też rys. 1.4).
} 
3) a następnie ich możliwą konwersję na innego typu relacje, ze względu na niski poziom rozwinięcia przestrzeni centralnej w wymiarze morfologicznym i instytucjonalnym.

Kluczową ideą w opracowanym katalogu rekomendacji jest określenie, czym ma być kształtowana przestrzeń centralna w odniesieniu do istniejącego centrum Łodzi. Jak wykazały przeprowadzone studia, uzupełnienie i wzbogacenie struktury funkcjonalnej może wpłynąć na wzrost atrakcyjności całego centrum, natomiast brak wizji rozwoju nowej przestrzeni centralnej w szerszym kontekście urbanistycznym spowoduje regres istniejącej przestrzeni centralnej, szczególnie w sytuacji, gdy stare i nowe przestrzenie centralne nie tworzą spójnej struktury. W tym kontekście zasadnym jest zatem dalszy rozwój przestrzeni centralnej Łodzi w sposób, który zwiększy jej poziom rozwinięcia. Ze względu na koncentrację współczesnych działań rewitalizacyjnych, głównie na terenach poprzemysłowych, proces naprawczy powinien zostać skierowany na obszar starej przestrzeni śródmiejskiej, która wykazuje się niedoinwestowaniem, czego wyrazem są m.in. wolne działki. W rezultacie wzrostowi ogólnego poziomu rozwinięcia przestrzeni publicznej może towarzyszyć wzrost zróżnicowania nowej i starej (zmodernizowanej) przestrzeni centralnej, co spowoduje przekształcenie współczesnych relacji słabo konglomeracyjnych (typu I) w kierunku relacji słabo kooperacyjnych (typu F).

Wydaje się, że ze względu na zbliżony wpływ procesu rewitalizacji terenów poprzemysłowych na dynamikę transformacji przestrzeni centralnej (por. rys. 8.1) i większe podobieństwo cech morfologicznych przestrzeni centralnej w Łodzi i w Lyonie niż w przypadku Łodzi i Manchesteru (patrz tab. 8.1), opracowany katalog powinien opierać się przede wszystkim na doświadczeniach miasta francuskiego. W tym kontekście kształtowana przestrzeń centralna w Lodzi powinna tworzyć obszar zintegrowany pod względem instytucjonalnym, przy jednoczesnym zachowaniu wieloelementowej struktury, co ma również miejsce w Lyonie. Na zasadność takiego rozwiązania wskazują także zakończone i aktualnie podejmowane działania rewitalizacyjne w śródmieściu Łodzi, obejmujące tereny „Manufaktury” i Nowego Centrum Łodzi, które nie są ze sobą powiązane przestrzennie, a w dalszej perspektywie także obszar posiadeł wodno-fabrycznych (Art_Inkubator, Księży Młyn) i Centrum Handlu, Biznesu i Rozrywki „Sukcesja" w sąsiedztwie kampusu Politechniki Łódzkiej przy alei Politechniki i ulicy Rembielińskiego (rys. 8.3). Rezultaty współczesnych inwestycji, wiążących się z przekształceniami morfologicznymi śródmieścia, niewątpliwie zdeterminują proces rozwoju przestrzeni centralnej w Łodzi w przyszłości. W tym kontekście istotne znaczenie ma także morfogeneza przestrzeni centralnej, jej współczesny zalążkowy stopień wykształcenia oraz liniowo-enklawowa struktura.

Przestrzeń centralna w Łodzi powinna docelowo składać się z dwóch obszarów powiązanych ze sobą hierarchicznie i zintegrowanych osią ulicy Piotrkowskiej, co wynika z jej historycznego znaczenia jako reprezentacyjnej przestrzeni publicznej miasta (rys. 8.3). W tym kontekście należy wyróżnić obszar północny (na północ 
od Trasy Wschód-Zachód), stanowiący główny biegun rozwojowy dla kształtowanej przestrzeni centralnej, oraz komplementarny w stosunku do niego obszar południowy (na południe od Trasy Wschód-Zachód). W związku z powyższym oczekiwane jest przestrzenne i funkcjonalne zintegrowanie starych i nowych fragmentów przestrzeni centralnej:

- „Manufaktury” ze zmodernizowaną północną częścią ulicy Piotrkowskiej, która ma charakter ciągu pieszo-rowerowego z uspokojonym ruchem samochodowym, poprzez przekształcenia przestrzenno-funkcjonalne kwartałów przylegających do Placu Wolności (także poddanego modernizacji) oraz renowację zabudowy i zagospodarowanie wolnych działek wzdłuż ulicy Zachodniej i Kościuszki na odcinku od ulicy Narutowicza-Zielonej do ulicy Północnej-Ogrodowej;

- ulicy Piotrkowskiej i Nowego Centrum Łodzi, poprzez przekształcenia morfologiczne kwartałów zlokalizowanych pomiędzy ulicami Piotrkowską-Narutowicza-Kilińskiego-Tuwima oraz poprzez kontynuację budowy bulwaru Narutowicza od ulicy Piotrkowskiej do ulicy Kopcińskiego, obejmującą przekształcenia obszaru wokół Placu Dąbrowskiego oraz Parku Staszica i Parku Moniuszki;

- południowej, wielofunkcyjnej części ulicy Piotrkowskiej z przekształcanymi współcześnie obszarami na posiadłach wodno-fabrycznych przeznaczonymi na funkcję mieszkaniową, biurową i usługową, głównie kulturalną (rys. 8.3).

Pomiędzy obszarem północnym i południowym sugerowana jest rozbudowa dzielnicy finansowej wzdłuż Trasy Wschód-Zachód (Mickiewicza-Piłsudskiego) pomiędzy ulicą Żeromskiego na zachodzie i Targową (południową częścią ulicy Nowotargowej planowanej do realizacji w ramach Nowego Centrum Łodzi) na wschodzie. We wskazanym rejonie mogą powstać obiekty wysokościowe (biurowe, usługowe i rezydencjonalne). Dzielnica finansowa ze względu na swoją odmienną fizjonomię i sposób użytkowania będzie stanowić strefę przejściową pomiędzy północnym i południowym fragmentem kształtowanej przestrzeni centralnej Łodzi. Jednocześnie będzie też czytelną w przestrzeni jednostką morfologiczną (rys. 8.3).

Istotnym czynnikiem determinującym proponowaną hierarchiczną strukturę przestrzeni centralnej jest budowa Trasy Wschód-Zachód w ciągu alei Mickiewicza i Piłsudskiego (rys. 8.3). Brak zagłębienia pod ziemią całości trasy wykazującej bardzo duże natężenie ruchu i de facto wygenerowanie nowej bariery przestrzenno-funkcjonalnej, trudnej do zniwelowania w perspektywie najbliższych dziesięcioleci, może spowodować trwałą dezintegrację śródmieścia, tak jak miało to miejsce w Lyonie w następstwie budowy śródmiejskiego odcinka autostrady A7, pogłębiającej izolację obszaru Confluence od północnej części Presqu'île'.

${ }^{5}$ Zdaniem autora inwestycja ta miałaby uzasadnienie, w przypadku gdyby została w całości zaprojektowana i wykonana jako tunel przeznaczony dla samochodów i tramwajów, a „odzyskana” $\mathrm{w}$ ten sposób przestrzeń została zagospodarowana na przestrzeń publiczną z dobrze zorganizowaną zielenią miejską i wysokiej jakości meblami miejskimi. Stanowiłaby ona przyjazną przestrzeń rekreacyjną i wypoczynkową dla mieszkańców i użytkowników (np. pracowników licznych instytucji wielkomiejskich) ścisłego centrum miasta. 


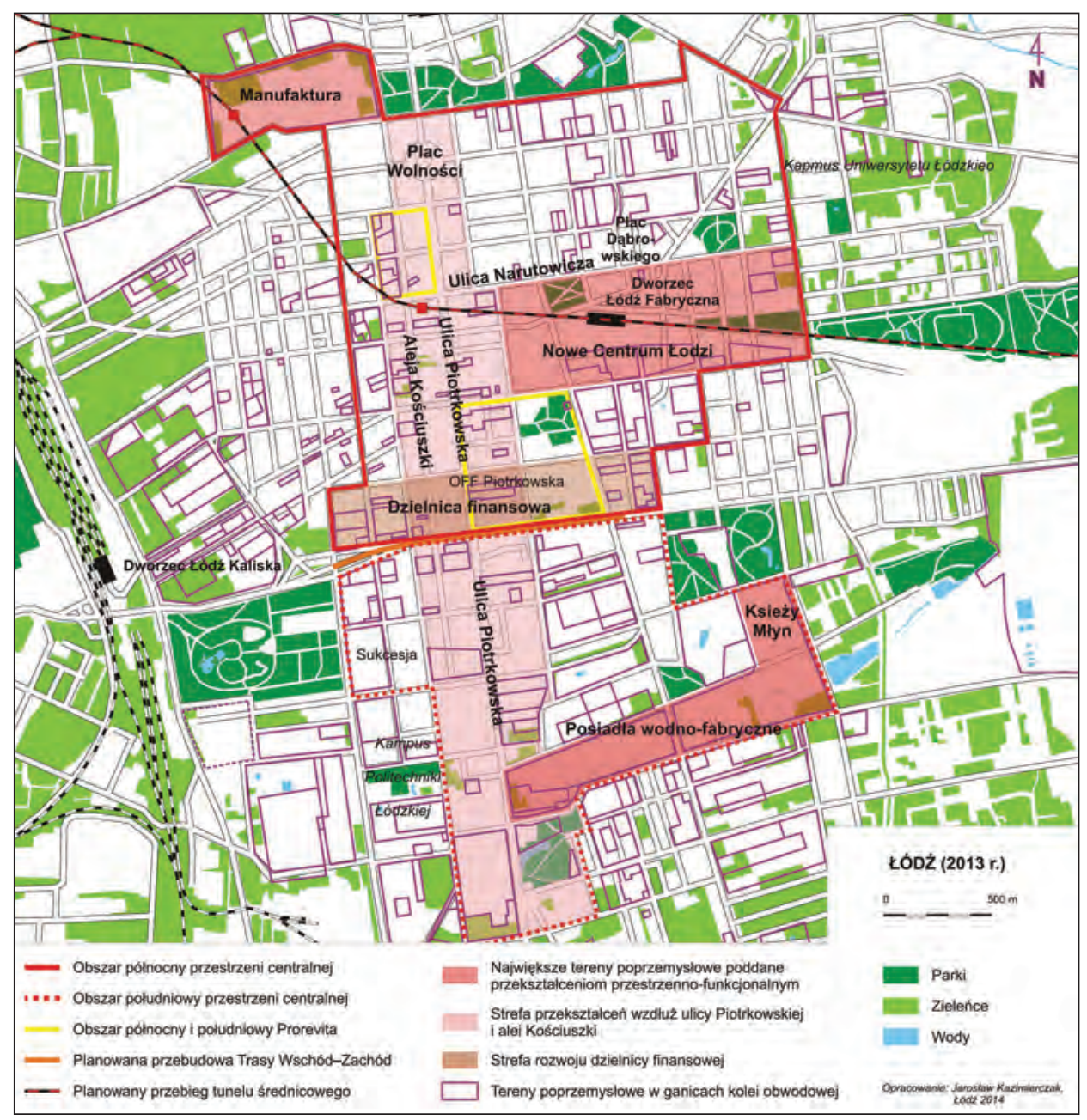

Rys. 8.3. Program rozwoju docelowej przestrzeni centralnej w Łodzi

Źródło: badania własne autora

W perspektywie najbliższych 15-20 lat istotny wpływ na sposób transformacji organizacji przestrzeni centralnej w Łodzi mają również plany budowy tunelu średnicowego dla tzw. Kolei Dużych Prędkości (PKD) i dla kolei aglomeracyjnej6. Kluczowe będzie w tym kontekście rozmieszczenie stacji, które będą generować ruch zarówno do, jak i ze stacji (rys. 8.3). Dla zwiększenia integracji ulicy

${ }^{6}$ Projekt PKD został przez Ministerstwo Infrastruktury i Rozwoju odłożony do realizacji do roku 2030. Niezależnie od jego realizacji władze Łodzi podjęły działania w celu pozyskania dofinasowania na realizację tunelu średnicowego ze środków finansowych Unii Europejskiej w latach 2014-2020. Budowa tunelu średnicowego umożliwi całościową realizację projektu Łódzkiej Kolei Aglomeracyjnej (ŁKA). 
Piotrkowskiej z „Manufakturą” i Nowym Centrum Łodzi w północnym obszarze wzrostu przestrzeni centralnej, czyli w jej „biegunie rozwojowym”, niezbędna jest budowa stacji pośredniej przy skrzyżowaniu alei Kościuszki i ulicy Zielonej oraz w okolicach „Manufaktury” (rys. 8.3).

Wskazane w rekomendacjach działania powinny obejmować zarówno rewitalizację wszystkich terenów poprzemysłowych we wskazanych rejonach interwencji, jak również towarzyszące im działania naprawcze na innych, sąsiadujących z nimi zdekapitalizowanych wielofunkcyjnych i mieszkaniowych terenach śródmiejskich, na co wskazują doświadczenia Manchesteru. W tym aspekcie wskazane jest rozszerzenie procesów modernizacyjnych rozpoczętych m.in. w ramach programu Prorevita (rys. 8.3). Pożądane jest zachowanie zabudowy postindustrialnej i jej przeznaczenie na lokalizację instytucji III i IV sektora oraz budowa nowych obiektów o oryginalnej architekturze, które będą stanowić nowe symbole miasta (landmarks). Jak wskazują doświadczenia Manchesteru w zakresie rewitalizacji i kształtowania centrum wielkomiejskiego, znaczna koncentracja



Rys. 8.4. Rekomendowany model rozwoju przestrzeni publicznej w kształtowanej przestrzeni centralnej Łodzi

Źródło: badania własne autora 
obszarów postindustrialnych w obrębie dzielnicy śródmiejskiej umożliwia wygenerowanie zwartej przestrzeni centralnej. W tym kontekście rozmieszczenie dawnych terenów przemysłowych będących współcześnie w fazie ugoru stwarza w dłuższej perspektywie czasowej możliwość integracji poszczególnych elementów starej (zmodernizowanej) i nowej przestrzeni centralnej w śródmieściu Łodzi w spójny obszar. Skoordynowany proces przekształceń morfologicznych w dzielnicy śródmiejskiej pozwoli na wygenerowanie zwartego centrum wielkomiejskiego o dwuośrodkowej strukturze przestrzenno-funkcjonalnej (rys. 8.3).

W kształtowanej przestrzeni centralnej (głównie w części północnej i na posiadłach wodno-fabrycznych) powinna zostać wygenerowana znaczna powierzchnia terenów ruchu pieszego, których celem będzie integracja placów miejskich (istniejących współcześnie i nowych) jako kluczowych elementów odnowionej przestrzeni publicznej w śródmieściu Łodzi (rys. 8.4). Sprawny system zorganizowanej otwartej przestrzeni publicznej z organiczonym ruchem kołowym i uprzywilejowanym transportem publicznym (tramwajowym i rowerowym), uzupełniona o elementy dośrodkowe (np. Galerię Łódzką i galerię handlową w „Manufakturze”) zachęci użytkowników do przebywania w przestrzeni centralnej, wydłużając dobowy i tygodniowy cykl jej użytkowania. Będzie to mieć pozytywny wpływ na koniunkturę poszczególnych elementów przestrzeni centralnej (starych i nowych) i jej wtórny rozwój jako jednego, złożonego układu.

Celem proponowanych rekomendacji dla kształtowania przestrzeni centralnej w Łodzi jest zatrzymanie niekorzystnego procesu formowania relacji konglomeracyjnych pomiędzy jej starymi i nowymi fragmentami, a następnie ich konwersja w relacje kooperacyjne. Przy planowaniu działań rewitalizacyjnych na wewnątrzmiejskich terenach poprzemysłowych należy uwzględnić aktualny stan złożoności, wielkości i intensywności przestrzeni centralnej w Łodzi w zgodzie z koncepcją cykliczności rozwoju przestrzeni centralnej w miastach europejskich. 


\section{LITERATURA}

Adams D., Watkins C., 2002, Greenfields, Brown Fields and Housing Development, Blackwell Publishing, Oxford Science.

Al Naib S. K., 1990, London Doclands. Past, Present and Future, Polytechnic of East London, London.

Aldridge M., 1979, The British New Towns - A Programme Without a Policy, Routladge and Kegan Paul, London.

Allman R., 1997, Manchester and its region: the history of the cotton textile industry, [w:] S. Liszewski, C. Young (red.), A comparative study of Łódź and Manchester. Geographies of European cities in transition, Wydawnictwo Uniwersytetu Łódzkiego, Łódź, s. 73-96.

Arct Z., 1974, Projektowanie architektoniczne zakładów przemystowych, Arkady, Warszawa.

Audin A., 1959, Essai sur la topographie de Lugdunum, Audin.

Barthes R., 1980, L'empire des signes, Seuil, Paris.

Bassett K., Griffiths R., Smith I., 2002, Testing Governance: Partnership, planning and conflict in waterfront regeneration, „Urban Studies”, 39, 10, s. 1757-1775.

Battiau M., 1976, Les industries textiles de la region Nord-Pas de Calais, t. 1-2, Lille.

Beaujeu-Garnier J., Chabot G., 1971, Zarys geografii miast, PWE, Warszawa.

Bell D., Jayne M., 2004, City of Quarters. Urban Villages in the Contemporaty City, Ashgate.

Benevolo L., 1995, Miasto w dziejach Europy, Wydawnictwo Krąg, Oficyna Wydawnicza Wolumen, Warszawa.

Ben Mabrouk T., Jouve B., 1999, La difficile émergence de la Région Urbaine de Lyon, [w:] B. Jouve, Ch. Lefèvre (red.), Villes, métropoles. Les nouveaux territoires du politique, Anthropos, Paris, s. $103-131$.

Bernat S., 2010, Doliny rzeczne i ich percepcja, [w:] J. Plit, U. Myga-Piątek (red.), Krajobrazy kulturowe dolin rzecznych. Potencjat $i$ wykorzystanie, Prace Komisji Krajobrazu, nr 13, Komisja Krajobrazu Kulturowego PTG, Sosnowiec, s. 167-178.

Berry J., McGreal S., Deddis B., 1993, Urban Regeneration. Property Investment and Development, Chapman and Hall.

Bertin D. (red.), 2012, Lyon de la Guillotière á Gerland: Le $7^{e}$ arrondissement 1912-2012, Éditions Lyonnaises d'Art et d'Histoire, Lyon.

Bartenshaw M., 1991, Sunrise to Sunset: A vivid Personal Account of Life in Manchester, Prinwise Publications, Bury.

Blackman T., 1995, Urban Policy in Practice, Routladge, London.

Bonnet J., 1982, L'espace lyonnais, , Revue de géographie de Lyon”, vol. 57, s. 191-204.

Bonneville M., 1997, Lyon. Métropole régionale ou euro-cité?, Anthropos, Paris.

Boudeville J. R., 1961, Les espaces économique. „Que sais-je?”, 950, PUF, Paris.

Bourdon D., 1999, Evaluer les Projets urbains, Cahiers de la Polique urbaine n. 3, Caisse de Dépôts et Consignations, Paris. 
Bourdin V., Petitet S., 2002, Du biopôle de Gerland à la Cité internationale de Lyon. La difficile transcription territoriale des ambitions internationales d'une ville, [w:] J. Malézieux, C. Manzagol, G. Sénécal (red.), Grands projets urbains et requalification, Publications de la Sorbonne, Paris, s. 35-55.

Breathnach P., 2000, Globalisation, information technology and the emergence of niche transnational cities: the growth of the call centre sector in Dublin, „Geoforum”, 31, s. 447-485.

Breen A., Rigby D., 1996, The new waterfron. A worldwide urban success story, McGraw-Hill, Singapure.

Briggs A., 1963, Victorian Cities, Oldhams Press, London.

Brintley T., Rydin Y., Stoker G., 1996, Remaking Planning, Routladge.

Bromek K., 1966, Użytkowanie ziemi w Krakowie i przylegtych częściach powiatu krakowskiego około 1960 roku, Zeszyty Naukowe Uniwersytetu Jagiellońskiego, Prace Geograficzne, z. 38.

Bromek K., Mydel R., 1972, Uwagi metodyczne do opracowania szczegółowej mapy użytkowania przestrzeni miejskiej, Folia Geographica, Series Geographica-Oeconomica, vol. V, PWN, Warszawa-Kraków, s. 149-160.

Broniewski T., 1980, Historia architektury dla wszystkich, Zakład Narodowy im. Ossolińskich, Wrocław.

Brownill S., 1990, Developing London's Doclands. Another Great Planning Disaster?, Paul Chapman, London.

Bruyelle P., 1954, L'industrie cotonniere a Lille-Roubaix-Tourcoing, Revue du Nord, s. 21-41.

Bryx M. (red.), 2009, Finansowanie i gospodarka nieruchomościami w procesach rewitalizacji, t. 7, Instytut Rozwoju Miast w Krakowie, Kraków.

Bryx M., Jadach-Sepioło A., 2009, Rewitalizacja miast w Niemczech, t. 3, Instytut Rozwoju Miast w Krakowie, Kraków.

Bury P., Markowski T., Regulski J., 1993, Podstawy ekonomiki miasta, Fundacja Rozwoju Przedsiębiorczości w Łodzi, Łódź.

Carley M., 2000, Urban partnership, governance and the regeneration of Britain's cities, „International Planning Studies”, 5, 3, s. 273-297.

Carter C. F., 1962, Manchester and its Region, Manchester University Press, Manchester.

Carter H., 1973, The Study of Urban Geography, Edward Arnold, London.

Castells M., 1982, Kwestia miejska, PWN, Warszawa.

Cattaneo T., 2007, Odnowa miejska i rewitalizacja budynków - wspólna metodologia kultury architektonicznej i projektowej, [w:] B. M. Walczak (red.), Rewitalizacja-nośnik tożsamości i rozwoju obszarów metropolitalnych, Monografia pokonferencyjna PRO-REVITA Łódź 2006, Wydawnictwo Biblioteka i Instytut Architektury i Urbanistyki Politechniki Łódzkiej, Łódź, s. 297-308.

Cayez P., 1980, Crises et croissance de l'industrie lyonnaise 1850-1900, Lyon.

Chmielewski J. M., 2001, Teoria urbanistyki $w$ projektowaniu i planowaniu miast, Oficyna Wydawnicza Politechniki Wrocławskiej, Warszawa.

Conzen M. R. G., 1960, Alnwick, Northumberland. A Study in Town - Planning Analysis, The Institute of British Geographers, Publication No. 27, London.

Conzen M. R. G., 1962, The Plan Analysis of an English City Centre, [w:] K. Norborg (red.), Proceedings of the IGU Symposium in Urban Geography, Gleerup, „Lund Studies of Geography", no. 24, Lund, s. 384-414.

Couch Ch., Dennemann A., 2000, Urban regeneration and sustainable development in Britain. The example of the Liverpool Ropewalks Partnership, „Cities”, 17, 2, s. 137-147.

Coudroy de Lille L., 2003, Lyon Confluence - metropolitalny projekt w widłach Rodanu i Saony w Lyonie, [w:] I. Jażdżewska (red.), Funkcje metropolitalne i ich rola w organizacji przestrzeni, XVI Konwersatorium Wiedzy o Mieście, Wydawnictwo Uniwersytetu Łódzkiego, Łódź, s. 267-275. 
Cudny W., 2011, Pomnik jako element przestrzeni miejskiej, [w:] I. Jażdżewska (red.), Przestrzeń publiczna miast, XXIV Konwersatorium Wiedzy o Mieście, Wydawnictwo Uniwersytetu Łódzkiego, Łódź, s. 145-156.

Cullen G., 2011, Obraz miasta, Ośrodek „Brama Grodzka - Teatr NN”, Lublin.

Czarnecki W., 1983, Projektowanie obiektów przemysłowych, Wydawnictwo Politechniki Białostockiej, Białystok.

Czyżewska A., 2009, Program waterfront - wyzwania dla rewitalizacji, [w:] A. Januchta-Szostak (red.), Woda w krajobrazie miasta, t. 1, Wydawnictwo Politechniki Poznańskiej, Poznań, s. 11-26.

Delfante Ch., Pelletier J., 2006, Plans de Lyon. Portraits d'une ville 1350-2015, Éditiond Stéphane Bachès, Lyon.

Dicken P., 1998, Global shift. Transforming the world economy, Paul Chapman Publishing, London.

Dixon T., Otsuka N., Abe H., 2011, Critical success factors in urban brownfield regeneration: an analysis of 'hardcore' sites in Manchester and Osaka during the economic recession (2009-10), „Environment and Planning A”, vol. 43, s. 961-980.

Domański B., 2000, Tereny poprzemysłowe w miastach polskich - kierunki i bariery przekształceń, [w:] I. Jażdżewska (red.), Miasto postsocjalistyczne organizacja przestrzeni i jej przemiany, XIII Konwersatorium Wiedzy o Mieście, Wydawnictwo Uniwersytetu Łódzkiego, Łódź, s. $139-143$.

Domański B., 2000a, Restrukturyzacja terenów poprzemysłowych w miastach, [w:] Z. Ziobrowski, D. Ptaszycka-Jackowska, A. Rębowska, A. Geissler (red.), Odnowa miast. Rewitalizacja, rehabilitacja, restrukturyzacja, Instytut Gospodarki Przestrzennej i Komunalnej, Wydawnictwo Politechniki Śląskiej, Gliwice, s. 107-142.

Domański B., 2009, Rewitalizacja terenów poprzemysłowych - specyfika wyzwań i instrumentów, [w:] W. Jarczewski (red.), Przestrzenne aspekty rewitalizacji - śródmieścia, blokowiska, tereny poprzemystowe, pokolejowe i powojskowe, t. 4, Instytut Rozwoju Miast w Krakowie, Kraków, s. 125-137.

Domański T. (red.), 1997, Marketing terytorialny; strategiczne wyzwania dla miast i regionów, Wydawnictwo Uniwersytetu Łódzkiego, Łódź.

Donzelot J., Mevel C., 2001, La pilitique de la ville: une comparaison entre les USA et la France, collection 2001 PLUS, DRAST-PUCA.

Dumała K., 1974, Przemiany przestrzenne i rozwój osiedli przemysłowych w Królestwie Polskim w latach 1831-1896, Ossolineum, Wrocław.

Dziedziuchowicz J., 2012, Wielkie centrum handlowe $w$ przestrzeni miejskiej i podmiejskiej: Manufaktura w Lodzi i Ptak w Rzgowie, Wydawnictwo Uniwersytetu Łódzkiego, Łódź.

Dziewoński K., 1956, Geografia osadnictwa i zaludnienia. Dorobek, podstawy teoretyczne i problemy badawcze, „Przegląd Geograficzny”, t. 28, z. 4, s. 721-764.

Dziewoński K., 1962, Zagadnienia typologii morfologicznej miast w Polsce, „Czasopismo Geograficzne", t. 33, z. 4, s. 441-457.

Dziewoński K., 1967, Teoria regionu ekonomicznego, „Prace Geograficzne IG PAN”, nr 39.

Dziewoński K., 1991, Początki i przemiany planowania przestrzennego w Polsce, Biuletyn KPZK PAN, nr 152, s. 65-75.

Falconer K., 2012, Local protection, [w:] J. Douet (red.), Industrial heritage re-toled, The TICCIH guide to Industrial Heritage Conservation, Lancaster, s. 94-100.

Fanger B., 2012, Adaptive re-use, [w:] J. Douet (red.), Industrial heritage re-toled, The TICCIH guide to Industrial Heritage Conservation, Lancaster, s. 110-117.

Frangopulo N. J., 1962, Rich Inheritance. A Guide to the History of Manchester, Manchester Education Committee, Manchester.

Franta A., 2004, Reżyseria przestrzeni. O doskonaleniu przestrzeni publicznej miasta, Seria Architektura, Monografia 368, Wydawnictwo Politechniki Krakowskiej, Kraków. 
Gabert K., 1964, Turin. Ville industielle. Etude de geographie economique et humaine, PUF, Paris. Garden M., 1975, Lyon el Lyonnais aux XVIII siècle, Paris.

Gasidło K., 1998, Problemy przekształceń terenów poprzemysłowych, Wydawnictwo Politechniki Śląskiej, Gliwice.

Gehl J., 2009, Życie między budynkami. Użytkowanie przestrzeni publicznych, Wydawnictwo RAM, Kraków.

Ghirardo D., 1999, Architektura po Modernizmie, Wydawnictwo VIA, Toruń.

Gibson Ch., 2003, Cultures at work: why ,culture” matters in research on the „cultural” industries, „Social \& Cultural Geography”, t. 4, nr 2, s. 201-215.

Goldzmat E., 1971, Urbanistyka krajów socjalistycznych. Problemy społeczne, Arkady, Warszawa.

Goldzmat E., 1980, Rozwój koncepcji nowego osadnictwa XX wieku, [w:] E. Goldzmat, Z. Jargina (red.), Prognozy rozwoju systemów osadniczych, doświadczenia historyczne i metodologiczne, PWN, Warszawa, s. 9-119.

Górka Z., 1988, Użytkowanie przestrzeni miejskiej-Stare Miasto i użytkowanie przestrzeni miejskiej wedlug kondygnacji - fragment Starego Miasta, [w:] Atlas miasta Krakowa, plansze 21 i 22.

Górka Z., 1995, Geograficzne metody badań centrum miasta, [w:] J. Kaczmarek (red.), Centra $i$ peryferie dużych miast. Transformacja i przeszłość. Pojęcie i metody badawcze, VIII Konwersatorium Wiedzy o Mieście, KGMiT UŁ, Łódź, s. 45-52.

Górka Z., 2004, Krakowska dzielnica staromiejska $w$ dobie społeczno-ekonomicznych przemian Polski na przełomie XX i XXI wieku, Instytut Geografii i Gospodarki Przestrzennej Uniwersytetu Jagiellońskiego, Kraków.

Graczyk R., 2009, Wpływ zbiorników wodnych na koncepcje zagospodarowania miast, [w:] A. Januchta-Szostak (red.), Woda w krajobrazie miasta, t. 1, Wydawnictwo Politechniki Poznańskiej, Poznań, s. 39-48.

Guzik R. (red.), 2009, Rewitalizacja miast w Wielkiej Brytanii, t. 1, Instytut Rozwoju Miast w Krakowie, Kraków.

Gzell S., 2000, Kwestie wynikające z dzielenia przestrzeni miejskiej na przykładzie Berlina $i$ Warszawy - po roku 1990, [w:] J. Kaczmarek (red.), Przestrzeń miejska i jej przemiany, XII Konwersatorium Wiedzy o Mieście, Wydawnictwo Uniwersytetu Łódzkiego, Łódź, s. 93-98.

Halbwachs M., 1992, On Collective Memory, Heritage of Sociology Series, University of Chicago Press, Chicago.

Hall J. M., 1990, Metropolis Now! London and its Region, Cambridge University Press, Cambridge.

Hall P., 1998, Cities in civilization: Culture, Innovation, and Urban Order, Weidenfield \& Nicolson, London.

Harwell C., 2010, Manchester, Pevsner Architectural Guides, Yale University Press, New HavenLondon.

Hochart S., 2013, Lyon Presqu'île d'hier á aujourd'hui, Editions Alan Sutton, Saint-Avertin.

Hołub A., 2002, Wspótczesna przestrzeń publiczna. Terapia patologii czy rozwój nowych terenów - poszukiwanie przesłanek projektowych, [w:] M. Kochanowski (red.), Przestrzeń publiczna miasta postindustrialnego, Wydawnictwo Politechniki Gdańskiej, Gdańsk, s. 9-25.

Hommouche A., 2004, Les dispositifs comme indicateurs des politiques culturelles, [w:], N. Bandier, A. Matuchniak-Krasuska, B. Sułkowski (red.), Practiques culturelles et logique des institutions. Cultural Practices and the Logic of Institutions (Lyon-Lódź), Wydawnictwo Uniwersytetu Łódzkiego, Łódź, s. 20-29.

Huret M., 1997, La management financier de la restructuration des grands ensembles, Cohiers de la politique urbaine, Caisse des Dépôts et Consignations, $\mathrm{nr} 1$.

Ilnicki D., 2003, Miasta polskie jako potencjalne metropolie o znaczeniu kontynentalnym (próba identyfikacji), [w:] I. Jażdżewska (red.), Funkcje metropolitalne $i$ ich rola $w$ organizacji przestrzeni, XVI Konwersatorium Wiedzy o Mieście, Wydawnictwo Uniwersytetu Łódzkiego, Łódź, s. 61-72. 
Imrie R., Thomas H., 1993, British Urban Policies and The Urban Development Corporation, Paul Chapman, London.

Jakóbczyk-Gryszkiewicz J., Marcińczak Sz., Siejkowska A., 2010, Dynamika i skutki procesów urbanizacji w regionach miejskich po 1990 roku na przykładzie regionu miejskiego Łodzi, Wydawnictwo Uniwersytetu Łódzkiego, Łódź.

Jakubczyk Z., Słodczyk J., 2005, Revitalization and the sustainable development of cities: a theoretical and empirical approach, [w:] I. Sagan, D. M. Smith (red.), Society, economy, environment - towards the sustainable city, University of Gdańsk, Department of Economic Geography, Bogucki Wydawnictwo Naukowe, Gdańsk-Poznań, s. 159-175.

Jałowiecki B., 1989, Nowe miasta, ideologia i rzeczywistość, Acta Universitatis Lodziensis, Folia Goegraphica 11, Wydawnictwo Uniwersytetu Łódzkiego, Łódź, s. 25-38.

Jałowiecki B., Szczepański M. S., 2010, Miasto i przestrzeń w perspektywie socjologicznej, Wydawnictwo Naukowe SCHOLAR, Warszawa.

Janas K., Jarczewski W., Wańkowicz W., 2010, Model rewitalizacji miast, t. 10, Instytut Rozwoju Miast w Krakowie, Kraków.

Januchta-Szostak A., (red.), 2011, Spoleczne i krajobrazowe walory wody w środowisku, Wydawnictwo Politechniki Poznańskiej, Poznań.

Jarczewski W., Jeżak J., 2010, System monitorowania rewitalizacji, t. 11, Instytut Rozwoju Miast w Krakowie, Kraków.

Jarczewski W., Kuryło M., 2009, Rewitalizacja terenów powojskowych, [w:] W. Jarczewski (red.), Przestrzenne aspekty rewitalizacji - śródmieścia, blokowiska, tereny poprzemysłowe, pokolejowe i powojskowe, t. 4, Instytut Rozwoju Miast w Krakowie, Kraków, s. 243-289.

Jaroszewska-Brudnicka R., 2011, Reżyserowanie przestrzeni publicznej miasta, [w:] I. Jażdżewska (red.), Człowiek w przestrzeni publicznej miasta, XXIV Konwersatorium Wiedzy o Mieście, Wydawnictwo Uniwersytetu Łódzkiego, Łódź, s. 129-140.

Jażdżewska I., 2008, Dlaczego warto stosować teorię grafów w badaniach geografii historycznej? Przyktady zastosowania, [w:] M. Kulesza (red.), Czas i przestrzeń w naukach geograficznych: wybrane problemy geografii historycznej, Wydawnictwo Uniwersytetu Łódzkiego, Łódź, s. $243-256$.

Jażdżewska I., Coudroy de Lille L., Lavot A., 2011, Nabrzė̇na przestrzeń publiczna w Lyonie. Nowa jakość przestrzeni publicznej nad Rodanem, [w:] I. Jażdżewska (red.), Człowiek w przestrzeni miast, XXIV Konwersatorium Wiedzy o Mieście, Wydawnictwo Uniwersytetu Łódzkiego, Łódź, s. 51-68.

Jelonek A., 1989, Próba określenia podstaw teoretycznych pojęcia „nowe miasto”, „Acta Universitatis Lodziensis, Folia Goegraphica" 11, Wydawnictwo Uniwersytetu Lódzkiego, Łódź, s. 39-47.

Jencks Ch., 1987, Ruch nowoczesny $w$ architekturze, Warszawa.

Jencks Ch., 1993, Heteropolis: Los Angeles, The Riots and the Strange Beuty of Hetero-architecture, Academy Edition, London.

Jewtuchowicz A., Suliborski A., 2009, Życie społeczne i kulturalne Łodzi w latach 1918-1989, [w:] S. Liszewski (red.), Łódź monografia miasta, Łódzkie Towarzystwo Naukowe, Łódź, s. 297-342.

Jones P., Evans J., 2009, Urban Regeneration in the UK, Sage Publications Ltd., London.

Juchnowicz S., 1971, Śródmieścia miast polskich. Studia nad kształtowaniem i rozwojem centrów, Zakład Narodowy im. Ossolińskich, PAN, Wrocław-Warszawa-Kraków-Gdańsk.

Kaczmarek J., 2000, Świat życia człowieka $w$ mieście postsocjalistycznym. Zarys koncepcji badawczej, [w:] J. Kaczmarek (red.), Przestrzeń miejska i jej przemiany, XII Konwersatorium Wiedzy o Mieście, Wydawnictwo Uniwersytetu Łódzkiego, Łódź, s. 53-59.

Kaczmarek S., 1999, Rewitalizacja a organizacja przestrzeni miejskiej, [w:] J. Kaczmarek (red.), Przestrzeń miejska jej organizacja i przemiany, XXII Konwersatorium Wiedzy o Mieście, Wydawnictwo Uniwersytetu Łódzkiego, Łódź, s. 43-49. 
Kaczmarek S., 1999a, Tourism and Urban Regeneration, [w:] T. Marszał (red.), „European Spatial Research and Policy", vol. 6, no. 1, s. 99-105.

Kaczmarek S., 2000, Społeczność miejska a proces rewitalizacji, [w:] I. Sagan, M. Czepczyński (red.), Wybrane problemy badawcze geografi społecznej w Polsce, Wydawnictwo Uniwersytetu Gdańskiego, Gdańsk, s. 121-126.

Kaczmarek S., 2001, Rewitalizacja terenów poprzemysłowych. Nowy wymiar w rozwoju miast, Wydawnictwo Uniwersytetu Łódzkiego, Łódź.

Kaczmarek S., 2005, The Space of Exchange: Revitalisation of Post-Industrial Areas in Modern Cities, [w:] Y. Murayama, G. Du (red.), Cities in Global Perspective: Diversity and Transition, Rikkyo University with IGU Urban Commission, Tokyo, s. 270-278.

Kaczmarek S., 2010, Proces rewitalizacji terenów poprzemysłowych a organizacja przestrzeni miejskiej Łodzi, [w:] T. Markowski, S. Kaczmarek, J. Olenderek (red.), Rewitalizacja trenów poprzemysłowych Łodzi, Biuletyn KPZK PAN, t. CXXXII, Warszawa, s. 7-18.

Kaczmarek S., Kaczmarek J., 2010, Tereny poprzemysłowe w Lodzi jako element potencjatu miasta, [w:] T. Markowski, S. Kaczmarek, J. Olenderek (red.), Rewitalizacja trenów poprzemystowych Łodzi, Biuletyn KPZK PAN, t. CXXXII, Warszawa, s. 68-79.

Kalinowski W., 1966, Zarys historii budowy miast w Polsce do połowy XIX wieku, Torun.

Kazimierczak J., 2010, Tablice pamiatkowe i pomniki jako obiekty upamiętniajace osoby i wydarzenia z przeszłości Łodzi, „Turyzm”, t. 20, z. 1., Wydawnictwo Uniwersytetu Łódzkiego, Łódź, s. 13-19.

Kazimierczak J., 2011, „Stara” versus „,nowa” przestrzeń publiczna centrum miasta. Przyklad Łodzi, [w:] I. Jażdżewska (red.), Przestrzeń publiczna miast, XXIV Konwersatorium Wiedzy o Mieście, Wydawnictwo Uniwersytetu Łódzkiego, Łódź, s. 127-143.

Kennedy L., 2004, Remaking Birmingham: the Visual Culture and Urban Regeneration, Aldershot, Ashgate.

Kennedy M., 1970, A Portrait of Manchester, Robert Hale, London.

Kenyon D., 1991, The Origins of Lancashire, Manchester University Press, Manchester.

Kidd A., 1993, Manchester, Ryburn Publishing. Keele University Press, Manchester.

Kidd A., 1997, The Historical Development of Manchester and its Region, [w:] S. Liszewski, C. Young (red.), A Comparative Study of Łódź and Manchester. Geographies of European Cities in Transition, Wydawnictwo Uniwersytetu Łódzkiego, Łodź, s. 35-56.

Klassen L., 1965, Area Economic and Social Redevelopment, Paris.

Kleinclausz A., 1978, Histoire de Lyon, Laffite Reprints, Marseille.

Kochanowska D., 2002, Przemiany śródmiejskich przestrzeni publicznych w Polsce, [w:] M. Kochanowski (red.), Przestrzeń publiczna miasta postindustrialnego, Wydawnictwo Politechniki Gdańskiej, Gdańsk, s. 55-84.

Kochanowska D., 2002a, Śródmiejskie przestrzenie publiczne - współczesne przekształcenia, [w:] M. Kochanowski (red.), Przestrzeń publiczna miasta postindustrialnego, Wydawnictwo Politechniki Gdańskiej, Gdańsk, s. 26-54.

Kochanowska D., 2010, Przestrzeń publiczna - kluczowy element miasta wspótczesnego - zintegrowana czy podzielona?, [w:] P. Lorens, J. Martyniuk-Pęczek (red.), Problemy kształtowania przestrzeni publicznej, Seria Miasto-Metropolia-Region, Wydawnictwo Urbanista, Gdańsk, s. 21-35.

Koncepcja miejscowych planów zagospodarowania przestrzennego dla obszaru Nowego Centrum Łodzi.

Kostof S., 1991, The City Shaped: Urban Patterns and Meanings Trough History, Thames \& Hudson, London.

Koter M., 1974, Fizjonomia, morfologia i morfogeneza miasta. Przeglad rozwoju i próba uściślenia pojęć, Zeszyty Naukowe UŁ, Nauki matematyczno-przyrodnicze, seria II, z. 55, s. 3-16. 
Koter M., 1976, Komentarz naukowy do cyklu prac na temat: „, Morfogeneza wielkiego miasta na przykładzie Łodzi” (Resume pracy habilitacyjnej), Acta Universitatis Lodziensis, Łódź.

Koter M., 1979, Struktura morfogenetyczna wielkiego miasta na przykładzie Łodzi, Zeszyty Naukowe UŁ, Nauki matematyczno-przyrodnicze, seria II, z. 21, s. 25-52.

Koter M., 1990, The Morphological Evolution of Nineteenth-century City Centre: Lódź, Poland, 1985-1973, [w:] T. Slater (red.), The Built Form of Western Cities, Laicester University Press, Laicester, s. 109-141.

Koter M., 1994, Od fizjonomii do morfogenezy i morfologii porównawczej. Podstawowe zagadnienia teoretyczne morfologii miast, [w:] M. Koter, J. Tkocz (red.), Zagadnienia geografii historycznej osadnictwa w Polsce. Materiały konferencyjne, UMK, UŁ, Toruń-Lódź, s. 23-32.

Koter M., 2002, Łódź i okolice w I połowie XIX wieku. Plansza IV, [w:] S. Liszewski (red.), Atlas Miasta Łodzi, Urząd Miasta Łodzi, Wydział Geodezji, Katastru i Inwentaryzacji, Łódź.

Koter M., 2009, Ksztaltowanie się tkanki miejskiej Łodzi do 1918 roku, [w:] S. Liszewski (red.), Łódź monografia miasta, Łódzkie Towarzystwo Naukowe, Łódź, s. 62-112.

Koter M., 2009a, Tkanka miejska Łodzi w latach 1918-1989, [w:] S. Liszewski (red.), Łódź monografia miasta, Łódzkie Towarzystwo Naukowe, Łódź, s. 218-264.

Koter M., Wiktorowska, 1974, Przemiany morfologiczne śródmieścia Łodzi na przykładzie bloku urbanistycznego: Piotrkowska - Moniuszki - Sienkiewicza - Tuwima, „Acta Universitatis Lodziensis, Zeszyty Naukowe UŁ, Nauki matematyczno-przyrodnicze", seria II, z. 55, s. 17-29.

Koter M., Wiktorowska, 1976, Procesy przemian morfologicznych śródmieścia Łodzi (w granicach byłej kolonii tkackiej) pod wpływem kształtowania się ogólnomiejskiego centrum usługowego, „Acta Universitatis Lodziensis, Zeszyty Naukowe UŁ, Nauki matematyczno-przyrodnicze”, seria II, z. 7, s. 41-88.

Kotlicka J., 2008, Przemiany morfologiczne terenów przemysłowych Łodzi, Łódzkie Towarzystwo Naukowe, nr 36, Łódź.

Kulesza M., 2011, Zagadnienia morfogenezy i rozplanowania miast średniowiecznych $w$ Polsce, Wydawnictwo Uniwersytetu Łódzkiego, Łódź.

Laferrère M., 1960, Lyon. Ville industrielle. Essai d'une geographie urbaine des techniques et des entreprises, PUF, Paris.

Lavedan P., 1926, Intoduction à une histoire de l'archiecture urbaine, H. Laurens, Paris.

Leszczycki S., 1972, Pojęcie czynnika przestrzeni i jego rola we współczesnej gospodarce, [w:] K. Secomski (red.), Elementy teorii planowania przestrzennego, Warszawa.

Lewis N., 1992, Inner Cities regeneration, Milton Keynes Open University Press, Milton Keynes.

Lever J., 1997, The Service Sector in the Centre of Manchester, [w:] S. Liszewski, C. Young (red.), A Comparative Study of Łódź and Manchester. Goegraphies of European Cities in Transition, Wydawnictwo Uniwersytetu Łódzkiego, Łódź, s. 159-173.

Lisowski A., 1990, Wstęp do geografii społecznej, Wydawnictwo Uniwersytetu Warszawskiego, Warszawa.

Lisowski A., 2003, Koncepcje przestrzeni w geografii czlowieka, Wydawnictwo Uniwersytetu Warszawskiego, Warszawa.

Liszewski S., 1977, Tereny miejskie a struktura przestrzenna Łodzi, Acta Universitatis Lodziensis, Wydawnictwo Uniwersytetu Łódzkiego, Łódź.

Liszewski S., 1978, Tereny miejskie. Podziat i klasyfikacja, Acta Universitatis Lodziensis, Folia Geographica, Seria II, z. 15, s. 3-30.

Liszewski S., 1992, The industrial as a tourist centre. Exemple of Łódź, „Turyzm”, t. 2., z. 1., Wydawnictwo Uniwersytetu Łódzkiego, Łódź, s. 9-22.

Liszewski S., 1997, Przestrzeń miejska i jej organizacja, [w:] B. Domański (red.), Geografia, czlowiek, gospodarka, Wydawnictwo Uniwersytetu Jagiellońskiego, Kraków, s. 55-65.

Liszewski S., 1999, Przestrzeń turystyczna miasta. Przyktad Łodzi, „Turyzm”, t. 9, z. 1, Wydawnictwo Uniwersytetu Łódzkiego, Łódź, s. 51-73. 
Liszewski S., 2006, Nowe przestrzenie $w$ miastach (na obszarach zurbanizowanych), [w:] I. Jażdżewska (red.), Nowe przestrzenie $w$ mieście ich organizacja $i$ funkcje, XIX Konwersatorium Wiedzy o Mieście, Wydawnictwo Uniwersytetu Łódzkiego, Łódź, s. 35-48.

Liszewski S., 2008, Formy i struktury przestrzenne wielkich skupisk miejskich, [w:] S. Liszewski (red.), Geografia urbanistyczna. Podręcznik akademicki, Wydawnictwo Uniwersytetu Łódzkiego, Łódź, s. 187-233.

Liszewski S. (red.), 2009, Łódź monografia miasta, Łódzkie Towarzystwo Naukowe, Łódź.

Liszewski S., Maik W., 2000, Osadnictwo. Wielka Encyklopedia Geografii Świata, t. 19, Wydawnictwo Kupisz, Poznań.

Liszewski S., Young C., (red.), 1997, A Comparative Study of Łódź and Manchester. Geographies of European Cities in Transition, Wydawnictwo Uniwersytetu Łódzkiego, Łodź.

Liszewski S., Gryszkiewicz J., Kaczmarek S., 1989, Nowe miasta jako przedmiot badań naukowych, „Acta Universitatis Lodziensis, Folia Goegraphica” 11, Wydawnictwo Uniwersytetu Łódzkiego, Łódź, s. 257-279.

Lorens P., 2002, Nowe instrumenty ksztaltowania przestrzeni publicznych miasta, [w:] M. Kochanowski (red.), Przestrzeń publiczna miasta postindustrialnego, Wydawnictwo Politechniki Gdańskiej, Gdańsk, s. 189-213.

Lorens P., 2005, Wstępna typologia obszarów zdegradowanych o funkcjach i potencjale metropolitalnym, [w:] T. Parteka (red.), Transformacja zdegradowanych struktur przestrzennych metropolii polskich, KPZK PAN, Warszawa, s. 57-74.

Lorens P. (red.), 2007, Rewitalizacja miast w Polsce: pierwsze doświadczenia, Biblioteka Urbanisty, Urbanista 10, Warszawa.

Lorens P. 2009, Ksztaltowanie nowego oblicza Młodego Miasta w Gdańsku, [w:] A. Januchta-Szostak (red.), Woda w krajobrazie miasta, t. 1, Wydawnictwo Politechniki Poznańskiej, Poznań, s. 27-38.

Lorens P., 2010, Rewitalizacja miast: planowanie i realizacja, Wydział Architektury Politechniki Gdańskiej, Gdańsk.

Lorens P., 2010a, Definiowanie wspótczesnej przestrzeni publicznej, [w:] P. Lorens, J. Martyniuk-Pęczek (red.), Problemy ksztaltowania przestrzeni publicznej, Seria Miasto-Metropolia-Region, Wydawnictwo Urbanista, Gdańsk, s. 6-20.

Lorens P., Martyniuk-Pęczek J. (red.), 2009, Wybrane zagadnienia rewitalizacji miast, Seria Miasto-Metropolia-Region, Wydawnictwo Urbanista, Gdańsk.

Lynch K., 1962, The Image of the City, The MIT Press, Cambridge, London.

Maik W., 2003, Pojęcie metropolii a problem badania funkcji metropolitalnych, [w:] I. Jażdżewska (red.), Funkcje metropolitalne $i$ ich rola $w$ organizacji przestrzeni, XVI Konwersatorium Wiedzy o Mieście, Wydawnictwo Uniwersytetu Łódzkiego, Łódź, s. 9-17.

Maik W., 2011, Przestrzeń publiczna w mieście: pojęcie, ujęcia badawcze, funkcje i ewolucja zjawiska, [w:] I. Jażdżewska (red.), Przestrzeń publiczna miast, XXIV Konwersatorium Wiedzy o Mieście, Wydawnictwo Uniwersytetu Łódzkiego, Łódź, s. 9-14.

Majer A., 2010, Socjologia i przestrzeń miejska, Wydawnictwo Naukowe PWN, Warszawa.

Makepeace Ch., 2013, Manchester Then \& Now in Colour, The History Press, Stroud.

Malisz B., 1981, Zarys teorii kształtowania układów osadniczych, Arkady, Warszawa.

Maliszowa B., 1974, Śródmieście - wybrane zagadnienia planowania, Arkady, Warszawa.

Marcińczak Sz., 2009, Przemiany struktury społeczno-przestrzennej Łodzi w latach 1988-2005, Wydawnictwo Uniwersytetu Łódzkiego, Łódź.

Marcińczak Sz., Sagan I., 2011, The socio-spatial restructuring of Łódź, Poland, „Urban Studies”, 48, 9, s. 1789-1809.

Markowski T., 1999, Zarządzanie rozwojem miasta, PWN, Warszawa.

Markowski T., Marszał T., 2006, Metropolie, obszary metropolitalne, metropolizacja: problemy i pojęcia podstawowe, Wydawnictwo KPZK PAN, Warszawa. 
Markowski T., Stawasz D. (red.), 2007, Rewitalizacja a rozwój funkcji metropolitalnych miasta Łodzi, Wydawnictwo Uniwersytetu Łódzkiego, Łódź.

Markowski T., Stawasz D., Sikora A. D., 2005, Polityka mieszkaniowa obszaru - cele i instrumenty, Zintegrowany Program Rewitalizacji Obszaru Centralnego Łodzi, Urząd Miasta Łodzi, Łódź.

Matczak A., 1989, Nowe miasta w Wielkiej Brytanii, „Acta Universitatis Lodziensis, Folia Goegraphica” 11, Wydawnictwo Uniwersytetu Łódzkiego, Łódź, s. 201-220.

Matczak A., 1992, Model badania ruchu turystycznego. Studium metodologiczne, Acta Universitatis Lodziensis, Wydawnictwo Uniwersytetu Łódzkiego, Łódź.

Mierzejewska L., 2006, Osiedla zamknięte jako nowe przestrzenie miast polskich (przyktad Poznania), [w:] I. Jażdżewska (red.), Nowe przestrzenie miejskie ich organizacja i funkcje, XIX Konwersatorium Wiedzy o Mieście, Wydawnictwo Uniwersytetu Łódzkiego, Łódź, s. 311-320.

Michalska-Żyła A., 2010, Psychospołeczne więzi mieszkańców miasta. Studium na przykładzie Łodzi, Wydawnictwo Uniwersytetu Łódzkiego, Łódź.

Michalski W., 1989, Bełchatów - miasto „nowe”. Próba definicji, Acta Universitatis Lodziensis, Folia Geographica 11, Wydawnictwo Uniwersytetu Łódzkiego, Łódź, s. 147-164.

Mironowicz I., Ossowicz T., 2005, Metodologia badania degradacji obszarów o funkcjach metropolitalnych, [w:] T. Parteka (red.), Transformacja zdegradowanych struktur przestrzennych metropolii polskich, KPZK PAN, Warszawa, s. 36-56.

Mumford L., 1961, The City in the History. Its Origins, Its Transformations, and Its Prospects, Harcourt, Brace \& World, Inc., New York.

Murphy R. E., Vance J. E., 1954, Delimiting CBD, Economic Geography, 30.

Muszyńska E., Brzezińska-Kwaśny B., 2010, Analiza możliwości wykorzystania terenów po poligonie wojskowym na „Brusie” w Lodzi - wytyczne urbanistyczne, [w:] T. Markowski, S. Kaczmarek, J. Olenderek (red.), Rewitalizacja trenów poprzemystowych Łodzi, Biuletyn KPZK PAN, t. CXXXII, Warszawa, s. 172-184.

Muzioł-Węcławowicz A. (red.), 2010, Przykłady rewitalizacji miast, t. 12, Instytut Rozwoju Miast w Krakowie, Kraków.

Müller W., Vogel G., 2003, Atlas architektury, t. I, Wydawnictwo Prószyński i S-ka, Warszawa.

Müller W., Vogel G., 2003a, Atlas architektury, t. II, Wydawnictwo Prószyński i S-ka, Warszawa.

Nevell M., 2012, Manchester: The Hidden History, The History Press, Stroud.

Nietyksza M., Pruss W., 1973, Zmiany w układzie przestrzennym Warszawy, [w:] I. Pietrzak-Pawłowska (red.), Wielkomiejski rozwój Warszawy do 1918 r., Książka i Wiedza, Warszawa, s. 21-68.

Nowakowski M., 1990, Centrum miasta. Teoria, projekty, realizacje, Arkady, Warszawa.

Noworól A., 2007, Planowanie rozwoju terytorialnego w skali regionalnej i lokalnej, Wydawnictwo Uniwersytetu Jagiellońskiego, Kraków.

Nouhaud J-P., Damez J., 2008, Lyon Le Confluence: Mémoires en mutation, Cahier no 01, Textuel/ Anatome, Paris-Lyon.

Odgen P. (red.), 1992, London Docklands. The Challenge of Development, Cambridge University Press, Cambridge.

Olenderek J., Lamorski R., Lewandowski J., 2010, Możliwości wykorzystania terenów powojskowych na ,Brusie” w Lodzi - koncepcje ksztattowania struktury architektoniczno-urbanistycznej, [w:] T. Markowski, S. Kaczmarek, J. Olenderek (red.), Rewitalizacja trenów poprzemysłowych Łodzi, Biuletyn KPZK PAN, t. CXXXII, Warszawa, s. 135-171.

Ostrowski W., 2001, Wprowadzenie do historii budowy miast: ludzie i środowisko, Oficyna Wydawnicza Politechniki Warszawskiej, Warszawa.

Otok S., 1987, Geografia społeczna, PWN, Warszawa.

Otsuka N., Reeve A., 2007, The contribution and potential of Town Centre Management for regeneration - shifting its focus from management to regeneration, „Town Planning Review”, vol. 78 , no. 2, s. 225-250. 
Pancewicz A., 2004, Rzeka w krajobrazie miasta, Wydawnictwo Politechniki Śląskiej, Gliwice.

Parysek J. J., 2003, Metropolie: metropolitalne funkcje i struktury przestrzenne, [w:] I. Jażdżewska (red.), Funkcje metropolitalne $i$ ich rola $w$ organizacji przestrzeni, XVI Konwersatorium Wiedzy o Mieście, Wydawnictwo Uniwersytetu Łódzkiego, Łódź, s. 19-40.

Parysek J. J., 2006, Stare i nowe obszary miast polskich, [w:] I. Jażdżewska (red.), Nowe przestrzenie w mieście ich organizacja i funkcje, XIX Konwersatorium Wiedzy o Mieście, Wydawnictwo Uniwersytetu Łódzkiego, Łódź, s. 35-48.

Parysek J. J., Guarino E., Mierzejewska L., 1995, Wybrane problemy teoretyczno-metodologiczne delimitacji centrum miasta, [w:] J. Kaczmarek (red.), Centra i peryferie dużych miast. Transformacja i przyszłość. Pojęcia i metody badawcze, VIII Konwersatorium Wiedzy o Mieście, KGMiT UŁ, Łódź, s. 25-39.

Paszkowski Z., 2011, Miasto idealne w perspektywie europejskiej jego zwiąki z urbanistyka wspótczesna, Wydawnictwo Universitas, Kraków.

Pawłowski K., 1972, Tony Garnier, pionier urbanistyki nowoczesnej, Warszawa.

Pawłowski K., 2007, Od ochrony krajobrazu miasta do mechanizmów ekonomiczno-społecznych jego rewitalizacji. Refleksje na temat norm międzynarodowych, [w:] B. M. Walczak (red.), Rewitalizacja - nośnik tożsamości i rozwoju obszarów metropolitalnych, Monografia pokonferencyjna PRO-REVITA Łódź 2006, Wydawnictwo Biblioteka i Instytut Architektury i Urbanistyki Politechniki Łódzkiej, Łódź, s. 29-36.

Payre R. (red.), 2013, Lyon: ville internationale. La métropole Lyonnaise á l'aussant de la scène international: 1914-1913, Libel, Lyon.

Peck J., Ward K. (red.), 2002, City of Revolution. Restructuring Manchester, Manchester University Press, Manchester.

Pellatier A., 2012, Histoire de Lyon: De la capital Gaules á la métropole européenne, Éditions Lyonnaises d'Art et d'Histoire, Lyon.

Pęski W., 1999, Zarządzanie zrównoważonym rozwojem miast, Arkady, Warszawa.

Piech M., 2002, Przemiany terenów przemystowych Łodzi w latach 1938-1999. Plansza XXVI, [w:] S. Liszewski (red.), Atlas Miasta Łodzi, Urząd Miasta Łodzi. Wydział Geodezji, Katastru i Inwentaryzacji, Łódź.

Piech M., 2004, Przemiany funkcjonalne terenów przemysłowych w latach 1988-1996 (w granicach kolei obwodowej), Wydawnictwo Łódzkie Towarzystwo Naukowe, Łódź.

Preite M., 2012, Urban regeneration and planning, [w:] J. Douet (red.), Industrial heritage re-toled, The TICCIH guide to Industrial Heritage Conservation, Lancaster, s. 101-109.

Quensey D., 2007, Retour á Lyon: Les memes lieux photographiés d'un siècle á l'autre, Les Beaux Jours, Paris.

Racine R., 2013, Lyon Rive gauche: Mémoire en Images, Editions Alan Sutton, Saint-Avertin.

Ratajczak N., Drzazga D., 2005, Rewitalizacja przyrodnicza a procesy zarzadzania rozwojem miasta na przykładzie Łodzi, Teka Kom. Arch. Urb. Stud. Krajobr., OL PAN, s. 135-148.

Regulski J., 1986, Planowanie miast, PWE, Warszawa.

Rewers E., 2005, Post-polis. Wstęp do filozofii ponowoczesnego miasta, Wydawnictwo Universitas, Kraków.

Roberts P., Sykes H. (red.), 2008, Urban Regeneration. A handbook, SAGE, Los Angeles-LondonNew Dehli-Singapure-Washington DC.

Robinson J., 2006, Ordinary cities: Between Modernity and Development, Routledge, London.

Rossiaud J., 2013, Lyon: la rivière et le flueve, Éditions Lyonnaises d'Art et d'Histoire, Lyon.

Rydzik W. (red.), 2009, Aspekty prawne i organizacyjne zarzadzania rewitalizacja, t. 6, Instytut Rozwoju Miast w Krakowie, Kraków.

Rykiel Z., 1995, Centra a peryferie dużych miast Polski, [w:] J. Kaczmarek (red.), Centra i peryferie dużych miast. Transformacja i przeszłość. Pojęcie i metody badawcze, VIII Konwersatorium Wiedzy o Mieście, KGMiT UŁ, Łódź, s. 13-15. 
Rykiel Z., Pirveli M., 2005, Przestrzeń a Środowisko w Geografii; ujęcie krytyczne, [w:] W. Maik, K. Rembowska, A. Suliborski (red.), Geografia jako nauka o przestrzeni, środowisku i krajobrazie, Łódzkie Towarzystwo Naukowe, Łódź, s. 130-148.

Sagan I., 2000, Miasto. Scena konfliktów i wspótpracy, Wydawnictwo Uniwersytetu Gdańskiego, Gdańsk.

Sepe M., 2007, Metoda „Wrażliwej Pomocy” jako sposób ustalania nowej tożsamości miejsc oraz rola dziedzictwa kulturowego $w$ procesie rewitalizacji obszarów poprzemysłowych, [w:] B. M. Walczak (red.), Rewitalizacja-nośnik tożsamości i rozwoju obszarów metropolitalnych, Monografia pokonferencyjna PRO-REVITA Łódź 2006, Wydawnictwo Biblioteka i Instytut Architektury i Urbanistyki Politechniki Łódzkiej, Łódź, s. 253-273.

Sikora D., Turała M., 2005, Rewitalizacja jako instrument determinujacy funkcje przestrzeni publicznej w miastach po-przemysłowych, Wydawnictwo Uniwersytetu Łódzkiego, Łódź.

Sjöberg G., 1960, The Preindustrial City: Past and Present, The Free Press, Glencoe.

Skalski K., 2009, Rewitalizacja we Francji: zarządzanie przekształceniami obszarów kryzysowych w miastach, t. 2, Instytut Rozwoju Miast w Krakowie, Kraków.

Słodczyk J., 2001, Przestrzeń miasta i jej przeobrażenia, Uniwersytet Opolski, Opole.

Słodczyk J., 2012, Historia planowania i budowy miast, Wydawnictwo Uniwersytetu Opolskiego, Opole.

Słodczyk J., Fortuński B., 2003, Rozwój funkcji akademickiej miasta Opola, [w:] I. Jażdżewska (red.), Funkcje metropolitalne $i$ ich rola $w$ organizacji przestrzeni, XVI Konwersatorium Wiedzy o Mieście, Wydawnictwo Uniwersytetu Łódzkiego, Łódź, s. 93-106.

Szmytkie R., 2009, Miasta-zlepieńce na Ślasku Dolnym i Opolskim, Wydawnictwo Instytutu Geografii i Rozwoju Regionalnego Uniwersytetu Wrocławskiego, Wrocław.

Soldatos P., 1987, La nouvelle genération des villes internationeles, Montreal.

Stawasz D., 2007, Rewitalizacja jako kompleksowy proces stymulujacy konkurencyjność miasta, [w:] B. M. Walczak (red.), Rewitalizacja - nośnik tożsamości i rozwoju obszarów metropolitalnych, Monografia pokonferencyjna PRO-REVITA Łódź 2006, Wydawnictwo Biblioteka i Instytut Architektury i Urbanistyki Politechniki Łódzkiej, Łódź, s. 159-165.

Stott P., 2012, Industrial Heritageand the World Heritage Convention, [w:] J. Douet (red.), Industrial heritage re-toled, The TICCIH guide to Industrial Heritage Conservation, Lancaster, s. 161-166.

Straszewicz L., 1987, Lyon - przemiany wielkiej metropolii regionalnej Europy Zachodniej, „Acta Universitatis Lodziensis, Folia Geographica” 8, Wydawnictwo Uniwersytetu Lódzkiego, Łódź, s. 131-163.

Suliborski A., 2010, Funkcjonalizm w polskiej geografii miast: studia nad geneza i pojęciem funkcji, Wydawnictwo Uniwersytetu Łódzkiego, Łódź.

Sułkowski B., 2004, Urban culture in the process of transformation, [w:], N. Bandier, A. Matuchniak-Krasuska, B. Sułkowski (red.), Practiques culturelles et logique des institutions. Cultural Practices and the Logic of Institutions (Lyon-Lódź), Wydawnictwo Uniwersytetu Lódzkiego, Łódź, s. 30-45.

Sułkowski B., 2010, Deregulacja kultury wielkomiejskiej na przykładzie Łodzi, [w:] A. Matuchniak-Krasuska, B. Sułkowski, N. Bandier, A. Hammouche (red.), Lokalne pola produkcji kulturalnej w Polsce $i$ we Francji, Wydawnictwo Uniwersytetu Łódzkiego, Łódź, s. 82-98.

Sumień T., 1992, Forma miasta - kontekst $i$ anatomia, Instytut Gospodarki Przestrzennej i Komunalnej w Warszawie, Warszawa.

Syrkus H., 1984, Społeczne cele urbanizacji. Człowiek i środowisko, PWN, Warszawa.

Szmytkie R., 2009, Miasta-zlepieńce na Ślasku Dolnym i Opolskim, Wydawnictwo Instytutu Geografii i Rozwoju Regionalnego Uniwersytetu Wrocławskiego, Wrocław.

Szymańska D., 2009, Geografia osadnictwa, Wydawnictwo Naukowe PWN, Warszawa.

Szymczak S. (red.), 1978, Stownik języka polskiego, t. II, PWN, Warszawa. 
Szymski A. M., 2006, O nowe oblicze miasta. Rewitalizacja poprzemystowych terenów Międzymorza z przeznaczeniem na nowe centrum miasta $w$ Szczecinie, [w:] B. M. Walczak (red.), Rewitalizacja miast poprzemystowych - rola dziedzictwa kulturowego, Monografia pokonferencyjna PRO-REVITA Łódź 2004, Wydawnictwo Biblioteka i Instytut Architektury i Urbanistyki Politechniki Łódzkiej, Łódź, s. 121-132.

Tylor S., Holder J. (red.), 2008, Manchester Northern Quarter. The gretest meer village, English Heritage, Manchester.

Tołwiński T., 1948, Urbanistyka, t. 1, Wydawnictwo 3, Warszawa.

Tonlemonde J., 1966, Naissance d'une metropole. Roubaix-Tourcoing an XIX, Tourcoing.

Topaczewska T., 2005, Rewitalizacja miasta, działania samorząów lokalnych, IGPiM, Warszawa.

Tölle A., 2006, Kształt i funkcje nowych kwartatów śródmiejskich na obszarach nadwodnych. Francusko-niemiecko-polskie porównanie, [w:] I. Jażdżewska (red.), Nowe przestrzenie w mieście ich organizacja i funkcje, Wydawnictwo Uniwersytetu Łódzkiego, Łódź, s. 193-200.

Tölle A., 2009, Przejście od ekstensywnego do intensywnego rozwoju obszaru aglomeracyjnego na przykładzie Wielkiego Lyonu, [w:] J. J. Parysek (red.), Wybrane problemy miast i aglomeracji miejskich na początku XXI wieku, Biuletyn IGSEiGP UAM, Seria Rozwój Regionalny i Polityka Regionalna, 6, Bogucki Wydawnictwo Naukowe, Poznań, s. 47-62.

Trzepacz P., 2006, Przekształcenia przestrzeni urbanistycznej Berlina w drugiej połowie XX w., [w:] I. Jażdżewska (red.), Nowe przestrzenie miejskie ich organizacja i funkcje, XIX Konwersatorium Wiedzy o Mieście, Wydawnictwo Uniwersytetu Łódzkiego, Łódź, s. 377-388.

Wallis A., 1979, Informacja i gwar o centrum miasta, PIW, Warszawa.

Wallis A., 1990, Socjologia przestrzeni, Niezależna Oficyna Wydawnicza, Warszawa.

Weber M., 2002, Gospodarka i społeczeństwo, Wydawnictwo Naukowe PWN, Warszawa.

Wesołowski J., 2002, Łódź w okresie wielkoprzemysłowym. Plansza V, [w:] S. Liszewski (red.), Atlas Miasta Łodzi, Urząd Miasta Łodzi, Wydział Geodezji, Katastru i Inwentaryzacji, Łódź.

Wesołowski J., 2006, Niektóre aspekty rewitalizacji obszarów śródmiejskich miasta poprzemysłowego na przykładzie Łodzi, [w:] B. M. Walczak (red.), Rewitalizacja miast poprzemysłowych - rola dziedzictwa kulturowego, Monografia pokonferencyjna PRO-REVITA Łódź 2004, Wydawnictwo Biblioteka i Instytut Architektury i Urbanistyki Politechniki Łódzkiej, Łódź, s. 21-34.

Whitehand J. R. M., 1979, Thestury of variations in the building fabric of town centres: procedural problems and preliminary in southern Scotland, „Institute of British Geographers, Transactions, New Series" 4, nr 4, s. 559-575.

Whitehand J. W. R. (red.), 1981, The Urban Landscape: Historical Development and Management. Papers by M. G. R. Conzen, „Institute of British Geographers, Special Edition”, 13, London.

Whitehand J. R. M., Whitehand S. M., 1983, The study of physical changes in town centres: research procesures and types of change, „Institute of British Geographers, Transactions, New Series” 8, $\mathrm{nr}$ 4, s. 483-507.

Willan S. T., 1980, Elizabethan Manchester, Chetham Society, Manchester.

Wojnarowska A., 2011. Rewitalizacja zdegradowanych obszarów miejskich. Zagadnienia teoretyczne, Wydawnictwo Uniwersytetu Łódzkiego, Łódź.

Wolaniuk A., 1997, Funkcje metropolitalne Łodzi i ich rola $w$ organizacji przestrzennej, Łódzkie Towarzystwo Naukowe, Łódź.

Wolaniuk A., 2008, Centra miast, [w:] S. Liszewski (red.), Geografia urbanistyczna, Wydawnictwo Uniwersytetu Łódzkiego, Łódź, s. 283-320.

Wolaniuk A., 2010, Uniwersytety i ich rola w organizacji przestrzeni, Wydawnictwo Uniwersytetu Łódzkiego, Łódź.

Wójcik A., 2008, Nowe przestrzenie publiczne - na przykładzie miasta Dublina, „Czasopismo Techniczne Architektura”, Wydawnictwo Politechniki Krakowskiej, Kraków, 1-A, s. 227-233. 
Wróbel T., 1971, Zarys historii budowy miast, Zakład Narodowy im. Ossolińskich, Wrocław.

Ziobrowski Z. (red.), 2010, Założenia polityki rewitalizacji w Polsce, t. 9, Instytut Rozwoju Miast w Krakowie, Kraków.

Ziobrowski Z., Domański B., 2010, Rewitalizacja miast polskich jako sposób zachowania dziedzictwa materialnego i duchowego oraz czynnik zrównoważonego rozwoju. Podsumowanie projektu, Wydawnictwo Instytutu Rozwoju Miast w Krakowie, Kraków.

Ziobrowski Z., Ptaszycka-Jackowska D., Rębowska A., Geissler A. (red.), 2000, Odnowa miast. Rewitalizacja, rehabilitacja, restrukturyzacja, Instytut Gospodarki Przestrzennej i Komunalnej, Wydawnictwo Politechniki Śląskiej, Gliwice.

Ziobrowski Z., Jarczewski W. (red.), 2010, Rewitalizacja miast polskich - diagnoza, t. 8, Wydawnictwo Instytutu Rozwoju Miast w Krakowie, Kraków.

Zukin S., 1995, The Culture of Cities, Blackwell, Oxford.

Zuziak Z., 1998, Strategie rewitalizacji przestrzeni śródmiejskiej, Seria Architektura, Wydawnictwo Politechniki Krakowskiej, Kraków.

\section{Inne opracowania publikowane}

City Centre Strategic Plan 2004-2007, Manchester City Council.

Karta Przestrzeni Publicznej, 2009.

Office of National Statistics 2011.

Plan Local d'Urbanisme de la comunnuate urbaine de Lyon.

Powierzchnia i ludność w przekroju terytorialnym w 2013 r., GUS 2013, Warszawa.

Rocznik Statystyczny Województwa Łódzkiego 2012, Wydawnictwo Urząd Statystyczny w Łodzi.

Strategia Zintegrowanego Rozwoju Łodzi 2020+, projekt Urzędu Miasta Łodzi.

Studium uwarunkowań i kierunków zagospodarowania przestrzennego miasta Łodzi, 2010, Urząd Miasta Łodzi.

Uchwata nr XVII/279/07 Rady Miejskiej w Lodzi z dnia 28 sierpnia 2007 roku w sprawie przyjęcia Programu Nowe Centrum Łodzi, Urząd Miasta Łodzi.

Uchwata nr LV/1146/13 Rady Miejskiej w Lodzi z dnia 16 stycznia 2013 roku w sprawie Strategii przestrzennego rozwoju Łodzi 2020+, Urząd Miasta Łodzi.

Uproszczony Lokalny Program Rewitalizacji wybranych terenów śródmiejskich oraz pofabrycznych Łodzi na lata 2004-2013 oraz Studium uwarunkowań $i$ kierunków zagospodarowania przestrzennego miasta Łodzi.

\section{Źródła internetowe}

http://www.ec1lodz.pl/pl/ [dostęp 10.10.2012].

http://www.eea.europa.eu/data-and-maps/data/urban-atlas [dostęp 14.11.2013].

http://www.geoportail.gouv.fr/accueil [dostęp 16.11.2013]. 



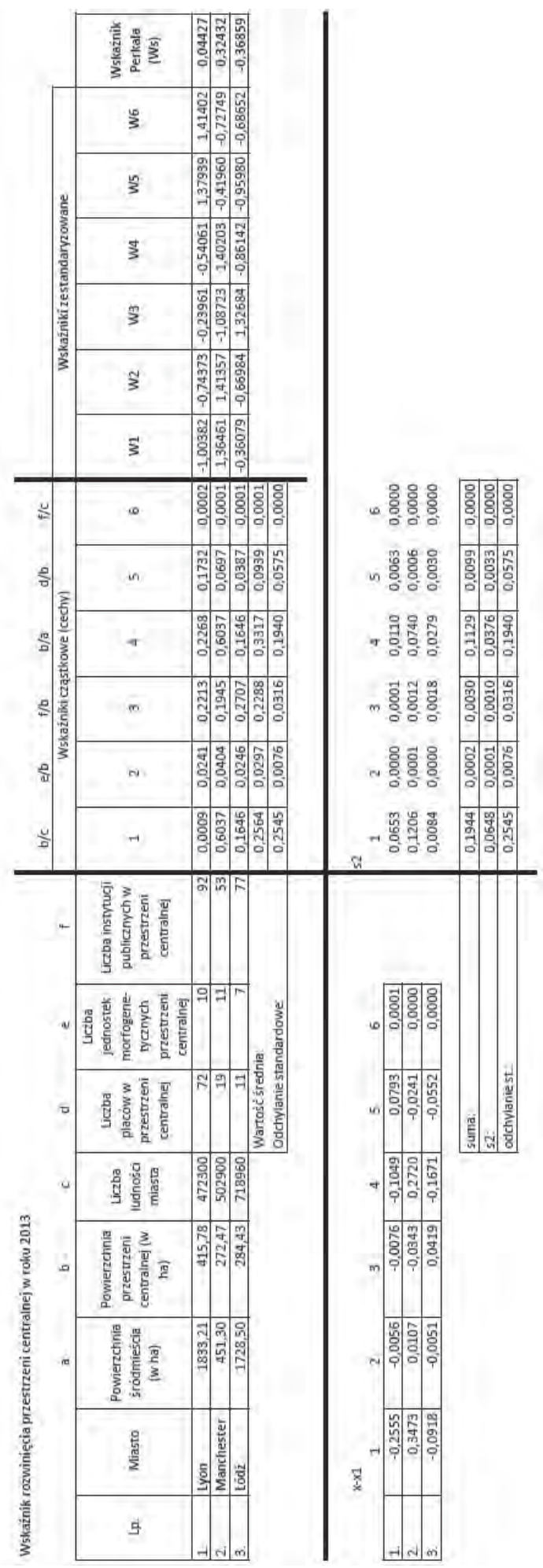





\section{REVITALIZATION OF POST-INDUSTRIAL URBAN AREAS AND ITS IMPACT ON ORGANIZATION OF CENTRAL SPACE IN MANCHESTER, LYON AND ŁÓDŹ. SUMMARY}

The revitalization of post-industrial urban areas is a new phenomenon in the context of city construction history. Functional and spacial transformations of post-industrial areas have led to the creation of a new morphological unit that brings about changes in the spacial organization of a whole city, which has been noticed by a number of authors specializing in urban geography (among others, Kaczmarek 2001, Lorens 2005, Kochanowska 2002a). One of the repercussions of revitalization initiatives is the disturbance of historically-shaped hierarchy of urban areas. This issue has been touched upon only sporadically in reference books and it does not usually accompany the studies on morphological changes of given industrial areas (Bury, Markowski and Regulski 1993, Parysek 2006, Sagan 2000). The matter of urban area hierarchy change seems to be particularly crucial when one takes into account post-industrial inner-city area revitalization programmes, which generate centrally-located urban spaces - the new central space. This observation brings one to the fundamental questions about the nature of the relation between the old (existing before) and the new central space and about the factors that influence the nature of this relation. Urban morphogenesis and the process of central space development in a given city constitute the key issues in this case. Central space is the part of urban space. It consists of varied morphological units and elements, which have gained the greatest importance during the development of the city due to the influence of numerous forces and processes of endogenic and egzogenic nature. Central space can include such spacial elements as streets and squares with the adjacent blocks, or some more morphologically complex structures, for example, districts.

This paper presents integrated studies on the morphological and functional structures of contemporary European cities' central space. The crux of the research problem is to answer the question: how does revitalization of inner-city post-industrial urban areas change the organization of central space in European cities?

The adopted research assumption allows for constructing the following hypothesis: as a result of the process of inner-city post-industrial area revitalization, a new central space is created, whose relations to the old central space are based on:

1) Cooperation of the old and the new central space;

2) Competition between the old and the new central space;

3) Conglomeration of several independent and non-integrated locations of central spaces.

In order to verify this research hypothesis, studies on Manchester, Lyon and Lódź have been conducted. These are formerly industrial (textile) cities, which now complement the capital cities and have a similar number of inhabitants. Nevertheless, the process of central space formation has been very different in each of those cities, which allows one to observe the influence of revitalization on the transformation of central space and identify the factors that determine the present relations between the new and the old ones. The following areas underwent detailed morphological research: 
Castlefield, City Centre and Gaythorn in Manchester, Confluence in Lyon, and in Łódź: „Manufaktura" area and a project connected with spatio-functional transformations of Łódź Fabryczna train station district.

On the basis of the central space development research in Manchester, Lyon and Łódź, it has been concluded that the development process proceeded in stages and it had its own individual nature in each of the cities. The number of central space development stages and their length was varied due to different economic, technological and geopolitical factors, which influenced the development of those cities.

The central space formation was analyzed in the context of three phases in the history of the development of those cities: pre-industrial, industrial and post-industrial. This division is reflected in the structure of the empirical chapters of this paper. In the pre-industrial phase of city development, the space of exchange had a superior role in the slow, but constant growth of the central space. Among the studied cities, Lyon experienced the fastest growth in this phase. Between the Roman period and the $19^{\text {th }}$-century industrial revolution in Lyon, the city experienced a continued growth, together with a gradual territorial and functional expansion. This contributed to generating a new central area, which initially complemented the previous central space structure. Later, it started gaining a dominant position in the urban area hierarchy. However, this process did not cause any material or institutional downgrade of the old central space. Due to Lyon's topographic conditions, its central space developed as a multi-part space. In the pre-industrial period, Lyon gained importance in national and international settlement networks, which was the result of its convenient geopolitical location. This importance was reflected in a high degree of complexity and intensity of Lyon's central space.

Until the turn of the 19th century, the central space in Manchester demonstrated a slower pace of growth than the one in Lyon. This was the effect of a lack of temporal and spacial continuity between the Roman and the Medieval core of the city. In the pre-industrial period, Manchester was a small city of handicraft and trade. It had a provincial character, which was reflected in the morphology of the central space being created at the time. Hence, the area was smaller in size, less complex and less intensive in comparison to the one in Lyon.

Among the three cities discussed, central space of Łódź was the least developed in the eve of the 19th-century industrial revolution. It was in the early initial phase. This stemmed from the fact that the spacial and functional city structures in those times were dominated by agricultural activities and from the lack of institutions which would have supralocal influence.

In the 19th century and in the first half of the 20th century, morphological structures of Manchester, Lyon and Łódź, especially their downtown parts, adjusted to the needs of a new citygenic phenomenon - industry, in particular, textile industry. Therefore, the central space organization changed significantly. Industrialization disturbed the traditional space of exchange and the public domain. This influence was more visible when central space was less developed in its size, complexity and intensity. In Lyon, industrial area development in the first half of the 19th century increased central space growth dynamics, though the area was still developing gradually. The crisis and breakdown of industry in the second half of the 20th century did not disturb the central space sustained transformation process either. This stemmed from a subordinate role of the industrial areas in comparison to other metropolitan functions, which were influencing the formation of the central space.

In contrast, morphological changes of Manchester central space showed a significant correlation with the process of new industrial area growth. The 19th-century industrialisation was decisive in the process of dynamic, complex and intensive central space growth while the crisis and collapse of industry in the 20th century caused recession. During the period of Manchester's industrial development, its central space was shaped abruptly, as it was in the preindustrial period.

In the 19th and the 20th century, Lyon and Manchester became international cities. Owing to the morphogenesis of Lyon's central space, deindustrialization of the city did not influence 
negatively its position in the international settlement network, in contrast to Manchester, which lost its metropolitan character of a central space due to the breakdown of industry. In the analyzed period, both cities developed into economically strong countries that owned numerous territories overseas. It was different in the case of industrially dynamic Łódź. In the 19th century it grew in economically-underdeveloped Russian Empire, which influenced the dynamics of the city's central space growth. The period of centrally-planned economy in the second half of the 20th century established Łódź's peripheral position in the European settlement network. This factor, coupled with the fact that the downtown morphological structure was dominated by industrial areas, limited to a large extent the expansion of the central space, which encompassed only the quarters along Piotrkowska Street and a few smaller enclaves. Similarly to central space in Lyon and Manchester, the one in Łódź experienced the most extensive growth during the 19th-century industrialization. However, due to geopolitical conditions, its growth was significantly less dynamic than the growth of the analyzed areas in Western European cities. The collapse of industry at the end of 1980s and the beginning of the 1990s did not affect Łódź's central space morphology as much as it affected such area in Manchester. The reason for that was a less significant position of central space in Łódź in comparison to the downtown industrial areas.

In all of the analyzed cities, transitions in the post-industrial period have led to the development of new central space as a result of post-industrial urban areas revitalization. In situ research has shown that the process of spatial and functional transformations had a high or intermediate level of intensity, which should be identified as revitalization in the broad sense - mainly a radical one. Revitalization initiated the secondary cycle of post-industrial areas land use, which resulted in creating new spatial and functional units. They are characterized by morphology adapted to the needs of modern urban space users.

As a result of inner-city post-industrial area revitalization, the organization of central space in Manchester, Lyon and Łódź has been changed. The consequences of morphological transformations differed in each of the cities. They depended on the old central space morphogenesis and its degree of development, meaning its size, complexity and intensity.

In Manchester, a revolutionary mode of forming the central space was identified. It was characterized by abrupt development process determined by the economic situation of the industrial areas during the 19th-century revolution and the contemporary post-industrial urban areas. Revitalised post-industrial areas show a low degree of variation in morphology and application types in comparison to the old (though modernized) central space. Consequently, these spaces have become competitors. The process of central space development in Lyon was evolutionary in nature. As a result of Confluence post-industrial area revitalization, the city's old central space was integrated with the new space, which complements it both spatially and institutionally. The present central space of Lyon is varied. On the basis of the conducted research, it has been concluded that there exists a cooperation between the old and the new space. In case of Łódź, one mode of creating the central space cannot be identified. The space consists of independently functioning enclaves, the biggest of which is Piotrkowska Street. The post-industrial area revitalization projects which have been finished or are being carried out now have led to creating new central space fragments, which do not form an integrated morphological structure. Their creation has led to a slight increase in complexity, size and intensity of Łódź's central space. The city's seeding, linear and enclave-based character, as well its lack of development patterns, have lead to the conclusion that relations based on conglomeration can develop between the old and the new part of central space in Łódź. Therefore, the adopted research hypothesis has been positively verified.

The results of analytical research conducted in Manchester, Lyon and Lódź have led to the conclusion that relations based on cooperation or competition have a positive influence on the central space organization while relations based on conglomeration impact it negatively. Revitalization of inner-city post-industrial urban areas has contributed to the process in which Manchester central 
space has been brought back to its former glory and in Lyon, its position has been strengthened. In contrast, in Łódź the concluded revitalization projects in the former industrial areas and the commenced revitalization projects pose a threat of aggravating the recent unsatisfactory condition of the central space, which might impede its further development in the future. Lyon post-industrial urban areas revitalization is a continuation of a stabilized, yet sustainable, central space growth, whereas in Manchester it has caused the space's secondary growth. In this context, it should be noted that the territorial integration or lack of it is a less important factor.

The conducted morphogenetic and morphological studies in three European cities, different in terms of spacial and functional structure, developing in different economic and geopolitical conditions, allow for indicating some existing tendencies in the central space development cycle.

Revitalization is another factor influencing the central space development in European cities. The research results confirm Conzenian concept of urban life cycle patterns, which was positively verified in the conditions of an industrial city by M. Koter $(1974,1976,1990)$. Industrial area life cycle has also been the subject of discussion for S. Kaczmarek (2001), who opines that revitalization contributes to stabilizing the cycle. The author of this paper studied the phases of post-industrial land use by sectors III and IV and thus identified the following:

- the secondary growth of the central space, demonstrated by the example of Manchester, where such growth contributed to the city regaining its position as a world metropolis that it had in the middle of the 19th century;

- the stabilization of a well-developed central space, which strengthened the metropolitan position of the city, demonstrated by the example of Lyon;

- the stagnation of a poorly-developed central space in Łódź, which preserves the provincial position of the city in the European settlement network.

Taking into account the present knowledge of urban geography found in Polish and international reference books, as well as the studies presented in this paper, it seems possible that there exists secondary growth of a well-developed central space stemming from the process of inner-city post-industrial areas revitalization.

The conclusions drawn on the basis of theoretical and empirical parts of the paper are the starting point to create a recommendation for modern central space development in Łódź. The Polish city and Lyon have more morphological similarities of their central spaces than Łódź and Manchester. Therefore, the catalogue of recommendations of Łódź central space development should be based mainly on the experiences of the French city. The factor indicating that it is the right path to follow is the fact that the influence of the post-industrial areas revitalization process on the dynamics of transformation has been similar in those cities.

The aim of the recommendations concerning Łódź central space development is to suppress the process of forming relations based on conglomeration between the old and the new central space, and then converting those relations into ones based on cooperation. When planning revitalization of inner-city post-industrial urban areas, the present complexity, size and intensity of Łódź central space should be taken into consideration to follow the concept of central space life cycle patterns in European cities.

Acknowledgements

The Author thanks the National Science Centre, Poland (Grant no: DEC 2011/03/N/HS4/03145) for the funding that has for its part enabled this research. 


\section{L'EEFET DE LA REVITALISATION DES FRICHES INDUSTRIELLES DANS L'ORGANISATION DE L'ESPACE CENTRAL Á MANCHESTER, LYON ET ŁÓDŹ. RESUMÉ}

Le renouvellement urbain des friches industrielles est un nouvel phénomène dans le contexte de l'histoire de la ville. Transformation spatiale et fonctionnelle des friches industrialles conduisent à l'émergence de nouvelle unité morphologique, qui apporte avec lui des changements dans l'organisation spatiale de ville entière, comme l'a souligné les nombreux auteurs qui travaillent dans le domaine de la géographie urbaine (Kaczmarek 2001, Lorenz 2005, Kochanowska 2002a, parmi d'autres). Une des résultats des activités de renouvellement urbain est le désordre de la forme historique de la hierarchie des zones urbaines. Ce problème a jusqu'ici été abordé de façon sporadique dans la littérature et n'a pas été associée à la recherche sur des changements morphologiques des particulieres zones industrielles (Bury, Markowski et Regulski 1993, Parysek 2006, Sagan 2000). Le problème du changement de la hiérarchie urbaine semble être particulièrement important dans le contexte des programmes de renouvellement urbain du friches industrielles de la centre-ville, qui se traduit par une génération d'un nouvel espace urbain de caractère central, ou un nouvel espace central. Cette observation soulève une question fondamentale sur la nature des relations qui existent entre l'ancien (déjà existant) et le nouvel espace central et les facteurs qui déterminent ces relations. L'essentiel c'est la morphogenèse de la ville et le processus de formation de l'espace central de la ville. L'espace central est compris comme la partie de l'espace urbain qui se compose de diverses unités et éléments morphogénétiques qui en raison du développement urbain et les effets des différentes forces et les processus endogènes et exogènes, ont acquis le niveau le plus élevé dans la hiérarchie des zones urbaines. Elles consistent des éléments spatiaux simples tels que les rues et les places avec des quartiers adjacents, ou des formes morphologiques plus complexes, comme les quartiers.

Ce document présente une étude intégrée de la structure morphologique et fonctionnelle de l'espace central dans les villes européennes contemporaines. L'essence du problème de la recherche est de répondre à la question: comment le renouvellement urbain des friches industrielles change l'organisation d'espace de centre-ville à des villes européennes?

La recherche adoptée permet d'impliquer la thèse suivante: à la suite du renouvellement urbain de friches industrielles du centre-ville, un nouvel espace central est formé qui, par rapport à l'ancien espace central conduit à:

1) La coopération entre l'ancien et le nouvel espace central;

2) La concurrence entre l'ancien et le nouvel espace central;

3) Le conglomérat de plusieurs localisaitons de l'espace central indépendant et non-intégré.

Afin de vérifier l'hypothèse de la recherche on a étudié le cas de Manchester, Lyon et Łódź. Ce sont des anciennes villes industrielles (textiles), actuellement complémentaires à la capitale nationale, qui possèdent le nombre d'habitants similaire. Dans le même temps ce sont les centres où le processus d'élaboration de l'espace central était tellement différent qu'on pouvait tracer le different influence du processus de développement de la transformation et d'identifier les facteurs qui déterminent la relation actuelle entre le nouvel et l'ancien espace central. À Manchester, un examen 
approfondi de la morphologie de friches industrielles a été fait dans Castlefield, Centre-ville et Gaythoern, à Lyon - Confluence, et à Łódź - l'espace „Manufactura” (La Manufacure) et aire de conception du nouvel centre de Łódź, associée à des transformations spatiales et fonctionnelles dans les environs de la gare Łódź Fabryczna.

Sur la base de recherche sur l'espace central à Manchester, Lyon et Łódź, on a constaté que ce processus a été itératif et individualisé dans chacune de ces villes. Le nombre d'étapes de formation de l'espace centrale mis en évidence et leur durée a montré les différences entre le développement de villes analysées dues à différents facteurs économiques, technologiques et géopolitiques. La formation de l'espace central des sites étudiés a été considérée dans le contexte des trois périodes de l'histoire de la construction de la ville: pré-industrielle, industrielle et post-industrielle. Cette division se reflète dans la structure empirique des divisions de travail.

Au stade pré-industriel de développement des villes, le rôle d'espace d'échange a été le plus important, ce qui a contribué à l'augmentation lente mais constante d'espace central. Parmi les villes étudiées, pendant cette période, Lyon a été marquée par le plus fort taux de croissance.

Entre la période romaine et de l'industrialisation de XIXe siècle à Lyon il y avait une continuité du développement et l'expansion progressive territoriale et fonctionnelle de la ville, contribuant à la création d'un nouvel espace central, qui, à l'origine, a complété la structure déjà existante d'espace central, puis a gagné une position dominante dans la hiérarchie des zones urbaines.

Ce processus, cependant, n'a pas causé la dégradation physique et de l'espace institutionnel du centre-ville. En raison des conditions topographiques, l'espace centrale de Lyon a développée en plusieurs parties. Dans une periode pré-industrielle Lyon a acquis une position importante dans le réseau de règlement intérieur et international, en raison du emplacement géopolitique idéal. Le status de Lyon se reflète dans le niveau élevé de complexité et d'intensité de l'espace central.

Depuis la fin du XVIIIe et au début du XIXe siècle, l'espace central de Manchester a montré un taux de croissance inférieur à celui de Lyon. Cela était dû à l'absence de continuité temporelle et spatiale de développement entre le noyau romain et médiéval de la ville. Pendant une periode pré-industrielle, Manchester était une petite ville de province de caractère commercial et artisanal, comme en témoigne la morphologie de la formation de l'espace central. Elle avait la taille, la complexité et l'intensité nettement inférieure par rapport à Lyon. Parmi les trois villes étudiées, à la veille de l'industrialisation du XIXe siècle, l'espace central de Łódź était le moins developpé, dans son preliminaire phase initiale. C'était la conséquence de la domination de la structure spatiale et fonctionnelle de l'époque - l'activité agricole et l'absence d' institution de couverture supralocal.

$\mathrm{Au}$ XIXe et la première moitié du XXe siècle, la structure morphologique de Manchester, Lyon et Łódź, et surtout de leur centre-ville, a été en degrés subordonnée aux besoins d'une nouvelle activité de la formation de la ville industrial, en particulier d'industrie du textile. L'industrialisation a considérablement transformée l'organisation d'espace centrale de villes européennes contemporaines, ce qui perturbe l'espace d'echange classique et le domaine publique.

Cet effet est le plus visible, les moins développé était un espace central en termes de la taille, la complexité et l'intensité. À Lyon, le développement du parc industriel dans la première moitié du XIXe siècle a augmenté le taux de croissance de l'espace central, mais c'était toujours le développement en continu. En outre, la crise et l'effondrement de l'industrie dans la seconde moitié du XXe siècle n'a pas bouleversée le processus de transformation durable de l'espace central, ce qui a abouti à un rôle inferieuer de zones industrielles par rapport à d'autres fonctions métropolitaines affectant la formation de la zone centrale de la ville à cette époque.

Contrairement à Lyon, les changements de la morphologie de l'espace central de Manchester montrent une corrélation significative avec le processus de création de nouvelles zones industrielles. L'industrialisation au XIXe siècle était decisive pour la croissance dynamique de surface, la complexité et l'intensité de l'espace central, alors que la crise et l'effondrement de l'industrie au cours du $\mathrm{XXe}$ siècle ont conduit à la récession. Dans le periode de développement industriel de Manchester il y avait l'expansion révolutionnaire de la zone centrale, comme c'était le cas à l'epoque pré-industrielle. 
Lyon et Manchester au XIXe et au XXe siècle, ont gagné dans le rang des villes du monde. La morphologie de l'espace central de Lyon détermina la désindustrialisation de la ville, ce qui n'a pas eu un impact négatif sur sa position dans le réseau international de règlement, par opposition à Manchester, qui à la suite de l'effondrement de l'industrie a perdu le caractère de métropole de l'espace central. Les deux villes au cours de la période analysée ont évoluées dans les pays économiquement forts, avec un certain nombre de territoires d'outre-mer.

En revanche, Łódź industrielle à grande échelle a été fondée en Empire Russe sous-développé économiquement, le fait décisive de la faible croissance du centre-ville. La période de l'économie planifiée et centralisée dans la seconde moitié du XXe siècle, a etablié la position périphérique de Łódź dans le réseau de la colonisation européenne. Ce facteur et la domination de zones industrielles dans la structure morphologique du centre-ville ont limités, dans une très large mesure, l'expansion de l'espace central, qui ne comprenait que les quartiers le long de la rue Piotrowska et un certain nombre de petites enclaves. Comme dans le cas de Lyon et Manchester, la plus forte augmentation de l'espace central de Łódź a été identifiée au cours de l'industrialisation du XIXe siècle.

Toutefois, en raison des conditions géopolitiques, le niveau de développement de Łódź était significativement plus faible que dans les villes de l'Europe occidentale analysées. Alors, l'effondrement de l'industrie dans les années 80 et 90 de XXe siècle à Łódź n'avait pas l'impact si négatif sur la morphologie de l'espace centrale comme il était le cas en Manchester. Cela était dû à la position subordonnée de l'espace central à Łódź par rapport aux zones industrielles du centre-ville.

Dans le développement de toutes les villes analysées, la période post-industrielle a été associée à la formation d'un nouvel espace central à la suite de la revitalisation des friches industrielles. Les études réalisées in situ ont montré que le processus de transformation spatio-fonctionelle était caractérisé par un niveau d'intensité élevé ou modéré, qui doit être identifié avec la revitalisation du sens plus large, dont la plupart de caractère radicale. Les projets de renouvellement urbain ont amorcé l'élaboration du cycle secondaire des friches industrielles, à la suite duquel les nouvelles unités spatiales et fonctionnelles ont été développées. Elles sont caractérisées par la morphologie et les méthodes d'exploitation adaptées aux besoins des utilisateurs modernes.

À la suite de renouvellement urbain de friches industrielles du centre-ville, on a changé l'organisation de l'espace central de Manchester, Lyon et Łódź. Les conséquences du processus de transformation morphologique étaient différentes dans chacune des villes. Ils dépendaient de la morphogenèse du vieux espace central et le niveau de son développement, ou la taille, la complexité et l'intensité.

Une façon révolutionnaire de processus de création de l'espace central a été identifié à Manchester, ou le processus est brusque et determiné par la situation économique de zones industrielles dans l'époque industrielle, et aujourd'hui - de friches industrielles. Les zones post-industrielles de renouvellement urbain sont caractérisées par les faibles niveaux de diversité morphologique et d'utilisation par rapport à l'ancien (mais modernisé) espace central, ce qui a déterminé la creation de concurrence parmi eux. Le processus de formation de l'espace central de Lyon était de nature évolutive. À la suite du renouvellement urbain des friches industrielles à Confluence, le vieux quartier central de la ville, a été enrichi par une nouvelle section, qui est complémentaire par rapport à lui, à la fois en fonction du territoire et de l'institution. L'espace central contemporain de Lyon est varié. Sur la base de la procédure de recherche on a identifié les relations de coopération entre l'ancien et le nouvel section de la ville. Mais dans le cas de Łódź, on ne peut pas spécifier exactement la méthode de la formation de l'espace central. Il se compose d'enclaves qui fonctionne indépendamment, dont la plus importante est la rue Piotrkowska. Les projets de renouvellement urbain de friches industielles déjà réalisé ou en train de réalisation, conduisent à la création de nouvelles sections de l'espace central, qui ne forment pas une structure morphologique intégrée. Leur formation a entraîné une légère augmentation de la complexité, la taille et l'intensité de l'espace central de Lódź. Le caractère de germe et d'enclave linéaire et le manque de précision dans le processus de formation de Łódź, nous permettent de conclure que, entre les anciens et les nouveaux fragments de l'espace central de Łódź, des relations de conglomérat pourraient être développées. 
Ainsi, l'hypothèse de recherche a été vérifiée positivement. Les résultats de procédure analytique effectuée sur l'exemple de Manchester, Lyon et Łódź révélent que les relations de coopération et de concurrence ont un impact positif sur l'organisation de l'espace central, alors que les relations de conglomérat sont négatifs pour lui. Le renouvellement urbain de friches industrialles a contribué à rétablir l'efficacité du centre de Manchester et à renforcer l'efficacité de Lyon.

À Łódź, toutefois, le processus de renouvellement urbain déjà fini dans les friches industrielles et des plans pour des projets de renouvellement urbain dont la réalisation a déjà commencé constituent une menace pour le renforcement de l'absence d'efficacité d'espace central, empêchant la poursuite de son développement dans l'avenir. Le renouvellement urbain des friches industrielles à Lyon entraînait une poursuite de la croissance régulière, mais calme de l'espace central, tandis que à Manchester le renouvellement a conduit à la croissance secondaire. Dans ce contexte, il convient de noter que l'intégration territoriale ou l'absence constitue un facteur de moindre importance.

Les études morphologiques et morphogénétiques de trois villes européennes, variant en termes de structure spatiale et fonctionnelle, et grandissant dans différentes conditions économiques et géopolitiques ont permis de détecter l'existance de schémas dans le cycle de développement de l'espace central. Le renouvellement urbain est un autre facteur qui a impact sur le processus de développement de l'espace central dans les villes européennes. Les résultats de l'étude confirment la conception cyclique des zones urbaines de M.R.G. Conzen, ce qui en termes d'une ville industrielle a été vérifié positivement par M. Koter (1974, 1976, 1990). Le cycle de vie d'une zone industrielle, cependant, a été etudié par S. Kaczmarek (2001), ces études confirment que le renouvellement urbain contribue à la stabilisation de développement de la zone. La phase d'utilisation des friches industrielles par les secteurs III et IV menent à l'identification par l'auteur de cette thèse de:

- la croissance secondaire de l'espace centrale, comme l'indique l'exemple de Manchester, où cette croissance secondaire a conduit à la récupération de la position de métropole mondiale de la ville, qu'elle avait dans la seconde moitié du XIXe siècle;

- la stabilisation d'espace central bien développé, qui a été constaté dans le cas de Lyon, ce qui a renforcé sa position de la métropole;

la stagnation d'espace central sous-développé dans le cas de Łódź, ce qui renforce la position d'une ville de province dans le réseau de reglement européen.

Compte tenu de l'état actuel des connaissances représentées dans la littérature polonaise et étrangère dans le domaine de la géographie urbaine et les résultats des études présentées dans cette étude, le développement secondaire d'un espace central bien développé, suivant le renouvellement urban de friches industrielles du centre-ville, semblent également possible.

Les conclusions rendues sur la base d'une partie théorique et empirique de l'étude fournissent un point de départ pour l'élaboration de recommandations pour le développement d'espace central moderne de Łódź. Il semble qu'en raison de la grande similarité entre la morphologie de l'espace central à Łódź et à Lyon, que dans le cas de Manchester, le répertoire développé devrait être fondée principalement sur l'exemple de Lyon. Le facteur validant cette approche est aussi l'effet similaire de processus de renouvellement urbain des friches industrielles sur la dynamique de transformation du centre des deux villes.

Les recommandations proposées pour le développement de l'espace centrale à Łódź menent à arrêter le processus négatif de formation des relations de conglomérat entre les anciens et les nouveaux fragments de Łódź, et leur conversion ultérieure en relations de coopération. Lors de la planification des activités de renouvellement urbain de friches industrielles du centre-ville, on doit tenir en compte l'état actuel de complexité, la taille et l'intensité de l'espace central à Łódź, ce qui doit être en conformité avec la conception de développement cyclique de l'espace central dans les villes européennes.

\section{Remerciements}

L'auteur remercie le Centre national des sciences, Pologne (subvention n ${ }^{0}$ : DEC 2011/03/N/ HS4/03145) pour le financement qui a pour sa part permis à cette recherche. 


\section{SPIS TABEL}

\section{Rozdzial 2.}

2.1. Zestawienie parametrów morfologicznych w ramach analizy pierwszego stopnia

2.2. Zestawienie parametrów z zakresu sposobu użytkowania w ramach analizy pierwszego stopnia

2.3. Zestawienie parametrów morfologicznych w ramach analizy drugiego stopnia

2.4. Zestawienie parametrów $\mathrm{z}$ zakresu sposobu użytkowania $\mathrm{w}$ ramach analizy drugiego stopnia

2.5. Wskaźniki cząstkowe do identyfikacji stopnia rozwinięcia przestrzeni centralnej w badanym mieście w czasie $T_{2}$

2.6. Typologia relacji w przestrzeni centralnej miasta

\section{Rozdzial 5.}

5.1. Przekształcenia morfologii i sposobu użytkowania terenów poprzemysłowych w Manchesterze w latach 1988-2013

5.2. Intensywność przekształceń morfologii i sposobu użytkowania terenów poprzemysłowych w Manchesterze w latach 1988-2013

5.3. Wybrane cechy morfologii i sposobu użytkowania starej i nowej przestrzeni centralnej w Manchesterze w $2013 \mathrm{r}$.

5.4. Stopień zróżnicowania wybranych cech morfologii i sposobu użytkowania starej i nowej przestrzeni centralnej w Manchesterze w $2013 \mathrm{r}$.

5.5. Wartości wskaźnika syntetycznego (Ws) i wartości standaryzowane cech opisujących poziom rozwinięcia przestrzeni centralnej w Manchesterze w $2013 \mathrm{r}$.

\section{Rozdzial 6.}

6.1. Przekształcenia morfologii i sposobu użytkowania terenów poprzemysłowych (ZAC 1 i w rejonie budowanego Muzeum Confluence) w Lyonie w latach 1998-2013

6.2. Intensywność przekształceń morfologii i sposobu użytkowania terenów poprzemysłowych w Lyonie w latach 1998-2013

6.3. Wybrane cechy morfologii i sposobu użytkowania starej i nowej przestrzeni centralnej w Lyonie w $2013 \mathrm{r}$.

6.4. Stopień zróżnicowania wybranych cech morfologii i sposobu użytkowania starej i nowej przestrzeni centralnej w Lyonie w $2013 \mathrm{r}$.

6.5. Wartości wskaźnika syntetycznego (Ws) i wartości standaryzowane cech opisujących poziom rozwinięcia przestrzeni centralnej w Lyonie w $2013 \mathrm{r}$. 


\section{Rozdzial 7.}

7.1. Przekształcenia morfologii i sposobu użytkowania terenów poprzemysłowych („Manufaktura") w Łodzi i stopień ich intensywności w latach 2000-2013

7.2. Wybrane cechy morfologii i sposobu użytkowania starej i nowej przestrzeni centralnej w Łodzi w 2013 r. (z uwzględnieniem planów Nowego Centrum Łodzi - NCŁ)

7.3. Stopień zróżnicowania wybranych cech morfologii i sposobu użytkowania starej i nowej przestrzeni centralnej w Łodzi w 2013 r. (z uwzględnieniem planów Nowego Centrum Łodzi)

7.4. Wartości wskaźnika syntetycznego (Ws) i wartości standaryzowane cech opisujących poziom rozwinięcia przestrzeni centralnej w Łodzi z uwzględnieniem projektu NCŁ .....

\section{Rozdzial 8.}

8.1. Zależności pomiędzy sposobem rozwoju przestrzeni centralnej, relacjami pomiędzy jej nowymi i starymi fragmentami a współczesnymi cechami i skutkami dla organizacji ..... 


\section{SPIS RYSUNKÓW}

\section{Mapy:}

\section{Rozdzial 1.}



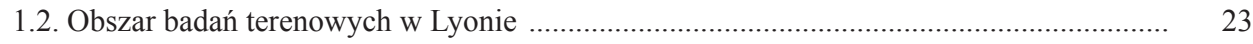

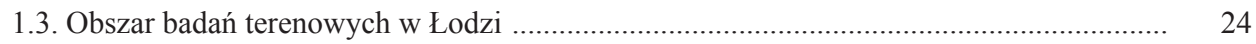

\section{Rozdzial 5.}

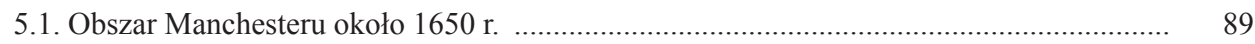

5.2. Jednostki morfogenetyczne w przestrzeni centralnej Manchesteru w 1773 r. .................. 90

5.3. Jednostki morfogenetyczne w przestrzeni centralnej Manchesteru w 1800 r. ................... 92

5.4. Jednostki morfogenetyczne w przestrzeni centralnej Manchesteru w 1916 r. ................... 94

5.5. Rozmieszczenie terenów przemysłowo-składowych i komercyjnych w dzielnicy śród-

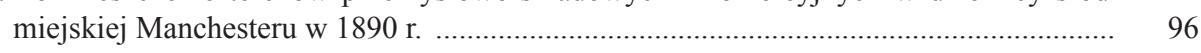

5.7. Jednostki morfogenetyczne w przestrzeni centralnej Manchesteru w 1976 r. ................... 99

5.8. Obiekty wysokościowe w Manchesterze wybudowane w latach 1959-1988 .................. 100

5.9. Obszary poddane przekształceniom przestrzenno-funkcjonalnym w Manchesterze w latach 1988-2002

5.10. Przebieg Metrolink w śródmieściu Manchesteru (2013 r.) ........................................... 105

5.11. Struktura morfologiczna w Castlefield w roku 1988 i 2013 .......................................... 108

5.12. Struktura morfologiczna w City Centre w roku 1988 i 2013 ........................................ 109

5.13. Struktura morfologiczna w Gaythorn w roku 1988 i 2013 ............................................ 110

5.14. Obszar zajmowany przez starą i nową przestrzeń centralną w Manchesterze w roku 2013

5.15. Rozmieszczenie obiektów wysokościowych w przestrzeni centralnej Manchesteru w 2013 r.

5.17. Rozmieszczenie terenów pieszych w przestrzeni centralnej Manchesteru w 2013 r. względem zrealizowanych projektów naprawczych

5.18. Użytkowanie ziemi w starej i nowej przestrzeni centralnej w Manchesterze w 2013 r. ..... 123

5.19. Jednostki morfogenetyczne w przestrzeni centralnej Manchesteru w 2013 r. ............... 125

\section{Rozdzial 6.}

6.1. Schemat przedstawiający obszar zajmowany przez Lugdunum w II w. n.e. 
6.3. Jednostki morfogenetyczne w przestrzeni centralnej Lyonu w 1818 r.

6.4. Jednostki morfogenetyczne w przestrzeni centralnej Lyonu w 1892 r.

6.5. Jednostki morfogenetyczne w przestrzeni centralnej Lyonu w $1990 \mathrm{r}$.

6.6. Infrastruktura komunikacyjna w Confluence w 1990 r.

6.8. Organizacja przestrzenno-funkcjonalna Cité Internationale w Lyonie w 2013 r.

6.9. Zakres przestrzenny projektu Confluence i etapów jego realizacji

6.10. Nowy program przestrzeni publicznych i komunikacji miejskiej w Confluence (stan na 2013 r.)

6.11. Struktura morfologiczna w Confluence w roku 1998 i 2013

6.12. Obszary działań naprawczych w Confluence w roku 2013

6.13. Obszar zajmowany przez starą i nową przestrzeń centralną w Lyonie w roku 2013 ....... 162

6.14. Rozmieszczenie terenów ruchu pieszego w przestrzeni centralnej Lyonu w 2013 r. ..... 168

6.16. Użytkowanie ziemi w starej i nowej przestrzeni centralnej w Lyonie w 2013 r. ........... 172

6.17. Jednostki morfogenetyczne w przestrzeni centralnej Lyonu w 2013 r.

\section{Rozdzial 7.}

7.1. Jednostki morfogenetyczne w przestrzeni centralnej Łodzi w $1840 \mathrm{r}$.

7.3. Jednostki morfogenetyczne w przestrzeni centralnej Łodzi w $1910 \mathrm{r}$.

7.4. Rozmieszczenie terenów przemysłowych w dzielnicy śródmiejskiej w Łodzi w 1938 r. ...

7.5. Jednostki morfogenetyczne w przestrzeni centralnej Łodzi w $1989 \mathrm{r}$.

7.6. Rozmieszczenie terenów przemysłowych i poprzemysłowych względem jednostek morfogenetycznych w śródmieściu Łodzi (stan na 1999 rok)

7.7. Rozmieszczenie przekształcanych lub przeznaczonych do przekształcenia terenów poprzemysłowch względem usługowego centrum Łodzi (stan na $2013 \mathrm{r}$.)

7.8. Zakres przekształceń przestrzenno-funkcjonalnych dawnego kompleksu fabrycznego Izraela Poznańskiego (stan na 2013 r.)

7.9. Planowany program przestrzenno-funkcjonalny zagospodarowania zachodniej części Nowego Centrum Łodzi (plany z 2013 r.)

7.10. Struktura morfologiczna Nowego Centrum Łodzi w 2013 r. i zgodnie z planami zagospodarowania do $2030 \mathrm{r}$.

7.11. Obszar zajmowany przez starą i nową przestrzeń centralną w Łodzi w r. 2013 (z uwzględnieniem planów budowy Nowego Centrum Łodzi)

7.12. Obszar strefy wielkomiejskiej Łodzi objęty programem rewitalizacji obszarowej w latach 2014-2020 z uwzględnieniem projektów priorytetowych

7.13. Rozmieszczenie obiektów wysokościowych w śródmieściu Łodzi w 2013 r. (wykorzystano planowany układ zabudowy)

7.15. Rozmieszczenie terenów pieszych w śródmieściu Łodzi w 2013 r. (z uwzględnieniem planów budowy przestrzeni publicznej w Nowym Centrum Łodzi)

7.16. Projekt rozwoju tzw. systemu przestrzeni publicznych wysokiej jakości $2020+$ w śródmieściu Łodzi

7.17. Współczesne przekształcenia w dzielnicy śródmiejskiej Łodzi (stan na 2013 r.)

\section{Rozdzial 8.}

8.3. Program rozwoju docelowej przestrzeni centralnej w Łodzi 


\section{Wykresy i schematy:}

\section{Wprowadzenie}

W.1. Schemat merytoryczny pracy

\section{Rozdzial 2.}

2.1. Ideogram graficzny przedstawiający sposób kształtowania przestrzeni centralnej w mieście oraz zmian jej organizacji

2.2. Ideogram graficzny pokazujący algorytm postępowania badawczego w zakresie przekształceń przestrzeni centralnej w mieście

2.3. Matryca zależności pomiędzy stopniem zróżnicowania i rozwinięcia przestrzeni centralnej a występowaniem relacji konkurencyjnych, kooperacyjnych i konglomeracyjnych w przestrzeni centralnej miast europejskich

\section{Rozdzial 4.}

4.1. Pierwotny i wtórny cykl zagospodarowania terenu (po)przemysłowego wobec procesu rewitalizacji i kształtowania nowej przestrzeni centralnej w mieście

\section{Rozdzial 5.}

5.6. Zmiany liczby ludności wobec etapów kształtowania przestrzeni centralnej w Manchesterze w latach 1801-2011

5.16. Struktura placów miejskich w przestrzeni centralnej Manchesteru w $2013 \mathrm{r}$.

5.20. Model sposobu rozwoju przestrzeni centralnej i terenów przemysłowych w Manchesterze

\section{Rozdzial 6.}

6.7. Zmiany liczby ludności wobec etapów kształtowania przestrzeni centralnej w Lyonie w latach 1876-2011

6.15. Struktura procentowa powierzchni placów w Confluence w $2013 \mathrm{r}$.

6.18. Model sposobu rozwoju przestrzeni centralnej i terenów przemysłowych w Lyonie ......

\section{Rozdzial 7.}

7.2. Zmiany liczby ludności wobec etapów kształtowania przestrzeni centralnej w Łodzi w latach 1820-2011

7.14. Wielkość placów miejskich zlokalizowanych w obszarze śródmiejskim Łodzi w 2013 r. z uwzględnieniem projektu Nowego Centrum Łodzi (NCŁ)

7.18. Model sposobu rozwoju przestrzeni centralnej i terenów przemysłowych w Łodzi .......

\section{Rozdzial 8.}

8.1. Model sposobu rozwoju przestrzeni centralnej w Manchesterze, Lyonie i Łodzi

8.2. Model cyklu rozwojowego przestrzeni centralnej w badanych miastach europejskich ......

8.4. Rekomendowany model rozwoju przestrzeni publicznej w kształtowanej przestrzeni centralnej Łodzi 



\section{SPIS FOTOGRAFII}

\section{Rozdzial 5.}

5.1. Manchester Central Convention and Exhibition Centre w hali dawnego dworca kolejowego Central Station

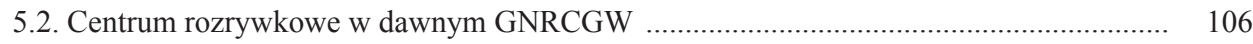

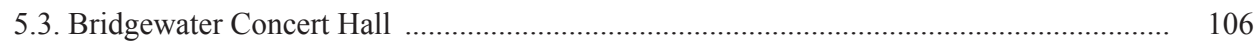

5.4. Beetham Tower widziany z Gaythorn .......................................................................... 106

5.5. Ratusz w Manchesterze jako przykład architektury eklektycznej z XIX w. .................... 115

5.6. Wielkomiejska zabudowa handlowej Portland Street ...................................................... 115

5.7. Zabudowa wielkomiejska z XIX i XX w. wokół placu Peter's Square ............................. 115

5.8. Budynek biblioteki centralnej jako przykład zabudowy z I połowy XX w. ..................... 115

5.9. City Tower i Ramada Renaissance Hotel jako przykład zabudowy wysokościowej w Manchesterze z lat 60. i 70. XX w.

5.10. Urbis i CIS Tower (na drugim planie) jako przykład nowej zabudowy w historycznej przestrzeni centralnej Manchesteru

5.11. Przykład połączenia XIX-wiecznej i XX-wiecznej zabudowy w starej przestrzeni centralnej Manchesteru - Chapel Street

5.12. Przykład połączenia historycznej i współczesnej zabudowy w Manchesterze przy Kings Street

5.13. Siedziba Royal Bank of Scotland w Spinningfields ................................................. 118

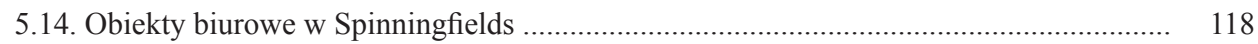

5.15. Budynek Civil Justice Centre w Spiennigfields ......................................................... 118

5.16. Zabudowa apartamentowa $w$ Spinningfields ........................................................... 118

5.17. Połączenie elementów zabudowy historycznej i współczesnej oraz wody i zieleni miejskiej w Castlefield ............................................................................................. 119

5.18. Integracja zabudowy poprzemysłowej i współczesnej w Gaythorn ................................ 119

5.19. Zabudowa wysokościowa i budynek dawnego GNRCGW przekształcony na centrum rozrywkowe w City Centre

5.20. Połączenie XIX-wiecznej architektury przemysłowej i współczesnej w City Centre ..... 119

5.21. Piccadilly Gardens jako główny plac miejski w Manchesterze ...................................... 122

5.22. Great Northern Square - rezultat rewitalizacji terenów poprzemysłowych ..................... 122

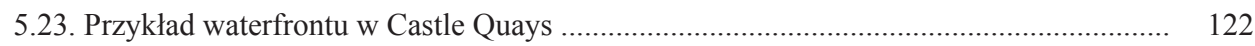

5.24. Exchange Square, na którym ustawione zostało koło widokowe ................................. 122 


\section{Rozdzial 6.}

6.1. Zabudowa wysokościowa w Part-Dieu .................................................................... 143

6.2. Zróżnicowana fizjonomia zabudowy w Part-Dieu ....................................................... 143

6.3. Centrum handlowe w Part-Dieu i wieżowiec EDF ........................................................... 143

6.4. Widok na Tour Part-Dieu ze wzgórza Fourvière ......................................................... 143

6.5. Biblioteka miejska w dzielnicy Part-Dieu ..................................................................... 144

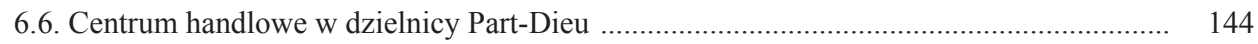

6.7. Budynek Galerii Lafayette w centrum handlowym w Part-Dieu ..................................... 144

6.8. Plac Ch. Beraudier przed wejściem do dworca SNCF Part-Dieu ..................................... 144

6.9. Place nautique jako nowa przestrzeń publiczna w Confluence ....................................... 155

6.10. Główna oś komunikacyjna w Confluence - Cours Charlemange ................................... 155

6.11. La Sucrière jako przykład zachowanej zabudowy postindustrialnej w Confluence (Quai Rambaud)

6.12. Współczesna architektura zabudowy mieszkaniowo-usługowej przy Place nautique budynki Lyon Islands

6.13. Le Monolithe i nowa zabudowa mieszkaniowo-usługowa przy Place nautique .............. 158

6.14. Oryginalna forma architektoniczna Le Cube w Quai Rambaud .................................... 158

6.15. Cours Charlemange i historyczna zabudowa w dzielnicy St. Blandine ......................... 158

6.16. Place des Archives i budynek Archiwów miejskich ...................................................... 158

6.17. Widok na zabudowę Presqu'île ze wzgórza Fourvière, po lewej Tour Part-Dieu ........... 165

6.18. Widok na zabudowę Presqu'île i na wzgórze Fourvière z La Croix-Rousse .................... 165

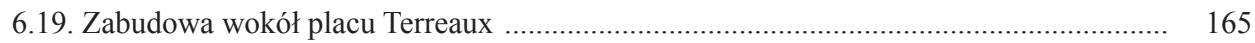

6.20. Zabudowa przy placu Bellecour ..................................................................................... 165

6.21. Widok z Presqu'île na katedrę St. Jean, Vieux Lyon i bazylikę Notre Dame de Fourvière

6.22. Jeden z najstarszych obiektów sakralnych w Lyonie - kościół St. Marie d'Ainay ......... 166

6.23. Reprezentacyjny budynek Lyonu - ratusz z XVII w. ..................................................... 166

6.24. Budynek Palais de la Bourse - symbol ekonomicznej potęgi XIX-wiecznego Lyonu ..... 166

6.25. Dom towarowy le Nouveau Grand Bazar w sąsiedztwie giełdy ..................................... 166

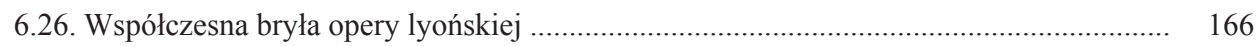

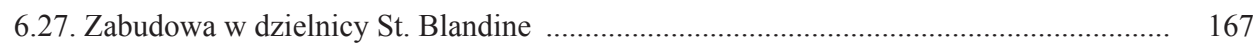

6.28. Jedyny obiekt sakralny w Confluence - kościół St. Blandine ........................................ 167

6.29. Widok na Cité Internationale ze wzgórza Fourvière ........................................................ 167

6.30. Charakterystyczna dla Cité Internationale zabudowa ze szklaną i pomarańczową elewacją

6.31. Centrum handlowo-rozrywkowe w Confluence jako najnowsza dośrodkowa przestrzeń publiczna w Lyonie

6.32. Dośrodkowa przestrzeń publiczna w kompleksie biznesowo-kongresowym Cité Internationale .

\section{Rozdzial 7.}

7.1. Zabudowa Śródmiejskiej Dzielnicy Mieszkaniowej i dzielnicy biznesowej w Łodzi .......

7.2. Historyczna zabudowa placu Wolności i ulicy Piotrkowskiej .......................................... 189

7.3. Ulica Piotrkowska po renowacji przeprowadzonej w latach 90. XX w. .......................... 193 
7.5. Parking na Placu Dąbrowskiego w 2002 r.

7.6. Plac Wolności z pomnikiem Tadeusza Kościuszki pełniący funkcję komunikacyjną ........

7.7. Przędzalnia Karola Scheiblera wybudowana w latach 1870-1878 adaptowana na obiekt mieszkalny w latach 2005-2010

7.8. Pałac Scheiblerów przy Placu Zwycięstwa jest współcześnie siedzibą Muzeum Kinematografii w Łodzi

7.9. Zabudowa śródmiejska Łodzi z drugiej połowy XX w. i jeden z wielu parkingów powstałych na terenach po wyburzonych kamienicach

7.10. Ulica Kilińskiego jako przykład ulicy śródmiejskiej odznaczającej się niską jakością estetyczną krajobrazu

7.11. Zadbana przestrzeń publiczna w „Manufakturze”

7.12. Estetyczna przestrzeń publiczna przed wejściem do „Galerii Łódzkiej” ......................... 199

7.13. Odsłonięte oficyny zabudowy przy ulicy Narutowicza .............................................. 210

7.14. Zdegradowana zabudowa przy skrzyżowaniu ulic Piotrkowskiej i Narutowicza ........... 210

7.15. Dom handlowy „Magda” wybudowany w latach 60. XX w. w pierzei XIX-wiecznej zabudowy ulicy Piotrkowskiej

7.16. Fragment łódzkiej dzielnicy biznesowo-administracyjnej z lat 70. XX w.

7.17. Neogotycka bazylika archikatedralna ze 102-metrową wieżą jest najwyższym budynkiem w Łodzi

7.18. Neoromański kościół ewangelicki pw. św. Mateusza przy ulicy Piotrkowskiej

7.19. Monumentalna zabudowa poprzemysłowa w południowej części kompleksu „Manufaktury"

7.20. Galeria handlowa wkomponowana w zabudowę postindustrialną „Manufaktury” ..........

7.21. Budynek EC-1 Południowy-Wschód zajęty przez Muzeum Bajki oraz komin EC-1 Wschód, który zostanie przekształcony na wieżę widokową

7.22. Integracja nowoczesnej i postindustrialnej formy architektonicznej w kompleksie EC-1 Wschód

7.23. Stylizowane latarnie i kioski jako element małej architektury w „Manufakturze” ..........

7.24. Szata informacyjna jako element małej architektury w „Manufakturze”

7.25. Rynek staromiejski - zaniedbana przestrzeń publiczna w sąsiedztwie „Manufaktury” .....

7.26. Szata informacyjna w „centrum” Łodzi przy skrzyżowaniu ulicy Piotrkowskiej z aleją Mickiewicza i Piłsudskiego (2012 r.) 